\title{
THE OTTAWA VALLEY JOURNAL AND THE MODERN COUNTRYSIDE: A CITY-COUNTRY NEWSPAPER AND THE NEW JOURNALISM IN EASTERN ONTARIO, 1887 TO 1925
}

\author{
by \\ DOROTHY-JANE SMITH
}

A thesis submitted to the Faculty of Graduate and Postdoctoral Affairs in partial fulfillment of the requirements

for the degree of

Doctor of Philosophy

in

History

Carleton University

Ottawa, Ontario

(C) 2018

Dorothy-Jane Smith 


\begin{abstract}
Studies of the press as a modernizing agent in the first two decades of the twentieth century usually look at the mass media of the city dailies. I argue that the country edition of an Ottawa daily, the rural Journal, equally was a modernizing agent. It involved itself in the definition of expert knowledge at the agricultural fair, in demonstrating professional road-building to rural residents, and in mobilizing producers against the middlemen and "poor business practices" of the global cheese market. These stories give insight into how a city-run newspaper dressed itself in rural clothing while presenting a model of modernity.
\end{abstract}

In 1899 the newspaper was renamed from the Ottawa Semi-Weekly Journal to the Ottawa Valley Journal as a statement that it was a newspaper for rural residents. In 1917, it became the Ottawa Farm Journal with the intent of being a regional farm paper. But what made the rural Journal special was activism in the style of the 1890 s urban New Journalism. The first two editors made news and not just reported it, but with differing approaches. Herbert Cowan was a city man who relied on the authority of experts for his initiatives. Robert Faith was a farm boy come to the city who saw himself as the voice of the farmer, following his own conscience on what was right.

The determination to be modern on their own terms led many of the readers to resist a hegemonic definition of modern based on technology and increased managerial government. They were interested in Cowan's spectacles of modernity but did not alter their behaviour. They responded to Faith's calls for mass protests as these expressed their ambivalence to "progress" and yet his "agitations" did not change rural conditions. Nonetheless, the rural Journal campaigns told readers that farm issues were important and affirmed readers' aspiration to be modern as well as their unease over the resulting 
sense of disruption. In doing so, the newspaper helped keep alive a radical spirit in the countryside but it was a spirit which did not challenge the capitalist structures in which producers were enmeshed. 


\section{Acknowledgements}

This study owes a great debt to many people but I must start with its beginningsthe finding and sharing of the sales pamphlet by my dissertation supervisor, Bruce $\mathrm{S}$. Elliott. This gave me a focus and a structure that allowed the study to take form. Beyond this, however, Dr. Elliott was both a patient and a thorough questioner and reviewer which kept me extending my reach. He also produced, almost out of a hat it sometimes seemed, interesting and useful ephemera on the Ottawa Valley Journal and its competitors. The study also profited immensely from the useful and timely comments of Paul Litt and John Walsh who as the dissertation committee worked to unnaturally tight deadlines. I am grateful as well for the time Ross Eamon gave me as a first year doctoral student in directing me through a crash course study on newspapers and particularly on what he called "the complex relationship between social discourse and historical events" found in newspapers. Catharine A. Wilson gave me encouraging feed-back on a conference paper and in addition both she and Barbara M. Freeman's comments at the defence have been constructive in strengthening my points.

I would also like thank the scholars who encouraged me as I ran the last mile. Dominique Marshall had directed me in the Disability Research Group and continued to give encouragement at every encounter. Kerry Abel encouraged me when I was her teaching assistant and continued her moral support even after our work together. Davina DesRoches gave me support as a scholar and a writer when we were doctoral candidates working through our various writing demons together and she has continued to send me words of encouragement even after she moved on to full academe. I have also been lucky in a wonderful boss, Rachel Perkins of the Cumberland Heritage Village Museum. She has been supportive both in the work I do for the museum and when we spoke about this 
dissertation. And, as with all students and researchers, nothing could have been accomplished without the librarians and archivists. There were many of these heroes but I am going to distinguish Sylvie Bertrand of the Canada Science and Technology Museums Corporation for her patience through my many months of work in that library and Rebecca Bartlett who, as the map librarian at Carleton University, produced the maps in this study. Just as important among the people who made a difference are the History Department administrators but I have long felt that Joan White deserves a special place of honour. As Graduate Administrator she keeps us all on the straight and narrow and when I strayed off into the university administrative jungle got me back on track.

All my sisters and brothers encouraged me in every conversation over the last several years. I only wish Pat was still here to see the end of this job. Finally, keeping the house going and a small dog happy only happened because my brother Edward picked up the slack. Even more importantly, however, as a former free-lance editor he was my go-to person for advice on grammar and words as well as rescuing me from computer disasters. It is family that made this dissertation a reality and I dedicate it to the story-tellers our family have lost: Edward and Mildred Smith, Dieter Krause and Patricia Bow. 


\section{Table of Contents}

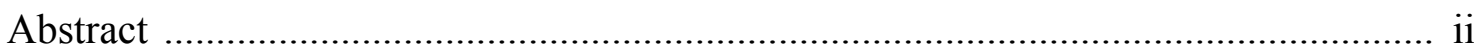

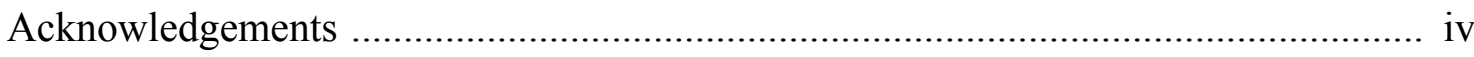

Table of Contents ........................................................................................... vi

List of Maps and Figures. ................................................................................ ix

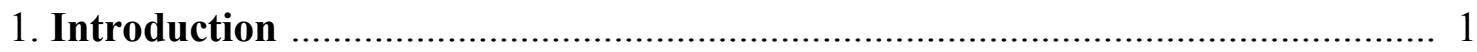

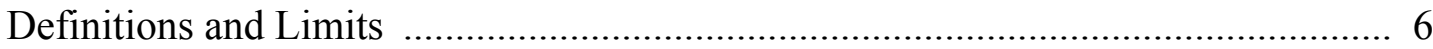

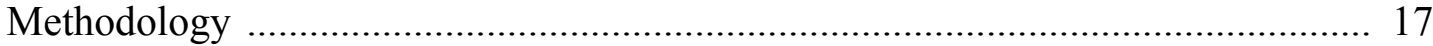

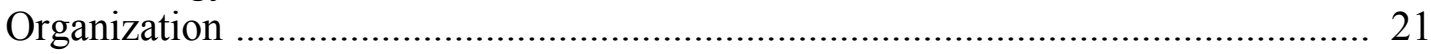

\section{Historiography of the Press: Mass Communication and}

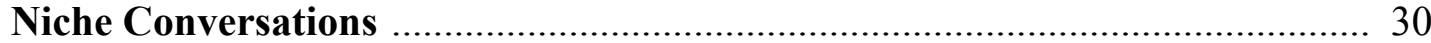

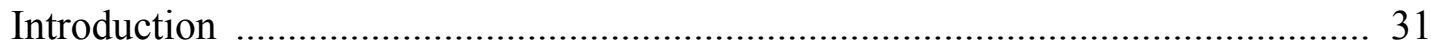

Critiquing Journalism History .......................................................................... 32

The Text as Written .............................................................................. 33

The Text as Read .......................................................................... 37

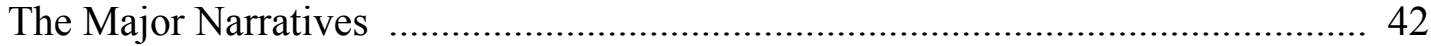

From Freedom of the Press to the Public Sphere of a Liberal Order .............. 43

The Commercializing Nineteenth-Century Press Makes Information

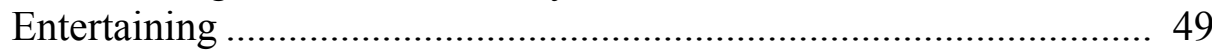

The Niche Newspapers .................................................................................. 56

Country Journalism Survives by Celebrating the Local ............................. 57

The Farm Press as Source and as Actor ..................................................... 61

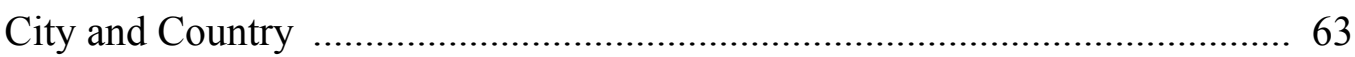

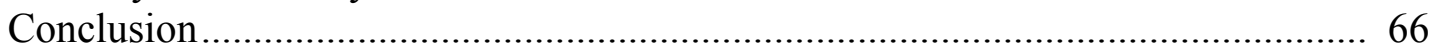

3. Being Rural, Being Modern ...................................................................... 70

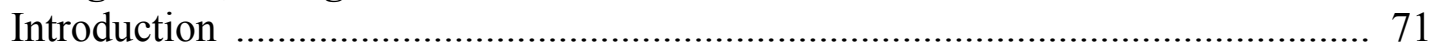

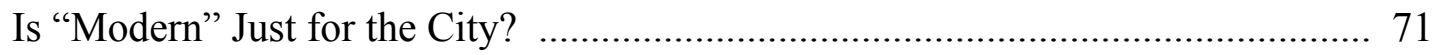

Defining Modern ....................................................................................... 72

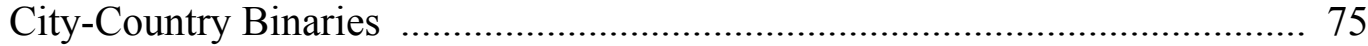

Thinking about Knowledge .......................................................................... 76

A Reform Stew for the Countryside: Agrarianism and Populism,

Progressivism and Country Life ............................................. 81

The American Histories ...................................................................... 82

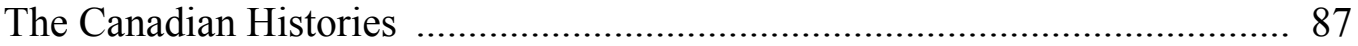

Being Agrarian, Being Modern: Binding a Binary ........................................ 92

Was There a Divide? ........................................................................... 93

Modernizing Agents ............................................................................. 98

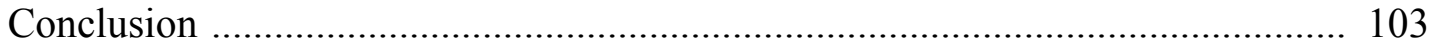

4. Newspaper Hybridity: The Ottawa Journal and Its Rural Face .................... 108

Introduction .................................................................................................. 109

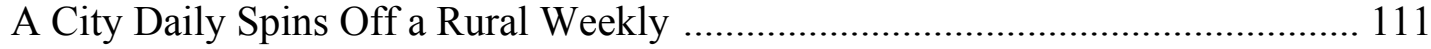

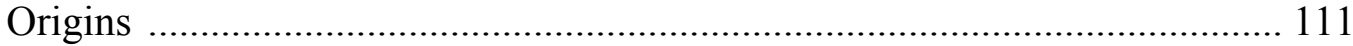

Why a Semi-Weekly? .................................................................... 113 
How Rural Was the Rural Journal? ............................................................... 119

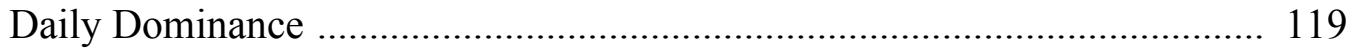

Independence ... of a Sort ................................................................. 120

How Rural Was the Staff? .................................................................... 123

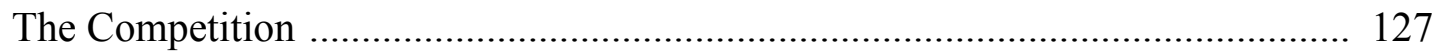

The Local Competition ........................................................................... 128

Competition from Beyond the Valley .......................................................... 133

An Urban Dish with a Soupçon of Rural Flavouring .......................................... 140

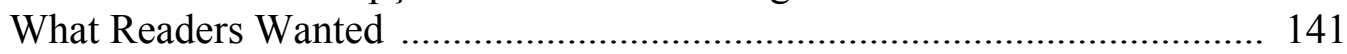

Selling the Semi ..................................................................................... 144

The Journal Content and its Evolution ...................................................... 151

The Newspaper Community .................................................................. 157

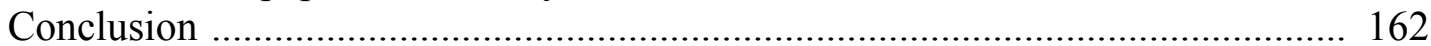

5. The Limits to Activism: The Ottawa Valley Journal's Agrarianism .............. 167

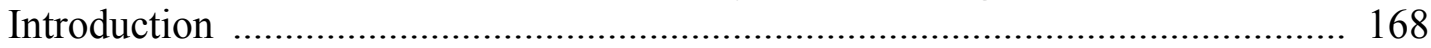

The Rural Journal as Activist ........................................................................ 170

New Journalism Activism: Cowan and the Agricultural Experts ................... 170

New Journalism Activism: Faith as Agrarian Organizer ................................ 174

Limits of Activism …………………………………................................... 177

The Politics of Conscription, Tariffs and Labour .......................................... 178

Country Life and the Country Family ....................................................... 186

Farm Work as Men's Work .................................................................. 195

Country Life and the Social Gospel ………………….............................. 197

Country Living, Cemeteries and the Community ………………………..... 203

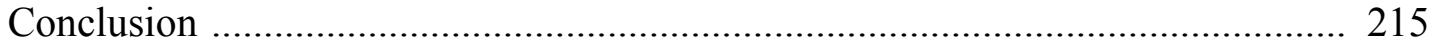

6. The Farmer and Expert Knowledge: Making the Fair News ......................... 219

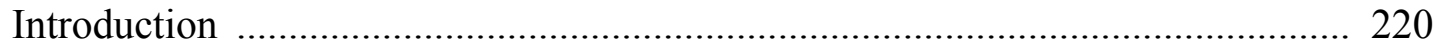

Fairs, Education and Hegemony …………………….................................... 222

What Was Expected of the Fair ................................................................. 223

Making Things Happen .............................................................................. 230

The Farmer's Advocate's Idea for Improving the Fair ................................. 231

The Journal Acts ................................................................................... 233

The Changing Nature of Knowledge .................................................................. 242

What Made an Expert Judge Expert? …………………............................... 243

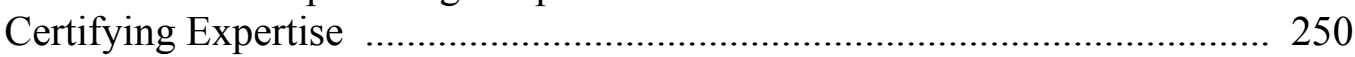

Did the Expert Change by 1920? ………………………........................... 251

Seeing is Knowing ... Once the Expert Tells You How ..................................... 253

Taking Observation Seriously .................................................................... 254

The Power of Observational Learning ………………............................... 255

Setting and Teaching New Standards ......................................................... 261

The Farmers' Reception of the Journal's Fair Campaign .................................... 263

And What Did the Farmer's Advocate Think? .................................................. 266

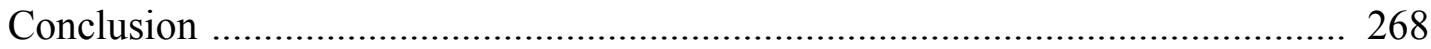


7. The Farmer and the Labour Theory of Value in Roads and Taxes .............. 273

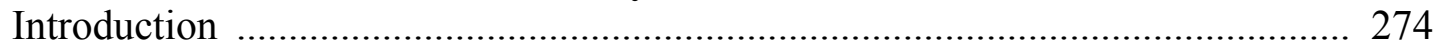

Labour, Property and Value .......................................................................... 276

The Labour Theory of Value ................................................................ 277

The Road Story ............................................................................ 280

Farmers and Technology ............................................................ 287

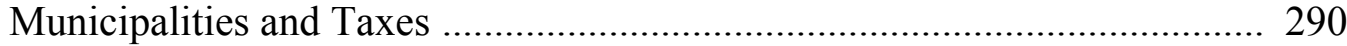

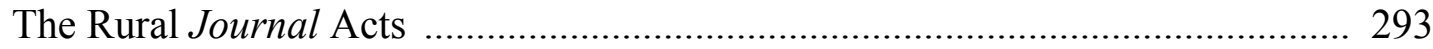

Good Roads Phase I (1900-1902) ........................................................... 294

Taxes $(1907-1910)$.......................................................................... 301

The City Triumphs: Good Roads Phase II (1913-1919) ........................... 305

All the Talk: Progress in Machinery versus Ownership through Labour ............. 308

Roads and the Modernity of Machinery .................................................... 309

Rural Resistance: Modern Machinery Was Not Enough ........................... 314

Reader Resistance: At Least They Knew How Statute Labour Worked ...... 319

Farmers and Their Labour ......................................................................... 322

Labour Theory of Value and the Single Tax ........................................... 329

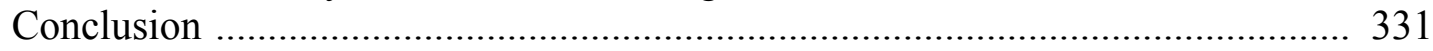

8. The Farmer and the Market: Producers, Middlemen and Cheese ................ 336

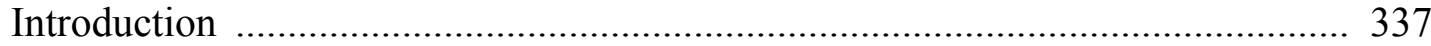

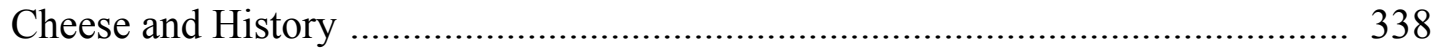

Producerism, Liberalism and the Market Economy ................................. 339

The Cheese Factory ........................................................................... 344

Marketing Cheese .................................................................................. 347

The Problem with Cheese Boards ........................................................... 349

Shifting Interventions: From Discussion to Disruption .................................. 352

Cowan and Discussion ........................................................................ 352

Faith and Disruption ...................................................................... 356

Farmer's Advocate as Public Forum ...................................................... 363

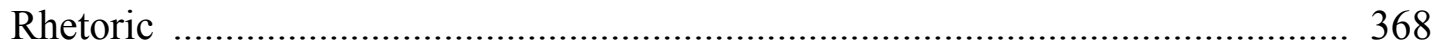

Fairness, Struggle and Producerism .................................................. 368

Credibility ............................................................................... 371

A Fine Mix of Radicalism, Business and Religion ................................ 373

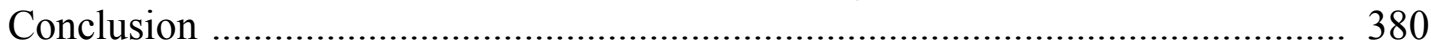

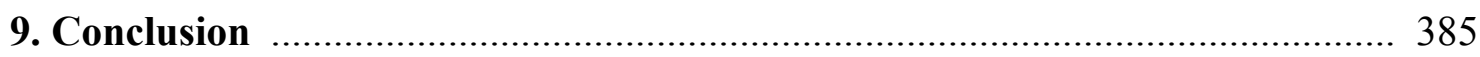

Appendix A: Sales Pamphlet Ottawa Farm Journal, circa 1920 ............................ 404

Appendix B: Timeline Rural Activism by Ottawa Valley Journal /

Ottawa Farm Journal ........................................................................... 406

Appendix C: Content Analysis ............................................................................ 408

Appendix D: Agricultural Potential in the Ottawa Valley .................................... 416

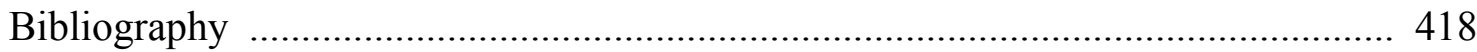




\section{List of Maps}

Map 1: Towns and Villages Supplying Local News to the Ottawa Valley Journal

Map 2: Circulation, Ottawa Farm Journal and Competitors, Ontario East of Toronto, c.1919/1920

\section{List of Figures}

Figure 2.1: Front page, Ottawa Semi-Weekly Journal, June 6, 1887 30

Figure 3.1: Illustration from Sales Pamphlet, Ottawa Farm Journal ............................ 70

Figure 4.1: "Journal move to new building"; Herbert Cowan and Robert Faith ............ 108

Figure 4.2: Space Allocation, 1888 to 1925: Changes in Content Emphasis .................. 154

Figure 5.1: “Aunt Joe's Household Department" ................................................... 167

Figure 5.2: Ottawa Valley Journal and Ottawa Farm Journal headers for the Household Department. 190

Figure 6.1: "Before Taking and After Takimg (sic)" .............................................. 219

Figure 7.1: "The Eastern Ontario Good Roads Train” ............................................. 273

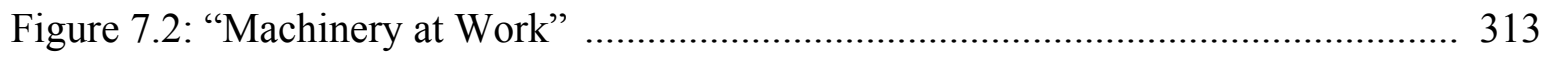

Figure 7.2: Split Lot Drag, Farmer's Advocate ..................................................... 317

Figure 8.2: "Scenes at the Ottawa Cheese Board" ................................................... 336 


\section{Chapter 1: Introduction}

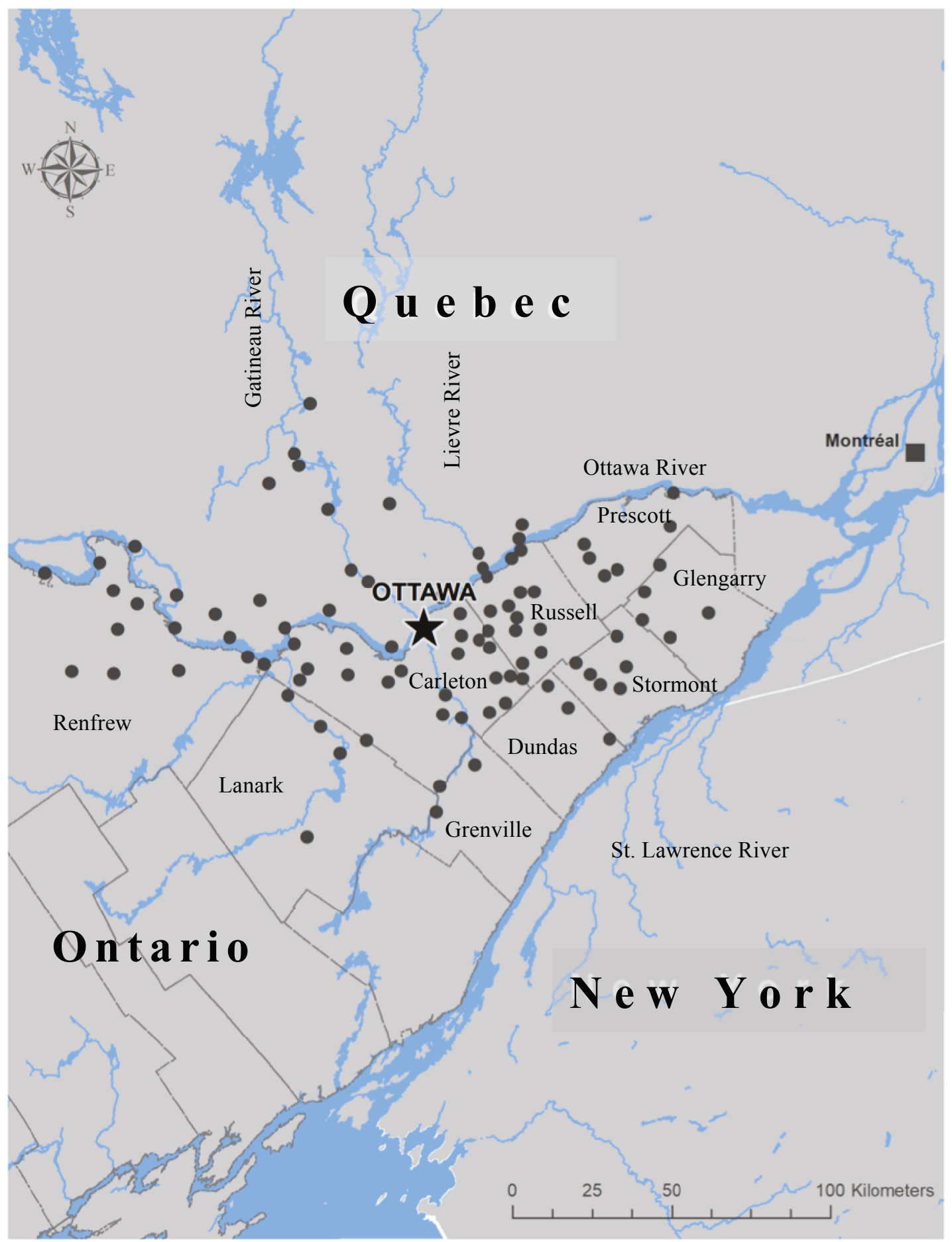

Map 1: Towns and Villages Supplying Local News to the Ottawa Valley Journal

In 1899 an Ottawa newspaper renamed its country semi-weekly edition the Ottawa Valley Journal. The name change, along with inclusion of specially-written agricultural information, was part of selling itself to the farmers and small towns of the city's rural hinterland. What made the rural Journal different from the other city-published semiweeklies was its claim to be an activist on the farmers' behalf. Map by Rebecca Bartlett, Carleton University. 


\section{Locations of Local Correspondents (1911 population)}

\section{Ottawa Valley Journal January 31, 1899 to January 31, 1917}

Ottawa River Counties
Renfrew Co.
Pembroke (6,000)
Westmeath (300)
Cobden (600)
Beachburg (400)
Foresters' Falls (300)
Eganville (1,000)
Douglas (400)
Renfrew (3,400)
Braeside (200)
Arnprior (4,300)
Lanark Co.
Almonte (3,000)
Carleton Place (4,100)
Pakenham (600)
Darcyville (pop. ng)
Carleton Co. (West -
Fitzroy to Nepean)
Fitzroy Harbour (250)
Antrim (50)
Kinburn (200)
Dunrobin (100)
South March (150)
Carp (300)
Hazeldean (100)
Ashton (300)
Bells Corners (100)
Carleton Co. (South -
N. Gower \& Osgoode)
Manotick (400)
Carsonby (75)
Kars (200)
Kenmore (600)
Dalmeny (30)
Edwards (pop. ng)
Vernon (150)
Carleton Co. (East -
Gloucester)
Blackburn (pop. ng)
Ramsayville (pop. ng)

Leitrim (pop.ng)

Carlsbad Springs (200)

Piperville (pop.ng)

Russell Co. (North Cumberland \&

Clarence)

Cumberland (300)

Navan (100)

Leonard (pop. ng)

Canaan (pop. ng)

Bearbrook (50)

Vars (200)

Rockland (800)

Clarence (150)

Hammond (200)

Russell Co. (South -

Russell \& Cambridge)

Russell (400)

Marvelville (pop ng.)

Metcalfe (500)

Casselman (300)

South Indian (250)

Prescott Co.

L'Orignal $(1,000)$

Fournier (200)

Plantagenet (325)

Riceville (200)

Hawkesbury $(4,300)$

Vankleek Hill $(2,000)$

St. Lawrence Counties

Glengarry Co.

McCrimmon (50)

Dunvegan (250)

Maxville (800)

Green Valley (200)

Apple Hill (300)

Stormont Co.

Moose Creek (400)

Avonmore (400)

Newington (300)

Finch (400)
Berwick (250)

Crysler (300)

Aultsville (400) (now under

the St. Lawrence)

Dundas Co.

Archer (pop.ng)

Chesterville (930)

Morewood (300)

Grenville Co.

Kemptville $(1,600)$

Burritts Rapids (250)

Merrickville $(1,000)$

Quebec (Pontiac \&

Wright Co.'s - Ottawa

River)

Fort Coulonge (811)

Bryson (477)

Portage du Fort (365)

Shawville (715)

Bristol Twp. $(1,957)$

Quyon (806)

Onslow S. Twp (878)

Luskville (pop. ng)

Aylmer (3,109)

Quebec (Wright Co. Gatineau River)

Templeton Twp $(3,502)$

Masham Twp $(3,009)$

Aylwin Twp (900)

Low Twp $(1,292)$

Kazabazua (pop. ng)

Danford Lake (pop. ng)

Northfield Twp (552)

Quebec (Labelle Co. -

Lievre River)

Masson (1,034)

Lochaber Twp $(1,821)$

Thurso (601)

Buckingham $(3,854)$

Poltimore (pop. ng)

Towns and villages from which a local correspondent sent at least three entries to the district news columns of the Ottawa Valley Journal (excludes places found in the main newspaper text in connection to crimes, disasters and other news events). Population figures from Province of Ontario Gazetteer and Directory 1910-11 ([Ingersoll, On.]: Union Publishing Company, 1910) and (for Quebec) Fifth Census of Canada, 1911, Vol. 1, Table I, Population. 
Sometime around 1919 or 1920 a farm family in the Ottawa Valley received, possibly in the mail, a pamphlet. It was advertising the recently renamed Ottawa Farm Journal. This semi-weekly edition of a city daily, the Ottawa Evening Journal, was rebranding itself from its former name of the Ottawa Valley Journal. This was intended to underline its agricultural content and its intent to move beyond its long-time market in the rural Valley. Happily for this historian, the family pushed the pamphlet into a drawer and forgot it. Nearly a century later it was found still in that drawer in furniture for sale at an antique fair. When it was shared with me for this study, I became interested in its claim that the rural Journal had been "always active in farmers' interests" and had worked for "agricultural progress."

The semi-weekly had a long life—-from 1887 to 1955 — under three different names: the Ottawa Semi-Weekly Journal to 1899, the Ottawa Valley Journal to 1917, and the Ottawa Farm Journal to 1955. It lasted four decades after the Journal's competitors in Ottawa had closed down their country semi-weeklies. It seems it was giving rural readers something they wanted. The question is what did they want and how (indeed whether) a city-published newspaper delivered it. To answer this question I have studied the differing practices of the first two editors of the rural Journal, Herbert Cowan and Robert Faith, in terms of the events they orchestrated and the rhetoric they employed to appeal to the farm population. Practice and language were part of the newspaper's claim to have been the farmer's friend as well as a proponent of the modern farm business.

I expected that tracing the stories connected with the pamphlet's claim would open a window into how a city-managed newspaper dressed itself in rural clothing. Underlying this study are the tensions within the discourses of 1900 around modernity, 
knowledge, value and community. The rural Journal described its readers as progressively modern - meaning rational and business-like. At the same time farm families retained traditional agrarian ideas which increasingly clashed with the reality of a changing Euro-American world. Many farm families held to the labour theory of value (attributing all value in a product to the labour which made it), extrapolated this into producerism (a political economy argument that the producer who supplied the labour owned the products created and their value) and capped it with traditional farmer fundamentalism (that agricultural labour was the fundamental value-setter, both economically and morally, for society). When taken to a logical end, this mix of ideas went against the nineteenth-century ideal of a mutualist and interdependent liberal community in which each individual's self-interest (whether farmer, manufacturer or commercial man) contributed to the wealth of all. Many farm families also continued to value practical knowledge and to distrust "book-farming."

In Chapter 3 I explore in more depth what modern means but in general it is a concept I approach cautiously. To the extent modern can be summarized, I view the word as encompassing ideas which valorize change, whether in intellectual concepts of how the world works, or in social relationships, or in economic relations. While I do not go as far as Bruno Latour to say we were never modern, individuals and societies may embrace economic change and new economic activities while trying to work out the changes within older views of social relationships. ${ }^{1}$ In the case of Eastern Ontario farmers, the

\footnotetext{
${ }^{1}$ Bruno Latour, We Have Never Been Modern transl. Catherine Porter (Cambridge, Mass.: Harvard University Press, 1993). See Royden Loewen, Family, Church and Market: A Mennonite Community in the Old and the New Worlds, 1850-1930 (Toronto: University of Toronto Press, 1993) for a study of a community which defined itself in terms of traditional values centred on family, household and religion while embracing continuous economic change both in Europe and in North America in order to preserve those traditional values.
} 
reality was that their farm products were commodities in a global market dominated by

cities that drew in, processed, circulated and ultimately set the value of the resources of a rural hinterland. ${ }^{2}$ In addition, in these first decades of the twentieth century, the supremacy of the practical knowledge of the farmer would lose in a competition with that of the government and college agricultural experts, leaving it at best "tacit" (practical and tolerable) but often "subordinate" knowledge. ${ }^{3}$ The virtue of agricultural work and of rural living was given lip service by all but was undercut in reality by urban Country Life reformers who aimed to reconstruct farm families as modern in terms of culturally dominant urban middle-class values. ${ }^{4}$ This meant farm men were to be competitive capitalists running their farms as businesses rather than as a way of life within a moral economy centred around their family, home and community. Farm women were to be non-producing housewives creating a home as a refuge from business. ${ }^{5}$ The gap between belief and reality underlines that the rural world of agriculture and small artisans was undergoing transition to a world of increasing industrialization. By 1900 being modern for many in the city meant celebrating disruption from the past as it took the form of an

\footnotetext{
${ }^{2}$ See William Cronon, Nature's Metropolis: Chicago and the Great West (New York: W.W. Norton, 1991); J.M.S. Careless, Frontier and Metropolis: Regions, Cities, and Identities in Canada before 1914 (Toronto: University of Toronto Press, 1989).

${ }^{3}$ See Michel Foucault, The Order of Things: An Archaeology of the Human Sciences (New York: Vintage Books, 1973); James C. Scott, Seeing Like a State: How Certain Schemes to Improve the Human Condition Have Failed (New Haven: Yale University Press, 1998).

${ }^{4}$ I use the term "culturally" because farming and farm families remained important economically and demographically through this period. Agriculture remained a significant sector while the number of rural residents only dropped below $50 \%$ of the population in the 1911 census; Ian M. Drummond, Progress without Planning: The Economic History of Ontario from Confederation to the Second World War (Toronto: University of Toronto Press, 1987). In contrast, by the end of the nineteenth century culture was being set in the cities in the form of consumerism and what it meant to be modern; see Paul Rutherford, $A$ Victorian Authority: The Daily Press in Late Nineteenth-Century Canada (Toronto: University Of Toronto Press, 1982); Keith Walden, Becoming Modern in Toronto: The Industrial Exhibition and the Shaping of a Late Victorian Culture (Toronto: University of Toronto Press, 1997).

${ }^{5}$ See William L. Bowers, The Country Life Movement in America, 1900-1920 (Port Washington, N.Y.: Kennikat Press, 1974); David B. Danbom, The Resisted Revolution: Urban America and the Industrialization of Agriculture, 1900-1930 (Ames: Iowa State University Press, 1979); Hal S. Barron, Mixed Harvest: The Second Great Transformation (Chapel Hill: University of North Carolina, 1997).
} 
abundance of factory-produced consumer products. ${ }^{6}$ For many farm families, disruption was a source of unease even as they enjoyed Eaton's mail-order catalogue.

I argue that the determination to be modern on their own terms led many farm families to a passive form of resistance to the hegemonic urban definition of modern. They showed great interest in the newspaper's fairs and roads campaigns but did not immediately make the changes editor Herbert Cowan expected. The campaigns of the second editor, Robert Faith, were different for they channeled rural resistance into mass meetings and petitions with the strongest protests targeting the domination of middlemen and agricultural export companies. At the same time, none of the newspaper's campaigns, nor the farmers' responses as seen in the published letters commenting on them, challenged the hegemonic capitalist structures that created the markets and their price setting mechanisms.

Cowan was a city man who relied on the authority of experts and agricultural leaders to give credibility both to his initiatives and to the knowledge he was presenting. Faith was a farm boy come to the city. Like Cowan he stressed the importance of being progressive, business-like and "wide-awake" but he attacked locally prominent dairy businessmen as well as government experts and the faceless export houses of Montreal. Faith presented himself as the voice of the farmer and expressed a "tacit" farmer's knowledge of what was right without concern for what experts might preach.

\section{Definitions and Limits}

The rural Journal along with its c.1919/1920 sales pamphlet frames the content, geography and periodization of my study. Content in Chapters 6 to 8 is bounded by the

\footnotetext{
${ }^{6}$ Anthony Giddens and Christopher Pierson, Conversations with Anthony Giddens: Making Sense of Modernity (Stanford, Calif.: Stanford University Press, 1998).
} 
issues underlying the pamphlet's list of achievements, while I discuss agrarian issues not pursued by the rural Journal in Chapter 5. The Journal's self-positioning as a farm newspaper was embodied in the Ottawa Farm Journal sales pamphlet (Appendix A) in the following achievements:

1. Conducted the first series of "Orchard and Dairy Meetings".

2. Formed the first "Circuit of Fairs" ever organized in the Dominion; initiated the Expert Judge System; and for four years in succession gave a handsome trophy to the Agricultural Society holding the best exhibition.

3. Built twelve miles of Model Roadway in different parts of Eastern Ontario.

4. Organized and carried through successfully the first series of Livestock Judging classes.

5. Has given away more than 3,200 pure-bred Pigs and Poultry, to improve the livestock of Eastern Ontario.

6. Started the first Seed Grain Fair, which has done so much to improve the yield of the different varieties of grain and potatoes.

7. Formed three big associations, namely, "The Eastern Ontario Fairs Association", "The Farmers' Mutual Rights Association", [believed to be "Municipal Rights"] and "The Farmers' Produce Association".

8. Organized a deputation of 600 farmers representing 16 counties in Eastern Ontario and Western Quebec which waited upon the Dominion Government in 1911, and asked for certain protection in the marketing of cheese and butter, which resulted in the appointment of a Royal 
Commission by the Dominion Government to inquire into the grievances of the dairymen.

9. Inaugurated a movement to clean up the rural cemeteries of Central Canada.

10. Assisted actively in the promotion of the Permanent Highway from Ottawa to Prescott.

11. Organized rural end of Dominion Good Roads Congress, Ottawa, April, $1917^{7}$

I found that the pamphlet was, not surprisingly, a sales job. It was not an accurate record of achievement but it does provide me with a list of the activities which the newspaper believed would interest rural subscribers. The list is rather long and diverse but it can be consolidated into three farmer roles which form the core of this study:

- as learners at agricultural fairs;

- as township ratepayers responsible for road building and local taxes; and

- as local producers selling into a global market.

I do not follow any of the issues into their after-life. For example, I do not address the development of Ontario's marketing boards despite their being logical outgrowths of the Farmers' Produce Association. Bounding the content by the pamphlet's achievements requires contextualizing them within a number of rural study themes: the Country Life Movement, technology, women and children as producers, and agrarian radicalism.

Geographically, in the late-nineteenth and early-twentieth centuries there were two rural Ontarios: the settled places of Southern Ontario and a New Ontario to the North. I am looking at "old" Ontario with its established farms and community

\footnotetext{
${ }^{7}$ Quoted from the Ottawa Farm Journal sales pamphlet circa 1919/1920, collection of Bruce S. Elliott.
} 
institutions. Instead of New Ontario's pioneering challenges, commentators on old Ontario worried about an erosion of the farming population as well as of the community institutions they had built. But where in Southern Ontario was rural? Was it a place countable in decennial statistics - the residue after deducting the populations of incorporated cities, towns and villages which the census counted as "urban" regardless of size? $?^{8}$ I argue that mapping rural Canada using the census definition of the period is meaningless. For example, in Eastern Ontario, Casselman was counted as urban in 1911 because it was an incorporated village but the village's residents would not have experienced daily life in the same way as Ottawans did. ${ }^{9}$ I suggest someone coming from Ottawa for a summer visit would have felt they were encountering rusticity in Casselman. At the same time, for all that Casselman may have seemed different to a citified visitor, rural historians have increasingly rejected the notion of a binary difference between country and city.

Trying to map rural Ontario fails partially because rural has long been more than a form of municipal administration, or population density or productive activity. ${ }^{10}$ Rural Ontario is, and was, as much a place of the mind as a place on the map. It is a space

\footnotetext{
${ }^{8}$ Ninth Census of Canada, 1951, Vol. 1, note p. xv. With the 1951 Census, Statistics Canada changed its definition of urban from one based on form of municipal government, i.e., incorporation, to a definition which counted "urban" based on size and density i.e., a city, town, or village with a population of 1,000 or more.

${ }^{9}$ Fifth Census of Canada, 1911, Vol. 1, Table 1, p. 88.

${ }^{10}$ Frederick H. Buttel and Philip McMichael, "Sociology and Rural History: Summary and Critique," Social Science History 12, 2 (Summer 1988): 93-120 argue that there was so little difference by the 1980s between city and country populations on characteristics such as adherence to tradition, population density, and degree of self-generated change that these were analytically meaningless. Sociologists Bill Reimer and Ray Bollman agree that definitional characteristics such as distance between adjoining population centres and population density mask differences of importance to public policy work; Bill Reimer and Ray D. Bollman, "Understanding Rural Canada: Implications for Rural Development Policy and Rural Planning Policy", University of Guelph http://www.uoguelph.ca/fare/FARE-talk/BOOK-Chapter-1-Bill-and-RayNEL-DOUGLAS-09-0405-001.pdf. Accessed June 9, 2014.
} 
marked "other" in a world defined by urban norms. ${ }^{11}$ It was also (and still is) an

economic resource extraction zone for a metropolitan-dominated economy. J.M.S.

Careless in his metropolitan thesis pointed to the economic and geographic links between town population centres and their surrounding hinterlands. Nineteenth-century Ottawa Valley farmers may have felt they were dealing locally in attending Ottawa's Byward market but Montreal, as Canada's "supreme" metropolis, set the prices found there. ${ }^{12}$

To cut the Gordian knot of definition, I have restricted my focus to what the rural Journal itself thought it was targeting. The Ottawa Valley Journal's territory is mappable from the places in which its regular local correspondents resided, from small mill towns to cross-road hamlets (see Map 1). They wrote from both sides of the Ottawa River, from Pembroke to the St. Lawrence River in Ontario and from Pontiac to Labelle Counties in Quebec. The newspaper's target audience, then, was the English-speaking population of the Ottawa Valley that lived beyond the city of Ottawa and its suburbs and outside the major mill towns of Cornwall, Ontario and Hull, Quebec.

The above sentence describing the target audience in geographic terms hides as much as it tells. In comparison with other parts of Ontario the agriculture of the Ottawa Valley suffers in terms of its soil quality while the region as a whole did not attract the level of industrialization found elsewhere. ${ }^{13}$ But there was also a disparity of

\footnotetext{
${ }^{11}$ Gerald W. Creed and Barbara Ching, "Introduction: Recognizing Rusticity, Identity and the Power of Place," in Knowing Your Place: Rural Identity and Cultural Hierarchy, ed. Barbara Ching and Gerald W. Creed (New York: Routledge, 1997), 1-38. This is a collection of studies of contemporary rural society by anthropologists and English literature theorists. Creed and Ching argue that in the rural/urban opposition, urban is taken for granted by urban dwellers but both categories are highly visible to rural residents.

${ }^{12}$ Careless, Frontier and Metropolis, 82-5.

${ }^{13}$ Donald Gordon Cartwright, "French Canadian Colonization in Eastern Ontario to 1910: A Study of Process and Pattern" (PhD. Diss., University of Western Ontario, 1973). Cartwright gives a table comparing the soils of the five counties east of Ottawa (Russell, Prescott, Stormont, Dundas and Glengarry) to those of York County and Oxford County. Overall the southwestern Ontario counties have greater amounts of rich arable soil and much less sand and gravelly soil. The comparison is brought home in his
} 
development and of agriculture within the rural Journal's target market. Simply put, the Valley is diverse geologically but also, and most importantly for defining an audience, economically and demographically. ${ }^{14}$

Broadly speaking the Ottawa Valley is made up of three soil regions whose effects were augmented by differences in distance to agricultural markets. On the south (Ontario) side of the river Renfrew County marks the beginnings of the Canadian or Precambrian Shield. Here there is thin soil and rock with pockets of arable land. On the north side of the Ottawa River in Pontiac County, Quebec Euro-settlers farmed the siltclay terraces along the long river valleys penetrating into the pre-Cambrian shield of the Gatineau hills while dealing with a shortened growing season. The area east of Renfrew County is an extension of the St. Lawrence Lowlands with relatively flat land which does not drain well. Here there is a mix of soils from stony loam in Stormont, Dundas and Glengarry counties to clay plains from Carleton County to Prescott County broken by a belt of sand-and-silt soil. As well there are bogs with the Mer Bleue in Carleton and Russell Counties and the Alfred Bog in Prescott County covering thousands of acres. ${ }^{15}$ The result in 1901 was differences in the kind of farming between the Valley's subregions as seen in choices of crops and livestock (see Appendix D).

That the Valley was not one agricultural region is visible in the difference between Renfrew County farmers growing wheat more extensively than elsewhere while Prescott and Glengarry County farmers had the highest proportions of land devoted to oats and hay. These last two were cash crops when sold in the city to feed the urban

table comparing the cost of farm land in 1881; first class Oxford land cost from a third more to double the cost of land in the five counties. See pp. 201-2.

${ }^{14}$ The following synthesis is taken from Cartwright's dissertation chapter on the physical environment of the Ottawa Valley combined with county aggregate data from Fourth Census of Canada, 1901.

${ }^{15}$ Cartwright, "French Canadian Colonization," 190-6. 
working horse. As well, an eastern switch into more extensive dairying is visible in the greater proportion of land devoted to growing corn (an ensilage crop enabling winter dairying), the increasing proportion of milch cows in the range of livestock kept by Prescott and Glengarry farmers (whereas in Renfrew County more sheep were raised than cows) and in the number of cheese factories in those counties compared to either Renfrew County or the Pontiac.

Agriculture does not constitute the only area of regional difference within the Ottawa Valley but the demographic differences other than ethnicity are harder to track. The majority of Euro-settlers in all counties were either British-American or FrenchCanadian but in 1901 French-speaking communities dominated in Prescott County to an extent not true of the other three Counties (although the linguistic line meandered across counties leaving significant French and English communities intertwined but separate throughout the region). Beyond these two groups, the Indigenous communities of the Ottawa Valley, the Anishinaabe, were centred at Golden Lake in Renfrew County and at Maniwaki in Pontiac County and there was a fourth group of late-nineteenth-century immigrants from Poland and Germany. By 1901 the latter formed a significant minority in Renfrew County. It is more difficult to establish differences in agricultural prosperity between the Counties and, even more so, between farmers within a county. There may have been a growing class of farmers who chose not to buy farms or could not afford to buy farms in the more developed areas given there were 145 tenant farmers in Prescott Co and 296 in Glengarry County versus 81 in Pontiac County and 131 in Renfrew County. However, reasons for tenancy are not always economic. ${ }^{16}$ Size of acreage might

\footnotetext{
${ }^{16}$ cf. Catharine A. Wilson, Tenants in Time: Family Strategies, Land and Liberalism in Upper Canada, 1799-1871 (Montreal: McGill-Queen’s University Press, 2009).
} 
be a better indicator although the larger proportion of farms sized at a hundred acres and more in Renfrew and Pontiac Counties may be a response to the greater proportion of poor land mixed with at best pockets of good farm land.

Glenn Lockwood makes a claim that economically the Ottawa Valley below Petawawa should be considered two regions based on a difference created in the early years of European settlement. Due to generous grants of land to non-resident United Empire Loyalists in Prescott, Russell and Carleton Counties, the post-Napoleonic War government subsidized British immigrant communities were concentrated in townships west of Ottawa. Settlement happened sporadically in the eastern parts of Carleton County and in Russell and Prescott Counties with concentrated population growth beginning relatively late. The result was that in the 1850 s, at the start of Canada's railway age, the population of the Ottawa Valley was densest west of Ottawa. As railway companies built their lines to ship lumber products from the upper Valley they sought to capitalize on the density of population centres in Lanark County, in the process spurring industrial development there. When the railways did come to east Carleton, Russell and Prescott in the 1880s, industrialization of south-western and central Ontario had advanced to the point that the railways carried manufactured goods into these sections stifling those artisanal industries that had developed. By1901 the result of these different development trajectories is visible in a relatively industrialized western Ottawa Valley with a number of small mill towns and an agricultural east with a few administrative and service towns (excepting the lumber mill towns of Rockland in Russell County and Hawkesbury in Prescott County which used the river to transport their products out of the region). ${ }^{17}$

Despite this divide the countryside of productivity addressed in the pamphlet and

\footnotetext{
${ }^{17}$ Glenn J. Lockwood, “The Pattern of Settlement in Eastern Ontario,” Families 30, no. 4 (1991): 256-7.
} 
in the Ottawa Valley Journal is almost totally agricultural as was made explicit with the newspaper's 1917 name change to the Ottawa Farm Journal. Beyond a general focus on agriculture, dairying was the agricultural activity of particular note. While there were articles on field crops and on caring for swine, for example, my count found that the Ottawa Valley Journal published over one thousand articles related to dairying in the years between 1899 and 1917. It was agriculture which made the rural Journal rural such that, while the daily Journal reported on mining and lumbering prices as part of its regular stocks and markets columns, the rural Journal's market news was solely about agricultural commodities. In effect the rural Journal erased from its frame nonagricultural rural economic activities. One would not suspect from its pages that half of the Lanark County labour force worked in the woolen mills of Arnprior or that $80 \%$ of Prescott County's labour force worked in Hawkesbury's lumber mills. ${ }^{18}$ These Ottawa Valley residents were not visible in the newspaper except when the occasional local correspondent reported on the spring return of shantymen to the mills.

Overall, the rural Journal's target market did not reflect the full diversity of the rural Ottawa Valley, for the names found writing to the newspaper were those of Britishorigin settlers. French Canadians appeared only in the persons of community leaders who occasionally wrote to the editor or, in Prescott and Russell Counties and in Quebec, were given space on meeting podiums. Nor did the rural Journal's content reflect the economic diversity of the Valley. Yet I accept agricultural issues as my study's content despite the reality of diversity in the newspaper's claimed market area and despite the New Rural History's argument that rural history is more than agricultural history. ${ }^{19}$ While I agree

\footnotetext{
${ }^{18}$ Fifth Census of Canada, 1911, Vol. 3, Table 12.

${ }^{19}$ In 1973 Robert Swierenga laid out the need for a New Rural History that went beyond frontier,
} 
with this argument, an agricultural focus reflects the rural Journal and its view of its readers' interests.

After the First World War the Ottawa Farm Journal sales pamphlet targeted a market beyond the Ottawa Valley when it compared its circulation in 1919/1920 with those of its competitors in the seventeen counties it described as "Eastern Ontario" (see map 2, Chapter 4). This second market excluded West Quebec while listing all the southern Ontario counties east of Oshawa-Whitby. This reflects the Journal's interest in becoming a farm journal, as seen in its 1917 name change. As well, going west targetted more prosperous agriculturists than could be found along the Ottawa River. It also presented the Journal with a greater concentration of English-language readers than in the Ontario counties east and south of Ottawa or in West Quebec.

After geography there is the question of periodization. The Ottawa Farm Journal sales pamphlet and its claimed achievements on behalf of farmers form the main parameters of the study. Five of the eleven achievements took place between 1900 and 1903 and were the initiatives of Herbert Cowan who had just become the newspaper's first dedicated rural editor. Then in 1903 he moved on, leaving Robert Faith as his successor. At first Faith carried on Cowan's initiatives until 1905 when he became an organizer for farmers' rights. The pamphlet list finished with initiatives focused on highway building from the First World War era. Thus the first two decades of the

agricultural and technology histories to the social and cultural history of the countryside: "Towards The 'New Rural History': A Review Essay," Historical Methods Newsletter 6, no 3 (June 1973): 111- 22. See also Swierenga, "Theoretical Perspectives on the New Rural History from Environmentalism to Modernism," Agricultural History 56, no. 3 (July 1982): 495-503; Hal S. Barron, "Rediscovering the Majority: The New Rural History of the Nineteenth-Century North," Historical Methods 19, no. 1 (Fall 1986): 141-52. For a British view of a similar determination to expand the boundaries of rural history see Jeremy Burchardt, Paradise Lost: Rural Idyll and Social Change in England since 1800 (London: I.B. Tauris, 2002), 2-3, passim and "Agricultural History, Rural History, or Countryside History," The Historical Journal 50, no. 2 (June 2007): 465-81. 
twentieth century constitute the period of interest for this study. These were the years when the rural Journal was active as a news-maker or (after 1912) at least claimed to be active. (See Appendix B for a time line of events). ${ }^{20}$

Prior to the pamphlet events, that is from 1887 to 1899 , the semi-weekly was almost in its entirety a reordered copy of the daily. I comment on it to the extent that it gives context to the changes introduced by Cowan and Faith as the first two rural editors. I have also included for context the period after the First World War up to 1925 to highlight that, despite the sales pamphlet's claims of activism in this period, the newspaper became increasingly sedate and non-controversial. I believe that the post-1912 claims were made to show that the rural Journal was still the farmer's champion irrespective of name change or an increased emphasis on didactic material.

This raises a question as to the nature of the newspaper's interest in rural issues at a time when farm politics dominated public discussion. The federal wartime conscription debate was followed provincially by the election of the United Farmers of Ontario (U.F.O.) government in 1919 and its downfall in 1923. The early 1920s was also a time of increasing pressure on the farm and rural press from the big city dailies. Rural Mail Delivery had begun in 1908 in the Toronto-Hamilton area and spread throughout the province over the next decade. This allowed the city dailies to be delivered directly to farm families, potentially reducing their interest in reading the news only twice a week when they picked up their mail at the local post office — or even less often, if delayed going into the village. Yet the Ottawa Farm Journal sailed on through the interwar years and the Second World War. There is no survey data to indicate what kept the rural

\footnotetext{
${ }^{20}$ As will be explored in the chapters which follow, the pamphlet achievements after 1912 are dubious claims with some being urban-driven activities and others consisting of commentary rather than action. Nevertheless they are worth studying as evidence of what the newspaper thought rural subscribers wanted.
} 
Journal circulation up in these years. I can only speculate that it kept going due to the lack of a competitor providing a cheap ( $\$ 1.50$ a year) mix of Ottawa and agricultural news and, perhaps, the farmers' loyalty to a newspaper which had indeed made an effort to be a friend to their interests.

Finally, the pamphlet frames my study by pointing to a potential comparison publication from among the four it called "the best and most widely read farm and home publications": the (Montreal) Weekly Star, The Farmer's Advocate, Farm and Dairy and Canadian Countryman. The Weekly Star was the most similar to the Ottawa Valley Journal in substance and style but the rural Journal was claiming to be more than just a hybrid news- and farm-journal. The Advocate is most comparable to the rural Journal in its claim to be a champion for the farmer. Although the advocacy of the Farmer's Advocate became less marked after the death of its founder William Weld in 1891, it remained part of its image as well as its name. ${ }^{21}$

\section{Methodology}

I began by asking whether, and how, the rural Journal delivered what rural residents were looking for in a newspaper. In a sense the question can be answered by the number of farm families willing to send in a dollar each year to pay for a subscription. This positive reader response at least determined whether the rural Journal was a business success for the publisher. The rural editors, however, aimed for more in the first decade of the twentieth century. They wanted, in the spirit of the New Journalism of the late nineteenth century, to change society. Chapters 6 through 8 take a close look at the

\footnotetext{
${ }^{21}$ The rural Journal can be viewed at the main library of Agriculture Canada and (with gaps) at Library and Archives Canada. The Farmer's Advocate is most complete at the University of Guelph and available with gaps at the Agriculture Canada library and the Canada Science and Technology Museum Corporation library.
} 
editors' activism but first I need to examine the newspaper as a business with a focus on the relationship between the rural Journal and its urban parent. I can then consider the level of the editors' independence in launching their campaigns. Digging into the editors' backgrounds also allows an assessment of their rurality and from this their likely understanding of rural issues and their credibility with readers on those issues.

I started by identifying as many of the rural Journal's editors and columnists as possible, by reading the newspaper and searching the Journal's business records and the digitized Might's Ottawa Directory for 1899 and $1909 .^{22}$ I then built profiles (both personal and family) for editorial staff, using the manuscript census, city directories, newspaper obituaries and other genealogical sources. As well, I looked at the personal and business records kept by the Journal's publishers (now split between Library and Archives Canada and the City of Ottawa Archives) for the scraps of personnel records and management information they contained.

The second part of the study is about the newspaper itself and its readers. The focus here is on the rural Journal as event creator and as popularizer of ideas. I digitized from microfilm each issue published over the newspaper's first thirty-eight years. ${ }^{23}$ Reading the headlines while digitizing gave me a sense of how the newspaper was structured (for example, where the editorial page with the masthead was placed, the nature of the first page news matter, placement of agricultural material). I then read each

\footnotetext{
${ }^{22}$ Using the search term "Journal" I found 21 names in 1899 and 35 in 1909 of individuals who were white collar employees of the Journal Company (i.e., excluding machinists, compositors and linotype operators, etc.). Only one person in 1899 (Herbert Cowan) and three in 1909 (Robert Faith, Thomas Swift and Kate Whelan) specified they worked for the rural Journal.

${ }^{23}$ I also kept an excel spreadsheet of the issues digitized which allowed me to determine that the Agriculture Canada collection had only a very few missing, torn or illegible issues, making its collection almost complete. I had initially thought of digitizing to give OCR capability but found the quality of the original was too poor to result in good search results. As well, it took so long to do the digitization on my first try that it was not feasible to continue. As a result, all references to digitization are to the simplest digitization process without the OCR function.
} 
issue and created an index of rural and agricultural items. This was not a quantified effort involving scientific coding and analysis. Rather I structured my reading around sixty-four subject categories which I developed in my initial scan while digitizing. Examples of these categories are: advertising aimed at farmers, agricultural societies/fairs, cheese board news, children (sub-divided into boy scouts, chores, entertainment), country schools, the Commission of Conservation, country merchants, country/city interactions, dairying (sub-divided into thirty-two sub-categories), the farm as a place (for example, the house, the farm yard), farmer activism, the Journal's self-advertising, the Journal's activist campaigns, livestock, local government, harvester expeditions, roads, technology, and women (differentiating items targeting rural women from more general items). For my planned comparison with the Farmer's Advocate, I used the same general categories, skimming the microfilm copies of the Eastern edition of the Advocate for the years 1900 to 1920 , reading in full articles on those same subjects. ${ }^{24}$

While care must be taken in applying modern communication theory and terms to an early-twentieth century country edition, some structure is required beyond straight narrative. Thus, even though the communications studies of Verica Rupar and John Budarick takes us well beyond the rural Journal both temporally and geographically, they do indicate the potential for tracing hegemonic ideas through how the press creates events. ${ }^{25}$ This starts with the identification of a series of actions as an "event" (event creation or gatekeeping), moving to naming the acceptable issues for debate (agenda

\footnotetext{
${ }^{24}$ I had earlier identified topics in Edwinna Von Baeyer's index which seemed to have garnered significant attention in the Farmer's Advocate and found they were much the same as what I then found in the rural Journal; Ontario Rural Society 1867-1930: A Thematic Index of Selected Ontario Agricultural Periodicals. Compiled by Edwinna von Baeyer (Ottawa: Bhakti Press, 1908).

${ }^{25}$ John Budarick, "Media Narrative and Social Events: The Story of the Redfern Riot," Journal of Communication Inquiry 35, 1 (2011): 37-52; Verica Rupar, "Newspapers' Production of Common Sense: The 'Greenie Madness' or Why Should We Read Editorials," Journalism 8, 5 (October 2007): 591-610.
} 
setting), and ending with the determination that the "event" has been resolved and can be dismissed from the gaze of the press and thereby of the public. In studying the rural Journal as an event creator, I reread items specific to the campaigns and related material, for example, reading carefully every item indexed for the cheese campaign and skimming general articles on cheese factories. I specifically looked for two things: first, how the Journal defined and then developed an event (its reporting of actions taken by itself and others), and second, how it presented the event in terms of rhetoric (its claims of an event's meaning and importance, the analogies and adjectives used in the text). For items of concern which were not related to the pamphlet campaigns, for example rural women, I skimmed a sampling of every tenth indexed item from 1900 to 1920 plus a few which I had highlighted when indexing due to something unusual catching my attention (for example, the, admittedly very few, comments made by the household editor on rural women's lives). Budarick also points to the importance of identifying sources in differentiating between mainstream newspapers and niche newspapers which, in his study, presented a different understanding of the events. In reading the Journal's campaigns, I paid attention to how the editors identified sources as credible (Chapter 5).

I also planned a high-level, thematic content analysis of the rural Journal in order to determine the proportion of rural and agricultural content within the paper. I did this for the years 1888 (the first full year of publication of the Journal as a semi-weekly aimed at rural residents), 1898 (the year the publisher claimed it had increased rural features), 1900 (the first full year as the Ottawa Valley Journal), 1907 (to determine if "rurality" was growing over the decade), and 1925 (the end year of the study). To understand the differences and similarities between the urban and the rural Journal I 
compared four issues (one issue from each season) of the rural Journal with the daily Journal in each of the sample years. This involved a search in the three issues immediately prior to the rural issue for common items. (See Appendix C for a fuller review of the Content Analysis work).

Reception analysis is important to understanding how rural residents read the rural Journal. Mary Vipond encountered the problem of knowing what pre-survey audiences thought in her study of early radio broadcasting in Canada, Listening In. She states in a footnote that in the period studied there were no "scientifically grounded listener surveys" undertaken in Canada although there were two geographically limited studies in 1930 (Toronto in one case and Saskatchewan in the other) which she considers comparable. ${ }^{26}$ Both subscriptions (sales) and letters to the editor are a potentially useful substitute. The newspaper directories give circulation numbers which were largely puffery at first but with push-back from the advertisers became steadily more accurate over the first decade of the twentieth century. Letters to the editor were an integral part of the Farmer's Advocate and, to a lesser degree, were also published in the Journal. John Fry used letters to the editor to good effect in his studies of the farm press and rural change. ${ }^{27}$ I included readers' letters in indexing the rural Journal and highlighted those pertaining to a campaign. As well, both Cowan and Faith published comments, both

\footnotetext{
${ }^{26}$ Mary Vipond, Listening In: The First Decade of Canadian Broadcasting, 1922-1932 (Montreal: McGillQueen's University Press, 1992):101-2; 314-5 fns. 129 and 133.

${ }^{27}$ John J. Fry, The Farm Press, Reform, and Rural Change, 1895-1920 (New York: Routledge, 2012). Letters are an uncertain source. One study indicates that over the nineteenth century editor-written material displaced reader contributions; William D. Jones, "Going into Print: Published Immigrant Letters, Webs of Personal Relations, and the Emergence of the Welsh Public Sphere," in Letters across Borders: The Epistolary Practices of International Migrants ed. Bruce S. Elliott, David A. Gerber and Suzanne M. Sinke (New York: Palgrave Macmillan, 2006), 175-99. In addition, many of the Journal letters were written to acknowledge receipt of a premium and followed a pattern of what one historian called "bowing," or the use of ritualistic phrases of courtesy to structure a letter; Anna D. Jaroszyńska-Kirchmann, "As if at a Public Meeting: Polish-American Readers, Writers, and Editors of Ameryka-Echo, 1922-1969," in Letters across Borders, 200-220.
} 
positive and negative, from other newspapers along with letters from readers expressing a range of opinions on whatever issue was under discussion. It is unfortunate that there were not more letters (although understandable given space limits) but those printed are helpful and, where there were no letters, the resulting silence could still speak.

\section{Organization}

Chapters 2 and 3 work together to provide the historiographical and theoretical context for a study which straddles the history of a newspaper and the history of rural/agricultural issues in the first two decades of the twentieth century. In Chapter 2, I seek to situate the rural Journal within journalism history. The country editions of city dailies have yet to be the object of sustained academic study which has tended to focus either on the large dailies as media of mass communication or on the small weeklies and niche papers as representative of special interests, whether local, ethnic or class. The history of the 1880s and 1890s New Journalism is central here for the rural Journal did more than preach about being progressive. ${ }^{28}$ Under Cowan it plunged into making headlines with campaigns which would make visible for rural residents "progressive" ideas about roads and agricultural fairs. Then Faith made headlines fighting those in the agricultural industry he said were profiting off the backs of ordinary farmers.

In Chapter 3, I look at the reform culture within which the rural Journal sought to be an activist and a newsmaker. In the first two decades of the twentieth century citybased reformers were concerned about what they saw as moral, demographic and productive degeneration in the countryside. At the same time federal and provincial

\footnotetext{
${ }^{28}$ This "New Journalism" predates the 1950s and 1960s New Journalism (characterized by the subjective and literary journalism of Tom Wolfe, Truman Capote and Hunter S. Thompson). The nineteenth-century version was characterized by the activist journalism of Joseph Pulitzer and Randolph Hearst.
} 
governments were emphasizing scientific knowledge and expertise as a means to increase productivity. This chapter will relate these threads to the historiography of agrarian reform as well as discuss what was meant by modern and by knowledge.

Chapters 4 and 5 look at the rural Journal itself as an object of study. Chapter 4 focuses on the history, personnel and content of the rural semi-weekly in order to understand its relationship with its urban parent. The focus is on the business of running a semi-weekly as well as on the degree of independence enjoyed by the rural editors. The key question is how Cowan as the first rural editor turned a newspaper he said had been losing subscribers into one with a loyal rural base. Chapter 5 looks at the limits to the rural newspaper's activism and to its application of the methods of urban New Journalism to agricultural issues.

I began my discussion of activism with the different approaches taken by the editors in appealing to authority versus general principles, particularly to fairness. I then look at the limits of activism as both editors intervened on male-dominated issues related to production and marketing but not on the political/economic issues of tariffs and farm labour. The rural Journal was concerned with the business of agriculture, and defined that business as male. On the controversial issues of politics and economics, including conscription and women's suffrage, both Cowan and Faith took the easy road of saying nothing original. Each in his turn simply reprinted the news and commentary written for the daily. I suggest that this is attributable to the rural Journal's position as the scion of an Independent (but still) Conservative daily newspaper. The fundamentally conservative nature of its views on rural society made the newspaper the farmer's friend but not the farm labourer's. The newspaper also showed an intrinsic conservatism in its lack of 
engagement with the Country Life reformers and their issues of community and family.

This period is associated with social issues of uplift, that is, of improving society. In the cities, Social Gospel reformers sought to uplift the poor as well as Canadianizing immigrants. Some reformers turned their eyes to the countryside as yet another field of social and economic missionary work. These Country Life reformers were an unorganized and rather motley group of government officials, college instructors and clergy. Government officials wished to turn farmers into self-regulating productive businessmen who would contribute to the national economy. Social reformers saw modern science and technology as a means to increasing prosperity and leisure and thereby rebuilding what they believed to be frayed social ties. They expected that this would maintain a virtuous rural population as moral ballast for the nation. The rural Journal responded with articles, usually written by Ontario Agricultural College experts, on such subjects as how to make the farm house a more pleasant place to raise a family and how to keep the farm yard a sanitary place for both the farm family and for the city family that drank the milk produced there. But it did not apply the New Journalism activist campaigns to these subjects nor were they mentioned in the 1919/1920 sales pamphlet, with one exception. The pamphlet spun a series of annual editorials into a claim of having initiated cemetery beautification in Eastern Ontario - a claim which is indirectly linked to the community beautification project of the Country Life Movement. I examine this claim and what was actually done as part of Chapter 5's consideration of the limits to the Journal's activism.

Continuing with the Ottawa Farm Journal sales pamphlet, Chapters 6, 7 and 8 each look at a subset of the production- and distribution-focused achievements along with 
closely-allied events found in the pages of the rural Journal in the period under study. I compare the words and actions of the urban-rural Journal with those of the thoroughly rural Farmer's Advocate in these areas.

Chapter 6 looks at how the newspaper positioned the farmer as a self-disciplined student of modern agriculture by examining the following achievements:

- $\quad$ achievement 1 orchard and dairy meetings;

- $\quad$ achievement 2 the expert judge system, fair circuits and trophies for the livestock exhibits;

- $\quad$ achievement 4 livestock judging classes; and

- $\quad$ achievement 6 seed grain fairs.

These were the initiatives of Herbert Cowan, then a young, energetic editor still in his early twenties. Cowan was not an iconoclast, however. He worked closely with the agricultural establishment in identifying issues and potential solutions. For the government officials with whom he worked, the major issue was encouraging farm men to produce more and to produce it more efficiently.

These initiatives demonstrate the tensions between the practical knowledge which had given farm men the security of being in control of their work and the new scientific knowledge being taught by government and college agricultural experts. I argue that underlying these campaigns was a concept of knowledge as trained and directed visual observation. At the same time, even as this period marks the start of a shift to the collegeeducated expert, the rural Journal continued to valorize experience, recommending experts to its readers based on their credentials as practical men.

Chapter 7 considers the achievements which relate to farmers' roles as taxpayers 
and road-builders:

- $\quad$ achievement 7 formation of ... the Farmers' [Municipal] Rights Association;

- $\quad$ achievement 3 model road building;

- achievement 10 promotion of the Ottawa-Prescott highway; and

- $\quad$ achievement 11 the rural portion of the 1917 Dominion Good Roads Congress.

In this Chapter Cowan's road work (achievement 3) is contrasted with the post-1912 activities (achievements 10 and 11). Achievement 3 had consisted of two summers of intense activity as Cowan brought together road machinery, railway transportation, government experts and county and township officials to build stretches of model stonegravel roads in townships across the Ottawa Valley. He aimed all this effort at rural residents who came out in their hundreds to see in action the great machines he had conjured out of a Hamilton, Ontario company. The achievement was a success as spectacle. It was less so in promoting good roads. Most of the farm families seem to have gone home unconvinced.

The other two achievements relating to roads - the promotion of a new highway between Prescott and Ottawa and inserting a morning's worth of speeches into the 1917 Good Roads Congress — share two problems. First, their genesis and their potential benefits largely belonged to the city, and second, there is no evidence in the newspaper that the rural Journal had anything to do with either one. Their inclusion supports an argument that the Journal felt it had to demonstrate to country residents that the Ottawa Farm Journal held to the same activist convictions as when it was titled the Ottawa 


\section{Valley Journal.}

Achievement 7—-the Municipal Rights Association—was the work of Cowan's successor Robert Faith. Both the roads and tax issues were informed by the underlying idea that labour determined both ownership and value. Cowan's belief that a demonstration of technology would modernize farm families' view of local roads missed the importance of the labour theory of value in constructing farmers' sense of ownership. The disconnect is visible in this campaign. Government experts saw roads as a public resource that, if brought firmly under centralized control, would deliver pragmatic benefits in the flow of goods to market and encouragement of tourism. The farmers saw the roads they built and maintained as the product of their labour and therefore it was their prerogative to decide how to manage and use those roads. By contrast to Cowan's work, Faith's property tax campaign and his Farmers' Municipal Rights Association grew out of the rural link between ownership and labour. He agreed with the farmers that the farm improvements their labour had made should be exempt from taxation.

There was, nonetheless, a contradiction within the rural idea of labour and its connected idea of producerism with respect to who had the right to the value produced. Both Faith and his readers only spoke of the farmer's labour, ignoring the daily labour of the farm family, that is, the labour of women and children. And certainly the farmers never suggested that hired farm labourers had any claim to the value of the farm products beyond their (sometimes meager) wages. Neither the farm men writing to the editor nor the editor himself commented on this contradiction in the farmers' rhetoric of the value of labour and of producerism. It seems all were blind to the farmers' intertwined roles as capitalist-owner and as worker-producer. They all accepted as "natural" the construction 
of the farmer as the moral and virtuous producer.

Chapter 8 looks at the farmer as a producer marketing within a global capitalist system through the last two achievements to be studied:

- achievement 7 formation of ... Farmers' Produce Association; and

- achievement 8 the farmer deputation seeking federal protection for producers.

With these two, Robert Faith organized farmers to challenge the international cheese marketing system by attacking the Montreal middlemen and their local agents. Some dairy experts recognized at the time and in the years after that the cheese market was structured against the producer and that Cheese Boards had failed as information-sharing price mechanisms. At the time, however, federal dairy department officials chose to focus on encouraging more efficient production in order to improve the quality of the export product. They ignored structural problems in marketing.

Many Eastern Ontario farmers were ready to follow Faith in his attack on the middlemen of the cheese industry. The farmers' continued adherence to the Labour Theory of Value and producerism was expressed in their conviction that the market system did not reflect their role as the fundamental creator of all wealth. Despite the radical tone of Faith's producerist rhetoric, he did not suggest that capitalist structures or profit distribution were part of the problem of being a local producer in a global market.

The concluding chapter considers the initiatives as a whole to summarize how a news-making urban-rural newspaper combined being modern and being agrarian. Cowan's interventions were based on hegemonic ideas of modernity as expressed by government experts and the leaders of the dairy industry. Faith countered hegemony with the rhetoric of the "square deal" and led farmers in confronting authority through mass 
meetings and petitions but his solutions, although they evolved with each rebuff, were intended to simply make the Montreal middlemen follow rules which protected the producer, specifically by inspecting and valuing the cheese at the factory and then paying for it as soon as the factory freighted the cheese to Montreal. Neither Faith nor the farmers suggested alternatives to the market structures.

I asked whether this city-country newspaper could deliver a product of interest to the farmers. In other words, was it a success? The conclusion will summarize the Journal's ability to deliver what its owners wanted from it as a business in terms of revenue and subscriptions. It will also explain why it was less successful in delivering what the two rural editors were hoping for in making the rural Journal a vehicle of New Journalism reform. Nevertheless, I argue that, before the United Farmers of Ontario became a political force during the First World War, there was for a few years a voice in the Ottawa Valley calling for change and advocating for the interests of farmers. 


\section{Chapter 2 - Historiography of the Press: Mass Communications and Niche Conversations}

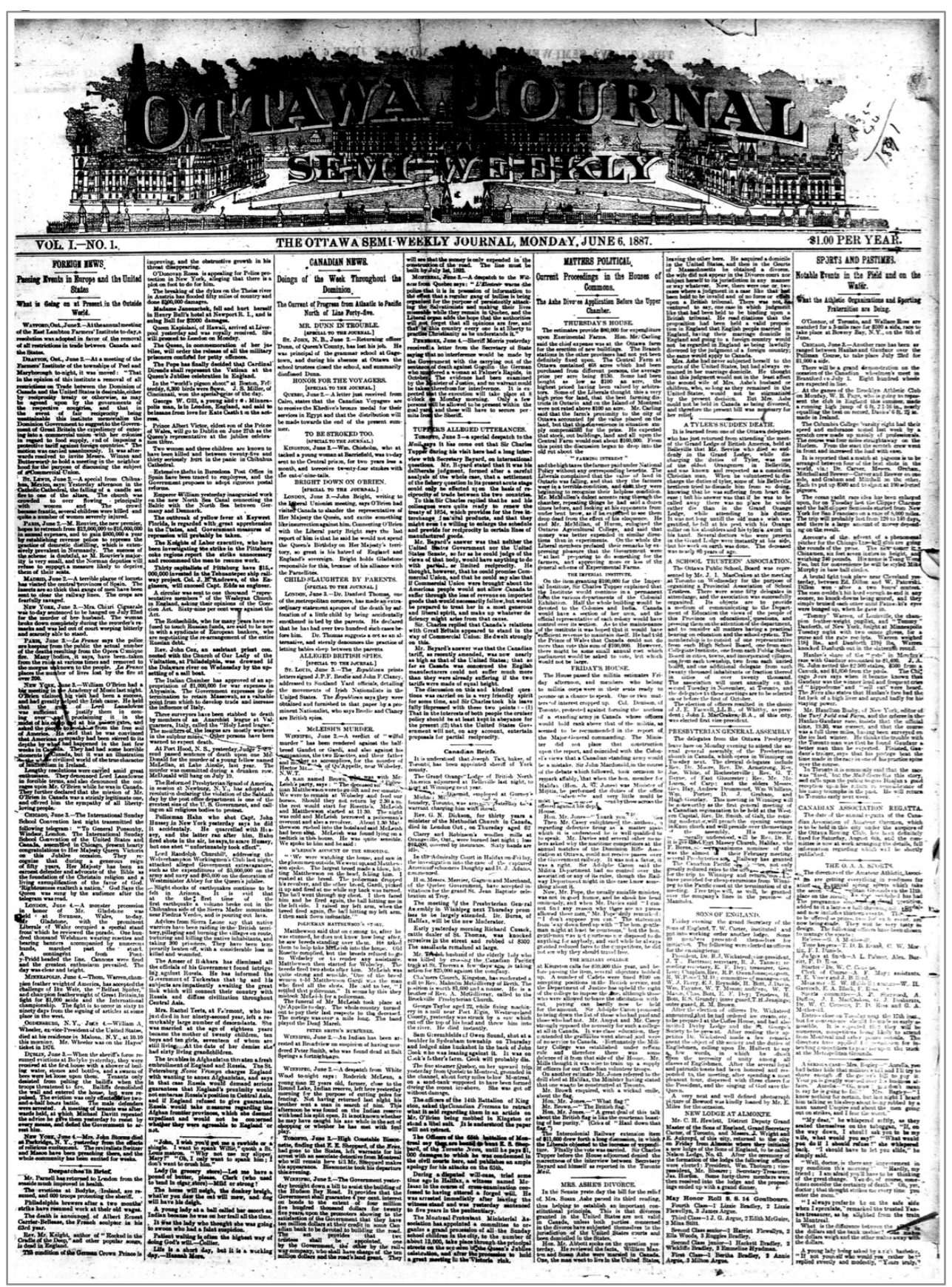

Fig. 2.1. Front page, Ottawa Semi-Weekly Journal, June 6, 1887.

The first issue of the Ottawa Journal's rural edition, with its image of the Parliament Buildings and its content taken from the urban paper, was not particularly rural. Yet it would later claim to have always been active in the interests of progressive agriculture. In this chapter I look at the historiography of the press as a context for understanding the rural Journal's self-making as a rural activist in the style of the New Journalism of the 1880s and 1890s. 


\section{Introduction}

In this chapter I look at the historiography of the press in order to contextualize the Ottawa Valley Journal as a newspaper at the beginning of the twentieth century. A striking characteristic of journalism history is that it is a shared field in which communications scholars, sociologists, cultural theorists, ex-journalists and even a few historians meet and, it sometimes seems, fail to understand each other. The result is a historiography which ranges from institutional studies of media ownership, to technology studies, to studies of mass media in society, and to more recent works exploring media as cultural construction. But almost all these histories are about the metropolitan daily newspaper with only a few commenting on the specialized communications of small niche newspapers. As well, some scholars caution that the historian's use of newspapers as a source ignores the rich history found studying newspapers as historical actors. And so this study goes somewhat against the grain of journalism history. My interest is in a very niche form of communication indeed - the rural edition of a city newspaper, the Ottawa Journal, between 1899 and 1920. Specifically I am concerned with how the rural Journal shaped itself and attempted to reshape its readers. In Chapters 6 through 8 I will be studying the rural Journal's activism in the first decade of the twentieth century.

The newspaper had two names during this period reflecting two different views of its mission. From 1899 to 1917 it was the Ottawa Valley Journal with a claim to represent the rural people of the Valley. From 1917 on, it was the Ottawa Farm Journal claiming to be a source of agricultural information. It advertised these claims in a sales pamphlet in 1919 or 1920 which described campaigns it had led in the pursuit of agricultural progress. Studying how the newspaper acted out these claims requires an 
understanding of the New Journalism or advocacy journalism of the late nineteenth century. As a result, I focus this historiographical chapter on newspaper history up to 1900. I begin, however, with the major critiques of journalism history including the problem of the production of meaning, and reader reception. I then consider the historiography of the nineteenth- and early-twentieth-century newspapers, first looking at the metropolitan newspaper and then the niche newspapers of the country weeklies and the farm press. Histories of the metropolitan newspapers have largely focused on two narratives: first, a struggle for freedom of the press and the liberal public sphere, and second, commercialization and the popular press. Country weeklies have been presented as the bastion of the local while farm journals have been studied as an agricultural source and more recently as an actor. The last aspect to be discussed is the penetration of the city into the countryside via the weekly editions of the city dailies.

\section{Critiquing Journalism History}

William Huntzicker states that there are two types of journalism histories, romantic histories and development histories. ${ }^{1}$ Particularly where the writer is a retired journalist, the romantic history is often the story of a reporter's or an editor's life, sometimes with the theme that there were giants in those days and sometimes simply telling tales. ${ }^{2}$ In the development histories the scholar traces the history of the "true newspaper" as the modern newspaper was called in Edwin Emery's influential textbook The Press and America. These development histories fit cultural theorist James W.

\footnotetext{
${ }^{1}$ William E. Huntzicker, The Popular Press, 1833-1865 (Westport, Conn.: Greenwood Press, 1999), 17981.

2 Three Canadian examples are Charles A. Bowman, Ottawa Editor (Sidney, B.C.: Gray's Publishing, 1966); Grattan O’Leary, Recollections of People, Press, and Politics (Toronto: Macmillan, 1977); and Canadian Newspapers: The Inside Story, ed. Walter Stewart (Edmonton, Hurtig Publishers, 1980).
} 
Carey's characterization of pre-1974 journalism histories as whiggish. ${ }^{3}$ In his 1962

second edition, Emery cited a 1930 article in Journalism Quarterly for seven

characteristics of a "true newspaper." The 2000 edition referred without citation to three

"twentieth-century standards" for identifying such a beast. Both the earlier criteria as well

as today's require 1) periodic publishing (daily or weekly), 2) general interest content

(thereby eliminating farm journals as well as business and religious newspapers), and 3)

timely news content (leaving a question of what is timely). ${ }^{4}$ In general, it appears that the

rural Journal can be considered a newspaper according to this old model but how should

its study be approached? I use a combination of a thematic content analysis (described in

Appendix C) and a close reading of each issue within a pre-defined categorization of

rural issues. The focus in this thematic reading is first on the text as it was written.

\section{The Text as Written}

Hazel Dicken-Garcia is a mass communication scholar who takes a more exacting view than Huntzicker in dividing the universe of journalism histories. She identifies three kinds of histories: descriptive (to which category she assigns the majority), the explanatory, and the exploratory in which communication scholars build theoretical models out of historical phenomena and events. Her purpose in writing on communication history is to foster the last of these as she considered such histories did

\footnotetext{
3 James W. Carey, “The Problem of Journalism History,” in The American Journalism History Reader: Critical and Primary Texts ed. Bonnie Brennen and Hanno Hardt (New York: Routledge, 2011), 23 (repr., from Journalism History, 1974). Carey judged whiggish history to be a valid model but one which no longer gave insight. John D. Stevens and Hazel Dicken-Garcia, Communication History (Beverly Hills: Sage Publications, 1980), 8, 33, 40-3 appear to agree with Carey in the preface but the text points out the blinders whiggish history places on scholars thereby inhibiting the creation of new explanatory models.

${ }^{4}$ Edwin Emery, The Press and America: An Interpretative History of Journalism, Second Edition (Eaglewood Cliffs, N.J.: Prentice-Hall, 1962), 5; Michael Emery, Edwin Emery and Nancy L. Roberts, The Press and America: An Interpretative History of Mass Media, Ninth Edition (Boston: Allyn and Bacon, 2000), 8 .
} 
not fully exist. ${ }^{5}$ This raises a question as to whether historical questions or communication models should be central to journalism history. Which side one comes down on affects what one sees as the necessary skills for writing journalism history. John Nerone, who trained as a historian, states that when historians use communication theory, they do so for self-reflexivity or as methodology but always the historical phenomenon remains central. ${ }^{6}$ Nonetheless, over the last few years there has been an increasing emphasis on journalism history, or media history more broadly, as an interdisciplinary study.

In 2006 Gene Allen and Daniel Robinson chaired a conference on Canadian media history from which they developed a book of essays, Communicating in Canada's Past. They argue that there are scholastic gains to be made in grounding media studies historically. They see this as studying media using the historian's strength in the archives coupled with the modern historian's attitude of "enlightened empiricism," i.e., building arguments on documentary evidence while recognizing that we cannot know the past as it was. In particular, situating a specific media type or example within its historical context can avoid a misapplication, or ahistorical application, of theory. While Allen and Robinson describe the dominant types of journalism histories as focused on the impact of changes in technology and institutional structures, they are interested in cultural history for teasing out the cultural webs of significance within which media operated historically. This focuses on media meaning as written and as read. ${ }^{7}$

\footnotetext{
${ }^{5}$ Stevens and Dicken-Garcia, Communication History, 16-25. Dicken-Garcia is identified as the author of this section.

${ }^{6}$ John Nerone, "Theory and History," in The American Journalism History Reader, 36-45.

${ }^{7}$ Gene Allen and Daniel J. Robinson, "Introduction: Media History as Concept and Practice," in Communicating in Canada's Past: Essays on Media History ed. Gene Allen and Daniel J. Robinson, (Toronto: University of Toronto Press, 2009), 5-10.
} 
Interdisciplinary media history promises the prevention of mis-reading or blindness to context which has been charged against some older journalism histories. William David Sloan critiques sociology-trained journalism historian Sidney Kobre's 1964 work The Yellow Press and Gilded Age Journalism as simplistic due to Kobre's belief that written history is a chronicle of dates and events. The result was that Kobre, in Sloan's assessment, did not fully understand the dynamics of late-nineteenth-century society. ${ }^{8}$ David Spencer recently produced in The Yellow Journalism a more interesting effort to relate the press to the social context of the period. Spencer organizes his chapters by historically-grounded behaviours and attitudes he identifies as characteristic of the period. For example, his chapter on the sensationalism of Yellow Journalism brings into the discussion a broader societal interest in the sensational which was the driving force behind P.T. Barnum's career. ${ }^{9}$ One can also look at the interrelationship between press and society by coming at the question through a general history where journalism is one of many factors looked at. Thus Alan Trachtenberg in The Incorporation of America focuses on broad social and cultural changes which leads him to link the spectacle of circus and sports events to the emergence of a mass audience that also purchased newspapers selling entertainment. ${ }^{10}$

The cultural approach to communication studies can be useful in my project. In

\footnotetext{
${ }^{8}$ William David Sloan, "Sidney Kobre and Sociological History," in Makers of the Media Mind: Journalism Educators and Their Ideas ed. Wm. David Sloan (New York: Routledge, 1990): 99-100; Sidney Kobre, The Yellow Press and Gilded Age Journalism (Tallahassee: Florida State University, 1964). Kobre presented the gilded age newspaper within the context of its time in his introductory chapter by touching on urbanization, industrialization, improvements in transportation and communication, an increase in middle class spending power, and rising diversity in recreation. But he ignored rising tensions around culture, class, race or ethnicity. Kobre then dropped the general context to focus on specific newspapers and their publishers with only limited reference to the social forces at work.

${ }^{9}$ David R. Spencer, The Yellow Journalism: The Press and America's Emergence as a World Power (Evanston, Illinois: Northwestern University Press, 2007).

${ }^{10}$ Alan Trachtenberg, The Incorporation of America: Culture and Society in the Gilded Age (New York: Hill and Wang, 1982), 122-3.
} 
the 1970s communications scholars began to ask how newspapers constructed contemporary reality by framing events and issues. ${ }^{11}$ As they were doing this, Carey urged that they extend their enquiry to how newspapers historically shaped consciousness. He meant by this a study of the symbolism through which people understood their world. ${ }^{12}$ Carey did not give directions on how to do this but one approach would be looking at the discourses used by newspapers to frame an issue (i.e., the packages of assumptions, arguments and semantics that actively apply a schema or view of the world even if unconsciously).

Examples of how cultural theory can open up the reading of a newspaper follow. To start, David Jones's article on the early-twentieth-century Canadian agrarian press focuses, not on questions of agrarian politics or the diffusion of agricultural science, but on the rhetoric of city danger versus country wholesomeness. ${ }^{13}$ For understanding the popular press and popular entertainment, Martin Conboy studies the commercial press of the nineteenth century within the context of British and American print culture. He finds that the commercial press succeeded in self-identifying itself as the people's press while selling a highly routinized and commercialized product. ${ }^{14}$ Kevin Barnhurst and John Nerone in The Form of the News extend rhetoric to newspaper layout (styles used in headlines, column length, use of graphics, etc) as a visual discourse in which meaning

\footnotetext{
${ }^{11}$ For example, see Gaye Tuchman, Making News: A Study in the Construction of Reality (New York: Free Press, 1978); Tuchman carried out a participant observation study of how the news was put together at a city television station and in a city newsroom to show the framing decisions which make the news.

${ }^{12}$ Carey, "The Problem of Journalism History," 26.

${ }^{13}$ David C. Jones, ““'There Is Some Power About the Land': The Western Agrarian Press And Country Life Ideology," Journal of Canadian Studies 17, no. 3 (1982): 96-108. He looks at how the Western Canadian agrarian press articulated one of the Country Life Movement's issues, the moral peril of the city to young country people who move there for work.

${ }^{14}$ Martin Conboy, The Press and Popular Culture (London: Sage Publications, 2002).
} 
was attributed to events and issues. ${ }^{15}$ Dominique Marquis uses content analysis and the rhetorical discourse of the newspaper form to explore the evolution of content in a Church-owned newspaper in Quebec. She argues that both the content and form of L'Action catholique evolved in parallel with the daily mass communication newspapers due to it being enmeshed in a "network of relationships" in the Quebec "journalistic system" of the early twentieth century. The system in Quebec included the non-Catholic newspaper competition which set the expectations for what a newspaper should look like, the Church which set content limits and readers who wanted a mix of religious news with secular news and entertainment. ${ }^{16}$

\section{The Text as Read}

I have been discussing the analysis of the text as it was written and not as it was read. Stuart Hall in his essay "Encoding/Decoding" argues that communication is not the steady flow of information suggested in Harold Lasswell's 1948 communication model of who says what to whom by which channel to what effect. Rather meaning or message is made in two separate and "determinate" processes of production and reception. ${ }^{17}$ In Hall's argument the "whom" is as much an actor as the "who." This comes out of his Cultural Studies Institute work on how television constructs events but it can be applied to newspapers. As he argues, the producer (or newspaper editor) defines a set of activities as constituting an event which is given a "preferred" or "dominant" meaning from within

\footnotetext{
${ }^{15}$ Kevin G. Barnhurst and John Nerone, The Form of the News: A History (New York: Guilford Press, 2001).

${ }^{16}$ Dominique Marquis, "The Catholic Press: A Challenge to the 'Journalism of Information' Paradigm" transl. Patricia Smart, in Communicating in Canada's Past: Essays on Media History ed. Gene Allen and Daniel J. Robinson (Toronto: University of Toronto Press, 2009), 26-31.

${ }^{17}$ Stuart Hall, "Encoding/decoding," in Culture, Media, Language: Working Papers in Cultural Studies, 1972-79, ed. Stuart Hall, Dorothy Hobson, Andrew Lowe and Paul Willis (London: Hutchinson \& Co, 1980), 128-38.
} 
preset "frameworks of knowledge." Readers then decode the text from within their frameworks of knowledge. The editor and the reader may share a framework in which case the reader will read the text as an affirmation of his or her own views. Other readers may know and even accept the dominant knowledge which framed the text but "negotiate" that meaning based on their own sense of exceptions to the dominant meaning. Yet other readers will understand but "oppose" the text with a contrary meaning based on their knowledge frameworks. ${ }^{18}$ While some later scholars pushed reader reception theory to argue that the text means whatever the reader determines, Hall assumes that there is a preferred reading of which all readers are aware. It is their response (whether positive, negative or nuanced) which can differ based on their knowledge and attitudes as developed within their cultural and social world.

David Morley worked with Stuart Hall on reader reception and meaning in the 1970s and 1980s. He brought into the equation concepts taken from cultural anthropology with a specific mention of Clifford Geertz. He rejects the notion that texts are legitimately polysemic, that is, that any meaning taken by a reader has equal validity to any other. He argues that both the text itself and the readers' cultural resources and social position direct and limit the range of readings open to them. He suggests that the "active audience" reads media in a "dialectical process," working between the original meaning and the meaning they read based on their social/cultural resources. ${ }^{19}$

Scholars of contemporary media can use surveys and other tools to generate data with which to analyze both production and reception processes. Studies of the historical audience of the radio and the cinema can use the sociological, psychological and

\footnotetext{
${ }^{18}$ Ibid., 130, 136-8.

${ }^{19}$ Huimin Jin, "British Cultural Studies, Active Audiences and the Status of Cultural Theory: An Interview with David Morley," Theory, Culture and Society 28, no. 4 (2011):130-3.
} 
advertiser audience studies which started to be carried out in 1911 in the United States. ${ }^{20}$ Unfortunately most historical newspaper texts do not come ready-made with such data. Subscription statistics can at least identify the newspapers which were successful in attracting any readership at all but care must be taken as to the veracity of those statistics and, even if true, what they were counting. We also need to be careful as to the significance of the numbers. A small readership of a niche paper may represent a larger proportion of the intended audience than the large readership of a mass communication vehicle. As well, the motives for subscribing to a newspaper may or may not represent agreement with its editorial comments. $^{21}$

It is possible to explore reader response using letters to the editor but they are anything but random samples of how readers read the original text, given that not every reader chose to write and not every letter received was published. A recent participant observation study of how four modern Portuguese newspapers selected letters to the editor identifies a complex process of gatekeeping. The editorial team in each case aimed to select letters which addressed an issue the newspaper considered newsworthy, were clearly written and interesting to read but not libelous or overly argumentative, and which together formed a balanced page of opposing opinions. They also had to be short enough

\footnotetext{
${ }^{20}$ Mary Vipond, The Mass Media in Canada (Toronto: James Lorimer \& Co., 2000), 81. For an example of how this data can be used historically see Lawrence W. Levine, "The Folklore of Industrial Society: Popular Culture and Its Audience,” American Historical Review 97, no. 5 (December 1992): 1369-99.

${ }^{21}$ In general the numbers given in the early McKim's newspaper directory were as much advertising hype as truth. When P.D. Ross became a partner in the Ottawa Evening Journal in 1887 he found that its subscription list was heavily salted with free copies (see Chapter 4). In 1901 Ayer's Newspaper Directory stated in its introduction that it asked newspapers to give a statement (with sworn statements having more weight) of the average number of newspapers sold through their subscription book, over the counter and by newsboys. The advent of the Audit Bureau of Circulations in 1914 helped to give credence to the statistics with Ayer specifying "ABC" for newspapers whose numbers had been audited. It also defined circulation as the average number of newspaper sold, excluding unsold, sample and exchange copies (N.W. Ayer and Son's Newspaper Annual and Directory, online digital.library.unt.edu/ark:/67531/metadc9271/, 1901, p. 6 and 1919, p. 8). In addition, circulation numbers do not tell us the motives for subscribing to a newspaper, motives that could include a newspaper carrying the best department store sale advertising in a city.
} 
to fit several letters onto the page. ${ }^{22}$

Opportunities to see behind a newspaper's letter page to the range of letters actually received are rare. David Paul Nord's 2001 chapter on early-twentieth-century letters to the Chicago Tribune editor which the publisher had kept gives insight into the degree to which readers were responding to the text as written. Nord identifies three categories of letters (and writers). There were letters which could not be connected to any editorial or other newspaper text, although the writers sometimes claimed to be doing so. At least two of these readers were writing from a psychiatric asylum. Of the readers whose letters did relate to something they had read, some wrote serious responses to the editorial, using it to guide their argument, whether for or against. But Nord finds that other readers used an editorial or news items as a "cue" from which they jumped to other issues of varying degrees of closeness to the original text. ${ }^{23}$ While the notion of polysemic text suggests the first set of letter writers might be of interest because they invent a completely new reading, they do not help in trying to understand the generality of readers' response to an issue as opposed to the purely idiosyncratic response. The second set of letters (from those who read the original text as written) can be analyzed within Hall's categories of reader response (affirming, negotiating, opposing). The third set, from writers who used the text to cue them to write on other issues, requires a broad view of reader response.

Anna Jaroszyńska-Kirchmann looks at a collection of over forty years of letters to the editor of a Polish-language American newspaper. Her focus is on how the letter

\footnotetext{
${ }^{22}$ Marisa Torres da Silva, "Newsroom Practices and Letters-To-The-Editor: An Analysis of Selection Criteria," Journalism Practice 6, no. 2 (2012): 250-63.

${ }^{23}$ David Paul Nord, "Reading the Newspapers: Strategies and Politics of Reader Response, Chicago, 191217," in Communities of Journalism: A History of American Newspapers and Their Readers (Urbana: University of Illinois Press, 2001).
} 
writers structured their letters and how the editor re-shaped them for print using corrections, deletions and even at time additions. How the readers understood the original text they read is not as clear. What is clear is that, as with Torres da Silva's Portuguese newspapers, the Polish letters were constructed as newspaper material through a process of editorial decision-making. ${ }^{24}$ There is a third study of letters written to a participant in a news event, rather than to an editor, and without an eye to eventual publication. John Carter Wood has studied letters connected to a closely-reported English murder trial in 1928 in which an abused wife was accused of murdering her husband. Many people, especially women, wrote to the defendant during and after the trial. The defence lawyer preserved about two hundred of these letters. Wood finds that the letter writers followed the newspaper accounts closely but interpreted what they read based on their own feelings, values and life experiences. ${ }^{25}$ Unfortunately in the Nord and Wood studies only a small portion of the original set of letters are extant and it is unknown what circumstances or choices preserved these letters and not others. As a result we have no indication for either study as to what proportion of letter-writers disengaged completely from the original text, engaged with it or used the text as a cue to expand the issue.

For this study of the Ottawa Valley (Farm) Journal, I lack surveys and direct observation studies. Yet sociologist Stephen Ellingson was able to pull useful conclusions on how newspapers constructed events in his study of debates on slavery carried out in the pages of an abolitionist newspaper and the opposing state-rights newspapers in 1836

\footnotetext{
${ }^{24}$ Anna D. Jaroszyńska-Kirchmann, "As if at a Public Meeting: Polish-American Readers, Writers, and Editors of Ameryka-Echo, 1922-1969," in Letters across Borders: The Epistolary Practices of International Migrants ed. Bruce S. Elliott, David A. Gerber and Suzanne M. Sinke (New York: Palgrave Macmillan, 2006), 200-220.

${ }^{25}$ John Carter Wood, “'Those Who Have Had Trouble Can Sympathize With You': Press Writing, Reader Responses and a Murder Trial in Interwar Britain," Journal of Social History 43, no. 2 (Winter 2009): 43963.
} 
Cincinnati, Ohio. He did so by connecting the dots between the newspaper's abolitionist articles, the editorial response in competing newspapers and the violence with which Cincinnati's citizens sought to shut down the abolitionist messaging. ${ }^{26}$ I will be comparing the Journal to a true farm newspaper, the Farmer's Advocate, but I have not found a good set of other comparative sources, for example, small town newspapers and diary entries written on the same events. I am left with the rural Journal's reprints of both positive and negative reporting in other newspapers along with the reader letters of support which it chose to publish. This is a limited source, moreover, because I do not know what proportion of total mail these letters represented. In addition, the rural Journal reported the size and enthusiasm of the audience at its three mass meetings (one on property tax assessment and two on the cheese market). Unfortunately, estimating crowd size is an imperfect art today and was even more imperfect in the past. ${ }^{27}$ In this study there are few dots to be connected. Agenda-setting is a two-way process to which readers must consent to accept the proffered agenda but there are no visible signs when an issue chosen by an editor fails to resonate. Reader resistance is evident only in silences. Even where there is a reader response the historian must be cautious not to overemphasize its significance for we do not know how many readers remained silent or why.

\section{The Major Narratives}

In general there have been two major issues driving the historical narratives in journalism history — press freedom and press commercialization — and both focus on the

\footnotetext{
${ }^{26}$ Stephen Ellingson, "Understanding the Dialectic of Discourse and Collective Action: Public Debate and Rioting in Antebellum Cincinnati," American Journal of Sociology 101, no. 1 (July 1995): 100-44.

${ }^{27}$ Robert Faith published both positive and negative comments written by the editors of other Eastern Ontario newspapers but this does not tell us what the readers of the other newspapers thought. I have not found either commentary or letters to the editor on the campaigns in the 1909 issues of the Journal's Ottawa competitor, the Central Canadian Citizen, nor in its farm-press competitor, the Farmer's Advocate.
} 
metropolitan newspaper. Separate from these ways of looking at the city daily is the narrative used for historicizing small town weeklies as community builders. The farm press has been largely looked at as a source for studies of agricultural life but recent histories have begun to examine it as a shaper of the representation of that life, that is, as an actor that shaped farmer group-consciousness. The rural editions of metropolitan dailies have not been theorized but this study of the rural Journal looks at it as both an actor and a commercialized product.

\section{From Freedom of the Press to the Public Sphere of a Liberal Order}

Whether scholars study the press of the United States, Britain or English Canada, a key narrative, particularly for the early press, has been about a "struggle" for freedom. ${ }^{28}$ William Buxton and Catherine McKercher are explicit on the problem with this theme in their comments on the first comprehensive history of the Canadian press, Wilfred Kesterton's A History of Journalism in Canada. They point out that Kesterton did not enquire whether or how newspapers act as contributors to democracy. He simply assumed it. ${ }^{29}$ Yet this theme is central to many histories in which scholars follow the model of authoritarian-libertarian dualism articulated by Frederick Siebert in his 1956 Four Theories of the Press. ${ }^{30}$ Siebert's essay on the authoritarian theory of the press used as its model the response of the Tudor, Bourbon and Hapsburg monarchies to the

\footnotetext{
${ }^{28}$ This historiography is mainly focused on the British-American press and in Canada on the English language press.

${ }^{29}$ William J. Buxton and Catherine McKercher, "Newspapers, Magazines and Journalism in Canada: Towards a Critical Historiography," Acadiensis 28, no 1 (Autumn 1998): 104-5; W.H. Kesterton, A History of Journalism in Canada (Toronto: McClelland and Stewart, 1967). Kesterton's text came out of course material he wrote starting in the 1940s for the School of Journalism at the then Carleton College.

${ }^{30}$ Fred S. Siebert, "Authoritarian Theory," "Libertarian Theory," in Four Theories of the Press, ed. Fred S. Siebert, Theodore Peterson and Wilbur Schramm, (Urbana: University of Illinois Press, 1956); see also Frederick S. Siebert, Freedom of the Press in England, 1476-1776: The Rise and Decline of Government Controls (Urbana.: University of Illinois Press, 1952). The other two theories were about the 1950s press. Peterson wrote on the extension of the libertarian theory to the idea of objectivity, i.e., equal time for political candidates. Schramm wrote on the Soviet press as a modern form of the authoritarian press.
} 
invention of the printing press. His assessment was that authoritarian elites sought to regulate the press, ostensibly to protect society from erroneous and potentially destructive ideas. His second essay on the libertarian theory explored the challenge to authoritarianism by classical liberalism's concept of the press as enunciated by Milton, Locke, Mill and Jefferson. In this view the press is a marketplace of ideas in which, as ideas contend, truth is found and an in-built self-righting process eliminates erroneous ideas. $^{31}$

I am following the activities of a newspaper which saw itself as acting in the public interest. The idea of a "free press" as a marketplace for ideas, thereby contributing to democracy, can be conceptualized as Jürgen Habermas's public sphere. Jeffrey McNairn in The Capacity to Judge makes this connection using Habermasian vocabulary. He places the early newspaper along with voluntary societies as the main fora in which Upper Canadian political culture was created and non-elite men learned how to act politically. ${ }^{32}$ Gerald Baldasty, however, argues that the idea of a public sphere gives a limited view of the nineteenth-century press. He says that in the United States earlynineteenth-century newspaper publishers and editors saw their readers as voters. Their purpose was to persuade those reader-voters of a specific truth such that they would then act on that truth by voting for the "right" party. ${ }^{33}$ In this argument there never was a public sphere. I would argue there was, even if less clear-cut that Habermas's original concept, but the growth of corporate ownership and the rise of advertising as the main

\footnotetext{
${ }^{31}$ Four Theories has had a long reach. Among the many who cite it are Kesterton, Alan J. Lee, The Origins of the Popular Press in England 1855-1914 (London: Croom Helm, 1976); and Andrew M. Osler, News: The Evolution of Journalism in Canada (Toronto: Copp Clark Pitman, 1993).

${ }^{32}$ Jeffrey L. McNairn, The Capacity to Judge: Public Opinion and Deliberative Democracy in Upper Canada, 1791-1854 (Toronto: University of Toronto Press, 2000).

${ }^{33}$ Gerald J. Baldasty, The Commercialization of News in the Nineteenth Century (Madison: University of Wisconsin Press, 1992): 5, 25-34.
} 
source of revenue lessened the sense of jousting newspapers found in Jeffrey McNairn's study. At the same time, the increasing tendency of newspapers to be read at home, and not in the communal discussion space of coffee houses or taverns, decreased the sense of a collective audience. In addition, most editors of small-town weeklies were arguably first printers, surviving on small print jobs done for local merchants, then newspaper publishers and only last newsmen. A recent study by Mark Hampton nuances this argument further saying that, irrespective of the reality of press behaviour, the idea of a public sphere is important for how the press has been understood both in the past and in the present. ${ }^{34}$ Further, the debate then and now about ownership consolidation and newspaper content reflects concerns Habermas himself raised about capitalist structural transformation of the press. ${ }^{35}$

Siebert's binary analysis (free and presumably liberal versus authoritarian) can be critiqued based on the conversation sparked by Ian McKay's paper on the liberal framework. ${ }^{36}$ That conversation brings out additional issues with regard to the press as a contributor to political thought and action. Jean-Marie Fecteau identifies three levels of potential meanings for a liberal framework in McKay's paper: 1) a redefinition of Canada

\footnotetext{
${ }^{34}$ Mark Hampton, "Representing the Public Sphere: The New Journalism and the Historians," in Transatlantic Print Culture, 1880-1940: Emerging Media, Emerging Modernisms, ed. Ann Ardis and Patrick Colliner (Basingstroke, U.K.: Palgrave Macmillan, 2008), 15-17.

${ }^{35}$ Habermas has been heavily critiqued. See Habermas and the Public Sphere, ed. Craig Calhoun (Cambridge, MIT Press, 1992) publishing papers presented at a conference organized following Habermas's book appearing in English in 1989, including Michael Schudson on whether the public sphere has any historical reality ("Was There Ever a Public Sphere?") and Nancy Fraser on the existence of nonbourgeois public spheres ("Rethinking the Public Sphere"). Douglas Kellner comments in a more recent (albeit undated) paper that Habermas was arguing for the ideal type of a "liberal public sphere" which modern commercial culture has changed into "a media-dominated public sphere" where opinion is manipulated and manufactured. As well, with the on-going discussion of Habermas's work, Habermas moved to a position that there was a dominant bourgeois sphere and an array of oppositional or simply "other" public spheres; Douglas Kellner, "Habermas, the Public Sphere, and Democracy: A Critical Intervention," http://www.gseis.ucla.edu/faculty/kellner/kellner.html. Accessed October 12, 2017.

${ }^{36}$ Ian Mckay, "A Liberal Order Framework: A Prospectus for a Reconnaissance of Canadian History," The Canadian Historical Review 81, no. 4 (December 2000): 616-45.
} 
as a historical elaboration and normalization of a particular set of political ideas and power relationships; 2) a means of theorizing about seemingly disparate historical phenomena via overarching values or logic; and 3) a means of directing historians to perceive and thereby de-naturalize the underlying logic in today's society. ${ }^{37}$ At the same time, McKay's framework has been questioned as a potentially totalizing look at Canadian histories and institutions. ${ }^{38}$ Nevertheless histories of the Canadian press are generally based on an essentially liberal view of Canada in which free individuals acting competitively and yet responsibly contribute to the betterment of society with the press as an important contributor to this process. ${ }^{39}$ Whether one views the press as an instrument of Gramscian hegemony or Foucauldian power-knowledge, it is useful to look at the press as one of the naturalizers of a liberal Canada. In this view mainstream Canadian newspapers were not likely to present substantive alternatives to a classic-liberal view of the world.

I suggest that the questions as to the actuality of a public sphere or the pervasiveness of the liberal order are not as relevant as the underlying concept that the press historically has been thought to have a special role in civil society. The most interesting scholarship sets aside the question of the historical reality of journalism ideals and standards and instead asks why they were thought to be important. Alan Lee, for example, asks what it meant when British liberals bemoaned the death of a political press

\footnotetext{
${ }^{37}$ Jean-Marie Fecteau, "Towards a Theory of Possible History? Ian McKay's Idea of a 'Liberal Order,"” The Underhill Review, Fall 2009, http://www3.carleton.ca/underhillreview/09/fall/reviews/fecteau.htm. Accessed October 12, 2017.

${ }^{38}$ Nancy Christie, "Revisiting Canada's Project of Liberal Rule," The Underhill Review, Fall 2009, http://www3.carleton.ca/underhillreview/09/fall/reviews/christie.htm. Accessed October 12, 2017.

${ }^{39}$ For examples, see two different histories in both time and content. Kesterton, History of Journalism on newspaper progress from colonial beginnings to the 1960s and Paul Rutherford, A Victorian Authority: The Daily Press in Late-Nineteenth Century Canada (Toronto: University of Toronto Press, 1982) on the Victorian press as a modernizing agent.
} 
in Britain at the beginning of the twentieth century. His answer is that in the "golden age" of liberal newspapers the middle class had been able to exercise social power while the commercialized press reflected large scale changes in politics, economics and social order. $^{40}$

Coming at the question from a slightly different direction, sociologist Michael Schudson asks why journalists made (and still make) objectivity their central professional standard. He points to a struggle between two models for the non-political newspaper which emerged in the mid-nineteenth century: first, a "narrative model" exemplified by Joseph Pulitzer's New York World and second, an "information model" seen in the New York Times. The rise of the information model was based, Schudson claims, on a social belief in an objective reality which was knowable if enough facts were gathered. But after seeing how governments manufactured propaganda during the First World War, journalists had to find a new understanding of how they served the public. Their answer was to promote "objectivity," the un-opinionated presentation of all sides of a story using rules and procedures taught in professional schools. ${ }^{41}$

Steven Maras contrasts Schudson's chronology with that of Dan Schiller (Objectivity and the News) who argues that objectivity emerged as a journalism idea in the 1830 s. $^{42}$ Maras brings the two together by arguing that the meaning of objectivity has varied over time but is in general a multi-faceted model which mixes values, practices and language in an effort to make news reports and opinions authoritative and credible,

\footnotetext{
${ }^{40}$ Lee, The Origins of the Popular Press in England, 15-20, 214-8, 233.

${ }^{41}$ Michael Schudson, Discovering the News: A Social History of American Newspapers (New York: Basic Books, 1978), 4-7, 121-59.

${ }^{42}$ Steven Maras, Objectivity in Journalism (Cambridge: Polity, 2013) citing D. Schiller, Objectivity and the News: The Public and the Rise of Commercial Journalism (Philadelphia: University of Pennsylvania Press, 1981).
} 
thereby asserting a claim to power. Maras views objectivity as evolving from a period of “proto-objectivity" from 1830 to 1880 in which the penny press made facts, information and independent comment a successful business model. Maras calls this a period of journalistic "fact-mindedness." It was also in tune with cultural changes privileging realism as found in the photograph and facts as discovered through science. Maras argues that after 1880 this commitment to reflecting the world realistically developed into an “organizational ethic" for news reporting and around 1900 it became an informational ideal used to critique Yellow Journalism. Objectivity then was a further step along the way of making newspapers respectable and trustworthy. ${ }^{43}$

An allied concept is gatekeeping - the selection of what is news and what are the public issues to be debated. While studies of gatekeeping are modern and the term itself dates to the mid-twentieth century, the concept of newsworthiness is not. Tim Vos and Teri Finneman undertook a content analysis of newspapers, trade publications and journalism textbooks to tease out how historically journalists have talked about news selection. Vos and Finneman find that the subject became a sustained issue for discussion in the 1870 s and that gatekeeping as the selection of what is newsworthy had fixed its meaning by the $1930 \mathrm{~s} .{ }^{44}$ In other words, gatekeeping became an object of professional knowledge at about the same time as objectivity. As a result, an active discussion of what was newsworthy and of the imperative of reporting facts was part of the North American journalist universe in which the rural Journal editors were plying their craft at the beginning of the twentieth century. At the same time, the concepts of objectivity and gatekeeping were still in a state of flux.

\footnotetext{
${ }^{43}$ Maras, Objectivity in Journalism, 8-11, 23-52.

${ }^{44}$ Tim P. Vos and Teri Finneman, "The Early Historical Construction of Journalism's Gatekeeping Role," Journalism 18, no. 3 (2017): 269-77.
} 
My study is concerned with the rural Journal as an activist in the first decade of the early twentieth century, before the First World War brought the truth of "facts" into question. As such, the newspaper's claim in the Cheese Board fight (chapter 8) to be the newspaper which told the facts fits within Schudson's information model. Both the rural editors also regularly published a balance of opinions in letters to the editor. Their objectivity, however, did not involve erasing the newspaper from the story in order to avoid subjectivity. I suggest they were able to combine the fact-mindedness form of objectivity with subjective advocacy partially because this was a period of transition when journalism was not yet fully professionalized and partially because advocacy fell squarely within the increasing value placed on public service. Indeed Vos and Finneman find that journalists were in this period beginning to justify sensational news by invoking a duty to serve the public good alongside an earlier justification that they were simply meeting market demand. ${ }^{45}$

A rethinking of the press as public service took place in the late-nineteenth and early-twentieth centuries at the same time as observers worried that newspapers had shed their old role of mobilizing voters for a new role of mobilizing consumers. This world of commercialized journalism is the world of the Ottawa Journal in both its city and its rural persona.

\section{The Commercializing Press Makes Information Entertaining}

To understand the Journal's conviction that it could act as well as report, particular attention must be given to the history of the "New Journalism" of the late nineteenth century. Its history generally starts in the 1830 s with James Gordon Bennett,

\footnotetext{
${ }^{45}$ Ibid., 273-4.
} 
the publisher of the New York Herald. Bennett created a profitable newspaper by dropping the price, removing the heavy and serious political and social commentary to a special page of succinct comment and opening up the rest of the newspaper to information written in a bright, easy style. Even the advertising had to be interesting for Bennett banned stagnant ads which never changed their content. ${ }^{46}$ The term "New Journalism" started with newspapers in the Mid-West in the 1870 s which were using the style of popular language and newsy information they saw in New York newspapers. But it came to prominence in the 1880 s and 1890 s with Joseph Pulitzer and William Randolph Hearst. Their extreme versions were called Yellow Journalism.

The early historiography of the commercialized press of the nineteenth century focused on the dominant personalities of the New York City papers, especially Bennett of the Herald, Pulitzer of the World and Hearst of the Journal. ${ }^{47}$ Later historiography brings to the fore the social forces which had only been mentioned in the earlier histories as the sea in which the Great Men had swum. The most common narrative, whether looking at dominant names or at social forces, links the rise of the cheap, entertaining, high circulation newspaper to industrialization (new technology in steam-run printing presses plus production of mountains of consumer goods needing to be sold) and urbanization (concentration of large numbers of people creating easily reached newspaper buyers). However, if industrialization and urbanization are sufficient to explain the rise of the commercial press, why do we see developments lagging in industrialized, urbanized

\footnotetext{
${ }^{46}$ James L. Crouthhamel, Bennett's New York Herald and the Rise of the Popular Press (Syracuse, N.Y.: Syracuse University Press, 1989).

${ }^{47}$ Dicken-Garcia attributes this to one of the earliest and most influential journalism historians, Frederick Hudson (Stevens and Dicken-Garcia, Communication History, 18). Hudson was the managing editor of Bennett's New York Herald. In 1873 he wrote a New York-centric history (Journalism in the United States, From 1690 to 1872) which was the definitive source for the histories which followed.
} 
Britain? There is a more complex story to tell, even in the United States.

Baldasty points out a change in the conduct of American politics in the 1830s just as the penny press was beginning to flourish in New York City. Improved transportation allowed candidates to meet with more potential voters while a cultural taboo against candidates personally soliciting votes disappeared (the taboo remaining only for presidential candidates). At the same time political parties became better organized and better able to get out the vote without the help of newspaper editors. Newspapers, in response, retained their political interests but ceased to be party "servants." ${ }^{, 48}$ On the other side of the Atlantic, Wiener points out differences in political life between Britain and the United States which flowed through to newspaper content and form. ${ }^{49}$ In Britain, universal male franchise was delayed to the late-nineteenth century (with the last of the property qualifications not being removed until 1918). At the same time the last of the British Stamp Acts kept the price of mainstream newspapers out of the reach of the masses. The result was a difference in audience and thereby newspaper culture.

In the United States the goal was to be the first to scoop the story and then to get the story onto the streets with headlines which would grab attention in a glance from the hurrying commuter. In Britain mainstream newspapers continued well into the 1860s to be leisurely in production, literary in tone and dull. Dynamism and colour only began to enter the major British newspapers after young British reporters came home from covering the American Civil War having seen American news reporting up close. ${ }^{50}$ But Weiner also points to the vernacular roots of newspaper entertainment. In Britain radical

\footnotetext{
${ }^{48}$ Baldasty, Commercialization of News, 12-14, 38-40.

${ }^{49}$ Joel H. Wiener, The Americanization of the British Press, 1830s-1914: Speed in the Age of Transatlantic Journalism (New York: Palgrave Macmillan, 2011).

${ }^{50}$ Ibid., 89-92.
} 
editors such as William Cobbett had sold cheap newspapers in the streets in the 1820s. The number of cheap (and illegal) titles exploded in the 1830s in the "War of the Unstamped" as a challenge to the remaining government taxes on newspapers. The most successful of these ha'penny newspapers had combined politics with the kind of popular culture found in street ballads and chapbooks (small cheap books) both of which featured stories of hangings, criminals' confessions, innocent girls done wrong and other such popular narratives. This press disappeared with the ending of the worst of the stamp taxes but Wiener does not point to anything specific to explain its demise. ${ }^{51}$

In From Politics to Profit Minko Sotiron argues, like Baldasty, that politics is a central part of the story of change in the Canadian press but he presents a different trajectory. First, he dates the change to the beginning of the twentieth century and, second, he stresses cost as the cause rather than changes in campaigning rules of politesse - probably because that was a specifically American development. ${ }^{52}$ This takes the narrative beyond politics to the cost of production. The late nineteenth-century introduction of new printing technology significantly raised startup and operating costs for newspapers. Publishers had to have access to a large amount of capital and were therefore either drawn from or became part of elite society. In Canada, publishers were, like other elites, enmeshed in politics. ${ }^{53}$ The result was that Canadian newspapers may have shaken off their party owners but they remained thoroughly partisan.

Historian Brian Beaven goes deeper by following the money through the Auditor

\footnotetext{
${ }^{51}$ Ibid., 42-5, 112.

${ }^{52}$ Minko Sotiron, From Politics to Profit: The Commercialization of Canadian Daily Newspapers, 18901920 (Montreal: McGill-Queen's University Press, 1997); Baldasty, Commercialization of News, 43-4. ${ }^{53}$ Sotiron, From Politics to Profit. See Carlton McNaught, Canada Gets the News: A Report in the International Research Series of the Institute of Pacific Relations (Toronto: Ryerson Press, 1940), 20-2 on the separation of the publisher-businessman from the editor-journalist with publishers taking elite business views. Baldasty gives production costs somewhat less attention perhaps because the greatest cost changes came after he pinpoints changes in the newspapers' political role.
} 
General of Canada Reports. He concludes that there simply were not enough printing and advertising contracts in Canada for governments to create a party press nor was there enough leverage achievable by handing out the odd postmastership here and there. ${ }^{54} \mathrm{He}$ also argues there was not enough money among "political friends" to fund newspapers although he points out one reeking fish story. Ottawa Journal publisher P.D. Ross in his reminiscences wrote about an altruistic helping hand from local businessmen — not mentioning that they were the local Conservative organizers. Beaven's analysis bores down through layers of possible explanation to conclude that Ross was not bought, but that there were good political reasons on all sides for the transaction. ${ }^{55}$ Beaven concludes that publishers were driven by commercial reality and not partisanship. First, consumerdirected advertising kept them afloat, and second, what political money there was tended to flow to papers of influence as proven by their circulation. But his analysis also points out that commercial did not mean non-political. In nineteenth- and early-twentiethcentury Canada, business was political. A party label identified who you were and gave you access to ready-made friends. ${ }^{56}$

A look at Jean Hamelin's and André Beaulieu's overview of the history of Quebec's French-language press suggests that the political climate also matters. Hamelin and Beaulieu follow Kesterton's pattern of tracking changes in newspapers from colonial to modern times applying the same overall narrative of progress. But they connected the first fight for freedom of the press to resistance to the Montreal commercial interests of "M. McGill et ses amis," that is, to the dominant British society. The commercialized

\footnotetext{
${ }^{54}$ Brian P.N. Beaven, "Partisanship, Patronage, and the Press in Ontario, 1880-1914: Myths and Realities," Canadian Historical Review 64, no. 3 (September 1983): 329-34.

${ }^{55}$ Ibid., 339-40. Story in P.D. Ross, Retrospects of a Newspaper Person (Toronto: Oxford University Press, 1931), 36-7.

${ }^{56}$ Beaven, "Partisanship, Patronage, and the Press in Ontario," 340.
} 
press of the next period developed on the same lines as elsewhere in Canada but in Quebec it co-existed with a clergy-dominated press which had been established to prevent the resurrection of the liberal patriote press of the 1830s. For much of the nineteenth and early twentieth centuries the reality in Quebec was one of clerical control over a significant number of mainstream newspapers. ${ }^{57}$ In Quebec this mattered as the Church defined what newspapers good Catholics could read or even work for. The press became another political tool for the Church. ${ }^{58}$

Technology is another explanatory factor which is often discussed in terms of costs but also goes beyond costs to the shortened shelf-life of news. In Britain, the repeal of the last paper tax in 1861 happened as the telegraph took full hold in transmitting information in that country. The result was an increase in the number of newspaper titles, both in London and in provincial cities, along with the expansion of the Manchester Guardian and Scotsman from weeklies into dailies. ${ }^{59}$ Telegraphy and railways have also been connected with the transformation of Canadian city weeklies into dailies starting with Toronto's Globe in 1853 and then Montreal's Gazette in 1854. Douglas Fetherling argues this was the result of the railway and telegraph combining with an expanding population base to create enough commercial money in the colonies to sustain daily advertising. ${ }^{60}$

In Canada, newspaper owners were also learning from the Americans that big city

\footnotetext{
${ }^{57}$ Jean Hamelin and André Beaulieu, "Aperçu du journalisme québécois d'expression française," Recherches sociographiques, 7, no. 3 (1966): 312-3.

${ }^{58}$ While good Catholics in Quebec may have felt constrained to read approved "Catholic newspapers," language seems to have been the main barrier to diffusion of the English language Ottawa Journal both in the city and the countryside. Catholics of Irish ancestry such as Kate Whelan and Grattan O'Leary worked for the Journal and the regular inclusion of Catholic obituaries suggests that there were Catholic readers.

${ }^{59}$ Weiner, Americanization of the British Press, 102-4.

${ }^{60}$ Douglas Fetherling, The Rise of the Canadian Newspaper (Toronto: Oxford University Press, 1990): 256. This is a synthesis history by a cultural commentator rather than a historian. Fetherling provides a bibliography of the secondary material he consulted but no footnotes.
} 
dailies could be profitable if they were interesting. Rutherford gives the title of the first "American-style" newspaper to the (Montreal) Star. Hugh Graham, who founded it in 1869, used "New York ideas" such as fresh-air vacations for city children as well as “slangy style, sensation and crusades, much amusing or entertaining matters and a surfeit of trivia." ${ }^{\prime 61}$ Rutherford, however, points out that Graham was not the only publisher practising a "people's journalism" which responded, he says, to "the stresses and strains that 'modernity' imposed on the life of the big city." "62 At the same time advertising money was changing newspaper owners' view of their customers in both the United States and Canada. The old political owners and editors had seen the reader as a potential voter to be persuaded. The commercial publisher saw readers as an anonymous mass of men, women and children of all classes who were potential newspaper customers as well as consumers of the goods sold by their advertisers. More ominously, perhaps, readers were also a commodity to be sold to those advertisers. ${ }^{63}$

Circulation wars broke out as each publisher sought to persuade advertisers that his newspaper was the key to reaching the people (especially women) who would buy their products. Bigness became a virtue-bigness in circulation but also bigness in number of pages, bigness in range of content, bigness in physical size of pages and headlines. In addition, publishers sought bigness in geographical distribution with dailies producing weeklies for the countryside around.

\footnotetext{
${ }^{61}$ Rutherford, A Victorian Authority, 51.

${ }^{62}$ Ibid., 53. Rutherford's examples of Graham's New Journalism activism reflect the Star's fiftieth anniversary booklet which not only celebrated its activities, generally presented as Graham's personal crusades, but implied that the Star was deeply involved in national and international events of the previous fifty years; Booklet, "Fifty Years 1869 to 1919 / Half Century Souvenir," collection of Bruce S. Elliott. ${ }^{63}$ Baldasty, Commercialization of News, 4-5; Russell Johnston, Selling Themselves: The Emergence of Canadian Advertising (Toronto: University of Toronto Press, 2000), 229.
} 


\section{The Niche Newspapers}

Journalism history studies of the commercializing press centre on metropolitan dailies and leave to the side as irrelevant rural and farm newspapers. After all, it is argued, the mass press of the cities has the greatest interaction with and influence upon society ${ }^{64}$ But students of the metropolitan press also enjoy the richest and most easily mined sources of evidence both for the newspapers themselves and for the people behind them. Students of the rural and farm press must search out their evidence although, as we will see in this section, it is possible to find some rich mother lodes for the farm press. Unfortunately good examples of rural editions of metropolitan newspapers, such as the rural Journal, are more elusive than any hen or her teeth and the historiography of the genre reflects this. Nevertheless it can be argued that niche newspapers were integrated into a commercializing world, were interacting with and influencing their targeted audience, and survived, or not, depending on how they came to terms with that commercial world while meeting the interests of their audience.

By the mid-nineteenth century the dailies were dominant in terms of circulation both in the city and beyond, even though the small town weeklies were still dominant in terms of the number of titles. The two lived more or less happily together in the Canadian Press Association until the 1908 introduction of rural mail delivery. As city newspapers lobbied for better mailing rates in order to extend their reach into the countryside, it

\footnotetext{
${ }^{64}$ For Canadian examples see Paul Rutherford, A Victorian Authority, 4-5; Kesterton, History of Journalism, 54-5. Kesterton presents the statistics of a continuing increase over the course of the nineteenth century in the number of weeklies which gave full news including national and international affairs but judges the dailies as having greater "impact" on readers because their circulation grew faster than that of the weeklies. But Kesterton does not define impact, or how to measure it, or his evidence for this judgment, while other scholars' comment on the difficulty of assessing past readership due to a lack of surveys and polls. Thomas C. Leonard addresses this problem in his history of newspaper readership by seeking evidence in traveler's accounts, paintings and illustrations of domestic interiors, and other forms of contemporary commentary in News for All: America's Coming-of-Age with the Press (New York: Oxford University Press, 1995).
} 
became clear that dailies and weeklies were in competition. The result was that the Canadian Press Association broke in 1919 into three associations, a daily association, a weekly association and a trade association. The farm journals were attached to the trade association while small town newspapers were part of the weekly association. ${ }^{65}$ A rural newspaper with an urban parent, such as the rural Journal, was invisible.

\section{Country Journalism Survives by Celebrating the Local}

It is generally claimed that newspaper commercialization created a gulf between city and country newspapers. The new model in the 1830 s, that of a cheap paper to be bought each day from street-based newsboys, required a concentrated customer base. In contrast, country weeklies and the country editions of the dailies continued to be sold by pre-paid subscriptions and mailed to the subscriber's post office. At the same time weeklies were insulated from dailies' need for production speed and therefore could meet demand with second-hand old-model printing presses. In the city, costs rose forcing the publisher-businessman to run his daily as a standardized product. Syndicated material became one method of achieving this, along with wire services.

Ted Smythe points out that the country publishers were also subject to economic pressures after the American Civil War and they too had to evolve in much the same way, that is, away from political funding and towards advertising dollars. ${ }^{66}$ And they too used a cost-saving mechanism which came to them from the city. Publishers could contract to receive from companies headquartered around the United States and Canada news-sheets pre-printed on one side. The newspaper then printed the local news and advertisements

\footnotetext{
${ }^{65}$ W.A. Craick, A History of Canadian Journalism, Volume II Last Years of Canadian Press Association 1908-1919 (Toronto: Ontario Publishing Company, 1959), 82-96.

${ }^{66}$ Ted Curtis Smythe, The Gilded Age Press, 1865-1900 (Westport, Conn.: Praeger, 2003), 44.
} 
on the blank side of these patent inside (sometimes called patent outside) sheets. In this way weeklies were as much a standardized product as a daily.

With respect to the history of the country newspapers published in small towns, there exists a small body of "nostalgia" writing. Stanford University hosts a website which includes a triumphal story of western small town weeklies as both town boosters and as markers of the western-moving frontier. The writers point to the stress placed on these newspapers from the introduction of rural mail delivery and the ban on misleading advertising reducing revenue from patent medicine ads. They describe the survivors as "hyper-local." Small town westerners could read national and international news in city newspapers while hearing stories and seeing ads from their own community in the local weekly. ${ }^{67}$ A Canadian example of the story of the weekly is George Johnston's celebratory history written for the fiftieth anniversary of the Canadian Weekly Newspapers Association which had just renamed itself the Canadian Community Newspapers Association. In line with that renaming, Johnston celebrates small town newspapers for reflecting the communities in which they are published. They survive by focusing on the local. ${ }^{68}$ But Johnston does not address their history, leaving the suggestion that the weekly of the 1970 s was a glorious insect caught in amber, looking and feeling much like the weekly of 1930 or 1900 . Nor have I found a history examining how the country weeklies and metropolitan dailies branched off the "evolutionary tree" and what DNA was kept by both and what was altered in the process.

\footnotetext{
${ }^{67}$ Krissy Clark and Geoff McGhee, "Did the West Make Newspapers, or Did Newspapers Make the West?" http://web.stanford.edu/group/ruralwest/cgi-bin/drupal/content/rural-newspaper-history. Accessed September 16, 2017.

${ }^{68}$ J. George Johnston, The Weeklies: Biggest Circulation in Town (Bolton, Ont.: Leaven Printers, 1972): 25. All of this was clearly written decades before the 2017 news in Ontario that corporate owners, having acquired ownership of local newspapers, decided to close down many of them.
} 
A 1928 textbook written by a journalism instructor at the University of Illinois, Charles Allen, gives a sense of the changes. He comments, for example, that, when city dailies and country weeklies were irrevocably parting company in the mid- to latenineteenth century, city newspapers were introducing the inverted pyramid style of writing. This apparently met the readers' desire to quickly grab the essential facts. Allen cautioned his country journalist students to continue using an older, more elaborate style because their readers would want to know more, particularly the local connection and the people involved. As well, the news was written about people the readers most likely knew. Where a city newspaper might choose to play up the sensational elements of a crime story, for example, the country editor had to be aware of sensitivities requiring sympathy. ${ }^{69}$ This suggests city and country readers were diverging in the late nineteenth century along with changes in the newspaper industry structure.

Another narrative is that the weekly was the haven of the independent-minded political small town editor while the city daily was the home of the businessman publisher cutting the editorial cloth to fit the advertising dollar. Three scholars argue against the notion of local independence in the weekly, saying there was instead a muting of opinion. Both Albert Blumenthal's 1920s participant-observation study of a small Montana town and David Cassidy's 1980 content analysis study of thirty-eight Illinois newspapers conclude that small town editors were first and foremost businessmen. They had to avoid political statements which would offend any of the various interests in town. Cassidy nuanced this conclusion to argue that the editors were opinionated about local doings but did not comment on controversial local topics or take minority positions. Instead, there were two main areas of comment: civic improvement heavily laced with

\footnotetext{
${ }^{69}$ Charles Laurel Allen, Country Journalism (New York: Thomas Nelson and Sons, 1928), 56-66, 92-4.
} 
boosterism and local politics beyond the immediate community (i.e., county politics).

The third text, Charles Allen's 1928 textbook, directed the aspiring country editor to present the community in the best possible light while boosting local businesses and institutions. Allen added that comment in editorials must be "friendly" and the timing right or no-one would listen. The contrary view to these three presentations of the muted small town editor is found in John Cameron Sim's 1969 history of country weeklies. He argues based on two studies that editors remained committed to outspoken opinions. ${ }^{70}$

Even the claim that the weekly was the last refuge of local news can be questioned. Beth Garfrerick makes a contrary argument based on her content analysis of weekly country newspapers from across the United States published between 1900 and 1980. She found that syndicated material pushed out locally written text, causing editors to change from being the "crusader editor of the eighteenth century" to the "newspaper businessman." ${ }^{, 71}$ But on the other side of the argument, Cassidy presents Irene Taeuber's 1931 content analysis study. Taeuber argued that syndication and ready-print material did not reduce the proportions of local versus non-local content over her period of study (1860 to 1929). What did drop was the amount of editorial or opinion content. ${ }^{72}$ This shift from opinion to news-entertainment along with an increased homogenization is a

\footnotetext{
${ }^{70}$ Albert Blumenthal, Small Town Stuff (1932; repr. Chicago: U.P., 1961), 178-81. This was Blumenthal's doctoral dissertation submitted to the University of Chicago's sociology program; David R. Cassidy, "The Content of the Rural Weekly Press in Illinois in 1882" (PhD diss., University of Iowa, 1980): 279; John Cameron Sim, The Grass-Roots Press: America's Community Newspaper (Ames: Iowa State University Press, 1969): 95-6, 101-2. Allen, Country Journalism, 94, 192-202. Sim's studies were a 1961 master's thesis using a questionnaire sent to 145 editors ( $75 \%$ response rate) and an undated set of interviews with 117 weeklies in Washington State.

${ }^{71}$ Beth H. Garfrerick, "A History of Weekly Community Newspapers in the United States: 1900 to 1980" (PhD diss., University of Alabama, 2009): 20-8, 31. Garfrerick also touches briefly in these pages on the financial necessity to avoid fearless opinion in editorials.

${ }^{72}$ Cassidy, "Content of the Rural Weekly Press," 122-6; cites Irene Barnes Taeuber, "Changes in the Content and Presentation of Reading Material in Minnesota Weekly Newspapers, 1960-1929" (PhD diss., University of Minnesota, 1931). Cassidy did find that the newspapers he analyzed used syndicated or ready prints (patent insides and later boiler-plate), pp. 172-6.
} 
phenomenon also observed in metropolitan newspapers over the same time period. ${ }^{73}$

\section{The Farm Press as Source and as Actor}

The farm press has been studied as minimally as the country weekly. In 1935 Fred Landon charted the development and histories of various farm publications in Ontario prior to Confederation. He argued that these were business enterprises espousing agricultural improvement. Only the Farmer's Advocate differed by being the product of a working farmer. Landon argued that it was worth studying historical examples of the agricultural press because they served as evidence in writing agricultural history. ${ }^{74}$ Albert Demaree made the same argument in his 1941 history of the American pre-Civil War agricultural press. $^{75}$

John Fry is one historian who uses the farm press as more than a source in his book The Farm Press, Reform, and Rural Change, 1895-1920. ${ }^{76}$ To determine how the farm press worked, what it was trying to do and how it influenced, or not, its readers, he asks who the publishers and editors were, what they espoused, and how readers responded. He answers the last question about readers from a range of surveys of Wisconsin farmers and other rural mid-westerners from the 1910s and 1920s. But he was able to profile readers from a set of club lists he found in the Iowa State University Library. ${ }^{77}$ The lists gave him the names of 194 subscribers to Wallaces' Farmer from

\footnotetext{
${ }^{73}$ Trachtenberg, Incorporation of America, 124-7.

${ }^{74}$ Fred Landon, "The Agricultural Journals of Upper Canada (Ontario)," Agricultural History 9, no. 4 (Oct. 1935): 167-75.

${ }^{75}$ Albert Lowther Demaree, The American Agricultural Press 1819-1860 (New York: Columbia University Press, 1941), xi.

76 John J. Fry, The Farm Press, Reform, and Rural Change, 1895-1920 (New York: Routledge, 2012).

${ }^{77}$ There were two types of clubbing. In this case, clubbing was a practice in which one person signed up a number of subscribers, effectively acting as the newspaper's agent but for premiums or a reduced price on his or her own subscription, rather than a commission. As will be discussed in Chapter 4 on the Journal as a business, clubbing could also refer to publishers bundling their publication with another to create a package for attracting subscribers.
} 
1925 to 1930 . Of these, he was able to identify 98 individuals, 61 of whom were farmers. Twenty of the 98 (making up the next largest occupational group) were professors and students at the Iowa State Agricultural College. Gender was not as easily determined but Fry was able to identify ten women among the subscribers. Linking the names to the census (both agricultural and nominative) gave him information for analyzing the economic and educational status of the subscribing farmers. He found that most had average-sized farms but as well there were both wealthy and struggling farmers.

Educationally, they were more homogeneous with fifty-six out of the fifty-nine for whom he had educational information having completed between five and nine years of schooling. Fry concludes that Wallaces' Farmer was reaching as diverse a group of agriculturists as it claimed. ${ }^{78}$

Fry's study of the publishers and editors concludes that publishers were businessoriented and urban while editors, although living and working in the city, had some limited farm links. He focuses his questions about content and reader response around key elements of the Country Life Movement (the church, the school and the family). His conclusions are much the same as communication studies have reached about the urban newspaper reader. Readers chose what they read, they chose what they understood from what they read, and they chose what actions (if any) followed based on what they read. Overall Fry is cautious as to the claim of earlier historians that there was a connection between the farm press and changes in agriculture practices. ${ }^{79}$

I have not found a Canadian equivalent to Fry's work. Instead the two studies

\footnotetext{
${ }^{78}$ Fry, The Farm Press, 72-9.

${ }^{79}$ Ibid., 158-9; Edgardo Luis Carniglia reaches the same conclusion in his sociological study of today's rural press and the rural reader - "Enclaves and Dilemmas of Rural Communication, Family Farmers and the Agricultural Press," Journal of Latin American Communication Research 3, no. 1 ([2013]): 103-27.
} 
related to a prominent Canadian farm journal, the Farmer's Advocate, were about its columnists. Adam Crerar examines the writings of Peter McArthur from the early 1910s to 1924 while Royce MacGillivray looks at John McIntosh writing under the pseudonym of Sandy Fraser from 1909 to $1948 .^{80}$ Both historians use readers' letters to determine what made the two writers popular. Crerar finds that city readers responded to McArthur's literary agrarian romanticism while country readers appreciated his combining this agrarianism with hard-headed farm information and comment. MacGillivray argues that rural readers responded to McIntosh's humour as a way of commenting on the harshness of farming particularly for women. There are two other scholarly looks at the Farmer's Advocate. Robert Cole summarizes the nature of the content carried by the paper's Western edition as a case study for "Print in Daily Life" in History of the Book in Canada for the years 1840-1918. Senita Kyeremateng writes about the Advocate in an article for a masters course at the University of Guelph. But she focuses more on the man behind the newspaper, William Weld, while her look at the newspaper itself is focused on its usefulness as a source. ${ }^{81}$

\section{City and Country}

The rural Journal was a hybrid which combined the virtues of the daily in providing international and national news, the weekly in giving space to local news via

\footnotetext{
${ }^{80}$ Adam Crerar, "Writing across the Rural-Urban Divide: The Case of Peter McArthur, 1909-24," Journal of Canadian Studies 41, no. 2 (Spring 2007): 112-37; Royce MacGillivray, "The World of Sandy Fraser," in "Sandy Fraser": A Bibliography of the Writings of John Everett McIntosh (1876-1948) in the Farmer's Advocate Under the Pen Name of "Sandy Fraser" ed. Royce MacGillivray (Waterloo, Ontario: privately pub, 1991).

${ }^{81}$ Robert Cole, "The Western Edition of the Farmer's Advocate and Home Magazine," in History of the Book in Canada, ed. Yvan Lamonde, Patricia Lockhart Fleming and Fiona A. Black, Vol. 2 (Toronto: University of Toronto Press, 2005); Senita O. Kyeremateng, "The Farmer's Advocate” Guelph University Collection Update No. 19, 2002 - Rural History. http://www.lib.uoguelph.ca/resources/archival_\&_special_collections/collection_update/19/ farmersadvocate.htm. Accessed October 10, 2012. This article has disappeared from the Guelph site as of November 2014 but I was able to retrieve a copy for my files from the University Library IT section.
} 
correspondents and the farm journal in providing agricultural information. Yet it can also be seen as part of the increasing intrusion of city commercial interests into the countryside. I will be arguing in the chapters which follow that it is an example of the late-nineteenth-century city journalism which aimed to make news and not just report it. Thus it fits with the issues and questions raised by historians in their study of the commercial press and how it changed the newspaper from pontificating on issues to selling entertaining information. But it also fits with the activist city journalism in claiming a special relationship with readers by raising issues and asking for reader feedback. I will consider in Chapters 6 through 8 how the rural Journal framed the issues it declared required public discussion.

Paul Rutherford looks at the Canadian metropolitan dailies as popularizers of "a particular dogma of modernity cobbled together out of the clichés of the editors' world," that is, a dogma based on ideas of progress, nationality and democracy. ${ }^{82}$ But these ideas were shared by rural editors and certainly predated the Victorian big city daily. For example, Robert Hill looks at the classic liberalism championed by the publisher-editor of a country weekly, Robert Sellar of the Huntingdon Gleaner. But while Sellar was preaching the "dogma” described by Rutherford, Sellar's central focus was fighting the political implications of Quebec's reduced Anglophone population and Roman Catholic Church control in Quebec. ${ }^{83}$ In turning to the rural Journal, the degree to which it presented Rutherford's dogmas represents a reality that the editors' clichés came out of a dogma shared by both city and country. We could even call this dogma an overarching "liberal framework."

\footnotetext{
${ }^{82}$ Rutherford, A Victorian Authority, 156-7.

${ }^{83}$ Robert Hill, Voice of the Vanishing Minority: Robert Sellar and the Huntingdon Gleaner, 1863-1919 (Montreal: McGill-Queen's University Press, 1999), 9-10, 43-4, passim.
} 
The historiography of the country weekly stresses its localness. This did not mean farm readers were uninterested in the world beyond the nearest village. But by the beginning of the twentieth century it was sensible for weekly editors to focus on the local rather than try to compete in news coverage with the increasingly available dailies. This does make the local newspapers useful for focusing on events in the daily lives of people outside the city. For example, Terry Currie's study of a massive 1870 Ottawa Valley fire and its aftermath shows that it is necessary to read the small town newspapers as only one Ottawa newspaper, the Free Press, carried the news. Bruce Elliott adds that the Free Press was so struck by its difficulty in knowing what had actually happened during and after the fire that it decided to engage more closely with rural readers by enlisting rural correspondents. $^{84}$

I have found only a few references to the interaction between city and country newspapers. Douglas Fetherling is one writer who does examine the connection between metropolitan dailies and the countryside via the weekly versions of city dailies. He characterizes these as providing old news leavened with slightly fresher material which was often agricultural. As well he names some of the city-rural weeklies which became provincial weekly magazines: the Family Herald out of the Montreal Star (1869), the Free Press Prairie Farmer out of the Manitoba Free Press (1872), and the Star Weekly out of the Toronto Star (1910) (although he describes the Star Weekly as aimed at the general public while the first two aimed specifically at farmers). ${ }^{85}$

This did not mean the rural editions of the city dailies were welcomed by their

\footnotetext{
${ }^{84}$ Terence M. Currie, The Ottawa Valley's Great Fire of 1870: The Nineteenth Century Press and the Reality of a Great Disaster ([Ottawa]: Creative Bound International, 2009); Bruce S. Elliott, "The Great Fire of 1870: A Review of a New Book and New Research on the Fire and Its Aftermath," Horaceville Herald 54 (March 2010): 1, 6-8, 13-16.

${ }^{85}$ Fetherling, The Rise of the Canadian Newspaper, 67-8.
} 
country cousins. In a study of the American agricultural press, Jack Van Derhoof notes in passing the tension which existed between the farm press and city newspapers when the latter wrote on agricultural subjects. In his example, the farm press first said the city newspapers were not qualified and then added they were publishing "cut and paste" agricultural information. In addition, Van Derhoof highlights the criticisms made by Orange Judd, a prominent agricultural publisher, in 1869 against the New York Times and the New York Sun. Judd's problem was that the two New York City newspapers were criticizing the federal Commissioner of Agriculture which he said was the job of the farm press because the farm press spoke for the farmer. ${ }^{86}$ Another view of how some found the city-rural press troubling is presented in Thomas Leonard's history of the newspaper reader. Leonard provides a short review of how early commentators saw the stretch of the metropolitan newspaper into the countryside as contaminating a pure yeomanry with city views. ${ }^{87}$ Alan Lee is another who refers to the country version of a daily in England, or as he calls them, "stable mates." He finds that their numbers increased in Britain between 1855 and 1914 in terms of the number of titles but the dailies had the lion's share of circulation. Nevertheless the rural newspaper had specialized material in stock and auction advertising which made it potentially very profitable. Lee argues that the role of these smaller circulation versions was to create "social cohesion in a rural community" and to serve as an "essential base" for the expanding dailies. ${ }^{88}$

\section{Conclusion}

The historiography of journalism history is divided between studies of

\footnotetext{
${ }^{86}$ Jack Van Derhoof, “Eastern and Mid-Western Agricultural Journalism, 1860-1900” (PhD diss., Columbia University, 1951): 41-2.

${ }^{87}$ Leonard, News for All, 66-7.

${ }^{88}$ Lee, "Structure, Ownership," 123; fn 16, p. 365, Lee cites R. Jeffries, Hodge and His Masters, 1880, quoting from a 1949 edition, pages 198 and 202.
} 
newspapers as businesses, as communication media and as cultural expressions. For historians the challenge is to recognize the newspaper is a historical object and not simply a source. Newspapers are cultural actors, aiming to shape readers' view of the world through how they frame events and issues. Communication studies have also shown that readers are not empty vessels to be filled. Studying a newspaper historically must, then, consider the complex relationship between its discourse, the events on which it wrote and the readers who read with their own view of how the world worked and what the events meant.

At the same time, histories of journalism have privileged the study of a particular form of the newspaper, the big city daily. This is due in part to a general emphasis by communication scholars on mass communication in which fact, opinion and/or entertainment are disseminated in varying amounts from the known few (the producers, editors and writers) to the unknown many. The many may be imagined as audience, customers (of the media and potentially of the media's advertisers) or citizens. These studies have focused on metropolitan dailies for practical and theoretical reasons. They are the most visible and most easily researched form of newspaper. At the same time scholars argue they have the greatest influence on society because they are read by so many. The result is that communication analysts and historians judge the daily to be the most interesting newspaper form to study. In the past they also saw it as the end-point in a story of continual improvement in content, technology and freedom of the press. The historical debate traditionally was on whether or not the newspaper had lost its democratic purpose of being a public sphere due to the increasing power of advertising dollars and what was seen as a concomitant trivialization of content. 
In the light of journalism history, the Ottawa Valley (Farm) Journal was about as niche as a niche publication could be. It was a semi-weekly claiming to be a local newspaper for the rural Ottawa Valley but it was the offspring of a city daily. Local weeklies have been studied by a few scholars in the form of the independent small town publications. Their interest is, speaking broadly, in how weeklies maintained an emphasis on the local and the particular in the face of the incursion into the countryside of the homogenizing city dailies and their rural editions. Yet small town newspapers were under similar cost constraints to the dailies despite being able to use lower cost, second-hand technology for their once a week, lower volume print runs. The weekly editors also had both the blessing of being close to their readers (thereby knowing what readers wanted to read), and the curse of being close to their readers. Studies of the small town press have remarked on the fine line the small town editor had to walk in order to be independent, interesting and still inoffensive in his or her editorials. In general, the weekly survived by virtue of its local content but even this has been questioned. Cost drove the need for a standardized product. This meant most weeklies took their content from the processed food of the newspaper world - the patent inside pages of news content and entertainment printed in the city and shipped by train to the town for the town editor to print local news and advertising on the blank backs.

The niche publication type with which the rural Journal claimed affinity was the farm press. Again this is a form of journalism which has not been given a great deal of scholarly focus. Rural historians have looked at the farm press but usually see it as a repository of information on rural life and farming. John Fry has gone beyond this to look at the farm press as an actor in his study The Farm Press, Reform and Rural Change. He 
focuses on how the mid-western newspapers of his study addressed the County Life agenda of church, school and family life. He finds essentially what communication studies find about the press in general. The farm journals could only suggest to readers what to think on issues. The readers chose their own reading of what had been published. Understanding the Ottawa Valley Journal's sudden interest in 1900 in becoming a mover and shaker in rural reform requires placing the Journal within the history of the North American newspaper. Canadian newspaper development followed the American trends but with Canadian twists as discussed by Paul Rutherford and Minko Sotiron. Due to differing conditions in Canada of politics, capital availability and size of market the links between political parties and newspapers lasted longer in Canada than in the United States. Yet, whether officially party-funded or officially independent, Canadian newspapers were always political. At the same time, as technology drove costs higher at the end of the nineteenth century, advertising dollars and circulation numbers became essential to Canadian newspaper publishers. Newspapers were a product that had to be attractive to a wide range of consumers. By the 1880 s the Montreal Star was introducing to Canada the idea of activist journalism, combining relentless salesmanship with human interest crusades in its efforts to sell itself as a people's newspaper.

Despite the rural Journal being off the beaten track of journalism history, I am encouraged as a rural historian to study the country-city relationship in its pages between 1899 and 1920. Specifically it must be looked at as a vehicle of reform, as this was expressed in the New Journalism of the 1880s and 1890s. The rural Journal opens a unique window on agrarian reform due to its use of the urban model of late-nineteenthcentury New Journalism to reach farm-based readers. 


\section{Chapter 3: Being Rural, Being Modern}

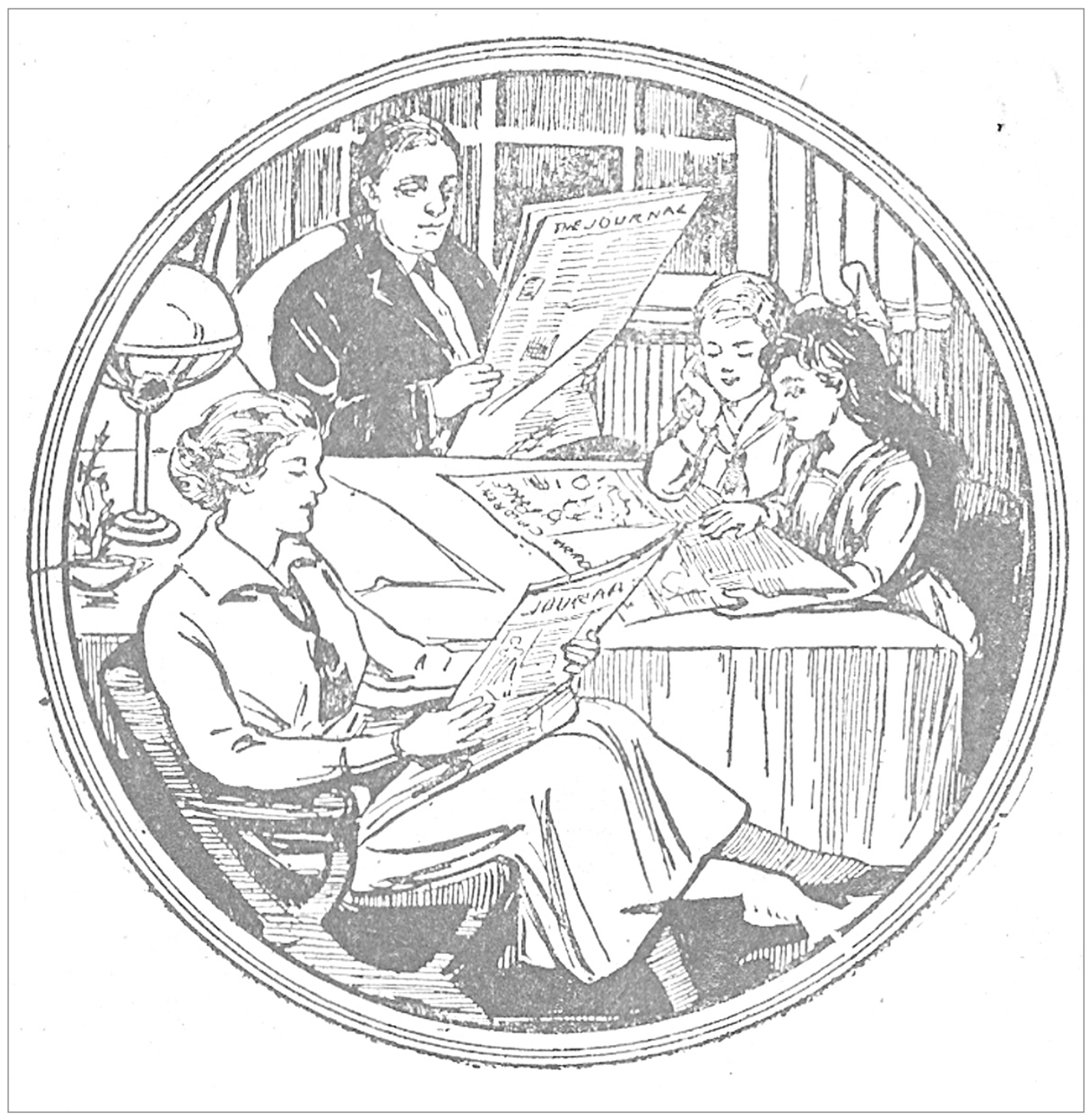

Fig. 3.1, Illustration from Sales Pamphlet, Ottawa Farm Journal, c.1919/1920, collection of Bruce S. Elliott. The same illustration was used on an expiry notice from the Ottawa Farm Journal dated October 1918 with the caption "The Home Circle."

(https://www.facebook.com/LostOttawa/posts/514990095266886) Accessed October 25, 2017.

At the end of the First World War the rural Journal depicted its "home circle" readers as a modern middle-class family in their dress, furnishings and, it seems, in limiting their family to two children. This chapter explores the context for the rural Journal's depiction of the modern farm family by looking at how "modern" has been defined and knowledge understood as well as the historiography of agrarianism. Together these contextualize later chapters exploring the newspaper's discourse about progress and improvement. 


\section{Introduction}

In Chapter 2 I looked at the historiography of the North American newspaper with particular focus on the New Journalism of the 1880s and 1890s, in order to contextualize the chapters on the rural Journal's activism in the early twentieth century. This chapter forms the other important contextual background, the intellectual milieu within which the newspaper was working. Specifically I look here at theorization of the terms "modern" and "knowledge" as well as the historiography of agrarianism in the period from the 1890s to the First World War.

"Modern" and "Modernity" together form a multi-faceted phenomenon in which changes in a range of external factors (inter alia the state and governmentality, economics and social relations, industry and business, mass production and consumption) alter how people understand themselves and the world around them. It has largely been theorized as urban but I argue that rural Eastern Ontarians experienced the same changes as urban Canadians although some changes came at them indirectly. I will first address how the term has been defined by sociologists and cultural theorists and then discuss scholarly work on knowledge with particular attention to the relationship between knowledge and modernity. I will follow this with the historiography of agrarianism to explain how scholars have discussed the relationship between being modern and being rural.

\section{Is "Modern" Just for the City?}

In the chapters that follow I ask how the rural Journal used the words "progressive," "modern" and "business-like" to commend a person, thing or idea. In this chapter I look at how various theorists of the Modern and Modernity address the theme 
differently while all pointing to an underlying theme of disruption. ${ }^{1}$ Disruption is not simply a result of change as all societies, even the most traditional, experience changing conditions. Disruption comes only when change is made obvious. Some individuals find self-affirmation in disruption, seeing themselves marching into the future unhindered by old ideas. Others find disquiet and doubt in disruption as they worry about what they might be losing.

\section{$\underline{\text { Defining Modern }}$}

While scholars have asked whether the term "modern" has any value as an analytical tool, I argue here that it is useful for explaining the tensions farm families felt in the early decades of the twentieth century. ${ }^{2}$ In the chapters which follow I will discuss the impact of increasing state-controlled agricultural education, state intervention in local roads, questions of property tax assessments, and access to British markets for cheese.

These were all connected to key elements of modernity in terms of the changing relationship of the individual with the state and with global capitalist markets for food and the resulting sense of disruption from local as well as rural practice.

David Harvey, a cultural geographer and social theorist, historicizes modernity as a product of the European Enlightenments in which certain ways of thinking came to dominate intellectual life. He describes this as a belief in rationality, science and technology, along with a privileging of the secular while dismissing religion as superstition. All of this, he argues, involves a definitive break from the past. He traces

\footnotetext{
${ }^{1}$ Modern and Modernity are often studied as a triplet with "modernism." I have set this third term aside as not being helpful for this study. It is generally used as a cultural term related to a style of art, architecture, literature and so on and is characterized by a break from classical forms of high culture.

${ }^{2}$ See the 2011 round-table articles in the American Historical Review 16, no. 3 (June 2011) for the range of views on the need for and usefulness of "modern" as an analytical concept. Even if scholars could agree precisely on what the term means, Post-Colonial studies have alerted academia to the European bias of the term and how it has been used to deny the legitimacy of non-European knowledge.
} 
this way of thinking forward to Nietzsche's concept of "creative destruction" in which the past must be eradicated branch and root if the present is to take its proper shape. The result is that people have broken away from their historic moorings. ${ }^{3}$ Anthony Giddens, studying modernity as a sociologist, finds it in expansionary capitalism, albeit a capitalism with the same "modern" values as those identified by Harvey. Another characteristic of this new capitalism is the prevalence of technological improvements aimed at increasing productivity. ${ }^{4}$ The result for Giddens is that the modern has a dynamism missing in non-modern societies, for "unlike any preceding culture [modern society] lives in the future rather than in the past."

Stuart Hall in his introduction to a collection of essays on the formation of "modernity" stresses that there is no single path to modernity. It is as much a cultural formation as it is economic. At the same time by focusing on formation of modernity and organizing the text into separate threads - the formation of the modern state, of a modern economy with changed labour relations, of the social sciences (sociology and economics), of new class and gender relations, of new cultural and religious values - the book points to a realization that none of these elements have to happen together. In particular, the formation of a modern state and capitalist structures can quickly outpace changes in class or gender as well as in values. To the extant that Hall gives a single answer as to what modernity is, he describes it as a conviction that change is inevitable, is already underway and is good. ${ }^{6}$

\footnotetext{
${ }^{3}$ David Harvey, "Modernity and Modernism," in The Condition of Postmodernity, (Cambridge, Mass.: Basil Blackwell, 1989), 10-38.

${ }^{4}$ Anthony Giddens and Christopher Pierson, Conversations with Anthony Giddens: Making Sense of Modernity, (Stanford, Calif., Stanford University Press, 1998), 95.

${ }^{5}$ Ibid., 94.

${ }^{6}$ Stuart Hall, "Introduction," in Modernity: An Introduction to Modern Societies ed. Stuart Hall, David Held, Don Hubert and Kenneth Thompson (Cambridge, Mass.: Blackwell Publishers, 1996), 11-17.
} 
The entries for "modern" in Routledge's Cultural Theory: The Key Concepts and in Keywords, a 2005 vocabulary guide, point out that the word has shifted from an original (and simple) naming of present time to a relational claim with, in addition, the connotation of novelty. In the eighteenth and nineteenth centuries modernity was most apparent in Euro-American technology and science. In the nineteenth century these became linked to the word "progress" and its figurative meaning of growth and improvement suggesting natural, desirable and necessary change. The Routledge guide, Cultural Theory, states that sociologists, starting with Emile Durkheim, brought the concept of the modern into academia as a binary of a pre-industrial traditional and an industrial modern. ${ }^{7}$

Susan Stanford Friedman is a cultural critic who finds that the three termsmodern, modernism, and modernity — are deployed in contradictory ways which make them problematic categories of analysis. The problem is further complicated as the words have slightly different meanings. Friedman argues that there are two approaches to understanding the terms. There is the definitional approach which uses the terms as Harvey and Giddens have done (as science, order, and rationality) but the definitions are constrained by the characteristics of pre-chosen exemplars the scholar believes the terms to encompass. The other approach is relational in which the scholar describes a rupture with whatever he or she defines as tradition, whether the science, order, and rationality of the Enlightenments or the progress and order of the Victorians. In general, the social sciences emphasize the definitional while cultural studies are concerned with the

\footnotetext{
7 "AE" [Andrew Edgar] "Modernism," in Cultural Theory: The Key Concepts, ed. Andrew Edgar and Peter Sedwick (London: Routledge, 2002), 244-6; Meaghan Morris and Naoki Sakai, "Modern," in New Keywords: A Revised Vocabulary of Culture and Society ed. Tony Bennett, Lawrence Grossberg and Meaghan Morris (Malden, Mass.: Blackwell Publishing, 2005), 219-24.
} 
relational. But the problem does not rest simply in uses by different disciplines. Friedman quotes from Harvey's The Condition of Postmodernity to argue that he uses both approaches in different parts of his argument. ${ }^{8}$ She concludes that the definitional mode has so much in-built dissonance as to be a useless category of analysis while the relational mode is insufficiently descriptive for understanding the process of forming a "modern" present. Still she argues that all the terms are needed if academics are not to drown in a sea of phenomena. ${ }^{9}$

\section{$\underline{\text { City-Country Binaries }}$}

In general, the dynamism and change associated with "modern" has been seen as a product of the city. It is this sense of modern which informs Walter Benjamin's work The Arcades of Paris and Michel de Certeau's The Practice of Everyday Life. Both use cities as spaces in which being modern is visible and therefore "thinkable." ${ }^{10}$ Cultural theorist Raymond Williams argues that starting with Hesiod in the 8th century BCE ideas about city and country give insight into the societal fears and aspirations of the educated elite of a period, that is those who express themselves in literature. ${ }^{11}$ Williams is perhaps the most sympathetic of non-agrarian writers to the concept of country, perhaps because he was trying to bring together his childhood in a working class village family and his adult life as a Cambridge academic. As he points out none of the literary concepts, from Karl Marx's "idiocy of rural life" to the dark dangers of the city, have anything to do with the realities of either country or city life. They underline, however, how rural is always

\footnotetext{
${ }^{8}$ Susan Stanford Friedman, "Definitional Excursions: The Meanings of Modern/Modernity/Modernism," Modernism/modernity, 8, no 3 (Sept 2001): 493-8, 503-4.

${ }^{9}$ Ibid., 503-10.

${ }^{10}$ Walter Benjamin, The Arcades Project, trans. Howard Elland and Kevin McLaughlin (Cambridge, Mass.: Belknap Press, 1999); Michel De Certeau, The Practice of Everyday Life, trans. Steven Rendall (Berkeley: University of California Press, 1984).

${ }^{11}$ Raymond Williams, The Country and the City (London: Chatto and Windus, 1973).
} 
othered while urban is the norm. If a writer fears that "modern" urban living is unnatural and thereby destructive of human virtue, "traditional" rural life is praised. If urban living is seen as the way of human freedom, rural backwardness is criticized.

The range of works cited by Williams, in time, in space, and in genres, illustrate his argument that both equations - country $=$ tradition and city $=$ modern - have simultaneously embodied aspiration and rejection going back probably to the earliest mud-brick village. Their meanings and values are constantly shifting depending on the cultural concerns of the period and the motivations of the speaker. Thus, a medieval commentary on the commercialism of city life critiqued different ills and different virtues in society than Charles Baudelaire did in writing about the mobility and freedom of the Parisian flaneur. Yet both reflect the interests and concerns of a class. ${ }^{12}$ The question then becomes, not whether a speaker is expressing a belief in a golden pastoral age or a belief in the potential of science and agricultural productivity, but why these ideas mattered to that speaker and why he or she assumed readers would share, or at least be receptive to, those ideas. We need to ask on hearing the word "modern" who was using it and to what purpose because there is power to condemn and to approve wrapped in it. The linguistic turn is not dead for scholars have learned from it to historicize terminology such as "modern" for its use as rhetoric. In the chapters on the campaigns I will look at how the rural Journal used words in defining modern knowledge.

\section{Thinking About Knowledge}

Chapter 6 looks at the Ottawa Valley Journal as it encouraged agricultural fair organizers to engage expert judges who could disseminate authoritative agricultural

\footnotetext{
12 Ibid., 289-91. And indeed Baudelaire's focus on the city flaneur ignores the much more numerous urbanites for whom the city is a place of work and not a place of exploration.
} 
knowledge. In that chapter I discuss both acceptance of and resistance to the hegemonic linking of expert judges and authoritative knowledge which grew out of the emerging new sciences of the late nineteenth century. Giddens calls expertise, and not just knowledge in general, "a key part" of the modern. ${ }^{13}$ There is a paradox here as expertise can be understood as whatever knowledge is official and authoritative in a particular society. Giddens's characterization of knowledge in a traditional society (singular, secret and learned in rituals) would seem to support such expertise as authoritative knowledge while he presents modern knowledge as ephemeral and multiple. This seemingly would lead to fragmented personalized knowledge and not authoritative knowledge. ${ }^{14}$ At the same time ephemeral and multiple knowledges reflect the sense of "disruption" attached to modernity.

Disruption does not automatically come out of "change" as such, even changes in dominant knowledge. Change always exists, even in traditional societies. Societies which are not self-consciously modern can make change seem to disappear by tweaking customs, culture and official knowledge so that they incorporate change. People who define themselves as "modern" may celebrate change as progress — that is, improvement — but even societies which consider themselves modern may invent "traditions" in order to create a usable past for help in coping with change. ${ }^{15}$ I suggest we need to disconnect expert knowledge from "modern" by considering the changing nature of authoritative knowledge and the kind of knowledge which challenges it.

Michel Foucault in The Order of Things looks at how three European historical

\footnotetext{
${ }^{13}$ Giddens and Pierson, Conversations, 110.

14 Ibid., 110-2.

${ }^{15}$ Eric Hobsbawm, "Introduction: Inventing Traditions," in The Invention of Tradition ed. Eric Hobsbawm and Terence Ranger (Cambridge, U.K.: Cambridge University Press, 1983), 2-3.
} 
periods organized knowledge of the world into classes of things which belong together versus things which do not. He calls these different ways of codifying the world "epistemes" and characterizes the first of these, a Renaissance episteme, as "relational." In this episteme, objects were understood and organized based on analogy and resemblance while boundaries between things and between groups of things were fluid. ${ }^{16}$ Thus, for example, the common garden perennial, the pulmonaria, was used as a cure for lung diseases because of the resemblance between its spotted leaves and a diseased lung (thereby acquiring its botanical name). Foucault calls his second episteme "classical" and links it to the European Enlightenments when knowledge was based on resemblances found through measurement. Objects in this knowledge-world were tightly structured into hierarchies allowing each to be known based on its place in the hierarchy and its linkages to other objects classified with them. But at the same time what is known is the outward manifestations. Foucault differentiates this from "modern" knowledge. Foucault's interest here, as in a number of his other texts, is to trace the "human sciences" which arose in the late nineteenth century and which, in the name of improving human life, can exercise power medically, legally and socially. Specifically he argues here that "modern knowledge" includes humans as objects of scientific study, presumably psychology, criminology, sociology. But he also writes that it aims to classify by underlying connections which I understand to be those connections which only a trained expert can draw out. ${ }^{17}$ What is key from this for my study is Foucault's argument that what is thinkable, knowable and say-able is constrained by the prevailing episteme of one's age. To put these forms of knowledge into agrarian terms, agricultural knowledge in a

\footnotetext{
${ }^{16}$ Michel Foucault, The Order of Things: An Archaeology of the Human Sciences (New York: Vintage Books, 1973), 17-30.

${ }^{17}$ Ibid., 53-8, 168-9, 345-55.
} 
classical knowledge-world was concerned with recognizing the science of animals and plants within botanical and biological "families" which could be studied and managed as "natural" hierarchies. Late nineteenth-century farmers looked at agriculture in this knowledge-world. The "classical" agrarian episteme is also different from "modern" agrarian knowledge. The "classical" expert would, for example, write in the newspaper about judging a bull's usefulness by looking for a masculine, heavy head. A "modern" agriculturalist would probably ignore the bull's head and ask for a sperm count.

There are also important distinctions between official knowledge or expertise and practical knowledge. In Seeing Like a State, James C. Scott looks at the difference between the official knowledge used by states in various utopian projects and practical or day-to-day knowledge which he places in opposition. He finds these official knowledges were expounded by experts who had learned their field of expertise by simplifying and systematizing the messy details of the real world. He calls practical knowledge "mētis" knowledge and describes it as unsystematized and thereby able to see and respond to details which disrupt systematized knowledge when it is put into operation. ${ }^{18}$ Bridget Hamilton and Elizabeth Manias present much the same opposition between practical and official knowledge in a study of nursing practices but they come to their analysis through Michel Foucault's concept of local knowledge. ${ }^{19}$

Jeffery Taylor in Fashioning Farmers looks at language as a barometer of knowledge. He argues that government agricultural experts in Manitoba joined with the new professionals of rural science to merge rural sociology, rural economics and

\footnotetext{
${ }^{18}$ James C. Scott, Seeing Like a State: How Certain Schemes to Improve the Human Condition Have Failed (New Haven: Yale University Press, 1998).

${ }^{19}$ Bridget Hamilton and Elizabeth Manias, "Foucault's Concept of 'Local Knowledges' for Researching Nursing Practice,” Aporia: The Nursing Journal 1, no. 3 (July 2009): 7-17.
} 
agricultural science into a conservative agrarian ideology. This ideology joined with structural forces created by the global wheat market to dominate agricultural education and eventually, by the 1920s, farmers' self-knowledge. He ends by arguing that a modern, business-centred ideology had "confront[ed] and transform[ed] the radical language of the Patrons of Industry leaving only a residual of radicalism available for farmers seeking to self-fashion themselves. ${ }^{, 20}$ I will continue to return to Taylor through the remaining chapters as I deal with the question of hegemonic knowledge. The rural Journal editors in their articles and their readers in published letters at times accepted certain ideas as so natural as to make anything else unthinkable but at other times resisted official claims as to what was correct knowledge.

The understanding of knowledge and language which underlies my own analysis is that they interact in the press through the adjectives and metaphors used to present commentary and advice as that of reasonable people, in short, knowledge which authority has made obvious and natural. John Walsh looks at how local newspapers constructed such a hegemonic knowledge of the desirability of modernity as part of celebrating Ottawa Valley Old Home Weeks in the early twentieth century. While Walsh references scholars who have characterized the events as an economic activity to draw in tourist dollars (which they were on one level), he is concerned with their effect of creating a sense of place for both visitors and residents. Walsh argues that the towns built a sense of a traditional, even nostalgic, place at the same time as they celebrated being modern. On the one hand newspapers sought out and highlighted stories by the expatriates about their childhood memories and places - the old school was a particular favourite. On the other,

\footnotetext{
${ }^{20}$ Jeffery Taylor, Fashioning Farmers: Ideology, Agricultural Knowledge and the Manitoba Farm Movement, 1890-1925 (Regina: Canadian Plains Research Center, 1994), 1, 90, 118. See more on the Patrons later in this chapter.
} 
they highlighted the industry and success of the town with "then and now" pictures in souvenir booklets which emphasized all the modern new buildings. ${ }^{21}$

When the newspapers chose in promoting their town Old Home Weeks to celebrate both the past and the present, they highlighted the modern as the small town desirable. Moving beyond specific historical events, the press generally had a choice as to whether it should ignore "foolish" or out-dated farm knowledge or correct it, which meant admitting its continued hold among some in the rural population. Yet such knowledge did continue whether it was "subjugated" knowledge which was actively suppressed or "tacit" knowledge which was tolerated because it greased everyday wheels. Moon-farming, as an example, had faded away into the safe category of folklore but farmers continued to try to balance what they were told to do by experts with what they knew about the specific conditions on their land. They also had to decide whether they would take their views on politics and economics from reformers with expert collegelearned knowledge or from radicals making a claim to authority based on agricultural fundamentalism. This balancing between authoritative and practical knowledge I consider in the Ottawa Valley Journal's campaigns on both agricultural fairs and roads in Chapters 6 and 7. In the next section I consider how scholars have characterized agrarianism as the rural face of broader reform movements.

\section{A Reform Stew for the Countryside: Agrarianism and Populism, Progressivism and Country Life}

In the United States of the 1890s, agrarian activism was expressed through the Populist Party and its connection with the Democrat presidential candidate William

\footnotetext{
${ }^{21}$ John C. Walsh, "Performing Public Memory and Re-Placing Home in the Ottawa Valley, 1900-58," in Placing Memory and Remembering Place in Canada, ed. James Opp and John C. Walsh (Vancouver: UBC Press, 2010), 25-56.
} 
Jennings Bryan. With Bryan's loss to William McKinley in 1896 and the beginnings of two decades of high produce prices and (comparative) agricultural prosperity, American farmers ceased to act out their resentments politically. Yet at the end of the nineteenth century the city began to set the tune to which both residents of small towns and farmers would have to dance. Reform activity did continue but involved a range of urban middleclass reform groups which have been lumped together as "Progressives.",22 There was a rural side to progressivism called the Country Life Movement in which experts sought to improve or modernize rural living conditions, but on urban terms. Agrarianism in Canada followed the American phenomena with no more than a few years delay.

The early life of the rural Journal was in the 1890s in the era of Populism in the United States and Patronism in Canada but the newspaper was then largely a copy of the urban daily. As will be explored in the next two chapters the rural Journal did not become active in rural issues until the first decade of the twentieth century. This was a period of relative agrarian quiet accompanied by increasing urban interest in improving how country residents lived. In this section I will begin by examining the American historiography on agrarianism in the 1890s through to Theodore Roosevelt's Country Life Commission in 1908-09. I will then consider the Canadian historiography.

\section{The American Histories}

John Fry structures his study of the farm press around the Country Life

Movement. He characterizes its historiography as shifting over time through three phases. In the 1960s and 1970s historians of progressivism told a triumphal story in which the

\footnotetext{
${ }^{22}$ Cf. Daniel T. Rodgers, "In Search of Progressivism," Reviews in American History 10, no. 4 (December 1982): 113-32 for a discussion of the analytical usefulness of the term "progressivism." Rodgers argues that, while no-one described themselves as a progressive (the term only came into use in 1910-11) and there were multiple ideas in contestation, reformers used a shared set of ideas for critiquing society.
} 
Country Life remaking of the countryside was an inevitable and progressive response to overwhelming forces of modernity (Fry's prime example being Robert Weibe's The Search for Order). In the 1970s agricultural historians wrote about resistance to the reformers' efforts to remake the countryside, a resistance which was in the end lost (David Danbom, The Resisted Revolution, and William Bowers, The Country Life Movement in America). He ends with the New Rural Historians presenting a complex relationship between farm families and forces of progress in which there were multiple paths towards modernity (Hal Barron, Mixed Harvest, and Danbom, Born in the Country). ${ }^{23}$ The only historiographical study I have found to date on the Canadian country reform experience is not about the movement itself, but rather about the origins of rural sociology in it. ${ }^{24}$

Fry does not mention that the American history of reform between the 1880 s and the 1930s is written by historians who largely have an urban story in mind. Certainly three of four major syntheses of the period are decidedly urban: Richard Hofstadter's 1955 The Age of Reform going from populism in the 1890s to the New Deal in the 1930s, Robert Wiebe's 1975 Search for Order for the period 1877 to 1920 and Alan

Trachtenberg's 1982 The Incorporation of America which ends with the 1893 Columbian Exposition. Trachtenberg chose this event as the point when Americans had acquired the

\footnotetext{
${ }^{23}$ John J. Fry, The Farm Press, Reform, and Rural Change, 1895-1920 (New York: Routledge, 2012), xviii-xix. His examples were Robert H. Wiebe, The Search for Order, 1877-1920 (New York: Wang, 1967); David B. Danbom, The Resisted Revolution: Urban America and the Industrialization of Agriculture, 1900-1930 (Ames: Iowa State University Press, 1979); William L. Bowers, The Country Life Movement in America, 1900-1920 (Port Washington, N.Y.: Kennikat Press, 1974); Hal S. Barron, Mixed Harvest: The Second Great Transformation in the Rural North, 1870-1930 (Chapel Hill: University of North Carolina Press, 1997); David B. Danbom, Born in the Country: A History of Rural America (Baltimore: Johns Hopkins University Press, 1995).

${ }^{24}$ T. Lynn Smith, "La sociologie rurale aux États-Unis et au Canada," Rural Sociology 6, 1 (1957):19-23.
} 
vocabulary to understand and thereby to critique large corporate interests. ${ }^{25}$ In all of these histories farm families are presented as an undifferentiated mass which was the object of reform activity. The fourth synthesis is different. David Danbom's 1995 Born in the Country takes rural America as its central site of analysis with rural people exercising agency. ${ }^{26}$ Yet this is the agency of the weak in which rural residents attempted to reshape forces of change which they had not initiated and could not control.

Academics have generally identified three forms of agrarianism based in different views of rural life which weave together in varying intensities depending on the writers and the writer's purpose. ${ }^{27}$ Most studies focus on the form in which the labour of farming was made the wellspring of all virtue (a view called pastoralism, agrarian romanticism, the agrarian myth, or urban agrarianism). Hofstadter argues that in the United States pastoralism was transformed into "a mass creed" connecting American democracy with the family farm. He illustrates its importance with a photograph of Calvin Coolidge wearing a white shirt and city shoes while dressed in overalls and sitting on a hay rig, his city car just visible in the background. ${ }^{28}$ This places Coolidge among the commentators on rural life whom Hofstadter calls flatterers. The second form of agrarianism was expressed by the commentators Hofstadter calls critics. These were urban-based officials

\footnotetext{
${ }^{25}$ Richard Hofstadter, The Age of Reform: From Bryan to F.D.R. (New York: Knopf, 1955); Wiebe, Search for Order; Alan Trachtenberg, The Incorporation of America: Culture and Society in the Gilded Age (New York: Hill and Wang, 1982).

${ }^{26}$ Danbom, Born in the Country.

${ }^{27}$ Different scholars have stressed one, two or all three depending on their purposes. As well as Hofstadter, Age of Reform (who takes a dated view, but useful for showing an urban perspective), see Bowers, The Country Life Movement in America for the tension between romantic and scientific agrarianism. Adam Crerar, "Writing across the Rural-Urban Divide: The Case of Peter McArthur, 1909-24," Journal of Canadian Studies 41, no. 2 (Spring 2007) looks at how one writer combined romantic and scientific agrarianism. See Williams, The Country and the City for a description of romantic agrarianism in British literary works across different periods. Agricultural romanticism was discussed in two articles in the 1930s, Paul Johnstone "In Praise of Husbandry," Agricultural History 11, no. 2 (April 1937): 80-95 and "Turnips and Romanticism," Agricultural History 12, no. 3 (July 1938): 224-55.

${ }^{28}$ Hofstadter, Age of Reform, 24-31.
} 
and experts who saw rural residents as obstructing progress. Rural life, starting with the people, needed to be transformed through agricultural science, rural economics and rural sociology. $^{29}$

I suggest that characterizing these forms of agrarianism as a division between flatterers and critics presents rural reform as a mix of farmer self-deception and political manipulation by those cleverer than the farmers. There was a third form of agrarianism called "agricultural fundamentalism" that grew out of the agrarian myth and served the farmers as a point of political resistance. But songs such as The Farmer Feeds Them All, declaring farm production the basis (or fundamental source) of all wealth, were increasingly a sign of farmer blindness to the realities of twentieth century economics. The Ottawa Valley Journal can be identified with two of these forms. Editor Herbert Cowan worked within scientific agrarianism while Robert Faith mixed farmer fundamentalism with his calls for better business deals for the farmer.

Histories of American political agrarianism largely focus on the nineteenth century up to the 1890 s and the Populists. ${ }^{30}$ Progressivism, on the other hand, has been seen as an urban movement. Unfortunately, the perception that the Country Life Movement was urban at its core left it understudied by rural historians while historians of Progressivism ignored it as boringly agricultural. ${ }^{31}$ Yet there are scholars who see that this combination is itself interesting. The first stirring of interest in the Country Life Movement began with two studies of Theodore Roosevelt's 1908-09 Commission on Country Life. Clayton Ellsworth's 1960 article traced the Commission’s intellectual

\footnotetext{
${ }^{29}$ Ibid., 30-5.

${ }^{30}$ For the regional variations of Populism, see Wiebe, Search for Order, 84-8, 100-10; Robert C. McMath, Jr., American Populism: A Social History, 1877-1898 (New York: Hill and Wang, 1993). McMath also looks at political agrarianism's cultural roots in rural social institutions of camp meetings and fraternities. ${ }^{31}$ Danbom, The Resisted Revolution, 183.
} 
history, process and results. ${ }^{32}$ Two years later Betty Clutts's doctoral dissertation "Country Life Aspects of the Progressive Movement" made the connection that there was a rural progressivism. Clutts put her focus on the key actors in the Commission, its work and the public response. ${ }^{33}$ In the 1970s William Bowers used the Commission to structure his more general look at the Country Life Movement by arguing that the Commission articulated the worries and ideas which informed that movement. ${ }^{34}$ All of these were largely institutional histories. Later histories centred directly on the worries discussed by Bowers while also considering the social effects of Country Life's efforts to modernize rural America.

Scott Peters's and Paul Morgan's 2004 critique of much of the accepted historiography of the Country Life Movement focuses back onto the Commission. They argue it made a real effort to include rural residents in finding holistic solutions to rural problems by widely distributing a survey on rural conditions through various channels. ${ }^{35}$ A 1974 analysis of the U.S. Census Bureau's 1908 partial tabulation of that survey supports this argument with $53 \%$ of the 94,000 returns tabulated having come from farmers. The 1908 analysis found that farmers (and the rural teachers who would have been closest to farm families) were the most pessimistic of rural residents about rural economic and social conditions. Those who were positive about conditions included rural newspaper editors and publishers, a finding of some interest for speculating how the

\footnotetext{
${ }^{32}$ Clayton S. Ellsworth, "Theodore Roosevelt's Country Life Commission," Agricultural History 34, no. 4 (October 1960): 155-72.

${ }^{33}$ Betty Carol Clutts, "Country Life Aspects of the Progressive Movement" (Ph.D. diss., Ohio State University, 1962).

${ }^{34}$ Bowers, The Country Life Movement.

${ }^{35}$ Scott J. Peters and Paul A. Morgan, "The Country Life Commission: Reconsidering a Milestone in American Agricultural History," Agricultural History 78, no. 3 (Summer 2004): 289-316.
} 
Ottawa Valley Journal might have responded had it been surveyed. ${ }^{36}$ The potential gap between newspaper editorials and reader response on agrarian issues is part of the puzzle being addressed in the chapters on the rural Journal's campaigns.

In general Peters and Morgan are rebutting a negative historical assessment of the general Country Life Movement with a positive view of a Commission which was a specific and time-limited activity by a small group of men. The general movement was, like progressivism, a much vaguer thing to try to understand, whether studying it in the United States or in Canada.

\section{$\underline{\text { The Canadian Histories }}$}

Louis Aubrey Wood's 1924 history may have been the first history of Canadian agrarian reform movements but it is really a first person memoir written by a participant. Wood, echoed by Richard Van Loon, states that the Grange or Patrons of Husbandry was "the tap-root" of all later Canadian political agrarianism. ${ }^{37}$ It had arrived in Canada from the United States in 1872. The Patrons of Industry or Patronism followed in 1889 and had formed a political party in Ontario by 1891. Patronism had some electoral success in 1894 but this was in the Ontario legislature which had no jurisdiction over the Patrons' big issue, the federal tariff. Patronism quickly dwindled while resistance to tariffs continued on as an issue of the Dominion Grange headed by future leaders of the United

\footnotetext{
${ }^{36}$ Olaf F. Larson and Thomas B. Jones, "The Unpublished Data from Roosevelt's Commission on Country Life," Agricultural History 30, no. 4 (October 1976): 585-9, 597. The Commission received 115,000 responses from a distribution of 500,000 questionnaires and arranged a test analysis on 94,000 returns (about $80 \%$ of the 115,000 returned). The process was stopped due to uncertainty that the responses could be made statistically useful in the time available. The United States Department of Agriculture later destroyed the survey material but the Census Bureau preliminary reports survived in the Cornell University archives.

${ }^{37}$ L.A. Wood, A History of Farmers' Movements in Canada (Toronto: Ryerson Press, 1924); 13; Richard J. Van Loon, "The Political Thought of the United Farmers of Ontario" (master's thesis, Carleton University, 1965), 13.
} 
Farmers of Ontario such as E.C. Drury. ${ }^{38}$ Van Loon states that with Patronism's disappearance as a political force in 1896, "the voice of the farmer became largely stilled" in Ontario until the United Farmers emerged during the First World War. ${ }^{39}$

Academic studies have tended to focus on the Canadian West where agrarian reform lasted much longer than in Ontario and places east. The first major works were those of University of Manitoba historian W.L. Morton on the Progressive Party in the 1920s Prairies and Paul Sharp on Western Canadian agrarianism more generally. ${ }^{40}$ Both historians focused on political programs, electoral activity and leaders. But this agrarianism was more than rural. It was a regional movement. Both town and country Westerners felt Eastern interests and the Liberal and Conservative parties had failed the West by implementing federal tariffs, railway subsidies and rail freight rates which imposed an unnatural east-west economy upon them. Recent studies of the United Farmers of Alberta and Manitoba (which preceded Canada's Progressive Party) have gone beyond institutional history. Bradford Rennie looks at how Albertan farmers went from a general discontent to forming something he argues was a movement and not just an organization. Jeffery Taylor argues that state-sponsored agricultural education eroded radicalism out of agrarian thought by $1920 .^{41}$

Ontario’s agrarian histories are largely biographical and political with a focus on the leaders, E.C. Drury, J.J. Morrison and W.C. Good. Three studies published after 2000

\footnotetext{
${ }^{38}$ Van Loon, "Political Thought," 28.

${ }^{39}$ Ibid., 30.

${ }^{40}$ W.L. Morton, The Progressive Party in Canada (Toronto: University of Toronto Press, 1950); Paul F. Sharp, The Agrarian Revolt in Western Canada: A Survey Showing American Parallels (1948, repr. New York: Octagon Books, 1971). Note that, in the Canadian West, progressivism was not the vague American movement of the early twentieth century but a rural political movement begun immediately after the First World War.

${ }^{41}$ Bradford James Rennie, The Rise of Agrarian Democracy: The United Farmers and Farm Women of Alberta (Toronto: University of Toronto Press, 2000); Taylor, Fashioning Farmers.
} 
have, however, looked at the agrarian experience in Ontario. Kerry Badgley examines the beliefs and ideals of rank-and-file members in Ontario in the 1910s while Mark Dorsey looks at how the United Farmers of Ontario shaped farmers' identity. Darren Ferry has looked at the same question of identity with respect to the earlier agrarianism of the Grange and the Patrons. ${ }^{42}$

The Country Life Movement in Canada has not been as deeply studied as it has been in the United States although it was quickly adopted by Canadian reformers. Just as in the United States the movement was largely driven by commentators concerned about the economic and moral danger to the nation from rural depopulation. But not everyone agreed this was an issue. William Young looks at a political debate which raged over depopulation between "radical" commentators such as the Weekly Sun, Drury and Good versus the Canadian Countryman and the Ontario Department of Agriculture. ${ }^{43}$ For those who saw danger in growing cities and stagnating country places, the answer was to modernize the countryside so that young people would not be enticed away to the city. This was to be achieved by modernizing farm family life and encouraging cooperativism. Speaking grossly, radicalism sought to preserve farmer power by changing society while reformers sought to change farmers to make them more urbanized in thought and behaviour and thereby more modern. Nevertheless, it can be argued that whether under the influence of reform or radicalism, farmers were increasingly aware in

\footnotetext{
${ }^{42}$ R. Kerry Badgley, Ringing in the Common Love of Good: The United Farmers of Ontario, 1914-1926 (Montreal: McGill-Queen's University Press, 2000); Mark Dorsey, "The U.F.O. and the Broadening-out Controversy: Crisis of Farmer Identity in a Changing World," in SURG (Studies by Undergraduate Researchers at Guelph) 2, no. 1 (Fall 2008): 39-46; https://journal.lib.uoguelph.ca/index.php/surg/article/view/797 Accessed July 16, 2017; Darren Ferry, "'Severing the Connections in a Complex Community': The Grange, the Patrons of Industry and the Construction/Contestation of a Late 19th-Century Agrarian Identity in Ontario," Labour 54 (Fall 2004): 947.

${ }^{43}$ William Robert Young, "The Countryside on the Defensive: Agricultural Ontario's Views of Rural Depopulation, 1900-1914” (master's thesis, University of British Columbia, 1971).
} 
this period that they had interests and concerns distinct from urban interests.

In the United States, the movement's principles and ideas had been first articulated in Roosevelt's 1908-09 Country Life Commission. The Canadian government announced the establishment of a Commission of Conservation the following year (1909) but it was inspired by a different Roosevelt commission, his 1908 National Conservation Commission concerned with water, forests, land and minerals. Both American commissions (Country Life and Conservation) as active governmental initiatives quickly faded into history. The Canadian Commission lasted much longer (to 1921) but its life, character and its eventual death were closely tied to the influence of its chair (and former Minister of the Interior in Laurier's Liberal government) Clifford Sifton. ${ }^{44}$ Its impact has, however, been largely studied in three non-agricultural history streams: environmental history, planning history and public health history.

The Canadian Commission took the same broad focus on natural resources as the American with a Land Committee focusing on agriculture and soil depletion. It added, however, a social dimension in a Public Health Committee. This last approximated Roosevelt's Country Life Commission although its chair from 1915 on, Thomas Adams, was concerned with town and city planning. ${ }^{45}$ Sifton, however, was concerned with rural depopulation as a "race" problem for the nation because he believed that most leading men in public life had come or their parents had come from farms. ${ }^{46}$ After all, if there

\footnotetext{
${ }^{44}$ P.J. Smith, "Commission of Conservation," in The Canadian Encyclopedia. http://www.thecanadianencyclopedia.ca/en/article/commission-of-conservation/. Accessed August 12, 2014. Frank Tough states that the Commission began holding annual conferences in 1910; Frank Tough, "Conservation and the Indian: Clifford Sifton's Commission of Conservation, 1910-1919," Native Studies Review 8, no. 1 (1992): 61.

${ }^{45}$ D.J. Hall, "The Commission of Conservation (1909-21)," in Clifford Sifton: A Lonely Eminence, 1901 1929 (Vancouver: University of British Columbia Press, 1985), 2: 253-8. Adams was a British town planner known for his writings on the Garden City.

${ }^{46}$ Ibid., 253. Undoubtedly true given that at the time most Canadians had a farm background, especially if
} 
were fewer farm families, whose sons would lead the country? Yet even though the Canadian Commission lasted much longer than its American predecessors, except for Adams's town planning work, it had equally limited results. Public health work was stymied by jurisdictional questions of who should do what or should anything be done at all. The Land Committee was stymied by farmers' disinterest in agricultural reform. ${ }^{47}$

The Canadian Country Life Movement is most clearly laid out in a 1913 book, Rural Life in Canada, by John MacDougall. ${ }^{48}$ MacDougall was a small-town (Spencerville, Ontario) minister writing at the request of the Presbyterian Church in Canada but he had influential connections. The book's original introduction was written by James Robertson, then chair of the Conservation Commission's Committee on Land. ${ }^{49}$ MacDougall raised two major problems for the Church to address. First he used statistics to prove the existence of rural depopulation (exacerbated in his opinion by the migration of French Canadians into Eastern Ontario and Quebec's Eastern Townships). And then he used his own experiences as a minister to show the adverse results on community life of the declining (and linguistically changing) population. ${ }^{50}$

MacDougall's solutions for economic problems (agricultural specialization, shifting waste land into forestry and organizing co-operatives) came out of the relatively new academic field of political economy and he presented his solutions as "modern" and

\footnotetext{
one counts back to farming grandparents as Sifton did. Nevertheless this is an instance of Canadian acceptance of the American agrarian myth that rural values were the basis of democracy. The myth perhaps was not as deep in Canada. The imagination rebels at the thought of R.B. Bennett or Mackenzie King being photographed in overalls as Coolidge had been.

${ }^{47}$ Ibid., 254, 257.

48 John MacDougall, Rural Life in Canada: Its Trend and Tasks (1913; repr., Toronto: University of Toronto Press, 1973).

${ }^{49}$ Ian M. Stewart, “James Wilson Robertson” in Dictionary of Canadian Biography, http://www.biographi.ca/en/bio.php?id_nbr=7962, Accessed August 12, 2014. Robertson was also a former Commissioner of Agriculture and Dairying with the Canadian Department of Agriculture and former head of the St. Anne de Bellevue (McDonald) Agricultural College.

${ }^{50}$ John MacDougall, Rural Life, ” 22-40, 44-52.
} 
"scientific." His chapter on the social ills of the countryside listed a number of problems - a shortage of farm labour, lack of social and recreational activities, and hard work destroying the capacity to appreciate the beauty and moral uplift of nature. But he did not have specific solutions to offer except to refer to the "social service" work, or social gospel, of the cities. At the same time he argued that the church did not have to lose its soul while trying to gain the (improved) world. The church could and must work on both spiritual salvation and improving social and economic conditions in this world. ${ }^{51}$ The end result would be to foster "traditional" co-operative values alongside modern rural production, technology, and gender roles in the Canadian countryside. In Chapter 5 on the limits to the rural Journal's activism, I look at its response to the Country Life Movement. The editors' hesitance in acting on these issues highlight their preference for the male work of farm economics and a certain disregard for the issues of gender relations which they may have seen as "soft" issues.

\section{Being Agrarian, Being Modern: Binding a Binary}

There is a general narrative of the Country Life Movement which can be encapsulated as city reform efforts and rural resistance. David Danbom in The Resisted Revolution argues that reformers were pushing for a form of modernization he calls the "industrialization of agriculture." ${ }^{, 2}$ As part of laying out his thesis he references Robert Wiebe's Search for Order. Wiebe argues that starting in the 1870s the early American world of "island communities" was slowly enfolded into an increasingly interconnected national society which was fundamentally urban, middle-class and managerially

\footnotetext{
${ }^{51}$ Ibid., 112-8, 147-8, 167-72, passim.

${ }^{52}$ Danbom, The Resisted Revolution, vii.
} 
bureaucratic. ${ }^{53}$ Christopher Shaw, however, critiques the idea that a single narrative of city versus country can explain the agrarian tensions at the beginning of the twentieth century. He argues this ignores rural class divisions. His prime example was corporate agriculturists successfully lobbying the U.S. Country Life Commission to remove a recommendation that immigrants be encouraged to take up farming. They wanted them as hired labour. ${ }^{54}$

\section{Was There a Divide?}

Adam Crerar points out in his 1999 doctoral dissertation that prior to the First World War country and city residents were not as fundamentally divided as some narratives claim. ${ }^{55}$ He looks closely at a range of sources: the census for demographic and economic change over the period, a collection of letters in which an Ontario farm family worked out their strategy for launching their children into city careers as well as farming, the writings of social science reformers starting with John MacDougall's Rural Life in Canada, and Peter McArthur's columns in the Farmer's Advocate blending literary allusions with realistic discussions of his life as a working farmer. Crerar finds that Ontario's farm population was stable and relatively prosperous through the period. Rural depopulation was not agricultural depopulation. Rather villages and small towns were declining as artisanal industry was out-competed by urban industrial manufacturing. At the same time, there was a continuing urban reservoir of approval for farmers and farm life from city dwellers who had grown up on farms and still retained connections to their farm relatives. Yet for all the positive notes, Crerar also pulls out the negative assessment

\footnotetext{
${ }^{53}$ Wiebe, The Search for Order, xiii-xiv, 18-23, 112-23, passim.

${ }^{54}$ Christopher W. Shaw, "No Place for Class Politics': The Country Life Commission and Immigration," Agricultural History 85, no. 4 (Fall 2011), 520-39.

${ }^{55}$ Adam Crerar, "Ties That Bind: Farming, Agrarian Ideals, and Life in Ontario, 1890-1930," (PhD diss., University of Toronto, 1999).
} 
of social commentators in the years after 1910 and an increasing antagonism in the city press during the First World War. In the examples he provides, the complaints contained vicious stereotypes of rural degeneracy.

Shaw's argument of a rural class divide needs to be considered here as well. While many farmers ignored Country Life encouragement to invest in mechanized and industrialized agriculture, commercial farmers did listen. They had capital to invest and their farm outputs were large enough to distribute increased input costs across production. They were a minority but they were the minority with whom the government experts preferred to work. Urban reformers were also allied with agricultural experts. Both, after all, were imbued with urban middle-class values but as well the social reformers saw an economic basis to societal problems. While the agricultural experts were trying to grow the national wealth, the social reformers wanted farm families to benefit from the twentieth-century promise of prosperity through science, mechanization and business methods. But this agreement created a mix of languages - agrarian myth with scientific agrarianism, traditionalism with modernism — in which different voices were heard simultaneously.

Hal Barron's sub-title, The Second Great Transformation, points us again towards the idea of disruption (as characterized by David Harvey and Anthony Giddens) for understanding rural America in the period around the turn of the twentieth century. ${ }^{56}$ But Barron argues that the rural story of transformation cannot be understood as a binary opposition between traditional and modern. Indeed he argues that even in urban history

\footnotetext{
${ }^{56}$ Hal S. Barron, Mixed Harvest: The Second Great Transformation in the Rural North, 1870-1930 (Chapel Hill: University of North Carolina Press, 1997).
} 
we are in danger of overstating the pervasiveness of change in the period. ${ }^{57}$ Overall he regards the end of the nineteenth and the beginning of the twentieth centuries as a period of change and continuity. In tracing both processes he looks at how farm families responded to the forces emanating from the urban world: first, as citizens responding to efforts to improve roads and consolidate schools; second, as producers establishing cooperatives; and finally as consumers mail ordering city goods. Rural residents were navigating changes which were not of their choosing but these changes were not so alien as to be easily rejected. Their mixed response to change was not due to a stubborn clinging to tradition. Rather they made their choices of how and what to change while maintaining an on-going commitment to control over the world around them. ${ }^{58}$

This concern to maintain control over the local distinguishes Barron's rural residents from Giddens's modern world. Giddens points to the effect of modern capitalism in "disembedding" people from the local. But Giddens argues that disembedding is more than economic. It also affects an understanding of how the world works. ${ }^{59}$ We do not know, for example, which assembly-line workers built the car we drive or which engineer inspected the bridge we drive over. Yet we assume the work was done according to standards and safety checks which are knowable. It is a different view of the world from that of someone who relies on the people and the processes he or she sees first-hand. It requires giving up control to unseen experts. In considering Giddens's characterization of the modern as being disembedded from the local with Barron's

\footnotetext{
${ }^{57}$ Barron makes this argument based on a range of studies; for example he cites Lizabeth Cohen, Making a New Deal: Industrial Workers in Chicago, 1919-1939 (New York: Cambridge University Press, 1990) for her argument that urban working-class Americans did not become "modern" as quickly or as monolithically as has been theorized. He then points to a different argument about the effect of the modern global economy on rural America in William Cronin, Nature's Metropolis: Chicago and the Great West (New York: W.W. Norton, 1991).

${ }_{58}^{58}$ Barron, Mixed Harvest, 8-12.

${ }^{59}$ Giddens, The Consequences of Modernity (Stanford, Calif.: Stanford University Press, 1990), 6, 21-9.
} 
argument that farm families were seeking to protect their sense of local agency and not blindly following tradition, I find that there is no simple way to characterize a rural devotion to the local. It seems that a demand for local agency reflects the rural residents' lack of such agency due to their sense (even if inarticulate) of being disembedded. Certainly late-nineteenth-century farmers who produced wheat or cheese were no longer operating in local markets with local buyers. They were part of a globally-driven economy as described by Jeffery Taylor in regard to Canadian prairie wheat farmers and, as I describe in Chapter 8 in regard to Eastern Ontario dairy farmers and the British cheese market. ${ }^{60}$ An overt devotion to the local can be a response to modernity by those who feel threatened by economic forces which they cannot control.

Ronald Kline's study of rural America finds both change and reshaping of change in the rural use of new consumer technologies. In doing so, he equates modernization with urbanization but not in term of demographics. According to Kline, reformers believed that farm families would change, not only their life styles, but also their views on life as they gained access to urban technology (electricity) and consumer products (from cars, to washing machines, to radios and telephones). They therefore encouraged rural residents to buy technologies first used extensively by urban residents and, in addition, to use them in the same way and for the same purposes. In short, it was not rural spaces that would be urbanized but rather the people in those spaces. He finds a different reality in which rural residents wove new products into existing ways such that, whether called "modernization" or "urbanization," change was a slow and fractured process. Kline's conclusion is that rural residents "create their own forms of modernity.,"61

\footnotetext{
${ }^{60}$ Taylor, Fashioning Farmers, 6-13.

${ }^{61}$ Ronald R. Kline, Consumers in the Country: Technology and Social Change in Rural America
} 
Allan Kulikoff theorizes on a "third way" of conceptualizing rural change, a way which is neither purely economic nor cultural. He would bring together the other two ways, first that of the economic historians who focus on structural changes creating the capitalist system and second that of social historians who use account books and diaries to study cultural resistance to external capitalist forces. He argues that we should study how economic and ideological behaviour intersected as farm families participated in the capitalist market. ${ }^{62}$ Christopher Clark calls this intersection an "interpenetration" of ideas and practices over time. ${ }^{63}$ These insights are borne out in Catharine Wilson's study of pioneer work bees in which a culture of reciprocity co-existed with settler families' awareness of the commercial value of shared work. ${ }^{64}$ Sara Spike, in her study of expressions of visuality in small town newspapers, cites Marshall Berman's All That Is Solid Melts Into Air to articulate her assessment that the rural residents of Nova Scotia were living in two worlds in the late nineteenth century. ${ }^{65}$ I suggest that this was the case for rural residents in Eastern Ontario in the early twentieth century. The result was that they expressed conflict in both modern and traditional terms, by critiquing the market using both business criteria and a standard of fairness. ${ }^{66}$ As well, historian Sally McMurry points out that both "a third way" and "interpenetration" point us away from the binary trap of assuming a conflict between "traditional" farming as a way of life or

(Baltimore: Johns Hopkins University Press, 2000), 6-10. 272-81.

${ }_{62}$ Allan Kulikoff, "The Transition to Capitalism in Rural America," The William and Mary Quarterly 46, no. 1 (January, 1989): 128-33, 136, 144.

${ }^{63}$ Christopher Clark, "Rural America and the Transition to Capitalism," Journal of the Early Republic 16, no. 2 (Summer 1996): 224.

${ }^{64}$ Catharine Anne Wilson, "Reciprocal Work Bees and the Meaning of Neighbourhood," Canadian Historical Review 82, no. 3 (September 2001): 431-64.

${ }^{65}$ Sara Spike, "Modern Eyes: A Cultural History of Vision in Rural Nova Scotia, 1880-1910" (PhD. Diss., Carleton University, 2016): 31-2.

${ }^{66}$ This conflict is most fully explored in the Chapter 8 discussion of the rhetoric used by Journal editor Robert Faith in his campaign on cheese. 
moral economy and profit-motivated farming, or assuming resistance to change was a contest between progressive innovators and backward traditionalists. ${ }^{67}$ It also points us away from assuming a conflict between a purely traditional language of agrarian values and a modern business language of scientific agriculture.

\section{Modernizing Agents}

Harvey, Giddens, Hall and Friedman all touch on disruption, or profound change, as one element of modernity along with a privileging of change and novelty. This is essentially definitional. I suggest it is more important to consider how the term "modern" is used. The Routledge Guide Cultural Theory states that in the nineteenth century modernity became a political agenda and not merely a way of distinguishing oneself or one's society from the past. ${ }^{68}$ As a relational word differentiating between the present and a past from which one wishes to distance oneself, "modern" can go beyond describing a state of mind on the part of the speaker to become a power word-a word used to condemn some people or groups based on their ways of thought and to approve others. In this section I consider how scholars have identified the actors who defined change as "modern" and thereby encouraged a way of thinking and acting for rural residents. I argue that while the metropolitan dailies have been identified as modernizing agents, rural newspapers could also be modernizers.

Some nineteenth-century commentators restricted themselves to advocating rural modernization but a number also acted as modernizing agents. For example, the federal government acted as a modernizing agent in establishing and operating experimental

\footnotetext{
${ }^{67}$ Sally McMurry, Transforming Rural Life: Dairying Families and Agricultural Change, 1820-1885 (Baltimore: The Johns Hopkins University Press, 1995), 23, 44-6, 234.

68 "AE", "Modernism," in Cultural Theory, 244-6.
} 
farms. The Ontario government also set up the province's first agricultural college at Guelph in 1874 to modernize and standardize agricultural processes. In 1907, it began to build a network of locally-based college-educated experts, the county agricultural representatives, to bring science to farmers. It also funded non-governmental groups, in particular agricultural societies, farmers' institutes, and women's institutes, to spread the message of modernization, while ensuring these groups were politically neutered. ${ }^{69}$

Another government-sponsored but essentially commercially-run modernizing agent was Toronto's Canadian National Exhibition (CNE). Keith Walden has studied it specifically for its role in modernizing Victorian society. ${ }^{70}$ His chapter headings encapsulate the themes he uses to examine this process: order, confidence, display, identity, space, entertainment, and carnival all leading to an epilogue entitled modernity. Much of Walden's study focuses on the modernizing of urban culture but he also addresses the expected modernizing impact of the CNE on the rural residents who visited it. Yet it was an ambiguous impact for even as fair-goers from city and country alike agreed on the wonderfulness of progress, they also watched the spectacle of freak shows and experienced the disorder of petty crime. Walden suggests this would have been particularly disconcerting for country visitors but freak shows and petty crime were regular elements in country fairs no matter how much agricultural society directors fought their presence. Country visitors were likely no more disconcerted by the disorder of the CNE than they were by the disorder of their local fairs. ${ }^{71}$ I suggest Walden's

\footnotetext{
${ }^{69}$ For a chronology of agriculture education in Ontario including subsidized non-government organizations see G. Elmore Reaman, A History of Agriculture in Ontario (Don Mills, Ont.: Saunders of Toronto, 1970), 1: 151-63, 2: 76-106.

${ }^{70}$ Keith Walden, Becoming Modern in Toronto: The Industrial Exhibition and the Shaping of a Late Victorian Culture (Toronto: University of Toronto Press, 1997).

${ }^{71}$ At the same time some who objected loudly to disorder at the county fair may have objected even more loudly when they could connect it to the immorality of the city.
} 
analysis is relevant when he speaks of country visitors being disoriented by crowds and fast-moving trolley traffic as well as being sneered at for their rural clothes and manners. These experiences would have left rural visitors ambivalent about the benefits and price of modernization and progress. ${ }^{72}$ In this respect I wonder whether we should not consider the CNE to have been equally an anti-modernizing agent for country visitors even as it impressed them with the technical wonders of modern lighting and new farm machinery.

Paul Rutherford views the Victorian big city dailies as modernizing agents in Canada. He argues it was in their nature as newspapers and the "logic of mass communication" to emphasize the new. And because these dailies reached so many readers, he declares them to have had great influence in shaping Victorian society. ${ }^{73}$ Rutherford describes "modernization" as an ambiguous term but nevertheless applies a definition which links being modern to industrial technology as well as to adjectives of “discordance," “transcience” (referencing Michael Katz’s seminal 1975 study, People of Hamilton), "weakened social bonds" and "social disorder." Rutherford states that all of these gave metropolitan dailies the power to influence people who needed a guide on how to think and act in their new urban world. ${ }^{74}$ He goes into greater depth on the press as a modernizing agent in his chapter entitled "Mythmaking." The first myth was "the dogma of modernity." He summarizes this dogma as encompassing progress, nationality and democracy with progress being "the most hallowed maxim of the age" and change as the fundamental fact of life. Newspapers as purveyors of new information were biased to see change as both fundamental and as essentially good, despite occasional editorials

\footnotetext{
${ }^{72}$ Walden, Becoming Modern in Toronto, 199-214.

${ }^{73}$ Paul Rutherford, A Victorian Authority: The Daily Press in Late Nineteenth-Century Canada (Toronto: University of Toronto Press, 1982), 5, 8.

${ }^{74}$ Ibid., 16-7, 242, fn. 10
} 
decrying some new fashion. ${ }^{75}$

Sandra Gabriele and Paul Moore look at the special weekend newspaper as yet another modernizing agent. The model for these weekend newspapers came from the United States and consisted of every weekend, without fail, the publication and sale of a special newspaper distinct from the newspaper's Saturday edition in terms of production, price and a content consisting solely of light and entertaining information. The concept was introduced in Toronto first through news agents selling the American editions and then in the late 1890s by Toronto's Globe and World both launching their own versions. Gabriele and Moore argue that these weekend newspapers formed part of the circulation of new ideas which brought together mass consumption of leisure, the idea of a leisure weekend, and a popular reading culture, imprinting the combination as modern. ${ }^{76}$ As these ideas centred on weekend leisure, farm families for whom work did not stop for a weekend were not the target audience. Yet the idea of special light weekend reading continued to circulate in the early-twentieth century as city dailies included equivalent features as regular supplements in their Saturday newspapers. In the case of the Journal, special features from the Saturday daily were at times copied into the rural edition in both the Tuesday and the Friday papers. Thus, despite many farm families being left outside the circulation of modern ideas of popular leisure culture, these ideas could penetrate the countryside.

Rutherford views the mass communication of the big city daily as the main shaper of society. Yet even though the big dailies carried a range of information to attract all

\footnotetext{
75 Ibid., 156-7.

${ }^{76}$ Sandra Gabriele and Paul S. Moore, "The Globe on Saturday, the World on Sunday: Toronto Weekend Editions and the Influence of the American Sunday Paper, 1886-1895," Canadian Journal of Communication 34, no. 3 (2009): 342-3.
} 
kinds of readers, they were still anonymous readers as were the readers of the weekend special editions. I suggest Rutherford ignores the power of newspapers that knew their readers and directly focused on their interests. Within the rural context, John Fry looks at the role of the farm press as it defined "modern" by espousing reform and change through school, church and family. He finds from the letters to the editor that readers were not mindlessly shaped by what they read. As in communications agenda-setting theory, the farm papers were giving their readers things to think about. But he also postulates other reasons for rural residents to buy and read newspapers which reflect the ability of newspapers to build a sense of identity. The newspapers talked about issues that generally mattered to their readers even as specific interests varied. As well, the newspaper was a forum for letter writing which appears to have served particularly women and children as a form of community for discussing modern life and tradition. ${ }^{77}$

In this dissertation's remaining chapters I explore how the Ottawa Farm Journal $1919 / 1920$ sales pamphlet sold the newspaper as the chosen reading material of the "progressive" farm family while over the previous two decades the newspaper used "progressive" as its main term of approval. Contextual words attached to progressive were "up-to-date," "wide-awake" and "modern." But this modern did not mean a commitment to the change and fluidity discussed by David Harvey and Anthony Giddens. ${ }^{78}$ I suggest it is more useful to adopt Danbom's practical understanding of "modern" as farmer acceptance of the commercialized business practices required by global markets. This takes us to Giddens's discussion of how modernity removes people

\footnotetext{
${ }^{77}$ Fry, The Farm Press, 157-61.

${ }^{78}$ Harvey, Condition of Postmodernity, 10; Giddens and Pierson, Conversations, 95.
} 
mentally, and sometimes culturally, from the local. ${ }^{79}$ But we must then nuance Giddens's argument with Barron's point that farmers were not fighting change because they were foolish traditionalists. Rather they were seeking control over their own lives in their local place. The effect, nevertheless, was one of disruption.

\section{Conclusion}

This chapter has looked at the literature on the reform culture within which the Ottawa Valley (Farm) Journal claimed to be a newsmaker. It was a culture which mixed the traditional language of pastoral or romantic agrarianism, in which the yeoman farm family was the bedrock of the nation, with scientific agrarianism, in which the unprogressive farmer was a drag on the nation. These threads came out of different views of being modern in the countryside.

Being modern has many meanings. Cultural and literary studies generally emphasize modern / modernity / modernism as linked words expressing the disruption required to eliminate the dead past and allow new ways of seeing and thinking. David Harvey links being modern to an Enlightenment belief in rationality and secularism along with science and technology. But he also quotes Nietzsche on the necessity of destroying the past in order to create the modern. This destruction is said to lead to a lack of connectedness. Anthony Giddens picks up on this in his description of embeddedness and disembeddedness. A person living a traditional life is embedded in the local. To be modern is to be disembedded from a sense of place.

These efforts to define or describe being modern assume that the city is the creator of modern life. The city is dynamic. It is a place where change is constant and

\footnotetext{
${ }^{79}$ Danbom, Born in the Country, 149-54; Giddens and Pierson, Conversations, 98.
} 
where Baudelaire's flaneur can drift without ties through the landscape. This was, of course, always a dream of the modern for the city is made of neighbourhoods where, just as in rural places, some belong and some do not. At the same time the city has been written about as the antithesis of the rural and therefore of the traditional. Knowledge is also part of defining modern and traditional. Michel Foucault's writings give us two ways to cut through the concept of knowledge. On one cut, we can separate out specific forms or epistemes of knowledge, each appropriate to a specific knowledge-world. But there is an important cross-cutting way of understanding knowledge and that is through the official or authoritative knowledge of experts versus everyday knowledge. Expert knowledge generalizes and systematizes in order to create structures which then blanket the particular. Everyday knowledge is "subordinate" in that it stands as resistance to a totalizing knowledge and it is "tacit" in that it is not enunciated in systems or structures.

"Country Life" was an amorphous idea more than an organized movement but it serves to gather together those reformers who were applying to a "rural problem" the equally amorphous Progressivism of the cities. The reformers defined the rural problem as depopulation endangering the moral well-being of the nation. They argued that depopulation created a vicious circle in which fewer rural young people meant a lowered social vitality in the countryside driving out even more farm families. John MacDougall's 1913 Rural Life in Canada was a prime exponent of this argument. Although a smalltown Presbyterian minister, his analysis was based on political economics and rural sociology. His solutions also came from the city. He advised farmers to become modern economic beings by specializing, by rejuvenating waste land through reforestation, and by cooperativism. He then listed various social ills related to the changing demography of 
the countryside but his only recommendation was to import urban social service programs.

These contemporary claims to a deep divide between the country and the city in terms of social amenities and economic opportunities and later claims to a divide in terms of agrarian strife and urban disdain have been challenged. Adam Crerar points out the numerous points of contact in Ontario between rural residents and their city cousins. American historians also question the idea that farmers rejected modern scientific ways out of a traditional agrarianism. Christopher Shaw points to the class divisions within rural society as creating as much clash as the divisions between city and country. Hal Barron questions the amount of change actually being experienced at the beginning of the twentieth century. Barron appears to assume there was a new spirit of modernity in the early twentieth century but argues that farm families chose their paths to this end. As in most of life, there was change and there was continuity. Barron focuses on control over the local as the driver of resistance to change and not a blind adherence to tradition. Ronald Kline emphasizes the agency of rural families in their choices of how to use the urban technology that corporate interests were promoting to them.

Rural history is generally treated as a story of the local opposing the global, or the traditional opposing modernizing forces of demographic change, or the history of agricultural technology, or the history of women fighting male patriarchy. And today when one says one is doing rural history some immediately think of a focus on environmental history. So, how do I study a newspaper targeting a rural market while emphasizing modernity? Throughout all the discussions of the modern, disruption is a key theme. I find this theme useful. In a traditional society, change happens but it is 
subsumed within the existing understandings of the world as people quietly tweak customs or invent new traditions. People who are self-consciously modern celebrate change as a sign of improvement. A third group, however, will be unable to either ignore or celebrate change because of its impact on their status, their identity or their economic stability. Whichever the case, we cannot assume that modern is a stable category which is synonymous with city life while tradition is the hall-mark of the rural. Modern is a word used to approve of some things, in some places and at some times. And it is a word that can be as easily used to disapprove of the very same things. This study will examine in the next chapters how the rural Journal used the term.

I will argue that, like the experimental farms, agricultural colleges and Toronto's National Exhibition, the rural Journal acted as an modernizing agent. The Ottawa Farm Journal sales pamphlet sold the newspaper as a newspaper for the progressive farm family. It told its readers what this meant in its illustration of a well-dressed citified middle-class husband, wife and two children—no beards, no overalls, no buns or aprons. The rural newspaper used the word "progressive" regularly in the decades under study as the key word for approving a person, a thing or an activity, particularly in the campaigns it highlighted in the pamphlet and the context made it clear that to be "progressive" was to be "modern." In Chapter 6 on the agricultural fair campaigns editor Herbert Cowan followed the lead of government experts in encouraging learning as the path to progress but there was ambiguity as to whether to privilege the knowledge of the college-trained expert or the practical knowledge of the experienced farmer. In Chapter 7 he presented the machinery of the road-building campaign as yet another sign of modernity but there are signs that the campaign failed in its objective of changing attitudes due to farmers' 
desire to retain local control over the roads they had built. Editor Faith gave a more ambivalent understanding of progress for he condemned his opponents in the cheese campaigns for not being "business-like" while attacking them for failing to meet an older desire for intra-community price equality. Being progressive and modern was nuanced by local and traditional knowledge and values.

Hofstadter says that politicians flattered farmers by telling them they were the bedrock of the economy. In the 1900s Journal rural editor Herbert Cowan claimed he was not aiming to flatter but how else can we describe his calling a group of men he was trying to draw into a project "progressive, wide-awake men ... men who are thoroughly abreast of the times"? ${ }^{80}$ While I can only approximate what being "progressive" meant to a young newspaperman in 1902, that is the task to be turned to next, starting with a study of the rural Journal as an element in an urban newspaper business in Chapter 4 and as a self-declared agrarian reformer in Chapter 5.

\footnotetext{
80 "Leading Farmers Hold a Meeting At Ottawa," Ottawa Valley Journal, February 18, 1902, 8.
} 
Chapter 4 - Newspaper Hybridity: The Ottawa Journal and its Rural Face
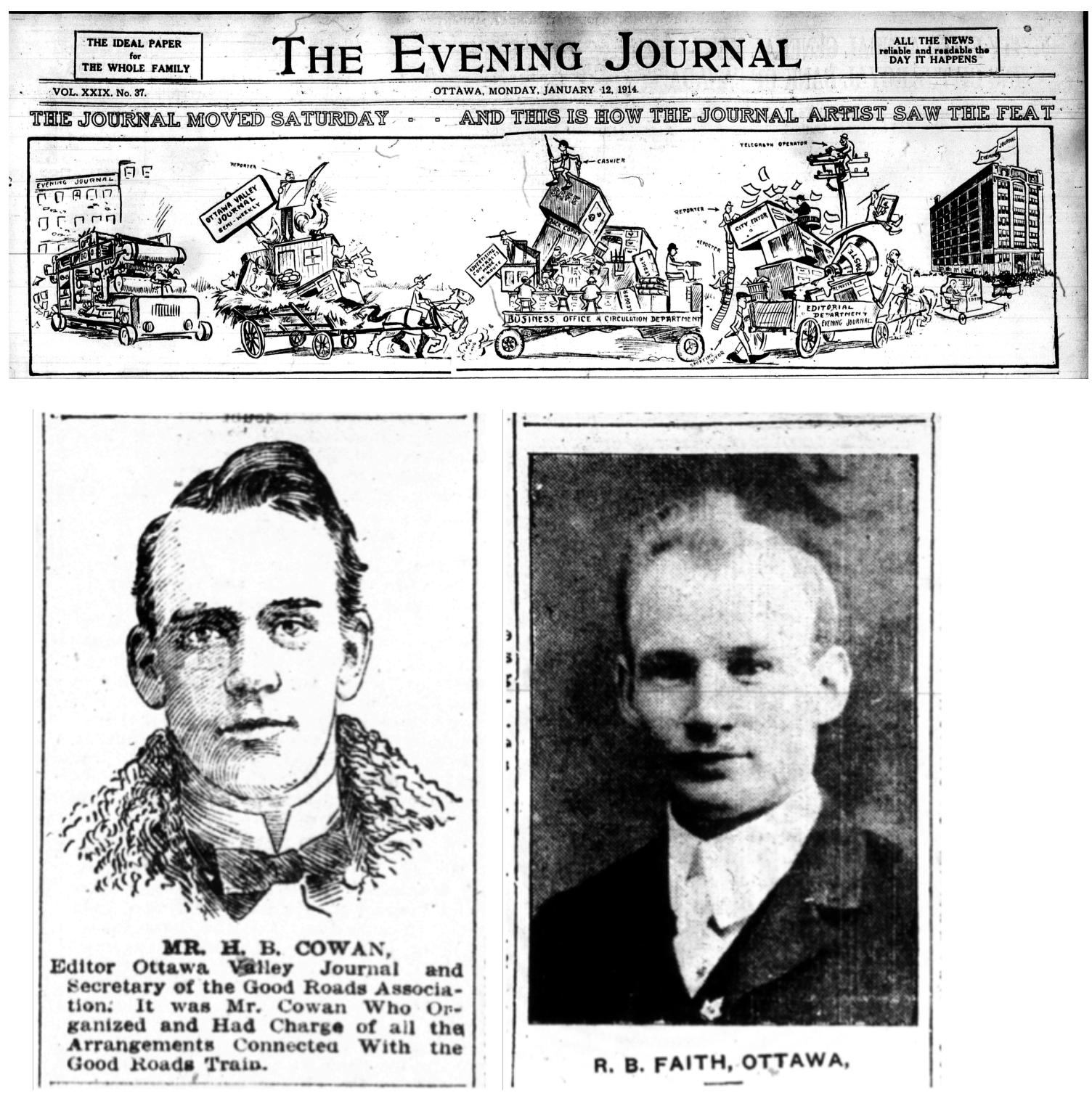

Fig. 4.1. Top, Journal move to new building: The Evening Journal, January 12, 1914, 1 and Ottawa Valley Journal, January 13, 1914, 1. Bottom left, Herbert Cowan, rural editor [1899] to 1903, Ottawa Valley Journal, January 9, 1903, 9. Bottom right, Robert Faith, rural editor 1903 to 1928, Ottawa Valley Journal, March 17, 1903, 8.

The rural Journal was an integral part of a city newspaper but the whimsical drawing above reflects its place in the company's order-behind the business office and the city news room. It only acquired an independent streak when Herbert Cowan became the rural editor in 1899. Both Cowan and his successor Robert Faith were young men when they became editor and both of them, in different ways, made the early Ottawa Valley Journal a rural activist in the style of the urban New Journalism where newspapers made news. 


\section{Introduction}

There are many ways of sub-classifying the field of journalism history. Two Canadian scholars, William Buxton and Catherine McKercher, approach their historiography of the literature by specifying five major types: historical overviews, memoires, biographies, studies of specific newspapers and thematic. ${ }^{1}$ In this chapter I explore the rural Journal and its personnel to explain its relationship with its urban parent, its competitors and its readers as well as the evolution of its content. I aim for a combination of biography with the business/institutional history of the newspaper along with a broad content analysis (described in Appendix C) and a thematic reading of the newspaper's approach to specific issues. The relationship with Ottawa's daily can be seen in the drawing which appeared on the front page of both the urban and the rural Journal announcing the company's move to a new purpose-built building. The newspaper's departments proceeded down the road led by the editorial and news department of the Evening Journal followed by the business and advertising departments. Third in line, and I suggest in priority (although ahead of the great printing presses), came the Ottawa Valley Journal. A man in a farm hat, a woman in an old-fashioned bonnet and a single reporter were the human occupants of a wagon filled with hay and livestock. But while the artist's representation suggested the Valley Journal was comically backward, it also showed it was an integral part of the Journal Publishing Company’s operations.

The Journal's rural semi-weekly has a long history from 1887 to 1955 . Yet it was a minor element in an urban business. It was written, edited and printed in the city by city men in order to scoop up extra readers and, at least after 1919, to serve as an accounting

\footnotetext{
${ }^{1}$ William J. Buxton and Catherine McKercher, "Newspapers, Magazines and Journalism in Canada: Towards a Critical Historiography," Acadiensis 28, no. 1 (Autumn 1998): 103.
} 
convenience for the parent corporation. At first there was very little agricultural or rural about it for its content was copied from the city edition. This is not a surprise. Contemporaries understood the country edition of a city daily to be an uninspiring and untimely pastiche of the daily. Journalism historians seem to agree. Their attention, on the few occasions when it wanders away from the metropolitan mass dailies, has been on the country weeklies of the small towns. Agricultural and rural historians, on the other hand, have focused on farm journals when they look at the press. But I argue here that the Ottawa Valley (Farm) Journal gained and then held an audience by mixing the urbanbased and lively New Journalism of the late nineteenth century with farmer-targeted information and leadership on selected agrarian issues.

In this chapter I focus on the rural Journal as a newspaper-how it sold itself, the evolution of its content and the background of the people, mostly men, who made it. I argue that it acquired an independent voice on rural issues with the naming of a dedicated rural editor in 1899. By 1920, however, the newspaper aimed to be a farm journal rather than a local newspaper for the Ottawa Valley. The rural editor now filled his portion of the newspaper with agricultural information and we no longer find correspondents writing in with the small tidbits of local life in the Ottawa Valley.

I will start with an outline of the rural Journal's institutional history with an emphasis on its place within the overall company. I will then profile key individuals who worked on the rural edition from 1898 to the 1920s. Next I will look at how its content evolved over the period. I will end with a comparison of the rural Journal with the newspapers with whom it competed for rural readers both in terms of circulation and in terms of community-building. 


\section{A City Daily Spins Off a Rural Weekly}

Given the role the rural Journal sought to play as an agent of change in the countryside, how local and how rural was it? When the Journal publisher P.D. Ross launched it in 1887 he gave it the unimaginative name of Ottawa Semi-Weekly Journal, a name which told the reader only the bare bones information of its relationship to the daily. On January 31, 1899 the publisher renamed it the Ottawa Valley Journal and Home and Farm News presumably to emphasize its local character. Another name change came on February 2, 1917 when it became the Ottawa Farm Journal. This time the editor stated the name change was part of making the rural edition an agricultural paper with appeal beyond the Ottawa Valley. The rural Journal continued to be published until 1955 under this last name.

\section{$\underline{\text { Origins }}$}

The rural Journal began life in 1887 when the publisher of a newly started urban daily, P.D. (Philip Dansken) Ross (1858-1949), chose to expand into the countryside with a semi-weekly. Ross was very much an urban publisher. His encounters with the rural, as recorded in his diaries, were strictly for recreational consumption. ${ }^{2}$ He had been born and raised in Montreal and was an engineering graduate of McGill University but had abandoned engineering to become a newspaper editor in Montreal and Toronto. In 1885 at the age of 27 he arrived in Ottawa as the Toronto Star's parliamentary reporter. That

\footnotetext{
${ }^{2}$ Library and Archives Canada (hereafter LAC), Philip Dansken Ross fonds, Diaries, R2236-0-7-E (MG 30, D98). Primary documentation on the Journal as a business and a newspaper is limited. LAC holds three fonds connected to the Journal: the Ross fonds which is largely his personal journals; the Senator Grattan O'Leary fonds with the political speeches of the newspaper's third managing editor and President; and the I. Norman Smith fonds with the personal papers of the last managing editor of the Journal and of his father, E. Norman Smith, the second President and managing editor. The City of Ottawa Archives holds business records deposited when the Journal was shut down in 1980. These last give insight into the company as a whole but only rarely show the workings of the rural edition.
} 
December Ottawa printer Alexander Smith Woodburn founded the Evening Journal as the youngest of the city's English-language dailies, the others being the Citizen and the Free Press. The Citizen was at that time a Conservative morning newspaper catering to the classes who had the time to read a paper in the morning as well as the money to pay the elevated price demanded for that privilege. The Free Press was a Liberal evening newspaper aimed at the masses whose leisure time for reading came after work. ${ }^{3}$ Woodburn declared that his new evening newspaper would be fearlessly independent. ${ }^{4}$

According to Ross, Woodburn set up the newspaper because he thought it would turn around the financial situation of his failing printing plant. ${ }^{5}$ Woodburn's first editor was J.W. Dafoe who quickly left for better journalism opportunities elsewhere. This left Woodburn looking in 1886 for a partner with newspaper experience. Ross wrote in his memoirs that he heard this and approached Woodburn, purchasing a half-interest and becoming the managing editor as of January $1,1887 .{ }^{6}$ Ross had trapped himself. When he later asked his father (the founder of a leading Montreal accountancy firm) for a loan to buy out Woodburn, his father declined saying the newspaper was a financial loss. ${ }^{7}$ Unfortunately Ross had paid $\$ 4,000$ for a half interest. Worse, all he had actually bought was a name and a circulation list of 1,700 (with 600 of these given out free), but not the

\footnotetext{
${ }^{3}$ This characterization of the classes and masses markets is based on Douglas Fetherling, The Rise of the Canadian Newspaper (Toronto: Oxford University Press, 1990), 66-7. There was also a French-language newspaper, Le Temps, established in Ottawa in 1894, which in 1900 appears to have collaborated with a group publishing a special agricultural weekly called La Semaine Agricole. The present day Le Droit was founded in 1913 as part of the campaign against the recently imposed "Regulation 17" prohibiting teaching in French in Ontario after the first grade.

4 "Prospectus," Ottawa Evening Journal (hereafter OEJ), December 12, 1885, [2].

5 In 1887 Woodburn's pecuniary strength was "F", i.e., between $\$ 10,000$ and $\$ 25,000$ and his credit rating was only 3 or "Fair". C.W. Mitchell, the owner of the Free Press had a pecuniary strength of E and a credit rating of 2 . The Citizen Printing and Publishing company had paid up capital of $\$ 25,000$ but no credit rating due to insufficient information. R.G. Dun \& Co., Mercantile Reference Book (1887): 113, $115,116$.

${ }^{6}$ P.D. Ross, Retrospects of a Newspaper Person (Toronto: Oxford University Press, 1931), 32-3; I. Norman Smith, The Journal Men (Toronto: McClelland and Stewart, 1974), 16-17.

${ }^{7}$ Ross, Retrospects, 32-3; LAC, Ross Diaries, Box 4, 1887, 1888.
} 
physical plant which produced the newspaper. ${ }^{8}$ There also appears to have been tension between the partners for Ross recorded having "words" with Woodburn in his diary. ${ }^{9}$ Ross later commented that he and Woodburn had "practically gold-bricked each other" for Ross had no business knowledge and Woodburn was running an essentially bankrupt newspaper. ${ }^{10}$ Ross and Woodburn remained locked unwillingly together until 1891. That year, a group of prominent Ottawa businessmen (and Conservative organizers) lent Ross the money to buy out Woodburn and finance new printing presses. ${ }^{11}$ In a little over three years Ross repaid the investors. From then until his death in 1949 he was the controlling owner.

Why a Semi-Weekly?

The Journal's semi-weekly was launched in June 1887 six months after Ross partnered with Woodburn. It was a reasonable decision. Journalism scholars have discussed the phenomenon of the daily and its country edition in Britain and the United States (see Chapter 2). Paul Rutherford in A Victorian Authority follows their analysis. He argues that late nineteenth-century urban dailies often ran country editions in response to increasingly intense competition for subscribers and in particular for the advertising dollars subscribers attracted. ${ }^{12}$ I find that a daily with a country edition was the norm in Ontario at that time. The 1899 McKim's Directory listed a weekly or semi-weekly

\footnotetext{
${ }^{8}$ These circulation numbers were turned around quickly. Ross's diaries for March 1887 show his weekly calculations of number of dailies sold by place of sale (ie., delivered by carriers, sold in the streets, sold in the office, sold by agents, sold in the hotels plus 530 sent to subscribers by mail) and advertising revenue received by type. On March 8, 1887 Ross recorded sales of 2,638 newspapers. He recorded this information only in the first few years of ownership while seeking a loan to buy out Woodburn.

${ }^{9}$ LAC, Ross Diaries, Box 4, April 2, 1887, April 9, 1887.

${ }^{10}$ Ross, Retrospects, 32. Gold-bricking was a scam in which a brick was given a thin coating of gold or, even more cheaply, some gold-like substance and then sold as gold to the ignorant and the unwary.

${ }^{11}$ Ibid., 33-7.

${ }^{12}$ Paul Rutherford, A Victorian Authority: The Daily Press in Late Nineteenth-Century Canada (Toronto: University of Toronto Press, 1982), 74-6.
} 
edition for forty-nine of the fifty-five Ontario dailies; thirty-nine of these were weeklies. ${ }^{13}$ The only distinctive feature of the Ottawa press was that its three dailies were among the minority of sixteen city newspapers printing semi-weeklies as their country editions. In a few cases the weekly or semi-weekly would have been a remnant of the newspaper's own pre-daily past; for example in Ottawa the Citizen had probably repurposed the semi-weekly out of which the daily had grown. ${ }^{14}$ Despite the high number of dailies publishing a country edition, by the late 1890 s these editions were starting to fall out of fashion.

A 1901 writer in Printer and Publisher forecast that weeklies (whether a daily's country edition or a town or village stand-alone weekly) would be dead by 1950 due to improved rural mail service and rural education. Not only would farmers get the newspaper more quickly but they would also read more quickly and therefore would read a full newspaper every evening. ${ }^{15}$ Even in the 1890 s, well before the 1908 start of free Rural Mail Delivery in the Hamilton, Ontario area, it seemed urban-based weeklies were dying. ${ }^{16}$ The New York Herald stopped publishing its weekly in 1895 with the comment that small town weeklies "fully met demand for weekly news."17 While only six Ontario dailies did not publish a country edition in 1899 , three of these were in Toronto and accounted for half of that city's dailies. The remaining three dailies without a weekly

\footnotetext{
${ }^{13}$ The Canadian Newspaper Directory, 1899 (Montreal: A. McKim \& Co., 1899), 241-5.

${ }^{14}$ The Citizen evolved from a weekly The Packet (1845), renamed the Ottawa Citizen 1849, became a semi-weekly in 1859 and a daily in 1865. "The Ottawa Citizen," The Canadian Encyclopedia, http://www.thecanadianencyclopedia.ca/en/article/the-ottawa-citizen/. Accessed September 27, 2017. ${ }^{15}$ S.D. Scott, "The Newspaper of 1950," Canadian Printer and Publisher 10, no. 3 (March 1901): 17. Note that the publication's title varies between Printer and Publisher (1896-1901, 1904-1921) and Canadian Printer and Publisher (1892-1895, 1901-1903, 1922-1989). I use the title Printer and Publisher in the text but cite the title of the issue as displayed on the front cover of the issue being referenced.

${ }^{16}$ It took several years for Rural Mail Delivery to become universal. In 1914 the rural Journal was still explaining the process for obtaining it; "How to Secure Rural Mail," Ottawa Valley Journal (hereafter OVJ), February 3, 1914, 12; “A Petition Necessary," OVJ, February 17, 1914, 12.

17 "The Outlook for Weekly Papers," Canadian Printer and Publisher 4, no. 9 (September 1895): 11.
} 
were recent start-ups, starting with the Hamilton Herald established 1889, the London News established 1896 and the Kingston Times established $1897 .{ }^{18}$ Eschewing a country edition spread over the first two decades of the twentieth century, from the initial six dailies in 1899 to twelve in 1909 to twenty-five in $1919 .{ }^{19}$

The announcement of the birth of the Journal's rural semi-weekly was part of a general news item on improvements to the daily edition. An editorial in the Evening Journal which was copied in the first issue of the new Semi-Weekly Journal explained that the owners had installed new presses. Their speed and capacity would remedy a problem of late delivery to urban subscribers and allow the publishers to print an eightpage special on Saturday. Publishers would also be able to meet "a growing demand in the surrounding counties for a semi-weekly or weekly edition." ${ }^{20}$ No details were given, however, on this "demand" or why Ross eventually chose to print a semi-weekly rather than a weekly. Perhaps he felt he had little choice but to match his competitors' semiweeklies as well as their city editions. At the same time, a semi-weekly gave Ross some financial advantages with very few drawbacks.

Ross argued in a discussion in Printer and Publisher that a local semi-weekly was competitive because it was local and because twice-a-week publishing ensured its content was fresh. He stated that since each issue of his semi-weekly was four pages long, at the end of a week it equaled an eight-page weekly at no greater print cost. Even better, advertisements appeared twice each week giving the publisher more money than

\footnotetext{
${ }^{18}$ Canadian Newspaper Directory, 1899, 68, 72, 75, 106, 241-5.

${ }^{19} \mathrm{Ibid}$. Between 1899 and 1909 the total number of Ontario dailies had remained steady at 55 but by 1919 that number had declined to 44 i.e., the total number of dailies was reduced by a fifth from 1909. At the same time, so few of these had a weekly, that the effect was to increase by four times the proportion of dailies which did not publish a country edition.

20 “The Journal," OEJ, June 4, 1887, 4 and Ottawa Semi-Weekly Journal (hereafter OSWJ). June 6, $1887,2$.
} 
placement once in a weekly would have done while using fewer advertisements. This arrangement also allowed more reading material to be inserted than was possible in a weekly. ${ }^{21}$ There were other benefits to a semi-weekly which Ross did not mention. In 1909 when the Free Press was developing a plan to negotiate with the Citizen and the Journal on fixing all three newspapers' advertising rates, an internal memorandum commented on its competitors "unfair advantage" due to having retained their semiweeklies. As a result, they could sell advertising space based on a combination of their daily and semi-weekly while offering advertisers a $33 \%$ reduction in the semi-weekly advertising rate. ${ }^{22}$

Ross also did not mention the financial advantages in spreading overhead expenditures across two revenue streams, from the urban newspaper and from the rural newspaper. Nevertheless, eventually this is what he did. In 1919 Ross set up the Journal Publishing Company as a holding company for three subsidiary companies, one of which was the Ottawa Farm Journal Limited. ${ }^{23}$ The subsidiary then made annual payments to the holding company against a debenture which had been "invested" in it. Exactly what the debenture might have been used to purchase is unclear as the semi-weekly used the company's printing plant. A 1934 report written by the manager of the holding company shows that the rural paper survived the Depression only because it was a conduit for redistributing costs and earnings. The manager made clear in his report that he was

\footnotetext{
21 "The Outlook for Weekly Papers," Canadian Printer and Publisher 4, no. 9 (September 1895): 11.

${ }^{22}$ LAC, I. Norman Smith fonds, MG 31 D 94, Box 6, file 2, Memorandum, Wm. Findlay to [E. Norman] Smith, October 20, 1909.

${ }^{23}$ City of Ottawa Archives (hereafter OA), Journal Fonds, MG-011, Box A2004-013, file 11-6-2; Applicants for the Ottawa Farm Journal Limited's federal charter were "Philip Dansken Ross and Ernest Norman Smith, Publishers; Richard Francis Parkinson, Manager; William Arthur Perry, Accountant; and Robert Bert Faith, Journalist." Ross became president and Faith, the editor of the Farm Journal, vicepresident. Faith was given ten shares each year in trust but could dispose of them only to the holding company at face value.
} 
addressing vice-president E. Norman Smith's belief that killing the rural edition would improve the bottom line for the holding company. The manager called the pre-1929 Farm Journal a success. It had met its direct costs, contributed towards the company's overhead costs, paid the interest on the 1919 debenture and left a small profit from which dividends were paid to shareholders (the holding company owned by Ross and Smith, along with Ross and Smith as individuals). In 1934 the Farm Journal's circulation and advertising revenues still covered its direct costs but the allocation of overhead as indirect costs created a loss in the rural company's books. However eliminating the rural edition and dismissing its staff would still have left overhead expenditures on the holding company's books without the rural revenues to offset them. In addition the holding company would acquire a liability of $\$ 11,303$ for prepaid rural subscriptions. ${ }^{24}$

Thus, as argued by Rutherford in regard generally to late nineteenth-century newspapers in Canada, the Ottawa Semi-Weekly Journal was likely launched as part of a three-way fight for subscribers between the urban Journal and its competitors, the Free Press and the Citizen. By the 1930s its successor, the Ottawa Farm Journal, was kept alive for its contribution to the bottom-line of the urban Ottawa Journal Publishing Company. In the long run, however, the rural Journal may have contributed to the city Journal's downfall. Former Ottawa Citizen editor Charles King claimed without explanation that the Journal and the Citizen had been very close in their overall circulation numbers but the Citizen "dominated" the city while the Journal had "the more widely-scattered and less profitable country circulation." 25 In 1998 Matt Snyder in

\footnotetext{
${ }^{24}$ OA, Journal Fonds, Box A2004-0113, minute book. Memorandum from W. Arthur Perry to E. Norman Smith, January 24, 1934.

${ }^{25}$ Charles King, "The Ottawa Papers: The Profits of Parochialism," in Canadian Newspapers: The Inside Story ed. Walter Stewart (Edmonton: Hurtig Publishers, 1980), 89.
} 
Ninety-Four Years of The Ottawa Journal dates the beginning of the two separate markets (urban versus rural) precisely to 1905 without an explanation of why that year and without a source. He claims "readers had identified the Journal as an Ottawa Valley paper, considering the Citizen to be more dedicated to the affairs of the city proper." This meant that in the 1960s the Journal was unable to take advantage of the growing number of suburbanites in the new cities of Nepean and Gloucester. ${ }^{26}$

Snyder calls this rural identity “the most mysterious aspect of the paper's history." He cites former Journal (and later Citizen) columnist Dave Brown as saying that the Citizen and the Journal had simply agreed to split the market between them in this way. Snyder counters that the newspaper owners might have had an agreement but market share was made by readers. He then cites three Journal informants (a former editorial writer and two former managers, all unnamed) on the question. They did not try to claim any knowledge of how the Journal came to be seen as wholly rural. It was simply an association which they could not shake. While at this point Snyder dates the beginnings of the Journal rural identity to 1905 , he also dates it to a co-operative agreement Ross and the Southams made around the period of the First World War. According to Snyder this coincided with the Journal "developing a unique arrangement with the residents of the Ottawa Valley on the strength of its Ottawa Farm Journal and a staff of permanent reporters throughout the region." ${ }^{27}$ Snyder's argument leaves questions. Rural editions were not "unique" and the Journal had been actively developing local correspondents as part of its relationship with rural readers since 1899. Despite

\footnotetext{
${ }^{26}$ Matt Snyder, Ninety-Four Years of The Ottawa Journal ([Ottawa]: Historical Society of Ottawa, 1998): 12-13.

${ }^{27}$ Snyder, Ninety-Four Years of The Ottawa Journal, 13, 7; Dave Brown's career spanned from 1965 to 2003. He would have had no personal knowledge of the newspapers' earlier histories or marketing decisions.
} 
these objections to Snyder's argument, it is true that when the Citizen closed down its rural edition in September 1916 it vacated the country market to the Ottawa Valley Journal. Being the only Ottawa daily with a special rural edition may have helped colour the Journal in its entirety as rural.

\section{How Rural Was the Rural Journal?}

John Fry finds in his study of four Midwestern farm journals that farm journal editors tended to have more 'farm cred' than their publishers. The latter generally speaking were urban businessmen while the editors as a group were more likely to have been raised on farms and a few of them had had an agricultural education. But all of the editors earned more than most farmers and all lived in the city. ${ }^{28}$ A country edition of a city daily would by definition have an urban businessman as publisher. The question for the rural Journal is how closely it was managed by the urban parent.

\section{Daily Dominance}

The Journal's rural editors barely rate a mention by the newspaper's historians. When I. Norman Smith described the offices on the editorial floor of the 1938 Journal Publishing Company, he placed in them company president P.D. Ross, managing editor E. Norman Smith, news editor Grattan O’Leary, city editor Vernon Kipp, and himself, then a junior editor. He names only two "rural" men: Bryan White and James Henry both of whom filled the job of rural editor at different times between 1928 and 1955. Smith says White went on "from that task to many senior posts in the company." 29 It seems that not only was the rural editor excluded from the top floor, the job was not in the eyes of

\footnotetext{
${ }^{28}$ John J. Fry, The Farm Press, Reform, and Rural Change, 1895-1920 (New York: Routledge, 2012), 2536.

${ }^{29}$ Smith, The Journal Men, 37, 118, 149.
} 
Smith one of the paper's "senior posts." The daily's dominance was even tighter before 1899 when both editions were produced in a single news room consisting of a managing editor, city editor, and four reporters. ${ }^{30}$

A comparison of four issues (one from each season) of the rural Journal in 1888 with the corresponding daily editions shows that it was exactly the cut-and-paste job that city weeklies were said to be. Except for a few ads, the content had been taken directly from the three previous days of the daily and then inserted apparently without order. On occasion, people fell sick on one page, were buried on the next and were expected to recover on the third. Rural readers were even shortchanged on market news as they only received a summary of news for Ottawa's By Ward Market without the daily's market price lists and information on outside markets.

Independence ... of a Sort

In December 1897 the rural Journal began to show signs of being managed as a separate publication. A “semi-weekly business manager" signed two ads announcing a circulation contest while the "Business Manager, Evening Journal" signed a third. ${ }^{31}$ The semi-weekly manager was Herbert Bronson (Brownson) Cowan (1877-1971). ${ }^{32}$ Cowan later said he joined the newspaper straight out of high school at the age of seventeen (i.e. in 1894). ${ }^{33}$ He first appeared in the City of Ottawa directory in 1896, still living with his parents but working as a Journal reporter. In the 1898 and 1899 city directories he was

\footnotetext{
30 "Another Step in 'The Journal's' Way up the Ladder of Prosperity / The Journal Force," OEJ, April 3 , 1893, 3, 4 and $O S W J$, April 3, 1893, 3.

${ }^{31}$ Referencing the Semi-Weekly manager - "To Our Readers," OSWJ, December 14, 1897, 8 and December 17, 1897, 5; “A Christmas Present," OSWJ, December 17, 1897, 3; signed by the Evening Journal but text refers specifically to the Semi-Weekly - "The Chance of the Year," OSWJ, December 17, 1897, 8.

${ }^{32}$ Baptismal Register, Emmanuel Congregational Church, Montreal, 1877 folio 7; Obituary, Ottawa Journal, September 3, 1971, 35.

${ }^{33}$ W.Q. Ketchum, "Faces of Ottawa: Herbert B. Cowan,” Ottawa Journal, July 18, 1970, 2.
} 
listed as circulation superintendent and then circulation manager. ${ }^{34}$ Cowan's youth is not a surprise. Journalism historian Fred Fedler states that journalism in the nineteenth century was a profession for the very young. Teenage reporters were typical. Only the young found that the promise of journalism romance and excitement made up for long hours and low pay. ${ }^{35}$ As well, youth may have given Cowan the energy and ambition to put some promotional whiz into building the stodgy Semi-Weekly Journal's circulation.

The first reference to Cowan by name in the rural Journal itself came when he participated in an 1898 award presentation to the winner of a contest for the most popular Ottawa Valley teacher. His position in the newspaper was not given but he was likely still circulation manager. And there was likely still no rural editor for it was the city editor G.H. Wilson who made the presentation. ${ }^{36}$ A year later, however, Cowan was listed in P.D. Ross's salary list as rural editor. Judging from his salary, this did not give him any importance. Cowan occupied the most junior rung among the Journal's editors, earning only $\$ 11$ per week versus the $\$ 14$ earned by the news editor and the $\$ 13$ earned by the city editor. He even earned a dollar less a week than the top reporter. ${ }^{37} \mathrm{He}$ was, after all, only twenty-two.

Not only did circulation promotional activity start increasing in 1898 , so did the amount of rural content written specially for the semi-weekly. Along with this, there is evidence of staff being hired for the rural edition. According to a 1904 Journal article Robert Bert Faith (1879-1968) came to Ottawa in 1899 and began working with the Journal as a general reporter. He is listed in the city directory as assistant editor on the

\footnotetext{
${ }^{34}$ Ottawa City Directory, (Toronto: Might Directory Company): 1896, p. 194; 1898, p. 203; 1899, p. 203.

${ }^{35}$ Fred Fedler, Lessons from the Past: Journalists' Lives and Works, 1850-1950 (Prospect Heights, Ill.: Waveland Press, 2000), 14-15.

36 “Teacher's Prize Presented, OSWJ, April 5, 1898, 8.

${ }^{37}$ LAC, Ross fonds, vol. 1, file 7, 1899, untitled statement of salaries.
} 
Ottawa Valley Journal in $1902 .{ }^{38}$ When Cowan left in January 1903, Faith was promoted to editor. Katherine Mary (Kate) Whelan (1883-1970) appears to have been the next hire. ${ }^{39}$ She appeared in city directories for the first time in 1902 as a stenographer at an unnamed place of work. She was specifically listed as working for the Ottawa Valley Journal in 1904 and continued with the Journal until 1959 when the editor made a passing reference to her having recently retired. ${ }^{40}$ There was one other long-serving member of the rural editorial office and that was James Henry (1859-1952). Henry joined the newspaper in 1917 aged 58 as associate farm editor (his wife's obituary states he joined as "agricultural editor"). He remained with the newspaper until sometime in the 1940s. He and his wife had immigrated to Canada from Scotland in 1913 and had come to Ottawa from Western Canada in $1916 .^{41}$ After Faith left the newspaper in 1928 Henry worked first as editor and later again as associate editor under Bryan White. He is last found in the Ottawa Directory in 1945. At the age of 86 he was the "rural editor" while

38 "Ottawa Cheese Board Has Made Great Progress," OVJ, April 19, 1904, 10. Faith first appeared in the 1901 Might's City of Ottawa Directory as "rep [representative or reporter] Ottawa Valley Journal," p. 242. In 1902 Might's directory listed him as assistant editor, p. 240.

${ }^{39}$ Whelan's first name is spelled Catherine on her baptismal record (Ancestry, Roman Catholic Records, Cyrville), the 1949 voter's list (Ancestry, Ottawa West, St. Vincent's Hospital, Urban Polling Division No $20 \mathrm{~b}, 2$ ) and the notice of her death (Ottawa Journal, January 22, 1970, 40). She herself signed her name Katherine in a note from the editorial staff to P.D. Ross dated New Year's Day, 1938 (LAC, Ross fonds, diaries, vol. 9, file 9). She was listed in the Ottawa Directories from 1902 to 1916 as Kate Whelan and then from 1917 to 1940 as Kathryn Whelan (the later spelling possibly to distinguish her from a relative also named Katherine Mary (Kate) Whelan). References to her in the newspaper were as Kate Whelan. I will refer to her in this study as Kate Whelan.

${ }^{40}$ Death notice, Ottawa Journal, January 22, 1970, 40; “I.N.S. Writes Santa Claus,” Ottawa Journal, December 12, 1959, 6. Whelan was a "stenographer" in the city directory until the 1938 directory when she was listed as editor of "women's work" with the daily Journal. The same year she signed a "get well" note sent to P.D. Ross from "Senior members of the Editorial Staff," (LAC, Ross fonds, vol 9, file 9, note dated New Year's Day, 1938.) She was identified in her mother's 1924 obituary as the "household editress" of the Ottawa Farm Journal - "Mrs. Annie Whelan," Ottawa Farm Journal (hereafter OFJ). February 8, 1924, 4. It appears she may have been incapacitated through the 1940s given that she is found in the documentary record only twice: in 1947 residing at "Joan of Arc House" (City of Ottawa Directory, p. 311) which was a convent running a school and a convalescent home for women, and in 1949 as a patient in the St. Vincent hospital (Federal Voters List). In 1952 she reappeared in the city directory as "secretary" and then, from 1955, as "private secretary" at the Journal.

${ }^{41}$ LAC, Canada Manuscript Census, 1921, Ottawa Sub-district 38 Wellington Ward, p. 19, household 212, line 10; Beechwood Interment Records, 1952, No. 35007; Mrs. J. Henry Dies Lover of Flowers," Ottawa Journal, July 26, 1939, 11. 
Bryan White was the Ottawa Farm Journal editor. ${ }^{42}$

There were others who worked in the rural Journal's editorial office but none worked there as long or would have had as great an impact on the newspaper's content as Cowan, Faith, Whelan and Henry. A teacher turned journalist, Thomas Swift (18501920), was described as a representative of the Ottawa Valley Journal when he gave a talk on "Education for the Farmer" at a meeting of the Farmers' Association in Lansdowne, Ontario. He appears to have worked for the rural Journal from about 1909 to 1915 when he left to become an inspector of bilingual schools. ${ }^{43}$ When Henry joined he was one of two "associate farm editors," the other being T.L. Dunkin but I have not found Dunkin in the company's 1923 payroll lists or after. ${ }^{44}$ Yet another staff representative, G.F. Marsh, was named as speaking at the Shawville Fair in 1912 but I have not found his name elsewhere in the rural Journal nor in other documents. ${ }^{45}$

\section{How Rural Was the Staff?}

Both Robert Faith and James Henry could claim a solidly rural background. Faith had been raised on a farm near Winchester, Ontario. Henry had been a working farmer in Scotland and he wrote a weekly column about his boyhood on a Scottish farm for the Ottawa Farm Journal. ${ }^{46}$ There is evidence that the Journal sought to hire writers with

\footnotetext{
${ }^{42}$ City of Ottawa Directory 1945, (Ottawa: Might's Directory, 1945): 301.

${ }^{43}$ Swift was a Englishman born in Liverpool who came to Canada in the 1870s. He does not seem to have had a rural or agricultural background. The obituary heaped praise upon him as a school inspector who was an influence for "harmony" as the schools became "law-abiding." Given that he was an Englishman inspecting bilingual schools in the "Regulation 17" period (banning French language instruction beyond Grade One), the obituary requires salt. "The Late Thos. Swift," Ottawa Farm Journal (hereafter OFJ), April 16, 1920, 6.

${ }^{44}$ Masthead, OFJ, February 16, 1917, 4 (the masthead continued to carry the associate farm editor names until April 19, 1918 when it was revised to name only the editor); OA, The Journal fonds MG-011, book BG-2-1, The Journal Publishing Company of Ottawa Limited, Individual Pay Roll Summary of Employees," 1923 through 1932.

45 "Seed Fair at Shawville," OVJ, March 12, 1912, 10.

${ }^{46}$ Enumerated as a farmer in 1891 and 1901. Ancestry, Scottish Census on-line, (1891) Ordiquihill parish,
} 
agricultural knowledge. There is a 1918 advertisement for a "man" who was a "good writer, thoroughly practical and experienced in the feeding, care and management of dairy cattle and swine. ${ }^{.47}$ The newspaper had lost an agricultural writer a few months before this ad appeared when a newly recruited member of the rural editorial staff, James Hugh McKenny, died suddenly. While he apparently had come to Ottawa from Montreal he was described as having originally been a farmer from Tillsonburg, Ontario. ${ }^{48}$

Turning to the other two significant members of the rural Journal staff, Kate Whelan's farm background was equivocal while Herbert Cowan could make no such claim. Whelan appears to have been a city girl raised in Ottawa, her father James Whelan alternatively described as gardener or labourer and later as a carpenter. The family came from Billings Bridge. Billings was rural in that it was a small village and farm community but it was just outside the city. Nevertheless she claimed farm credibility in introducing herself to the children of the rural Journal's young readers' page:

I am a Canadian; I was born on a farm, and I have always been closely associated with country life. In practically every year of my early school days, I spent the two months' summer vacation in the country, and had occasion frequently to regret that my parents left the farm for city life. ${ }^{49}$

Herbert Cowan, who made the initial changes which "ruralized" the semi-weekly, was all urban. He had been born and raised in Montreal and was the son of a Montreal-

ED: 3; Page 4, Line 15; (1901) Ordiquihill parish, ED: 3; Page 1; Line 1; (1911). The weekly Journal column began January 10, 1919, 10.

47 "Newspaperman Wanted," OFJ, October 29, 1918, 10.

48 "J.H. McKenny Died Today After A Brief Illness," OFJ, May 21, 1918, 2. I have found H.J. McKenny, agt., in Lovell's Montreal directory, 1916/1917 (p. 1572), 1917/1918 (p. 1594) but not found 1918/19.

49 "The Editor's Weekly Chat," OFJ, March 26, 1920, 10. James Whelan's occupation from Census of Canada, 1901 Ottawa, Dalhousie Ward, p. 26; City of Ottawa Directories 1893, p. 427, 1896, p. 402, 1898, p. 423,1909 , p. 666. While the Whelan family appears to have left Billings Bridge (and farming) by the time Kate Whelan was a child, through her mother, Annie Dewan, Kate Whelan had aunts, uncles, cousins and grandparents who were farming on Concession 2 in Osgoode Township until at least 1911 (Census records 1871 to 1911$)$. 
born furrier and hat-maker and his American- (and urban-) born wife. ${ }^{50}$ In 1888 the older Cowan had moved his family and his business to Ottawa where Herbert spent his high school years. Herbert Cowan left the Journal in 1903 to work for the farm journal Agricultural World in Springfield, Massachusetts. ${ }^{51}$ A few months later he moved to Toronto where he took up the position of Ontario Superintendent of Fairs. In 1906 he gave up his government job, bought the farm monthly Canadian Dairyman and Farming World (renamed in 1909 Farm and Dairy) and moved to Peterborough, Ontario. ${ }^{52}$

Cowan's Globe and Mail obituary claimed that he was one of twenty-four men who founded the United Farmers of Ontario (U.F.O.). ${ }^{53}$ Specifically he had been part of the 1911 farm delegation which had gone to Ottawa to urge a reciprocal trade deal with the United States. He was also said to have been "the guiding force behind the formation of the Canadian Dairy Farmers Federation (est. 1934) and the Canadian Federation of Agriculture (est. 1935). His devotion to the agrarian cause may even have extended to naming one of his sons after the United Farmers leader and Ontario Premier, E.C. Drury, his son being Garth Drury Cowan. ${ }^{54}$ Drury in his autobiography Farmer Premier called Cowan "a personal friend" who drove him to Grange-organizing meetings in Prince Edward County. One of these trips was memorable because the pair got lost after a

\footnotetext{
${ }^{50}$ Cowan's personal information taken from Ancestry.ca - Montreal Emmanuel Congregational Church baptismal record and church Yearbooks (1877 to 1888), City of Ottawa directories, and obituary "Herbert Cowan / Farm Activist a UFO founder," Globe and Mail, September 4, 1971, 4.

51 "Ontario Personals," Printer and Publisher 12, no. 1 (January 1903): 11.

52 "Toronto News," Printer and Publisher 15, no. 11 (November 1906): 27. He acquired the funds to purchase the monthly from his former employer, P.D. Ross, who recorded Cowan visiting him in his office to raise more stock, saying "Didn't encourage him." Ross recorded a later meeting with Cowan about Canadian Dairyman and receiving next day partial payment on the note he had out on it; LAC, Ross Diaries, volume 5, July 30, 1907, November 27, 1907, November 28, 1907.

53 "Herbert Cowen / Farm activist a UFO founder," Globe and Mail, September 4, 1974, 4.

${ }^{54}$ Full name given 1945 U.S.A. Social Security Application SSN 113229866; Ancestry.com. U.S., Social Security Applications and Claims Index, 1936-2007.
} 
meeting. ${ }^{55}$ Drury's biographer Charles Johnston repeats this story but also quotes correspondence from Cowan to W.C. Good in 1917 on agrarian politics. This material suggests that Cowan was one of those drawn to a more elite form of agrarianism. He wrote to Good that Drury should simplify his speeches because farmers were "ignorant." As well Johnston cites an undated but apparently much later interview with Cowan by an Orillia local historian. Cowan said that Drury could communicate with good farmers because he was one, but he could not communicate with the "average" or "dirt" farmer. ${ }^{56}$

Faith's career as the rural Journal editor was much longer than Cowan's but I have found no suggestion that he was ever involved in organized agrarian politics. At first he continued Cowan's promotional work but he started on an independent path in 1905 when he created the Eastern Ontario Fairs Association. Two years later he launched campaigns to change how property tax assessment and cheese marketing were done. $\mathrm{He}$ continued to fight on both subjects until about 1912/1913 when these campaigns disappeared from the pages of the rural Journal. It is difficult to say whether Faith was propelled by a deep sense of probity or was simply inclined to argue. I suspect it was both but the gadfly was certainly visible to some of those who knew him. In 1905 Faith chose to comment publicly in the pages of the Ottawa Valley Journal on a delay by the new Superintendent of Fairs in setting the fair circuit dates despite, according to Faith, having more than sufficient time and staff to do the work. The new Superintendent was Faith's former boss, Herbert Cowan. Cowan shot back a week later with a letter he insisted be published to give his side. He begins, however, by commenting in the first paragraph that

\footnotetext{
${ }^{55}$ E.C. Drury, Farmer Premier: Memoirs of the Honourable E.C. Drury (Toronto: McClelland and Stewart, 1966), 57-8.

${ }^{56}$ Charles M. Johnston, E.C. Drury: Agrarian Idealist (Toronto: University of Toronto Press, 1986), 29, 46, 186. Johnston identifies the interview as located at the Orillia Public Library but upon enquiry the current reference librarian cannot find it.
} 
either Faith does "not understand conditions or that [Faith is] deliberately endeavoring to create trouble."57 The spat between them was resolved and all of Faith's later comments regarding Cowan were flatteringly positive but Cowan's initial comment is suggestive.

Faith's editorship after 1912 was generally quiet though he showed signs of his crusader persona in 1925. In resigning from the Central Canada Exhibition Board of Directors he published his letter of resignation charging that the directors favoured entertainment over the needs of cattle exhibitors and paid themselves bonuses despite the fair's deficits. ${ }^{58}$ He resigned as editor of the Ottawa Farm Journal effective December 31, 1928 and the next month took up a new post with the Holstein Friesian Association in Brantford. He later moved to Oshawa where he was Secretary and Industrial Commissioner of the Oshawa Chamber of Commerce from 1938 to 1943 . He returned to Ottawa about 1946 . He seems to have lived as a pensioner (he was in receipt of a $\$ 500$ per annum pension from the Journal). Oddly, even though he lived on McLeod Street in urban Ottawa, his occupation in the city directory was "farmer." 59

\section{The Competition}

The rural Journal had competitors on all sides but within thirty years the rural Journal was the sole representative left of the three Ottawa-published country weeklies. It had also held its own against the local weeklies of the Valley, the Montreal and Toronto newspapers that had expanded the reach of their dailies by means of subsidized postal rates and daily train service, and even the national farm journals. Readers had had

\footnotetext{
57 “Exhibition Prize Lists," OVJ, May 23, 1905, 10 and June 2, 1905, 12.

58 "Resigns Offices Connected with Ottawa Fair," OFJ, November 6, 1925, 12.

${ }^{59}$ Death Notice, Ottawa Journal, April 22, 1968, 30; OA, Journal fonds, Payroll Summary 1940 to 1942 (previous registers did not include these monthly annuity-type payments); City of Oshawa Directory, Vernon Directories Ltd., 1937, 400; Ottawa City Directory, Might's Directory Ltd., 1946, 207.
} 
many choices as to what newspaper they would read. The Journal's success in delivering something wanted by rural readers is looked at here within the context of the competition.

\section{The Local Competition}

Both the Free Press and the Citizen had been mailing semi-weeklies to customers in the countryside for many years before the Journal joined the party in July 1887 . They were, then, already meeting rural demand for national and international news as well as local news. As well, the Citizen was up until the early 1900s a Conservative newspaper and the Ottawa Valley countryside had a long tradition of Conservative partisanship. Ross's declaration of the Journal as Independent Conservative put a little political space between the two newspapers which may actually have been to the Citizen's benefit. ${ }^{60}$

Charles W. Mitchell had founded the Liberal newspaper the Free Press in 1869. His semi-weekly country edition had been a leader in the field since the $1870 \mathrm{~s} .{ }^{61}$ It appears, based on McKim's directory, that Mitchell or his successors stopped publishing the semi-weekly sometime between 1899 and $1905 .{ }^{62}$ Mitchell sold the Free Press in 1903 to a Toronto newspaperman, Alfred Wood, who historian Minko Sotiron claims was a front for local businessman Warren Y. Soper. Soper was part of a consortium fighting public opposition to its control over local utilities. ${ }^{63}$ Wood (or rather Soper) then sold it to another Ottawa consortium in 1905. The new owners were fronted by local businessman

\footnotetext{
${ }^{60}$ McKim's Directory listed the Ottawa Citizen as Conservative in 1905 (p. 84), Independent-Conservative in 1909 (p. 55) and Independent in 1919 (p. 57). In later years, the Citizen gained a reputation as Liberal which may have helped to lean the Conservative readers of the Ottawa Valley towards the Journal but in their beginnings the Citizen would have been at least slightly more attractive to Conservative readers. ${ }^{61}$ Bruce S. Elliott, "The Great Fire of 1870: A Review of a New Book and New Research on the Fire and Its Aftermath," Horaceville Herald 54 (March 2010).

${ }^{62}$ Canadian Newspaper Directory, 1899, 85; 1905, 84; 1907, 82. In 1907 the Free Press no longer printed a semi-weekly. The Citizen dominated both city and rural markets with a sworn circulation of 12,567 for its daily and 9,898 for its semi-weekly.

${ }^{63}$ Minko Sotiron, From Politics to Profits: The Commercialization of Canadian Daily Newspapers, 18901920 (Montreal: McGill-Queen's University Press, 1997), 147, 153-4.
} 
H.A. (Henry Allen) Bate who gave the newspaper its necessary Liberal face. ${ }^{64}$ But for the first year after the sale, the real owners were Wilson Southam of the Citizen and P.D. Ross of the Journal. Their purpose was to prevent new investment in the Free Press which might have created a strong Liberal competitor to their own papers. Ross persuaded Bate to front the deal as well as interviewing and then, with the agreement of Southam, engaging E. Norman Smith, a Toronto newspaperman, to be the managing editor. Despite the camouflage offered by Bate it appears the word went around in Ottawa leaving Southam and Ross feeling somewhat embarrassed to be owning a Liberal paper. In 1907 they loaned Smith the money to buy it. ${ }^{65}$

I have not found any reference to when the Free Press cancelled its semi-weekly. As Smith later recalled that he had taken over an essentially bankrupt newspaper, either Mitchell or Wood might have stopped it for financial reasons sometime between 1900 and $1904 .^{66}$ The Citizen's semi-weekly lasted about a decade longer. It was first called

\footnotetext{
${ }^{64}$ Henry Allen Bate (1856-1910) was the son of another prominent Ottawa merchant and supporter of the Liberal Party, Henry N. Bate (among other genealogical records see Beechwood Interment Record 12201). H.A. Bate was described in the announcement regarding the Free Press as a "mainstay of the Ottawa Liberal Club" and "special A.D.C." to Sir Wilfrid Laurier on a trip to England, "Free Press Sold to Mr. H.A. Bate," Ottawa Evening Journal, December 2, 1905, 1.

${ }^{65}$ LAC, Ross Diaries, volume 5, November 30, 1905 ("saw Harry Bate, F.P. ... Letter from Woods recommending Norman Smith of Toronto Globe for job."); December 1, 1905 ("Things pretty well formed up re H.A.B. appearing as purchasing of F.P."); December 2, 1905 (“A.M. - lengthy interview w E. Norman Smith - afterwards saw W.M.S. [Wilson Southam] and decided to engage Smith"); September 21, 1906, Ross records detailed Free Press business figures following meeting with Southam and Smith but it appears not with Bate, the supposed owner). The historian of the Southam family, Charles Bruce, and the main Journal biographer, I. Norman Smith (an editor and later President of the Journal as well as son of E. Norman Smith) give the same explanation of the motivation for the Southam-Ross purchase. Charles Bruce, News and the Southams (Toronto: Macmillan of Canada, 1968): 98-9; I. Norman Smith, The Journal Men, 88. The level of cooperation between the Citizen and the Journal seems to have been a case of holding friends close and enemies closer. They were wary of each other and did not allow their reporters or editors to copy material from the other as they each did with other newspapers. At the same time they had several agreements to reduce cut-throat competition in circulation and advertising and were negotiating (and may have agreed on) an exchange of stocks in each other's company. Bruce, 100; Sotiron, 94-5.

${ }^{66}$ LAC, I. Norman Smith fonds, MG 31 D 94, Box 6, file 2. E. Norman Smith, "The Ottawa Newspaper Field," March 26, 1923. Smith presents the Consortium at face value as a Liberal group headed by Bate and says Ross acted as an honest broker in bringing him to Ottawa. If Sotiron is correct on Soper's earlier involvement aimed at countering opposition to his utilities, Soper had no reason to maintain the country
} 
the Twice-a-Week Citizen but at some point early in the twentieth century it became the Central Canadian Citizen and then simply the Canadian Citizen. Under this last name it ran until September 1, 1916 when it was replaced with a mail-out of the daily on Tuesdays and Fridays, the days subscribers had previously received their semi-weekly. At the time the Journal attributed cancellation of the Citizen's special-run semi-weekly to its steadily decreasing subscriptions and advertising. The Journal congratulated itself on its own steady increase in both. ${ }^{67}$

I have seen a copy of the Canadian Citizen dated Friday, July 14, 1916 and disjointed runs of the Central Canadian Citizen from 1909 to $1913 .{ }^{68}$ Under both names, the newspaper nameplate claimed that it was "An Independent Newspaper-Practical Farming, Home-Making, Municipal Progress and World-Wide News.” The earlier newspaper from the period 1909 to 1916 provided about three pages of purely agricultural news and information in the form of a general farm page, a dairy page and occasionally a poultry page, farm market news as well as columns of local correspondents. There was also a women's page with recipes and household management tips plus a serial story. The 1916 issue carried in addition a page of comics but was nevertheless a poorer quality product than either the rural Journal of the same date or the pre-War rural Citizen. This particular issue was 10 pages long while the Ottawa Valley Journal of the same date was fourteen pages. Both newspapers carried the war news, local news, a serial story, a women's page, comics and Ottawa and Montreal market news. The 1916 rural Journal gave readers in addition four pages of agricultural

edition making him another suspect in the killing.

67 "The Editor's Message," OVJ, September 8, 1916, 1.

${ }^{68}$ Osgoode Museum, Vernon Ontario, catalogue number 2012.104.1. LAC has a limited run from 1909 to 1913. 
information, material which the Citizen semi-weekly appears to have dropped. The rural Citizen also had an old-fashioned look with the editorials on the front page down the left side and only one graphic on that page. In contrast, the front pages of the Citizen daily and the Ottawa Valley Journal of the same date carried only news on their front pages with the rural Journal placing in a prominent position a map of the armies on the Eastern Front. It is possible that the Citizen stopped its special country edition due to the increased publishing costs which were affecting all newspapers during the War along with reduced advertising revenues. ${ }^{69}$ Yet doing so, when the Journal chose not to turn its rural edition into an economic sacrificial lamb, suggests that the Citizen had already decided on its future as a wholly urban newspaper.

All three semi-weeklies cost the same and all were significantly cheaper than their parent editions. Between 1887 and 1917 the rural Journal cost $\$ 1.00$ a year after which it cost $\$ 1.25$. In comparison, in 1888 a subscription to the Evening Journal was $\$ 3.00$ a year for delivery in the city and suburbs and $\$ 4$ for mail delivery in the country. ${ }^{70}$ By 1916 the daily cost $\$ 3.60$ irrespective of destination. ${ }^{71}$ In 1899 , the Journal's competitor, The Citizen, cost $\$ 6.00$ per year for the deluxe service of a morning paper (also delivered for the same price to towns across the Ottawa Valley), $\$ 3.00$ per year for the Evening Citizen (without reference to a country clientele) and $\$ 1.00$ for The-Twice-a-Week Citizen going to farm homes. ${ }^{72}$

The rural Journal reported in 1898 that it was losing subscribers but the Ottawa

\footnotetext{
${ }^{69}$ For the effect of the First World War on newspaper costs and revenues see Sotiron, From Politics to Profits, 85.

${ }^{70}$ The daily was mailed to subscribers' post offices in the same manner as the semi-weekly rural edition.

${ }^{71}$ The rural Journal price taken from the masthead and a subscription renewal reminder. The Evening Journal price taken from advertisement, OEJ, January 25, 1888, 2; January 24, 1916, 12.

${ }^{72}$ Advertisement, City of Ottawa Directory (Toronto: Might Directory, 1899), xi.
} 
competition had been there long before it came into being. It is possible that country subscribers were dropping the newspaper because it was out-competed by the small weeklies in the Valley. Certainly there was a lot of local competition in the towns along the Ottawa River, from the Pembroke Observer to the Hawkesbury Post on the Ontario side, the Shawville Equity to the Lachute News on the Quebec side. And there were more weeklies published in towns along the St. Lawrence River such as the Gananoque Journal. A review of McKim's 1899 newspaper directory lists forty-seven such weeklies able to meet the desire of Ottawa Valley residents for the news of their own place. Twenty-eight of these pre-dated the Journal Semi-Weekly, eighteen of them by a decade or more. There were eleven new locals established in the period 1890 to 1897 when the Ottawa Semi-Weekly Journal was losing subscribers. An additional eight town weeklies were established at the same time as the rural Journal was remaking itself and growing its circulation between 1897 and $1899 .{ }^{73}$ It can be argued that the launch of each of the eleven weeklies bit deeper into the Journal's potential market to a point where the Journal management had to change something. I am not convinced of this. With the exception of the Arnprior newspapers, these new newspapers were local while the Journal was marketing to the entire Valley. Presumably losses in a few small towns should not have accumulated to such an extant. I also feel that the Journal's apparent rebound even as the competition was augmented by almost as many newspapers again

\footnotetext{
${ }^{73}$ The eleven were the Alexandria News (1892), Arnprior Watchman (1890), Arnprior News (1895), Carp Star (1894), Chesterville Record (1895), Cobden Sun (1895), Eganville Star (1890), Lanark Era (1890), Vankleek Hill Review (1893), Buckingham Post (1895), and Lachute News (1894). The towns varied in size from 750 (Cobden) to 4,000 (Arnprior) but most had a population of about 1,000. All these were onenewspaper towns except Arnprior which already had one English-language newspaper and thus became a three-newspaper town and Alexandria and Lachute which became two-newspaper towns with the newcomers named here. All the newspapers were still publishing in 1905 except two: the Carp Star which had been replaced by another newspaper and the Eganville Star which had amalgamated with the preexisting town newspaper.
} 
(the eight launched between 1897 and 1899) can be put against this argument despite the newcomers being in very small towns indeed. ${ }^{74}$

\section{Competition from Beyond the Valley}

In the 1890s a new kind of outside competitor entered the Ottawa Valley market. According to Sotiron, the Toronto and Montreal dailies were not just selling semiweeklies and weeklies in the countryside. Subsidized postal rates for carriage on railways plus the expansion of the rail lines themselves meant the bigger metropolitan newspapers could send their morning editions into the countryside for reading the same day, all for a low price of a dollar to $\$ 1.50$ a year. ${ }^{75}$ In other words, rural families could get daily news plus special features for the same price as news twice a week out of Ottawa. Sotiron's examples, however, of the same day newspaper delivery were for the Toronto papers selling into Western Ontario. As well, families living some distance from the railway station had to wait for the start of Rural Mail Delivery in 1908 to make a daily worthwhile. Roll-out of mail delivery took a few years in the Ottawa Valley but it did eventually make a daily newspaper in the roadside mailbox a real possibility.

Nevertheless, Sotiron dates expansion of the Montreal Star and the Witness into the Upper Ottawa Valley and northern Ontario to 1898 with the opening of Canadian Pacific's Ottawa-Montreal Short Line, augmented in 1902 with the merger of the Ottawa, Arnprior and Parry Sound Railway with the Canada Atlantic Railway. ${ }^{76}$ By 1898 , however, the rural Journal was already beginning to rebuild its circulation numbers and

\footnotetext{
${ }^{74}$ Douglas Advocate (1897). Quyon Times (1897), Crysler Ensign (1898). Chelsea Beacon (1898), Finch Advertiser (1899), Hawkesbury Post (1899), Russell Review (1899), Aylmer Review (1899).

${ }^{75}$ The dailies were selling below cost, sometimes substantially so, but losses were more than offset by increased advertising revenues due to the increased circulation numbers; Sotiron, From Politics to Profits, 70-6; W.A. Craick, A History of Canadian Journalism II (Toronto: Ontario Publishing Company, 1959), $82-7$.

${ }^{76}$ Sotiron, From Politics to Profits, 70-3.
} 
it seems to have held on to its rural subscribers even in the face of the outside dailies. I suggest the inclusion of good agricultural reading material after 1899 was likely its most important advantage over the dailies.

While the rural Journal's efforts to be a farm paper may have helped it against the invasion of city dailies, it created yet another kind of competition. Batten's Agricultural Directory for 1908 listed 458 agricultural newspapers published in the United States that year (either solely agricultural or family newspapers with a strong agricultural bent). It listed only 39 in Canada. Most of the 39 covered specific interests from pigeons to bees to farm implements. ${ }^{77}$ The more general agricultural papers included the publications identified by the Journal as its competition. In 1895 P.D. Ross told Printer and Publisher that the Ottawa semi-weeklies as a group had only two major competitors: the weekly version of the Montreal Star (i.e., the Family Herald and Weekly Star) and the weekly version of the Toronto Mail. He dismissed the Mail in a few words but described the Star's twelve page weekly as a quality product. ${ }^{78}$ There was, however, a second set of competitors named in the Ottawa Farm Journal sales pamphlet of c.1919/1920. The pamphlet called these competitors "the best and most widely read farm and home publications." They were Montreal's Weekly Star, the Farmer's Advocate, Farm and Dairy and Canadian Countryman.

The pamphlet listed circulation numbers for the rural Journal and its four main competitors broken down by county for Ontario east of Toronto (see Appendix A for the pamphlet and Map 2 next page). The Ottawa Farm Journal was the overall winner but

\footnotetext{
77 Batten's Agricultural Directory (New York: George Batten Co., 1908). The frontispiece identifies the company as "advertising agents."

78 “The Outlook for Weekly Papers," in Canadian Printer and Publisher 4, no. 9 (September 1895): 11.
} 


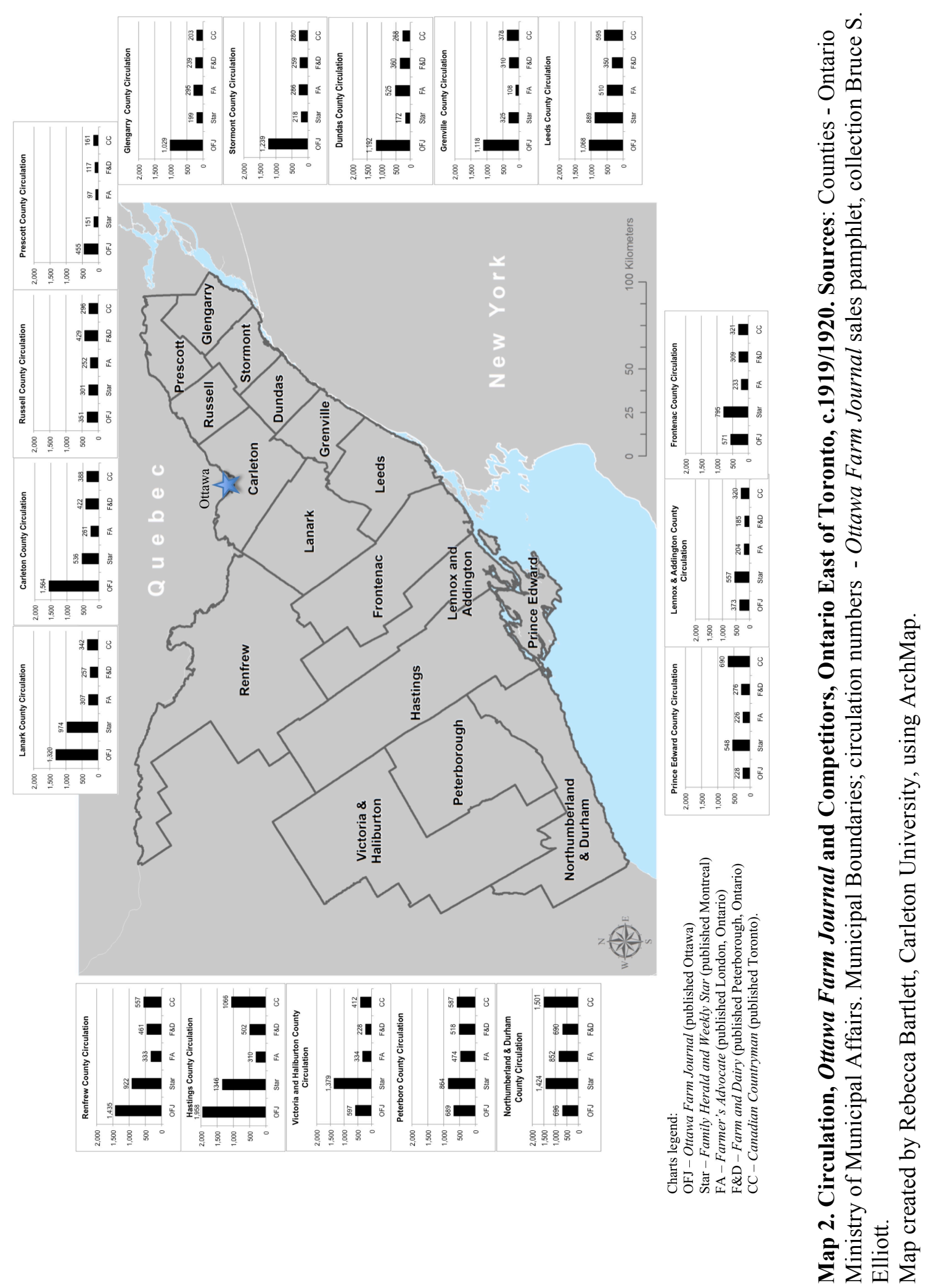


its circulation was almost entirely in Eastern Ontario. The other publications had significant presences beyond Eastern Ontario. It claimed, for example, that the Montreal Star had a local circulation of 11,600 just behind the Journal's 15,883. Nationally, however, the Star dwarfed the Journal. In 1921 McKim estimated the weekly Star's national circulation at 147,000 (J.J. Talman estimates its average Ontario circulation in 1917 at 39,400 based on numbers from 1924 and 1930). ${ }^{79}$ In comparison, the Ottawa Farm Journal's national circulation of 18,210 was effectively its local circulation. The same story applies to the other three. The Canadian Countryman of Toronto, established in 1912, had the highest circulation of the three farm newspapers. Its national circulation in 1919 was 36,995 but it only circulated to 8,465 Eastern Ontario homes. Farm and Dairy also had a high national circulation in 1919 of 18,089 while the pamphlet claimed it had an Eastern Ontario circulation of 5,912. The Farmer's Advocate had the lowest Eastern Ontario circulation of 5,607 but was among the higher national circulations at 30,826 while its western edition printed in Winnipeg added another 33,603 subscribers. ${ }^{80}$

The sales pamphlet gave the county numbers without reference to the potential readership. This varied from area to area. For example, the Journal only had a circulation of 351 in Russell County just east of Ottawa. But by the beginning of the twentieth century Russell County was largely French Canadian. These 351 newspapers actually represented sales to $9 \%$ of the total British origin population which would have translated into a much great proportion of English-speaking households outside the County's only

\footnotetext{
${ }^{79}$ McKim Directory, 1919, pp. 118. The source of circulation numbers broken down by county as used in the pamphlet is unknown. I have not seen this level of detail published in McKim's or Ayers although the newspapers themselves must have had the information and may have shown it to advertisers in selling advertising space. J.J. Talman states that only Lydiatt's Canadian Market and Advertising Data Book gave circulation numbers broken down by province; "Reading Habits of the 1917 Ontario Farmer," in Second Annual Agricultural History of Ontario Seminar 1977, Proceedings, ed. T.A. Crowley (Guelph: University of Guelph, 1977), 70, $88 \mathrm{fn} 12$.

${ }^{80}$ McKim Directory, 1919, pp. 118, 83, 62, 45, 186, 57.
} 
town. Trying to understand the actual penetration of the five publications requires translating the numbers into a percentage of the potential market for an English language newspaper aimed at rural readers. ${ }^{81}$ The Journal was strongest in the counties immediately surrounding Ottawa and dropped off as one went further west. The competitors were strongest in the counties nearest to Toronto. The pamphlet does not show circulation in West Quebec. Perhaps the numbers were not available for comparison but there was also the barrier of language and the likelihood that each of the publications had achieved as much market penetration as possible given the size of the Anglophone population. The more enticing market for the Ottawa Farm Journal was west of Kingston where almost all households would have been potential readers.

The Montreal Family Herald and Weekly Star was the most similar to the Ottawa Farm Journal in that it was a special edition of a city daily which targeted the farm market. It was also the most popular of the rural Journal's competitors. Hugh Graham had founded the daily Star in 1869 and the next year spun off a weekend supplement. In 1874 he separated the weekend edition from the management of the daily and began selling it as a separate newspaper outside Montreal. Jennifer Marotta's doctoral study of the Family Herald and Weekly Star, like this study, is concerned with the press as an agent of change but she focuses on middle-class "respectability" rather than agrarianism. ${ }^{82}$ She therefore analyzes the newspaper's correspondence section and its

\footnotetext{
${ }^{81}$ The Census tables for 1921 broke down "language spoken" by province. The 1931 Census tables broke down the numbers by census division which is helpful even though it post-dates the pamphlet by a decade and does not provide a rural-urban split. Unfortunately language is given for the total population and not household. This means, for example, the 351 newspapers sold in Russell (each one presumably to a household of anywhere from one to ten or twelve people) was read by an even greater proportion of the Anglophone potential market than I assume here, perhaps as many as four times more if there was an average of four persons per Anglophone household. All these unknowns make calculation of market share speculative.

${ }^{82}$ Jennifer Susan Marotta, “A Moral Messenger to the Canadian Middlemost: A Reading of The Family
} 
legal advice column. She does not look at the differences between the Star's city and rural editions. Nor does she need to. There was a much greater distance between the Weekly Star and its parent than this study finds between the two Journals. Marotta comments in passing that there is no data on the Family Herald's employees but she does find indicators that the weekly staff was steadily growing over the 1880 s and 1890 s. $^{83}$ More directly, an 1895 profile of Hugh Graham describes the weekly in glowing terms and underlines its independence:

[The weekly] has an editor and staff of its own. Much of the reading material is specially written and set up for it. ... [It] is not, as so many weekly editions of city dailies are apt to be, merely a receptacle of so many columns of matter from the daily papers, shoveled in with more or less haste, chiefly more. The proprietor takes as keen an interest in every issue of the weekly as the daily. ${ }^{84}$

The name of its 1899 editor speaks to its quality. Douglas Fetherling in the Canadian Encyclopedia calls J. W. Dafoe, future editor of the Manitoba (Winnipeg) Free Press and then editor of the weekly Star, "one of the most influential journalists in Canadian history." ${ }^{, 85}$ But was it a farmer's newspaper? Printer and Publisher described the Weekly Star as aiming "for the domestic circle" and says nothing about either agricultural or rural content. Despite this emphasis on the domestic, its content was strong in both areas. ${ }^{86}$

The Farmer's Advocate offered quite a different form of competition. Talman opines that "[a]s an agricultural journal the Farmer's Advocate was far superior to the

Herald and Weekly Star, 1874-1914," (PhD diss., Queen's University, 2006).

${ }^{83}$ Ibid., 83-5.

${ }^{84}$ A.H.U. Colquhoun, "The Man Who Made the Montreal Star - Hugh Graham, Esq," Canadian Printer and Publisher 4, no. 4 (April 1895): 7.

${ }^{85}$ Douglas Fetherling, "John Wesley Dafoe," in The Canadian Encyclopedia (2008, edited 2016), http://www.thecanadianencyclopedia.ca/en/article/john-wesley-dafoe/. Accessed January 23, 2017.

${ }^{86}$ Colquhoun, 7; "The Weekly Subscription Rate in Canada," in Canadian Printer and Publisher 8, no. 6 (June 1899): 2. 
Family Herald." ${ }^{87}$ It was not the largest of the Ottawa Farm Journal's competitors yet I have chosen to focus on it for comparison because of its history of being just what its name said - an advocate. The Farmer's Advocate and Home Magazine had many family features of general interest but its raison d'être was to improve agricultural practices in Canada. There have been a few profiles of the founder William Weld (1824-1891) but no major studies of his farm journal. ${ }^{88}$ In 1866 he began publishing the Advocate as a monthly journal out of his farm at Delaware, Ontario near London because he saw a need. Canadian farmers needed to be educated about modern scientific agriculture. He was also personally affronted that neighbouring farmers had brought unpedigreed animals into the show ring and ignored his own pedigreed horse. ${ }^{89}$ Weld took strong stands on agricultural issues and ran an experimental farm to back up his various positions. ${ }^{90} \mathrm{He}$ was undoubtedly not an average farmer but contemporaries would have approved of his newspaper as giving a "practical man's" advice.

The monthly was a quick success and soon required Weld's full attention. Leaving his grown sons to run the farm, he established a full printing shop with a large staff in London, Ontario. Almost immediately Weld had a provincial audience. In 1890 he opened an office in Winnipeg to publish a western version, after which the newspaper

\footnotetext{
${ }^{87}$ Talman, "Reading Habits," 75. Talman's review of the contents of the December 27, 1916 issue presents a weekly that had much the same range of content as the Ottawa Valley Journal of that date.

${ }^{88}$ There is a short article exploring the newspaper as a useful source for identifying topics of interest to agriculturalists at particular times - Senita O. Kyeremateng, "A Report on the Farmer's Advocate", Guelph University Collection Update No. 19, 2002 - Rural History.

http://www.lib.uoguelph.ca/resources/archival_\&_special_collections/collection_update/19/farmersadvocat e.htm. Accessed October 10, 2012.

${ }^{89}$ Ian M. Stewart, "Weld, William," in Canadian Dictionary of Biography (http://www.biographi.ca/en/bio/weld_william_12E.html). Accessed September 15, 2103; W.A. Irwin, "The House of Weld," in MacLean's, July 15, 1931, 10.

${ }^{90}$ Stewart in the Canadian Dictionary of Biography claims Weld ceased to run his farm as an experimental farm in 1874 with the establishment of the Guelph College of Agriculture, but Fred Landon, "The Agricultural Journals of Upper Canada (Ontario)," Agricultural History 9, no. 4 (Oct. 1935): 17 claimed the Weld family was running the experimental farm at that time. Landon was referring to Weldwood Farm on the outskirts of London which was owned and managed by the Weld Publishing Company.
} 
could claim to have national importance. The Advocate itself claimed in a 1924 ad aimed at potential advertisers that it reached 50,000 farm homes weekly. What is more, the paper stressed that its subscribers were consumers of interest to business. The majority of them owned over fifty acres and as a result had a greater per capita wealth than the average Canadian farmer. ${ }^{91}$ Advertisers seem to have taken his claim seriously. For example, in 1916 the Farmer's Advocate carried extensive advertising for almost every make of car available in North America, from the cheapest Ford to a $\$ 1,600$ Overland $6 .{ }^{92}$ This sign of consumer culture is a reminder that farm journals were businesses selling consumers to advertisers just as the big city dailies were doing. In the case of the Farmer's Advocate the consumers it was selling also wanted good reporting on agricultural issues and the Advocate responded by continuing to make agriculture its central focus. Weld's sons and grandsons ran a successful publication well into the twentieth century. The paper finally closed in 1965 .

There was never any question as to the rurality of the Farmer's Advocate. The same cannot be said for the rural Journal. That question is looked at below.

\section{An Urban Dish with a Soupçon of Rural Flavouring}

In Chapter $2 \mathrm{I}$ looked at the historiography of the press with a particular focus on the commercialization of the late-nineteenth-century newspaper and the development of New Journalism. Commercialization meant that newspapers provided more than political comment and business news. They had new features ranging from comics to women's departments while reporting the news in a lively, slangy style and emphasizing the

\footnotetext{
${ }^{91}$ Batten, 200; Advertisement "Direct your advertising to this great unit of consumer purchasing power," The Globe (Toronto), March 1, 1924, 5.

${ }^{92}$ Advertisement, Farmer's Advocate (hereafter $F A$ ), January 6, 1916, 36
} 
prurient news of the police court. New Journalism went beyond these content changes to a new style of reporting in which newspapers did not wait for news to happen; they made it happen. In this section I look at how the rural Journal's content evolved between 1887 and 1925 in terms of two issues: first, the degree to which the rural Journal's content was rural, and second, its resemblance to the urban commercialized press. The question of the rural Journal as a news maker in the style of the New Journalism is the subject of the next four chapters. Throughout this and the next chapters, the focus is on the rural Journal's success in using what was essentially an urban model.

\section{What Readers Wanted}

The rural Journal claimed in 1899 that it was changing to meet readers' desire for a newspaper that was more than a digest of the latest news. Instead it would focus on what was unique in the lives of its rural readers - their livelihood and their way of life as agriculturists. While there was more than farming in the countryside, it was the dominant occupation. Yet the amount of local and farm content ebbed and flowed over the years. So what was the appeal of the rural Journal to country readers?

Beth Garfrerick states that country weeklies were of interest to farmers who could only get to the post office once a week. ${ }^{93}$ Russell Johnston claims that by 1900 rural journalism was the "poorer" or even the "backward" cousin of the urban press. ${ }^{94}$ Contemporary assessments also claimed that farmers were just making do with a weekly. They could have said farmers took a weekly or semi-weekly because the newspapers were cheap. But when we look for clues as to what rural readers wanted, at least as seen

\footnotetext{
93 Beth H. Garfrerick, "A History of Weekly Community Newspapers in the United States: 1900 to 1980 " (PhD. diss., University of Alabama, 2009): 35.

${ }^{94}$ Russell Johnston, Selling Themselves: The Emergence of Canadian Advertising (Toronto: University of Toronto Press, 2001), 19-20.
} 
by contemporary newspaper publishers commenting from their own experience, a more complex picture emerges. In 1893 Printer and Publisher published a paper given at a meeting of the New Jersey State Editorial Association. It claimed that country readers wanted a mix of local and national/international news presented in short paragraphs and larded with light literary pieces. Another commentator said that farmers were only interested in taking a city daily which carried information on local and non-local farm markets. A country publisher said that, while he had to keep his editorials simple and statistic-free, he had to provide strong agricultural coverage ${ }^{95}$ Readers were not insisting that all this be offered in one package. The same country publisher said that the farmers in his district took a city daily for national and international news, the town weekly for local information and a farm journal for trade information. ${ }^{96}$

It seems, however, that the rural Journal's readers were very demanding customers indeed. The first issue of the renamed Ottawa Valley Journal in 1899 carried a confession. The newspaper had been steadily losing subscribers for some time. The editorial then gave a savage assessment of its own content and linked that content directly to subscribers voting with their feet—or rather their dollars:

A year ago, the Semi-Weekly Journal, like the other Ottawa semi-weekly papers was a dumping ground for printed matter from the daily paper.

The Ottawa semi-weekly editions were all mostly used to palm off second-hand stuff upon the residents of the counties around Ottawa, and get a dollar a year for it.

As a result, the semi-weekly papers were stagnant. ...

For years prior to last January [1898], the Semi-Weekly Journal was stationary or worse. Its subscription list was falling off rather than

\footnotetext{
95 "Plated Matter in Country Weeklies," in Canadian Printer and Publisher 2, no. 8 (August 1893): 17; James Fisher Confederate, "Markets in Country Weekly (sic)," in Printer and Publisher 9, no. 2 (February 1900): 15-16; A.G.F. Macdonald, "The Editorial in a Country Weekly," in Printer and Publisher 9, no. 2 (February 1900): 12, 14.

${ }^{96}$ A.G.F. Macdonald, "Country Correspondents," in Printer and Publisher 5, no. 2 (February 1896): 24, 26. Macdonald published Glengarry News in Alexandria, Ontario on the Ottawa to Montreal Canada Atlantic rail line allowing publishers in both cities to deliver their dailies by rail to his town.
} 
increasing. ...

The Journal determined upon a change. A different policy was planned, namely the policy of endeavoring to turn out a really good paper which would be useful to the counties and worth the money of subscribers. ${ }^{97}$

The editorial went on to enumerate changes which had been implemented in 1897 and 1898: editing the copied news so that it appeared "in better shape," increasing the number and geographic range of country correspondents, and more careful editing of market reports and an expanded range of markets reported upon. The editor had also introduced "information especially useful to farmers" although he did not specify what this was. The name change was presented as a sign that the rural paper would be worth buying on its own merits - that it was "no longer a mere second fiddle to the daily."98

There had been previous promises of improvements but no follow-through. For example, starting in October 1890 and off and on through 1892 the daily Saturday Journal had carried a "Farmer's Corner" which was repeated in the Monday semi-weekly edition. This was a cut-and-paste assembly from various farm journals. In November 1895 the semi-weekly announced that there would be a specially edited "Farm and Garden" feature but nothing appeared for several months. When new printing presses allowed the publisher to enlarge the daily to eight pages, the newspaper teased the rural readers with the news. The April 3, 1893 semi-weekly was printed by replacing the daily front page with the rural front page and sending out the daily otherwise unchanged. Rural readers then read that the newspaper was now doubled in size. Those who did not notice that all references were to "the Journal" and not the "Semi-weekly Journal" might have thought that their rural paper would now be twice as large. But it was back to four pages

\footnotetext{
97 “Change of Name," OVJ, January 31, 1899, 4.

${ }^{98}$ Change of Name"; the newspaper was doubled in size as of August 31, 1897. OSWJ August 31, 1897, 1 , 2.
} 
in the next issue and was not enlarged for another four years despite a December 1893

promise to enlarge the paper in the coming year. ${ }^{99}$ This delay may have been a cost input decision given Ross's 1895 statement that his semi-weekly was competitive partially because its four pages twice a week equaled a weekly’s eight pages at less cost. ${ }^{100}$ However, the confession of falling circulation prior to 1898 suggests that Ross should have looked beyond cost inputs to judge the rural edition's success. That he did not do so indicates how peripheral the rural Journal was to his business.

\section{$\underline{\text { Selling the Semi }}$}

Journal management seemed to lack a vision of how to sell the rural Journal beyond sweetening subscriptions with "clubbing" on the one hand and premium (prize) offers on the other. Clubbing here refers to a promotion in which a newspaper sold another newspaper or a magazine for a small supplemental charge as a perk for subscribing to its own paper. ${ }^{101}$ Sotiron has looked at clubbing as a point of tension between the commercialized city dailies and small town weeklies. The Toronto and Montreal dailies were forced to expand into the countryside by the business logic which linked advertising money to subscriber numbers. The town weeklies agreed to the clubbing blandishments of the city papers but still complained of unfair competition. The competition extended beyond the question of poaching subscribers to the loss of the patent medicine advertisements. These had often been the main revenue stream for small

\footnotetext{
${ }^{99}$ Untitled editorial, OSWJ, November 5, 1895, 2; "Another Step in The Journal's way up the Ladder of Prosperity," and "The Journal" OEJ, April 3, 1893, 3, 4 and OSWJ, April 3, 1893, 3, 4; "On Premiums," OSWJ, December 7, 1893, 2.

100 "The Outlook for Weekly Papers," in Canadian Printer and Publisher 4, no. 9 (September 1895): 11.

${ }^{101}$ Clubbing also refers to a group of subscribers buying their subscriptions through another subscriber who receives the publication at a discount in return for collecting the group's money and sending in the names and addresses; Jack Van Derhoof, "Eastern and Mid-Western Agricultural Journalism, 1860-1900” (Ph.D. diss., Columbia University, 1951): 72. This last is the kind of club list John Fry used as a key source in his book The Farm Press (see Chapter 2).
} 
weeklies but the companies could now reach the countryside through a few placements in the clubbed city papers. ${ }^{102}$

Printer and Publisher carried a debate on the merits of clubbing. A number of writers warned that it was in effect selling your own newspaper at a discount and thereby admitting your newspaper was not a quality product. Ross, however, in his contribution to the debate judged the rural Journal's clubbing with the American journal Farm and Home to be "harmless," a "philanthropic" gesture "to facilitate farming reading for our farmers." But he did not think it increased the semi-weekly's circulation. ${ }^{103} \mathrm{He}$ was probably right. This offer had been advertised in the same period when the Ottawa SemiWeekly Journal was apparently losing subscribers. Clubbing did give rural readers easy access to the wide range of printed material which the publisher thought readers wanted. In the case of the rural Journal clubbing a farm journal, management assumed their readers wanted farm news.

Premiums were the other method of increasing circulation in what Sotiron called the "aggressive marketing strategies" of the 1890s dailies. He points to the Montreal newspapers giving away books in 1894 while Toronto newspapers gave away pictures and flower seeds in order to sell their newspapers. ${ }^{104}$ Ross specifically said he did not offer inducements to get country residents to buy his daily because he did not aim to increase the daily's territory. ${ }^{105}$ This underlines Sotiron's link between premiums and

\footnotetext{
102 Sotiron, From Politics to Profits, 72-3.

103 "Criticisms of the Clubbing System - Views of City, Town and Country Publishers on the Question," Printer and Publisher 7, no. 9 (September 1898): 6.

${ }^{104}$ Sotiron, From Politics to Profits, 55-6.

105 "Criticisms of the Clubbing System," in Printer and Publisher 7, no. 9 (September 1898): 6. Despite this Ross was mailing the daily into the countryside as of 1933 (in addition to selling the special country version). In describing the daily's production process, Ross stated that among the various runs of the newspaper print over the day, at 2:15 they produced "the country edition of the Evening Journal timed to get into the mail" followed at 2:45 by the main Journal run. P.D. Ross, "Inside a Newspaper," Speech to
} 
clubbing as flowing out of the increased competition between city dailies in the 1890s. At the same time one contemporary claimed that weeklies should not use the "usual" means of promoting circulation — premiums and prizes— but the reason given was simplistic. Circulation premiums did not work for the small weekly because "[y]ou cannot ape the airs or assume to fill the place and do the work of the city daily or the provincial weekly." ${ }^{106}$ Despite such advice, in 1893 and 1894 the rural Journal offered the illustrated Canadian Annual to subscribers while the coronation of Edward VII gave the opportunity to offer a free colour reproduction of a picture of the King and Queen. ${ }^{107}$

Sotiron mentions contests becoming popular marketing gimmicks in the 1890s and remaining popular into the early twentieth century. These contests came in a wide range of formats. They might involve a game which one had to subscribe to enter, perhaps an invent-a-jingle promotion or finding the pictures hidden in the newspaper text. More directly they could involve signing up new subscribers with substantial prizes for the individuals who sent in the most subscriptions. These circulation contests sometimes overlapped with premiums in which a wide range of small prizes were given to people who sent in new subscriptions, the value of the prize increasing with the number. During the First World War they actually increased in numbers as well as becoming more elaborate (and more expensive to run). ${ }^{108}$ Gerald Baldasty, in his history of the commercialization of the news, mentions that neither contests nor premiums were common outside of big city metropolitan dailies. ${ }^{109}$ But even city newspapermen had

\footnotetext{
Canadian Club at Montreal, February 1923, P.D. Ross fonds, file 9.

${ }^{106}$ J.H. Thompson, "The Country Weekly," Printer and Publisher 5, no. 2, February 1896, 12-13.

107 "The Journal for 1893," OSWJ, January 2, 1893, 1; "Free to Subscribers," OSWJ, December 25, 1894, 4; "The Ottawa Valley Journal's New Premium," OVJ, May 10, 1901, 2.

${ }^{108}$ Sotiron, From Politics to Profits, 56.

${ }^{109}$ Gerald J. Baldasty, The Commercialization of News in the Nineteenth Century (Madison: University of Wisconsin Press, 1992), 134-6.
} 
their doubts on the efficacy of contests for increasing circulation. In 1906 E. Norman Smith of the Ottawa Free Press and his business manager William Findlay discussed the approach they would take to increasing circulation. Findlay wrote Smith that "circulation gained in bunches is expensive and ephemeral in character." Findlay proposed to avoid contests as a short-sighted way to gain subscribers. ${ }^{110}$ Yet the rural Journal did run two circulation contests before dropping them in favour of premiums.

Premiums seem to have been favoured by almost all. Baldasty names a few small cities (such as Elmira, New York) where both premiums and contests were used to build circulation. Baldasty, however, does not dig further to determine whether the prizes on offer were chosen to meet the interests of readers in smaller centres. John Fry in his study of the American farm press identifies subscription contests and premiums as being among the causes of a significant expansion of farm circulation in the 1890s and into the early years of the twentieth century. The four farm journals that he studied offered a wide range of goods as premiums but most appeared to be household or personal items (for example, sewing machines, pocket knives, books). Fry does identify two premiums which were farm-oriented, a staple puller and wire splicer and a corn sheller, but he does not identify any other efforts to make premiums particularly rural. ${ }^{111}$ In Canada I have found that the Farmer's Advocate, the Citizen's semi-weekly and the rural Journal all offered premiums in various forms for encouraging subscribers both to continue their subscription and to bring in more subscribers. ${ }^{112}$

\footnotetext{
${ }^{110}$ LAC, I. Norman Smith fonds, MG 31 D 94, Box 6, file 2. Memorandum, Wm. Findlay to E. Norman Smith, February 23, 1906.

${ }^{111}$ Fry, The Farm Press, 10-2.

${ }^{112}$ The July 14, 1916 edition of the Canadian Citizen ran only one premium ad, a quarter-page ad offering kitchen utensils. I might have found a wider range of offerings if I had sample issues from the fall and early winter when subscription drives were underway. At the same time the newspaper may have chosen not to offer expensive premiums given the economic challenges newspapers were experiencing during the war. It
} 
There is also a question of the style in which subscription campaigns were offered. In the case of the rural Journal, after 1897 these were carried out with a liveliness and a relentlessness not found in the daily Journal at that time. The daily did regularly carry small notices encouraging an untargeted audience to take out ads but I have found neither subscription campaigns nor large ads promoting the newspaper content to readers, much less specific types of readers. The new liveliness in the rural edition started when Cowan became the semi-weekly circulation manager. He commenced with a large and boldly printed front page ad for a new circulation contest followed by two small ads on inside pages. At the same time the "Evening Journal's Business Manager" was making a clubbing offer in a more restrained back page ad. This last clubbing offer was repeated three times between January and April 1898 until the Evening Journal's Business Manager alerted readers that only a few copies of the offered encyclopedia and Farm and Home subscriptions were left. In contrast Cowan followed up his announcement of the circulation contest with weekly publishing of letters from participants and exhortations to sell what was touted to be a great newspaper. When he declared the competition closed in February 1898, he announced the top winners with some fanfare plus the names of 303 new subscribers. ${ }^{113}$ A second subscription competition was launched immediately along with the semi-weekly's first voting contest for the Valley's favorite country teacher. ${ }^{114}$

is also possible that, if a decision had already been taken to stop printing a special country edition in two months, the Citizen's circulation department was damping down its subscription campaign.

113 "Do You Want to Win a Prize," "A Christmas Present," "To Our Readers," OSWJ, December 14, 1897, 1, 6, 8; "The Chance of the Year," OSWJ, December 17, 1897, 8; "Here Are the Winners," OSWJ, February $15,1898,1$. The competition would have brought in $\$ 303$ in new subscriptions while paying out three top prizes amounting to $\$ 150$ plus an indeterminate amount in small prizes.

114 "The Most Popular Teacher in the Ottawa Valley. Who Do You Say He or She is?" OSWJ, January 25, 1898,1 . (The rural was following the lead of the daily which had earlier run a contest in which readers sent in coupons clipped from the newspaper to vote on their favorite local athlete.) 
The voting contest was a success as the newspaper had kept the excitement going with regular updates on the number of votes received by contending teachers along with comments by readers. The second subscription competition was not. It was undermined when the semi-weekly went whole hog into premiums in April 1898. The newspaper announced it would send a pedigreed piglet to subscribers who mailed in twelve paid-up subscriptions for the rural Journal. Not only did the rural Journal continue to repeat this premium until at least 1925, it expanded the offer to a wide range of livestock, from bees, to setting eggs, to a bull calf (the last requiring a good fifty subscriptions). ${ }^{115}$ Herbert Cowan took credit for the pig premium concept in a 1906 article in Printer and Publisher under the title "The Circulation Manager - The Livestock Offer." Cowan called it "the most successful circulation scheme the Journal ever introduced." Cowan explained that the pigs had cost five dollars and in some cases were acquired free when the breeder took the advertising that the contest gave them in lieu of payment. ${ }^{116}$ Cowan started offering pig premiums in his own farm journal, Farm and Dairy, in 1909 while the Central Canadian Citizen was also playing the livestock card that year. ${ }^{117}$ The pig premiums were highlighted in the Ottawa Farm Journal's c.1919/1920 sales pamphlet claim that it had given away 3,200 pure-bred pigs and poultry in order to improve the livestock of Eastern Ontario. It thereby rebranded a circulation stunt as agricultural improvement.

The original 1900 advertisement for the premiums made clear that it was all about the newspaper's circulation: "Remarkable Offers with a View to Increasing the

\footnotetext{
115 Advertisement "Pure-Bred Pigs In Return for Subscription Lists," OFJ, January 16, 1925, 11.

116 "The Circulation Manager - The Livestock Offer," in Printer and Publisher 15, no. 9 (September 1906): 33.

117 "Free Pigs for All," Farm and Dairy, April 1, 1909, 20; other premiums offered in the same year in Farm and Dairy were a general accident insurance policy (March 4, 1909, 17) and board and rail fare to Guelph for a short winter course (January 7, 1909, 8). "What We Want," Central Canadian Citizen, January 1, 1909, 2.
} 
Circulation of the Ottawa Valley Journal." ${ }^{\prime 18}$ The change of emphasis had come by 1907 when the premium advertisements linked the livestock premiums with being a progressive farmer: "Is Your Name in This List / Of Progressive Farmers Who Have Won / Pure-bred Pigs Offered as Premiums by the Ottawa Valley Journal." ${ }^{\text {119 }}$ The advertisements which followed presented the pig premiums almost as if they were a new initiative: "Live Stock Improvement / A Big Campaign Started in Eastern Ontario. / The Journal is at the Bottom of it. A New Method Whereby Enterprising Farms can Secure Pure-Bred Pigs," and a week later "The Journal has the Greatest Proposition Ever Placed Before the Farmers. Something for Nothing." ${ }^{120}$ This change in emphasis allowed the newspaper to advertise itself and simultaneously cover itself with virtue.

Self-advertising was a necessity for all new newspapers in the competitive market of the late-nineteenth and early-twentieth centuries. Another sign of an increasingly competitive newspaper environment was the rise in importance of the business office and the decreased importance of editorial staff. ${ }^{121}$ The Montreal Star put out an advertising booklet in 1919, under the guise of a souvenir booklet celebrating fifty years of the Star. It told its own story in terms of the publisher Hugh Graham and the Star playing a pivotal role in campaigns related to civic, national and international events over the previous fifty years. ${ }^{122}$ Self-advertising was also undertaken by both the daily and the rural Journal. As well as the c.1919/1920 Ottawa Farm Journal pamphlet which sparked this study, the Journal Publishing Company put out a booklet on the City of Ottawa and the daily

\footnotetext{
118 "Pure Bred Stock as a Gift," OVJ, October 2, 1900, 5.

119 "Is Your Name on the List," OVJ, January 22, 1907, 10.

120 “Live Stock Improvement," OVJ, August 16, 1907, 12; “Successful Pig Breeding," OVJ, August 23, 1907, 12.

${ }^{121}$ Sotiron, From Politics to Profits, 47-9,

${ }^{122}$ Booklet, "Fifty Years 1869 to 1919 / Half Century Souvenir," collection of Bruce S. Elliott. The booklet mentions the rural Family Herald and Weekly Star exactly twice, first on the title page and second on the last page giving its circulation in 1919.
} 
Journal. This booklet, however, was aimed at attracting advertisers rather than

subscribers. ${ }^{123}$ I hesitate, however, to speculate on the impetus for the Journal's two advertising pamphlets. ${ }^{124}$

\section{The Journal Content and its Evolution}

Since the rural Journal began improving its content in 1897 and 1898 at the same time as it ran high energy circulation schemes, it is not possible to say what readers responded to- -better targeted content or free pigs. But the newspaper was giving readers something they wanted, for Cowan claimed that the subscription count had "come within 300 of doubling" in 1898. Subscriptions continued to grow in the years that followed, from 4,047 in March 1899 to 8,360 in 1906-1907. The 1907 rural newspaper's circulation was almost as large as the daily's circulation of $9,344 .{ }^{125}$ I suggest that whether content or pigs drove subscriptions does not matter. Both initiatives made the semi-weekly a farm-focused product. Yet the rural Journal was still a newspaper, and not a farm journal. To quantify this statement I carried out a high level content analysis of the types of material carried in the rural Journal based on sampling nine issues taken randomly in each of four selected years: 1888, 1898, 1907 and 1925. I coded each item as to its fit within 12 categories:

1. general news

\footnotetext{
123 "The 'Journal' - More Than a Newspaper," booklet, [late 1919, from internal reference to "this peace year" and photo of its 1919 booth at the Ottawa Exhibition], http://online.canadiana.ca/view/oocihm.87379/1?r=0\&s=1. Accessed November 19, 2017.

${ }^{124}$ While we have examples of advertising pamphlets for the Ottawa Farm Journal, the Evening Journal and the Montreal Star, all dating from 1919 to maybe 1920, we cannot assume that these were the only such examples published either specifically by the three newspapers or by other newspapers, or that the Journal was responding to the Star's competition. The Journal may have been responding to increased pressure from the Citizen as the Southam company made management changes after 1915 which turned its collection of newspapers into a national chain (see Sotiron, From Politics to Profits, 90-1 on the Southam chain and his claim that Southam's new structure had substantially changed the newspaper industry by 1919).

${ }^{125}$ Advertisement, The Canadian Newspaper Directory (A. McKim: Montreal, 1899): 310.
} 
2. agricultural news

3. opinion-editorials

4. entertainment

5. farm information/education

6. general information/education

7. Valley personals and local events

8. Ottawa personals and local events

9. Ottawa and national consumer ads

10. ads targeting farmers

11. ads for patent medicine, and

12. Journal self-news and information.

I measured each coded item and then calculated the proportion of the column filled by it. This allowed me to calculate how many total columns of material were filled in each category and then, for the purposes of comparison, the percentage of total newspaper space in that sample year devoted to each category. (See Appendix C for process and table of results.)

I also compared four issues (one from each season) in each of these years with the daily of the three preceding days. This showed that in 1888 almost all the content had been taken from the daily and that proportion never dropped below $70 \%$ over the next 37 years. This is because in each edition all news, editorials and most entertainment features came directly from the daily. In addition, even as the newspaper increased in size, it carried more individual items in each category and therefore the category proportions shifted only slightly. What is interesting are the changes to the categories which are 
graphed in Figure 4.2 (next page) and Appendix C: agricultural news, entertainment, information, personals/local events, and advertising.

To start with the most dramatic change, entertainment features grew to become by 1925 the second most important feature, in terms of amount of content, just as was happening in the daily newspapers generally. In the case of the rural Journal, entertainment had started in 1888 as a serial story plus some jokes shoved in as fillers. But since between two or three columns to almost a full page of the four page newspaper was consumed by the serial story, entertainment amounted to $10 \%$ of the total content and remained at about $8 \%$ through to 1907 . The addition of the comic page and a special children's page, both around World War I, pushed up the entertainment content to $20 \%$ in 1925. The children's page actually straddled entertainment and the growing amount of practical information in the newspaper. It was filled with educational articles about nature as well as "Uncle Henry" (James Henry) telling stories of his Scottish farm childhood. But most of the content was children's letters solicited by the paper on subjects set for them. While Henry wrote pedantic commentary exhorting the children to practice their letter formation and their spelling, the families no doubt read the page for the pleasure of seeing their child in print. For this reason I coded the children's page as entertainment.

Another important section of the newspaper was (almost) unique to the rural Journal, at least after 1900_agricultural news, general information and farming information. The sample issues of the 1888 semi-weekly contained no agricultural material beyond the market news and a few classified ads selling farms and looking for strayed livestock. Even much of this was taken directly from the daily. But agricultural 


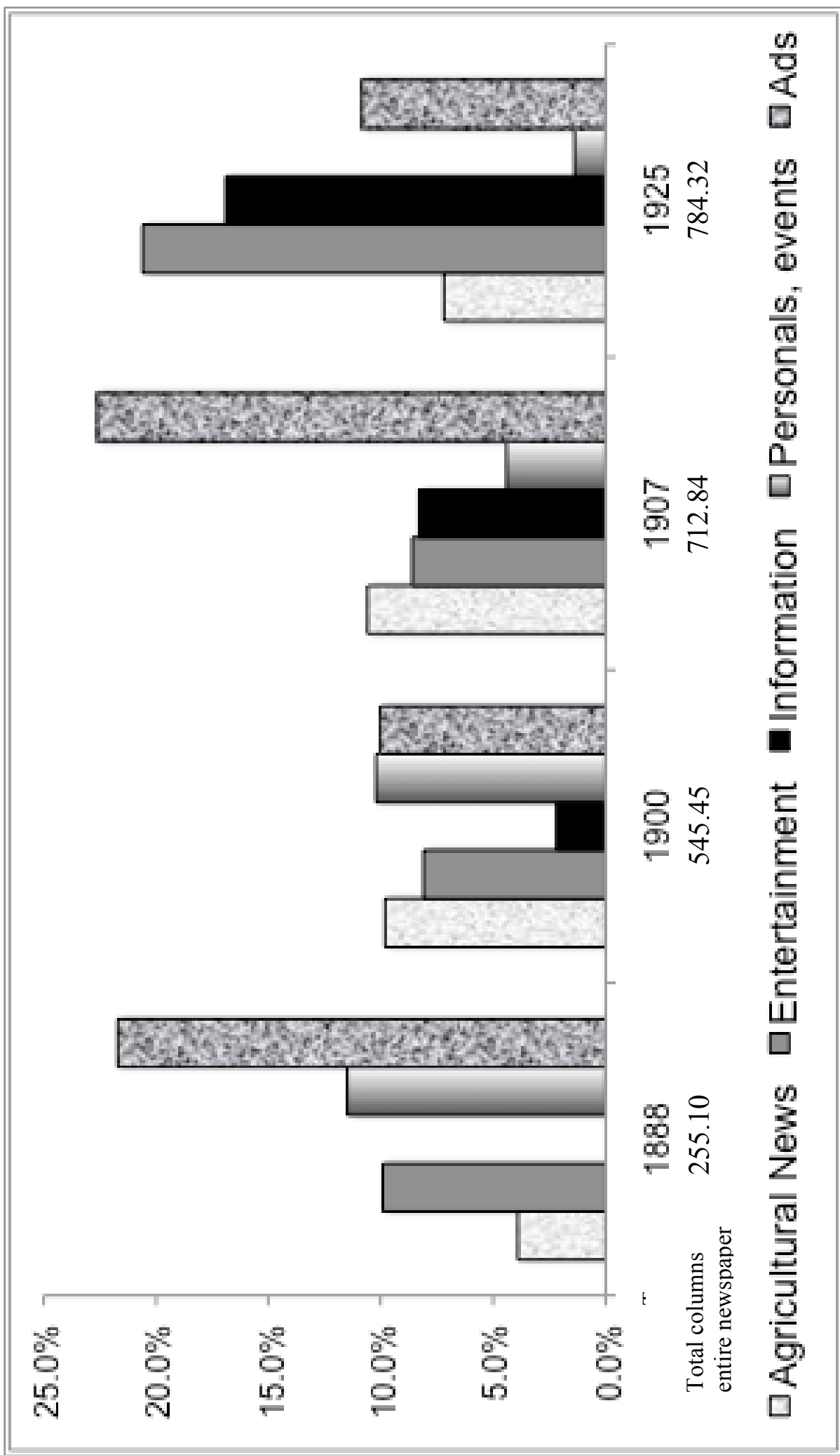

\begin{tabular}{|c|}
\hline 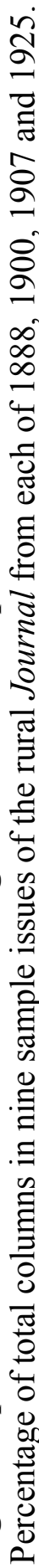 \\
\hline
\end{tabular}


news increased from $8 \%$ of the news in 1888 to $15 \%$ in 1925 . Since the total news content remained at almost the same proportion from 1888 to 1925 (hovering around $50 \%$ ) the increase in agricultural news came at the expense of the non-agricultural news. Agricultural news had become a significant contribution to the unique nature of the rural Journal. Advertising had also become more uniquely agricultural with almost half (43\%) of advertising consisting of farm-oriented classifieds (strayed livestock and farms for sale) but especially companies advertising farm goods, from flypaper to milking machines.

The percentage of informational content grew steadily. In 1888 there was only one item which I could stretch into an information category whereas in 1925 there were up to four pages and sometimes more of informational material. This included a page of dairy information, a second page answering questions about farming and livestock plus up to another page on general rural practices. The big winner, however, was general nonagricultural information. There had been a half page of such information in 1900 which had grown by 1907 to almost a full page of household and fashion items. By 1925 there was a men's page on car care and radios as well as a full women's page on household management. As well, starting in 1902 the women's material had become targeted to rural readers as "Aunt Joe" answered questions and dispensed advice in a weekly column. This was in addition to occasional urban-oriented women's information and, starting in December 1921, Dorothy Dix’s syndicated column of relationship advice.

There was one significant loser between 1907 and 1925 and that was local personals written by ordinary people in small towns and villages about their neighbours. The correspondence columns which had sometimes filled almost a whole page in 1907 
was gone in 1915. This may have been related to the newspaper's effort to free itself from the confines of the Ottawa Valley or to the cost pressures from the increased wartime price of newsprint combined with space pressure on local news from war news. ${ }^{126}$ The lack of local colour, however, can make the entire newspaper feel less interesting to today's reader looking for a view into the social life of the rural past. But for those farmers who wanted to know quickly what was happening in the world — from politics to crime to interesting anecdotes - along with some straight forward how-to's on improving one's stock, for example, the Ottawa Farm Journal probably was worth the $\$ 1.50$ a year it cost in 1925 .

These changes developed gradually between 1914 and 1925 but the end result felt like a different newspaper from the pre-War Ottawa Valley Journal. The only external change that happened in the period was the addition of E. Norman Smith to the senior management of the Journal Publishing Company (with the Journal's absorption of Smith's newspaper, the Free Press, in 1917). Smith records that when he was made managing editor of the Journal in 1917, P.D. Ross directed him to take full charge and to consult him only about editorials. ${ }^{127}$ Grattan O'Leary, then one of the editors and later the managing editor and President of the company, later told Smith's son I. Norman Smith that in contrast to Ross his father was a real newspaperman. He managed the Journal

\footnotetext{
${ }^{126}$ Under the header "District Jottings" the correspondence section became both smaller, less prominent and more irregular over the course of 1914. In 1913 it had been headlined "Local District News" but the sub-headline "Carefully and Accurately Gathered: Interesting and Tersely Written by Special Correspondents" suggests that correspondent sections had come to be seen as uninteresting and verbose. ${ }^{127}$ LAC, I. Norman Smith fonds, Memorandum from E. Norman Smith, no addressee, dated February 23, 1946. Smith brought over a number of his Free Press employees who were integrated into the Journal organization. This bumped at least one employee. T.V. Armstrong, who wrote to P.D. Ross to say that he regretted leaving the post of Business Manager due to "[t]he new arrangement" but would work hard in his new job managing "the country circulation." (LAC, Ross fonds, Diaries, T.V. Armstrong to Mr. Ross, February 28, 1917.)
} 
rather than just let it come out each day. ${ }^{128}$ I can only speculate that this new sense of purposeful management might have extended to how the rural Journal was put together.

\section{The Newspaper Community}

One of the features of metropolitan dailies' New Journalism was relentless selfadvertising. In this spirit, in 1898 the Ottawa Semi-Weekly Journal began filling pages with large ads advertising its own value. The Farmer's Advocate did this as well, the newspaper business being both competitive and costly. As each newspaper "puffed" itself by publishing letters of thanks from happy subscribers, something greater than simply selling the newspaper happened. The Journal's Semi-Weekly Business Manager made appeals to "friends" in the December 1897 announcements of the new subscription competition. The more sedate clubbing offer by the daily's business editor made only one reference to an appeal to friends and the reader had to wade through almost the entire item to reach it. ${ }^{129}$

Long before Benedict Anderson drew the link between the nation, the press and imagined community, a journalism historian A.L. Demaree made a similar link in 1939. He argued that agricultural newspapers "fostered the growth of group consciousness which was appearing among farmers." This was done partially by the regular presentation of farmers as Jefferson's yeomen on whom the health of the nation depended. But it was also done by creating a virtual community of friendship. Demaree states that farmers were encouraged to regard the editors as friends by means of newspaper comments on presents and visits received from their readers. This feeling of friendship extended

\footnotetext{
${ }^{128}$ I. Norman Smith, The Journal Men, 27.

129 "To Our Readers," OSWJ, December 14, 1897, 8 and December 17, 1897, 5; "A Christmas Present," OSWJ, December 17, 1897, 3; "The Chance of the Year," OSWJ, December 17, 1897, 8.
} 
beyond the editor-reader relationship to readers feeling themselves connected with other

readers based on common interests and concerns they found in the letters to the editor. ${ }^{130}$ Marotta identifies the same theme of friendship in her study of the Family Herald and Weekly Star. She notes that the newspaper achieved a cultural hegemony through a "culture of correspondence" as well as its informational columns. Together these spread a liberal vision of the ideal citizen The weekly Star offered readers "intimacy" not only with the editors but with people like themselves across the country. ${ }^{131}$

The Farmer's Advocate relied heavily on readers' letters to fill its pages but used other means as well to create a sense of reader identification with both the newspaper and a farm community. For example, in 1888 the Advocate offered cash prizes for essays on set topics. It judged the essays, it said, not on grammar and spelling (for it wished "to encourage farmers who have enjoyed few educational advantages") but on the ideas in them. The editor also asked readers to send in a completed form clipped from the issue to help investigate the economic components of agricultural conditions in Eastern Canada. ${ }^{132}$ In addition, while much of the content in 1888 was uni-directional agricultural news and informational material (from the editor to the reader), there were letters in which readers shared farm tips and experiences. For example, W.A. of Auguston, Ontario described how he built a combined pig pen and hen house. In the same pages "A Subscriber" in Antrim (near Arnprior in the Ottawa Valley) wrote about a dispute he was having with a neighbour as to what caused blackened teeth in pigs. The two agreed the

\footnotetext{
${ }^{130}$ A.L. Demaree, “The Farm Journals, Their Editors, and Their Public, 1830-1860," Agricultural History 15, no. 4 (October 1941): 184, 186.

${ }^{131}$ Marotta, “A Moral Messenger,” 51-4, 59.

132 Editorial, "Our Monthly Prize Essays. Conditions of Competition," "Investigating the Condition of the Farmer," "A Noted Clydesdale Stallion," FA, January 1888, 1, 3.
} 
Advocate would settle the dispute. ${ }^{133}$ In the following years the Advocate expanded its community-building to women and children and eventually young farmers as a specific demographic. In 1900 children had sent to the Advocate puzzles, jokes and riddles they had created. In 1910 the newspaper carried in every issue a junior and senior Beaver Club column publishing children's letters on subjects that had been set for them. For women there was the "Ingle Nook" where they too could write on pre-set subjects to share their experiences. In 1916 the Advocate began a new department entitled "Canada's Young Farmers and Future Leaders" with set topics for discussion. The editor promised to pay for those readers' articles it published "in cash at a liberal rate." "134

The rural Journal was not as focused on creating a sense of friendship. I suggest this was a result of the farm pages of each edition amounting to two to four pages, with the rest being news and entertainment copied from the daily. ${ }^{135}$ There was simply less room for letters. Cowan commented on rural readers dropping by the Journal office to drop off ballots when they came to town and discussing the excitement of whatever contest was underway. But the only "official" invitation to visit came when the new Journal Building was opened in January 1914. The rural Journal staff announced it would show the building to visitors in town for the Fat Stock Show. ${ }^{136}$

For over a decade the rural Journal staffed a tent at the Ottawa Exhibition for

\footnotetext{
${ }^{133}$ Letters, $F A$, January 1, 1888, 10-11.

134 “Canada's Future Leaders," FA, June 15, 1916; “Topics for Discussion,” FA, January 25, 1917, 128.

${ }^{135}$ The Ottawa Valley Journal slowly expanded in size from eight pages to ten pages (as of June 1902) to twelve (as of October 1905) and finally an oscillation between ten, twelve, fourteen and sixteen pages (as of February 1912). Each growth spurt began by expanding the Friday edition and, some months or even a year or two later, expanding the Tuesday edition.

136 "The Journal Has Moved Unto Its New Building." OVJ, January 13, 1914, 12. The invitation was unique to the rural Journal coverage of the move. The invitation did not specify why rural residents were specifically invited to visit. Speculation suggests city residents might well drop by regularly simply for business but it also might have had something to do with the sheer number of potential city visitors versus country visitors.
} 
rural visitors to sit in comfort and eat the picnic lunches they had brought with them. In 1902 special mention was made that the Household Department editor would be in the Journal's "household annex" each afternoon to meet and talk with her readers. She was not, however, identified that year as the friendly "Aunt Joe" to whom readers were writing. The following year the newspaper had apparently learned to maximize the value of the character it had created. It now said that Aunt Joe would be there. ${ }^{137}$ In 1903 and 1904 the Journal provided fresh water, chairs, tables, and writing material so visitors could do more than just rest. In 1904 there was even a telephone with which visitors could make a local call for five cents and a long-distance call at the usual rates. ${ }^{138}$ In 1910, however, the tone of the rural Journal's presence at the Ottawa Exhibition changed to a mix of friendship and business with business apparently dominating. The newspaper announced that instead of its usual tent at the main gate it would have a "fair grounds office." It invited visitors to check parcels and wraps for free but it also invited readers to renew their subscriptions and place any advertisements they might have. For this last activity a representative would help find the most effective wording. It concluded by asking readers "to call whether you have business or not if we can be of any service to you." ${ }^{139}$ No longer did the Journal's invitation sound like a friend inviting a chat.

There is an exception to this shift from community to business and that is the 1919 start of the rural Journal's children's page. As with "Aunt Joe" personifying the household editor, the children's editors evoked a sense of kinship in their personas as

\footnotetext{
${ }^{137}$ Perhaps visitors had come to the tent asking for Aunt Joe the previous year.

138 "When You Come to the Fair," OVJ, September 12, 1899, 7; "Journal Tent at Central Fair," OVJ, September 11, 1900, 8; "The Journal's Tent," OVJ, August 19, 1902, 1; "The Journal's Tent, OVJ, August 25, 1903, 8; "The Journal at the C.C.E." OVJ, September 16, 1904, 12.

139 "The Ottawa Valley Journal At The Central Canada Fair," OVJ, September 9, 1910, 1.
} 
Aunt Kate (Kate Whelan) and Uncle Henry (James Henry). Norah Lewis has printed a collection of children's letters to "clubs" which appeared in four Canadian publications (Family Herald and Weekly Star, Free Press Prairie Farmer, Farmer's Advocate and the Grain Growers' Guide). ${ }^{140}$ She uses the letters as a source for historicizing rural childhood (presenting her analysis in the Introduction and through how she organizes the letters thematically by chapter, for example a chapter with letters on school and a separate chapter with letters on pets.) She does not enquire into the actual experience for the children of writing and reading the letters.

I argue that we can see in the letters the children's desire for connection and friendship within a rural community which extended beyond their own locality. For example, Lewis gives us Clifford Philips's last letter to the Family Herald and Weekly Star as he had reached the age limit of sixteen. He asked why club members joined. Was it to "gain correspondents" or just to see themselves in print? He hoped it was the former as he thought the letters so interesting. He went on to say that he had finished school and was trying to find an office job. He wondered if other ex-members of the club were doing the same. Perhaps this was why he asked ex-members to write to him care of the editor. As a teenager on an Ontario farm eight miles outside Port Hope, Philips may have wanted to feel less alone in taking his first steps away from the farm. Other children asked if club members would write directly to them. A boy named R.S. Sarty in New Brunswick specifically asked "Rideau Lassie" to write him while William Bridge of North Bay, who was working as a timekeeper on the railroad, was interested in correspondence generally

140 "I Want To Join Your Club": Letters from Rural Children, 1900-1920 ed. Norah L. Lewis (Waterloo, Ont.: Wilfrid Laurier University Press, 1996). 
with other fifteen year old boys and girls. ${ }^{141}$

While the rural Journal only began its letter writing club in January 1919, the children responded to it immediately. Given the late date compared to the farm publications Lewis looked at, the concept was likely familiar to everyone by this time. In the first batch of letters published, ten-year old Alexander McPherson of Glengarry County said: "You don't know how glad I was when I read your New Year's message to all us boys and girls. I'm sure it will be a great pleasure to have a page all to ourselves." Isobel of Hastings County ended her letter saying that she hoped other children would write about what Santa had brought. Ethel of Stormont County hoped other children would write about their pets while she planned to write about her "bunnies" in her next letter. ${ }^{142}$ It is not clear why the rural editor decided to dedicate a full page once a week to children but adult men were writing on farm subjects and adult women were sharing their household and cooking tips. What the children added, perhaps because they were children, was an overt acknowledgement of a desire to hear about the lives of people like themselves — and to acknowledge that they saw themselves as a community.

\section{Conclusion}

In this chapter I explored the Journal as an urban business publishing both a city daily and a rural semi-weekly. The Ottawa Valley (Farm) Journal was as commercialized a product as any metropolitan newspaper of its day. Its only difference was that rather than downsizing politics and news for the sake of entertainment, it introduced farmoriented information pages for men, women and children along with entertainment. In the process it contributed to a sense of community among rural residents across Eastern

\footnotetext{
${ }^{141}$ Ibid., 243, 247-8.

142 "Our Young Readers At Work and Play,” OFJ, January 10, 1919, 10.
} 
Ontario.

Initially the Journal management did not create an independent organization to target its rural readership as Hugh Graham did with the Family Herald and Weekly Star. Nor did it begin life with the sense of mission which characterized William Weld and the Farmer's Advocate. Its first issue had been published by A.S. Woodburn and P.D. Ross on June 6,1887 because new machinery allowed them to improve the efficiency of printing the daily and, on the side, issue a semi-weekly version for rural readers. In latenineteenth-century Ontario most city dailies published a specially-prepared country edition and most of these were weeklies. Ross's decision, to produce a semi-weekly instead, matched its Ottawa competitors, the Citizen and the Free Press in the contest for subscriptions and the advertising dollars which came with a large circulation. Ross also pointed out in Printer and Publisher the financial advantages of printing a semi-weekly rather than a weekly. Altogether a rural edition of a city daily served a daily's bottom line by bringing in a few more subscribers and additional advertising dollars as well as serving as an accounting vehicle for spreading overhead costs.

Little changed in the Ottawa Semi-Weekly Journal until 1899. Then the newspaper was renamed the Ottawa Valley Journal, underlining the importance of the countryside as the intended market. The newspaper management's decision in 1898 to place a young man, Herbert Cowan, in charge of the rural Journal's circulation had already led to a new dynamism. In 1899 management went a step further and made him the rural editor, a post which had not existed before. As a result, even though the rural Journal continued to be a round-up of the news and entertainment from the three days prior, it also began increasing its amount of agricultural news and information. It is 
impossible to say whether the rapid increases in circulation that followed were the result of bribing readers with pigs as premiums or of giving readers agricultural features not available from its competitors. Despite this increased agricultural flavour, only two of the four long-time rural Journal editorial staff members (Robert Faith and James Henry) had a solidly agricultural background. And it was the very urban Cowan who started the rural Journal on its path of active rural news-making independent of the daily and then went on to a life-long career as the publisher of a farm journal, Farm and Dairy, as well as a personal relationship with the United Farmers of Ontario premier, E.C. Drury.

The rural Journal was a successful newspaper in terms of out-competing Canada's most important country weekly, Montreal's Family Herald and Weekly Star, as well as three dedicated farm journals, based on its own comparison of circulation numbers in a 1919 or 1920 sales pamphlet for the Ottawa Farm Journal. This success, however, was confined to the Journal's home field of the Ottawa Valley. Two of its four farm press competitors, the Farmer's Advocate and the Canadian Countryman, each had double the Journal's circulation when looked at nationally, while the Family Herald and Weekly Star dwarfed all the others.

The Weekly Star was the closest of the rural Journal's competitors in terms of it being the weekly edition of a city daily but the Farmer's Advocate was closest in its declared purpose of being an activist for agricultural progress. This latter criterion makes the Advocate an illuminating comparison to the rural Journal and its claim to be the farmer's friend. At the same time, the Journal was a newspaper. Most of its content was news and all of that was taken from its urban parent. By 1925 the rural editor had four to five pages to fill with information of interest to his readers but overall there was less 
space for readers to talk to the editor as well as to other readers than can be found in the competing rural publications. The kind of virtual community found in the Farmer's Advocate and the Family Herald and Weekly Star feels muted in the rural Journal. As well, the disappearance in 1914 of the local correspondence section and the news of who was visiting whom and who was feeling poorly leaves the Ottawa Farm Journal of 1925 colourless to an historian looking for traces of the community in the newspaper. Only the children's page with their letters talking about their lives on farms and in small towns maintained the sense of the local and the everyday.

Some historians of the commercializing newspaper focus on the big city daily and present premiums and contests as city devices. But everyone, from stores to big city dailies to rural newspapers, offered premiums. Another feature of the commercialized newspaper of the late nineteenth century was the emphasis on entertainment. Even small town weeklies and serious farm publications such as the Farmer's Advocate carried serial stories and jokes. All of this reflected the increasing commercialization of the press in the late-nineteenth and early-twentieth centuries. The changes inaugurated by the Journal's first rural editor, Herbert Cowan, to turn around the declining circulation after 1898 indicate that the rural edition was as responsive as any metropolitan newspaper to the commercial spirit of nineteenth-century journalism.

The name change to the Ottawa Farm Journal came in 1917 after a period of decreasing activism by its second rural editor, Robert Faith. By 1925 the newspaper had effectively eliminated both local news and rural politics in favour of didactic and useful agricultural information. However, since the rural edition was still substantially unchanged from being the daily with a small dose of rurality added, I would argue that in 
1898 Herbert Cowan had found the key to what rural readers wanted. They were as interested as city people in the national and international news. But they also wanted livestock premiums and agricultural tips and ideas. At the same time both Cowan and Faith had gone beyond this, adding commercial features of the sort found in big city New Journalism. This was more than comic strips and stories. The New Journalism was about making news interesting with activist journalism. It was acting like big city newspapers to make itself into a distinctive product but did so on the smaller canvas of rural Eastern Ontario.

Irrespective of how Cowan gained a readership, the question is why and how he went beyond selling a newspaper to claiming to being an agrarian leader and the farmer's friend. In short, what did the Journal do, having acquired its rural readership? That is the question addressed in the next chapters. 


\section{Chapter 5 - Limits to Activism: The Ottawa Valley Journal's Agrarianism}

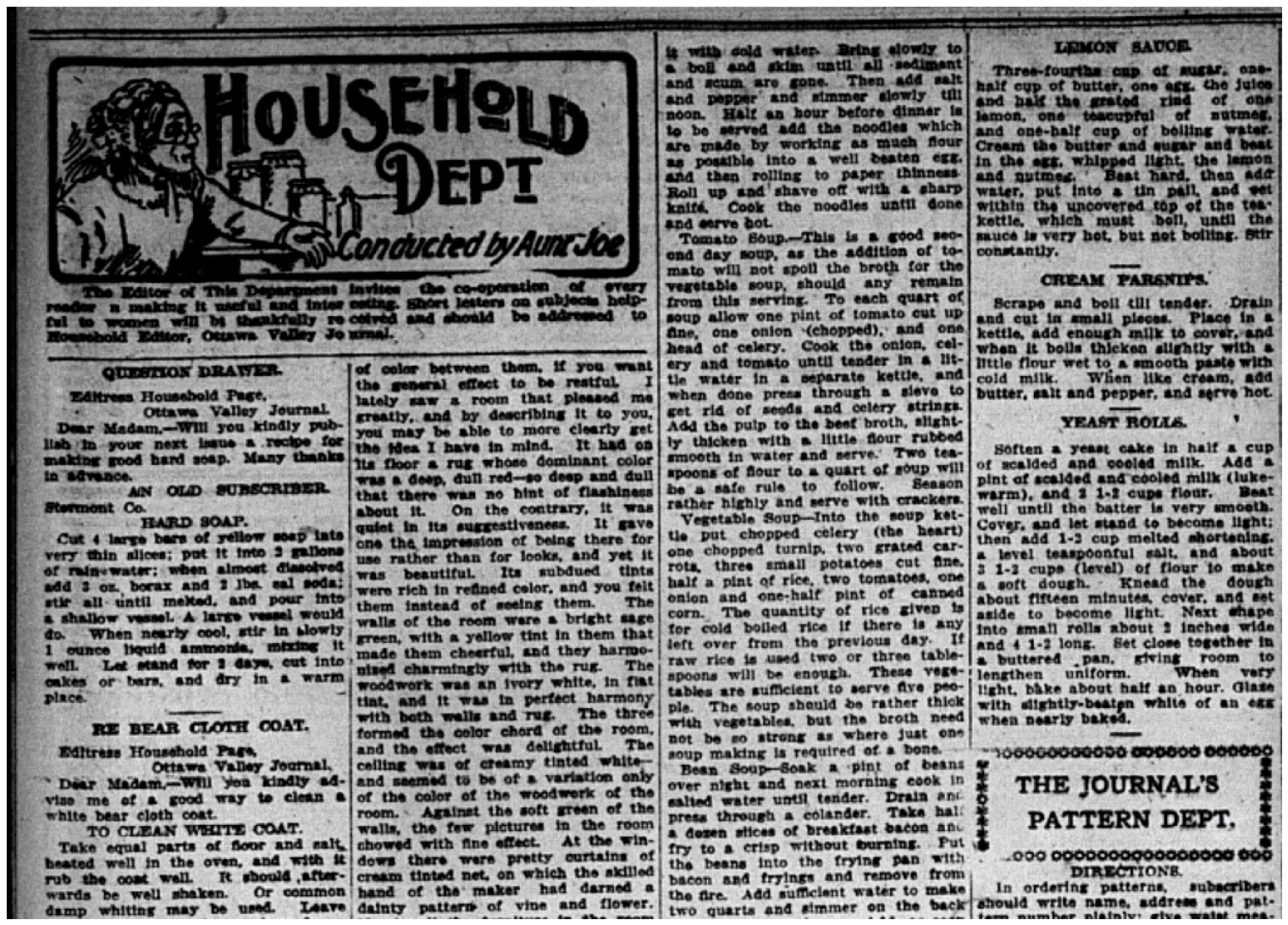

Fig. 5.1. “Aunt Joe's Household Department,” Ottawa Valley Journal, August 15, 1902, 7.

Starting in 1902 the rural Journal regularly carried material aimed at farm women. The persona it created for its women's page editor, a traditionally dressed older woman sitting in front of the fruits of her labour in the form of jars of preserves, represented the newspaper's expectations for the column. Despite women's role in the farm household as a producer, the women's department would focus on its female readers' domestic roles. By contrast, the newspaper editors presented farm men with agricultural information aimed at increasing farm productivity. Gendering farm roles limited the activism of its New Journalism to agricultural progress. 


\section{Introduction}

In Chapter 4 I explored the Ottawa Valley (Farm) Journal as a newspaper and as a business. In this chapter I ask how the rural Journal applied the New Journalism of the city to its rural subject matter. By the 1880s and 1890s the nineteenth-century model of a market-driven press combining entertainment with information had become in its extreme form of Yellow Journalism a byword for sensationalism. It was not, however, sensationalism which made New Journalism different but newspaper editors and publishers making news and not just reporting it. The rural Journal applied this model to the agrarian issues of the Ottawa Valley countryside but not as a single model. The two editors who initiated the agrarian campaigns both believed that a newspaper was capable of making change happen but took very different approaches.

When the newspaper was conducting its campaigns between 1900 and 1913, the farmer driven activism of the Patrons of Industry and the Grange had been reduced to a whisper. Their agrarian descendants in the United Farmers of Ontario focused on fighting the federal government's tariff regime. ${ }^{1}$ The loudest voices speaking on rural issues were now those of agricultural experts expounding scientific agrarianism as a means of achieving the national policy of agricultural competitiveness in the export market. Then, beginning around 1910 the reformers of the Country Life Movement expounded a rural version of the Social Gospel which aimed to rejuvenate community life in the countryside. But while there were three possible forms of Canadian agrarian activism (political anti-tariff, scientific productivity and Country Life social improvement), the rural Journal focused on scientific agrarianism, male productivity and the marketplace.

\footnotetext{
${ }^{1}$ Richard J. Van Loon, "The Political Thought of the United Farmers of Ontario" (master's thesis, Carleton University, 1965): 28.
} 
The next three chapters look at the Journal's campaigns in these areas. In this chapter I explore paths not taken, in particular the newspaper's limited efforts on political and Country Life issues. I posit that by looking at what was not done we can see the fundamentally conservative and gendered nature of the agrarianism espoused by the newspaper.

I address New Journalism and agrarianism in three ways. First, I compare the differences in agenda-setting and reader involvement in the activities of the newspaper's first two editors Herbert Cowan and Robert Faith. Second, I look at the rural Journal as a commentator on the political issues of the tariff and the $1917 / 1918$ conscription debate, as well as the economic issue of the farm labourer. Third, I consider the Journal's equivocal gendering of family roles on the farm at a time the Country Life Movement was encouraging urban role models for the countryside. Finally, I look at the Journal as an activist on its only two Country Life issues - first, encouraging the clergy to involve themselves in teaching farmers about agricultural progress and second, encouraging communities to undertake country beautification in the public spaces of cemeteries.

I argue that the newspaper editors chose areas of activity which were, at least in their beginnings, non-partisan, that is, not associated with the various farmer political movements. On overtly political issues such as the tariff, the rural Journal as the scion of an Independent Conservative metropolitan newspaper strove to maintain a neutral position. As will be discussed later in this chapter the newspaper also seemed reluctant to immerse itself in the community issues of the Country Life Movement. The editors were much more interested in the hard economic (and male) issues of agricultural productivity than the soft (and female) issues of changing family roles on the farm. When the 
newspaper stepped beyond agricultural issues, it did so on a community-building issue, beautification, while ignoring the gender division of production on Ontario farms. There is nevertheless ambiguity in their response. On the one hand the rural Journal did not join the Country Life effort to remove women from farm productive work and on occasion celebrated that work, but on the other hand its women's department addressed women's work within the domestic non-productive sphere.

\section{The rural Journal as Activist}

In 1957 John Schlebecker looked at two successful American journals (Hoard's Dairyman and the Jersey Bulletin) to enquire into the nature of farm journalism in the late-nineteenth and early-twentieth centuries. He finds they gave ideas to and passed on ideas from regular farmers. ${ }^{2}$ The publications Schlebecker studied also conducted campaigns on specific issues such as margarine and bovine tuberculosis, marshalling news and presenting editorial comment. ${ }^{3}$ The work of the Farmer's Advocate fits well within this model. The Ottawa Valley Journal proceeded differently. In the spirit of the New Journalism of the 1890 s, it made news happen. At the same time its source of authority changed between Herbert Cowan's activities and Robert Faith's. Cowan worked with government and industry. Faith followed his inner voice.

\section{New Journalism Activism: Cowan and the Agricultural Experts}

Charting the various Journal-led events chronologically shows that the newspaper

\footnotetext{
2 I suggest Habermas's public sphere in which private persons discussed and developed views on public issues is not as useful an analytical concept as hegemony. While Jeffrey McNairn used the early Upper Canadian press to explore public debate on issues outside the control of the government (The Capacity to Judge: Public Opinion and Deliberative Democracy in Upper Canada, 1791-1854 (Toronto: University of Toronto Press, 2000)) the mid- to late-nineteenth-century commercial press has not been widely historicized as a public sphere given the degree to which discussion was controlled and even orchestrated. ${ }^{3}$ John T. Schlebecker, "Dairy Journalism: Studies in Successful Farm Journalism," Agricultural History 31, no. 4 (October, 1957): 31-3.
} 
began with two activist years in 1901 and 1902 when Herbert Cowan became the first dedicated rural editor. During this short but energetic period he initiated a number of the pamphlet's list of achievements: the introduction of an expert judge system, running a competition between agricultural fairs for the best exhibit of county livestock, establishing a fair circuit, organizing the Good Roads Train to build stretches of model roads in counties across the Valley and organizing instructional dairy meetings for cheese producers. Activities which did not make it into the 1919/1920 sales pamphlet included the first livestock auction, an investigation into cheese price-setting, being the official organ of the Eastern Ontario Dairymen's Association and the Eastern Ontario Good Roads Association and a campaign against the statute labour system used to maintain rural roads. It all began in 1900 when Cowan organized a regional ploughing match for the winners of the county contests at which he had assisted. His conversations with farmers at these events gave him ideas of where he could intervene in rural life.

The city-bred Cowan could be seen as representative of the Country Life progressive reformer doing good for the good of rural residents. American historians have characterized the Country Life Movement as spear-headed by urban middle-class reformers concerned that the health of the nation was endangered by the loss of the independent "yeoman farmer." "They followed a version of the Social Gospel but, instead of uplifting urban immigrant labourers, they sought to uplift farm families using the new science of sociology to identify and solve social problems. Cowan, however, was a newspaperman and his social activism was ultimately about making news for the rural

\footnotetext{
${ }^{4}$ There is a good amount of American literature on the Country Life Movement but less Canadian literature. A starting point is William L. Bowers, The Country Life Movement in America, 1900-1920 (Port Washington, N.Y.: Kennikat Press, 1974). While Bowers is focused on Theodore Roosevelt's 1908 Country Life Commission he provides an overview of the movement, a biography of one of its chief movers in the United States, Liberty Hyde Bailey, and a view of its afterlife.
} 
Journal in the style of the urban New Journalism. This is apparent in his speech at the 1900 banquet closing the regional plowing match. It seems "management" had toured the countryside around Ottawa and discovered that farmers were reading agricultural publications from outside the region. Cowan claimed this meant Ottawa Valley farmers knew more about the agricultural worlds of Guelph, Toronto and London than about their local agricultural community. He said that this discouraged "mutual assistance and pleasant rivalry." Cowan described the problem as both "a great opportunity" and "a great obligation" for the newspaper:

Farmers needed to be aroused; they needed to be introduced to each other; they needed to be made to feel that only by all joining together in a common effort could they best advance the agricultural interests of this portion of our fair Dominion. In fact, gentlemen, they needed a farmers' paper of their own.

When a comparatively small matter like a plowing match scheme is taken up and carried through in such an enthusiastic manner by the agricultural societies, farmers' institutes and county councils of the Ottawa Valley what, gentlemen, is to prevent more important movements such as a series of good farms competitions, a good roads reform and similar matters being taken up and advanced in the same successful manner? ${ }^{6}$

This sounds like the Country Life determination to build an urban reform vision of a new community spirit in rural Canada but Cowan was careful not to get ahead of his readers. In the above quote Cowan pointed to the potential of various projects but he actually began work on the purebred livestock auction. He had floated this idea in August 1900 with the suggestion that it could take place that autumn as part of Ottawa's Central Canada Exhibition. But even as Cowan told readers that the exhibition directors had agreed and he had interviewed "a number of well-known men" on the subject, he claimed it was up to the readers whether to hold an auction in a month's time: "Readers of the

\footnotetext{
5 "Ottawa Valley and District Farmers Now United," Ottawa Valley Journal (hereafter OVJ), October 30, 1900,8 .

${ }^{6}$ Ibid. At least Cowan did not say, "They needed me."
} 
Journal to Decide Whether this Sale Will be Held." The Journal would organize one if fifty farmers and stockmen wrote to support the idea. A week later the newspaper had received "some letters" which Cowan published. In September he announced there was not enough time to organize an auction for the Ottawa Exhibition but he was still talking to the local livestock associations. By the end of September the major breeders had attended a meeting chaired by the Minister of Agriculture and an auction date had been set for February $1901 .^{7}$

All Cowan's initiatives followed this pattern. He first published information from an external source to highlight an issue he said had to be addressed. Just as importantly, he sought to make the source credible by describing it as authentically rural. Often he pointed to federal Department of Agriculture experts or "prominent men" by which he usually meant owners of mechanized farms or of large cheese factories. ${ }^{8}$ He would also suggest that they were local agriculturists to whom he had talked while he was out on the concession roads. He thus made it clear that he was not sitting in the city talking at farmers. By 1901 Cowan was popping up at meetings, writing to interested parties and making proposals. He did not go out on any limbs in doing so, except perhaps once. On December 6, 1901 he published a letter in which a reader suggested that the government establish a central exchange for selling cheese. Cowan commented that he had put this idea to "quite a number of prominent dairymen" the majority of whom approved (although the published letters from the dairymen seem only cautiously interested). A

\footnotetext{
7 “Auction Sale Thoroughbred Stock," OVJ, August 7, 1900, 7, August 14, 1900, 8, September 7, 1900, 8; "More About the Auction Sale of Purebred Stock," and "Big Thing For The Farmers," OVJ, September 25, $1900,5,6$.

${ }^{8}$ It is impossible to say who controlled or even influenced whom in Cowan's encounters with the experts. I suggest that it was mutual in that Cowan was a journalist looking for dragons to slay but, being in his early twenties and having no knowledge of either farm life or rural living, he likely needed to have issues given to him.
} 
week later he printed two strongly worded letters of opposition from important cheese factory owners. ${ }^{9}$ And that ended the conversation. In this case Cowan gave precedence to the factory owners' opinions over that of the original writer. As will be discussed in Chapter 8 , ordinary dairy farmers had opinions on how cheese was marketed but Cowan's quick shut-down of the question was a gate crashing closed. Faith took a different approach.

New Journalism Activism: Faith as Agrarian Organizer

When Faith took over as rural editor after Cowan's departure in January 1903 to pursue farm journalism in the United States, he continued Cowan's initiatives until four years later when he erupted with increasingly heated reform campaigns. Faith's interventions involved mass meetings, to which he invited all interested farm men, as well as mass reform organizations. He started, however, on his independent path in 1905 by leading an exodus of Eastern Ontario agricultural societies from the Ontario Fairs Association. This was not a major event. The rural Journal's competitor, the Farmer's Advocate, reported it in a single short paragraph under the headline "Fairs Association Dissension." The daily Journal gave it equally short shrift. ${ }^{10}$

The facts are simple. The delegates to the 1905 Ontario Fairs Association conference passed a resolution to make Toronto the permanent site for the Association's annual meetings. Only the three lone Eastern Ontario delegates were opposed. They protested that most Eastern Ontario agricultural societies could not afford to travel to

\footnotetext{
9 "How Present Difficulties Might Be Overcome," OVJ, December 6, 1901, 1; “A Government Exchange Building At Montreal," OVJ, January 3, 1902, 1.

${ }^{10}$ Fairs Association Dissension," Farmer's Advocate (hereafter FA), March 2, 1905, 302; the Ottawa Evening Journal (hereafter $O E J$ ) carried only a cryptic two paragraph announcement inviting societies to a meeting to form an Eastern Association: "A Meeting of Agriculturists," OEJ, February 22, 1905, 11; it also carried a short item about the actual Association, noting the "Journal's" role without specifying it was the rural Journal, "New Fairs Association," OEJ, March 10, 1905, 6.
} 
Toronto. Faith then stood up to say that they would form their own association. ${ }^{11}$ On his return to Ottawa he published an announcement about a meeting to establish an Eastern Ontario Fairs Association. The leaders of the local agricultural societies were invited to come, which they did, and the new Association was born. The rural Journal's announcement of its birth underscored that it would be independent of the Toronto organization and would deal directly with the Ontario Minister of Agriculture. The Journal claimed this was necessary because a Toronto-based organization would not have given Eastern Ontario "a square deal." This was important because the Fairs Association was the government's mechanism for consulting on issues such as grant money and fair entertainment. ${ }^{12}$ Faith became secretary-treasurer of the new Association, a position he continued to fill through the next decade of its life. It seems to have faded quietly away when it was superseded around 1913 by the division of the Ontario Fairs Association into districts, including an Eastern District. (I have not found a reference to it being officially closed down).

What is noteworthy is that this was the first time Faith went beyond Cowan's initiatives. Furthermore, he was not, like Cowan, trying to educate farmers. He was organizing them. It was also the first Journal initiative which did not involve preconsultation with the usual prominent men or government officials, at least as far as can be seen in the newspaper reports. While Faith must have spoken to the three delegates who were at the Toronto meeting, he does not claim to have involved anyone in the initial declaration to the Ontario Association nor in calling an organizing meeting for the new Eastern Ontario Association.

\footnotetext{
${ }^{11}$ Government Grants to Agricultural Societies," OVJ, February 21, 1905, 10.

12 "County and Township Agricultural Societies," OVJ, February 24, 1905, 10; "Eastern Ontario Fairs Association Formed," OVJ, March 14, 1905, 1.
} 
Two years later, in 1907, Faith launched two campaigns within months of each other and in two completely different spheres. His first campaign was presented as driven by the readers searching for a better, and fairer, way of assessing property taxes (discussed in Chapter 7). But his other campaign on cheese marketing (see Chapter 8) was a personal attack on alleged wrong-doing by sellers and buyers on the Ottawa Cheese Board. What makes Faith's muckraking on the Ottawa Cheese Board unusual was that as editor he was investigating an organization of which he was secretary. Lack of clarity as to Faith's role became an issue at board meetings as Faith reported in the newspaper everything said there while editorializing on sellers and buyers acting against the interests of the dairy producers. ${ }^{13}$ Faith further distanced himself from Cowan's earlier, quieter activism when he organized mass meetings of hundreds of farmers rather than Cowan's closed meetings of agricultural leaders and government officials.

Faith had great confidence in 1907 as to what farmers and a fighting newspaper could achieve but he was clear success required both. He told farmers to put their shoulders to the wheel claiming "the Eastern Ontario farmers can fix this matter [property tax assessments] in less than two years if they will only co-operate." It seemed to Faith that all could be solved "if you give the Journal the support it is entitled to." ${ }^{\prime 4}$ Even though he chose the issues, he needed readers to respond in order to turn issues into campaigns. On the cheese issue he was the sole instigator but on the tax issue, he identified a reader's letter as meriting discussion. ${ }^{15}$ Throughout the tax campaign Faith

\footnotetext{
13 "Cheese Board Is Not Fulfilling Its Mission, OVJ, July 16, 1907, 10; "Journal's Attack Against Ottawa Cheese Board," OVJ, July 23, 1907, 10; "Ottawa Valley Dairymen Lose Seventy Thousand Dollars Annually," OVJ, July 30, 1907, 12; "Dairymen Are Heavy Losers," OVJ, August 2, 1907, 12; "Ottawa Valley Dairymen Severely Punished by Cheese Buyers Last Week," OVJ, August 9, 1907, 10, 12.

14 “Assessment of Farm Property," OVJ, April 30, 1907, 10.

${ }^{15}$ The original tax letter was highlighted with a note from the editor requesting reader response. It cannot be said whether or not it had been planted. "Letters to the Editor," A.F.S., Stormont County, OVJ, April 5,
} 
continued to ask readers to write on the subject. ${ }^{16}$ And, despite the 1911 mass meeting on cheese being the last step in Faith's self-imposed fight with Montreal cheese exporters, he still implied that he was being dragged into a farmer-organized campaign: "A representative of The Ottawa Valley Journal has been asked to attend ... He will be there." $" 17$

Cowan and Faith also differed as to how they presented issues to their readers. Both men used business as their standard. Faith, however, wrote in negative terms as he condemned a lack of proper business method on the part of opponents. He also mixed his references to business with agricultural fundamentalism in which farming created the nation's wealth. At the same time, Faith showed ambiguity as to power. While he regularly, both in print and on meeting platforms, loudly insulted municipal and dairy leaders, he never claimed such men were not important. While he was secretary-treasurer of the associations he created (the Eastern Ontario Fairs Association, the Farmers' Municipal Rights Association and the Farmer's Produce Association), all the other officers were agricultural society leaders, local reeves and councillors and cheese factory owners. As well he invited to the mass meeting on property tax reform township politicians and officials even as he was inviting farmers to "[c]ome out, as farmers should and hold a big convention among yourselves. Every man will be on equal footing."18

\section{Limits of Activism}

While Cowan identified issues by working with officials and industry leaders and

1907,12

16 "Letter to the Editor" James Clark, Glengarry County, OVJ, May 28, 1907, 10; "The Farmers' Convention" and "Big Convention of Farmers Will Be Held In The City Hall, Ottawa, Wednesday, June 12th," OVJ, June 4, 1907, 7, 10; "Last Call For Farmers Convention To Discuss Assessment Of Farm Lands," OVJ, June 7, 1907, 12; “Special Railway Rates To Farmers' Convention,” OVJ, June 11, $1907,10$. 17 "Are the Ontario and Quebec Farmers Ready to Hold Big Dairy Convention," OVJ, January 3, $1911,10$.

18 "The Farmers Convention," OVJ, May 31, 1907, 12. 
Faith chose his own issues, neither man pursued all or even most of the agrarian issues that were in the wind at the time. In particular, among issues not pursued were the family oriented elements of the Country Life Movement and the political/economic issues of the federal tariff, conscription and relations between farmer and farm labourer. I will argue in the next three chapters that Cowan's focus was on improving farm productivity and Faith on changing the marketplace, both of which centred on the male work domain. Here I will first look at how the rural newspaper's position in an urban newspaper company drove it away from addressing political issues and then I will examine its approach to gendered farm issues.

\section{The Politics of Tariffs, Conscription and Labour}

The rural Journal, despite its self-declared role as the friend of the farmer, throughout the years of the Reciprocity Debate over federal tariffs reported on its politics but did not take a position on it. Yet tariffs and conscription were significant issues in creating an urban-rural divide in Canada. With respect to tariffs, farm families throughout the late-nineteenth and the early-twentieth centuries complained of paying high prices in a protected market for consumer goods and agricultural equipment while having to accept low prices set for their produce in an unprotected global market. The tariff bound together farmers from across the country against the government. Conscription did so as well, or more specifically Prime Minister Robert Borden's decision in April 1918 to rescind the Union Government's promise not to call up agricultural workers. Adam Crerar argues that a rural-urban divide developed over the years of the First World War as urban people found food costs going up and considered farm support for the war effort, 
in terms of both men and money, inadequate. ${ }^{19}$ The farmer's anti-conscription protest in May 1918 deepened the divide.

A Liberal newspaper could support the farm voice on tariffs with ease for the Liberals were traditionally the free trade party. The Farmer's Advocate could call on the doctrine of its founder William Weld to remain neutral. ${ }^{20}$ Weld had been consistent in refusing to accept a party label while exhorting farmers to avoid being split by a spirit of party-ism. ${ }^{21}$ The rural Journal had a more complicated path to navigate due to its relationship with the urban Evening Journal. The daily was officially Independent Conservative and its publisher, P.D. Ross, was involved in municipal politics as a Conservative. During the First World War Ross led a municipal Association in support of the Unionist Government and was a strong supporter of Prime Minister Robert Borden. But according to a future Journal editor, Grattan O'Leary, each of the two words, “independent" and "conservative," was in ascendency at different times. Between elections the editors were free to take whatever stand they felt correct and to criticize whomever they felt required criticism. It was a different story during elections. ${ }^{22}$ I posit that both figuratively and literally there was little space for the Journal's rural editor to take a position that was independent of the daily. Objecting to conscription was even more difficult than fighting the tariff during the 1911 Reciprocity Election for it would

\footnotetext{
${ }^{19}$ Adam Crerar, "Ties That Bind: Farming, Agrarian Ideals, and Life in Ontario, 1890-1930," (PhD. diss., University of Toronto, 1999): 277-91.

${ }^{20}$ The Farmer's Advocate had a larger editorial staff than the Ottawa Valley Journal while the managing editor, John Weld, was described as a man with a good nose for news but no writing skills. He directed but did not write the Advocate. (W.A. Irwin, "The House of Weld," McLean's Magazine, July 15, 1931, 45). Since I cannot pin any particular Advocate employee to its editorials, I will ascribe actions and editorials to the Advocate in general.

${ }^{21}$ Ian M. Stewart, "Weld, William" in Canadian Dictionary of Biography points this out as one reason for Weld's initial involvement with the Grange. http://www.biographi.ca/en/bio/weld_william_12E.html. Accessed September 15, 2013.

${ }^{22}$ I. Norman Smith, The Journal Men (Toronto: McClelland and Stewart, 1974): 26.
} 
have been unpatriotic and potentially illegal under the War Measures Act. In addition, there were physical limitations as Faith had only three to at most six pages for original material including agricultural news and information. Editorial comment in the rural Journal was culled from the daily edition and therefore conveyed only the urban (and political) interests of that newspaper.

As a result, in the 1890 s farmers read in the rural Journal that farm land prices were not "stagnating" because of tariffs but because cheaper land was available in the West. Indeed, according to the Journal, Canadian farmers were better off than farmers in the United States and Britain. ${ }^{23}$ Later editorials commented on the increasing anger of Western farmers against tariffs but one editorial had a tone of intellectual distance on the subject, as seen in the title "Rough on Farmers." ${ }^{, 24}$ Another editorial claimed farmers called for tariffs to protect their own products but fought tariffs which raised the price of the manufactured goods they bought. ${ }^{25}$ The conscription crisis produced similar editorials. In April 1916 the daily editor pointed out that voluntary enlistment could never achieve the goal set by the Prime Minister for the recruitment of 500,000 more soldiers. The editorial did not use the word "conscription" but the writer concluded that the government must "use every possible expedient" to achieve its goal. ${ }^{26}$ In discussing the debates around the Military Service Act, the Journal's attitude was first that rural Ontarians were sensible patriotic people and second that the Act would benefit farmers by directing needed men to jobs on farms and in industry and sending only non-essential workers into the army. It claimed this would be an improvement over the volunteer

\footnotetext{
23 "Farmers and Free Trade," OEJ, July 23, 1892, 2 and Ottawa Semi-Weekly Journal (hereafter OSWJ), July 25, 1892, 2; "Why Is the Farmer Poor?" OEJ, April 18, 1896, 4 and OSWJ, April 21, 1896, 2.

24 "Rough on the Farmers" OEJ, November 4, 1893, 4 and $O S W J$, November 6, 1893, 2.

${ }^{25}$ Untitled Editorial, OEJ, January 31, 1894, 4 and $O S W J$, February 1, 1894, 2.

26 "'A Stronger Army and a Shorter War,"” OVJ, April 25, 1916, 4.
} 
system in which the best men volunteered even when they were needed in agriculture. ${ }^{27}$

When the rural Journal carried political news of interest to farmers, it generally repeated items from the daily. Only occasionally is there a hint of a difference of opinion. On March 27, 1903 the Ottawa Valley Journal reported on an anti-tariff farmer delegation on two different pages in the same issue but with two different tones. On page six it reprinted a news item from the daily Journal which had been written with factual language and a neutral headline. On the agricultural page it carried more substantive coverage with a two-column, three deck headline starting with "Farmers Kick Against a Higher Tariff." The article then gave the full text of the memorandum which the Canadian Farmers' Association delegation had delivered. ${ }^{28}$ The placement of the second item at the top left hand corner, giving it two columns of space, and the language used in the headline indicate that editor Robert Faith was fully aware of the farm interest in this subject.

During the Reciprocity Election the rural Journal took the approach of allowing farmers to debate the issue. While this created a public forum for discussion, the "objectivity" of printing letters on both sides of the question highlighted that not all farmers were demanding reciprocity and the elimination of tariffs. The newspaper had begun with a report on what Stormont County farmers were saying for and against reciprocity and pointed out this was an important issue that farmers needed to discuss. It

\footnotetext{
27 "The Farmer and Conscription," OFJ, July 27, 1917, 4; "Agriculture and the Military Service Bill," OEJ, September 13, 1917, 4 and $O F J$, September 18, 1917, 4. In practice, the Act required every man within the call-up ages to register for conscription but Prime Minister Borden promised not to actually enlist farm workers into the army. When the Government changed this informal policy and issued draft notices, farmers were outraged despite many of the young men being given agricultural leave almost immediately for sometimes extended periods of time.

28 "Farmers and the Tariff," OEJ, March 25, 1903, 1 and $O V J$, March 27, 1903, 6; "Farmers Kick Against a Higher Tariff," OVJ, March 27, 1903, 10.
} 
asked for letters to clarify the points in contention which it then printed. ${ }^{29}$ The rural Journal editor took no position himself on the subject despite the vehemence with which Faith was at that time pursuing the urban forces controlling the cheese industry.

The same approach of giving two sides to an issue was used in reporting the 1918 Farmers' delegation demanding that the Government reinstate the exemption it had given farm workers from being called for military service. The question of patriotism made this event a trickier issue than tariffs and for the most part reporting was taken directly from the daily. Both the urban and the rural Journals gave a banner headline to the Government position and captioned a photograph of Sir Robert Borden as “Canada's Fearless Prime Minister." At the same time, the daily gave a sympathetic description of the protesting farmers that was much different from what Crerar finds in the Toronto press. ${ }^{30}$ An accompanying colour piece on the delegation emphasized that the 4,000 Ontario and Quebec protesting farmers had spent many thousands of dollars in Ottawa for accommodation and food. It ended by describing the farmers as "agriculturists of the best type. Prosperous looking, they typify the modern farmer." Most were described as men over 35 and there were even many "greybeards," suggesting responsible men and not wild-eyed agitators as well as men not personally afraid of being conscripted. It finished with the farmers" position that "withdrawal of the order conscripting farmers is imperative unless Canada's production is to be much lower than that of last year." ${ }^{31} \mathrm{We}$

\footnotetext{
29 "Agricola - Staff Representative on the Trail," "Stormont Co. Farmers Discuss Reciprocity," OVJ, February 17, 1911, 12. Examples of letters: "Stormont County Farmer Opposed to Reciprocity," Charles McGill to Editor, OVJ, April 4, 1911, 12; Free Trade Agreement," D. Shaw of Lanark Co. to Editor, [for Reciprocity], and "Russell County Farmer" to Editor, [opposed to reciprocity], OVJ, April 21, 1911, 2.

${ }^{30}$ Crerar, "Ties That Bind," 286-91. He finds a range of hostile comment and even one semi-favourable comment in the Toronto Telegram insisting that the protesters were not real farmers who, according to the newspaper, had stayed working on their farms.

31 "Government Standing Pat In Its Draft Policy," and "Is Far the Biggest Deputation Ottawa So Far Entertained," Ottawa Farm Journal (hereafter OFJ), May 17, 1918, 3 and OEJ, May 14, 1918, 1.
} 
can take from the daily Journal publishing a positive report on the farmer delegation even as it supported the Prime Minister's decision that the city Journal was sufficiently aware of its rural reader base that it did not intend to needlessly offend farmers.

The rural Journal followed with two letters in the next issue which presented two sides on the issue but they were not given equal prominence. I suggest the differing placement indicates where the rural editor's preference lay. Fred P. Instant's letter giving the farmer's position was placed in the most visible position (top left hand corner) and given an eye-catching headline of two decks laid across two columns. Instant countered the argument that in a battle crisis there was a greater need for soldiers than for farmers by pointing to France which had found it necessary to keep able-bodied men on the farms producing food. In rebuttal to urban comments on farmers having time to waste on protests when they claimed to be hard-pressed by work, he pointed out the time-wasting he had seen at the Barriefield Camp the previous week. ${ }^{32}$ As part of the latest enlistment call up, nearly a thousand men (conscripts with their farmer fathers) had been kept away from their work for two days in order to process and then exempt the young men from immediate call-up. ${ }^{33}$

The second letter, signed only as Beckwith of Lanark County, was given a visually lower profile underneath the first letter with a one-column headline and without an additional explanatory header. That writer was critical of a previous letter from a

\footnotetext{
${ }^{32}$ Instant was likely addressing Toronto newspaper claims that protesting farmers were wasting time they should have spent working on their farms; see Crerar, "Ties That Bind," 289.

${ }^{33}$ Frederick Peter Instant was a farmer on Amherst Island near Kingston, Ontario (LAC, Manuscript Census of Canada, 1911, Lennox and Addington, Amherst Island, p. 3 and 1921, Lennox and Addington, South Fredericksburg Twp, p. 5). One son, David Ernest Instant, had volunteered in June 1917 and was discharged in January 1918 following seven months in hospital with pneumonia and an operation for empyema (accumulation of pus in the chest) (LAC, First World War personnel records, regimental number 1090118). A second son, Hugh Reginald Instant, was drafted and was processed at the Barriefield Camp on May 7, 1918. He never served overseas but was only discharged in January 1919. (LAC, First World War personnel records, regimental number 3058464).
} 
"Goulbourne (sic) Farmer." Beckwith claimed that, contrary to that earlier letter, Goulbourn Township did not lack able-bodied workers. First, he or she claimed that young men (calling them "self-styled farmers and farm laborers") had returned to the family farm in order to avoid conscription. Second, there were always the women who were part of the working population in farming communities. As well, returned soldiers could do farm work even if they had no experience with it, and would be willing to do so as long as the pay was commensurate with wages for labour elsewhere. As to the problem of harvesting with fewer men, farmers should be prepared to sacrifice (what was not stated) but the writer claimed it was unlikely they understood that word. Beckwith added: "It is a matter of national need, not personal greed." If the farmer was unwilling to do his bit, then the government should step in. Beckwith's letter implied, not with much subtlety, that Goulbourn farmers were greedy, lazy, self-serving, unpatriotic and that most were not even real farm workers. ${ }^{34}$ This letter gave the arguments Crerar finds in the pages of the journal Saturday Night, one of the most vociferous critics of farmers. ${ }^{35}$ The rural Journal editor did not comment on either Instant's or Beckwith's letter but the placement of the two letters suggests he intended in this apparently even-handed presentation of both sides to the argument to confirm the ignorance of the other side for his farm readers.

The rural Journal also carried commentary on the economic and class question of farm labour, a far less contentious issue than either tariffs or conscription. Here too the newspaper claimed to be neutral but can be seen leaning to one side, in this case towards the farmer and not the labourer. The issue first appeared in the Ottawa Semi-Weekly

\footnotetext{
34 “The Farmers' Viewpoint Anent Taking Their Sons in Military Service Draft, Fred P. Instant to Editor, and "Says Goulbourne Farmer in Wrong (sic)," Beckwith to Editor, OFJ, May 21, 1918, 8.

${ }^{35}$ Crerar, "Ties That Bind," 286-7.
} 
Journal in 1890 with a complaint by a Bell's Corners farmer, David Hartin. He claimed that on a recent trip to Ottawa and Hull to hire workers, none of the unemployed men he met were willing to accept his terms. He asserted that, based on his conversations with the men, they preferred to be idle while waiting to go to the shanties. ${ }^{36}$ But that was all that was said in the rural Journal in the period when its editorial page and local news were taken wholly from the daily edition.

As the Ottawa Valley Journal, the newspaper carried original material on the farm labour issue. As one example, in 1901 the rural Journal carried a letter from S.G. Drew, Reeve of Westmeath, asking the editor to "advocate" for farmers in "a serious crisis in the agricultural interests of the province." The departure of Ontarians for the West had created a scarcity of farm labour. He felt the government should do something to help farmers by encouraging farm labour immigration to Ontario. The editor, Herbert Cowan, commented: "The following letter brings up for discussion a matter which has for some time been making itself severely felt. The Journal trusts other farmers will join in the suggested discussion." The next issue carried a reply from "Laborer." He argued that the problem was the conditions of work. Farm labourers had long been expected to work long hours curtailed only when it was too dark to see. As they were also poorly paid, hired men had jumped at the opportunity to leave for the West. Farm labour could be found if employers would only respect the labourer's right to a decent living. "Farmer" then wrote to counter these claims. "Laborer" came back with another reply but this time Cowan as editor editorialized with a header saying "Both Are Right." Cowan agreed with "Laborer" that in the past many farm labourers had been overworked and underpaid. He also agreed with "Farmer" that many of the labourers now available to be hired were

\footnotetext{
36 “Won’t Do Farm Work" OEJ, October 3, 1890, 2 and $O S W J$, October 6, 1890, 4.
} 
lazy. He declared the problem to be "lack of system." By this he meant the farmers did not have a clear sense of what work would need to be done and therefore could not make a clear agreement with the employee. Having a plan for the season's work meant the farmer could make an agreement that would be completely clear on what was expected from the labourer, including hours of work. To prove that he was not speaking foolishly or naively, Cowan cited a statement by the Hon. John Dryden at the Guelph Fat Stock Show that the work on his farm was done within preset hours. ${ }^{37}$ Cowan's intervention was to assert the value of modern business practices for farming. The possibility of deeper underlying problems between farmer and labour was not considered.

The rural editors seemed to have had a narrow concept of the agriculturist which I suggest stemmed from the focus on productivity (in the case of Cowan) and the marketplace (in the case of Faith). The question of farm labour scarcity and the conditions of work and pay continued to come up in the years that followed with an average of about a letter or article per month. In February 1910 the editor, presumably Robert Faith, as an end comment to a letter from an immigrant on his experiences as farm labour in Canada, wrote that the whole question was "getting to be a serious one." He then urged "a free and easy discussion concerning the matter in the columns of The Ottawa Valley Journal." ${ }^{, 38}$ On this issue the rural Journal was to be no more than a forum for discussion.

\section{Country Life and the Country Family}

While the Country Life sessions of the Congresses held in Canada between 1911

\footnotetext{
37 "Scarcity of Farm Help," OVJ, December 3, 1901, 8; “A Farm Laborer," OVJ, December 6, 1901, 8; "Farm Help," OVJ, December 20, 1901, 8 and December 27, 1901, 8.

38 "Problem of Hired Help," OVJ, February 18, 1910, 12.
} 
and 1918 under the sponsorship of the Commission of Conservation have been ignored by most rural historians, gendering of farm work within the family has been a subject of study. ${ }^{39}$ As part of saving the farm family from itself, middle-class urban Country Life reformers aimed to change it from an economic and productive unit into a haven for the moral teaching of children. To do this women needed to became wise household managers rather than farm producers. Boys and girls needed to be removed from the work world of the farm and instead taught farming and gardening as school subjects. ${ }^{40}$ Only the farm man was seen as an economic actor. At the same time both farm and house needed to be mechanized in order to end the curse of overwork which was said to destroy women's physical and mental health as well as the vitality of country social institutions.

This speaks to Jeffery Taylor's argument that the rise of farm home economics shifted women away from being partner-producers (even if subordinate partners) to being skilled consumer managers working under the general direction of the husband as farm CEO. ${ }^{41}$ Yet a 2005 dissertation by Amy Mattson Lauters, "More than a Farmer's Wife," found that American farm journals did not strictly follow the Country Life gospel with regard to separating women from farm work. Instead the American journals presented a stable construction of farm women as practical businesswomen whose work was central

\footnotetext{
${ }^{39}$ For examples see Cynthia Sturgis, “'How're You Gonna Keep 'Em Down on the Farm?': Rural Women and the Urban Model in Utah," Agricultural History 80 no. 2 (Spring 1986); Sherry Lee Ann McNeil, "Urban Reform, Middle-Class Values, and Agricultural Society in Ontario, 1880-1914" (master's thesis, Wilfrid Laurier University, 1997); Mary S. Hoffschwelle, “'Better Homes on Better Farms': Domestic Reform in Rural Tennessee," Frontiers: A Journal of Women's Studies 22, no. 1 (2001); Edith M. Ziegler, “'The Burdens and the Narrow Life of Farm Women': Women, Gender, and Theodore Roosevelt's Commission on Country Life," Agricultural History 86, no. 3 (Summer 2012).

${ }^{40}$ The importance of teaching children to commune with nature is underscored by the introduction of gardens as an activity for city children. See Peter G. Anderson, Ottawa School Gardens in the Early 1900 's, Bytown Pamphlet Series No. 76 (Ottawa: Ottawa Historical Society, 2010).

${ }^{41}$ Jeffery Taylor, Fashioning Farmers: Ideology, Agricultural Knowledge, and the Manitoba Farm Movement, 1890-1925 (Regina: Canadian Plains Research Center, 1994), 55-8.
} 
to farm success. ${ }^{42}$ The rural Journal also gave positive examples of women as skilled and experienced producers. The 1897 Ottawa Semi-Weekly Journal reprinted two items from American farm journals on high-profile women involved in dairying. ${ }^{43}$ In 1901 , the Ottawa Valley Journal published a locally-written story from Mrs. Joseph Yuill of Carleton Place. She had written a letter to the Journal describing how she raised chickens using an incubator. The newspaper sub-headed her story "Letter Written for the Journal by an Expert.” Mrs. Yuill was not keeping a few poultry for pin money. She described how she sold pullets and cockerels for breeding purposes while she fattened chickens not suitable for breeding and sold them in the Montreal and British markets. In 1902 the newspaper profiled Laura Rose, a graduate of the Ontario Agricultural College (O.A.C.), who had been hired by the Nova Scotia government to teach butter-making - although not to creamery operators. She taught only farmers' wives through a travelling dairy school. In 1910, the rural Journal urged farmers' wives and daughters to compete in the butter-making competition at Ottawa's Central Canada Exhibition. They could start in the amateur class and move up to the expert class with practice. The newspaper assured them it would eventually lead to more money when selling their butter. ${ }^{44}$

This support for women as producers, even if restrained, disappeared in the material written specifically for women. Like metropolitan dailies, the rural Journal was departmentalized into men's sections (livestock, the farm, machinery and later automobiles) and women's sections (household tips, recipes, fashion, literary and

\footnotetext{
${ }^{42}$ Amy Mattson Lauters, “More than a Farmer's Wife: Constructions of American Farm Women In Selected Media, 1910-1960" (PhD diss., University of Minnesota, 2005).

43 "Thoughts for the Dairy / One Woman's Method and Her Wise Reflections and Conclusions," OSWJ, July 16, 1897, 3; "Mrs. E.M. Jones / Sketch of the Life of Canada's Leading Dairywoman," OSWJ, February 26, 1897, 3. These were unique to the semi-weekly.

44 "A Lady's Experience Last Year Hatching Chickens in an Incubator," OVJ, March 22, 1901, 26; "Scientific Butter Making," OVJ, August 22, 1902, 8; "Competitions In Butter Making," OVJ, September 6, 1910, 10 .
} 
spiritual articles all of which followed the content found in an urban page written for women). Specially-written agricultural sections, which were written as if the readers were all men, appeared first in 1900. Women had only a column of fashion information copied from the daily until May 1902 when the Ottawa Valley Journal introduced in the Friday issue "The Journal's Household Dept Conducted by Aunt Joe." This was a speciallywritten in-house department aimed at farm women headed by its own "editress."

In contrast to the rural editors whose names and photographs were published in conjunction with their "outside" activities (the associations of which they were secretary), the household editor remained anonymous until the Aunt Joe persona suddenly “disappeared" in 1920. She may have been the one female rural Journal employee I have identified, Kate Whelan. ${ }^{45}$ She was, however, almost from the start, given a "face" in a header drawing (see figure 5.2). Perhaps this was done to give women readers a sense of community, friendship and trust so that they would be encouraged to share recipes and home tips, The original “Aunt Joe” was pictured from August 1902 to 1916 as an older traditionally-dressed woman, the kind of experienced woman to whom young women needing advice would turn, at least, perhaps, in the newspaper's estimation.

In January 1916 the cut was changed to rotate between two different drawings (figure 5.2). One week the header dropped the reference to Aunt Joe and pictured a

\footnotetext{
${ }^{45}$ The Aunt Joe character disappeared sometime between April 16, 1920, when she was represented in the column header, and April 30 when the header said only "Household Department." As the April 23 newspaper is missing, I cannot specify the date or say if the newspaper explained the change. It is possible that Kate Whelan was the woman behind the name in later years. Kate Whelan was working in 1902 but it is not known where. If she was the editor in 1902 she would have just joined the newspaper as an eighteen year old who had been in school only two years before. If this is correct, the newspaper had good reason to hide her identity. I have yet to find, however, another woman working for the rural Journal. There are later references to Whelan as household editor but the clearest came after the demise of the character. In 1924 she was described in her mother's obituary as "household editress of the Ottawa Farm Journal," ("Mrs. Annie Whelan," OFJ, February 8, 1924, 4). It may be significant that the Aunt Joe image disappeared one month after "Aunt Kate" was born as the co-editor of the children's page.
} 
family group in which an older woman sat with a young short-haired woman reading a

book plus a toddler and two youngish men. This cut is crowded and in every issue I have looked at visually difficult to distinguish. The older woman is particularly obscured in contrast to the young woman. ${ }^{46}$ On alternating weeks the name "Aunt Joe" was

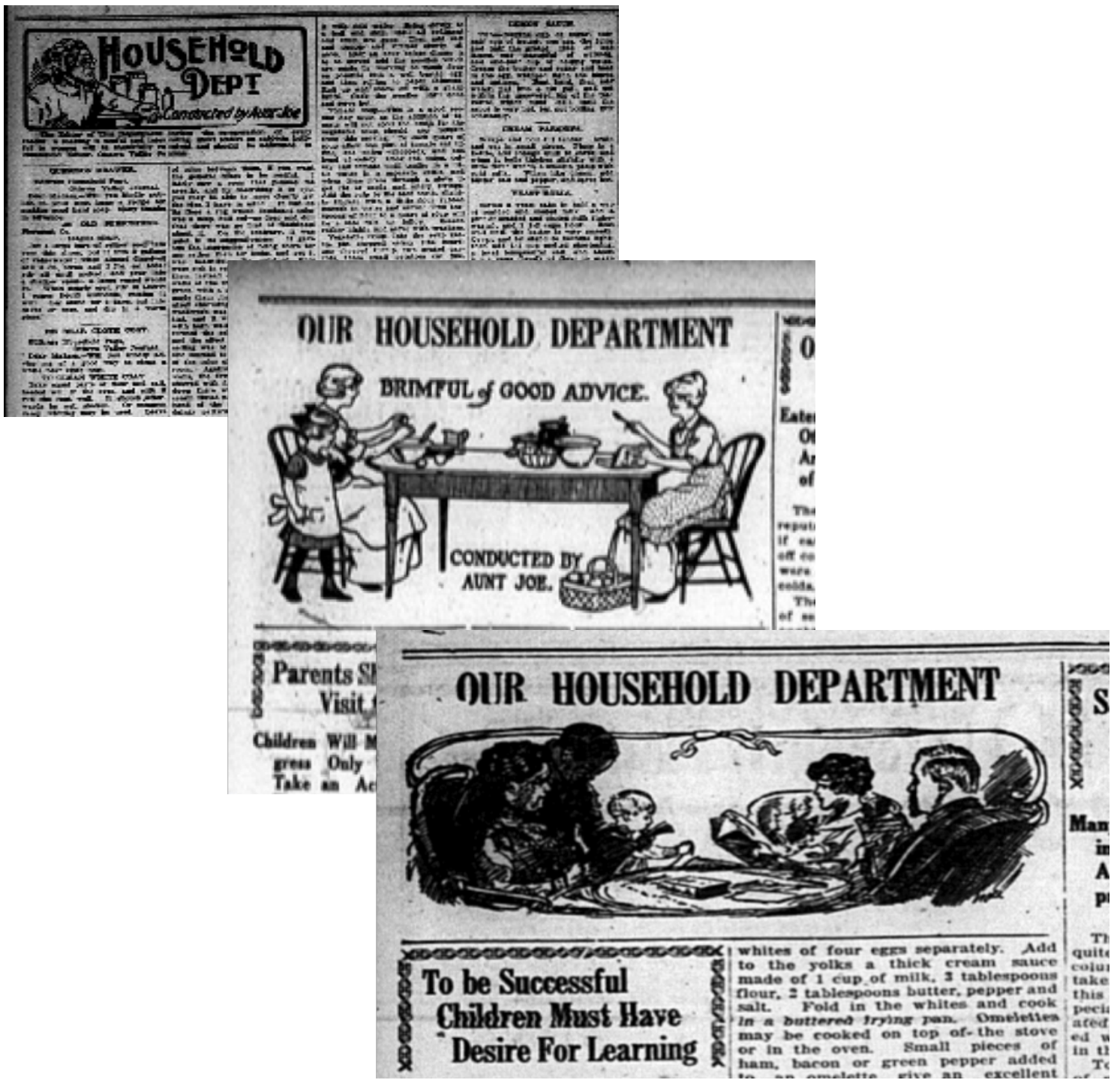

Fig. 5.2. Ottawa Valley Journal and Ottawa Farm Journal headers for its Household Department. Top image ran from 1902 until January 1916. The centre and bottom images appeared on alternate weeks from January 21, 1916 until April 16, 1920.

\footnotetext{
${ }^{46}$ I am hesitant to say whether this was a case of bad graphic design or a deliberate effort to downplay the Aunt Joe character. Certainly from a design point of view, the alternate "Aunt Joe" graphic is cleaner than this "family Aunt Joe".
} 
back while the family grouping was shrunk to Aunt Joe, a young women and a little girl with both women seated at what appears to be a kitchen table. I have found nothing in the text to explain the reason for the two different looks The content of the columns appears to be much the same each week and yet the headers, despite sharing the theme of an intergenerational family socializing and working together, are sufficiently different to suggest two different editors at work. At the same time, despite the women's long dresses in this post-war period, the household advice was being modernized, for example, to the research needed to buy a washing machine. ${ }^{47}$ The ambiguity of the post 1916 header may reflect the newspaper's own ambiguity about how modern or how traditional its household department should be.

The household department was introduced in 1902 with a declaration of women's special interests:

At last our right to a share of the space in the Ottawa Valley Journal has been recognized and I am sure you will all rejoice with me over the fact that in future we will have several columns weekly for the discussion of our personal affairs and other matters in which men are not supposed to be interested. ${ }^{48}$

Despite this bold statement there was never a comment in these columns on such female interests as suffrage or the division of household duties. As well, even though the column was written specially for farm women and gave advice on the special issues of domestic work in a farm house, it said nothing on the productive work of farm women. Instead women were given a short poem followed by housecleaning, cooking and childraising tips plus illustrations from the May Manton pattern company. Starting in November 1909 the newspaper offered to act as an agent for Journal subscribers who

\footnotetext{
${ }^{47}$ OFJ, January 19, 1917, 9

48 "Household Department," OVJ, May 30, 1902, 10.
} 
wished to order patterns from New York City. After 1910 the column reported on Women's Institute meetings. It also published short (usually two-sentence) enquiries from readers for kitchen or general housekeeping information to which Aunt Joe gave the answer. For example, in 1911 Gertrude of Grenville Country asked how to wash a silk blouse. In 1916 D.M. of Stormont County asked for a recipe for homemade "cough candy." 49 A few readers wrote to share tips and recipes. In 1903 Ella H. Cooper wrote on how to properly darn socks while Emma Gary Wallace wrote in 1916 on the importance of starting child-training in infancy. ${ }^{50}$

The contents of the rural Journal's women's page is essentially the same as that found in the Farmer's Advocate and more than likely gave women what they wanted as stated by the household editor in 1902 - information on their "special interests." But in other farm publications Ontario farm women were discussing the difficulties of balancing farm work with domestic work. On the one hand they compared their lives unfavourably to urban women who had labour-saving devices while they had to make do because the husband held the purse-strings on what investments should be made. On the other hand, even as they understood the economic importance of mechanizing the farm, they expressed the gender tensions created on many farms by "the barn" taking precedence over the house. ${ }^{51}$ Monda Halpern also highlights this as an issue for farm women, an issue she finds was discussed in the women's pages of the farm press, including the Farmer's Advocate. ${ }^{52}$

\footnotetext{
49 "Household Department," OVJ, January 20, 1911, 8; OVJ, January 28, 1916, 9.

50 "Household Department," OVJ, November 6, 1903, 8; February 11, 1916, 11.

${ }^{51}$ Kerry Badgley, Ringing in the Common Love of Good: The United Farmers of Ontario, 1914-1926 (Montreal: McGill-Queen's University Press, 2000), 115-21.

${ }^{52}$ Monda Halpern, And On That Farm He Had a Wife: Ontario Farm Women and Feminism, 1900-1970 (Montreal: McGill-Queen's University Press, 2001), 30-4.
} 
I have not found such discussions in Aunt Joe's column nor did readers share either in 1902 or 1920 their opinions on politics or gender relations. But for one brief moment the household editor did. A reader asked in January 1903 why women were not as successful as men. Twenty-five years before Virginia Woolf wrote $A$ Room of One's Own, Aunt Joe penned a feminist reply to the reader's letter. She made two points which still have relevance. First she commented on the difficulties women had developing their talents because of the demands, often trivial, made on a woman's time, demands not made on men. Second she commented on how women work twice as much as men for half the pay. ${ }^{53}$ This one response to a household letter shows that the person writing as Aunt Joe was thinking, if not about the vote, at least about women's place in a maledominated work world. In light of this one item, it seems strange that, despite the daily Journal supporting women's suffrage in its editorials, neither suffrage nor women's labour was addressed in the rural Journal's women's pages. ${ }^{54}$

Children were given their own department in January 1919 with a special Friday children's page entitled "Our Young Readers at Work and Play." The page consisted of a puzzle of the connect-the-dots type, an "Editor's Weekly Chat" by "Uncle Henry" and a column he wrote on his boyhood days in Scotland. The bulk of the page was filled with letters written by children on whatever subject appealed to them as well as on subjects set for them from time to time. I believe that "Uncle Henry" was James Henry, who had joined the Ottawa Farm Journal in 1917 as an associate editor. ${ }^{55}$ The page was such a

\footnotetext{
53 "Why Women Fail," OVJ, January 16, 1903, 2.

${ }^{54}$ Equal Rights for Women," OVJ, November 17, 1916, 4; "Women and the Ballot," OVJ, November 24, $1916,4$.

${ }^{55}$ James Henry was a Scottish immigrant (Census of Canada 1921, Ontario, Ottawa, Wellington Ward, p. 19). He had been born in Banffshire near Aberdeen (Library and Archives Canada; Form 30A Ocean Arrivals (Individual Manifests), 1919-1924; Rolls: T-14939 - T-15248). "Uncle Henry" wrote in his column that he had grown up on a farm outside Aberdeen.
} 
success that the managing editor R.B. Faith wrote the "weekly chat" of March 19, 1920 to explain that he had brought "Aunt Kate" in to help. From this point on Kate Whelan wrote the Chat column while Henry continued to write the Scottish column. Children wrote about school, family, pets and the pride they took in their own farm work.

The rural Journal did not at any time suggest that the children should question their economic role in the farm family. Instead when eleven year old Carman Pettapiece of Carleton County spoke of working the corn binder, mowing hay and occasionally milking five or six cows, Henry simply congratulated him on being "a busy little farmerin-the-making." ${ }^{56}$ When Robert Faith wrote the March 1920 "chat" to introduce "Aunt Kate" to the readers, he remarked that, no matter how far the children reading the column travelled in life, they should remember that the farm home was best. He said that, like most country children, he had longed for the city where there were "big stores and the bright lights shine at night." He had left his farm home and now, having spent twenty years in country life and twenty in the city he considered that country life was best. ${ }^{57}$ Country Life reformers reading the page would have been comfortable with the newspaper encouraging the children to see their farm lives as valuable and interesting though uneasy that it accepted, even celebrated, children as economic contributors to the family unit.

Despite having specialized columns for women and children the family was never the subject of a rural Journal campaign to change either productive or consuming roles within the family. Aunt Joe did comment on farm women's need for labour saving devices for the home. Her most explicit comment was made during the First World War

\footnotetext{
${ }^{56}$ Carman Pettapiece to Editor, OFJ, March 26, 1920, 10.

57 “The Editor's Weekly Chat," OFJ, March 19, 1920, 8.
} 
when the lack of farm labour meant that women could no longer expect their men to have time to do anything more than field work. The women, therefore, had to find other ways to get help in their farm work "in the dairy, the garden or the poultry yards" as well as in their domestic work. She then listed five items that should be top of the list for farm investment, from a power washing machine to an ironing board. ${ }^{58}$ The Journal also carried articles on improving the farm house, from a how-to article on building a sink side table for draining washed dishes to numerous articles on keeping the house healthily ventilated in winter. As well, in 1906 it conducted a series of articles on building "Up-todate Homes." For a time the Ottawa Valley Journal ran "The Journal's Farm Building Department" in which a man who claimed twenty years of experience gave advice on how to plan the house and out-buildings. ${ }^{59}$ The Journal could have gone further and run competitions for model farm houses, as the Farmer's Advocate did, or good farms competitions (which included good farm houses) as Farm and Dairy did under its owner and ex-Journal editor Herbert Cowan. The Journal reported on one of Farm and Dairy's competitions but did not suggest it was something for itself to undertake as a means of assisting rural women. ${ }^{60}$ It seems neither encouraging women to acquire labour-saving devices nor encouraging the sanctity of the home in the form of non-producing children was considered a potential subject of a Journal "agitation."

\section{Farm Work as Men's Work}

Despite the children's letters on their farm work and occasional hints that women

\footnotetext{
58 The Household Department, OFJ, June 14, 1918, 8.

59 "Handy Sink Table In Farm Kitchen," OVJ, January 30, 1920, 9; "Ventilation of Farm House in Winter Regulates Health and Happiness of Family," OVJ, October 27, 1916, 16; "Plans and Specifications of Inexpensive Farm House," OVJ, November 23, 1906, 12; "Planning Farm Buildings,” OVJ, January 29, 1915, 11.

60 “Good Farms Competition,” OVJ, March 15, 1910, 12.
} 
did farm work of their own, the rural Journal accepted the wisdom of the time that men were the primary producers and the focus of all serious farm improvement attention. This comes through clearly in the campaigns discussed in the next three chapters, all of which were aimed at men. Here, I touch on how the rural Journal's male-centred activism played out in its circulation premium prizes.

As discussed in Chapter 4 Cowan had introduced livestock as premium prizes for readers who sold a certain number of pre-paid subscriptions. The advertising tended to stress the offer of pigs but the Journal was also giving away egg settings for hatching. At this time poultry tended to be women's work. ${ }^{61}$ Most of the livestock announcements were gender-neutral but on occasion the Journal circulation staff wrote as if the recipients of the eggs were men. For example, in 1900 a two-column ad for all the premiums on offer, consumer goods and livestock, specifically addressed the livestock premiums to the "Head of the House.",62 Then in 1909 and 1910 an ad for egg premiums was run appealing to "Live Farmers." ${ }^{\prime 3}$ In 1914, the newspaper told readers "It would be easy for any young farmer or farmer's son, to get together the required number of subscriptions to secure one or other of these most advantageous offers [pigs or eggs.]" The newspaper printed the names of a few women who had won eggs, such as Tillie Mulligan of Cantley and Mrs. D.R. McRae of Lodi. ${ }^{64}$ There may have been other women who raised poultry from eggs ostensibly acquired by the husband as the Journal premium winner but they are invisible.

\footnotetext{
${ }^{61}$ See for example, Badgley, Ringing In The Common Love, 127 regarding women's complaints over control of the poultry money they earned.

62 "Have You Decided Yet?" OVJ, October 5, 1900, 5.

63 “Ottawa Valley Journal Offers Valuable Premiums," OVJ, April 10, 1914, 14; "To Live Farmers," OVJ, October 5, 1909, 7 and October 4, 1910, 3.

64 "Valuable Prizes for Our Friends," OVJ, January 19, 1900, 2.
} 


\section{Country Life and the Social Gospel}

The limits on the rural Journal with regard to politics and class interests can be understood in terms of its ties to an Independent Conservative daily. The limits on dealing with Country Life issues are not as clear, particularly given its claim in the 1919/1920 sales pamphlet to have "interested itself in conditions in the country." The newspaper and its readers were aware of the Country Life Movement but the Journal carried only occasional articles on the official Commissions which structured the amorphous interests of urban reformers in the countryside.

In 1908 the Ottawa Valley Journal printed without commentary a letter to the editor saying that Canada had the same problems Roosevelt was addressing through his Country Life Commission. A year later the Journal reprinted an article from the American magazine Harper's Weekly on some of the results of the survey being carried out by Roosevelt's Commission. ${ }^{65}$ It paid only slightly more attention to the Canadian Commission of Conservation. It carried a few editorials, all of which it copied from the daily edition. ${ }^{66}$ It did publish original news reports on the Commission's illustration farms. ${ }^{67}$ This included an enthusiastic report on an illustration farm in near-by West Quebec. The enthusiasm extended from the results of the Commission's crop rotation experiment to the farm itself with its "up-to-date residence ... equipped with all that's modern ... a model of convenience and good taste." It also had a well laid-out farm yard

\footnotetext{
65 "Agriculturist" to Editor, OVJ, October 2, 1908, 12; "What's Wrong on the Farm," OVJ, February 2, 1909, 9.

66 "The Saving of the Land," OEJ December 23, 1910, 6 and OVJ, December 27, 1910, 4; "Farms and Fisheries," OEJ, August 18, 1911, 6 and $O V J$, August 22, 1911, 6.

67 "Improvement Of Farms," OEJ, August 7, 1912, 1 and $O V J$, August 9, 1912, 6; "The Conservation Commission," OVJ, February 21, 1913, 9 (this item was unique to the $O V J$ and was a longer, more detailed report than the August 1912 news item).
} 
and outbuildings, and excellent soil. ${ }^{68}$ An astute farmer might well have decided that the Commission was interested in successful, commercialized and generally superior operations.

Both Country Life and the Commission of Conservation were urban-driven initiatives with strong connections to the Protestant Social Gospel. This is clear in an American article the rural Journal reprinted on the religious page explaining how to organize a Country Life Institute. The writer described these institutes as "rural schools of religion" intended to train over the course of at least a day and preferably a week "religious people" in local social service work. He advised that a dinner be served as it would not only feed the attendees but "employ the women of the community in a sympathetic and happy way." In addition, he advised organizers to avoid the usual practice of naming a chair from among prominent local businessmen or politicians. The chair should instead be a man with extensive knowledge of the needs of the poor and the duty of the church. The writer said such knowledge could be found in "colleges, seminaries and universities. ${ }^{69}$ I suggest that presenting community women solely as suppliers of food and downgrading the role of local prominent men in the proceedings indicates these Institutes were outside forces acting on the community. In short, they were the urban social gospel transplanted into the countryside with the clergy in charge.

A year later the rural Journal published its first reference to Country Life activity in the Ottawa Valley in the announcement of a special Country Life meeting at Pakenham, Ontario. There was another such announcement for a "Rural Community Life

\footnotetext{
68 "Splendid Crops On Illustration Farm In Pontiac County," OVJ, August 21, 1914, 12.

${ }^{69}$ Dr. W.H. Wilson, "How To Manage a Country Life Institute," OVJ, June 20, 1913, 12.
} 
Institute" at Russell in June $1918 .^{70}$ And that was all as far as what is visible in the rural Journal. Nor did the newspaper say anything specific as to who was involved in the initiation and organization of these Country Life meetings. There were also a number of national Social Service Congresses in Canada during the life of the Canadian Commission of Conservation. Country Life, however, was at best one session while all other sessions focused on urban issues.

In general the Ottawa Valley Journal showed signs of schizophrenia with respect to the role of the clergy and the "rural problem." The Country Life Movement in Canada was articulated most clearly by John MacDougall and his 1913 book Rural Life in Canada $^{71}$ MacDougall was a Presbyterian minister in a small Eastern Ontario town who argued that the clergy should lead farmers in addressing the economic and social problems he had identified. The reality of the social problems he described can be questioned. Some contemporary commentators dismissed his claim that the rural population was decreasing. They argued that the village, not the farm, was under threat. ${ }^{72}$ To further support the counter-argument that the claim of a disappearing rural population was overstated, MacDougall included in his assessment of rural Canada's social problems the replacement of Anglophone Protestants with French-Canadian farmers. This suggests that a form of nativism was at work in some elements of the Country Life Movement. Nevertheless the rural Journal did not express any caveats on MacDougall's book, instead recommending it to their readers. It also claimed credit saying that MacDougall's

\footnotetext{
70“"Country Life To Be Subject of Address," OVJ, March 3, 1914, 5; Some Economic Problems Confronting the Farmer in Need of Attention," OFJ, July 5, 1918, 10.

${ }^{71}$ John MacDougall, Rural Life in Canada: Its Trends and Tasks (1913; repr., Toronto: University of Toronto Press, 1973). See Chapter 3 for a fuller discussion.

${ }^{72}$ Among those who claimed rural Ontario was under threat as farm families supposedly moved either to the prairies or, worse, to the cities were agrarian leaders E.C. Drury and W.C. Good. The provincial department of Agriculture saw a positive move of surplus population out of the Ontario countryside, ensuring that farms would not be sub-divided into unproductive units.
} 
book was in line with the "agitation" the newspaper had begun in the fall of 1912, that is, in articles suggesting ministers should help the farmers in their congregations become better producers. $^{73}$

On September 6, 1912 the newspaper published an article by "a Staff Representative on the Trail" who was likely a paid correspondent. The writer argued that in Canada the clergy had to go beyond questions of the spirit to economic questions. Not only was the clergy's duty to assist farmers in their congregation with the "knotty problems" they faced, but the Church's own prosperity (and presumably that of the incumbent minister and his family) depended on farm prosperity. The writer then moved on from the need to help farmers achieve economic prosperity to a recommendation that the Minister and his wife involve themselves in the local Farmers' Club in order to use their education and taste "to elevate rural life." Three weeks later, the Journal carried an article pointing to an American example of ministers attending state-run agricultural courses. $^{74}$

The Journal also reported in September 1912 that "a large number" of ministers had sent letters to the newspaper giving their opinion on what they could and should be doing for their farm congregations. The newspaper said it would publish the letters every Friday which it did through to December. ${ }^{75}$ As an example of what was received and published, the Methodist minister in Manotick described the church as "the most essential institution in country life [which could] save the country" even when the church was

\footnotetext{
73 "Rural Life in Canada," OVJ, August 1, 1913, 10.

74 "Should The Church Take a More Active Part in Assisting Farmers to Solve Their Problems," OVJ, September 6, 1912, 14; "Kentucky Clergymen Making a Special Study of Agriculture," OVJ, September $17,1912,14$. The newspaper carried occasional articles with the same suggestions in 1913, for example "Relation of the Church to Rural Agriculture, OVJ, July 11, 1913, 10.

75 "Many Clergymen in Rural Districts Endorse Suggestion Made by the Journal," OVJ, September 20, $1912,12$.
} 
"narrow in its conception of its mission, slow in responding to the progressive spirit of the age." As in the urban social gospel, the church had a duty to improve life on earth and not simply promise a better life in the hereafter. ${ }^{76}$ Most of the clergy whose letters were published wrote in generalities of how they could support their congregations, noting that whether urban or rural an effective minister took the time to understand his congregants and their economic and social problems. This meant that country clergy had to be ready at least to understand farming issues but at best to help the farm men in their congregations become more scientific, and thereby more productive, agriculturists. Unlike preachers of the urban social gospel, country ministers were going to have to take courses so they could "talk farming."

In 1913, the rural Journal carried an article congratulating itself, claiming the government was planning to act on its suggestion from the Fall of 1912 to pay the expenses of clergymen taking the short courses at the O.A.C. ${ }^{77}$ The article must have been approved by Faith as it appears in a prominent position on the agricultural page but it was written by a "Staff Representative on the Trail" who claimed to have heard this from the agricultural expert working with the Commission of Conservation. The sentiments expressed seem to distance the newspaper from the farmers in assuming that farmers needed, or wanted, advice from a clergyman. ${ }^{78}$

\footnotetext{
${ }^{76}$ Rev. W.T. Brown, "Relation of the Church to the Rural Community," OVJ, December 20, 1912, 23.

77 "Suggestion made by O.V.J. Likely to be Acted Upon," OVJ, July 18, 1913, 14. The suggestion, as worded in the September 17, 1912 article, was a general recommendation that clergy take short courses but did not go so far as to suggest the government subsidize this. There is no evidence that this plan ever went beyond the conversation the writer had with the Commission of Conservation's expert.

${ }^{78}$ The idea that ministers, who were not agricultural specialists even if they had lived on a farm as a child, could be useful to people with years of experience muddled the message that farming was a scientific job requiring training. This same muddle was seen during the First World War when government officials and urban observers claimed town and city people, from boy scouts to office workers, could help farmers bring in the harvest. In the next chapter I discuss the hegemonic message that begins to be heard in the first two decades of the century regarding the college-trained agricultural expert. Adam Crerar has dissected how the
} 
Despite the rural Journal's articles on clergy leadership in agricultural improvement, I find one small sign of dissension among the newspaper writers. In 1914 the Ottawa Valley Journal carried two contradictory columns. A news item on March 6, 1914 reported approvingly on the speeches made that day at the one rural session of the three-day Social Service Congress of Canada. ${ }^{79}$ The second article by an unnamed writer was printed three weeks later. It pointed out a problem. Even though the session had been chaired by Dominion Grange leader (and future leader of the United Farmers of Ontario) E.C. Drury, the speakers consisted of clergymen, a professor from the Ontario Agricultural College and a promoter of farmers' banks. No farmers. The Journal asked "[w]ho should know more about the farmers' wants, necessities and ambitions than the intelligent farmer himself?" It went on to argue that the farmer must find his own solution to the country problem:

They [well-intentioned men and organizations] assume that the farmer is badly off, and that he is powerless in himself to remedy matters. Thus, instead of bringing him in as a first, most important and self-helping factor in the solution of the problem of the country, he is set aside as a member of a body that had in its composition neither initiative nor co-operation. This treatment not unnaturally awakes in the farming community a sense of the invasion of unasked-for interference and engenders an excusable coldness and unresponsiveness to the approach of even kindly effort in their behalf. $^{80}$

This is an astute observation but can it be squared with the same newspaper's positive report of the session? The answer may lie with the reporting of the Ottawa Evening Journal on the main Congress. Each day the daily carried positive reports of all

\footnotetext{
war effort to bring urban residents into agricultural work undercut the hegemonic narrative of agriculture as requiring scientific study. He points out that the farmers themselves saw the hypocrisy and used the hegemonic claim around agricultural expertise to argue that they could not replace their farm sons with just anyone. Crerar, "Ties That Bind," 281-2.

79 "Social Service Congress Tackles Rural Problems," OVJ, March 6, 1914, 14.

80 "The Social Service Congress," OVJ, March 27, 1914, 10.
} 
the major speeches. ${ }^{81}$ The daily's coverage was so extensive that perhaps the urban Journal reporter who wrote on the other sessions wrote the laudatory article despite it being unique to the rural edition, whereas perhaps a reporter or editor for the rural Journal wrote the cautionary article on March 27.

The rural Journal did not show a great deal of interest in the home life and social justice issues of either the Social Gospel or the Country Life Movement. Instead the editor was apparently content for the staff writer to advocate that the clergy deal with such issues. It seems that the rural Journal's advocacy was relevant for male, economic issues, and not social issues.

\section{Country Living, Cemeteries and the Community}

What was done for country living was done in the country graveyard but in the end, it was little more than had been done with respect to encouraging the country clergy to combine agricultural improvement with their spiritual work. The rural Journal's pamphlet claim to have contributed to rural improvement through a campaign to beautify cemeteries was related to one of the Country Life Movement's designs for modernizing the countryside - country beautification. Country beautification overlapped with scientific agriculture and the goal of better, cheaper and more food for cities through farm efficiency and farm yard sanitation. At the same time, by making rural homes more attractive, reformers believed farm children would choose to remain in the countryside when grown. Country beautification generally is obscured by the more prominent discussion of the City Beautiful even though the latter was preceded by "Village

81 "Social Service Congress Deals with Three Important Matters," "Defective Child Subject of Miss Macmurchy Talk," and "Labor Movement, Churches and Vexed Questions Are Laid Before the Social Service Congress," OEJ, March 4, 1914, 1, 7, and 10; "Social Service Congress Discusses Immorality Problem," OEJ. March 5, 1914, 5; "To Give Civil Servants All Their Political Rights and Appoint Them By Commission," OEJ, March 6, 1914, 5. 
Beautification." The idea of people working together to beautify their community had started in 1853 when residents of Stockbridge, Massachusetts formed a "village improvement society" to attract summer resort visitors who would boost the town economy. Over the next forty years national magazines publicized the town and society as an example to emulate and this then fed into the City Beautiful Movement. ${ }^{82}$ Country Beautification in a sense took the City Beautiful back to its roots.

Country Life reformers had an on-going interest in farm beautification but it was a matter of experts talking at farm families. When the rural Journal addressed farm beautification it stayed within the farm yard and house with short pieces advising farmers to keep their yards tidy and their buildings painted. It also printed a comment by Frederica of Grenville County that tidy farms were the marker of "the intelligent farmer.. ${ }^{83}$ In 1907 an Ottawa Valley Journal representative reported on the meeting he or she had had with horticulturalist W.T. Macoun at the Central Experimental Farm, Ottawa. In this article the writer told the readers about Macoun's advice for making a lawn and planting trees and shrubs which would beautify the farm house and keep the children in the country when they reached adulthood. ${ }^{84}$ But all of this focused on beautifying private spaces. The Farmer's Advocate went beyond the private. In advising farmers to plant roadside trees it pushed the boundaries of farm beautification into public spaces. An

\footnotetext{
${ }^{82}$ The popular story of the origins of the village society actually starts in a cemetery. A townswoman was visiting her parents' grave and noticed how unkempt it was with broken fences and headstones, and wandering cattle. On the way home, she noticed that even the town streets were neglected and she resolved to do something about this. An alternative origin story drops the cemetery. Kirin J. Makker, "Village Improvement and the Development of Small-Town America, 1853-1893," Journal of Planning History 13, no. 1 (2014).

${ }^{83}$ For examples, "A Good Farmer," OVJ, October 24, 1902, 9; "Paint the Buildings," OVJ, April 7, 1903, 8; "Farm Adornment," OVJ, April 27, 1906, 12; Frederica, "Beautify the Surroundings," OVJ, June 16, $1905,12$.

84 "Attractive Farm Houses," OVJ, May 14, 1907, 10; "Beautify the Countryside," OVJ, February 15, 1910, 9.
} 
Advocate editorial described the consequences of rural residents not seeing the public spaces along roads as deserving special care. Village merchants dumped packing boxes and barrels in roadside ditches, the blacksmith dumped scrap metal, and farmers dumped their orchard refuse. ${ }^{85}$ At the same time the Advocate continued to write about the beauty of roads lined with shade trees. ${ }^{86}$

When the Journal finally shifted its attention to the beautification of public spaces it did so with respect to the cemetery in a multi-year campaign that would later be highlighted in the Ottawa Farm Journal sales pamphlet. The academic history of the cemetery has focused on the architecture of death and/or on the cemetery as a cultural place. Both narratives touch only briefly on the North American country cemetery as ground zero to the more interesting town and city cemeteries. ${ }^{87}$

It is necessary to contextualize the newspaper comments on cemetery beautification with an overview of the development of American and Canadian cemeteries in the nineteenth century. ${ }^{88}$ In general we find a progression of philosophies and styles in town and city which began by replacing in-town New England burying grounds with "rural cemeteries" which were in fact geographically suburban.

\footnotetext{
85 "Aestheticism in Rural Life," FA, September 1, 1904, 1164.

86 "Revive Interest in Arbor Day," FA, April 20, 1905, 577; Wm. Whitman Bailey, "Why 'Clean Up' the Roadside?" FA, April 19, 1906, 652; "Plant Trees Along the Roadside" FA, August 9, 1906, 1255; "Grass, Trees and Vines for Every Farm," FA, April 18, 1907, 659.

${ }^{87}$ For examples see Philippe Ariès, The Hour of Our Death, transl. Helen Weaver (1981: repr., New York: Vintage Books, 2008); Thomas A. Keselman, Death and the Afterlife in Modern France (Princeton: Princeton University Press, 1993): Nigel Llewellyn, The Art of Death: Visual Culture in the English Death Ritual, c. 1500 - c. 1800 (London: Reaktion Books, 1997); Elizabeth A. Wright, "Rhetorical Spaces in Memorial Places: The Cemetery as a Rhetorical Memory Place/Space," Rhetoric Society Quarterly 35, no. 4 (Fall 2005): 51-81; Jennifer McKendry, Into the Silent Land: Historic Cemeteries and Graveyards in Ontario (Kingston, Ont.: Jennifer McKendry, 2003); John Belshaw and Diane Purvey, Private Grief, Public Mourning: the Rise of the Roadside Shrine in B.C. (Vancouver: Anvil Press, 2009).

${ }^{88}$ The overview is a synthesis from David Charles Sloane, The Last Great Necessity: Cemeteries in American History (Baltimore and London: Johns Hopkins University Press, 1991): Blanche M.G. Linden, Silent City on a Hill: Picturesque Landscapes of Memory and Boston's Mount Auburn Cemetery rev. ed. (Amherst: University of Massachusetts Press, 2007); Richard F. Veit and Mark Nonestied, New Jersey Cemeteries and Tombstones: History in the Landscape (New Brunswick, N.J.: Rivergate Books, 2008).
} 
Confusingly for this study, histories of the evolution of North American cemeteries emphasize the development of what is called the "rural cemetery," or sometimes (and less confusingly) the "garden cemetery." "Rural" here does not mean the actual countryside of production. Rather it was an artificial construct for urban residents who hoped an idealized countryside of trees, shrubs and gardens could heal grief and pain. The demand for displacement of the dead came out of attitudinal changes which were partially driven by a new science of public health which had linked the eighteenth century concept of "miasma," or poisoned air, with disease. The new "rural cemeteries" were also conceptually urban, being designed to remove the miasma-causing dead out of the "burying grounds" in the centres of towns. Cemeteries had become dangerous to the living body. There were also new cultural ideas about the body leading to a revulsion against the momento mori of eighteenth-century tombstones with their emphasis on the corrupted body, as well as new sentiment about the family leading to a middle-class demand for family grave plots. The new cemetery fashion of trees and winding walks began with the Père Lachaise cemetery in Paris in 1804 but was quickly reproduced in the United States with the first "rural" or "garden" cemetery at Mount Auburn near Boston (1831).

In the second half of the century the business of death became commercial with a new breed of professional cemetery managers, landscapers and superintending engineers along with a professional association and a trade journal. Among the earliest and most prominent professionals was Adolph Strauch in Cincinnati who redesigned Spring Grove cemetery in 1855 in a more open and less garden-like design. David Sloane states that by 1900 there were three American cemetery types: 1) cemeteries controlled by ethnic, 
racial or religious groups who continued to fill the space with headstones and family monuments; 2) in many small towns a variation of the "rural-cemetery" in which families filled their plots with large markers and small shrubs and plants; and 3) the lawn-park cemetery reflecting Strauch's vision of less obtrusive family monuments in a carefully controlled landscape which could be efficiently maintained. ${ }^{89}$ The last was the selfconsciously modern cemetery of 1900 .

There are almost no histories of what happened to country cemeteries while these developments were happening in urban burial. Roger Hall and Bruce Bowden, in their overview of the nineteenth-century Ontario cemetery, comment on a growing difference between urban and country cemeteries. They find that cemeteries in the countryside continued into the early twentieth century as community-centred spaces in which financial management was haphazard and maintenance was dependent on the sociallyorganized work of the bee..$^{90}$ The focus on community-based work is found as well in Catherine Paterson's study of the efforts to reclaim pioneer burial grounds in the Niagara region from increasing neglect experienced over the nineteenth century. ${ }^{91}$ She finds that a continued family connection to many of these places started to be manifested about 1900 . At that time some families sought to restore closed cemeteries by working together on special clean-up days. Paterson links this to a new interest in community and family heritage. She does not comment on the existence or even possibility of a broader cultural

\footnotetext{
${ }^{89}$ Sloane, The Last Great Necessity, 125-6. Sloane links the public acceptance of the lawn-park cemetery to the City Beautiful movement and its preference for formal planned layouts. The "rural cemetery" did not disappear overnight in 1855. As an example of its continued popularity in Canada, Ottawa's Beechwood Cemetery was laid out in 1873 in the best "rural cemetery" style.

${ }^{90}$ Roger Hall and Bruce Bowden, "Beautifying the Boneyard: The Changing Image of the Cemetery in Nineteenth-Century Ontario," Material Culture Review / Revue de la culture matérielle [Online], 23 (1 January 1986) journals.lib.unb.ca/index.php/MCR/article/view/17261 Accessed March 8, 2018.

${ }^{91}$ Catherine Paterson, "The Heritage of Life and Death in Historical Family Cemeteries of Niagara, Ontario" (PhD. diss., McMaster University, 2013).
} 
activity of cemetery beautification.

Yet there are records of "Decoration Days" in Montreal sometimes described as synonymous with the American Memorial Day. On May 30, 1899 Henri Césaire Saint Pierre, a prominent Montreal lawyer and a Civil War veteran, gave a speech at Montreal's Mount Royal Cemetery about the first American Decoration Day as he remembered it from May $1866 .{ }^{92}$ Brian Young's history of Mount Royal mentions Decoration Days in passing when describing the relationship between cemetery management and The Last Post charity established in 1909 to ensure proper burial of indigent veterans. ${ }^{93}$ Decoration Day appears to have escaped the military association in at least one place. A recent study of today's Decoration Days in the southern Appalachians claims that they predate Memorial Day. In this region families gather to clean the cemetery in advance of Decoration Day. They then return on the day itself for a religious service followed by placing flowers on all the graves and ending with family picnics. ${ }^{94}$

In 1906 the Farmer's Advocate was the first to extend beautification to the cemetery as a public space requiring public care by the community. "O.C." of Wentworth County started this, giving as an example the American practice of a day (left unnamed) when the graves of "fallen heroes" were decorated. He or she then condemned the filial lack of respect which "ignores the last resting place of its pioneers" but then took the idea beyond the familial obligation identified in Paterson's study. "O.C." stated: "This matter of the care of the country cemetery is one that concerns the community as a whole." Both

\footnotetext{
${ }^{92}$ H.C. Saint Pierre, Oration Pronounced at the Mount Royal Cemetery on Decoration Day, May 30th, 1899 (Montreal: C.A. Marchand, [1899?]).

${ }^{93}$ Brian Young, Respectable Burial: Montreal's Mount Royal Cemetery (Montreal: McGill-Queen's University Press, 2003), 143-8.

${ }^{94}$ Alan Jabbour and Karen Singer Jabbour, Decoration Day in the Mountains: Traditions of Cemetery Decoration in the Southern Appalachians (Chapel Hill: University of North Carolina Press, 2010).
} 
church congregations and township councils needed to consider how to care for all graves, including those whose families had moved away. ${ }^{95}$

Three years later the Journal also noticed cemetery neglect and began its campaign. In August 1909 the newspaper carried a "Special article written for The Ottawa Valley Journal by a Staff Representative.” The attention of the representative had been "directed to the neglect of so many rural cemeteries in this part of the province." "96 Who directed that attention is left unsaid. Herbert Cowan would have told the readers for he always claimed he learned of a problem from local farmers, often revealed to be "prominent men." But not only did the cemetery campaign miss Cowan's careful orchestration of credibility, it did not reflect Faith's brand of activism even though he was editor at the time. This was a polite campaign. Instead of trying to shake up established ways, the Journal representative recommended decorating cemetery plots with flowers. ${ }^{97}$ Over the following years each spring the unnamed staff representative wrote a "special" article encouraging rural residents to act as a community in rescuing local cemeteries from neglect. But he or she did not report on the clean-up meetings as they occurred, something Cowan and Faith had done in their initiatives.

Neither the Advocate nor the rural Journal writer raised concerns about public health which had been an important driver of change in the nineteenth-century urban cemetery. Public health was less of an issue in the countryside with its lower population density. The main concern in the country was community image and heritage. "O.C." had said a neglected cemetery reflected poorly on the community while the Journal referred to a speech by O.A.C. horticultural professor H.L. Hutt on beautification of homes,

\footnotetext{
95 “O.C.", "Care of Our Country Cemeteries," FA, June 28, 1906, 1039.

96 "Clean Up The Cemeteries," OVJ, August 13, 1909, 12.

${ }^{97}$ Ibid.
} 
school grounds, streets, parks and playgrounds. ${ }^{98}$ The Journal commented that Hutt should have gone on to address cemeteries and then, like "O.C.", spoke of filial duty: "respect for departed humanity demands it; lingering affection in the living for those gone before will quickly, when once aroused, insist on it."99

The Journal ignored another important change in the cemetery, the professionalization of cemetery care. Instead it focused on cemeteries as a place of community and family obligation. In 1910 it ran an announcement from the trustees of Springhill Cemetery near Metcalfe, Ontario inviting local residents to join a work party it was planning. The Journal connected this project to its own August 1909 article and urged other cemetery trustees to follow Springhill's example. ${ }^{100}$ Then, in 1915 , cemetery clean-up made the front page. The sub-headline was "This Cemetery Reform Started by The Ottawa Valley Journal Last Year Should be Continued and Spread Throughout the Country-It Should Appeal to Every Self-respecting Family in Every Rural Community." The newspaper made a claim in this article to having taken on the issue of neglected cemeteries as a special obligation: "The Ottawa Valley Journal has had this truly progressive rural movement at heart for a number of years past and will keep at it until a neglected cemetery in Eastern Ontario or Western Quebec, at least, is so rare a thing that it will become an object of special notice." ${ }^{101}$ It also published photos the writer had taken the previous year at "several of these cleaning-up meetings" as

\footnotetext{
${ }^{98}$ Howard Laing Hutt's advice had been published in the Ontario report on Horticultural Societies. He was a professor at O.A.C. from 1893 to 1914. As well as carrying out the usual duties of improving commercial fruit culture, he established a program of Landscape Gardening with a focus on flowers. The O.A.C. biography states that after his retirement in 1914 flowers and landscape were subordinated to the commercial/agricultural topics of fruit and vegetables. "140 Faces of OAC," Posted September 2014, www.uoguelph.ca/oac/140faces/howard-laing-hutt. Accessed March 5, 2018.

99 "Clean Up The Cemeteries," OVJ, August 13, 1909, 12.

100 "Springhill Cemetery," OVJ, May 17, 1910, 12.

101 "Canadians Would Be Willing To Decorate The New Graves Of Their Heroic Soldiers," OVJ, May 21, $1915,16$.
} 
"illustration and object lesson" of how to do the work. According to the text the project was now a "special day":

For several years past the Ottawa Valley Journal has been making an effort for the reclamation of rural cemeteries from that condition of abandonment into which so many of them have been allowed to lapse. Last year those efforts culminated in naming a special day, called Cemetery Clean-up Day, for the work of renovation. ... From reports received quite a number of cemeteries were overhauled, cleaned up and generally improved, to the credit and satisfaction of the different communities participating in the work. ${ }^{102}$

I have not found evidence, however, for the newspaper's claim that the 1914 rural Journal had declared a special clean-up day. ${ }^{103}$

There was still a question as to what a country cemetery should look like. Julie Rugg's recent study of country cemeteries in England found that early types persisted alongside modernized municipal and corporate cemeteries and often were updated to follow the newest urban fashion. ${ }^{104}$ The Journal referenced the nineteenth-century call for cemeteries to be spiritual places of healing through nature, urging readers to make the cemetery "a positive beauty spot and a quiet source of peace and consolation to many a weary heart." Doing this would be "a pious act."105 On the other hand, in 1915 the newspaper's word-picture of the ideal country cemetery reflected contemporary cemetery fashion with the addition of specific rural concerns about weed seeds and cows. The description emphasizes how the cemetery should interact with the road, indicating that the Journal saw the audience for the community's work as passers-by who would judge the community on what they saw:

\footnotetext{
102 "Cemetery Cleaning Up Day Is Now Fast Approaching," OVJ, May 14, 1915, 1.

${ }^{103}$ As only one issue, November 20, 1914, is missing and only two issues have pages missing (two pages each), I am reasonably confident that had a day been named, I would have found some reference to it.

${ }^{104}$ Julie Rugg, Churchyard and Cemetery: Tradition and Modernity in Rural North Yorkshire (Manchester: Manchester University Press, 2013).

105 "Clean Up the Cemeteries," OVJ, May 9, 1911, 12.
} 
Well, it should look like a cemetery, a little city of the dead, with all its monuments and tombstones, those mournful yet becoming structures standing out upright and clear to the view of the passers-by. This view should not be interfered with by misplaced shrubs, bushes or trees. The ground should be a carpet of lawn kept as green as facilities and circumstances will permit, and not of course growths of unsightly and obnoxious weeds that are a pest to the farm lands around. Gravelled walks should run here and there, serving the double purpose of convenience and prettiness. Above all, a cemetery should have a neat and very permanent fence to keep out straying cattle and to give the place that air of sacredness associated with it. It should not be hidden from the roads by trees and bushes, so that passers-by, as they drive past, may remark, 'What a pretty cemetery!' and feel that they are in the midst of a Christian community who show the highest self-respect in the respect which they pay to the memory of the dear ones departed. ${ }^{106}$

Perhaps because the Great War had made death an intimate fear for many, the Journal published a series of articles on cemeteries in May 1915. The sub-headline of the third article made the connection with patriotism: "How Many Readers of the Ottawa Valley Journal Have Ever Thought in This Campaign to Clean up the Rural Cemeteries the Work is Just as Noble, Praiseworthy and Truly Patriotic Viewed From Any Standpoint." The article began by recognizing the desire to visit where a loved one was buried in Europe but then moved to the local cemetery. For the first time the newspaper went beyond a generalized filial duty to a sense of heritage. Farm families ought to care for the graves of the "[great-grandfather] who first settled on the land you now possess in plenty; your grandfather who cleared that land to its final acres; or your father who brought the farm up to its present creditable state of cultivation." It then connected the past with the present. These men were lying peacefully at home but their lives too had been a battle, a battle to make a living out of the soil. They too had been "heroes," “empire-builders" and there was an obligation to pay the debt owed for present prosperity

\footnotetext{
106 “Cemetery Cleaning Up Day Is Now Fast Approaching,” OVJ, May 14, 1915, 1.
} 
by rescuing country cemeteries from neglect. ${ }^{107}$ The staff writer's pious language was particularly heavy in the 1916 and 1917 articles. In 1916 the neglect of graveyards was described as a failure to show the "reverence due to the Divine Deity" and, again, a link was made to where loved ones had been killed and buried in Europe. In 1917 readers were urged to "renew our covenants with those who have gone before."108

In both 1909 and 1917 the writer suggested that the local minister should lead with a committee to get the work done. ${ }^{109}$ Given the 1909 sub-header "Clergymen Should Take Action," the newspaper had not planned to take on cemetery beautification as a new field of activism for itself. The suggestion of ministers leading was more in line with the kind of community leadership many may have expected from their minister than the Journal-led discussion from 1912 of clergy as agricultural advisors. It also reflected the reality that many cemeteries in the countryside were denominational and located around a church. Yet in the city there was a trend towards professional cemetery management of which at least one country minister was aware. In 1914 the Reverend Stuart Wood of Riverside, Quebec wrote that all cemeteries should be incorporated with a board of trustees responsible for upkeep and families legally obliged to pay for care. ${ }^{110}$ This suggestion, however, went against another view, as typified in the earlier letter from the Springhill Cemetery trustees, which had seen country cemeteries as community spaces rather than as professional or commercial enterprises. In 1910, the trustees asked for a day of community support with men bringing their work tools and a special request to

\footnotetext{
107 "Canadians Would Be Willing To Decorate The New Graves Of Their Heroic Soldiers," OVJ, May 21, $1915,16$.

108 “The Journal's Annual Appeal to Clean Up the Cemeteries," OVJ, May 12, 1916, 18; "Rural Cemeteries Send Forth The Annual Call for Spring Clean-up," OFJ, April 27, 1917, 16.

109 “Clean Up The Cemeteries," OVJ, August 13, 1909, 12; "Rural Cemeteries Send Forth The Annual Call for Spring Clean-up."

110 "Suggestion to Have Incorporated All Cemeteries," Rev. Stuart A. Woods of Riverside, Que. to Editor, OVJ, June 19, 1914, 14.
} 
"the ladies" to come with picnic baskets "so that a good day's work may be done."

As suggested by the Springhill trustees' request, cemetery work was gendered. In 1911 the Journal called on communities in general to take responsibility for local cemeteries but the obligation was first laid on farm men for what the writer said would be at most a half day or a day in spring. Women were given a support role of providing "a little taste and a few seeds" and to keep the flowers watered through the summer. This article appeared on a page carrying items about improved country living ("Spring Cleaning Around the Homestead" and "How to Keep Your Boys and Girls on the Farm") as well as the usual agricultural enquiries. ${ }^{112}$ Despite the gendered suggestions for the division of work, women were taking a lead in beautifying the cemetery. This is in line with what Lynne Marks finds as women in small towns became active in raising (and spending) money on beautifying churches in the same period. ${ }^{113}$ A 1906 letter to the Farmer's Advocate gave a real life example of clean-up of an Essex County church cemetery. "M.R." wrote that a woman had said at the Ladies' Aid meeting "that it ought to be done; the others fell in line." The women set up a cemetery committee and were given a grant of $\$ 15$ with which they hired men to spade, level and put down grass seed and then they bought a lawn mower. Every year the committee called a "cemetery bee" on the afternoon of May 24th. They gave the men tea in the church basement, and had "a general good time.” They also decided to pay a caretaker $\$ 25$ a year. ${ }^{114} \mathrm{~A}$ few years later the Journal profiled the work of a committee of five women and three men in cleaning up the Protestant Cemetery of Vankleek Hill, Ontario after some years of neglect. The

\footnotetext{
111 "Springhill Cemetery," OVJ, May 17, 1910, 12.

112 "Clean Up the Cemeteries," OVJ, May 9, 1911, 12.

${ }^{113}$ Lynne Marks, Revivals and Roller Rinks: Religion, Leisure, and Identity in Late-Nineteenth-Century Small-Town Ontario (Toronto: University of Toronto Press, 1996), 77-9.

114 “M.R.", "How One Cemetery was Improved," FA, July 12, 1906, 1111.
} 
workers seem to have been the women for the newspaper reported that the "ladies" had seeded a lawn as well as having the walks graveled and the gravestones straightened. They were now planning to install water. To pay for these improvements they raised money in the community with a concert and a dining-hall tent at the Vankleek Hill agricultural fair. $^{115}$

This might seem a move towards the urban practice of professional cemetery management except that the same cemetery organizations who were hiring caretakers continued to bring the community together in an annual work bee. Nevertheless country residents were, in these examples, shifting to modern business-like management practices by paying for on-going maintenance rather than relying on a once-a-year volunteer effort. This trend was in line with the rural Journal's focus in its other campaigns (as will be explored in the next three chapters) of equating the modernity of male production with being business-like. Nevertheless, the lead 1915 cemetery article highlighted the community element of cemetery care saying it would be easily done by fifteen to twenty "healthy, sturdy, God-fearing" men. ${ }^{116}$

\section{Conclusion}

In this chapter I have looked at the limits of a city-published newspaper claiming to be a farm journal and advocate for the farmer. Political limits were set by virtue of being a version of a daily metropolitan newspaper which wrote the news and editorial pages. This is of interest as one of the ways metropolitan views were disseminated out into the countryside. I suggest, however, that for assessing the rural response to issues, it is more useful to track the rural editors' gate-keeping function. Gate-keeping went

\footnotetext{
115 “A Beautiful Rural Cemetery,” OVJ, October 11, 1912, 12.

116 "Cemetery Cleaning Up Day Is Now Fast Approaching," OVJ, May 14, 1915, 1.
} 
beyond determining which issues should be discussed and which ignored. Once the editors decided that an issue was important they had to bring their readers with them through the gate they were trying to open. Both Cowan and Faith regularly called on readers to respond with letters in order to indicate whether they should pursue an issue. At the same time readers' letters gave each campaign credibility, but the two editors differed in the kind of credibility they sought. City-born Herbert Cowan published letters from agricultural leaders in the persons of government officials and wealthy producers and cheese manufacturers. Country-born Robert Faith sought credibility in the sheer number of ordinary farmers who were willing to march with him whether vicariously through letters or literally taking a petition to Parliament Hill in 1911.

The most obvious source of the limits on the rural semi-weekly came from being a compilation of the parent daily. As discussed previously, rural editions were largely cut-and-paste versions of the daily and this was equally true of the rural Journal's news and editorial pages. On politics and economics the reader of the rural Journal was reading the metropolitan parent newspaper which meant reading the views of an Independent Conservative but still Conservative newspaper. The rural newspaper got around this by claiming objectivity in printing letters on both sides of contentious agrarian issues, whether tariffs, conscription or farm labour.

Limits were also created by the editors' privileging of male productive activity while presenting an ambivalent picture of farm family production. There was recognition that women carried out productive activities on the farm but this was downplayed in the household page. Despite the household editor answering a question posed by a reader as to "why women failed" by stating the problem was one of lack of training and lack of 
undisturbed space in which to achieve success, women's potential as producers was not part of the column. On the other hand the productive farm family was celebrated as children's productive activities were encouraged by printing the letters in which they wrote with pride about their contribution to the farm as well as their pleasure in pets and special school events.

The most significant limit is found in the editors' gendered response to issues, in which they involved themselves in organizing activities related to male productive issues but simply published articles, written by unknown staff members and paid correspondents, on the softer issues coming out of the Country Life Movement. The rural Journal only intervened on the community improvement issues of the Country Life Movement in articles which made suggestions, even if a later sales pamphlet made the interventions sound larger than they had been. Specifically, articles on cemetery beautification appeared once each year for close to a decade but this was a one-off effort for the rural Journal. It was most different from the Journal's other campaigns in the inclusion of women and especially in an emphasis on community volunteerism rather than on business. At the same time, it had only a peripheral connection to the Country Beautification element of the Movement. While the newspaper did recommend the work as a way of presenting a "pretty" community face to passers-by, it urged the work on as an act of filial devotion and, during the First World War, of patriotism. It may well have resonated with an unspoken need by many to do something for the dead in the face of so much death in Europe. However the rural Journal never tried to lead an open discussion about the duty of the community to care for public spaces. Instead the articles formed a one-way conversation from the unnamed writer to rural residents. In addition, even 
though the newspaper profiled communities that were introducing an on-going businesslike approach to cemetery maintenance, the articles continued to emphasize once-a-year community work bees. As a result, even though it described the improved cemetery as telling people who drove by that they were passing though a progressive and modern community, the emphasis on volunteer community work distinguished this campaign from the campaigns which will be discussed in the following chapters in which being modern meant being business-like.

This chapter, in examining the limits to the newspaper's activism, underlines that both the restraints of its daily parent's politics and the gendered interests of the editors restricted what was possible. In the next three chapters I will look at the newspaper's activism in the male agricultural world of production, distribution and marketing. In these campaigns Cowan tried to change the farmer while Faith tried to force Montreal middlemen in the global market to respect local rules. Despite some fiery rhetoric, however, Faith was as convinced as Cowan that the capitalist market was natural and desirable. 
Chapter 6 - The Farmer and Expert Knowledge: Making the Fair News

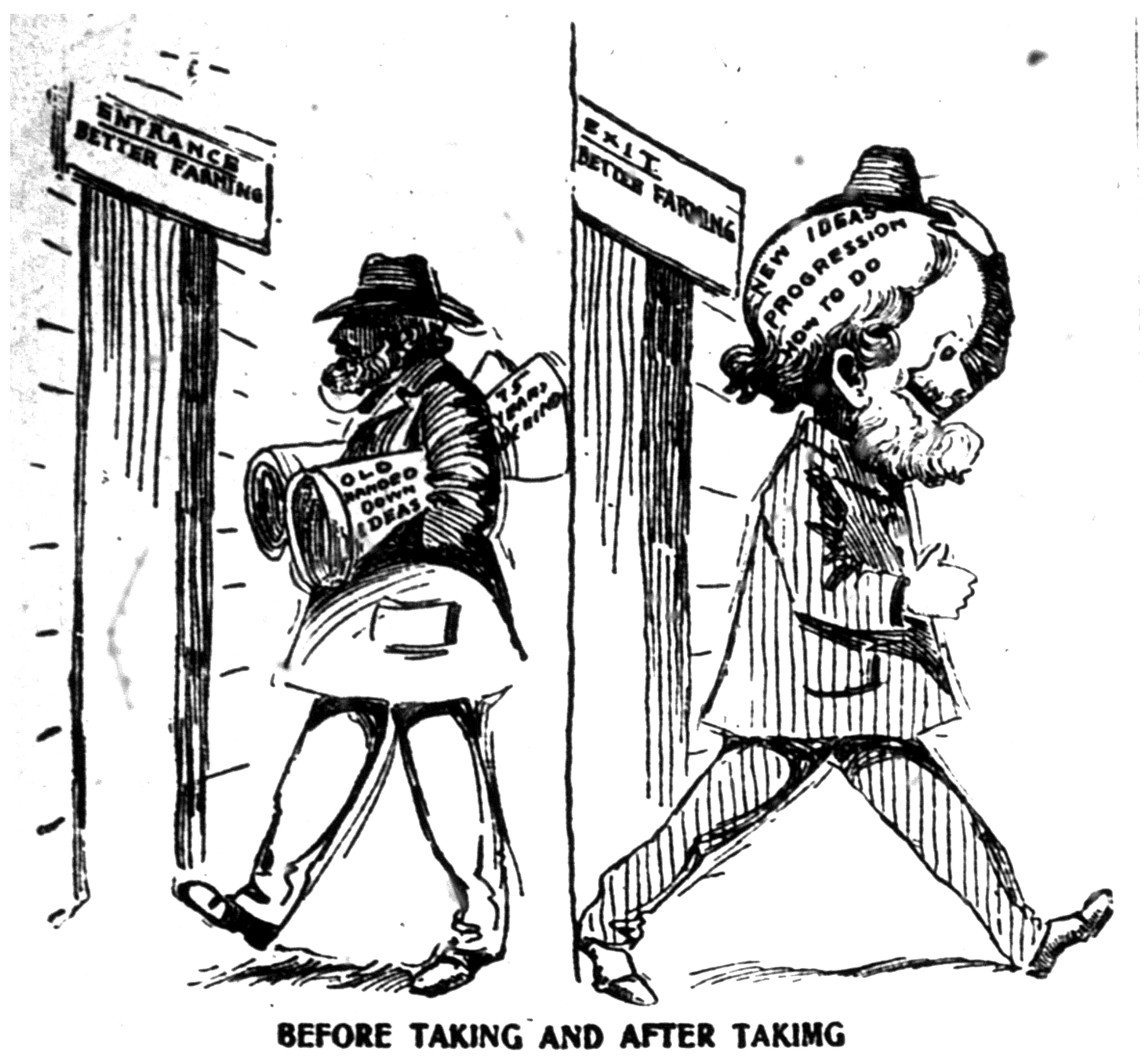

Fig. 6.1. "Before Taking and After Takimg (sic)," Ottawa Valley Journal, December 3, 1909, 12.

The above cartoon headed a report on the stock judging classes the rural Journal initiated. The attending farmers were said to have declared the classes "a splendid educational factor." This chapter looks at how the newspaper conceived of and presented agricultural knowledge to its readers as a necessary part of being modern producers. 


\section{Introduction}

In 1909 the Ottawa Valley Journal published a cartoon to illustrate how better farming and agricultural education went together (figure 6.1). The farmer enters a building signposted "Better Farming." He is shadowed and carrying "old handed-down ideas." But after taking the course he emerges with the light on his face and his head swollen with "new ideas." In this chapter I examine how the newspaper's claim to be dedicated to agricultural progress was acted out in the years between 1901 and 1905 by intervening in the educational function of the county agricultural fair and working with government officials to run special educational meetings. Specifically, I will look at the following six initiatives which the renamed newspaper, the Ottawa Farm Journal, highlighted in a 1919/1920 sales pamphlet: ${ }^{1}$

1. established the expert judge system,

2. formed the first circuit of fairs to coordinate fair dates,

3. ran a competition for the best exhibition,

4. organized the first livestock judging classes in Eastern Ontario for young farmers and farmers' sons, ${ }^{2}$

5. organized the first seed fair in Eastern Ontario, and

6. initiated dairy and orchard meetings.

We could view the newspaper's linking of the fair, special meetings, education and agricultural improvement as the pursuit of an ideal of what agricultural education could achieve outside a classroom. We could also view it as support of the state's hegemonic messaging on how farm families should act as rational middle-class producers

\footnotetext{
${ }^{1}$ Sales Pamphlet, Ottawa Farm Journal, 1919/1920, collection of Bruce S. Elliott.

2 "Livestock" as one word is the common use today (for example see the Canadian Livestock Records Corporation) but in 1900 the term "live stock" was customary. I will use "livestock" unless quoting.
} 
farming as a business rather than a way of life. What distinguishes the rural Journal from other press commentators that encouraged agricultural education was that the Journal went beyond words. The Journal chose to act. What is interesting is that it chose to act by facilitating the use of expert livestock judges at county fairs. The Journal also organized dairy and orchard meetings but these were organized on the lines of popular adult education which mixed demonstrations with socializing and recreation. In all the newspaper's interventions, however, it only showed an interest in educating farm men.

These interventions happened as government increasingly viewed the formal education of college and college extension work as the royal road to agricultural knowledge. Jeffery Taylor argues that the increasing dominance of formal agricultural education over the first two decades of the twentieth century led to intellectual experts replacing experience-based experts. ${ }^{3}$ The rural Journal's campaigns, however, told farm men in the same decades that expertise was the result of combining formal education with practical experience. I will draw on the conceptualization of knowledge as discussed by Michel Foucault and James C. Scott in which the dominant knowledge of the expert exists in tension with practical knowledge. ${ }^{4}$ In addition I will draw on the insights of Eilean Hooper-Greenhill and Lianne McTavish about the intersection between observation and knowledge. ${ }^{5}$ The newspaper expected expert judges to teach by demonstration (by placing some animals above others in the prize rankings) and by verbal explanations given at ringside. The classes organized by the newspaper also

\footnotetext{
${ }^{3}$ Jeffery Taylor, Fashioning Farmers: Ideology, Agricultural Knowledge and the Manitoba Farm Movement, 1890-1925 (Regina: Canadian Plains Research Center, 1994).

${ }^{4}$ Michel Foucault, The Order of Things: An Archaeology of the Human Sciences (New York: Vintage Books, 1973); James C. Scott, Seeing Like a State: How Certain Schemes to Improve the Human Conditions Have Failed (New Haven: Yale University Press, 1998).

${ }^{5}$ Eilean Hooper-Greenhill, Museums and the Shaping of Knowledge (London: Routledge, 1992); Lianne McTavish, "Learning to See: Vision, Visuality, and Material Culture, 1862-1929," in Defining the Modern Museum: A Case Study of the Challenges of Exchange (Toronto: University of Toronto Press, 2013).
} 
followed this pattern of demonstration and explanation. The newspaper assumed that the Baconian method of learning by direct observation required skilled teaching of correct observation. ${ }^{6}$ Whether organizing classes or expert judges, the Ottawa Valley Journal contributed to official efforts to teach agriculturists how to be fully modern producers. Observation was directed to recognizing and valuing the relatively hidden commercial standards of, for example, bacon hogs in preference to the easily seen older standards of the strange and visually spectacular. Yet even as the editors accepted the commercial logic of the capitalist market, they continued to valorize expertise based on practical experience as an adjunct to the new college expertise.

I begin this chapter by describing the general interest of the Ottawa Valley Journal in improving agricultural fairs within the context of how fairs have been studied as a hegemonic site of agricultural education. I follow this with a review of the events involved in the six initiatives. I then look at the question of how the Ottawa Valley Journal defined an expert judge and the nature of the expert knowledge involved in judging at agricultural fairs and in producer meetings. Finally I discuss the response of readers and of the Farmer's Advocate to these issues.

\section{Fairs, Education and Hegemony}

In this section I explore the historiography of agricultural education and fairs in order to contextualize the Journal's initiatives. A key theme is the link between agricultural exports and fairs with both federal and provincial policy focused on increasing production for the export market by encouraging new livestock breeds, seed

\footnotetext{
${ }^{6}$ Both Hooper-Greenhill, Museums and the Shaping of Knowledge, and McTavish, "Learning to See," address observation as a learned skill. This will be discussed further in this chapter.
} 
cultivars, techniques and mechanization. ${ }^{7}$ In the early years of the nineteenth century the government pursued increased production through grants to the informal, but still institutionalized, educational mechanism of the agricultural fair. ${ }^{8}$ By the end of the century the government controlled a range of formal educational institutions and yet it continued to fund agricultural fairs. I suggest that the rural Journal's interventions targeted the fair because it was an educational site where the newspaper could be an independent actor.

\section{What Was Expected of the Fair}

The Journal's initiatives were part of a hegemonic view that the sole purpose of the agricultural fair was educational. Antonio Gramsci in his Prison Notebooks wrote of the State creating a "social conformism which is useful to the ruling group's line of development." He went on to speak of a social group's "common sense" which he said in the masses was a spontaneous or instinctive understanding distinct from what dominant groups disseminated through the education system. ${ }^{9}$ Gramsci was concerned, inter alia, with the replacement of the popular common sense with that of the dominant group. These extracts point to my understanding of hegemony as a dominant societal view of how the world (whether political, economic or social) works and which is

\footnotetext{
${ }^{7}$ On links between improvement and government agricultural policy see Vernon C. Fowke, Canadian Agricultural Policy: The Historical Pattern (Toronto: University of Toronto Press, 1946) and W.M. Drummond, W.J. Anderson and T.C. Kerr, A Review of Agricultural Policy in Canada (Ottawa: Agricultural Economics Research Council of Canada, 1966). Both books argue that Canadian agricultural policy was driven by export market interests with Fowke pointing to the empire and Drummond et al pointing to British mercantile interests prior to Confederation. Both frame government interest as focused on improving inputs to the staple industries of fish, fur, timber, etc until agriculture began to produce exportable surpluses in the mid-nineteenth century. After this, policy objectives became growth through increased productivity along with immigration to settle a Western and northern Ontario farm frontier. It was not until the 1930s that the government began to recognize a requirement to stabilize producer income.

${ }^{8}$ For government policy use of societies see Drummond et al, A Review of Agricultural Policy, 4-5.

${ }^{9}$ Antonio Gramsci, Selections from the Prison Notebooks, ed. and transl. by Quintin Hoare and Geoffrey Nowell Smith (New Delhi: Orient Blackswan, 2011), 195-9.
} 
transmitted in formal channels to all groups in society. Particularly since the nineteenth century, hegemonic messaging has worked through the educational system and mainstream publications. ${ }^{10}$ Foucault and Scott, on the other hand, point to a continued presence of popular knowledge which is in tension with the dominant knowledge taught through institutions. In the case of the agricultural fair, the idea that they were educational was a matter of "right thinking" for the governments that funded them, the agricultural societies that received the funds and serious-minded improving farmers. ${ }^{11}$ One such was William Henry McNish of "Lyn" (Lynn), Ontario who wrote to the Ottawa Valley Journal in 1908 on the subject. He said that both Farmers' Institutes and agricultural fairs were "the farmers' university." Fairs should, therefore, be made completely educational by eliminating their fun fair elements. This would contribute "to the building up of a first-class agricultural community." $12 \mathrm{McNish}$ was repeating a message few would have challenged even if they did not observe it in their actions. The educational fair was an obvious "natural" and making the fair more educational was an equally obvious intervention for a "farmer's friend" like the Ottawa Valley Journal.

At the same time I argue that the government-sponsored and educational nature of agricultural societies limits a possible analysis of them as a public sphere. Jeffrey McNairn, in his study of Upper Canadian politics in terms of Jürgen Habermas's public sphere, argues that agricultural societies and mechanics' institutes did not serve as such

\footnotetext{
${ }^{10}$ Gramsci also presents hegemony (or spontaneous consent) as invisibly backed by the coercive power of the state to enforce elite control when consent fails (Ibid., 12-13).

${ }^{11}$ I distinguish the kind of farmer who responded to the fair as an educational event from the great mass of farmers who were interested only in the entertainment. While the newspaper carried letters from the "serious" farmers as if they were typical, given the complaints that the crowds focused on the races, we should see these farmers as atypical.

12 "Do The Fairs Educate Farmers?" W.H. McNish of Lyn, Ontario to the Editor, Ottawa Valley Journal (hereafter OVJ), February 18, 1908, 10.
} 
spaces. They were "designed to instruct and inform" rather than to debate public issues. ${ }^{13}$

I would add that they were dependent on government funding and in later years were required to report on their activities. ${ }^{14}$ This gave county societies a governmentality role in which the government distributed grant money through them to township societies. It was expected this would result in a county-level elite exercising social control over "lower orders."15

In 1935 Columbia University sociologist Wayne Neely analyzed agricultural fairs in terms of three functions: education, recreation, and socialization (the development of a rural identity). ${ }^{16}$ The fairs were perhaps the biggest of the rural community events which brought farm families together within a common identify as agriculturists. Furthermore, they were built around displays of individual competence, whether in the livestock exhibits or the women's work, which reflected back on the community when the nearby town and city newspapers published their customary reports on each local fair. Even those who came to the fair for the fun observed their neighbours' work and, as in Leslie Prosterman's title on the mid-west fairs of the 1980s, Ordinary Life, Festival Days, by

\footnotetext{
${ }^{13}$ Jeffrey L. McNairn, The Capacity to Judge: Public Opinion and Deliberative Democracy in Upper Canada, 1791-1854 (Toronto: University of Toronto Press, 2000), 69-102, 109.

${ }^{14}$ By the beginning of the twentieth century the Ontario government was bureaucratizing the management of agricultural fairs, for example in 1902 naming a Superintendent of Agricultural Fairs within the bureaucracy. Elmore Reaman states that Dr. G.C. Creelman was made the first superintendent in 1899 but he also states that H.B. Cowan became the superintendent in 1901-when Cowan as seen in this study was working in Ottawa as a newspaper man: G. Elmore Reaman, A History of Agriculture in Ontario (Don Mills, Ont.: Saunders of Toronto, 1970), 2:79. In 1902, the Ottawa Valley Journal reported on the expectation that Creelman would be appointed to a newly-created position of Superintendent. "A Superintendent May Be Appointed," OVJ, February 25, 1902, 8. (This increased oversight appears not to have extended to government discipline. The government regularly threatened to cut grants to agricultural societies that hosted a horse race. Yet it appears the threat was rarely, if ever, carried out.)

${ }^{15}$ Ross D. Fair, "Gentlemen, Farmers, and Gentlemen Half-Farmers: The Development of Agricultural Societies in Upper Canada, 1792-1846," (PhD diss., Queen's University, 1998): 234-7; Thomas W. Irwin, "Government Funding of Agricultural Associations in Late Nineteenth Century Ontario," (PhD diss., University of Western Ontario, 1997).

${ }^{16}$ Wayne Caldwell Neely, The Agricultural Fair (1935; repr., New York: AMS pres, 1967. Neely structured Part III of his book into three chapters, each one covering one of the three functions.
} 
their presence validated the ordinary work life of the countryside in a festival day. ${ }^{17}$

Through the recreation and socialization functions, agricultural societies could help rural residents deal with the disruption they felt acting locally in a national and global economy. The grass-roots "localness" of volunteer-run groups is touched on by James Calnan in his study of fraternal lodges in small town Ontario. He identifies a grass-roots commitment to the local community as a point of conflict with the national organizers' insistence on tight controls over members' benefits. ${ }^{18}$ But community does not include everybody in a place. While Jodey Nurse finds in her study of the mid-century Peel County Fall Fair that it enjoyed wide support from the local community, I found a different story in studying an early twentieth-century fair in a linguistically divided place. The Prescott County (Vankleek Hill) Agricultural Society was Anglophone-dominated in the midst of a Francophone-majority population. The few Francophones I found participating in the Society or visible as regular exhibitors at the fair had mixed-language parentage or business interests in Vankleek Hill. I concluded that the Prescott County society and its fair reflected the limits of community in a place. Sara Spike's study of the 1882 Yarmouth District exhibition finds evidence for participation by some Acadian and Mi'kmaw people (the latter exhibiting handicrafts) and at least one black sailor but there is insufficient information to speculate on why these individuals participated. Overall she agrees with studies that find agricultural fairs reinforced social hierarchies. ${ }^{19}$

\footnotetext{
17 Dorothy-Jane Smith, "The Community and the Fair: Vankleek Hill, West Hawkesbury Township and the Agricultural Fair, 1900 to 1950" (master's thesis, Carleton University, 2012), 158-60. Leslie Prosterman, Ordinary Life, Festival Days: Aesthetics in the Midwestern County Fair (Washington: Smithsonian Institution Press, 1995).

18 James E. Taylor Calnan, "'Blessed Be the Tie That Binds': Voluntary Associations and Community in Picton, Ontario, 1870-1914” (PhD. diss., University of Guelph, 1999).

19 Jodey Nurse, "Reaching Rural Ontario: The County of Peel Agricultural Society and the Peel County Fall Fair, 1853-1883," (master's thesis, University of Guelph, 2010); Smith, "The Community and the Fair," 134-40; Sara Spike, "Modern Eyes: A Cultural History of Vision in Rural Nova Scotia, 1880-1910"
} 
Neely's history and those that followed show that rhetoric locked agricultural fairs and education together from the fair's beginnings in the eighteenth-century British agricultural improvement movement. ${ }^{20}$ Gentlemen farmers with an interest in science aimed to apply scientific principles to cultivation techniques, crop selection and livestock breeding but believed it was not enough to experiment with new agricultural ways. New knowledge had to be passed on. By the end of the eighteenth century three types of educational mechanisms were in place: agricultural societies where gentlemen could share their interests though learned addresses, agricultural journals (both those published as commercial ventures and those published by the societies), and agricultural events in the form of demonstrations, cattle shows and plowing matches. These polite and learned activities were repeated in North America. Starting in 1785 gentlemen such as George Washington and Thomas Jefferson joined newly formed agricultural societies in Philadelphia, Boston and Charleston. But little of the new knowledge reached working farmers.

The nature of both the North American agricultural society and its fair began to change in 1810. That year the owner of a woolen mill, Elkanah Watson, organized a livestock demonstration to encourage the raising of Merino sheep in New York State. What was different from the British fairs was that Watson offered monetary prizes and added spectacle (processions) and recreation (dances). Put together the result was a fair that operated without the condescension found in more learned events. Though the idea of a non-elite but educational agricultural fair began in 1810, it did not take off in the United States until the 1840 s.

(PhD diss., Carleton University, 2016),101-5.

${ }^{20}$ The description which follows of the history of the American agricultural fair and its British predecessor is taken from Neely, The Agricultural Fair, 29-67. 
The first agricultural fair in Ontario was essentially a gentlemanly demonstration sponsored by Upper Canada's Lieutenant Governor John Graves Simcoe in $1792 .{ }^{21}$ After this there was very little further activity until the 1830 s when the colonial government began to fund agricultural societies as the main educational mechanism for increasing agricultural production. Growth took off in the 1840s when government funding was systematized and eventually made permanent in legislation. At this point most Canadian societies chose to follow Elkanah Watson's fair model. That is, agricultural societies put on agricultural fairs that taught through competitive display and enticed potential farmerstudents into the fair with horse races and other forms of recreation.

Over the course of the nineteenth century the fair changed from being the main means of government funded agricultural education to one of a number of such mechanisms. Farm journals had emerged in parallel with North America's agricultural fairs, the first commercial farm journals being published in Upper Canada in the 1840s. American journals had been circulating in the colony since the $1820 \mathrm{~s}^{22}$ The commercial journals provided education at no cost to the government and, with increasing rural literacy, reached more ordinary farmers. The government-sponsored Upper Canadian Board of Agriculture also put out a learned journal of its proceedings but this did not reach as far as the American commercial journals. Nevertheless, by the mid-nineteenth century both American and Canadian governments saw the need for state intervention in agricultural improvement. Post-secondary agricultural education began in the United

\footnotetext{
${ }^{21}$ The Ontario history is taken from Fair, "Gentlemen, Farmers, and Gentlemen Half-Farmers" and E.A. Heaman, The Inglorious Arts of Peace: Exhibitions in Canadian Society during the Nineteenth Century (Toronto: University of Toronto Press, 1999).

${ }^{22}$ Fred Landon, “The Agricultural Journals of Upper Canada (Ontario)," Agricultural History 9, no. 4 (October 1935): 167-8.
} 
States in the $1860 \mathrm{~s} .^{23}$ In Ontario the Department of Agriculture founded the Ontario Agricultural College (O.A.C.) at Guelph in 1874 as the central point for post-secondary agricultural education. ${ }^{24}$ Over the next quarter century the provincial government augmented the education available through the O.A.C. with extension classes and regional education centres. The province also offered short courses of a few days or perhaps a week or two to target farmers who wanted specific subject knowledge but not a college education. In 1885 the federal government founded the experimental farm system to carry out scientific research with the objective of determining the best breeds, cultivars and techniques for use in the Canadian West. In the process, it created experts able to educate as well. $^{25}$ At the very bottom of the educational pecking order, and closest to working farmers, Ontario's Department of Agriculture gave grants to and provided a roster of speakers for locally-run Farmers' Institutes. These institutes were described in 1900 as an "itinerant lecture system for the instruction of farmers.",26

Neely took the rhetoric about a fair's educational purpose seriously even as he recognized that there was on-going debate through the nineteenth century and up to his own time about the tension between education and recreation. Studies since the 1980s have focused on this debate, directing interest toward cultural history and the subversion of the fair's hegemonic rhetoric of education. For these studies, Neely's second function of the fair, recreation, was a site of power relationships affecting his third function, the

\footnotetext{
${ }^{23}$ Lee S. Duemer, "The Agricultural Education Origins of the Morrill Land Grant Act of 1862," American Educational History Journal 34, no. 1 (2007): 135-46.

${ }^{24}$ For a history of agricultural college education in Ontario see Alexander M. Ross and Terry Crowley, The College on the Hill: A New History of the Ontario Agricultural College, 1874-1999 (Toronto: Dundern Press, 1999). There had been earlier (and generally unsuccessful) efforts which continued into the twentieth century to include agriculture in public schools. See A.J. Madill, History of Agricultural Education in Ontario (Toronto: University of Toronto Press, 1930) for a positive, even heroic, story of this effort. ${ }^{25}$ Drummond et al, A Review of Agricultural Policy, 17-18.

${ }^{26}$ L.H. Bailey, Farmers' Institutes: History and Status in the United States and Canada (Washington: Government Printing Office, 1900), 5, 24.
} 
socialization or creation of identity. ${ }^{27}$ Yet for Neely writing in 1935 it was a mechanism, not of social control, but of social expression of community. I would describe his concept of recreation as celebrating the local against the global. Darren Ferry also presents recreation as creator of local community — a form of social glue - although he points out its role in constructing a hegemonic structure in Canada of a liberal mutualist community ${ }^{28}$ Closely related to the cultural studies is Leslie Prosterman's ethnological work using interviews and observation to study small Mid-Western American fairs between 1979 and $1982 .{ }^{29}$ Fairs can also be sites for studying modernity as Keith Walden does with the Toronto Canadian National Exhibition and Sara Spike in her dissertation on Nova Scotia fairs. ${ }^{30}$

The agricultural fair was a back road to education by 1900 but it had one huge advantage in the eyes of officials. The fairground was the place where educators could preach past the choir to men and women who had no intention of going near formal education. The provincial government continued to fund it as an educational vehicle. At the same time, progressive observers continued to give at least lip service to the fair's potential to educate farmers in modern agriculture - if only farm people would apply themselves to the lessons presented at the fair.

\section{Making Things Happen}

Herbert Cowan was an activist editor looking for things to change. He was told

\footnotetext{
${ }^{27}$ As examples see David C. Jones, Midways, Judges, and Smooth-Tongued Fakirs: The Illustrated Story of Country Fairs in the Prairie West (Saskatoon: Western Producer Prairie Books, 1983); Heaman, The Inglorious Arts of Peace (1999): David Mizener, "Furrows and Fairgrounds: Agriculture, Identity, and Authority in Twentieth Century Rural Ontario," (PhD diss., York University, 2009).

${ }^{28}$ Darren Ferry, Uniting in Measures of Common Good: The Construction of Liberal Identities in Central Canada, 1830-1900 (Montreal: McGill-Queen's University Press, 2008), 16-18.

${ }^{29}$ Prosterman, Ordinary Life, Festival Days.

${ }^{30}$ Keith Walden, Becoming Modern in Toronto: The Industrial Exhibition and the Shaping of a Late Victorian Culture (Toronto: University of Toronto Press, 1997); Spike, "Modern Eyes."
} 
the agricultural fair needed to improve and his solution was to put into action an idea first developed some years prior in the Farmer's Advocate, an idea to replace amateur judges with experts. He was successful in implementing the idea but he did not revolutionize the fair as a learning experience for the masses.

The Farmer's Advocate's Idea for Improving the Fair

Laments over the subversion of the educational purpose of the fair had padded politician's speeches and newspaper editorials since the mid-nineteenth century. One person who did something about this was William Weld (1824-1891). Weld was a farmer who applied the latest scientific knowledge to his work, importing both new cultivar seeds and purebred livestock. His personal interest in improving agricultural fairs arose from a slight to the horse he had imported from England. He had competed the horse in a small township fair in the 1860s in order to show the locals what a quality coach horse looked like. When it lost first place to a local horse of no pedigree, Weld's response was to educate Ontario's farmers on the importance of good breeding in livestock by launching a monthly journal, the Farmer's Advocate, in $1866 .^{31}$

Right up to Weld's last years as the Advocate's publisher, he sought to make fairs educational demonstrations of the best and most modern agricultural practices. A children's column in the 1888 Farmer's Advocate exhorted the children to look for the "honey" in the fair and avoid the "poisons." Boys should study the livestock and implement exhibits while girls should study exhibits of butter-making, baking and fancy work. The "poison" was for the boys the "gambling" (newspaper's emphasis) of the

${ }^{31}$ A later telling of this story by Weld's son, John Weld (then the Farmer's Advocate publisher) suggests that perhaps the Township made the award based on the practicality of the non-pedigreed horse in frontier conditions. W.A. Irwin, "The House of Weld," in MacLean's Magazine (July 15, 1931): 10, 44. Also see A. Bogue, "The Fighting Farmer, William Weld," in Western Ontario Historical Notes 3 no. 4 (December 1945): 75-8. 
wheel-of-fortune stalls and the "literal poison" of alcoholic beverages. "Poisons" for teenage girls were the stalls selling cheap jewelry and the temptation to spend the day trying to attract the attention of boys. ${ }^{32}$ But teenagers continued to be teenagers. The Advocate might have hoped to have more effect on the educational nature of the fair with respect to another problem already clearly recognized in 1888 , that of judging.

The Advocate hosted a Farmer's Club called the Dominion Farmers' Council which met monthly in London, Ontario. ${ }^{33}$ At each meeting one or two attendees read a paper on a set subject followed by discussion and a vote to establish the group's consensus on the subject. The proceedings formed a regular column in the Advocate. In December 1888 the subject was "The Selection of Judges for Agricultural Fairs." Richard Gibson of Delaware, Ontario read a paper arguing that agricultural societies should replace the prevailing practice of a jury of three unpaid amateur judges with a single paid professional judge. Gibson argued that societies that paid for the expertise of a “competent judge" would be rewarded with fewer disputes over judges' decisions. He answered a question that was posed as to who was "competent" by suggesting the breeder's organizations could recommend judges. Another speaker at the same meeting described changes in poultry judging which had come out of the United States some years previous. The American Poultry Association had introduced a "system of judging by a single expert" based on a points system (i.e., a scoring system awarding points for specified aspects of the animal). The Association also certified who was qualified to judge. The result, according to the speaker, was that poultry shows had become more

\footnotetext{
32 “Uncle Tom's Department," Farmer's Advocate (hereafter FA), October 1888, 319-20.

${ }^{33}$ The Council is referred to in other publications (for example The Canadian Horticulturist, February 1889) as a Farmer's Club in London Ontario whose reports appeared in the Farmer's Advocate. It appears to have been an Advocate-hosted Club.
} 
educational. In the discussion which followed several people expressed their preference for a single expert judge. One comment suggested that the O.A.C. could give examinations and grant certificates to judges. The Council then passed a resolution endorsing the idea of replacing the jury of three local judges with a single expert judge. ${ }^{34}$ That was where the Farmer's Advocate left the issue, but the idea did not disappear. By a round-about way it came to Herbert Cowan of the rural Journal.

\section{The Journal Acts}

The Journal repeated the following story several times to explain its interest in improving Eastern Ontario fairs. In 1900 "a Journal representative” (who I believe to have been Herbert Cowan) had visited "most of the county fairs" and thereby had learned of problems that he felt the newspaper could help solve. ${ }^{35}$ In fact, the interest seems to have come out of conversations with officials and exhibitors at just two fairs, the Prescott County fair in Vankleek Hill and the Carleton County fair in Richmond. The Journal reported that both fairs had the same two problems. First, directors could not find judges whose rulings exhibitors accepted as authoritative. Second, farmers and stock breeders did not support their own county fairs. As a result only the biggest (and most commercial) of the local stock men exhibited along with equally commercial "professional" exhibitors. ${ }^{36}$ Cowan, having underlined that it was the fair directors who had identified the problems, then proposed his solutions.

\footnotetext{
34 “Dominion Farmers' Council," FA, December 1888, 368.

35 "Three Big Features for Ottawa Valley Fairs Next Fall," OVJ, April 19, 1901, 1; "The Three Expert Stock Judges," OVJ, September 10, 1901, 1; "Leading Farmers Hold a Meeting At Ottawa," OVJ, February $18,1902,8$.

36 "Prescott County's Annual Fair," OVJ, September 14, 1900, 8; "Carleton's 56th Fair," OVJ, September 18, 1900, 8. "Professional" exhibitors showed a select group of exhibits (livestock and/or women's work) at numerous fairs having acquired (sometimes temporarily) the exhibits for the sole purpose of making money from the premiums on offer.
} 
By 1904 the story had evolved into a purposeful intervention in which the newspaper had sent a staff person to carry out "a close study" of Eastern Ontario fairs and their spending of government grants because it was concerned over the deterioration of agricultural fairs caused by the increasing amount of entertainment. ${ }^{37} \mathrm{~A}$ few years later The Breeder's Gazette published yet another version of the story:

Several years ago an energetic weekly newspaper man in the Ottawa district in Ontario began taking an active interest in the fall fairs in that locality. Among other things, he noticed that the judging of live stock at these fairs seemed to be done in a careless and haphazard manner. Men were selected as judges who knew little or nothing about the animals they were to judge. Others had axes to grind and the awards often went where they did not belong. Altogether the whole business was conducted in such a way as to lessen the educational value of the fair and to make both exhibitors and visitors dissatisfied.

At one or two of these fairs some good judging was done and this journalist thought it would be a good idea to have these judges act at more fairs in the district. The fair boards were consulted. They fell in with the idea and the following year the fairs in the district so arranged their dates as to permit of a couple of competent judges placing the awards in live stock at a number of fairs. The government was asked for help. It was given and a couple of competent judges sent on (sic) for fairs that fall.

This was the beginning of what is known as the expert system of judging at the fall fairs, now so common in Ontario. ${ }^{38}$

In the spirit of the New Journalism, the "energetic newspaper man" Herbert Cowan had made things happen. ${ }^{39}$

When Cowan announced his proposal to organize three expert judges, one for each of the different groups of classes, he also announced he had the support (with funding) of the Dominion Live Stock Commissioner, Frederick W. Hodson. Hodson had

\footnotetext{
37 "Agricultural Society Holding the best Exhibition in 1904 Will Receive Handsome Secretary's Office," OVJ, May 3, 1904, 10.

38 "Expert Judging at Agricultural Fairs," OVJ, January 5, 1909, 9; reprint of J.W. Wheaton, Breeder's Gazette (original date unstated)

${ }^{39}$ The newspaper generally did not name individuals working on a story but the smallness of the rural Journal staff and the later identification of Cowan as the chief actor leads me to identify him as the general author of the 1901 and 1902 rural Journal projects. I have therefore named him in the text even where the newspaper itself did not do so.
} 
not only been one of the Farmer's Advocate editors in 1888, he had been secretarytreasurer for the Dominion Farmers' Council which had proposed the single judge system. He later became Director of the Farmers' Institutes and then in 1899 the Dominion Commissioner. ${ }^{40}$ I suspect that Cowan heard Hodson speak at the January meeting of the Eastern Ontario Dairymen's Association (E.O.D.A.) and immediately saw potential for action. On April 5, 1901 the rural Journal published Hodson's speech and two weeks later announced the new initiative with a full front page spread complete with a banner headline. But while Cowan announced he had assurances of government funding for expert judges, this did not cover everything. Now he had to persuade at least seven local agricultural societies to be sufficiently interested to commit $\$ 10$ for the judges' travel costs. ${ }^{41}$

It had taken thirteen years for the Farmer's Advocate work to bear fruit and when it did it was due to the Journal's view of itself as an actor as well as an advocate and preacher. Cowan's first initiative, the implementation of the Advocate's "expert judge" idea, was intended to improve the educational nature of Eastern Ontario's agricultural fairs. The second was a contest in which the expert judges while carrying out their work also judged which fair would receive a banner for the best livestock exhibits belonging to local farmers. This was intended to encourage ordinary farmers to become exhibitors so that they would take advantage of the education available at the fair. A third initiative, encouraging agricultural societies to hold amateur athletic contests during their fairs, did not make it into the newspaper's sales pamphlet nor have I addressed it here in depth. Its

\footnotetext{
40 "Frederick William Hodson, 1905," Archives at Whitby Public Library, http://images.ourontario.ca/whitby/51357/data. Accessed May 20, 2017.

41 "Do We Hold Too Many Small Agricultural Fairs," OVJ, April 5, 1901, 6; "Three Big Features for Ottawa Valley Fairs Next Fall,” OVJ, April 19, 1901, 1, 3.
} 
purpose was to replace sideshow entertainment and horse races with the good clean fun of athletics. It was also expected to encourage friendly inter-county rivalry when the winners of the county meets competed in a final regional meet in Ottawa. The Journal maintained this third initiative for four years, from its introduction in 1901 to 1905 , but only about five to nine fairs at most participated. No explanation was given when it was quietly dropped in $1905 .^{42}$

Cowan's New Journalism activity of effecting change and not just reporting on change was as much self-promotion as it was community service. He was after all in the newspaper business. From April through August 1901 Cowan met with societies to sell his idea while reporting in the newspaper on each meeting with ample quotes in which “prominent men" (agricultural society directors and officials) endorsed the Ottawa Valley Journal's activity. ${ }^{43}$ The compliment by the Co-Operative Farmer of New Brunswick must have been sweet: "The Ottawa Valley Journal is among the hustling newspapers of Canada and it always hustles to some practical and public good. ... The Journal deserves the thanks and support of all lovers of progress in its good work."44 The Journal maintained excitement, and kept its name before the public after the fair season was over as well. The winning agricultural society of the 1901 livestock competition was

\footnotetext{
${ }^{42}$ The announcement of the athletic contest was one of the "three big features" announced in the OVJ, April 19, 1901, 1, 3. It was reported on at various times in 1901, 1902, 1902 and 1904 (as examples, see "Prescott and Glengarry Counties are a Tie," OVJ, October 25, 1901, 8; "The Journal's Field Day," OVJ. June 27, 1902, 9; "Advice to Athletes," OVJ. August 28, 1902, 10; ); "“"Championship Won by Glengarry County," OVJ, October 14, 1904, 9 (last entry found).

${ }^{43}$ All from OVJ: "Agricultural Societies Have Given Their Approval," April 23, 1901, 8; “Journal's Fair Suggestions are Meeting With Approval," April 26, 1901, 8; "Interest in Next Fall's Fairs Will Probably Be Increased," May 3, 1901, 3; "Six Counties Will Compete In an Exhibit of Live Stock," May 7, 1901, 1; "Directors of the Ottawa Valley County Fairs," May 10, 1901, 10; "Russell County Will Compete," May 24, 1901, 8; "Prescott County is Unable to Compete," and "North Renfrew Is In the Fight," June 18, 1901, 8; Two Counties To Compete," July 12, 1901, 8; "Carleton or Russell Co." July 19, 1901, 8; "Expert Live Stock Judges Will Visit the Aylmer Fair," August 2, 1901, 8; "Two Leading County Fairs," August 27, 1901,8 .

44 “Distant Farming Districts Are Watching Our Agricultural Societies," OVJ, May 17, 1901, 8.
} 
announced in November on the front page with a three column, four deck headline - all the fanfare a county's prominent men could desire. ${ }^{45}$ Then there was a banquet to present the winner with the banner. This too required detailed reporting on who was there and what speeches were made with reminders that this was all thanks to the Journal. ${ }^{46}$

The Journal did not waste time after the 1901 initiatives in putting forward another "suggestion" which eventually it would highlight in its 1919/1920 claim to have always been active in promoting agricultural progress. Cowan suggested the 1902 fairs be organized into circuits such that their dates would follow each other in logical geographic order. This would make the travel of expert judges from fair to fair efficient and economical. Cowan requested comments indicating he would be led by the agricultural community in the matter. But he made two things clear. First, he had already obtained the support of the leaders of at least some agricultural societies. Second, neither the Journal nor the government would subsidize the cost of expert judges for any society not in a circuit. ${ }^{47}$ The newspaper hosted a meeting to settle the matter. The result extended even further the newspaper's aim to make news and not just report it. The newspaper item on the meeting began with the outcome. Three men, G.C. Creelman (the Farmer's Institute superintendent), J. Lockie Wilson of Alexandria and Cowan "of the Ottawa Valley Journal" had been appointed to set up a fair circuit schedule. ${ }^{48}$ By the end of March

\footnotetext{
45 "What Ottawa Valley County Has the Best Live Stock?” OVJ, September 27, 1901, 8; "Russell County Will Probably Win the Flag," OVJ, October 15, 1901, 8; "Russell County Wins the Journal's Flag," OVJ, November 15, 1901, 1; "The Banner Will Be Given," OVJ, December 31, 1901, 8.

46 "The Banner Presented to Russell County," OVJ, January 17, 1902, 8; "The Russell Banquet," OVJ, January 21, 1902, 8 (in a rare overlap, a much shorter news item was carried in the daily." The Banner Is Presented," Ottawa Evening Journal (hereafter OEJ), January 16, 1902, 9).

47 "Should the Ottawa Valley and District County Fair System be Re-organized?" OVJ, November 5, 1901, 1; "Some Suggestions Regarding Our Fairs," OVJ, December 6, 1901, 6; "Improve the Fair System," OVJ, December 13, 1901, 8 .

48 "To Strengthen the Fairs in This Part of Country," OVJ. January 24, 1902, 8; "Attractions Promised," OVJ, February 7, 1902, 8; "Leading Farmers Hold a Meeting At Ottawa," OVJ, February 18, 1902, 8.
} 
twelve societies had signed on. The Journal emphasized that this circuit was the first in Ontario. $^{49}$

When Herbert Cowan left the Journal in January 1903, Robert Faith, who had been assistant editor, took over. Faith continued Cowan's initiatives but also worked on a new initiative, Ottawa’s first Seed Grain Fair, in April 1903. The 1919/1920 Ottawa Farm Journal sales pamphlet claimed this was one of the newspaper's successes. The Journal admitted at the time that the fair was less than a success. It had been held too late in the sowing season to make a difference to local farmers purchasing seed and there had been very few exhibitors. It was also reported that farmers were uncertain as to the purpose of the fair. ${ }^{50}$ These problems probably were the result of both poor timing and poor management. Unlike Cowan's usual practice, Faith had not published a constant stream of pre-event reporting to talk up the seed fair. It is also possible neither Faith nor Cowan had much to do with this initiative. Two short articles in late 1902 on plans for the fair suggest that the Department of Agriculture was behind it but another article in March 1903 said the organizers were the "Carleton and Russell Counties Association." 51 Still the Journal was involved to the extent that Faith presided over the afternoon meeting. ${ }^{52}$ The sales pamphlet claimed a great importance for the 1903 Seed Fair as having "done so much to improve the yield of the different varieties of grain and potatoes." Whatever was achieved in the years that followed was the work of others, for while the rural Journal

\footnotetext{
49 “A Circuit of Fairs Is Being Arranged," OVJ, March 21, 1902, 8; “Twelve County Fairs Arranged In a Circuit," OVJ, March 25, 1902, 8; "Brockville Exhibition," OVJ, April 1, 1902, 8; "The Cornwall Exhibition," OVJ, April 8, 1908, 8; “The Journal's Expert Judges," OVJ, August 15, 1902, 10.

50 "Seed Grain Growers Form an Association," OVJ, April 14, 1903, 8.

${ }^{51}$ See "Seed Fair for Ottawa," OVJ, November 21, 1902, 10; “A Seed Fair,” FA, December 1, $1902,879$. "Big Seed Fair," OVJ, March 17, 1903, 6; The establishment of Seed Growers Associations in general was specifically linked to James Robertson of the Department of Agriculture, "Seed Growers' Association," OVJ, April 7, 1903, 8. The local Association, once formally formed, was officered by representatives from Carleton and Russell Counties.

52 "Seed Grain Growers Form an Association," OVJ, April 14, 1903, 8.
} 
reported the seed fairs each year, it was clear that it was not involved in organizing them.

In 1903 Faith made his first major change to Cowan's initiatives by arranging a prize for the 1904 livestock and fair competition that was more than a banner to be sought for glory alone. The banquet at which the 1903 banner was presented to the Russell County Fair in Metcalfe was a big affair — so big the president of the Journal Publishing Company, P.D. Ross, presented the banner even though he had not shown great interest in his rural paper previously. Ross perhaps thought that the announcement to be made that evening of the next year's prize, given both the commercial partnership involved in the prize and its generosity, warranted an announcement by more than a mere rural editor. The Journal had partnered with the International Portland Cement company to offer a building worth $\$ 1,000$ to serve as the secretary's office of the winning agricultural society. Much of the announcement and follow-on reporting was puffery for cement as a modern building material saying the prize would "give an object lesson to Eastern Ontario Farmers as regards the usefulness and attractive appearance of Portland cement construction." ${ }^{, 53}$ The 1904 competition for best livestock and fair exhibit was the last, perhaps because the prize given that year could not have been surpassed.

The last judge-centred campaign began in February 1905 with a short item suggesting that stock judging competitions for "farmers" sons" might be interesting for spectators and educational for participants. Previous to making this "suggestion," Faith sent letters to all the Eastern Ontario agricultural societies offering to match prizes put up by societies for such a competition. A month later the newspaper published a reader's

\footnotetext{
53 "Russell County Receives the Journal's Banner at a Banquet Held at Metcalfe Thursday Night," OVJ, January 19, 1904, 8. The Ottawa Evening Journal carried a condensed version of the same article three days earlier but with Ross's speech and the offer of the special 1904 prize carried in full, "Received Banner for Best County Fair," OEJ, January 16, 1904, 7.
} 
letter which said that the competition would be even more educational if it was preceded by stock judging classes. Faith agreed and arranged with government officials and agricultural societies to have an O.A.C. professor hold such a class in different centres around the region. ${ }^{54}$ Livestock judging competitions were regular events at the Toronto and Ottawa Exhibitions. What was innovative was, first, Faith moved a city exhibition event to the countryside. Second, he specifically excluded the O.A.C. students who were the contestants in the city events in favor of young men who had no college training. Both changes were important but particularly the second.

O.A.C. students were expected to become the professional experts of the future and thereby future livestock judges. Yet at the same time it was a widely-held conviction that farmers needed at a minimum to learn to recognize good livestock when they saw it if they were going to breed up their stock. This is clear in the connection the rural Journal made when it wrote that all should attend because by attending "object lessons" in their own district "they will be given some information regarding the [judging] work and receive information that will not only help them in judging the animals at the fairs, but also in selecting stock to increase their herds and flocks." 55 The newspaper only sponsored the livestock competitions for this one year although it gave good play to the results with articles through the year and two full pages with photos reporting on the competition result. $^{56}$

1902 began with organizing dairy meetings followed the next year with the first of the orchard meetings. These were straightforward exercises of working with

\footnotetext{
54 "New Feature Suggested for the Fall Exhibitions," OVJ, February 10, 1905, 10; A. McPhadden, Glengarry Co to Editor, and "Another Good Suggestion," OVJ, March 31, 1905, 10.

55 “Live Stock Instruction Classes for Farmers' Sons,” OVJ, May 19, 1905, 12.

56 "Bright Young Farmers (sic) Sons Who Took Part in the Journal's Live Stock Judging Competition," OVJ, December 15, 1905, 10-11.
} 
government experts and, in the case of the dairy meetings, the various cheese boards around the Ottawa Valley. ${ }^{57}$ At the same time they were part of the newspaper's ongoing focus on (male) producer improvement. These meetings reflected popular rural education by being a mix of education and sociability as seen in Grange picnics, some Institute and all Chautauqua meetings. ${ }^{58}$

In 1901, the newspaper had reported that the dairymen around Kemptville were planning a "convention" for sharing information and suggested this should be done by all the cheese boards in Eastern Ontario. The Journal said it would do the organizing but needed "to hear from the officers of the different cheese boards" before it acted. ${ }^{59}$ Once the work began, ostensibly it was the E.O.D.A. and the cheese boards that organized and ran the meetings, but the rural Journal had been made the organization's "organ" and Cowan its corresponding secretary in 1901 (this relationship is discussed further in Chapter 8). As a result Cowan was closely involved and the meetings were extensively reported in the Ottawa Valley Journal in terms of that involvement. ${ }^{60}$ The orchard meetings followed much the same pattern but without the local associational patronage. Cowan's successor, Robert Faith, organized the first orchard meeting in 1903 following

\footnotetext{
${ }^{57}$ Cheese Boards were locally-organized marketplaces which brought together salesmen and buyers to trade in cheese in a public forum. See Chapter 8.

${ }^{58}$ Chautauqua had various manifestations. The formal Chautauqua quickly grew from a camp in 1874 to an Institute with correspondence courses and even a university presence. The Independent Chautauquas and the Chautauqua circuits were two separate phenomena. The circuits travelled from town to town and presented a week long event under a tent putting on each day in the week a unique set of lectures and entertainment. The circuit Chautauqua did not reach Canada until 1917. There had been, however, a Methodist camp at Grimsby, Ontario since 1852. In 1891 this camp advertised itself as the Chautauqua of Canada. All of these manifestations were well known to rural residents as learning combined with fun and entertainment. See Joseph E. Gould, The Chautauqua Movement: An Episode in the Continuing American Revolution (New York: State University of New York, 1961); Sheilagh S. Jameson, Chautauqua in Canada (Calgary: Glenbow Alberta Institute, 1979); Grimsby Park: The Chautauqua of Canada, (Toronto, Braugh A. Caswell, [1891]) http://archive.org/details/grimsbyparkchaut00brou. Accessed April 2, 2018.

59 "Dairy Conventions for Eastern Ontario," OVJ, September 20, 1901, 1.

60 "Where the Dairy Conventions Are Likely To Be Held," OVJ, November 1, 1901, 1; "First Local Dairy Convention Held at Vankleek Hill," OVJ, November 22, 1901, 1; "Dairy Interests of Eastern Ontario Should be Thoroughly Organized," OVJ, November 26, 1901, 1.
} 
the example of a series of meetings organized by the Ontario Fruit Growers Association along the Saint Lawrence. ${ }^{61}$ His "partner" in 1903 was Alex. McNeil of the federal Agricultural Department, Fruit Division. The next year the Journal reported that McNeil had "directed" Faith to organize the meetings while in 1905 it said Faith had "engaged" McNeil to speak. Irrespective of the changing roles assigned to McNeil, the rural Journal identified itself as being at the centre. ${ }^{62}$ Unlike the Fruit Growers' session, the Journal's orchard meetings were summer events allowing a festive day for the whole family, with "ladies" specially invited and assurances there would be picnic facilities, a talk on Household Economy and music. ${ }^{63}$

What I do not see in the rural Journal's efforts to improve the fairs' educational opportunities was any interest beyond livestock and the masculine agricultural world. In Chapter 5 I discussed the limits of its activism in terms of the issues of concern to women. Farm men, women and children all spent time at the fair looking at and being impressed by new machinery. The Ontario government encouraged manufacturers to exhibit as part of its policy of increasing productivity through the mechanization of farm work. Equipment for the home, including model kitchens, was displayed as part of making the farm women efficient domestic managers and consumers. The small amount of attention the rural Journal paid to these aspects of the agricultural fair in its campaigns to improve them speak to the limits on what the rural Journal thought was important.

\section{The Changing Nature of Knowledge}

Jeffery Taylor in Fashioning Farmers argues that the introduction in the late-

\footnotetext{
61 "Fruit Growers will Meet," OVJ, March 14, 1902, 8.

62 "An Orchard Meeting Will Be Held at Cumberland August 16th," OVJ, August 5, 1904, 10; "The Spraying Demonstration Given at Kenmore Tuesday was a Success," OVJ, May 26, 1905, 10.

63 “Orchard Meetings," OVJ, July 3, 1903, 10.
} 
nineteenth century of the new sciences of economics and sociology came together to create a new idea of agricultural knowledge which centred on university training rather than the experience of ordinary agriculturists. Where he goes further than other studies of the new agricultural sciences is in his argument that by the 1920 s the sciences had altered how the average farmer understood his world, replacing agrarian language with that of rational capitalist economics. David Monod's review essay on Fashioning Farmers argues that Taylor does not take into account the ways in which new knowledge can be reshaped to integrate with pre-existing knowledge. ${ }^{64}$ I find that at the beginning of the twentieth century the rural Journal identified both academic and experiential knowledge as the mark of the expert in its educational and production initiatives. Later commentators on judges also indicated that the agricultural expert remained more than a book-farmer for many years beyond the 1920s.

\section{What made an Expert Judge Expert?}

Judges were key in the Journal's fair campaigns of 1901 to 1905 . But not just any kind of judge and absolutely not the old style of whoever was available and cheap. The Ottawa Valley Journal used "expert judges" as a stock phrase so often it sounded like a verbal tick. For many, "expert judges" were the obvious way to make fairs more educational and education was the obvious purpose of a fair. The importance of expert judges goes further than this, however. By encouraging agricultural societies to engage such judges as well as helping with the logistics involved, the newspaper was making a statement as to who had the capacity to define the knowledge to be learned in livestock

\footnotetext{
${ }^{64}$ Taylor, Fashioning Farmers, 118-9; Monod, David. “Down on the Farm: Reading Jeffery Taylor's Fashioning Farmers: Ideology, Agricultural Knowledge and the Manitoba Farm Movement," Manitoba History, 32 (Autumn 1996), 2-9.
} 
exhibits. So what was an expert judge and what did such a judge do?

Heaman has pointed out that judging was central to the fair since, without judging, a fair "was just a bazaar." Judging made the educational purpose of the fair explicit by pointing to the best item in a display and thereby making it clear what one must emulate to improve one's own work. Judging was supposed to be authoritative but the reality was that both spectators and exhibitors disputed judges' decisions.

Commentators believed that the problem lay with the common use of three-man juries in which no-one was willing to take responsibility for a decision. As well, the use of locally prominent men working for free was said to favour politicians and businessmen as judges despite sometimes having little practical experience with the breed being judged. And because the men were local, they were always suspected of bias. When the rural Journal editor asked exhibitors and agricultural society leaders to assess the 1901 experiment of the one man expert judge, the responses emphasized satisfaction not only with the judges' knowledge and capability but also with the fact they were not local. ${ }^{65}$

The expert judge appeared at the end of the nineteenth century when professional knowledge was increasingly a mark of the modern in agriculture just as it had become in the sciences generally. Jeffery Taylor argues that a new bourgeois agrarian ideology of farm men and women as managers, rather than producer-workers, grew out of a latenineteenth-century restructuring of agricultural knowledge into agricultural science. This science was made up of agricultural economics, home economics and rural sociology. And just as was true of the professional scientist, so the modern professional agriculturist had followed a course of institutional study and had been declared an expert by men-

\footnotetext{
${ }^{65}$ Heaman, Inglorious Arts of Peace,124-5; Jones, Midways, 4-6, 19-25. ; "Should the Ottawa Valley and District County Fair System be Re-organized," OVJ, November 5, 1901, 1.
} 
professors — who had already reached that state. ${ }^{66}$ Certainly the beginning of the twentieth century saw increasing emphasis on college-learned expertise. In 1903 the rural Journal headlined the addresses given at the annual convention of the Kingston Dairy School "Cheesemakers Are Advised to Attend a Dairy School." The speakers, from the Ontario Minister of Agriculture conferring the diplomas to the Chief Dairy Instructor for Eastern Ontario giving the opening address, all pointed out, not surprisingly given the occasion, the importance of attending the school. ${ }^{67}$ In 1907 the Journal reprinted an article from Nor'West Farmer regarding the Manitoba Agricultural College. The Farmer stated that a young farmer would not achieve the agricultural knowledge he sought by reading agricultural journals and books while remaining on the farm. The increasingly scientific nature of agriculture and a lack of system in reading would instead lead to "a hodgepodge of agricultural ideas and not [to] a clear understanding of the latest science.",68

Despite this negative comment on home learning, the rural Journal made little distinction between expertise gained at the agricultural college and expertise based on practical or experiential knowledge. At the opening of an agricultural collegiate-level school on 1907 the Journal claimed that "[d]uring the past quarter of a century agriculture has been rising more and more to the level of a scientific pursuit, and those men who have been following it as a science as well as an art are among the most progressive farmers to-day" (my emphasis). ${ }^{69}$ Earlier the newspaper had printed articles

\footnotetext{
66 Taylor, Fashioning Farmers, 86-9.

67 "Cheesemakers Are Advised to Attend a Dairy School," OVJ, January 30, 1903, 2.

68 "Farm and College," OVJ, August 20, 1907, 6.

69 "School of Agriculture," OVJ, July 5, 1907, 12.
} 
discussing college training as a supplement to the practical training of farmers' sons. ${ }^{70}$ The Journal's introduction of various expert judges was even more telling. None of the expert judges engaged in 1901 were trained or certified as judges, but they had experience and therefore were "recognized authorities." One of the judges was "one of the greatest swine breeders in America" as well as being an "expert breeder" of cattle. His pigs had won the championship at Toronto for nine years running as well as winning prizes at the Buffalo Exposition. Live Stock Commissioner Hodson was quoted that this judge was "considered one of Canada's most reliable and expert live stock breeders." The second judge was the Dominion Horse Breeders’ Association's nominee and had judged at the city fairs of Toronto and Ottawa. The third judge had been a breeder for thirty years, an exhibitor for twenty-five years, and was an official of the Ontario Provincial Winter Fair. ${ }^{71}$

The Journal continued its emphasis on practical knowledge and wide experience over the next few years. In 1905 the newspaper described one judge, James Irving as a “Dundas County Farmer." The Ontario Department of Agriculture had engaged him as an expert judge of light horses for five Eastern Ontario fairs. He had been breeding hackney horses for thirteen years, had imported Cleveland Bay stallions and had won prizes at Kingston, Toronto, Guelph and Ottawa. As well, he had been judging light horses for twenty-five years and was past president of the Winchester Township Agricultural Society. No initials for he was simply James Irving, Esq. ${ }^{72}$

Of course having a college education, and the initials which went with it, did not

\footnotetext{
70 "Education for Farmers' Sons," OVJ, January 12, 1904, 10; "Should the Country Boy go to College?" OVJ, December 29, 1905, 9. "The Macdonald College At St. Anne de Bellevue," OVJ, September 11, 1906, 10.

71 "The Three Expert Stock Judges" and "The Judges of Live Stock," OVJ, September 10, 1901, 1, 8.

72 “James Irving, Esq," OVJ, August 18, 1905, 12.
} 
disqualify a person from being an expert judge but education had to be accompanied by experience. The Journal introduced the experts judging the 1905 stock judging competition with a photo of each man captioned with his name and his college degree (Dr. Standish, V.S. and F.M. Logan B.S.A.) ${ }^{73}$ It seems that at some point Logan had to be replaced for the final report named D. Drummond, an employee of the Department of Agriculture at Ottawa, as the second judge. The biographies for both men stressed their practical knowledge. Yes, Standish was a honours winning graduate of the Ontario Veterinary College. He was also a practicing veterinarian, a farmer who raised carriage and heavy horses and he had been a horse judge at fairs for twenty-eight years. Drummond was currently a government official and a Farmers' Institute speaker but he came from a dairying family and his brother still farmed. He himself had been a prize winning breeder of Ayrshire cattle and he had won a silver medal in a provincial competition for the best managed farm. ${ }^{74}$ But practical experience on its own was not enough. An expert judge had to have a reputation beyond the local area. This was a requirement with a practical rationale that went beyond establishing authority. It seemed obvious to the Journal that men with large reputations would be concerned that every one of their decisions upheld that reputation. ${ }^{75}$

Seed Fairs also required expertise and again it was represented as practical expertise. In reporting on the 1903 Seed Fair, the rural Journal claimed some value for what had been a poorly attended event by saying it had "resulted in a great deal of valuable information being imparted by practical farmers." The "practical farmers" who

\footnotetext{
73 "Experts in Charge of Judging Competition," OVJ, July 28, 1905, 10.

74 "Bright Young Farmers (sic) Sons who Took Part in the Journal's Live Stock Judging Competition," OVJ, December 15, 1905, 10.

75 "Should the Ottawa Valley and District County Fair System be Re-organized," OVJ, November 5, 1901, 1.
} 
were first mentioned included Carleton County Councilors, the Mayor of Hull speaking in French to the Francophone farmers in attendance and R.B. Faith. The other beneficial result was the organization of an Ottawa Valley Seed Grain Association. ${ }^{76}$ The next year in reporting on the success of the second Seed Fair, the Journal clarified the fair's purpose. It was to encourage the improvement of grain seed by awarding prizes for the best exhibits of clean seed of good quality (that is, taken from plants which had given a high yield and not harbouring weed seeds or smut) as well as making seed available for purchase. $^{77}$

Taylor's argument suggests that there was a growing gulf over the first two decades of the twentieth century between scientists and farmers. While there is support for this argument (for example, an O.A.C. professor was engaged as judge for the 1904 fair and as speaker at its evening session), the gulf was not very large prior to the 1930s and the development of hybrid seeds. In the mid- and late-nineteenth century, William Weld of the Farmer's Advocate had been an early actor in improving seed quality. Due to his belief that the Ontario government was not doing enough to improve agriculture, he imported seed, experimented with it on his farm and sold it through a mail-order store he called The Emporium. ${ }^{78}$ Seed certification is a more formal process which Kathy Cooke describes as developing in the United States out of a healthy collaboration between science and experience. Scientists at American government experimental farms/stations were developing new strains of grain at the turn of the century as well as working to purify existing strains. To build up commercial supplies, they partnered with farmers who

\footnotetext{
${ }^{76}$ Seed Grain Growers Form an Association," OVJ, April 14, 1903, 8.

77 "Seed Fair a Success," OVJ, March 11, 1904, 1.

${ }^{78}$ Irwin, "The House of Weld," 44; Bogue, "The Fighting Farmer, William Weld," 75-8; The Weld Publishing Co later bought a farm on the outskirts of London which it ran as an experimental farm through at least 1935 .
} 
were prepared to isolate and closely monitor their crops in order to ensure seeds would remain true-to-type. ${ }^{79}$ James Robertson, the Dominion Commissioner of Agriculture, was responsible for the same activity in Canada when, starting in 1899, he offered prizes to Junior Farmers to collect grain seeds. A week before the first Ottawa Seed Fair, the rural Journal had published a short report on Robertson's plans to form a federal Seed Growers' Association which would register seed strains as to their purity. ${ }^{80}$ The article did not make the connection to the local seed fair scheduled to happen that week. ${ }^{81}$

The Dairy and Orchard meetings did not use judging to direct education. Instead the meetings' authority came from its speakers who were a mix of experts from the federal Department of Agriculture and prominent local men. In Fallowfield the dairy meeting was presided over by Father Foley of the local church. There were demonstrations in the orchard and at $4 \mathrm{pm}$ speeches. Then "dainty refreshments were served by the ladies." At Vernon more ladies served "delicious sandwiches, cakes, bonbons and other luxurious dainties." One wonders how much was learned if the size of the crowd the newspaper was trumpeting as a marker of success was true. Three hundred people attended the meeting in Fallowfield in Mr. Robert Wallace's orchard. The same week another three hundred people attended the Metcalfe "orchard picnic" as it was called in a sub-header. Without loudspeakers and a clear sight of what was being demonstrated, it was probable most came to enjoy an event rather than gain an education. The speakers at the Metcalfe event were described as "practical growers and prominent

\footnotetext{
${ }^{79}$ Kathy J. Cooke, "Expertise, Book Farming, and Government Agriculture: The Origins of Agricultural Seed Certification in the United States," Agricultural History 76 no. 3 (Summer 2002).

${ }^{80}$ In 1904 Robertson formed the Canadian Seed Growers Association which was separate from the government but which continued to be led by Federal Department of Agriculture officials until 1925. Seed Growers website, http://seedgrowers.ca/about-csga/rooted-in-history/. Accessed March 1, 2018.

81 “'Seed Growers' Association," OVJ, April 7, 1903, 8.
} 
farmers." The named speakers were the government Senior Fruit Inspector, Mr. Macoun of the Central Experimental Farm, and the dairy instructor for the Ottawa cheese and butter board, R.B. Faith and the Township Councilor. Mr. Whiteside who owned the orchard and four men who were not described (Messrs. McLaurin, Murray, Dennison and Loney) were presumably the "practical fruit-growers." $\$ 2$

\section{Certifying Expertise}

The idea of certifying judges as competent was still occasionally mentioned fifteen years and more after it was suggested in the 1888 Farmer's Advocate article. But it was not a widely-held opinion. Live Stock Commissioner Hodson mentioned in 1903 that both the federal and Ontario governments offered short courses in judging and suggested that anyone judging regularly should take at least one course each year. ${ }^{83}$ Yet in 1907 Lockie Wilson, who was now the Superintendent of Fairs, said in a speech that he sent out as expert judges only "qualified men and before engaging them they must be recommended by at least three progressive farmers in their district." ${ }^{84}$ In 1909 the Journal reprinted an article from the Breeder's Guide which suggested that more than good references were needed. In admitting that even expert judges had personal ideas of the ideal type against which they were judging, the Guide recommended that judges follow a course to learn "uniform standards." Furthermore, the government should make the short course in judging a prerequisite for certification as a judge. ${ }^{85}$

The question of what makes a qualified judge was still open-ended in 1911. Wilson reported at the Ontario Fairs Association annual meeting that "he hoped the time

\footnotetext{
82 "Journal's Orchard Meetings Were a Marked Success," OVJ, July 19, 1903, 10; "Meeting Was Great Success," OVJ, July 14, 1903, 8.

83 “Agricultural Exhibitions Require Re-Organization," OVJ, April 28, 1903, 8.

84 "Annual Convention Fairs Association," OVJ, March 8, 1907, 12.

85 "Expert Judging at Agricultural Fairs," OVJ, January 5, 1909, 9.
} 
would come when it would be possible to have every judge pass an examination and receive a diploma before being sent out." This was followed at the meeting by a discussion of a resolution that the department examine judges "for fitness" in order to standardize judging. This resolution did not pass after comments that it implied current judges were not qualified. ${ }^{86}$ By 1917 "expert judges" were meeting in conference at the Central Experimental Farm to be trained in the "ideal type" by which they were to judge. The trainers of these "experts" came from the agricultural colleges and the Experimental Farm but also "prominent breeders" were there as instructors. ${ }^{87}$

Despite this work to standardize judging there were still problems in the 1920s. An article in the Ottawa Farm Journal cautioned agricultural societies to pick experts and not personal friends or someone with "political pull." The same year an exhibitor at the Vankleek Hill Fair felt he had cause to complain. Recent judging by a governmentappointed judge had placed second a bull that was chosen as among the best in Ontario by the committee organizing exhibits for the Syracuse fair. He concluded that the government's process for selecting judges for the fairs was a "ridiculous parade" put on for the agricultural community. ${ }^{88}$

Did the Expert Change by 1920 ?

Taylor argues that the new ideology of agricultural science came to fruition with the 1920s expert who was no longer the experienced farmer. The expert agriculturist had become an intellectual in the person of a college graduate working for government or in

\footnotetext{
86 “Annual Convention of Ontario Fairs Association,” OVJ, February 14, 1911, 12.

87 "Expert Judges Hold Conference to Get Instruction," Ottawa Farm Journal (hereafter OFJ), July 13, $1917,11$.

88 "Judges at Our Exhibitions," OFJ, August 24, 1923, 8; “Takes a Crack at Judges, H.J. to Editor, OFJ, September 28, 1923, 10.
} 
academe. ${ }^{89}$ Yet Neely writing in the 1930 s and Prosterman's interviews from the 1980 s show the failure of the intellectual expert to displace the experienced expert, at least on the fairground. Neely did comment on agricultural colleges and stations being a source of judges which seems to support Taylor's argument except that a decade after 1920 Neely saw this as a "recent phenomenon." In 1935 Neely still summed up judges as "[m]en who by experience and training are acquainted with the purposes and the qualities of the products which they pass upon." They were judges with a lifetime experience in breeding and farming. 90

Prosterman in her 1980s interviews with exhibitors and fair officials reports that judges were always being judged by the exhibit directors as well as by knowledgeable exhibitors and spectators. As a result, while the society treated a judge's decisions as authoritative, it was authoritative for that day. If a director felt a judge's decision went against "the consensus of the community" on what standards applied to an item or caused too many exhibitor complaints, that judge would not be engaged the following year. Prosterman's interviewees clearly preferred judges with practical experience in the field along with educational theory. They were especially skeptical of academics who, they said, applied theory without regard to everyday use and needs. ${ }^{91}$ It seems the intellectual expert had not displaced the experienced expert, at least for fair judges, by 1920 or for many decades after.

What did change was the expectation that a judge was, of course, a man, even when sitting in judgment on women's work. Linda Borish details from diaries the

\footnotetext{
${ }^{89}$ Taylor, Fashioning Farmers, 86-9.

${ }^{90}$ Neely, The Agricultural Fair, 172. In 1930s there were women judges for women's work. I assume Neely used the male person as a general term for judges out of the gendered conventions of his time.

${ }^{91}$ Prosterman, Ordinary Life, Festival Days, 111-4.
} 
experience of women at the agricultural fair in the mid-nineteenth century. While the women were proud to show their skill and craft in public displays of both their practical and fine work, as well as in their productive work of dairying, power relationships meant all their work was judged by men. ${ }^{92}$ My study of the Prescott County Fair at the beginning of the twentieth century found that the Society hired its first female judge for the women's work classes in 1906. That judge, however, had not been brought in from outside as expected for livestock judges. She had been hired by her cousin, the society's secretary-treasurer. ${ }^{93}$ Gender also affected the value assigned to the different classifications of exhibits with livestock having more value than women's work. In my earlier study I found that premium book cover illustrations emphasized cattle and horses to such an extent that only one out of 92 books included women's work on a cover. I also found that the rural Journal's headlines summed up the success or failure of specific Valley fairs in terms of the quality of their livestock displays, and again with special emphasis on the cattle and horse exhibits. This preference for horses and cattle even over other livestock was magnified in their preference over women's work. ${ }^{94}$

\section{Seeing is Knowing ... Once The Expert Tells You How To See}

The agricultural college combined practical work with the class-room work we find familiar-lectures and text books which overtly laid out what the student was expected to learn. Fairs worked in an older way. First they tried to excite an interest in

\footnotetext{
${ }^{92}$ Linda J. Borish, " 'A Fair, Without the Fair, is No Fair at All': Women at the New England Agricultural Fair in the Mid-Nineteenth Century," Journal of Sports History 24, no. 2 (Summer 1997): 162-66.

${ }^{93}$ Smith, "The Community and the Fair," 179.

94 Ibid., 168-71. This was a matter of economics and hierarchy. Prior to the First World War horses were the main source of farm power while cows were economic drivers as dairying became a dominant rural industry in Eastern Ontario. But judging was still about hierarchy with the amount of premiums offered placing horses and cattle over poultry while judging ranked individual animals within their class.
} 
learning by appealing to a combination of human competitiveness and the mercenary desire for prizes. The actual teaching was done through visual observation of things on display. The observer then tried through trial and error to imitate what had been seen. Observation, as opposed to book learning, was considered particularly relevant for farmers. Even in the 1930s, Neely cautioned that "[e]specially for those who are not students by training or habit, word of mouth and visual demonstrations may well be the most effective method of instruction., ${ }^{95}$

\section{Taking Observation Seriously}

The idea that one could learn by careful observation also underlay another site of self-learning, the museum. Eilean Hooper-Greenhill's study of museums asks what a museum is and what constitutes knowledge in a museum. In answering these and other questions, she aims to tease out the effect of delivering knowledge through museums, for she argues that this is not an innocent and natural process. She starts with Michel Foucault's example, in his preface to The Order of Things, of a Chinese encyclopedia. It seems the ancient Chinese classified animals in a way which we cannot understand and which we therefore assume is not classification but caprice. Foucault uses his example to argue that we cannot understand other ways of thought if we do not begin to see the boundaries which divide for us the rational from the unthinkable.

Hooper-Greenhill identifies tools which we can take from Foucault for doing this, starting with looking for the history of "practices" and in particular looking for practices we now think irrational. For the rupture from our own practices and from the worldview which underlies them can, if sizeable enough, make visible practices that we would

\footnotetext{
${ }^{95}$ Neely, The Agricultural Fair, 182-3.
} 
otherwise not notice. While we start by seeing them as errors, if we recognize them as rational in their own time, we have a chance to understand the otherness of the past. But to achieve this, we must take them seriously. The second tool Hooper-Greenhill takes from Foucault is the idea of "epistemes" or the structures of knowing which form how the world is understood in different periods (see Chapter 3 for a fuller discussion) ${ }^{96}$ Hooper-Greenhill uses these "tools" from Foucault to dissect the Medici palace, the modern museum and, from the period between these two, the classical museum. First she looks at the Medici Palace as a form of knowledge. In the palace Medici power was the narrative on display but at a time of transformation in practice from earlier treasure gathering to Renaissance collecting. (The Renaissance collectors privileged objects from the classical world chosen as much for their evocation of history as for beauty or value.) Second, she analyzes those museums through Foucauldian "technologies" of power and knowledge as expressed in physical space, practices of display, practices of monitoring and care and so on. These technologies all work to direct and focus the gaze onto what one is expected to learn from the objects on display.

I find instructive these examples of what can be learned if, like Foucault, we set aside existing standards of rationality. We should examine seriously the Journal's expectation that, because the stock judging classes "develop[ed] observation and knowledge," they had been exactly what the headline claimed: "A Great Educational Feature and One of the Best Methods of Teaching Stock-judging. ${ }^{, 97}$

\section{The Power of Observational Learning}

Tom Nesmith's dissertation on the philosophy of agricultural learning points to

\footnotetext{
${ }^{96}$ Hooper-Greenhill, Museums, 4-5, 9-12.

97 “Journal's Stock Judging Contest Should Be Continued,” OVJ, January 23, 1906, 10.
} 
the traditional importance of observation and the slow movement away from it over the nineteenth and early-twentieth centuries. Mid-nineteenth-century agricultural science had continued in the path of empirical learning associated with Francis Bacon (1561-1626). Bacon's empiricism assumed that it was possible to know the natural world and how it worked through direct, close observation. By the late-nineteenth century, however, it was increasingly clear that a student could see what was happening but not see the how and the why. Nesmith is interested in the fundamental transformations in understanding of knowledge which the O.A.C. faculty went through in grappling with this realization. At first the college authorities turned away from teaching general principles in favour of teaching technical "what-to-do" knowledge. But by the end of the century the college was using a new idea of "practical idealism" to combine teaching of scientifically-learned principles from soil chemistry and bacteriology with practical experimental results. ${ }^{98}$ Nevertheless, at least one of the short courses designed to teach agricultural extension students ran into problems with practical idealism. The Professor of Dairy Husbandry H.H. Dean commented in 1904:

The [dairy] instructors expressed themselves well pleased with the [short] course. Some of the cheese and butter makers did not stop long enough to become interested. It is difficult for the average cheese and butter maker to see much connection between bacteriology, chemistry and practical factory work. ${ }^{99}$

For the average dairy man, experience and what could be observed were what mattered. Farmers writing to the Ottawa Valley Journal to endorse the 1905 stockjudging classes expressed their support in these terms. Andrew Cochran of Lanark had found the classes "better" than Farmers' Institute meetings because "farmers receive

\footnotetext{
${ }^{98}$ Tom Nesmith, "The Philosophy of Agriculture: The Promise of the Intellect in Ontario Farming, 18351914" (PhD. diss., Carleton University, 1988), 176-90, 229-53.

99 “O.A.C. Dairy Notes,” OVJ, April 29, 1904, 2.
} 
more benefit from practical illustrated lectures than mere platform theory." ${ }^{\prime 100}$ C.G.

McKillican of Prescott County echoed this assessment saying there is no benefit "until you get something practical, something alive, that you can touch and feel, and something that gives you a chance to test your skill."101 The Journal summed up another set of letters with the headline "The General Impression Seems to Prevail That the Agriculturists Need Practical, Illustrated Lectures.",102

Learning by observation was sufficiently important that making space for it was a necessary part of advocating improvements to the fair. The Journal did not campaign for better fairgrounds although it did include fairground buildings as a judging point in the Best Fairs contests of 1903 and 1904. But the problem of space for judging was raised, usually by judges and sometimes by commentators, in letters to the newspaper. The newspaper itself commented that judges at the 1906 Prescott County Fair were forced to assess the pigs in the wagons in which the pigs had been brought to the fair. The same complaint was made two years later along with the suggestion that the directors needed proper security to keep the crowd outside the ring: "The cattle judge was the worst sufferer from this annoyance, and several times had his view impeded by the crowding around of several persons who wanted to handle the cattle."103 The newspaper seemed to have assumed this was ignorance or bad manners but it equally may have been a continuing belief that the ordinary farmer was as well qualified as the professional to judge if only that farmer could place his hands on the animal. The newspaper also reported on the talk of a Farmers' Institute speaker on making the agricultural fair more

\footnotetext{
${ }^{100}$ Instruction Classes in Live Stock for Farmers," OVJ, July 7, 1905, 10.

101 “Journal's Stock Judging Contest Should Be Continued,” OVJ, January 23, 1906, 10.

102 "Opinions of Farmers," OVJ, July 11, 1905, 10.

103 "The Prescott County Fair" OVJ, September 18, 1906, 10; "Prescott Co. Annual Fair Held at Vankleek Hill was a Big Success," OVJ, September 18, 1908, 12.
} 
educational. Along with the usual comments about banning amusements, he raised the need to erect a ring for judging. This would keep the spectators back, leaving the judge room to work. It would also place winning animals in a highly visible location so spectators could make their own visual comparisons between the different animals after the judging was done. ${ }^{104}$ The Farmer's Advocate was still commenting on the problem of the space of judging and making judging visible in $1919 .{ }^{105}$

It is likely neither the newspaper not the letter-writers thought one could learn using a vague and untrained gaze. Rather observation had power when fully developed as a critiquing act. Hooper-Greenhill recounts the ability of the merchants of Renaissance Italy to accurately gauge quantity and quality through trained observation. ${ }^{106}$ Nor is the idea of training observation to a high level of skill confined to the deep past. Lianne McTavish in her study of the outreach activity of the Natural History Society in New Brunswick points out that observation was seen as a trainable act. The Society prepared sample cases for teachers across the province to use in "visual training" of school children in how to examine an item systematically, what to notice and how to assimilate intellectually what is seen. McTavish describes the idea of vision in the late-nineteenth century as an intellectual, directed, active engagement with the world. She contrasts such a purposeful vision with today's concept of vision as a passive activity with display downgraded to mere spectacle. ${ }^{107}$

\footnotetext{
104 "Conducting a Fair Along Educational Lines," OVJ, February 12, 1904, 12.

105 "Prepare for the Coming Show Season," FA, July 10, 1919, 1297.

${ }^{106}$ Hooper-Greenhill, Museums, 42-3.

${ }^{107}$ Lianne McTavish, "Learning to See: Vision, Visuality, and Material Culture, 1862-1929," in Defining the Modern Museum: A Case Study of the Challenges of Exchange (Toronto, London: University of Toronto Press, 2013), 56-70. Cf Peter G. Anderson, Ottawa School Gardens in the Early 1900's, Ottawa: Historical Society of Ottawa, 2010. Anderson links the urban garden classes of the 1900s and 1910s to the same "new education" (a child-centred education stressing training in systematic "sight-perception") which underlay the New Brunswick nature kits studied by McTavish. The city classes added an expectation that
} 
Sara Spike's study of visuality and rural modernity in Nova Scotia builds on McTavish's work with an in-depth look at an effort which went beyond teaching children about nature through observation. In Nova Scotia the provincial Superintendent of Education and amateur naturalist A.H. McKay sought to turn the observations of teachers and public school students into scientific data. What Spike finds can be related to James Scott's discussion in Seeing Like a State regarding the flattening effect of "high knowledge" on the particularity of local knowledge. ${ }^{108}$ Spike, however, finds that high knowledge in Nova Scotia was being quietly and probably unconsciously resisted. McKay directed administrators to assess the observations sent in by categorizing entries as accurate or inaccurate based on the administrators' knowledge of historical records. He also told them to exclude observations which reflected economic decision-making in determining planting and harvest times (dismissing these reports as idiosyncratic).

I suggest that the exclusion of data reflecting economic intrusions into agricultural decision-making did, to some extent, fit with McKay's scientific purpose of environmental study and his goal of mapping Nova Scotia's micro-regions. At the same time, as Spike points out, McKay's determination to find a single date for agricultural events by excluding dates set by farmers' secondary occupations imposes a rigidity on the actual range of practical dates. More importantly Spike's reading of the comments made by the administrators reveals the tenacity of local knowledge. Despite annual exhortations to follow the official guides for identifying plants, teachers and students continued to use their own identifications and names. Spike states that the teachers who sent in "wrong" answers were neither resisting efforts to create a scientific bank of "unnatural" urban streets. This was the flip side of the Country Life Movement.

${ }^{108}$ Scott, Seeing Like a State, 310-9, passim. 
knowledge nor rejecting modernity. Rather they saw their knowledge as co-existing with the administrators' scientific knowledge. This is a more nuanced analysis than to claim the continued use of local names was simply resistance to the legitimacy of modern science. I would call Spike's findings a look at the "stickiness" of local names which characterized the tacit knowledge held by the teachers and children. ${ }^{109}$

Scott describes local knowledge, or mētis, as formed out of "close and astute observation" of the details of the environment in which the knowledge-holder is trying to survive and if possible thrive. ${ }^{110}$ The agriculturist also observes his animals but combines observation with handed-down knowledge which can make that local knowledge what I have called "sticky" or persistent at an unconscious level. For example, a farmer was not necessarily refusing to learn what made pure-breeds "superior" in his continued use of "grade" animals. Rather he already had a mental picture of a superior animal. What made that image "sticky" was its combination of familiarity and knowledge of the best animal for the family's circumstances (counting production, cost and risk).

This was not the approved knowledge because it was made up of many elements, some conscious and some unconscious. For the college-trained expert, even farmers who agreed with lecturers and officials as to which animals were superior were said to "know" only when they could articulate what made the animal superior. ${ }^{111}$ A farmer who knew a good animal based on instinct developed through years of experience did not really know. The Ottawa Valley Journal commented on farmers' ignorance of what to look for in an animal: "While attending the Eastern circuit of fairs the writer was greatly

\footnotetext{
${ }^{109}$ Spike, "Modern Eyes," 46-90.

${ }^{110}$ Scott, Seeing Like a State, 324.

111 "Bright Young Farmers (sic) Sons who Took Part in the Journal's Live Stock Judging Competition," OVJ, December 15, 1905, 10-11.
} 
impressed with the fact that a great many farmers have not made a study of [what kind of cow makes for success]. But all were anxious to learn and listened very attentively to the valuable information given by the expert judge." ${ }^{\prime 12}$ This points to the newspaper's conviction that farmers could not learn right observation by observation alone, not even by watching a judge trained in the systematic observation. ${ }^{113}$ The farmers' had to be guided by an expert who would talk them through a lesson.

The importance of guided observation explains why the Ottawa Valley Journal's 1901 plan for expert judges involved the judges teaching orally as well as visually. Judges were directed to explain at ringside what they were judging for and why, and what were the shortcomings and strengths of each animal. Spectators would learn both by hearing and by seeing. In 1901, whenever the number of animals to be judged and the time available did not allow this best of all pedagogy, the judges were asked to provide a report which the newspaper published. The written reports probably did not work as well as the ringside comments which allowed words and observation to work together. For example, a written comment that one bull was "well fleshed, showing a large proportion of valuable meat and a comparatively small percentage of offal" would have been fully instructional when the bull in question was there to be seen. ${ }^{114}$

\section{$\underline{\text { Setting and Teaching New Standards }}$}

Combining oral learning with observation was not new. Neely reports that in the early-nineteenth-century fairs, judges told onlookers the basis of their assessments. But Neely also points out that breed standards did not exist at that time. Each judge used

\footnotetext{
112 "To Tell a Good Dairy Cow," OVJ, October 9, 1903, 2.

113 The observation that was taught in nature classes and in the colleges was a structured approach of moving from the general to the specific in a set of taught steps.

114 “A Tremendous Display of Valuable Pure Bred Live Stock," OVJ, October 4, 1901, 8.
} 
whatever evaluation measure he thought relevant. The development of standards happened in parallel with the development of expert judging. ${ }^{115}$ Sara Spike shows the difficulty exhibitors, directors and judges had at the end of the century even agreeing on when a squash was a squash and not a pumpkin, these being judged in different classes. ${ }^{116}$ But even if you placed your entries in the right class, what was it being judged against? In Canada breed standards were worked on by the Canada Department of Agriculture with the breed associations which had been established in the late-nineteenth century. In 1903, Live Stock Commissioner Hodson stated that there was a plan to put out "an authorized standard of excellence of each breed of live stock ... All awards should be based on this standard" as approved by the breed societies. Hodson expected the result to be "a great improvement both in judging and in the type of animals found throughout Canada." 117

Neely contrasts the new standards based on "quality, utility and beauty" with the nineteenth-century standards which often rewarded spectacle, whether in the form of the biggest pumpkin or the fattest baby. ${ }^{118}$ These standards had been self-evident. The new standards focused on qualities the market demanded in a product, qualities which might not be obvious. Farmers had to be taught the new officially-sanctioned standards through "visual educational stimuli." For example, Neely recounted how he witnessed in 1932 one judge explaining that mutton was paying better than wool and therefore he was judging the sheep class before him on what he could feel of their meat and not on what he

\footnotetext{
${ }^{115}$ Neely, The Agricultural Fair, 162-3.

${ }_{116}^{116}$ Spike, "Modern Eyes," 126-31.

117 “Agricultural Exhibitions Require Re-Organization," OVJ, April 28, 1903, 8.

${ }^{118}$ These standards were not as whimsical as they appear. Hooper-Greenhill points out the use of the strange and the grotesque as part of Francis Bacon's dictums on a proper Cabinet of Curiosities which would serve to train the memory as one skill required for developing new knowledge. Hooper-Greenhill, Museums and the Shaping of Knowledge, 149-50
} 
could see of their wool. ${ }^{119}$

Even the farmers who did not belong to breed associations were constantly told about the pre-eminence of market standards by Farmers' Institutes speakers, farm newspapers and journals, as well as through the agricultural society premium books and the way exhibits were divided up on the fairgrounds. The way animals, crops and women's work were categorized for competition and display created "objects" in the minds of the observers; for example, agricultural improvers were keen for farmers to distinguish beef cattle from dairy cattle rather than keeping their "general purpose cows." Objects were then further subdivided into the breeds which had been developed over the nineteenth century. ${ }^{120}$ The Ottawa Valley Journal's report on the South Renfrew fair further emphasized that a pig was not necessarily a pig. It might be a "bacon hog" if one thought in terms of the market. That was certainly the intent of the Journal's suggestion to have such a category in the South Renfrew's prize book instead of grade pigs: "Farmers should be shown just what style of hog it is that is required to meet the demands of the market and this is one of the best ways of doing it, as such exhibits of pigs afford splendid object lessons." ${ }^{, 21}$

\section{The Farmers' Reception of the Journal's Fair Campaigns}

In order to understand where farmers stood as learning shifted from observationbased knowledge to science-based knowledge, it is important to realize that farm families in Ontario were not isolated intellectually. They had access to a wide range of knowledge. Adam Crerar has written on the cultural engagement of farm families around

\footnotetext{
${ }^{119}$ Neely, The Agricultural Fair, 166-7.

${ }^{120}$ Ibid., 156-8, 165-9.

121 "Farmers of South Renfrew Should Feel Proud," OVJ, October 1, 1901, 8.
} 
1910 , reporting that surveys showed two-thirds of respondents subscribed to an agricultural newspaper. Books were inexpensive and readily available through mail order and by the 1910s most farms in long settled areas were within eight kilometers of a public library. ${ }^{122}$ At the same time there is little to show what the rural Journal's readers knew or understood about the world. The newspaper printed only a few readers' letters on the subject of education, and even fewer on expert judges. Those it did print mainly came from the agricultural society leadership and exhibitors. The usual letters of thanks printed by the Journal for the Best Fair prizes between 1902 and 1905 emphasized the Journal's good work in encouraging education. The North Renfrew Agricultural Society wrote: "The interest you have created and the new features you have introduced have undoubtedly greatly strengthened our exhibitions." The society added: "It is largely due to the Journal's efforts that the side attractions are being abolished and educational work introduced." ${ }^{123}$ When we hear the response of ordinary farmers it is filtered through the Journal's reporting on the success of meetings it held. For example, in respect to the stock judging classes, headlines included the claim: "The Eastern Ontario Farmers and Particularly the Young Men are Taking Great Interest in the Work Inaugurated by the Journal." The text reported on the gratefulness of farmers for the learning opportunities being offered them. ${ }^{124}$ There is one letter from a self-described "agriculturist," E.E. Boyce of Rideau View in Carleton County. He commended the judging competitions as adding "interest" and thought it was "instructive to a marked degree [to] receive professional instruction as to the desirable and undesirable points of live stock." He

\footnotetext{
${ }^{122}$ Adam Crerar, "Writing Across the Rural-Urban Divide: The Case of Peter McArthur, 1909-24," Journal of Canadian Studies 41, no. 2 (Spring 2007): 125.

123 "The North Renfrew Society Receives a Silver Cup," OVJ, January 23, 1903, 10.

124 “Large Crowds Attend Live Stock Classes," OVJ, June 16, 1905, 12.
} 
thought they would help farmers breed their animals with more control. ${ }^{125}$

Despite the good words in these letters, there are indications that little changed as to behaviour. For example, in 1906 the Journal reported that the expert judges at the Winchester Fair gave educational talks at the livestock exhibits which, along with other "educational features," were near the main gate. But it also reported that seven-eighths of the fair-goers went past these to the grandstand "seeking amusement." And there were initiatives which were not repeated. The 1905 stock judging competition was labeled a success in terms of interest raised among onlookers. Yet the Journal finished its report by saying it would only repeat the experience if it received fifty letters from "young men" interested in participating in the competition the following year. ${ }^{126}$ The Journal primed the pump with a few letters from young men expressing interest. But the letters of support must not have arrived in sufficient numbers as no more was heard in the newspaper on the subject. Stock judging classes and competitions were started up again in 1909 but by the newly appointed Ontario Agricultural Representatives. ${ }^{127}$

The new "Ag Reps" taught livestock judging to children as part of educating future farmers who could identify approved qualities in livestock through trained and systematic observation. In some places these were features in the school fairs which had been introduced in the early twentieth century as a way of giving the young the educational distillation of the agricultural fair in a controlled venue. This was the case in Nepean Township but it was not a consistent practice in Eastern Ontario. In Prescott

\footnotetext{
125 “Opinions of Farmers," OVJ, July 11, 1905, 10; E.E. Boyce Rideau View to Editor, OVJ, June 16, 1905, 12.

126 "Journal's Stock Judging Contest Should Be Continued," OVJ, January 23, 1906, 10.

127 "Big Attendance at Short Judging Course," OVJ, December 3, 1909, 12; "The Course at Lancaster," and "Short Course Pleased Farmers," OVJ, December 7, 1909, 12; "Good Attendance at Avonmore," OVJ, December 17, 1909, 12; "Big Meeting at Avonmore," OVJ, December 21, 1909, 12; "Short Course a Success," OVJ, February 1, 1910, 12; "Interest in Short Courses," OVJ, March 8, 1910, 12.
} 
County the agricultural representative, Ferdinand Larose, organized stock-judging classes in the 1920s to prepare teenagers and young men to compete at the Ottawa Winter Fair but he did not attach such classes to the School Fairs he also organized. He was consistently disappointed, however, with the result as it was difficult to find participants. Francophones were especially unlikely to involve themselves for the rules required them to give their reasons for placing the animals in English. ${ }^{128}$

\section{And What did the Farmer's Advocate Think?}

I started the farm press assessment of the need for expert judges with the 1888 discussion in the Farmer's Advocate on making the agricultural fair more educational by replacing a jury of amateurs with a single expert judge. The Advocate made the same assumptions as the Ottawa Valley Journal about the educational power of observation while being equally uncertain as to observation alone being sufficient. In 1907, Advocate commentator W.D. Watson wrote about the new expert judges as an important improvement in the educational character of the fair. Similar to the Ottawa Valley Journal writers, Watson thought that education would be better served if the new expert judges would explain the points of excellence in the winning exhibits. Twelve years later in a 1919 editorial. the Advocate editor advised boys to "follow the judge in his work, and endeavor to fix in the mind the type which he seems to favor, and the ideal which apparently guides exhibitors in the presentation of their animals." ${ }^{\text {129 }}$ Unlike the Journal in 1901, however, the Advocate was not coordinating the work of judges and therefore could not require judges to explain their decisions at ring-side, or in notes left beside the

\footnotetext{
${ }^{128}$ Smith, "The Community and the Fair," 184-91; Ferdinand Larose, Annual Report for Prescott-Russell, Ontario Department of Agriculture, Agricultural Representative Branch, 1921-22, 27.

${ }^{129}$ Editorial "A Day at the Fair," FA, August 7, 1919, 1423.
} 
entry, or in follow-on reports. One suspects it would not have mattered given Sara Spike's finding that fairgoers to the 1882 Yarmouth Fair were urged to bring a note book with them in which to write down the lessons they saw. Spike's focus is on the assumption that the visual memory needed to be reinforced with words. ${ }^{130}$ We can see by juxtaposing her finding with the Advocate's 1919 editorial advice that after forty years systematic learning at the fair remained an ideal and not a reality.

Despite the ongoing commentary by governments and newspaper editors about what made a proper agricultural fair, the Advocate still had to point out editorially in 1916 that the job of the agricultural fair was to educate and not to run horse races. ${ }^{131}$ Letters to the Farmer's Advocate after the Ottawa Valley Journal's 1901 to 1905 campaigns show that the Advocate's readers saw little change. Expert judging may have been the norm by this time but not only had it failed to transform the agricultural fair, it had failed to stop complaints of incompetent judging. In $1907 \mathrm{H}$. McLean of Lambton County wrote the Advocate to complain about two expert judges sent by the Ontario Department. He had expected expert judges to be selected from the "many good farmers and experienced breeders" but it seems they were neither experienced nor academic experts. Instead one was an undertaker and the other a butcher. ${ }^{132}$ He then described the erratic rulings made by the butcher in judging sheep. ${ }^{133}$ The Advocate made no comment on this report, neither to agree, disagree nor to suggest a way to change things as Cowan had done in 1901. An Advocate editorial in 1917 also questioned the competence of some judges but again made no suggestions on how to change the situation:

\footnotetext{
${ }^{130}$ Spike, "Modern Eyes," 122-4.

131 “Thoughts For Fair Boards," FA, November 16, 1916, 1880

${ }^{132}$ One cannot imagine why these men were sent unless it was because they both dealt in bodies.

${ }^{133}$ H. McLean of Lambton County to Editor, FA, “Expert Judges," November 28, 1907, 1850.
} 
The way some acting judges grope and grip and punch the same animals over and over again, without ever appearing to think of standing off and taking a general survey in making their comparisons and decisions, sometimes leaves the impression that they have hesitated till they are lost, and their ultimate decision in such cases often leads the onlooker to conclude they have been going it blind, and in desperation have jumped to a conclusion. A judge, of all men, should keep a cool head, take a little time to think, take a stand-off view and consider whether he is rating butchers' or breeding stock, and make his rulings accordingly. ${ }^{134}$

The Farmer's Advocate and the Ottawa Valley Journal told the same lessons to their readers: visit the fair with an intent to be educated; expert judges will guide you in assimilating what you observe into useable knowledge; you will return home a better farmer whether you are purchasing or breeding livestock or choosing seed varieties for sowing. The only difference was that the Journal customer base was concentrated in a limited geographical region, not spread out from Ontario to the Maritimes as was the case with the Advocate. As a result in 1901 the rural Journal could work with local decisionmakers, the agricultural society directors, whose cooperation was needed to change how judging was done. And indeed the Journal's campaigns of 1901 to 1905 did improve how judging was carried out in Eastern Ontario. But what the mass of fairgoers wanted-a day of fun and sociability — was older and stronger then either newspaper editorials or newspaper campaigns could change. In the years after the Journal campaigns, the newspaper reverted to the usual press practice of preaching about education and the fair.

\section{Conclusion}

The Ottawa Valley Journal highlighted six initiatives from the years 1901 to 1905 in its pamphlet selling itself as the "farmer's friend," five of which involved or were dependent on the use of "expert judges." By closely examining all six initiatives, we can

\footnotetext{
134 “Judging Sheep,” FA, September 26, 1917, 1524.
} 
see how the newspaper articulated the official or hegemonic view of the early 1900s, first, as to what made a modern agricultural expert and second, how to learn at the fair. That this hegemonic message was made by a rural edition of a city newspaper underlines the range of channels through which the message was sent.

By 1900 the agricultural fair had become one of several mechanisms the government funded in order to disseminate agricultural knowledge but it was the only one where farmers who were uninterested in pursuing education could be found. There was consensus among government officials and agricultural elites that the agricultural fair was still a useful educational institution. It just needed to be saved from the desire of fairgoers for fun and sociability. Herbert Cowan of the Ottawa Valley Journal thought he had learned the secret for improving the fairs when he heard Dominion Live Stock Commissioner Hodson's paper recommending that Agricultural Societies engage one expert judge from outside the fair area. This was an idea the Commissioner had endorsed years earlier when he was editor of the Farmer's Advocate. But the Journal did more than re-publish the idea in the newspaper. It immediately initiated a project to establish the expert judge system in Eastern Ontario and this project led naturally to other projects intended to improve agricultural education in the Ottawa Valley.

In helping agricultural societies engage expert judges, the Ottawa Valley Journal made real an idea which most observers, both in government and among agricultural improvers, considered an obvious answer to the problem with fairs as an educational institution. It was also a statement as to who had the authority to define correct agricultural knowledge at a time when the nature of the expert was in transition. By the beginning of the twentieth century agricultural colleges had begun to professionalize both 
agricultural knowledge and the agricultural expert in their teaching of agricultural economics, rural sociology, and the sciences of the hidden (soil chemistry and bacteriology).

In contrast to the intellectual expert of the agricultural colleges, the Ottawa Valley Journal described the expert judges engaged for the Eastern Ontario fairs as practical experts, stressing their experience in livestock breeding and exhibiting. This did not mean the Journal dismissed agricultural education as leading to "book farming." Rather it presented the value of the agricultural colleges and short courses as supplements to training received on the farm. Two twentieth-century studies of the agricultural fair, by Wayne Neely in 1935 and Leslie Prosterman in 1995, indicate that agricultural societies and exhibitors retained a faith in the validity of experiential knowledge at least into the 1980s. Equally unchanging was resistance to the idea that judges should be certified professionals. The Farmer's Advocate had suggested this in 1888 and it came up several more times in the first decade of the twentieth century. But those who suggested that judges follow special courses on which they would be examined appear to have been in the minority. The Ottawa Valley Journal reported the idea but that was all.

The Journal's initiatives also point to changes in the concepts of how to learn, that is changes to Baconian empiricism in which one learns through observation. By the late nineteenth century this idea had been nuanced by the belief that even experienced farmers had to be trained in critical, systematic and intellectual observation. In introducing the expert judges in 1901 the rural Journal insisted that judges educate orally and visually. They were to give exhibitors and on-lookers an explanation of what they were judging for and how the details of the animal being judged lined up against that. It 
also printed letters to the editor to show that farmers agreed that combining demonstration with oral explanation was the best method of teaching. Observation was sufficiently important that the Journal commented on the necessity of fairgrounds having good judging rings, although this improvement was never pursued as one of the newspaper's campaigns. The Ottawa Valley Journal and the Farmer's Advocate continued to comment on poor judging facilities up to and after the First World War. Despite this, the Journal endorsed the fair as a place to observe and learn but with experts to tell the farmer what exactly was to be learned. This was necessary partially because exhibit standards were changing. Instead of judging the obvious, whether the biggest or the strangest, judges were judging against a mental image of what kind of cow or pig would result in the roast beef or bacon consumers wanted to buy. As well as asking judges to explain their decisions, the newspaper began to comment on improving agricultural societies' premium books by classifying livestock and again creating marketoriented "objects" in the minds of farmers.

The beginning of the twentieth century also saw the introduction of women judges for women's work, although this innovation is not found in the pages of the Ottawa Valley Journal. Perhaps this was because the newspaper was following the government agenda which focused on increased agricultural production. But it can also be argued that all parties, including the agricultural societies, saw cattle and horses (the men's work) as intrinsically more important. This was a hegemonic given for all involved. The Journal did not stray far from what most participants considered to be the obvious focus of the fair.

Overall, the Ottawa Valley Journal was an appendage of a city daily but its work 
on the agricultural fairs was in line with even such a prestigious farm journal as the Farmer's Advocate. Effectively they were arguing for the same thing: that the education available at the agricultural fair required an expert judge whose credibility rested on experience which might, but did not have to be, augmented through education. With this credibility the judge then both demonstrated and simultaneously explained modern livestock standards to farmers. The difference is that for a few years the Journal thought it could make this ideal a reality by intervening and working with agricultural society management. But the ideal remained an ideal and the Journal returned to editorializing on what agricultural societies ought to be doing. In the end even the successful introduction of the expert judge had not made the fair a site where education triumphed over entertainment. 


\section{Chapter 7 - The Farmer and the Labour Theory of Value in Roads and Taxes}

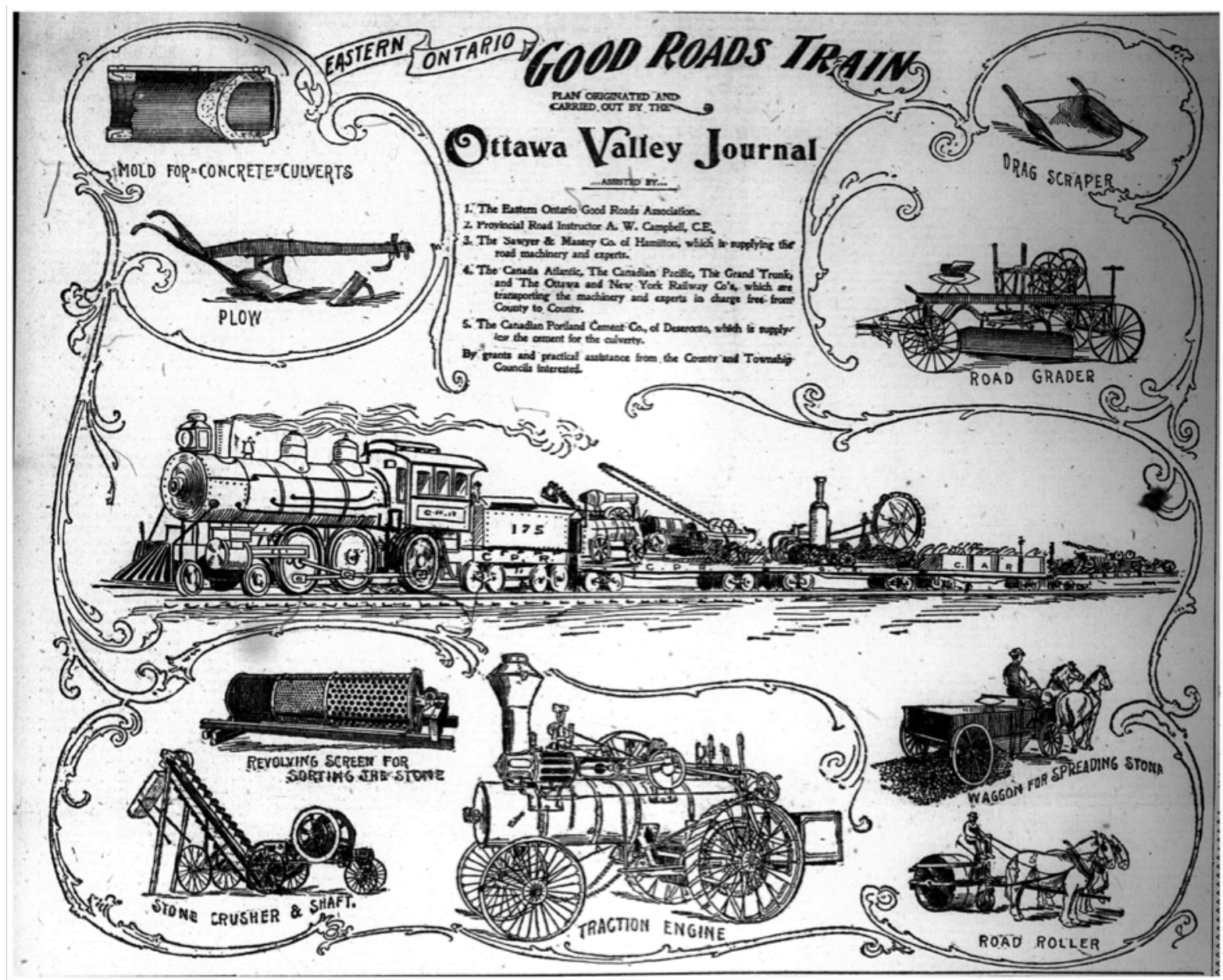

Figure 7.1. “The Eastern Ontario Good Roads Train,” Ottawa Valley Journal, June 18, 1901, 1.

Editor Herbert Cowan believed that farmers would want better roads if they saw modern road machinery in action. His Good Roads Train evoked great interest but demonstrating modernity in the form of technology did not change the farmers' reluctance to pay for better roads. The underlying problem was the farmers' adherence to the Labour Theory of Value in which their labour on roads made those roads their private assets. The same equation underlay the farmers' view of property tax assessment. Within the decade, urban voices would submerge the rural voices on both issues. 


\section{Introduction}

In 1901 and 1902 Herbert Cowan of the Ottawa Valley Journal ran a highly successful project called the Good Roads Train to bring knowledge of modern roadmaking to the countryside. Two decades later the Ottawa Farm Journal sales pamphlet could legitimately claim this as an achievement even if it did exaggerate the mileage. ${ }^{1}$ The final outcome was less of an achievement. Farmers were certain that because their labour built the roads, they owned them and had the final say on what to invest in them. The sales claim also ignored the reality that the modern roads of the 1901 campaign were gravel roads built for horse-drawn traffic. Within ten years automobiles speeding at up to 30 or even $40 \mathrm{mph}$ would chew them up, prompting calls for expensive hard-surface roads. ${ }^{2}$ Over the same period the Good Roads movement shifted to advocating inter-city highways. Farmers were left in the dust of local dirt roads.

In 1907, six years after the Good Roads Train had travelled the Ottawa Valley, Cowan's successor, Robert Faith, called a mass meeting of farmers on the subject of property tax assessment. Farmers had written to the rural Journal arguing that their labour had built the improvements on the land and that labour should not be taxed. Enthusiasm ran high at the meeting and Faith orchestrated the formation of a special association to carry the issue forward. The Farmers' Municipal Rights Association would be another achievement claimed in the Ottawa Farm Journal's 1919/1920 sales pamphlet. Yet despite two years of active farmer interest, farm tax assessment was also

\footnotetext{
${ }^{1}$ Sales Pamphlet, Ottawa Farm Journal, c.1919/1920, collection of Bruce S. Elliott.

2 Ford's model ' $\mathrm{T}$ ' had a top speed of $45 \mathrm{mph}$ but the speed limit to which most city people would have been accustomed was $20 \mathrm{mph}$. It is likely that people who valued their skins, not to mention their vehicle's chassis, stuck to 10 to $20 \mathrm{mph}$ in the countryside and then only when they found good country roads. See Caesar Avarez, "1908 Ford Model T," https://www.topspeed.com/cars/ford/1908-ford-model-tar32509.html. Accessed August 27, 2017; David Blanke, The 1910s (Westport, Conn.: Greenwood Press, 2002), 132; David W. Monaghan, Canada's New Main Street: The Trans-Canada Highway As Idea and Reality, 1912-1956 (Ottawa: Canada Science and Technology Museum, 2002), 8.
} 
submerged by urban interests.

I argue that the rural Journal's handling of these issues demonstrates three aspects of modernization in rural Eastern Ontario. First, both Cowan's 1901-1902 roads campaign and Faith's 1907 tax campaign illustrate a continued rural attachment to the labour theory of value even as academic economic theory was shifting to marginal utility theory in which price and thereby attribution of value is determined by demand. Cowan's road initiatives failed to win hearts and minds because he was assuming there was a problem of technical knowledge and did not understand that farmers assessed investment versus potential benefits based on labour creating value. Faith's tax assessment campaign, on the other hand, was supported by hundreds of Ottawa Valley farmers who came out to his mass meetings because, like them, he believed that the fruits of labour belonged solely to the labourer. Second, the campaigns illustrate the Ontario government's shift away from rural issues to urban issues as both campaigns disappeared from the pages of the rural Journal. By 1910 urban interests, even in a rural-targeted newspaper, submerged the rural. Third, it shows the changing relationship of farmers with the state as the local municipality became increasingly bureaucratized and thereby less under the farmers' direct control.

In this chapter I start with the labour theory of value and its connection with ownership and rights in land, improvements and roads. I follow this with a contextual history of the Good Roads movement in Ontario, concluding with a short discussion of municipal taxation. I next outline events as they unfolded in the rural Journal, highlighting the contrast between Cowan on roads and Faith on property taxes. This is followed with an exploration of the parallel narrative published by the Farmer's 
Advocate regarding the modernity of up-to-date road work, expert road-making knowledge and machinery. The Advocate focused on the cost problem rather than the "technology gap" assumed by Cowan and gave value to the farmers' experiential knowledge. I finish with what can be learned regarding how farm men understood roads, taxes and ownership as seen in the readers' letters on the campaigns.

\section{Labour, Property and Value}

For over a century prior to 1880 the labour theory of value was economic orthodoxy in the Anglo-American world with economists declaring that the labour of production created the value of the resulting object. As will be discussed this was changing by 1900 as North American economists, including agricultural economists, adopted a new orthodoxy of marginal utility theory in which economic value was determined by market demand. Ordinary farmers, however, still adhered to the older understanding of labour and value. In this study I am concerned with how the farmer responded to demands made on them regarding roads, and their own demands on the state regarding property taxes, reflected the continued hold of the labour theory of value over the countryside in the first decade of the twentieth century. This expands the history of roads beyond a binary between farmers' traditionalism and urban progress as seen in engineering feats and market expansion. It also opens up a rural history on taxes. In both the road and the taxation histories, farmers decided on an appropriate level of road maintenance and an equitable tax base based on their understanding of the link between their labour, property and value. ${ }^{3}$

\footnotetext{
${ }^{3}$ As explored in Chapter 3, the Ottawa Valley Journal aimed its campaigns at farm men. I am very much aware, however, that even though the majority of rate-payers were men, and statute labour was specifically about farm men, farm women also had views on taxes and especially on roads. Nonetheless I will refer in
} 


\section{The Labour Theory of Value}

The labour theory of value is most commonly discussed in labour history where it is treated as an idea underpinning producerism, the latter being a political economy theory on who ought to reap the value of production, the worker or the capitalist. I will discuss producerism in the next chapter when examining Faith's campaign regarding cheese marketing. In this chapter I focus specifically on the theory as an idea which continued to direct farmers' views of roads and taxes into the early twentieth century.

The fullest explanation of the theory is given by James Huston in his study of the American concepts of wealth distribution from the American revolution to the increasing domination of corporations in the 1880 s. $^{4}$ Huston links the theory to Locke via Adam Smith and the Scottish Enlightenment. The latter modified the Lockian argument that property resulted from labour to an argument that value was determined by labour. ${ }^{5}$ Labour was the ultimate input to the cost of goods since it also determined the value of other inputs such as the material and tools used to create the goods. Huston then places the theory at the heart of the revolutionary discussions of the nature of the new Republic and links it to what he calls "an expression of the cultural value of individualism" which had been reified in the United States as "an objective, scientific, universal truth."

Despite the theory's longevity and apparent hegemony, it contributed to on-going disputes due to differing ideas of what constituted labour. American theorists identified as labour everything from manual work to mental work to management work. At the beginning of the nineteenth century economist David Ricardo (1772-1823) changed this

\footnotetext{
this chapter to farmers as they were the intended audience of the campaigns.

${ }^{4}$ James L. Huston, Securing the Fruits of Labor: The American Concept of Wealth Distribution 1765-1900 (Baton Rouge: Louisiana State University Press, 1998).

${ }^{5}$ Ibid., 10-12

${ }^{6}$ Ibid., 357.
} 
wide-open definition as he struggled with the question of how to use labour to measure value. His initial solution was to define labour as the physical work of producing an object. ${ }^{7}$ This definition was adopted by European socialists, including Karl Marx who used it to argue that capitalists could only make a profit if they underpaid the main source of a product's value, labour. Labour history has since focused on how unions used labour theory in their fight against capitalist monopolies by arguing that all the fruits of their labour belonged to the workers - in other words, the entire value obtained when a product was sold. By the 1890 s the Patrons of Industry were using the theory to express the rights of farmers. Jeffery Taylor quotes from the Canadian Patrons of Labour newspaper, the Patron's Advocate, to show its place in agrarian reform in Canada. For example, one letter writer opined: "Labour must have the exclusive right to the produce, if we are ever to achieve permanency and stability in agriculture." ${ }^{8}$ Many farmers would have nodded, as this confirmed what they thought. They had laboured to produce food for society but had not been given a fair return.

The Patrons' use of the theory was parallel to the unions' use, not derivative. The Canadian farmer was part of the same North American popular tradition in which, Huston says, the theory had been pervasive from the American Revolution up through the nineteenth century. Among academics there had been a cooling towards the theory starting in the nineteenth century (note that European theorists, other than socialists, had never been as enthusiastic as British-American academe). British academics were the first

\footnotetext{
${ }^{7}$ A 1904 discussion of Ricardo and the Labour Theory of Value argued from examining his later writings and letters that Ricardo continued to question what labour was and might have reached a different answer had he lived longer. Jacob B. Hollander, “The Development of Ricardo's Theory of Value," Quarterly Journal of Economics 18, no. 4 (August 1904): 455-91.

8 "Pro Patria," Patron's Advocate, March 13, 1895 quoted by Jeffery Taylor, Fashioning Farmers: Ideology, Agricultural Knowledge, and the Manitoba Farm Movement, 1890-1925 (Regina: Canadian Plains Research Center, 1994), 91.
} 
to become uneasy with the theory due to socialist use of the Ricardian version to attack capitalism but Huston argues it did not lose its shine in the United States until the 1880s. What eventually took its place among economists was a new economic theory, marginal utility, which theorized that demand drove market price rather than inputs. It was consumers who created value, not workers, and they did so by deciding whether or not to pay a given price for a good based on it delivering the utility they were seeking, whether meeting their taste for one brand over another or choosing which product to purchase versus others given finite resources. ${ }^{9}$

While North American unions may to some extant have reflected the continued use of the theory by European socialists, the Patrons' use in the 1890s can only be explained by their continuing to draw on a theory which valorized their place in the economic order as the ultimate creator of wealth. Yet even in the countryside the labour theory of value was under academic attack. Taylor argues that agricultural economists trained in the new economics were influencing teaching at the Manitoba Agricultural College such that by the 1920 s they had converted agrarian thought and language to the new economics. ${ }^{10}$ At the beginning of the century, however, farmers who were not college-trained had no reason to abandon an understanding of value they had been told for generations was the truth about the relations between economic interests. I will look further at how readers of the Ottawa Valley Journal saw labour, property and value at the end of this chapter as I look at the readers' response to the campaigns of both Cowan and Faith in the first decade of the twentieth century.

\footnotetext{
${ }^{9}$ Huston, Securing the Fruits of Labor, 357.

${ }^{10}$ Taylor, Fashioning Farmer, 48-54, 70-3, 98-100.
} 


\section{The Road Story}

As history, roads have been studied as engineering feats or as economic stories. ${ }^{11}$ Those histories which mention rural residents usually do so in terms of rural opposition, either to the car or to spending money on improved roads, or both. Particularly in popular works the rural response is presented as amusingly luddite. Bruce Seely in his history of road engineers and the American national road system begins by considering how the narrative of Good Roads as a benefit for farmers was constructed. He claimed that the Good Roads Movement was born in the city of bicycle parents who then sold it to farmers. Specifically American bicycle manufacturer Colonel Albert Pope, who was also the head of the League of American Wheelmen, established the first Good Roads Association in 1889. In 1891 he persuaded the United States government to create within the Department of Agriculture an Office of Road Inquiry (ORI) staffed by professional engineers and by officers of the Wheelmen Association. These government experts carried out much of the research and public relations for Good Roads in the United States. ${ }^{12}$

Events in Canada followed hard on American events but it is questionable whether the bicycle had much influence on road development here. Anita Rush points to

\footnotetext{
${ }^{11}$ For Canadian examples see Dean C. Ruffilli, "The Car in Canadian Culture, 1898-1983" (PhD. diss., University of Western Ontario, 2006); Donald Davies, "Dependent Motorization: Canada and the Automobile to the 1930s," Journal of Canadian Studies 21, no. 3 (Fall 1986); Steven Davies, " 'Reckless Walking Must Be Discouraged': The Automobile Revolution and the Shaping of Modern Urban Canada to 1930," Urban History Review 18, no. 2 (October 1989). The first major history of Canadian transportation (G.P. de T. Glazebrook, A History of Transportation in Canada (1938, repr. Toronto: McClelland and Stewart, 1964) was written at the start of the "automobile age" and as a result focuses on water and rail transportation as driving economic development. The first road history (Edwin C. Guillet, The Story of Canadian Roads (Toronto: University of Toronto Press, 1966) is a story of progress. David W. Monaghan, Canada's New Main Street focuses on the engineering and the politics of the Trans-Canada Highway. Mathieu Turgeon and François Vaillancourt, "The Provision of Highways in Canada and the Federal Government," Publius 32, no. 1 (Winter 2002) argue that the Canadian government failed to take a federal view of highways for many years due to a lack of political will, and not because of the division of powers.

${ }^{12}$ Bruce E. Seely, Building the American Highway System: Engineers as Policy Makers (Philadelphia, Temple University Press, 1987), 11-23.
} 
the limited response bicyclists gave the Canadian Wheelmen's Association when its publication (The Canadian Wheelman) raised the road issue. ${ }^{13}$ Glen Norcliffe argues that the Canadian Association had an interest in roads but as only one group among many. He further argues that farmers were pressing for good roads well before the bicyclists.

I have difficulties with his and others' argument that farmers were the drivers of the Good Roads Movement in Canada. First, I would counter-argue that it was not farmers who launched the Good Roads movement here. It was the Toronto-based Canadian Institute which called the February 1894 meeting establishing the Ontario Good Roads Association. ${ }^{14}$ Norcliffe argues that the Association's 1894 decision to provide road exhibits and instruction “at all Farmers' Institutes, County, Dairymen, Creamery, Cheesemen, and other Association meetings" shows that agriculturists were interested in road improvement. ${ }^{15}$ I suggest that targeting farm meetings with educational material does not equate to farmers wanting better roads. It can instead be city interests telling farmers what they should do and think. Robert Summerby-Murray also places farmers at the centre of the Good Roads Movement but his explanation for their interest includes farmers adopting trucks to take produce to market and as a result wanting hard-surface

\footnotetext{
${ }^{13}$ Anita Rush, "The Bicycle Boom of the Gay Nineties: A Reassessment," Material Culture Review 18 (Fall 1983): 4.

${ }^{14}$ The Canadian Institute was founded in 1849 as a professional organization of engineers, architects and surveyors led by Sir Sandford Fleming but immediately expanded its mandate to the promotion of science in general. C.E. Heidemreich, "Royal Canadian Institute," The Canadian Encyclopedia, 2002, edited, 2012, https://www.thecanadianencyclopedia.ca/en/article/royal-canadian-institute/. Accessed July 12, 2017.

${ }^{15}$ Norcliffe, The Ride to Modernity, 149-50, 170-1; Norcliffe's sources are the Good Roads Association reports to the Ontario government and a short memoire written fifty years after the events, W.S. McKay, "Highway Development in Ontario, 1793-1900," The Municipal World (March 1944): 59. McKay claims without sources that Farmer's Institutes and Dairymen's Associations were the first to see a need for improved roads. He also gives James Sheppard of Queenston sole credit for the Good Roads Train in Eastern Ontario. The Journal identifies Major Sheppard of Queenston as manager for the machinery work while Cowan organized and managed the overall project ("Full Particulars of the Arrangements That Have Been Made for the Good Roads Train," Ottawa Valley Journal (hereafter OVJ), June 18, 1901, 1, 8)
} 
roads. ${ }^{16}$ Farmers were using trucks by the 1920 s, particularly in south-western Ontario, but not in the 1890s when the Good Roads movement began.

Certainly market-oriented groups such as the Dairy Associations, governmentsponsored experts with the Farmers' Institutes and the farm press (as seen in the Ottawa Valley Journal and the Farmer's Advocate) told farmers that Good Roads were good for them. ${ }^{17}$ And there were farmers demanding Good Roads. John Dow of Kenmore, Ontario wrote to the Journal that "[g]ood roads and good drainage would increase the value of farming land throughout the province from 50 to 100 per cent." ${ }^{\prime 18}$ Cheesemaker F. Reid of Russell County wrote that the good roads near Kingston had allowed farmers to deliver more milk in one load to his old factory than was possible at his current factory. The Russell County roads also limited how far farmers could haul their milk before the bouncing churned it. He urged the rural Journal to "advocate good roads in connection with successful dairying." 19

Seely argues from American government documents that the American Wheelmen accomplished a clever public relations twist in the 1890s. They started talking about economic and social benefits for farmers. ${ }^{20}$ They did such a good job of directing the conversation that Ottawa Valley politicians as well as the Journal and the Advocate made the same claims throughout the next few decades. Good Roads, they said, would give farmers access to markets irrespective of weather and at reduced costs. Farm children would not miss school in bad weather. The whole family would enjoy social

\footnotetext{
${ }^{16}$ Summerby-Murray, "Statute Labour," 40.

17 “Good Roads Convention," Ottawa Evening Journal (hereafter OEJ), December 28, 1901, 6 and OVJ, December 31, 1901, 2; “Government Road Grant," Farmer's Advocate (hereafter FA), July 1, 1902, 485; "Bad Roads and Good Roads," FA, January 25, 1906, 113; "Wanted: Good Roads" FA, March 15, 1906, 397.

18 “Drainage," John Dow to Editor, OVJ, June 28, 1901, 3.

19 "Good Roads Wanted," F. Reid, Russell County to Editor, OVJ, September 6, 1907, 12.

${ }^{20}$ Seely, Building the American Highway System, 12.
} 
visits more regularly. Life would be better and cost-conscious farmers need not worry

that good roads cost too much when the benefits were considered. ${ }^{21}$ These arguments also

fitted well with the Country Life Movement's focus on encouraging agricultural

prosperity, improving rural social life and maintaining a strong and virtuous rural base in

the nation. Good roads, then, were sold as both economic and social facilitators. But there

was also an interaction between roads and consumption. Not only could country people

travel further to purchase goods, but the roads themselves became a site of advertising for

city consumer goods. At the same time improved roads accelerated the process by which

the countryside became a commodity for consumption, first by urban cyclists, then by

touring automobilists and finally by cottagers. ${ }^{22}$

Despite these arguments for improved roads, both the Journal and the Farmer's

Advocate had to campaign for many years against farmer resistance to commuting statute

labour and to spending money on roads. To do this they used the arguments developed by

city interests although the Advocate showed a greater awareness that the underlying issue

was cost and not farmer shortsightedness. The problem was that with the exception of a

few key roads, townships remained responsible for building and maintaining most

\footnotetext{
${ }^{21}$ For examples of these arguments see an address by James Robertson (Dominion Agriculture and Dairy Commissioner) on the decreased market losses to farmers, "Good Roads as a Factor in Civilization," OVJ, March 1, 1901, 8; a quote taken from Sheriff Hagar of Alfred that he would be able to draw twice a load of hay to market with a good road, "A Good Roads Picnic Held at Plantagenet," OVJ, June 13, 1902, 10; a daily editorial on the cost-benefits, including intangibles, of good roads, "Good Country Roads," OEJ, November 14, 1902, 2 and $O V J$, November 18, 1902, 4.

${ }^{22}$ Catherine Gudis, "The Road to Consumption: Outdoor Advertising and the American Cultural Landscape, 1917-1965 (PhD. diss., Yale University, 2005); Jason W. Lee, “An Economic Analysis of the Good Roads Movement in the 20th Century," (PhD. diss., University of California, Davis, 2012); Christopher W. Wells, "The Changing Nature of Country Roads," 143-166; also see Jeremy Burchardt, Paradise Lost: Rural Idyll and Social Change in England since 1800 (London: I.B. Tauris, 2002), 2-3, passim. Much of Burchardt's work is concerned with England in the years after the First World War and focuses on a countryside organized for consumption by those who live mentally and physically outside the space.
} 
country roads. ${ }^{23}$ Maintaining the road was in most places and on most roads a question of statute labour in which each adult male up to the age of sixty was assessed so many days of statute labour, that is, obligatory labour based on the assessed value of the farm. It was a tax payment which avoided an outlay of cash but was nevertheless, like most taxes, something most people preferred to avoid or minimize.

From 1815 on the Government of the two Canadas gave some money to assist local authorities in building roads but the funds were not large. ${ }^{24}$ As well, prior to the creation of township governments in 1850 , farmers petitioned district magistrates for the authority to build roads that did not follow the original survey road allowances. ${ }^{25}$ When the magistrates granted the request, they assigned a surveyor to mark the route but it was up to the farmers to fell the trees and build the road. There was an alternative to provincial and township roads and that was the toll roads built and maintained by private companies for profit. The roads were expected to be either planked or macadamized but complaints about quality continued. ${ }^{26}$ As profit-ventures they ran where the owner

\footnotetext{
${ }^{23}$ For chronology of road development in Ontario see Glazebrook, History of Transportation, 114-8, 44252 and Guillet, Story of Canadian Roads, 39-63. Glazebrook stated that "certain main roads" were the responsibility of the provincial government but not the local roads (117). Guillet also comments on provincial roads with the story of "trunk roads," Yonge Street going from colonial York on Lake Ontario to Lake Simcoe, Dundas Road, Danforth Road and Kingston Roads from Hamilton to Kingston. These were built by soldiers as was a road to Penetanguishene on Georgian Bay during the War of 1812. They were roads with a strategic or nation-building purpose, including colonization and trade. As well there is a military road in Prescott County also built around the time of the War of 1812 (now highway 34 from Cornwall to the Ottawa River).

${ }^{24}$ Guillet, Story of Canadian Roads, 22.

${ }^{25}$ For example see the Ottawa District Road Book: Ontario Archives, Ottawa District Court of General Quarter Sessions of the Peace. Road Report Book, 1816-1850. RG 22-66. The survey reports described having to deviate repeatedly from a straight survey line in order to get around swamps and beaver meadows. Since the resulting meandering road crossed private and crown land without regard to the township lot and concession lines, the District magistrates had to approve the survey results before road construction could begin.

${ }^{26}$ Guillet, Story of Canadian Roads, 55, 65-71, 80-3. Planked roads were made of planks sawn at a sawmill to make them completely flat, placed over a drained bed and then covered with dirt to reduce friction. Macadamized roads were stone roads in which a base of large rocks was "cemented" into place by being packed with increasingly smaller stones and top-dressed with gravel. The complaint was made that many toll roads only approximated a macadamized road by throwing down gravel over the dirt road.
} 
expected to get a lot of traffic. This was generally on a route leading to a town market (for example, farmers paid to go to the Ottawa Byward Market from the south along the privately-owned macadamized toll road which is now Bank Street, from the west on the Richmond Road toll road and from the East along the toll road which is now the Eastview section of Montreal Road). The daily Journal regularly carried complaints about toll roads and these were copied by the rural edition. ${ }^{27}$ Turning toll roads into public roads (that is, county roads which ratepayers would have to pay taxes to maintain) was part of the Good Roads Campaign but these were not the roads Cowan was asking farmers to improve. Farmers deplored the toll roads and blatantly went around the toll gates but Cowan focused attention on the township roads. These were the roads farm families felt they owned because they had built them. Farmers had cut out the roads, graded them with plows and drags, and then maintained them. They may not have done the work well and farmers were as quick as anyone to bemoan the ruts they literally were in. But it was their labour which they chose to spend to the extent they wished to spend it and therefore these were their roads. The story of Good Roads is a slow shift by farmers from seeing the roads beside their farms as their roads to seeing them as public roads.

\section{Historian Ronald Kline and sociologist Trevor Pinch comment on farmers'}

proprietary view of country roads based on having built and maintained them but they do not explore this point further. ${ }^{28}$ Christopher Wells also argues that farmers saw the roads as a private asset while city automobilists and the government saw them as a public

\footnotetext{
27 "Away with the Tolls," OEJ, February 22, 1893, 4 and OSWJ, February 23, 1893, 4 (focus on cost to the city as farmers could more cheaply sell by train to places other than Ottawa); "Tired of Toll Roads," OVJ, March 28, 1902, 2; "Toll Roads," "Resident Nepean" to Editor, OVJ, June 14, 1907, 8; "Purchase of Toll Roads," OEJ, September 7, 1912, 1 and OVJ, September 10, 1912, 6.

${ }^{28}$ Ronald Kline and Trevor Pinch, "Users as Agents of Technological Change: The Social Construction of the Automobile in the Rural United States," Technology and Culture 37, no. 4 (October 1996): 771.
} 
resource but he finds a change in mentalité as farmers began to make greater use of county road systems to travel further away from their farms. ${ }^{29}$ Hal Barron takes the closest look at the ambivalent response of farm families to the automobile and roads. He rejects the dualism of traditional versus modern but he is concerned with the negotiations farm families went through as they adapted to an increasingly centralized economy, an increasingly powerful state and the increasing consumerism of society. He describes controversy over roads as resistance to the claims of outside experts (road engineers) versus local methods of road maintenance. The problem centred on changing power relationships in which new township, county and state administrators replaced the old relationships of neighbours as pathmasters. There was an additional problem of who paid. $^{30}$

Local roads were paid for out of township property taxes and the residents with the most property were the farm families. Whether paying taxes in cash or by statute labour, few families wanted to increase their civic obligations. ${ }^{31}$ Barron finds that the decisive factor was who bore the cost. As road costs moved away from the local township level, that is away from the farmer in the form of statute labour or township taxes, the opposition to improved roads dropped. What was left was antagonism to the state's preference for funding scenic tourist roads and inter-city freight-carrying roads. Barron finds, however, that this too changed as farmers increasingly saw themselves as a political interest group and organized to obtain "their" share of state road money. ${ }^{32}$

\footnotetext{
${ }^{29}$ Wells, "Changing Nature of Country Roads," 144-5. 150-1.

${ }^{30}$ Barron, Mixed Harvest, 25-7.

${ }^{31}$ Prior to the 1901 Highways Improvement Act a man could ask his Township Council for an individual commutation and then pay his road duties in cash at a pre-set rate. At times townships were happy to get the cash but at other times labour was even harder to come by and commutation might be refused.

${ }^{32}$ Barron, Mixed Harvest, 33-9. It must also be recognized that the city was equally a site of contention between modernizing improvers and ratepayers who had to pay for infrastructure improvements abutting
} 


\section{Farmers and Technology}

There is a popular conception that farmers opposed automobiles because they were traditionalists who opposed modernity from the depths of the ruts in their dirt roads. Rural historians dispute this. Don Kirschner looks at how Mid-Western rural residents responded to the increasing urbanization of the 1920s. While much of his analysis is quantitative and political, he also points out the balancing act farm families conducted between the belief they were pursuing a simple and virtuous way of life and their keen interest in technology and progress. By the end of the First World War they had shifted to fully embracing the technology and consumerism of the urban world while still being ambivalent about urban values. ${ }^{33}$ Ronald Kline takes a particular look at the rural response to technological change. He uses the term "urbanization" to frame his analysis of how reformers sought to change rural people by encouraging the spread of technology used by city residents. He sees this as a self-contradictory effort to keep rural residents in the countryside with all the rural virtues but with certain urban improvements in their mentalité, for example women becoming "housewives" rather than "farm wives." $\mathrm{He}$ argues that reformers believed farm families would change as they used technology such as electricity and consumer products from cars, to washing machines, to radios and telephones. The reality that Kline identifies is that rural residents wove the new products into their existing ways of living. He concludes that as a result rural modernization was a

\footnotetext{
their property. Geographer Phillip Gordon Mackintosh traces the campaigns of two liberal newspapers in Toronto, the Globe and the Star, as they pushed city officials to asphalt roads in the city. As well as a clash over who had to pay, there was conflict as to what material should be used. The city works official knew that asphalt (as it was then constituted) was not durable but the newspaper editors chose to emphasize that it sealed the city from the effusions and mud of the ground while creating an aesthetic surface by being perfectly smooth. The newspapers, Mackintosh argues, were attempting to realize a newspaper ideal of a modern city. Phillip Gordon Mackintosh, Newspaper City: Toronto's Street Surfaces and the Liberal Press, 1860-1935 (Toronto: University of Toronto Press, 2017).

${ }^{33}$ Don S. Kirschner, City and Country: Rural Responses to Urbanization in the 1920s (Westport, Conn,: Greenwood Publishing, 1970), 247-50.
} 
slow and fractured process. ${ }^{34}$

Kline focuses on the United States government (for example the Department of Agriculture and the Rural Electrification Administration) and corporations such as General Electric and various telephone companies as modernizing agents. But he also looks at farm journals, with their letters to the editor, and trade magazines in which manufacturers and sales people exchanged ideas on how to overcome resistance to their wares. With these sources he is able to tease out how rural residents resisted adopting urban sensibilities as they adopted urban technologies.

Kline had anticipated his chapter on automotive technology in an article he wrote with Trevor Pinch, a sociologist of science and technology on Pinch's concept of SCOT (Social Construction of Technology). ${ }^{35}$ Kline and Pinch's example of a SCOT finding is that young men, on the one hand, and women and older men, on the other, drove bicycle technology development. They do not, however, start their analysis by putting these groups together based on gender and age (although gender and age assist in understanding the dynamics at work). Rather they defined the two groups based on each group's expectations for the technology. The young men thought about the bicycle as an opportunity to give a daring performance of masculinity as they mounted their highwheelers. Women and older men understood the bicycle as transportation. Fairly quickly this latter understanding led to the "safety bicycle" which is today's bicycle form. SCOT, then, focuses the analyst, not merely back onto the user, but as importantly onto the range of ways users could understand technology. By stressing the inherent flexibility in

\footnotetext{
${ }^{34}$ Kline, Consumers in the Country, 16, passim.

${ }^{35}$ Kline and Pinch, "Users as Agents", 763-95.
} 
technology SCOT avoids technological determinism. ${ }^{36}$

In the case of the automobile, Kline and Pinch (and Kline alone in his later book) argue that the rural users of automobiles did more than simply adapt the technology to new uses. They were active agents in the development of the automobile based on their expectations for the technology. Thus the original hostile response of farmers (but also of other groups in towns and even in cities) was to the automobile as a dangerously driven contraption only affordable by the rich who disregarded the rights of others (Toad of Toad Hall in Kenneth Grahame's 1908 Wind in the Willows is the quintessential driver of the period. $)^{37} \mathrm{~A}$ change in attitude came as automobile prices came down and farm families redefined the car as a cost-effective engine on wheels - in effect, a source of power for many farm jobs. ${ }^{38}$ Kline and Pinch point to the interaction with gender in this re-shaping of the automobile. Since farm men had traditionally seen themselves as mechanically sophisticated, once they reinterpreted the automobile as a flexible form of farm power they gendered the actions of both driving and repairing the car as male. ${ }^{39}$

Stephen Davies traces the change in attitude towards automobiles in Ontario in the pages of the Farmer's Advocate. He gives examples of complaints against automobilists as a menace taken from Advocate editorials and readers' letters between 1900 and 1910. He asserts, however, that the complaints were really about the "imposition of will by the city over the farmer." ${ }^{, 40} \mathrm{He}$ sees a change starting in 1910 as

\footnotetext{
${ }^{36}$ As in Reception Theory, the technology is not just what the communicator (in this case manufacturer) intended but how the receiver of the technology refigures it.

${ }^{37}$ For the response of early non-motorists to the automobile in Canada see Dean C. Ruffilli, "The Car in Canadian Culture, 1898-1983."

${ }^{38}$ Kline, Consumers in the Country, 62-79.

${ }^{39}$ Kline and Pinch, "Users as Agents," 778-81; there are of course always exceptions as to who a driver is, as pointed out by Kline and Pinch with evidence taken from interviews with rural residents.

${ }^{40}$ Stephen James Davies, "Ontario and the Automobile, 1900 to 1930: Aspects of Technological Integration," (PhD. diss., McMaster University, 1987): 307.
} 
editorials started to appear about the benefits in time and money of buying a car. At the same time cars were coming down in price and becoming more suitable for rural use. Even as farmers became motorists themselves, they continued to write to the Advocate that they had paid for the country roads and therefore those roads existed for the farmers' utility and not for tourist and town recreation. ${ }^{41}$ The farmers' continued belief in the labour theory of value also underlay their views on municipal taxes. Here, however, they had to fit their ideas into a world of law and the relationship between citizens and the state.

\section{Municipalities and Taxes}

Ontario municipalities have had authority to tax, and have levied taxes on property owners, since the province's beginnings as Upper Canada, one of the first tasks having been the establishment of a legal framework for extracting taxes and assessing property for taxation. By 1793 legislation was in place authorizing district councils to name assessors annually to determine the value of all real and personal property. ${ }^{42}$ In 1849 the first Municipal Act gave the townships authority to tax real property (land and buildings), personal property (household goods and in the case of farms, livestock and equipment) and personal income. ${ }^{43}$ The longevity of the process had not endeared it to residents by 1900 .

That it was possible to change municipal taxation was demonstrated when in 1904 Ontario replaced municipal taxation of personal property with a business tax. ${ }^{44} \mathrm{But}$ Ontarians wanted more. E.A. Heaman claims that by 1900 there was a "single-tax revolt"

\footnotetext{
${ }^{41}$ Ibid., 324-9, 343-5.

${ }^{42}$ Frederick H. Finnis, An Introduction to Real Property Taxation (Toronto: Sir Isaac Pitman, 1972), 11.

${ }^{43}$ J. Harvey Perry, Taxation in Canada (Toronto: University of Toronto Press, 1961), 13-25.

${ }^{44}$ Ibid. Provincial income tax was not eliminated in Ontario until 1936.
} 
underway in Canada as a wide swath of the population demanded a narrower municipal tax base of what could be taxed. While she highlights the single tax ideas of one writer, Henry George, she does not confine the revolt to his apostles. She instead claims his ideas, reified as a "single tax movement," was a "lingua franca" drawing together working class and middle class people against the state. ${ }^{45}$ It was perhaps the most widespread idea on taxation and rights in Ontario at the time Robert Faith was launching his campaign on farm property tax in 1907 and parallels can be drawn between them. While I will discuss later in this chapter the limited interaction between Faith's campaign and the single-tax movement, it requires an overview here.

Henry George was an American reformer who published in 1879 a book, Progress and Prosperity. He and his followers are generally looked at within economic history. In Canada historians focus on the Western cities where limited forms of the single tax were, with more or less success, implemented. ${ }^{46}$ Ramsay Cook extends "Georgism" beyond economic history into social history as he describes the connection with the Social Gospel. George was asking the question many Protestant clergy, social critics and labour reformers were asking: why the industrial and technological progress they saw around them was accompanied by huge disparities of wealth and poverty. Cook argues that George's ideas were sufficiently ambiguous to feed a wide range of social

\footnotetext{
${ }^{45}$ E.A. Heaman, Tax, Order and Good Government: A New Political History of Canada, 1867-1917 (Montreal: McGill-Queen's University Press, 2017), 281.

${ }^{46}$ For Canadian examples see Herbert T. Owen, "Canada," in Land-Value Taxation around the World: Reports on Current and Historical Efforts to Apply the Principle of Collecting the Community-Created Value of Land for Community Benefit, ed. Harry Gunnison Brown, Harold S. Buttenheim, Philip H. Cornick and Glenn E. Hoover (New York: Robert Schalkenback Foundation, 1955, HeinOnline Legal Classics); Gregory J. Levine, "The Single Tax in Montreal and Toronto, 1880 to 1920: Successes, Failures and the Transformation of an Idea," American Journal of Economics and Sociology 52, no. 4 (October 1992); Garry B. Nixon, "Canada" in Land-Value Taxation Around the World: Studies in Economic Reform and Social Justice, ed. Robert V. Andelson, (Malden, MA.: Blackwell Publishers, 2001); Mary Rawson, "L.D. Taylor: The Man Who Made Vancouver," American Journal of Economics and Sociology 75, no 1 (January 2016).
} 
criticisms. $^{47}$

George's solution, however, came from political economy. He proposed that municipalities should tax only land but at the same high rate whether improved or unimproved. He argued that this would discourage speculation in land which artificially reduced productivity and thereby depressed the economy while simultaneously raising land prices beyond the reach of the working poor. While his solution, when applied in the West, was not successful in managing the Western land boom or preventing the subsequent bust, Heaman argues that "Georgism" remains interesting as an idea which gave a tongue to many across the country in opposing capitalism and landlordism. She makes only one oblique comment on the idea's antecedents in the labour theory of value when she says it came out of a "libertarian argument" that the state had no right to the fruits of one's labour. ${ }^{48}$

Versions of Georgism circulated in Ontario through the Single Tax Association (established in Toronto in 1897-1898), the cartoons and chalk talks of J.W. (John Wilson) Bengough, contemporary novels, and the agrarian journal The Canada Farmers' Sun. ${ }^{49} \mathrm{~A}$ recent university textbook states that despite its acceptance in Western Canada and Australia, Georgism floundered in the United States due to "hostility" from farmers. ${ }^{50}$ Certainly, agrarian reformers had to navigate around Henry George's belief that, once his idea of a single tax was fully implemented, there would no longer be a right to own land but only a right to the use of land. Heaman, however, claims that farmers' organizations

\footnotetext{
${ }^{47}$ Ramsay Cook, The Regenerators: Social Criticism in Late Victorian English Canada (Toronto: University of Toronto Press, 1985), 108-10.

${ }^{48}$ Heaman, Tax, Order and Good Government, 292, 298

${ }^{49}$ Cook, The Regenerators, 115-8. See also Gregory J. Levine, "The Single Tax in Montreal and Toronto" and for its spread to British Columbia in the 1890s see Mary Rawson, "L.D. Taylor". In the West it had a powerful voice for reaching farmers in the Grain Growers' Guide.

${ }^{50}$ Robert D. Dykstra and Jo Ann Manfra, The Gilded Age: Industrial Capitalism and Its Discontents (Malabar, FL.: Krieger Publishing, 2006), 67.
} 
in Ontario were interested in the single tax and indeed that they brought the farmers into the conversation on municipal taxation. Her evidence is the interest of Ernest Drury, future leader of the United Farmers of Ontario, as stated by his biographer Charles Johnston. ${ }^{51}$ Drury was a prosperous farmer with a college degree from the Ontario Agricultural College and was the son of Ontario's first Minister of Agriculture. He was not the average farmer. I will return to the question of what connection farmers made between their long-held labour theory of value and the single-tax advocacy of the early nineteenth century when I discuss the response of Ottawa Valley farmers to Robert Faith's tax campaign.

\section{The Rural Journal Acts}

The Ottawa Farm Journal sales pamphlet from c.1919/1920 boasted that the Journal had established the Farmers' Municipal Rights Association on property tax as well as three initiatives centred on Good Roads:

- Built a mile of Model Roadway in each of twelve Eastern Ontario townships;

- Promoted the Permanent Highway from Ottawa to Prescott;

- Organized rural session of the 1917 Dominion Good Roads Congress.

The roads campaign was in fact accompanied by another achievement which did not make it into the pamphlet. This was Cowan's campaign to modernize the rural municipal tax system by replacing statute labour with cash payments. This section will travel through these initiatives chronologically, starting with the statute labour campaign of 1901, followed by the Good Roads Train and model road-building of 1901 and 1902. The story will then jump forward to Faith's taxation campaign of 1907 and finish with the

${ }^{51}$ E.A. Heaman, Tax, Order and Good Government, 313, 330. 
significance to be found in the Journal's highly dubious claims to have been active on rural interests in Good Roads during and just after the First World War.

Model Road-building and the Municipal Rights Association were real accomplishments reflecting the New Journalism model of making news. At the same time taxes and roads reflect the rural Journal's own shifting urban-rural priorities between 1900 and 1920. Good Roads started in the Ottawa Valley Journal as a rural-driven project which used urban-centred language equating progress with scientific knowledge and modern machinery. After 1903 the subject of roads died in the rural newspaper. Then in 1907 Faith launched a campaign around farm property taxes. In that campaign farmers expressed their position based on the value of labour dictating ownership. This campaign was also submerged in the rural pages by news of single tax campaigns in the cities of Toronto and Ottawa. On taxes and on roads, farm ratepayers quickly found themselves outside the conversation. How far outside the conversation is highlighted in the final recounting of the reporting on the last two claimed achievements, the Prescott Highway and the 1917 Good Roads Congress, which the rural Journal simply copied from the urban Ottawa Evening Journal.

Good Roads: Phase I (1900-1902)

When Cowan launched his first road campaign in 1901, he was joining a movement already in progress, led by provincial authorities and in particular by A.W. (Archibald William) Campbell (1863-1927). Campbell had been the City Engineer for St. Thomas, Ontario since 1891 and was one of the founders of a journal aimed at municipal authorities, Municipal World. He was also the Good Roads editor and writer in that journal. In 1896 he joined the provincial government as Provincial Roads Instructor, 
became shortly after the Provincial Roads Superintendent and by 1900 was

Commissioner of Highways (a position sometimes called Deputy Minister of Public Works). He was chiefly responsible for the 1901 Highways Improvement Act. ${ }^{52}$ The Act gave authority for two major objectives of Good Roads advocates. First, it set out a legal process for rural municipalities to replace statute labour with a cash tax system. Second, it gave authority for creating a system of improved county roads with grants to pay for the improvements, if the road network and the improvements were approved by Campbell.

In general, until 1900 articles on roads in the rural Journal were either informational items on how to build good ones or comments taken from the city daily on the benefits of good roads for farmers. ${ }^{53}$ Herbert Cowan, as the Journal's first rural editor, changed the dynamic to one of active involvement which culminated in the Good Roads Train — a special train which traveled through Eastern Ontario during the summers of 1901 and 1902 carrying machinery and expert engineers to build stretches of model gravel roads. Cowan's earlier roads activism did not make it into the Ottawa Farm Journal's sales pamphlet, but it was the necessary prelude to the Train. Throughout Cowan was focused on modernizing how farmers saw road construction and maintenance.

It all began in 1900 when Cowan was out in the countryside organizing a regional plowing match. He reported that "a large number of farmers of all classes in various

\footnotetext{
${ }^{52}$ Robert Craig Brown, "Campbell, Archibald William," in Dictionary of Canadian Biography, volume 15, 1921-1930 (University of Toronto/Université Laval, 2003-2018.) http://www.biographi.ca/en/bio/campbell_archibald_william_15E.html. Accessed November 16, 2016. ${ }^{53}$ For example, "For Good Roads In Ontario," OEJ, January 11, 1895, 1 and Ottawa Semi-Weekly Journal, January 16, 1895, 1; "Roads and Agriculture," OVJ, February 24, 1899, 5; "A Day for Good Roads," OEJ, March 30, 1899, 6 and OVJ, March 31, 1899, 1; "Good Roads," OVJ, June 16, 1899, 7.
} 
counties expressed a wish that the Journal would take up the good roads movement." 54 His response, as always, was to ask "prominent farmers and public men" what changes were needed. From this mini-survey he concluded that the big issue was statute labour. Cowan then did some fact-finding by writing to municipalities that had already abolished statute labour and to local officials on current road costs. He finally declared the newspaper a public space for discussion so that "the pros and cons of the case could be thoroughly discussed, and the public at large be given an opportunity to arrive at an intelligent decision in the matter." But Cowan was not content with simply hosting a public forum. He enquired as to how farmers could force a vote on commutation. ${ }^{55} \mathrm{He}$ then selected Goulbourn Township at random for a test vote on statute labour and persuaded Reeve S. Mann to help with the required petition. When Cowan, accompanied by Mann to give introductions, took the petition around the township, he immediately got the necessary one hundred signatures. Cowan and Mann then called meetings to discuss the petition. ${ }^{56}$ Cowan could claim victory when Goulbourn Township ratepayers voted for commutation in January 1901.

Cowan was also closely involved in the establishment of the Eastern Ontario Good Roads Association at a February 1901 Good Roads Convention called by the Carleton County Council, it seems at Cowan's instigation. The decision recorded in the Council minutes referred first to a general public support for permanent roads as

\footnotetext{
54 "Goulbourne (sic) Has Set the Example," OVJ, January 11, 1901, 8.

55 "The Question of Good Roads," OVJ, June 15, 1900, 5; "Present Road System a Poor One," and "Our Road System Behind the Times," OVJ, November 13, 1900, 5, 8; "More Farmers Talk on Subject Good Roads," OVJ, November 23, 1900, 8.

56 "What Goulbourne (sic) Ratepayers Will Vote On," OVJ, December 11, 1900, 2; "The Good Roads Campaign in Goulbourn has Opened," OVJ, December 25, 1900, 8; "A Lively Discussion Regarding Statute Labor," $O V J$, December 28, 1900, 2 (appears to be a fictional conversation giving the two sides of the question).
} 
demonstrated in the Goulbourn commutation vote. It then commented that the rural Journal "with its usual progressiveness has at the request of influential ratepayers of the County made arrangements with Provincial Road Instructor Campbell for a meeting or series of meetings." The Council therefore resolved to call a Good Roads Convention "in conjunction with the Journal and others interested" in the question. ${ }^{57}$ The city Ottawa Evening Journal carried short pieces on the event which was held in Ottawa but the rural Journal gave it detailed full page coverage. As well, the rural edition emphasized that the Convention was a joint effort between the Council and the Ottawa Valley Journal.

Cowan had picked up on the idea, raised it with the Council, became very much involved and then gave himself and his newspaper the credit for taking the lead on a rural improvement project. In this case, he wrote to municipal politicians to seek their support for a convention and he did much of the organizational work. Cowan seems to have worked on the same lines as he was doing at that time with respect to expert judges and fair circuits (see Chapter 6), by arranging a select meeting of responsible parties. The result in this case was a meeting of township politicians and officials followed by the formation of the Eastern Ontario Good Roads Association. The Ottawa Valley Journal was named as its official organ and Cowan became its secretary. ${ }^{58}$

\footnotetext{
${ }^{57}$ City of Ottawa Archives, Carleton Council Minutes, January 22, 1901.

58 "Will Hold Good Roads Convention," OVJ, January 25, 1901, 10 (this is a much-expanded version of a short news piece carried in the daily under the same title, OEJ, January 22, 1901, 6). Articles only found in the Ottawa Valley Journal - "The Good Roads Convention Will be an Important Affair," February 1, 1901, 2; "Mr. Wood, ex.M.P.P. Will Speak," February 5, 1901, 7; "Big Event in the Good Roads Movement," and "Progress That Has Been Made By The Good Roads Movement," February 12, 1901, 1, 8; "Campaign for Good Roads in Eastern Ontario has Begun in Earnest," February 19, 1901, 1; The speeches were printed verbatim in the issues which followed "Morning Session of the Goods (sic) Roads Convention," February 22, 1901, 8; "Canada's Roads are Behind Those of Other Countries," February 26, 1901, 2; "Osgoode Township is in the Procession," and "A Township Which Commuted Statue Labor," March 1, 1901, 7, 8; "An Object Lesson for Local Counties in Road Making," March 5, 1901, 8; "The Good Roads Association Is Now Fully Organized," March 8, 1901, 1. Articles carried in the Ottawa Evening Journal - Good Roads Convention," February 11, 1901, 9; "Good Roads Convention," February 15, 1901, 9; "Hon. Frank Latchford's Important Statement," and "Good
} 
Cowan's next major project was to organize single-handedly the Eastern Ontario Good Roads Train which operated over the summers of 1901 and 1902. Cowan said he had read about an American Good Roads Train in a New York newspaper. But while the American project had been largely organized and paid for by the United States government, Cowan achieved a miniature version without government aid. Instead he persuaded companies to donate material and services. A Hamilton, Ontario manufacturer of road making machinery provided thousands of dollars worth of the newest equipment. The four rail companies operating in Eastern Ontario gave free transportation. Another company provided moulds and an expert to build and give lessons on the making of concrete culverts. Two cement companies were persuaded to provide thousands of dollars worth of cement to build the culverts. The importance of the partnerships Cowan made for this project is visible in the daily Journal. It had carried only short news items on the 1901 Convention which Cowan had helped organize. Reversing the usual pattern in which the rural copied material from the daily, the Ottawa Evening Journal re-printed from the rural edition all its material announcing the Good Roads Train, while pointing out that it was the work of the Ottawa Valley Journal. ${ }^{59}$

The Journal further used this Good Roads Train as self-promotion in the Ottawa Valley newspapers although in some cases the promotion was delayed. The Almonte Gazette carried the Good Train illustrations that had been published in the Ottawa Valley Journal in announcing its start on June 18, 1901. It only appeared, however, on November 15, 1901. On January 15, 1903, the Shawville Equity in West Quebec carried

Roads Officers," February 16, 1901, 3, 11.

59 “'Object Lesson in Making Good Roads," OEJ, May 18, 1901, 1 and $O V J$, May 21, 1901, 6; "Good Roads Train Coming," OEJ, May 22, 1901, 6 and OVJ, May 24, 1901, 6; "Full Particulars of the Arrangements That Have Been Made for the Good Roads Train," OVJ, June 18, 1901, 1, 8 (a shortened version was copied by the daily, "The Good Roads Train," OEJ, June 22, 1901, 11). 
Cowan's final report from the Journal issue of January 9, 1903. Both the Gazette and the Equity are carbon copies of the Journal illustrations suggesting that the Journal was distributing its stereotype plate. ${ }^{60}$ Dominion Livestock Commissioner F.W. Hodson recounted the story of the 1901-1902 Good Roads Train in the Shawville Equity in 1905 before going into detail on how the model roads were built. ${ }^{61}$

Cowan wrote at the time that, while he felt the Eastern Ontario Good Roads Association would support the project, he had done the organizational work and negotiations "as a representative of the Ottawa Valley Journal." Perhaps there were contractual issues involved. Perhaps Cowan wanted to move more quickly than he could hope to move if seeking at every step the approval of the municipal politicians who were the Association officers. Irrespective of his reason, he brought to the officers for approval what appears to have been a fully formed and resourced project. Then he had to get enough municipal governments on board the train he had started to make the project worthwhile. He asked the county and township councils to choose the road stretch they wanted improved and to agree to provide certain additional resources. Participating townships had to supply stone for the road material, workers and horses to do the work, and hardwood and water for the traction steam engine. The county councils had to provide money for wages and expenses.

Enough townships signed on that Cowan could announce that a mile of road in

\footnotetext{
${ }^{60}$ A stereotype in printing is a metal plate made from a mold of the set type. It obviates the need to reset type when reprinting as well as immediately freeing the type to be melted for the next stereotype.

${ }^{61}$ Almonte Gazette, November 15, 1901, 7; Shawville Equity from Bibliothèque et archives nationales du Québec http://collections.banq.qc.ca:8008/jrn03/equity/src/1903/01/15/01/83471_1903-01-15-01.pdf.

Accessed December 27, 2017; F.W. Hodson, "The Value of Good Roads," in Shawville Equity, December 14, 1905, 2 http://collections.banq.qc.ca:8008/jrn03/equity/src/1905/12/14/83471_1905-12-14.pdf.

Accessed December 27, 2017.
} 
twelve different counties would be completed in the summer of $1901 .{ }^{62}$ Unfortunately delays in starting, bad weather and poor local support in a few places meant that by October 1901 work had not been started in some counties and less than the planned mile had been completed in the others. Cowan got to work and managed to persuade all the companies involved to extend their commitment into the summer of 1902. At the end of that summer the project was declared a resounding success with eleven stretches of road from a half to four-fifths of a mile in length built in townships across eight counties with a few more stretches just being completed. ${ }^{63}$

Robert Faith took over as rural editor in January 1903 when Cowan left for new journalism opportunities in the United States. At this time the rural Journal's activism on roads subsided, perhaps because Cowan had taken the post of secretary of the Eastern Ontario Good Roads Association with him. One sign of the Journal's reduced interest is seen in the decidedly understated pre-publicity it gave the 1904 Eastern Ontario Good Roads Association convention. The first announcement for that meeting appeared only two weeks before it was held. ${ }^{64}$ In the years that followed the newspaper did continue to report on commutation discussions and on the efforts of the Carleton County Council to get funding for a county road system. ${ }^{65}$ But Faith did not comment or intervene further.

\footnotetext{
62 Good Roads Train Coming"; “Arrangements To Be Made For Proposed Good Roads Train,” OVJ, June 11, 1901, 8; "Full Particulars of the Arrangements That Have Been Made for the Good Roads Train." 63 "Has Gone Out of Business," OEJ, November 4, 1902, 2 and $O V J$, November 4, 1902, 8; "The Famous Good Roads Train of the Eastern Ontario Good Roads Association," OEJ, January 10, 1903, 13 (the spaces in the page's title banner where "Valley" and the day should appear have been blanked out suggesting the newspaper reused the layout used in the rural Journal the previous day) and OVJ, January 9, 1903, 9. 64 "Good Roads Convention," OVJ, March 1, 1904, 10.

${ }^{65}$ The process took several years. The rural Journal reported on the ongoing debate regarding the composition of an interconnected county road network, as each township insisted on its chosen roads receiving the provincial grant money. The internal fight for money may have led the newspaper to avoid that field of action.
} 
$\underline{\text { Taxes }(1907-1910)}$

As described in Chapter 5, Faith had started his own headline-creating initiatives in 1905 with the formation of the Eastern Ontario Fairs Association. He began what he would call an "agitation" around property taxes in April 1907 when a reader wrote that assessing farm land in February was unfair. The initial problem seemed simple. Property taxes consisted of the value of the land plus the value of improvements. "A.F.S." pointed out the obvious. In February the assessor was looking at fields covered with snow and therefore he guessed the value of the land based on what he could see-the buildings. “A.F.S." called this unfair because those buildings might have been forced out of poor land by the farmer's hard labour. Faith invited readers to begin a public discussion on the issue, and twice urged in later editions that more letters be sent. ${ }^{66}$ The letters came in for the next six months, most making the same points. ${ }^{67}$ First the writers agreed that assessing land quality in February was unfair. The townships should instead assess every second or third year while paying a little more to entice a local farmer to do the work sometime between April and June (assessors were often local farmers). But the letters raised a second issue respecting what kind of property should be taxed. This required a change to Ontario's Assessment Act. Readers had opinions as to the two main optionsland and improvements or land alone. ${ }^{68}$

The shift from being a public forum to leading a mass movement came, apparently, at the initiative of a reader. In May, after a month of the Journal publishing

\footnotetext{
66 "Letters to the Editor," A.F.S., Stormont County, OVJ, April 5, 1907, 12;" Assessment Of Farm Property," OVJ, April 19, 1907, 12 and OVJ, April 30, 1907, 10.

${ }^{67}$ A sample of letters published in the OVJ follows: W.H. Latourell of Carleton County, April 19, 1907, 12; J.B. Ross of Renfrew, April 30, 1907, 10; A.H. Foster, Twin Elm, and "Manitoba Reader," Pulmas, Manitoba, June 25, 1907, 10; John E. Rice, Lanark County, June 28, 1907, 12; “They Are Still At It," July 5, 1907, 12; Nap. Longtin, the Brook, July 16, 1907, 10; Alex Fraser, Stormont County, August 9, 1907, 12; "The Square Deal," October 29, 1907, 10.

68 “Assessment of Farm Property," OVJ, April 16, 1907, 10; April 19, 1907, 12; April 30, 1907, 10.
} 
letters, one reader wrote that it was time farmers moved from discussion to action. He asked those who agreed with him to send a card to the editor saying they wished to meet on the issue. If "Mr. Faith" decided there was enough interest, he could make the arrangements, a proposal to which Faith agreed. ${ }^{69}$ A week later Faith printed extracts from the letters of six of a "number of progressive farmers" who had written to say they would attend. ${ }^{70}$ How many "progressive farmers" in total wrote is not addressed in the article. Faith continued to ask for letters of support while advertising the meeting heavily, saying that politicians would listen only if the farmers showed the tax assessment issue was important by attending in large numbers. ${ }^{71}$ In the end, about five hundred interested persons attended the June 12, 1907 meeting. The meeting voted to form a Farmers' Municipal Rights Association made up of the wardens, reeves and deputy reeves of Eastern Ontario with Faith as secretary. The new officers agreed that their first task was the presentation of the meeting's resolutions to the Ontario legislature. ${ }^{72}$ And at this point everything went into slow motion.

The Association officers set a date in September to meet in Ottawa at the Central Canada Exhibition. In the meantime they agreed to ask every council in Eastern Ontario to endorse the June meeting's resolutions. ${ }^{73}$ Faith was the main and perhaps sole actor on the issue through the summer of 1907 having volunteered at the June meeting to consult

\footnotetext{
69 "Farmers' Big Convention To Discuss Municipal Rights," OVJ, May 24, 1907, 12. It is possible Robert Faith planted this letter although it would have been an unusual way of proceeding for the Journal, at least as conducted by Herbert Cowan. Cowan would say he had been talking to farmers and had been asked to do such and such and here are the letters in support. That is not how this letter was presented.

70 "The Farmers Convention," OVJ, May 31, 1907, 12.

71 "Letter to the Editor" James Clark, Glengarry County, OVJ, May 28, 1907, 10; “The Farmers' Convention" and "Big Convention of Farmers Will Be Held In The City Hall, Ottawa, Wednesday, June 12th," OVJ, June 4, 1907, 7, 10; "Last Call For Farmers Convention To Discuss Assessment Of Farm Lands," OVJ, June 7, 1907, 12; "Special Railway Rates To Farmers' Convention," OVJ, June 11, 190710.

${ }^{72}$ Farmers' Convention Greater Success Than Was Anticipated By Promoters," OVJ, June 14, 1907, 1. (The rural Journal devoted all of its front page to this item. The city edition shortened the item into two and a half columns, "Farmers Form Association," OEJ, June 13, 1907, 12.)

${ }^{73}$ Ibid.
} 
all the county councils. He attended their meetings and he asked the newspaper's readers to tell their municipal representatives to give the necessary endorsement. ${ }^{74}$ In this process he was attacked by Carleton County Councilor Caleb Hardy. Hardy said that the tax issue was nothing more than a newspaper circulation scheme and that farmers should trust their representatives on Council to resolve issues for them without the Journal's intervention.

The Journal later reported that Hardy had accused the Good Roads candidate in Gloucester Township "of being a tool of the Ottawa Valley Journal to further the aims of the Municipal Rights Association, an organization formed by that paper., ${ }^{, 75}$ There was likely more to Hardy's animosity than who should speak for farmers. Hardy was a member of the Ottawa Cheese Board which Faith was accusing at that same time of cheating producers (discussed in Chapter 8).

In 1908 the subject of property taxes disappeared from the pages of the Ottawa Valley Journal. The municipal reeves and councillors who were the officers of the Municipal Rights Association should have been finalizing the text of the memorial that would bring the June 1907 resolutions to the provincial government. Perhaps they were working behind the scenes and the rural Journal did not report on the progress as it was not yet "news." I consider it very possible that nothing was happening since the draft memorial printed in the newspaper when it finally started moving forward in February 1909 was essentially what the newspaper had printed in December $1907 .{ }^{76}$ Nevertheless Faith invited readers to comment on the draft memorial as well as on a meeting of the

\footnotetext{
74 "Farmers Convention Greater Success Than Was Anticipated By Promoters"; "They Are Still At It," OVJ, July 5, 1907, 12; "They Desire Law Changed," OVJ, September 20, 1907, 1.

75 "Deputy Reeve Hardy's Opposition Crushed Again," OVJ, December 20, 1907, 12; "Your Taxes Mr. Farmer," OVJ, December 24, 1907, 10; "Taxes Are Too High Great Cry of Farmers," OVJ. December 27, 1907, 12; "Township Nominations," OVJ, January 3, 1908, 7.

${ }^{76}$ Compare "Taxes Are Too High Great Cry of Farmers," OVJ, December 27, 1907, 12 and "Resolutions Ready for the Legislature," OVJ, February 16, 1909, 12.
} 
Association. He also published a letter from the Dominion Grange promising cooperation when the resolutions were presented along with a letter from the Single Tax Association in Toronto asking for cooperation on their resolution (seeking legislation giving municipalities flexibility to allocate property tax assessments between land and improvements as they saw fit). Finally, in March 1909, Faith was one of a delegation of forty-three who presented the memorial and the June 1907 resolutions to the Ontario Government. ${ }^{77}$ In May 1909 the Journal reported that the Ontario Government had appointed a special committee to investigate property assessment. ${ }^{78}$ The resolutions then seemed to have suffered death by committee as the Journal reported nothing further either on them or on the Association.

Throughout the farm taxation campaign the Ottawa Evening Journal had largely ignored the discussions in the rural Journal. When it reported on a meeting in 1910 of the Farmers' Municipal Rights Association with local MPPs it correctly listed the resolutions but ascribed them to the Eastern Ontario Fairs Association. ${ }^{79}$ By contrast it gave full coverage later to Ottawa politicians who were seeking to introduce a single tax motion into the Ontario legislature. ${ }^{80}$ The issue of farm property had been superseded by the urban. The one small editorial mentioning rural interest in property taxes appears not to have been paying attention to the rural Journal's activities. In 1911, only two years after Faith had been part of the Ottawa Valley municipal delegation to the Ontario legislature, an editorial in the daily asked why rural politicians were not "clamoring for the land tax

\footnotetext{
77 "Taxation of Farm Lands," OVJ, January 29, 1909, 12; "Carleton County Council Endorse All Resolutions," OVJ, February 2, 1909, 12; "Resolutions Ready For The Legislature," OVJ, February 16, 1909, 12; "A Strong Deputation," OVJ, March 12, 1909, 12.

78 "Taxation of Farm Property," OVJ, May 28, 1909, 12.

79 "Resolutions of Fairs Association," OEJ, February 13, 1909, 19.

80 “Assessment Amendment," OEJ, March 10, 1910, 3 and $O V J$, March 11, 1910, 4.
} 
assessment law" as the city politicians were doing. The editorial went on that it was not clear what rural Ontario thought on the subject and that "missionary work" was needed. ${ }^{81}$

\section{The City Triumphs: Good Roads Phase II (1913-1919)}

With Faith showing little interest in a rural Good Roads campaign, after 1903 the rural Journal simply published news and informational material on Good Roads taken from the daily, and the news from the city was inter-city highways. Yet the daily still could make a pitch in a 1914 editorial for local municipalities to improve their county roads. The editorial claimed that this would allow "farmers and residents in rural communities to get into closer touch with towns and cities; to permit the farmer to market his produce in larger quantities and at greater distances, and generally to bring about a closer relationship between rural and urban life.” Improving the county roads would, once they linked up, create the through highways that the cities wanted while giving immediate benefits to farmers. ${ }^{82}$ This one editorial, however, does not alter the fact that the road issue was now an urban issue. In 1909 one rural reader noted the negative impact of the Ontario government encouraging county road systems to connect towns and cities. The reader stated that rural taxpayers were forced "to build and maintain a road of that kind for the benefit of tourists and pleasure-seekers, while the man that bears the burden in other parts of the township must wade through mud axle-deep in order to reach a cheese factory, store or post office. ${ }^{, 3}$ In general, however, the rural Journal did not publish many letters on roads in these years.

The second road improvement campaign listed in the sales pamphlet, the Ottawa-

\footnotetext{
81 "Farmers And The Land Tax," OEJ, May 11, 1911, 6 and $O V J$, May 12, 1911, 6.

82 "As To Good Roads," OEJ, March 20, 1914, 6 and $O V J$, March 24, 1914, 4.

${ }^{83}$ Letter to the Editor, "Observer" of Grenville County, OVJ, November 30, 1909, 12.
} 
Prescott Highway (today's Highway 16 and Highway 416), began just immediately before the First World War but did not a result in a completed highway until after the war. It is difficult to give credence to the Ottawa Farm Journal's claim in its sales pamphlet to have assisted actively in this work. It started in the city in October 1913 when former Ottawa mayor Charles Hopewell, representing the Ottawa Valley Motor Car Association, appeared before Ontario's Public Roads and Highways Commission to present the case for the Ottawa-Prescott highway. Hopewell's point was that American tourists were bringing their cars and their dollars across the St. Lawrence River but did not continue to Ottawa because of poor roads. His sales pitch was followed by years of delegations and lobbying all of which the Ottawa Evening Journal reported and which the Ottawa Valley Journal copied without adding a rural slant or comment. ${ }^{84}$

Much the same happened with the pamphlet's third road improvement claim, that the country edition of the Journal had inserted rural elements into the agenda of the fourth annual Dominion Good Roads Congress in Ottawa in April 1917. Both the rural and the city Journal carried pre-advertising for the Congress and then closely reported on its proceedings. The rural Journal emphasized that the planned program had a strong rural content and would be interesting and non-technical for all, including the lone session on "rural road problems." The newspaper also stressed that the President of the Dominion Good Roads Association wanted to talk to farmers about the benefits of good roads ${ }^{85}$ But the welcome on the front page of the April 6 Ottawa Farm Journal refers in

\footnotetext{
84 "New Road Needed for Common Good," OEJ, October 29, 1913, 12 and OVJ October 31, 1913, 1, 6; "Highway From Ottawa To St. Lawrence River Will Be Built By 1915," OEJ, June 25, 1914, 1 and OVJ, June 26, 1914, 1; "Road to Prescott," OEJ, April 20, 1915, 2 and OVJ, April 23, 1915, 2; "Prominent Men Launch Effort For Prescott Rd." OEJ, July 10, 1917, 12 and Ottawa Farm Journal (hereafter OFJ), July 13, 1917, 5; "Ottawa-Prescott Road Now Provincial Highway," OEJ, June 191, 1918, 5 and $O F J$, June 21, $1918,4$.

85 "Roads Congress Is Sure To Be Success," OEJ, March 3, 1917, 28 and OFJ, March 6, 1917, 5; "Roads
} 
several places to "Journal newspapers" with both newspapers presented as having been for some time "in the vanguard of the good roads movement." ${ }^{" 86}$ The pamphlet claimed, however, that the rural Journal had been an active player in inserting rural issues into the conference. It is possible the newspaper was more involved in the Congress than appears in its pages but a discreet modesty seems out of character.

The extent to which roads had ceased to be a matter of special concern to the rural Journal is exemplified in the reporting on the second coming of the Eastern Ontario Good Roads Association. The first Association seems to have quietly disappeared in the early 1900s and a new association was formed in July 1918. Both the rural and the daily Journal announced the upcoming meeting to form the association as being of particular interest to the surrounding rural municipalities. ${ }^{87}$ Yet the Journal reporter writing up the actual meeting in the daily either suffered from amnesia or had not talked to rural Journal staff who might have remembered the earlier Association and its close connection with the newspaper. In fact only one delegate remembered that Good Roads had a history and even his memory was limited. E. Proulx, M.P. for Prescott, commented that there had been an Ontario Good Roads Association in the past but an organization specifically for Eastern Ontario would help shift the provincial government's attention from Western to Eastern Ontario.

The meeting itself appears to have been urban-driven, unlike the original Eastern Ontario Good Roads Association of 1901. The 1918 list of delegates and report of

Congress Aims To Rouse Rural Interest," $O E J$, March 17, 18917, 1, 4 and $O F J$, March 20, 1917, 3; “Good Roads Congress An Appeal To Farmers," OEJ, March 28, 1917, 14 and OFJ, March 30, 1917, 6.

86 "Good Roads Congress and Highways Number," OFJ, April 6, 1917, 1, 13. The city edition carried the highways articles in its Saturday edition, OEJ, April 7, 1917, 17-21.

87 "Is Lively Interest In Meeting To Form Roads' Association," OEJ, July 2, 1918, 1 and $O F J$, July 2, 1918, 8. 
speeches and motions shows that Ottawa municipal politicians were prominent. This was despite Valley politicians being present and being made officials in the new organization. Alderman Findlay of Ottawa was voted in as president while an ex-Mayor of Ottawa (Fred Cook), a current Ottawa Controller, and a mix of sitting and ex-Ottawa Aldermen were highlighted in reporting the proceedings. Further underlining that the rural Journal was no longer leading on the Good Roads issue, the new Association's newspaper committee included only one delegate from the Journal: "J.S. Crate of The Journal newspapers. ${ }^{188}$ Crate is found in the 1915 City of Ottawa Directory as managing editor of the Journal Printing Company and continued to be listed as a daily Journal editor until his sudden death in $1927 .{ }^{89}$ Rural roads had been pushed to the side by city interests.

\section{All the Talk: Progress in Machinery versus Ownership through Labour}

Cowan was leading what can be called a one-way urban to rural conversation on modernizing road work. He wrote on the progress exemplified by modern road machinery and printed letters from municipal leaders who agreed with him. It is difficult to determine what ordinary farmers thought of the road machinery as we have almost no letters expressing a view on the subject. The conversation seen in the statute labour campaign gives a better picture of the range of views in Eastern Ontario as Cowan published both enthusiastic letters from officials and more cautious letters from ordinary rate payers. A competitor to the rural Journal for the agricultural audience, the Farmer's Advocate, also emphasized the need to build better roads, but it showed more insight than

\footnotetext{
88 "Eastern Ontario Good Roads Association Formed," OEJ, July 9, 1918, 9 and OFJ, July 12, 1918, 10. At this time both the city and the rural editions pluralized references to themselves.

${ }^{89}$ The Ottawa City Directory 1915, (Ottawa: Might Directory), 342; Beechwood Cemetery Register (19211954), Interment 21973. Crate was a career newspaperman who had been news editor with Toronto Star in 1914 (Toronto City Directory 1914, p. 670.)
} 
the Journal into the farmers' interests and concerns about cost. As in Cowan's statute labour campaign, Faith was seeking changes to how the farmer interacted with local government. But the goals of the property tax campaign were not as intrusive as Cowan's aims; that is, Faith was not intruding on the countryside with urban ideas. His campaign relied wholly on letters from readers. These letters made explicit the farmers' views regarding the relationship between labour and ownership.

\section{Roads and the Modernity of Machinery}

In 1902 the Advocate carried an article by Ontario Commissioner of Highways A.W. Campbell saying that farmers were interested in road reform. ${ }^{90}$ He stated that the challenge was persuading farmers that reform would not cost them more. ${ }^{91}$ The solution offered by Campbell and the editors of the Ottawa Valley Journal and the Farmer's Advocate was modern machinery operated with the latest engineering knowledge to build cost-effective roads. Thus Cowan's reporting of the Eastern Ontario Good Roads Train stressed the modernity and efficiency of the machinery at work.

Historian Robert Craig Brown suggests that Campbell's interest in Good Roads was partially driven by the economic benefits of improved roads but also by his interest in advancing the professionalization of road engineering. ${ }^{92}$ Certainly he was a constant advocate of ending statute labour with its dependence on "laymen" as road builders. $\mathrm{He}$ was also a major player in disseminating in Canada the dominant understanding of Good Roads, good road building and municipal and government responsibilities. But while his

\footnotetext{
${ }^{90}$ We have met Campbell earlier in this chapter as the professional civil engineer who made improving Ontario's roads his career.

${ }^{91}$ A.W. Campbell, "Road Reform in Ontario," FA. September 1, 1902, 632-3.

${ }^{92}$ Robert Craig Brown, "Campbell, Archibald William," in Dictionary of Canadian Biography, volume 15, 1921-1930 (University of Toronto/Université Laval, 2003-2018.)

http://www.biographi.ca/en/bio/campbell_archibald_william_15E.html. Accessed November 16, 2016.
} 
pulpit as the Good Roads editor in Municipal World allowed him to preach to municipal authorities, persuading ratepayers required a regular round of Farm Institute talks and other personal appearances at meetings across the province. The newspapers and farm journals were also important for broadcasting Campbell's arguments against statute labour and for building good roads using modern machinery.

Cowan's take-up of Campbell's road message and the publicity he gave it in the Good Roads Train project of 1901 and 1902 was particularly effective for the way it conveyed the importance of machinery. When Cowan described the first project of roadbuilding carried out in Gananoque he wrote that the work of the machinery had been "simply wonderful." The traction engine pulled the road grader "as straight as an arrow while the grader shaped up the earth as if it had been moist instead of being baked and dry." The scraper went to work the next day and its work was also declared to have been "wonderful," scraping an area of one square yard in every trip with just one team of horses. ${ }^{93}$ In all the reports that followed for each succeeding stretch of road work, Cowan stressed that the onlookers were "amazed" by the road work machines. In announcing the restart of the road train in 1902 the Journal added that all those who came to see the roads work should bring picnics. ${ }^{94}$ Road-building had become spectacle but the best kind of nineteenth-century spectacle. It was useful spectacle in which observation directed by experts would result in up-to-date knowledge. ${ }^{95}$

\footnotetext{
93 "What Good Roads Train Has Done at Gananoque." The machinery included a stone crusher which used an elevator to lift the crushed stone into wagons while the wagons were manufactured to drop the stone evenly across the roadway as the driver opened the wagon bottom with a lever while driving along the prepared road-bed.

94 "Will Hold Picnics," OVJ, April 8, 1902, 8; “A Good Roads Picnic Held At Plantagenet," OVJ, June 13, 1902, 10; "Bad Piece of Road Made Good," OVJ, July 22, 1902, 8; "Many Advocate Good Roads," OVJ, August 12, 1902, 5.

${ }_{95}$ There is an entire field of study studying spectacle as performance merging respectable learning, visual excitement and sometimes transgressive frisson ranging from studies of Chicago's 1893 Columbian
} 
Cowan's rhetoric on modern road machinery emphasized efficiency. What is missing is a presentation of either machinery operators or the machinery itself as masculine. Catharine Wilson finds in her study of Ontario ploughing matches that they were at all times displays of masculinity but the nature of that masculinity changed with technology as well as with changes in the official discourse on the nature of agriculture. In nineteenth-century matches the competition with the walking plough was a display of a man's strength and stamina and judging looked at the regularity and neatness of the furrows produced. By 1920 the matches involved ploughing with a tractor and the standard on which contestants were judged was the number of acres ploughed in the time allotted. It was still a display of masculinity but the organizers, who were often government officials, were teaching agriculture as business, and efficiency as the mark of the modern farmer. They were echoed in this message by the farm press reporting on the matches. The press described the men as operators and their masculinity in terms of their management of the machine to the point of being able to know by listening how best to work it. ${ }^{96}$ Cowan's rhetoric resembled what Wilson found with respect to the 1920 ploughing matches' emphasis on modern, efficient business but with a difference. He did not tell farm men that working the road machinery would display their masculinity. There was no need to, for he did not expect them to be the operators. Just as the machine operators on the Good Roads Trains were specialists hired for the work, Cowan expected that ratepayers would replace their own labour with specialized municipal workers. The

\footnotetext{
Exhibition to the freakery of the traveling sideshow. For examples of various approaches to the study see Tony Bennett, "The Exhibitionary Complex," in New Formations. 4 (Spring 1988): 73-102; Peter Stallybrass and Allon White, The Politics and Poetics of Transgression (London: Methuen 1986); Elizabeth Grosz, "Intolerable Ambiguity: Freaks as/at the Limit," Freakery: Cultural Spectacles of the Extraordinary Body ed. Rosemarie Garland Thomson (New York: New York University Press 1996).

${ }^{96}$ Catharine Anne Wilson, “ A Manly Art: Plowing, Plowing Matches, and Rural Masculinity in Ontario, 1800-1930," Canadian Historical Review 95, no. 2 (June 2014).
} 
farm men attending the Good Roads Train events were simply spectators.

Awakening interest in modern road machinery was presented as the major good effect of the train: "When it is remembered that the residents of the township would not hear of the idea of buying machinery before the good roads train visited their section, considering that the old methods of road construction were quite good enough, it will be seen good work has been done by the Good Roads Association.. ${ }^{97}$ A long set of headlines made the same point: "An Object Lesson Afforded / By means of the good roads train the farmers of every county have been given an opportunity to see just what road machinery can do in the way of improving a road, and have also been shown just how good a road it is possible to make by means of modern implements." ${ }^{, 98}$ This theme of the value of modern machinery was repeated in the President's report at the 1903 Eastern Ontario Good Roads Convention. The President boasted that two years before farmers knew very little "about modern methods of road construction" and were very much against changes. But the Good Roads Train had shown people what "modern machinery" can do."

As seen in Cowan's introduction of the expert judge system in the agricultural fair (Chapter 6), he saw the importance of expert knowledge and was determined to address what he saw as its lack in the countryside. He quoted the Roads Train works manager, Major James Sheppard, that farmers needed to defer to experts: "There is a science in road making as about most other matters. ${ }^{100}$ Cowan seems to have used expert knowledge as a rhetorical tool, even a marker or guarantee of quality. Thus Cowan

\footnotetext{
97 “A Good Roads Picnic Held At Plantagenet," OVJ, June 13, 1902, 10.

98 "The Famous Good Roads Train of the Eastern Ontario Good Roads Association," OVJ, January 9, 1903, 9.

99 "Good Roads Convention Is In Full Swing," OVJ, March 13, 1903, 1; "Dominion Government Will be Asked to Establish a Good Roads Division," OVJ, March 17, 1903, 8.

100 “A Good Roads Picnic Held At Plantagenet,” OVJ, June 13, 1902, 10.
} 
faithfully presented what Campbell said to ratepayers at the Gananoque stop of the Good Roads Train, pointing out in the text and showing in the illustration (figure 7.2) that Campbell had worked the grader himself. ${ }^{101}$ The newspaper reported that he even showed Gananoque workers that "a shovel can be used in a scientific manner." ${ }^{, 102}$ Campbell was to be respected for doing and not just talking.

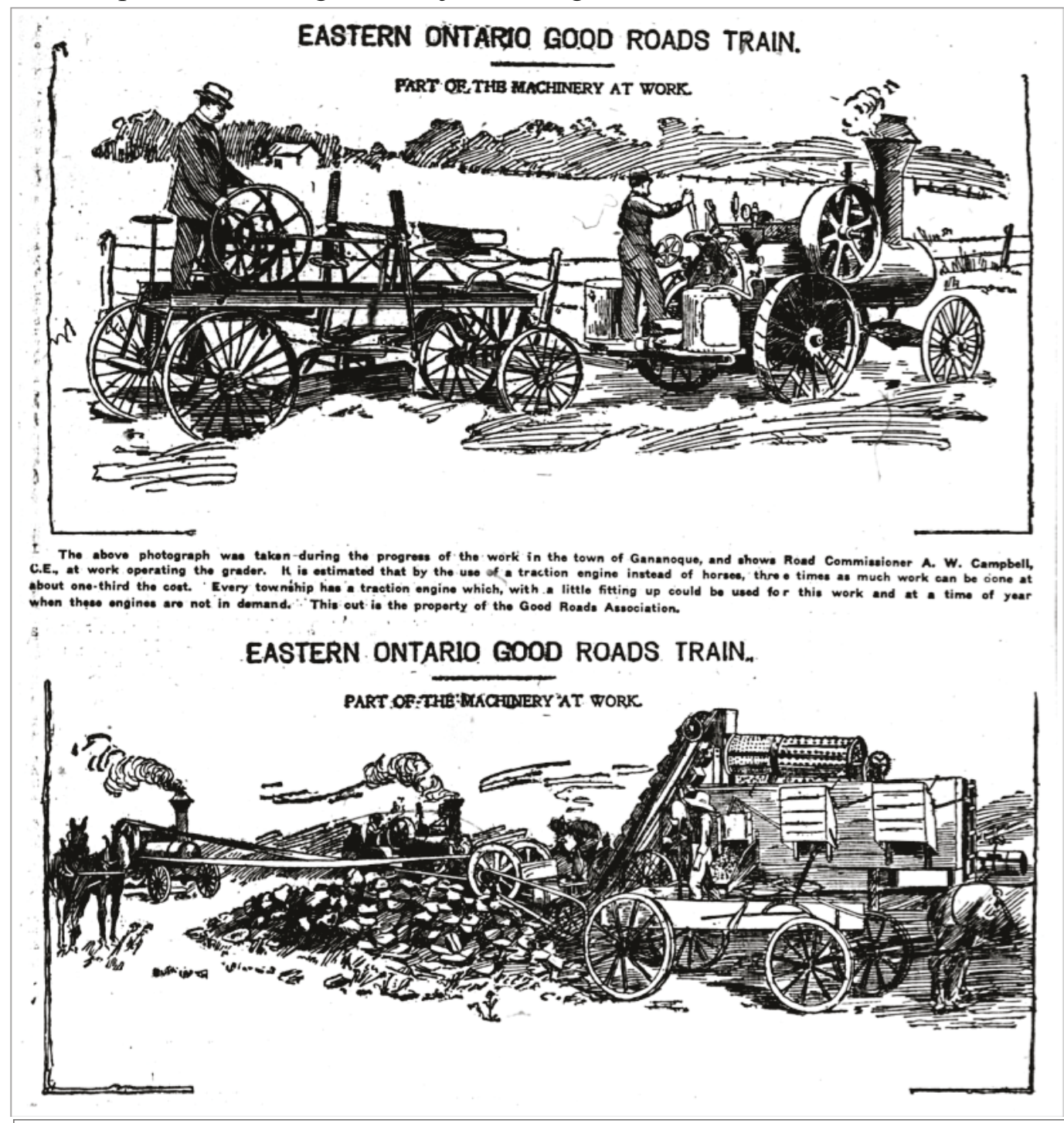

Fig. 7.2. Ottawa Valley Journal, August 13, 1901, 10.

The imagery of machinery carried by the Ottawa Valley Journal included the picture of civil engineer A.W. Campbell dressed in a city suit but doing the practical work of road building.

\footnotetext{
101 "Eastern Ontario Good Roads Train," OVJ, August 13, 1901, 10.

102 "What Good Roads Train Has Done at Gananoque," OVJ, July 26, 1901, 8
} 
Road improvement was the subject of newspaper advice on what farm communities ought to do to bring their public spaces up to city standards. The rural Journal's advice assumed the display of modern machinery would be sufficient to persuade all those who came out with their picnic baskets to see the sight of modernity at work. But costs remained an issue for the ratepayers who had to invest either cash or their own labour and time for better roads. The Farmer's Advocate recognized and took this into consideration to a greater degree than the Journal.

\section{Rural Resistance: Modern Machinery Was Not Enough}

Cowan declared his machinery demonstrations a great success in drawing crowds, but persuading farmers to pay for modern machinery was a different question. He solicited and printed letters on the road work but all these came from township officials. It appears that no matter how amazed ratepayers were, they were not so amazed as to write a letter. Even a success story, as told to Cowan by Gananoque Councillors, was apparently not winning hearts and minds. They had persuaded the Council to buy the county's first stone crusher in the face of opposition from other Councillors. Now, Cowan's interlocutors said, the county had many happy farmers. Yet these Councillors still found it difficult to get ratepayers to pay for "more up-to-date methods."103

Cowan had assumed that upon commutation townships would issue a debenture (or an unsecured bond) to borrow the $\$ 4,400$ cost of a complete set of road-making equipment. He estimated this would only raise the average ratepayers' taxes by a dollar. ${ }^{104}$ When the work overseer, Major James Sheppard, spoke at the closing meetings

\footnotetext{
103 "Good Roads Train is Now At Work," OVJ, July 12, 1901, 8; "Now At Work In Gananoque," OVJ, July 23, 1901, 1; "What Good Roads Train Has Done at Gananoque," OVJ, July 26, 1901, 8.

104 "The Commutation of Statute Labor in Goulbourne (sic) Township," OVJ, December 10, $1901,1$.
} 
of the work in Carp he estimated the cost of a road, such as the one just built, at $\$ 500$ to $\$ 1,000$ per mile. ${ }^{105}$ When Cowan made his final report on the Good Roads Train, he calculated its cost at about $\$ 882$ per mile of improved road. This did not include the wages for the specialized machinery operators but, offsetting this, Cowan pointed out that councils had selected their worst roads for the work. ${ }^{106}$ These figures, whether $\$ 500$ per mile or $\$ 882$ per mile would have seemed momentous to the farm families of Eastern Ontario, even with the Province potentially paying a third of the cost — and the government grant only applied if their roads qualified as a county road. Cowan also did not address the issues of centralized township management and the increased costs over and above the legislatively-set commutation rate that would be incurred once commutation replaced the system of pathmasters and farmers working "their beat." Because the Journal retreated from extensive Good Roads commentary after 1903 it is difficult to know whether Faith, as the new editor, realized that the road-making demonstrations had not dented farmers' conviction that they were being asked to pay too much for too few benefits. Perhaps he shared the farmers' perspective.

Like the Journal, the Farmer's Advocate began its road work with a campaign against statute labour. But it did not take on a whole township as Cowan had done in 1900 and $1901 .^{107}$ Instead the Advocate editors wrote articles arguing that local farmer knowledge of how to build a good road was out-of-date and inadequate. Perhaps the Advocate editors had more life experience than Cowan for, unlike his ignoring the question of how the roads would be maintained after commutation, they made it clear that

\footnotetext{
105 "Prominent Men At Carp, OVJ, July 4, 1902, 10.

106 "The Famous Good Roads Train of the Eastern Ontario Good Roads Association," OVJ.

${ }^{107}$ The eastern edition of the Farmer's Advocate for 1903 and 1904 (January to May) is missing from the Agriculture Canada microfilm so analysis is limited to 1900 to 1902 and June 1904 to 1920.
} 
it was not enough simply to commute statute labour. The old system had to be replaced with a modern system of road management in which townships used "expert direction" to plan and manage road work. Good roadwork was "done by contract and under the supervision of a competent civil engineer."108

This is not what happened. The Advocate saw statute labour replaced with poor management, poor controls and no planning. It found itself arguing that intelligent use of even old-fashioned machinery would be an improvement over current work. In 1905 it presented a case where proper use of "the old-fashioned road scraper" meant a township need not feel it ought to use the expensive machinery it had bought on all jobs. By 1906 it was printing letters from readers writing about their regret for having voted for commutation. ${ }^{109}$ In 1907 it pointed to townships that used expensive graders intended for road construction for everyday maintenance, wasting the grader and destroying the road. ${ }^{110}$ In the same period the Advocate began to write about a low-technology alternative from the United States: D. Ward King's split-log drag (see Figure 7.3).

King had first promoted his drag in 1904 and 1905 on one of the American Good Roads Trains. The log drag was not the kind of heavy machinery Cowan had extolled in his reports on the Eastern Ontario Good Roads Train. It was something any farmer could put together and make work from local materials and could be understood within local knowledge. The Advocate was quick to see that the drag was interesting, calling it the "modern substitute" for the "old-fashioned leveler." and it was equally quick to

\footnotetext{
${ }^{108}$ Untitled comment, FA, June 15, 1901, 400; "Road Improvement," FA, June 30, 1904, 917-8; "How Not to Make Roads," FA, May 10, 1906, 765.

109 "Wanted Good Roads, FA, March 15, 1906, 397; "How Not to Make Roads," FA, May 10, 1906, 765; for an example of readers regretting commutation see "How to Improve the Roads, John Lawson of Middlesex County to Editor, $F A$, May 31, 1906, 885.

110 “The Old-Fashioned Scraper," FA, April 27, 1905, 625.
} 


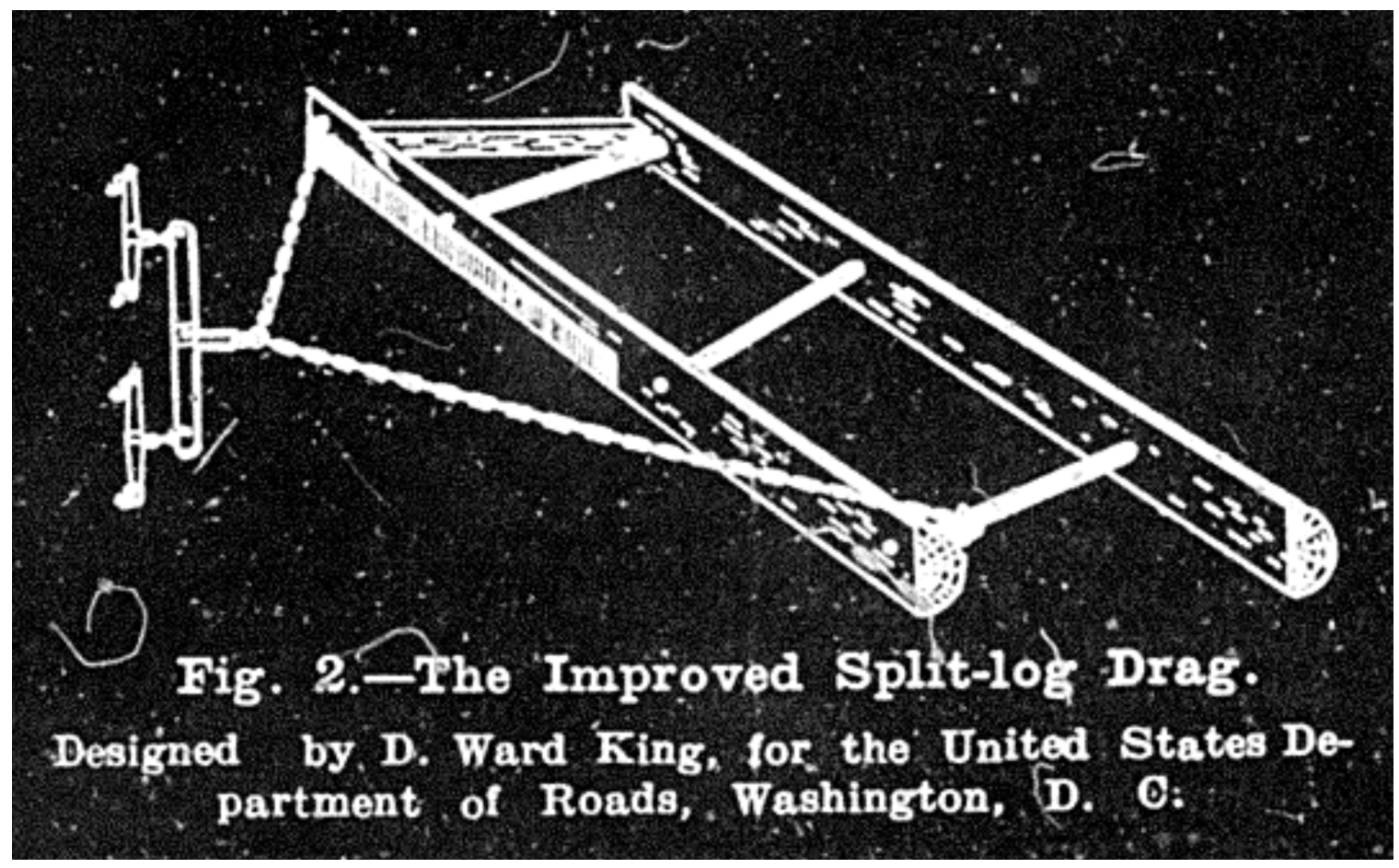

Fig. 7.3. Split-Lot Drag, Farmer's Advocate, April 2, 1908, 597.

King's drag was an improvement on existing log levelers. The first log broke up dirt clods while the second log smoothed out the broken clods to fill ruts and holes and create a smooth surface. By offsetting the two logs from each other, the drag pushed dirt into the centre of the road to create a crown which would shed water. It worked particularly well on roads still damp from the snow melt which meant it was best used before farmers became busy with the spring seeding.

investigate it seriously. The rural Journal, on the other hand, did not bring the split-log drag to the attention of its readers until 1909 and then only in a reprint of a report by the State Engineer of New York. Four years later, in 1913, it reprinted another American bulletin giving information on the drag. ${ }^{111}$ By contrast, in 1906 the Advocate writer described what he had read about the drag and asked whether any of the readers had

\footnotetext{
111 "How to Make Good Roads," OVJ, June 1, 1909, 6; "How to Improve Country Roads," OVJ, July 25, 1913, 13 .
} 
experience with it. ${ }^{112}$ It seems Canadian farmers had not worked with King's drag for no letters were published. This led the Advocate to encourage a Canadian learning process.

In 1907 the Advocate announced a contest with substantial cash prizes for farmers willing to use the drag for a season. Ontario’s Commissioner of Highways A.W. Campbell agreed to provide government judges to choose the best road sections for the prizes but the newspaper underlined that it wanted all the competitors to send in their assessment of how the drag had worked. The drag's contrast to Cowan's modern machinery is highlighted in the surprise of an Advocate reader at its recommendation which "savored of cutting grain with a sickle or threshing it with a flail."113

More than sixty farm men entered the competition, forty-three competing for the prize for the section west of Toronto and twenty for the prize offered to the section east. From the judges' evaluations and the competitors' comments, the Advocate concluded that the drag was effective in making good dirt roads. In other words, it was a tool for the back roads. While the editor and Campbell stated their preference for expert built and maintained crushed stone roads even on the back roads, they preferred a good dirt road maintained by statute labour and the split-log drag to a stone road maintained with misused expensive machinery and badly done township work. The Advocate emphasized, however, that even when using the drag and statute labour, municipalities still had to manage and plan the work using a "businesslike system.",114

Readers were intrigued by the possibilities of this technology. A reader from

\footnotetext{
112 "Dragging Muddy Clay Roads," FA, May 25, 1905, 777."Do Not Cover a Loam-surfaced Road with Clay," FA, May 17, 1906, 810. "How Not to Make Roads," FA, August 9, 1906, 1242; "Has Any Reader Tried a Split-log Drag," FA, October 18, 1906, 1625.

113 "The Split-log Brigade," FA, April 11, 1907, 615.

114 "Let Us Try The Split-Log Drag," FA, March 7, 1907, 385; "The Split-log Brigade"; "Drag the Roads in Autumn," FA, October 31, 1907, 1704; "The Split-Log Drag Competition," FA, December 12, 1904, 1932$3,1975$.
} 
Prince Edward Island wrote that he was so impressed by what he read in the Advocate about the split-log drag that he had built and used one the previous year. He ended by asking whether other users had tried altering the slant of the scraper. The editor replied that indeed one of the competitors had done so and then opined that "each piece of road and each drag should be studied and adapted by the operator."115 The competitors' comments were published in April 1908 and they tended to emphasize that the drag was simple to make, easy to use and effective. One letter remarked on the scoffers who had watched his progress all season and were in the end silenced. ${ }^{116}$ The Farmer's Advocate's competition did not create the spectacle of the Journal's Good Roads Train but it was more effective in sending its message. It allowed farm families to use experiential or tacit knowledge to determine for themselves how to maintain good dirt roads within the traditional framework of local statute labour. This put off for a while shifting control over road work away from the farmer amateur to the expert hired engineer. It was also used according to the farmer's own schedule on dirt roads, that is, the farmer's road on which he drove his horses and wagons. ${ }^{117}$ It was his tool for his roads. The Farmer's Advocate continued to write on the value of crushed stone roads and expert road workers but matched its efforts at persuasion with a practical suggestion which accepted the reality of the farmer's attitude about roads.

\section{Rural Resistance: At Least They Knew How Statute Labour Worked}

Letter writing on roads had begun in the rural Journal in 1901 even before Herbert Cowan powered up the Good Roads Train. At the beginning of the year he

\footnotetext{
115 A.A. Moore, Queen's Co., P.E.I. to Editor, FA, January 23, 1908, 120.

116 "What the Competitors Thought of the Split-log Drag," FA, April 2, 1908, 595-7.

117 “Turned Down By Council," OVJ, December 9, 1904, 1.
} 
invited readers to say what they thought about statute labour and commutation. Most of the published letters came from township officials who saw statute labour as antiquated and inefficient. As well, Cowan published a letter from a farmer, J. McDonald of Ormond, who said his township had "been trudging on this old way for the last fifty years" making it time to try something new. But there were other letters opposing commutation and most of these came from farmers. W. Bradley of Stittsville argued it would be hard on the poor farmers to have to pay road taxes in cash. Other writers were simply unsure that commutation would be an improvement. ${ }^{118}$ None argued for the current system as effective and efficient and none directly challenged Cowan's stated belief that commutation "almost invariably" led to better roads. ${ }^{119}$ But the question mark was there. "W.T.G." said it was not a problem of good roads versus bad roads but making good roads without sinking into debt. He specifically disagreed with A.W. Campbell that farmers opposed commutation because they were opposed to good roads. Rather rural residents were not convinced that commutation was the right solution given how little money a township could raise under it and how much a good road cost. His proposed solution was to shift the problem onto the province or the Dominion. Otherwise municipalities would be sunk in debt upgrading roads. ${ }^{120}$

Three other letter writers also offered counter suggestions to commutation. J.B. Long from Merivale wrote twice, presenting himself as an ordinary person taking a common-sense view. In the first letter he said he was still a boy and in the second that he was writing "in [his] own uneducated country way of writing." 121 His suggestion was

\footnotetext{
118 “Where Statute Labor Has Been Abolished," OVJ, December 8, 1900, 7.

119 "The Commutation of Statute Labor in Goulbourne (sic) Township," OVJ, December 10, $1901,1$.

120 “Letters from Subscribers," W.T.G., OVJ, March 26, 1901, 8.

${ }^{121}$ James Buchanan Long was a twenty-four year old farming on his own account and heading a household
} 
based on his experiential knowledge of work done in his section under the direction of good pathmasters. Statute labour would work if the local council did their job by insisting on good work and hiring, not experts, but simply good men who cared about doing a job right. In response Cowan questioned whether it was possible to have all hundred-plus township pathmasters do their job well but Long reiterated in the second letter that it could be done if council gave sufficient care and attention. ${ }^{122}$ Letters from John Callaghan of Manotick and Q.W. Morrison of Vars also pointed to a problem of enforcement. Callaghan, like Long, presented evidence from experience that statute labour could be made to work. His father as pathmaster had called out the men on his beat after a snowstorm and they had made the road passable in less than a day. He questioned whether as good a job would be done after commutation. Cowan simply replied that townships with commutation paid the farmers along the road to clear snow. Morrison wrote that councils managed their existing funds so poorly that the solution was to elect "an honourable council," get rid of pathmasters and road commissioners and apply pressure by fining farmers five dollars for not keeping the roads around their farms in good repair. ${ }^{123}$

Turning to the Good Roads Train, the newspaper carried numerous letters of congratulation but these were all from municipal officials. At the same time, the readiness to believe rumours circulating about the Train in 1901 and 1902 suggests that farm families were suspicious of the lesson being given. These rumours, that the Good

of himself and his sister. (Library and Archives Canada, Manuscript Census of Canada, 1901, Carleton County, Nepean Township E3, p. 10).

122 "With Certain Improvements Statute Labor System Is Alright," J.B. Long of Merivale to Editor, OVJ, January 8, 1901, 8; “Another Letter Favoring Stature Labor, ”J.B. Long, Merivale to Editor, OVJ, February 1,1901

123 “More About Statute Labor,” John Callaghan, Manotick, to Editor, OVJ, January 25, 1901, 10; “Another Letter Favoring Stature Labor,” Q.W. Morrison, Vars, to Editor, OVJ, March 26, 1901, 8. 
Roads Train was a vote-getting game put on by the governing Ontario Liberals or an "advertising dodge" for the companies involved, were persistent. ${ }^{124}$ Some farmers had thought the project involved building expensive hard-surface roads. Cowan quoted an Iroquois Township Councillor that the council had put the model road in the town because the farmers were opposed to the project thinking it would be a concrete road. When the farmers saw it was a packed gravel road costing half what they had heard, they were angry at their councillor for losing the opportunity to improve a road in their section. ${ }^{125}$ The farmers wanted the roads they knew and which they had experience in maintaining. The rumour of fancy urban roads resulted in a general rejection of road improvement as likely to be more than was necessary for their purposes.

\section{Farmers and their Labour}

Part of the problem in persuading farm families to pay more for roads was an attitude of ownership which was rooted in the labour the farmers had expended in building the roads fronting their farms. As discussed earlier, Hal Barron links the change in farmer attitude to the removal of the cost factor. As the various levels of government in the United States realized it was not possible for a township tax base to create the kind of infrastructure required to boost the economy, the tax burden was shifted up and thereby fell less heavily, as well as less visibly, on farmers. At the same time the introduction of license fees for motorists moved the system closer to user pay. But while active farmer resistance died down with these changes, farmers had new cause for resentment in the

\footnotetext{
124 "No Politics About the Good Roads Train," OVJ, August 27, 1901, 8; "The Good Roads Train," OVJ, May 13, 1902.

125 “The Good Roads Train At Work," OVJ, September 13, 1901, 1; “A Township Councillor," OVJ, September 13, 1901, 8 .
} 
emphasis on inter-city highways at the expense of the dirt back roads. ${ }^{126}$

In the first years of the century, Ontario farmers still thought of all country roads as theirs. In 1902 Campbell as Provincial Highways Commissioner wrote in the Advocate that part of the problem facing road reformers was farmers thought only about their own bit of road:

People engaged in keeping up their own piece of road had reached the conclusion that they had nothing to do with other sections ... They rarely thought that the other sections were of about as much importance to them as their own and, as a matter of municipal economy, it was their duty to see that in every section due importance was attached to the work and every [statute labour] day and every dollar spent should be spent to the best advantage. ${ }^{127}$

The perception of having "their own piece of road" contributed to the farm families' conviction that there was a mismatch between themselves paying for road maintenance and city automobilists using the roads. The result of only being concerned with the roads one saw was acrimony over outsiders using what one believed to be a private asset. Farm hostility was softening in this period as farmers saw that automobiles could be useful.

Nevertheless the Ottawa Valley Journal published a letter that questioned the claim that farmers would benefit from good roads:

Is a man going to give a big price for bad land because there is a fine house on it, or because there is a good road nearby? ... What about the roads off the main roads? Farmers want to get out from the back roads. The farmers are expected to pay their share, but receive no return. ... It is hard to keep good roads where automobiles are allowed to run. They do more damage in one week than the farmers do in three months. The farmers have to build and keep the roads in repair for the automobiles and take the ditch themselves. ${ }^{128}$

Farmers were also writing letters on property tax assessment and the Farmers'

\footnotetext{
${ }^{126}$ Barron, Mixed Harvest, 33-9, 76-7

${ }^{127}$ A.W. Campbell, "Road Reform in Ontario," FA. September 1, 1902, 632-3.

128 "Rural Roads in Carleton," Binnington of Carleton County to Editor, OVJ, September 14, 1909, 12.
} 
Municipal Rights Association, often stating a demand for "fairness" rather than raising closely-argued economic arguments. This demand for fairness was not caprice or a vague idea but the long-held economic theory of value and labour. ${ }^{129}$ The first letter which had sparked Robert Faith's interest appeared in the newspaper of April 5, 1907. It stressed that the current system taxed labour. ${ }^{130}$ A late October letter from "The Square Deal" argued that taxing improvements was unjust and pointed out that the Farmers' Association and the Grange were pursuing the same objective of removing taxes on improvements such that unimproved and improved land would be taxed the same, making it unprofitable to speculate by leaving land unimproved. In between two to three letters were printed almost every week repeating many of the same ideas. ${ }^{131}$

The Journal received several letters from "Manitoba Reader." This writer gave the most articulate explanation of the economic argument about land, labour and taxes. This was likely the result of experiencing the Single Tax experiments then underway in the West. He reported that in Manitoba farm improvements and personal property were exempt but his unimproved land was assessed at the same amount as his improved land. He then pointed out that land became valuable depending on where it was located. To reflect this, land should be assessed based on the selling price of the farm minus cost of improvements. In addition, the farmer's crop had a value made up of wages for his labour, interest on his capital, and rent "for use of the soil." The rent should be the tax.

\footnotetext{
${ }^{129}$ Summing up Faith's taxation campaign with the one word, "fairness," can be criticized as vague and so it is. Yet it was the constant thread running through Faith's rhetoric and the farmers' letters. I continue to stress the word because it had a real meaning for the farmers despite it not being "parse-able" as an analytical term.

${ }^{130}$ Letters to the Editor, “A.J.S”. of Stormont County, OVJ, April 5, 1907, 12.

131 "The Square Deal," OVJ, October 29, 1907, 10. Other letters included W.H. Latourell of Carleton County, April 19, 1907, 12; J.B. Ross of Renfrew, April 30, 1907, 10; A.H. Foster, Twin Elms, and "Interested Reader, Pulmas, Manitoba, June 25, 1907, 10; John E. Rice, Lanark County, June 28, 1907, 12; "They Are Still At It," July 5, 1907, 12; Nap. Longtin, the Brook (Warden of Prescott-Russell), July 16, 1907, 10; Alex Fraser, Stormont County, August 9, 1907, 12.
} 
This meant, given how little was left after deducting an allowance for expenses, wages and interest, that farm taxes should be low. Taxes instead should fall most heavily on town sites because their value was climbing yearly and it was farmers' labour that created town land values. Finally the farmer was a consumer who paid "a heavy tax" on his industrial purchases. "Manitoba Reader" wrote again to say that the current system "fined" farmers for improving their farms. It was time for farmers to fight for "this small measure of fair play." ${ }^{132}$ Fairness thus came back into the argument even for this most articulate of the letter writers to the rural Journal.

Faith took the call for fair play seriously. He placed inserts with slogans, such as "[c]ome along and help your brother farmers right the wrongs that are burdening you and hindering your progress at the present time," around the newspaper announcement of the June 1907 property tax meeting ${ }^{133}$ Much of his and his readers' demand for fairness was based on two assumptions: that farmers created wealth through the improvements they built with their labour and that farm labour was fundamental to the nation's wealth. ${ }^{134}$ Faith's call to farmers to meet on property taxes suggested that more than a few dollars were at issue: "Will you loosen the chains?"135 A week later Faith printed a four-column spread with the sub-headline "Evils Burdening Farmers and Hindering Their Progress Will be Relegated." He proclaimed that the aim of the meeting was "to bury the [tax assessment] system so deep that it will never rise again" because farmers were entitled to "an up-to-date and more progressive system of assessing farm lands and buildings:",136

\footnotetext{
132 "Manitoba Reader," “Assessment of Farm Property,” OVJ, April 30, 1907, 10' "Honest Way of Assessing," OVJ, May 10, 1907, 12.

133 The Farmers' Convention" and "Big Convention of Farmers Will Be Held In The City Hall, Ottawa, Wednesday, June 12th,” OVJ, June 4, 1907, 7, 10.

134 “Special Railway Rates To Farmers' Convention,” OVJ, June 11, 190710.

135 "The Farmers Convention," OVJ, May 31, 1907, 12.

${ }^{136}$ The Farmers' Convention" and "Big Convention of Farmers Will Be Held In The City Hall, Ottawa,
} 
Business men meet and formulate plans for future business. Why should not the farmers? Their interests are too great to be trifled with ... Will you help the Ottawa Valley Journal in righting the wrongs that now exist which are certainly a burden to you and your fellow countrymen? All working together will place this part of the province on a much higher plane socially, intellectually and financially. ${ }^{137}$

The June 11 newspaper came out the day immediately prior to the convention and again gave voice to agricultural fundamentalism: “Agriculturists who follow the most important branch of industry in Canada, and to whom is the credit of Canada's great prosperity, have not been able to assert their porition (sic) on account of their scattered forces." An almost over-the-top radicalism came out very clearly as Faith urged farmers to attend the meeting in order to "send your names ringing down through the avenues of posterity as the deliverers of Canada's noblemen from the evils that so long harassed and beset them.",138

Faith's language was not carried forward into a general critique of ownership and taxes as far as can be read in his full front-page report of the June 12, 1907 discussion. The MPP for Stormont County, George Kerr, had been named chair and Faith was secretary. The meeting was asked to address four specific questions: 1) how often assessments should be done; 2) should assessments be done in summer or winter; 3) should there be more than one assessor to do the work; and 4) should farm buildings be exempted from taxation. As each question was addressed a resolution was drafted and put to the meeting for a vote. The last resolution passed was that farm buildings be exempted. ${ }^{139}$ At the end of the meeting Kerr added that he had thought there would be a

\footnotetext{
Wednesday, June 12th," OVJ, June 4, 1907, 7, 10.

137 “The Farmers Convention," OVJ, May 31, 1907, 12.

138 "Special Railway Rates To Farmers' Convention," OVJ, June 11, 190710.

${ }^{139}$ The rural Journal report on the meeting did not publish formally the resolutions but it did state "the motion that farm buildings be exempted from taxation was put and carried unanimously." "Convention
} 
discussion of taxes paid by big corporations compared to farm taxes, for farmers carried the main burden of taxation in Canada. ${ }^{140}$ As discussed in Chapter 5 on the limits to the rural Journal's activism, the newspaper did not pursue political questions of class or partisan issues such as the federal tariff. Its agrarianism was, it seems, more conservative than even that of the elected Conservative MPP George Kerr. The resolutions seem to have taken a further right-hand turn after the meeting. I find that the wording as it stood in the final memorial was watered down from the original resolution. Instead of specifying a desire for changes with respect to exempting buildings or improvements generally, the December 1907 publication of the draft memorial asks the government to assess rural property "en bloc as it was previous to 1904" and give the municipalities the choice of timing for assessments. Faith claimed that "any ratepayer can see that they stand for equalized assessment and a marked reduction in same."

The end of the nineteenth and beginning of the twentieth centuries was a period of transition for farmers in which a new discourse of business was being diffused through the Ontario Agricultural College and the Farmers' Institutes. Reflecting this, a few letters took a slightly different view. These writers agreed the current land tax system needed to be changed, but they did not make labour the prime justification. Instead they appeared to be drawing a parallel with business, arguing that taxation should fall on the revenueproducing elements of the farm. W.E. Ross was explicit that improvements directly affecting land such as drainage should be taxed along with the land. The farm buildings, however, should be exempt because they did not generate revenue. Two years later G.E.

Greater Success Than Was Anticipated By Promoters," OVJ, June 14, 1907, 1. I would be more comfortable if the newspaper had published the resolutions exactly as worded but it does seem that, if that was the wording, it is not found in later reports on the resolutions to be taken to the Ontario legislature.

140 "Convention Greater Success Than Was Anticipated By Promoters," OVJ, June 14, 1907, 1.

141 “Taxes Are Too High Great Cry of Farmers," OVJ, December 27, 1907, 12. 
Sproule of Prescott County said essentially the same thing: "The land being the chief source of revenue should bear the burden [of taxation]."142

At the same time readers' letters on property taxes showed farmers harboured dark suspicions against their neighbours, suspicions based on their view that only labour created value. This began with the very first letter published in April 1907. "A.F.S." had stated that the "farmer is assessed for his many year's of toil and hard labour and has to pay into the municipal treasury for his toil and hard labour half as much more than his neighbor who did not labor and toil to improve his farm." Several writers claimed they knew of men who were putting their money into bank accounts and loans, rather than into their farms. Thomas Brown Sr. of Goulbourn said the current system of assessment was not "fair" because the man who worked to build up his farm paid more tax than the man who instead banked or lent out his money, building up wealth in tax-free interest. James Clark and "F.C." of Farran Point repeated the charge that farmers with poor buildings were banking their money to get untaxed interest. The editor also repeated a conversation between a "progressive farmer" in Glengarry County and a Journal representative in which the farmer claimed he was taxed high because he put all the money earned from the farm back into his buildings. His neighbour was taxed low, despite having more cash to pay taxes, because he had banked all his returns. ${ }^{143}$ Thus the sense of injustice driving this issue came not just from the taxation system but also from farmers believing others to be benefitting more than themselves from a capitalist system which created wealth through non-tangible assets. The virtuous farmer created real wealth through labour.

\footnotetext{
142 "Letters to the Editor" W.E. Ross, Renfrew County, OVJ, April 9, 1907, 10; G.E. Sproule, Prescott County., OVJ, March 2, 1909, 12.

143 "Letters to the Editor," "A.F.S". of Stormont County, OVJ, April 5, 1907, 12; Thomas Brown Sr, of Goulbourn, OVJ, May 21, 1907, 10; James Clark of Glengarry County, OVJ, May 28, 1907, 10; "F.C." of Farran Point, June 14, 1907, 1; "Special Railway Rates To Farmers' Convention," OVJ, June 11, 1907, 10.
} 


\section{Labour Theory of Value and the Single Tax}

The letters I have seen in the Ottawa Valley Journal indicate that, despite the pervasive single tax movement which Heaman finds, grass-roots farmers were advocating for change based on their own long-standing understanding of the labour theory of value. Eastern Ontario farmers did not reference the "single tax" in their letters to the editor even though they may have heard of it from reading the Farmer's Sun or listening to a Bengough chalk talk. They may also have read articles by W.C. Good in the Farmer's Advocate, some published in 1906 and others in 1916, which took readers step by step through a political economy argument about land. Good was a working farmer but also a University of Toronto graduate and a former professor at the Ontario Agricultural College. He would go on to be one of the leaders of the United Farmers of Ontario. In 1919 he consolidated his articles into a book, Production and Taxation in Canada, in which he wrote on "our Rural Problem." He defined the problem as unprofitable agricultural production and a reduced social life due to depopulation. ${ }^{144}$ Good argued that taxing improvements discouraged individuals from investing their money and/or labour which then diminished the wealth of all. Land was different because it only gained value from society. For example, a lot which was untouched and isolated had next to no market value. But once a road was built, and a market and schools and all the other things which constitute a community, the lot became valuable. Since the value came from the presence of a community, a portion of that value had to be paid back to the community. ${ }^{145}$

Reformers such as Good generally agreed with Henry George's premise that land,

\footnotetext{
${ }^{144}$ W.C. Good, Production and Taxation in Canada (Toronto: J.M. Dent \& Sons. 1919). Articles were "Studies in Political Economy," parts I through XI, FA, March 9, 1916 to May 18, 1916, pp. 394, 453, 501, $553,606,650,744,788,832,875$.

${ }^{145}$ W.C. Good, “Taxation of Land Values," FA, August 19, 1909, 1318, August 26, 1909, 1354, September 2, 1909, 1392.
} 
labour and investment worked together to create wealth. The problem of poverty was one of distribution. The degree to which they embraced George's solution varied. A recent summary of Henry George's book states that he advocated taxing land but not wages (return on labour) nor interest (return on capital). The Georgist argument was that if unimproved and improved lands were taxed at the same high rate, owners would bring unimproved land into production, thereby ending land speculation. Owners would in effect be forced to improve their land in order to generate some earnings to offset the taxes while land prices would drop allowing the urban unemployed to move out of the city because they could buy farm land. At the same time the untaxed labour (wages) and capital (interest) would encourage productivity through investment in more improvements. In George's vision eventually land would be held in common and occupied under long term leases with the "rent" payable on land being effectively the tax. Individuals would, however, own outright everything on the land which they built. ${ }^{146}$

Both Good and the farmers agreed with George that labour produced wealth (wages) which is owned by the laborer and should not be taxed. George, however, also argued that capital produces wealth (interest) which is owned by the capitalist and equally should not be taxable. Good agreed that middlemen and capital were wealth creators and only objected to monopolistic behaviour. ${ }^{147}$ This is where Georgism and Good parted company with many farmers. The farmers in their letters considered that their neighbours who were creating income through investment of capital were parasites.

\footnotetext{
${ }^{146}$ Henry George, Progress and Poverty (London: Hogarth Press, 1966); Bob DeNigris, "Henry George and The Single Tax," published by the Arden Georgist Guild in Arden Delaware, 1996, updated October 2007. http://www.henrygeorge.org/pdfs/denigris.pdf Accessed July 16, 2017. The sharing of land on cooperative principles has been put into effect in Arden, a village in Delaware, U.S.A. The Arden Georgist Guild is dedicated to spreading George's ideas.

${ }^{147}$ Good, Production and Taxation, 3-6, 47-8.
} 
Only physical labour could create wealth.

\section{Conclusion}

In this chapter I have looked at the activities of the rural Journal related to Good Roads and property taxes. The arc of events follows the general arc of the rural Journal as a rural activist in the tradition of the New Journalism. At first, like the crusading city newspapers, the rural Journal made headlines and sold papers by loudly fighting in the public's interest. It began with two years of road-building spectacle under rural editor Herbert Cowan in the first years of the century. The aim of this campaign, however, was to educate farmers in the dominant discourse of modern road machinery and efficiency. The second editor, Robert Faith, shifted the fight to organizing farmers using a rhetoric of fairness and arguing their right to all the value created by them. Both campaigns were equally unproductive but they highlight two sides of agrarianism: Cowan's citydominated modernization agrarianism and Faith's producer-based agrarianism. The final stages of the rural Journal's work on behalf of farmers came during the First World War when its New Journalism had run its course and Faith had settled down to simply providing agricultural information to his readers.

Both Cowan's road campaign and Faith's tax Association were highlighted in the Ottawa Farm Journal's sales pamphlet of 1919/1920 as examples of how the rural newspaper had long been interested in country conditions and progress. They were joined in the pamphlet by two other claims which do not have the same credibility: promoting a highway from Ottawa to Prescott and organizing the rural end of the 1917 Dominion Good Roads Congress. I cannot say how the pamphlet claims were received—with derision, with a gentle shrug or with wholehearted belief in their veracity. The inclusion 
of these last two dubious claims suggests that the publisher believed they needed to convince rural residents that the renamed newspaper remained an activist advocating their interests. It also suggests a belief that road improvement would still resonate with residents. It seems it did for the rural Journal readership grew significantly between 1919 and 1922 from 19,152 to 24,194 . At the same time the city Journal grew from 22,912 to 26,349 (although this was less than the circulation of its Saturday edition which had been 27,000 in 1919). ${ }^{148}$

The road and property tax campaigns reflect the shifting alignments between rural and urban issues in this period. While Good Roads had multiple origins, it took its strength in the United States from the lobbying of a well-placed bicycle manufacturer, Colonel Albert Pope, and the new urban recreation of bicycling. The chief architect for Good Roads in Canada was A.W. Campbell, a single-minded civil engineer who worked first as a city employee of the town of St. Thomas, Ontario and then as a senior civil servant with the Ontario government and finally the federal government.

Equally the two campaigns reflect the urban-rural divide of the period. The failure of the Good Roads Train to convert farm ratepayers into enthusiastic investors in roads stems from a mismatch between the urban-born Cowan's understanding and the farmers' understanding of roads. The Train carried into the countryside the latest road machinery. The machines were big and they were impressive and they were accompanied by engineering experts giving talks on modern methods of road building. The accompanying newspaper reports presented a discourse on the modernity of roads as progress. But Cowan had missed the real reason for farmers' negative attitude on Good Roads. Farmers

\footnotetext{
${ }^{148}$ Ayers American Newspaper Annual and Directory (Philadelphia: N.W. Ayers and Son), 1919, p. 1133 and 1922, pp. 1140-1. In comparison the Citizen was almost standing still, having grown from 28,506 to just 29,071.
} 
did not suffer from a knowledge gap. They simply were not convinced that they, as ratepayers, could afford to purchase the machinery and hire expert operators. Above all, however, they knew that they had built the roads and therefore those roads were their roads. They were not prepared to cede control over them to a hired Township administrator (or worse the County). Changing farmers' attitudes towards investing in roads required shifting more of the cost away from the farmers. This change came at the same time as farmers changed their opinion on the automobile itself. By 1910 farmers with the money to buy one had begun to see it as their newest work horse instead of a rich man's plaything and were increasingly travelling on roads far away from their own section. With this they, too, began to see the benefits of Good Roads.

Faith's property tax campaign was a success in the countryside in terms of his ability to mobilize five hundred farmers to attend a mass meeting in June 1907, the middle of the farm work season. He channeled their dispute into an Association which presented a memorial to the government demanding that only land be taxed and not the improvements which had been built upon the land. But he did not take the question of taxation further despite MPP George Kerr questioning why the June 1907 property tax meeting had not addressed the disparity between high farm taxes and low corporate taxes. Faith understood that farmers saw the issue in basic terms of fairness and he responded himself in those terms. But he was not prepared to question the capitalist system itself by criticizing as unfair the privileges given over years of economic nation-building to manufacturers and railways.

Using the rural Journal to hear the voices of farmers is more difficult. The newspaper had followed up the Good Roads Train work with a full page report on the 
success of the Train, complete with letters of approval from municipal officials from across the region. Yet there were no letters from ordinary ratepayers, either approving or disapproving. They were silent on the modern road and modern machinery in the Ottawa Valley Journal in contrast to the enthusiastic readers who wrote to the Farmer's Advocate on its low-technology split-log drag which represented their own practical knowledge. The Advocate's intervention gave their knowledge value and credibility. Ratepayers were not silent, however, on Cowan's earlier project to commute statute labour to cash payments. Cowan had intended this project to be an example of modern businesslike methods of municipal road management. Readers' letters to the Ottawa Valley Journal expressed their doubts that the benefits being promised would be realized. The day of the neighbourhood corvée was passing but farmers saw no reason to rush to kill it until they were certain that the replacement would work.

There was another issue around roads which continued to simmer along with the question of how to build and maintain them. Campbell wrote as an expert municipal engineer and a senior government administrator. He had been an important player in establishing provincial legislation which, beginning in 1901, favoured commutation of statute labour and the building of networks of improved county roads. The claim was made by Campbell in speeches and editorials and repeated by the rural Journal and the Farmer's Advocate that these roads would deliver real practical benefits for farmers in market access and reduced wear on equipment. At the same time, however, the benefits came with an obligation to maintain good roads as a public resource, whether by statute labour or preferably by taxes. Farmers writing to the editors of both publications presented a counter to this dominant knowledge with their traditional view that labour 
created ownership. Since they built and maintained the roads, the city touring car had no right to intrude on those roads in the pursuit of recreation. By 1910 their views did not matter as the provincial government's focus had shifted to intercity highways and tourist roads.

Roads, like the agricultural fair discussed in Chapter 5, were another arena in which the experiential or tacit knowledge of the agriculturist was subordinated to a discourse of dominant or official knowledge focused on urban needs, even while speaking of benefits for farmers. While both the rural Journal and the Farmer's Advocate prioritized the knowledge of the expert road engineer, the Advocate recognized that for real progress reformers had to make use of agriculturists' own knowledge. This drove the Advocate to intervene by recruiting farmers to test and report on a low technology option in the form of D. Ward King's split-log drag. This solution kept control of local roads in the hands of the farmers who lived beside them and who saw them as their roads.

The Good Roads Train was a spectacle of great interest to farm families but ratepayers did not take the expected next step of asking their Councillors to invest in the machinery. The property tax campaign resulted in a 1909 memorial to the provincial government but the government did not act on it. I do not regard these outcomes as making the rural Journal's early activist campaigns less significant. They illustrate the difficulties farmers were facing in a time of transition, not just in transportation, but in their relationship to local government and in reassessing labour as a marker of value. 


\section{Chapter 8: The Farmer and the Market: Producers, Middlemen and Cheese}

\section{SCENES AT THE CHEESE. BOARD.}

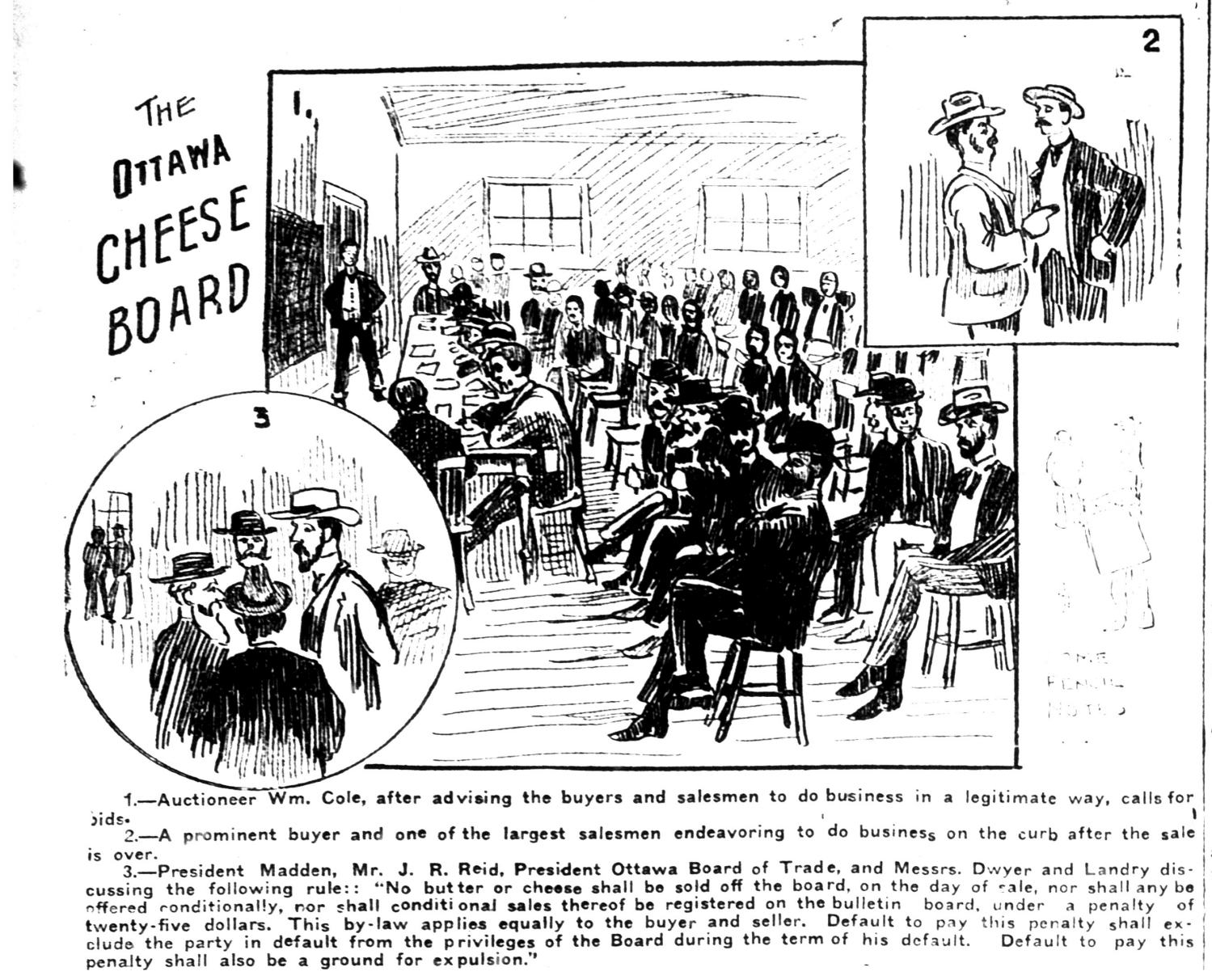

Fig. 8.1. Ottawa Valley Journal, August 5, 1904, 10.

Cheese Boards were set up to equalize the market knowledge of cheese producers with that of cheese exporters but the Ottawa Valley Journal began questioning the Ottawa Board's procedures almost as soon as it was established.. The above drawing looks like a polite gathering of businessmen but the text highlights the conflicts between producers and buyers. Editor Robert Faith channeled the frustrations of producers into a fight that escalated from shaming the Board buyers, to establishing farmer-organized selling organizations, to seeking government protection for producers. What he did not do was look beyond the Montreal export houses to question the market system as a whole. 


\section{Introduction}

Among the wide range of achievements which the Ottawa Farm Journal highlighted in its c.1919/1920 sales pamphlet were two from the Ottawa Valley Journal's campaign to change the cheese marketing system in Eastern Ontario:

- establishment of ... the Farmers' Produce Association; and

- $\quad$ organizing 600 farmers to meet with federal government Ministers regarding marketing of cheese and butter which led to a Royal Commission. ${ }^{1}$

These two activities brought rural Journal editor Robert Faith into conflict with agricultural policy makers and the dairy industry elite. Despite starting his job as editor by continuing his predecessor's good relations with government and industry leaders, in 1905 Faith started down an independent path. With no greater approbation than his own convictions, he led farmers in fights for greater local control over agricultural fairs (Chapter 6) as well as systemic changes to the property tax process (Chapter 7). But these were mild affairs compared to his last fight to change the cheese export market.

Underlying the cheese campaign was the producers' relation to and view of the “modern” commercial market. The question, however, is not when Ontario farmers became commercial producers but how they responded to being part of a global commercial market. I argue that the positive response of Eastern Ontario farmers to Faith's calls for mass meetings and a petition demanding government protection illustrate that they had maintained their belief in the agricultural version of producerism. They believed they were entitled to a "fair price" based on calculations of labour even as their product was sold in a capitalist market. This producerism was at variance with a liberal

\footnotetext{
${ }^{1}$ Sales pamphlet, Ottawa Farm Journal, circa 1919/1920, collection of Bruce S. Elliott.
} 
doctrine of the mutuality and interdependence of interests in society which is visible in the contrasting response of the Farmer's Advocate to the same questions of how the cheese market worked. The cheese campaign also illustrates how Faith could merge what appears to be a radical rhetoric with a belief that the global system worked if only everyone followed the rules. His campaign was doomed to failure because the powers of government and industry arrayed against the producers were too strong to be taken down by one young rural editor in Eastern Ontario. Above all else, however, it failed due to the political weakness of Ontario agriculture. Ontario farmers were divided into many produce sectors and simply could not exert the kind of pressure on government policy which Western farmers were beginning to enjoy thanks to their wheat monoculture. Yet Eastern Ontario dairy producers were just as enmeshed as the Western farmers in a global market that they fundamentally did not understand.

I begin this chapter with the historiography of producerism with specific attention to farmers as participants in the commercial market. I next focus on the history and structure of cheese marketing from the shift of cheesemaking into factories to the longstanding role of middlemen in marketing cheese both across the country and internationally. I then present the actions taken by the Ottawa Valley Journal as it made news in its cheese campaign. For comparison, I then look at the more guarded commentary of the Farmer's Advocate on the cheese market. I will finish the chapter by looking at the rhetoric of the Ottawa Valley Journal's cheese campaign as it reflected the radical and conservative agrarianism in play at the beginning of the twentieth century.

\section{Cheese and History}

The Farmers' Produce Association was the Ottawa Valley Journal's answer to 
farm families' dilemma in seeking the benefits of the global commodity market while trying to keep their independence within that market. The answer assumed the problem was with the most visible of the middlemen in the British cheese market, the Montreal export companies. Farmers' traditional antagonism against middlemen was the logical end point of the Labour Theory of Value. For if labour determined both value and the right of the labourer to the full share of that value, what did middlemen add? ${ }^{2}$ Among agriculturists, producerism could extend into an agricultural fundamentalism which claimed agricultural labour drove all of society. ${ }^{3}$ The cheese campaign, however, illustrates the limits of producerism for rural editor Robert Faith was naïve in his understanding of the market problem facing dairy producers. He extended the rhetoric of conflict between the producer and non-producers into an attack on one of the layers of middlemen involved in the cheese market while ignoring, not only the other middlemen, but the way the system as a whole worked. He also ignored in his rhetoric the close linkages between government policy and the exporters.

\section{Producerism, Liberalism and the Market Economy}

Under producer ideology or producerism, the labour of the producer created all the value found in an object and therefore the producer had the right to the dollar returns created by the object. It is an idea which has been studied in terms of Henry George's writing on the single tax as well as in terms of the role it played in industrial working-

\footnotetext{
${ }^{2}$ William Cronon has described the hard lessons some producers learned about what middlemen did when they set up purchasing cooperatives. While many no doubt ascribed any losses which followed to some continued hidden conspiracy by the city, he quotes at least one Granger organizer who came to recognize that they could not replicate the trading networks between wholesalers and retailers which permitted safe transfer of goods from where it was produced to where it would be consumed. William Cronon, Nature's Metropolis: Chicago and the Great West (New York: W.W. Norton, 1991), 362-4.

${ }^{3}$ In this pre-plastic age, farm products did extend well beyond food for eating to most industrial inputs, for example, hay for feeding the city delivery horses, leather for machinery belts and animal fats for lubricating machinery (although the last was being displaced by products from the petroleum industry).
} 
class rhetoric. It also underlay an agrarian rhetoric which made agricultural labour, as it was exercised in the farm household (farm man, woman, children and hired labourers all producing wealth which went to the household) the fundamental wealth creator.

Gregory Kealey and Bryan Palmer characterize the roots of producer ideology as an assumption that employers and employees had a common interest in production. As a result strikes were counter-productive for both. They then claim that increasing tensions between the two groups meant that the producer ideology had become obsolete by the 1880s. Rather than it being an authentic idea capable of radicalizing labour relations, they find it was expressed most clearly in the career of one of the opportunistic (even corrupt) individuals whose careers they explore in their study of the Knights of Labour. ${ }^{4}$ Shelton Stromquist, however, gives a different view of producerism, citing an observer who in 1880 saw adherents of the ideology as promulgating class warfare between labour and property. ${ }^{5}$ Despite the difference claimed as to the roots of producerism, Kealey and Palmer agree with Stromquist that producerism was an urban ideology.

Darren Ferry in his study of voluntary and fraternal organizations in the nineteenth century, Uniting in Measures of Common Good, and Hal Barron in Mixed Harvest bring producerism into the agricultural world. ${ }^{6}$ Barron sees agricultural fundamentalism and Jeffersonian republicanism as initially causing farmers to see their

\footnotetext{
${ }^{4}$ Gregory S. Kealey and Bryan D. Palmer, Dreaming of What Might Be: The Knights of Labor in Ontario, 1880-1900 (Toronto: New Hogtown Press, 1987), 178-9.

5 Shelton Stromquist, Re-inventing "The People”: The Progressive Movement, the Class Problem, and the Origins of Modern Liberalism (Urbana: University of Illinois Press, 2006), 4-5, 20, 35; see also for a definition linking to Henry George, Lawrence M. Lupin, "Nature, the City, and the Family Circle: Domesticity and the Urban Home in Henry George's Thought," Journal of the Gilded Age and Progressive Era 13, no. 3 (July 2014): 312.

${ }^{6}$ Darren Ferry, Uniting in Measures of Common Good: The Construction of Liberal Identities in Central Canada, 1830-1900 (Montreal: McGill-Queen's University Press, 2008); Hal S. Barron, Mixed Harvest:

The Second Great Transformation in the Rural North 1870-1930 (Chapel Hill: University of North Carolina Press, 1997).
} 
interests as integrated with the interests of the nation as a whole. ${ }^{7}$ At this point producerism was the ideology of common interests described by Kealey and Palmer. The ideology began to change in the late nineteenth century as milk producers in New York State encountered outside pressures on their farming practices in the form of uniform quality standards. These were imposed as a condition of doing business with the corporations distributing milk into the cities as well as the monopolistic Borden company which produced evaporated and condensed milk. The awareness of having separate interests from the manufacturers developed into a new radicalism and eventually strikes (withholding milk from the market). Barron analyzes the central problem for the New York State dairymen as a question of retaining local control in an organizationally centralized and corporation dominated market. The solution of building dairy cooperatives and a Farm Bureau (as advocate for farm interests) then created new tensions as they became large, bureaucratic organizations with a leadership separated from the grass-roots farmer. ${ }^{8}$

Ferry's study is not about agriculture per se although he looks at the Grange (Patrons of Husbandry) in the 1870s and 1880s and the Patrons of Industry in the 1890s in exploring four characteristics of a liberal community in Ontario and Quebec. One of the characteristics he identifies, the primacy of "honest labour," can be attached as a noneconomic intangible connected to the Labour Theory of Value and of Producerism. At the same time he finds that a second characteristic, the interdependence of all interests in society, was at variance with the antagonism of producerism to whoever was seen as a

\footnotetext{
${ }^{7}$ Barron, Mixed Harvest, 81.

${ }^{8}$ Ibid., 87-102.
} 
non-producer. ${ }^{9}$ This leads to a discussion of the contradictions within farmer activism.

First, the Grange could not sustain its claim that a common identity as agriculturists trumped the different interests of the commercial farmer, the small farmer, the tenant farmer and the farm labourer. Second, producerism pointed two ways. On the one hand, farmers and workers were claimed to have common interests as producers who created wealth and should therefore cooperate against the moneyed interests who were parasites on the labourers' wealth. On the other hand, farmers felt that agricultural labour was the fundamental wealth creator, driving a wedge between them and industrial workers. Third, the liberal doctrine of mutualism in society was in itself in tension with the emphasis in liberal thought on the individual as the fundamental constituent of society. A fourth contradiction was between the farmer as worker-producer and the same farmer as a market participant selling his products and not his labour, as such, as the waged workingman did, and at the same time employing workers whose labour (as stated in the Labour Theory of Value) he was confiscating.

In the Ottawa Valley these contradictions became most evident as the farms turned into full-time dairy enterprises. In the early nineteenth century Valley farm families had used a number of strategies for sustenance much in the same way as found in studies of rural families in Atlantic Canada. ${ }^{10}$ A farmer, farmers' sons and even the

\footnotetext{
${ }^{9}$ Ferry, Uniting in Measures of Common Good, 16-18. The other two of the four characteristics were 3) separation from party politics and sectarianism when participating in associational activities and 4) camaraderie and wholesome recreation as a social glue forming a sense of commonality within a liberal identity. Ferry treats honest labour as a key thread across all the societies he studies, even in what would appear to be an unlikely site of labour - the scientific and literary societies of the late nineteenth century. ${ }^{10}$ The essays in Contested Countryside together illustrate the various ways in which the seasonable work of agriculture and the resource extraction industries created an interdependency within the Atlantic Provinces. For the dependency between farm production and factory/mine wages, see Daniel Samson, "Dependency and Rural Industry: Inverness, Nova Scotia, 1899-1910," and Rusty Bittermann, "Farm Households and Wage Labour in the Northeastern Maritimes in the Early 19th Century," in Contested Countryside: Rural Workers and Modern Society in Atlantic Canada, 1800-1950, ed. Daniel Samson (Fredericton, NB.:
} 
farmers' horses could add a cash infusion to the family by working for wages (including an allowance for the use of the horses) in the winter lumber camps. In summer, rural men without a farm (including farmers' sons) could again pursue waged labour in the lumber mills. Farming and lumbering also went together as a market activity in which Ottawa Valley farmers provisioned the lumber camps. ${ }^{11}$ Nevertheless selling surpluses in the market is not the same as having a market consciousness.

Jeffery Taylor has argued that by 1920 Manitoba farmers had become entrepreneurial operators who accepted the mechanisms of market pricing they had learned from the agricultural economics taught at the Manitoba Agricultural College. David Monod in a review essay of Taylor's work has pointed out that the college may have taught economic theory but many farmers integrated it with their existing producerist views. ${ }^{12}$ We also should consider that the price-setting marketplace was developing through the nineteenth century. Economist Winifred Rothenberg had noted in her use of price deflators for studying probate records that price differentials between New York and Philadelphia narrowed over her time period of 1750 to 1850 . She identifies this as a signal of the working of commercial market mechanisms over long distances. I take particular interest in her point that the changes in differentials showed that by the mid-nineteenth century agricultural values in the American countryside were determined by city wholesalers. ${ }^{13}$ This indicates that when farm men and women were exchanging even a small surplus for a few goods at the local general store, they were

\footnotetext{
Acadiensis Press, 1994).

${ }^{11}$ Ian M. Drummond, Progress without Planning: The Economic History of Ontario from Confederation to the Second World War (Toronto: University of Toronto Press, 1987), 29.

12 Jeffery Taylor, Fashioning Farmers: Ideology, Agricultural Knowledge and the Manitoba Farm Movement, 1890-1925 (Regina: Canadian Plains Research Center, 1994); David Monod, "Down on the Farm: Reading Jeffery Taylor's Fashioning Farmers,” in Manitoba History 32 (Autumn 1996): 2-9. ${ }^{13}$ Winifred Barr Rothenberg, From Market-Places to a Market Economy: The Transformation of Rural Massachusetts, 1750-1850 (Chicago: University of Chicago Press, 1992), xiii-xiv, 2-3.
} 
working within a much larger commercial system. But they could not see the system and their mistrust focused on the one element they could see, the local merchant. By 1900 the global market had become visible to the Eastern Ontario dairy farmers and their distrust had extended much further to the export merchants of the big city.

The late nineteenth and early twentieth centuries were times of transition for agriculture. While change is a constant in all societies, the perception of it varies. At the turn of the twentieth century, North American farmers were becoming uncomfortably aware that their status as the bedrock of society was eroding. Earl Hayter argues that fastmoving change caused farmers to express uncertainty and discomfort with two different but equally irrational responses. Some showed gullibility in jumping on every passing bandwagon of agricultural fashion. Others dug in, resisting every new idea. Hayter argues that as more sources of information became available (from the farm press, particularly those including letters with ideas from other farmers, to government circulars to Institute speakers) farmers became comfortable taking decisions in the new world of commercial and scientific agriculture. ${ }^{14}$ Russell Hahn on the other hand argues that Ontario farmers were struggling in the late nineteenth century to find a language with which to critique the changes they were experiencing. Hahn posits that they found this language in Grange picnics in the 1870s and 1880s and in Patrons of Industry meetings in the $1890 \mathrm{~s} .{ }^{15}$ The remainder of this chapter explores transition and discomfort in the dairy industry.

\section{The Cheese Factory}

In 1900 cheese was a mature industry which had enmeshed Eastern Ontario

\footnotetext{
${ }^{14}$ Earl W. Hayter, The Troubled Farmer: 1850-1900 Rural Adjustment to Industrialism (Dekalb: Northern Illinois University Press, 1963), 4-11.

${ }^{15}$ Russell Hahn, Farmers Confront Industrialism: Some Historical Perspectives on Ontario Agrarian Movements (Toronto: New Hogtown Press, 1975), 5-6.
} 
farmers in a global market of great interest to the federal government. Cheese was

actually more important than western wheat at that time. Most histories, for example the

Dairy Farmers of Canada in their in-house history and Harold Innis in The Dairy Industry

in Canada, link the growth of the industry to the shift from women making non-

commercial cheese on the farm to men making commercial cheese in a factory. ${ }^{16}$ Heather

Menzies challenges this in her book, By the Labour of Their Hands. ${ }^{17}$ She traces the mid-

nineteenth-century foundational work of key Ontario women cheesemakers, such as

Lydia Chase Ramney, who was producing farm cheese in commercial quantities by the

1850s. Menzies presents the shift to cheese factory production as a change in

organizational structure, rather than in technique. Essentially the factory allowed farms to

co-operate in cheese making by pooling their milk. ${ }^{18}$

American historian Sally McMurry dates the first cheese factory to 1851 in Upper

New York State. As factory cheesemaking spread in the United States in the 1860 s, it

also spread to Ontario with Canadians adopting the two basic American organizational

factory forms, producer-owned on the one hand, and entrepreneur built and run on the

other. ${ }^{19}$ In the first form, a group of producers or farmers, called "patrons," agreed to

\footnotetext{
${ }^{16}$ Veronica McCormick, A Hundred Years in the Dairy Industry: A History of the Dairy Industry in Canada and the Events That Influenced It. 1867 - 1967 (Ottawa: Dollco, 1968),13; H.A. Innis, "Introduction," in The Dairy Industry in Canada ed. H.A. Innis (Toronto: Ryerson Press, 1937).

${ }^{17}$ Heather Menzies, By the Labour of Their Hands: The Story of Ontario Cheddar Cheese (Kingston: Quarry Press, 1994).

${ }^{18}$ Ibid., 26-32.

${ }^{19}$ Sally McMurry, Transforming Rural Life: Dairying Families and Agricultural Change, 1820-1885 (Baltimore: The Johns Hopkins University Press, 1995):123-4; McCormick, A Hundred Years, 13; J.A. Ruddick, "The Development of the Dairy Industry in Canada," in The Dairy Industry in Canada, 45-9; H.E. Erdman, "The 'Associated Dairies' of New York as Precursors of American Agricultural Cooperatives," Agricultural History, 36, no. 2 (April 1962): 84. Erdman argues that the early farmer-run cheese factories in New York State were among the first examples of agricultural co-operative activity. Ruddick gives a less positive view that "the germ of cooperation" could be found in all cheese factories but it was limited in the entrepreneurial factories to milk pooling. (Pooling later took on another meaning of indiscriminate mixing of milk without penalizing the farms who supplied skimmed or dirty milk); McMurry identifies the cheese factory system as built on a traditional idea of cooperative ventures centred
} 
build a factory, supply it with milk and hire a cheesemaker to manufacture and package the cheese. The patrons might delegate one of themselves or charge the cheesemaker with selling the cheese or they might hire a salesman. At the end of the year, they split the profits among themselves based on the amount of milk each had contributed. Menzies describes this model as most common in central Ontario. She states that the most common form in Eastern Ontario (but not the exclusive form) was the entrepreneur factory. A local businessman (sometimes but not always a farmer) or a group of investors called a syndicate built the factory, hired the cheesemaker and sold the cheese. ${ }^{20}$ The factory owner might, but according to McMurry usually did not, buy the farmers' milk. If he did, he became owner of the final product but it was more common for the entrepreneur to instead contract with local farmers to manufacture cheese on their behalf in his factory and then to sell it, again on their behalf. ${ }^{21}$

McMurry distinguishes between factory production of cheese and industrial production. A typical cheese factory, whether in the United States or Canada, was always located somewhat away from a large city. This was because the closer a farmer was to a major population centre, the more financially rewarding it was to sell fluid milk to families for home consumption. The factory itself was a small building of varying degrees of sophistication. For example, it might, or might not, have had a specialized

on kinship, neighbourhood or ethnic ties.

${ }^{20}$ Menzies, By the Labour of Their Hands, 40-1. Menzies cites J.A. Ruddick's work The Dairy Industry. Ruddick gave the same breakdown of ownership forms in an address to the Eastern Ontario Dairymen's Association as reported in the newspaper, "Dairy Commissioner Ruddick Discusses Dairy Situation," Ottawa Valley Journal (hereafter OVJ), January 12, 1909, 9. The Journal called factory owner Patrick Madden of Jockvale. Ontario a "shrewd business farmer," "Journal's Attack Against Ottawa Cheese Board" OVJ, July 23, 1907, 10. For Madden's profile see Bruce S. Elliott, The City Beyond: A History of Nepean, Birthplace of Canada's Capital 1792-1990 (Nepean, Ont.: City of Nepean, 1991), 149, table 13; Elliott states Madden owned the Jockvale factory from 1893 (closed by 1921) as well as the Keystone C\&B factory (opened 1906) and may have owned a third factory which opened in 1901.

${ }^{21}$ McMurry, Transforming Rural Life, 128; Ruddick, "Development of the Dairy Industry," 48-9; Menzies, By the Labour of Their Hands, 40-4. 
room cooled with ice to cure the finished product. But the work was usually done by two people at most (a cheesemaker and perhaps an assistant) following an undifferentiated work flow; that is, the work was not broken into stages carried out by different workers. Large scale industrial factories would not become the norm in the United States until after the First World War. ${ }^{22}$ Prior to the war, the manufacture of cheese fitted into traditional rural life in terms of artisanship, scale and control even after it moved off the farm and into a factory. The same was not true of cheese marketing.

Much of the recent writing on cheese factories has focused on gender and the effects caused by dairying shifting from a female occupation practised as a handed-down art to a male occupation taught as a science in agricultural colleges. ${ }^{23}$ Selling cheese has not been studied as closely. Yet it is a part of how Eastern Ontario farm families became integrated into a commercial world where the market is a state of mind and not just a place. This state of mind, or mentalité, once fully formed, made the capitalist market hegemonic - a natural way of doing things.

\section{Marketing Cheese}

Marketing cheese began in a way which on the surface fit well within a face-toface economy. Buyers visited each factory to negotiate a price. The buyers might even be local men. But while they were the face of the market for the milk producers, they were agents of the actual buyers. Cheese was being sold in the United States within a national

\footnotetext{
${ }^{22}$ McMurry, Transforming Rural Life, 126-7.

${ }^{23}$ There is a debate as to whether this was good or bad for farm women. Cf Deborah Fink, "'Not to Intrude': A Danish Perspective on Gender and Class in Nineteenth-Century Dairying," Agricultural History 83, No. 4 (Fall, 2009): 468-72; Mary Neth, Preserving the Family Farm: Women, Community, and the Foundations of Agribusiness in the Midwest (Baltimore: Johns Hopkins University Press, 1995); Barbara Handy-Marchello, Women of the Northern Plains: Gender and Settlement on the Homestead Frontier, 1870-1930 (St. Paul: Minnesota Historical Society Press, 2005); Patrick Nunnally, “'From Churns to Butter Factories': The Industrialization of Iowa's Dairying, 1860-1900," Annals of Iowa 49 (Winter 1989): 55569; McMurry, Transforming Rural Life; and Marjorie Griffin Cohen, "The Decline of Women in Canadian Dairying," Histoire sociale / Social History 17, No. 34 (November 1984): 307-34.
} 
market system as early as the 1830 s. This system linked northern farm houses to southern plantations feeding cheap protein to their enslaved workers via New York City "factor" companies. Cheese became an international commodity when Britain expanded its food supply zone across Europe and into North America after the 1846 repeal of the Corn Laws. ${ }^{24}$ American cheese sellers, however, became less interested in the British market after the American Civil War as immigration expanded their domestic market. This gave Canadian cheese exporters the opportunity to grow their sales, which they did. In doing so, they made cheese so important that until 1906 it was one of the largest components in Canada's balance of trade with Britain. The high point for Canadian cheese was in 1904 when 234 million pounds went overseas. Then both the volume of exports and the Canadian share of the British market began to drop as domestic dairy consumption rose due to immigration and as refrigerated shipping made New Zealand a competitor. ${ }^{25}$

Cheese producers had a long involvement in a capitalist market but their belief in the producerist labour theory of value and the moral economy goes back just as far. Deborah Valenze looks at English cheesemaking as a story of changing attitudes about the market and fair price setting. She records buyers as early as the late eighteenth century trying to teach makers to think competitively regarding quality and price as opposed to demanding intra-community price equality irrespective of product quality. ${ }^{26}$ McMurry examines the same phenomenon in her study of nineteenth-century New York State. The early sales negotiations were conducted at the farm gate as the producer and the buyer's agent agreed on a set price for a full season's cheese. Word of mouth ensured

\footnotetext{
${ }^{24}$ McMurry, Transforming Rural Life, 44-59.

${ }^{25}$ McCormick, A Hundred Years, 14-6.

${ }^{26}$ Deborah Valenze, "The Art of Women and the Business of Men: Women's Work and the Dairy Industry c.1740-1840," Past and Present 130 (February 1991): 164-5.
} 
that everyone quickly learned what price was being offered for a contract and each farm insisted on as good a price as the neighbours. McMurry goes deeper than Valenze as to why the New York State farm families were applying a traditional understanding of community equality to economic decisions within a market system. She argues that they valued their produce in terms of the labour involved while seeking for themselves a "competency" (a level of return giving the family all the necessities and a reasonable level of comfort). They expected that, because all cheesemakers invested the same amount of labour, the product value and thereby the product price should be the same.

When buyers in the American market shifted to payment on delivery every few weeks, producers could no longer compare offers, and buyers could negotiate different prices within the same community. ${ }^{27}$ Despite this change happening in the mid-nineteenth century, Dominion Dairy Commissioner J.A. Ruddick complained in his 1909 address to the Eastern Ontario Dairymen's Association (E.O.D.A.) that all the cheese factories expected to get the same price for their cheese irrespective of quality. ${ }^{28}$ It seems that the notion of a "fair price" had not been eliminated in over fifty years of buyers trying to modernize farmers by encouraging them to think like competitive entrepreneurs. Producers continued to see the problem as how to share market knowledge so all would enjoy what they believed to be a "fair price."

\section{The Problem with Cheese Boards}

Cheese manufactured in the Ottawa Valley went into the British market via firms in Montreal that bought through local agents. The mechanism which brought producers and exporters together was the turn of the century cheese board. In 1937 W.M.

\footnotetext{
${ }^{27}$ McMurry, Transforming Rural Life, 53-5, 59-60.

28 "Dairy Commissioner Ruddick Discusses Dairy Situation," OVJ, January 12, 1909, 9.
} 
Drummond, a Canadian professor of rural economics, wrote that cheese boards with their public auctions were established to share market knowledge by being "recognized priceregistering machines." ${ }^{29}$ Dairy Commissioner J.A. Ruddick stated the first cheese board auction could be documented to 1892 but he recalled there being earlier auctions. Irrespective of start date, they caught on quickly. By 1906 there were about forty boards run by cheese factories in Ontario with each board setting its own rules and procedures. ${ }^{30}$ The factory would send a salesman to a weekly meeting to "board" their cheese; that is, the amount and kind available for purchase would be marked beside the factory name on a physical chalk board. Once the chair opened the meeting for bids, a buyer for an export house would offer a price per pound for a lot of cheese listed on the board. The factory salesman might accept the offer or refuse it if he thought the price could be made to go higher. The buyer might repeat his offer to a second or third or more factories until he either got acceptance or decided to rescind his bid. Other buyers would go through the same process until all the cheese had been sold or everyone present felt that there would be no agreement on price and ended the meeting with cheese unsold or "left on the board." This was the easy part of the process. It was what happened outside the board meeting which caused much grief and upset. Quite simply, expectations and reality were far apart. It was this gap that drove the Journal cheese campaign.

A major complaint was "curb-selling" or price fixing. Buyers and salesmen either agreed before the auction on the price (with intimations of tips and favours passing

\footnotetext{
${ }^{29}$ W.M. Drummond, "Problems of the Canadian Dairy Industry," in The Dairy Industry in Canada, 158-60.

${ }^{30}$ Ruddick, "Development of the Dairy Industry," 49-50; I.W. Steinhoff, "Rise and Progress of Canada's Cheese Industry," Farmer's Advocate (hereafter FA) (December 13, 1906): 1963 (Steinhoff dated "organized cheese boards" to about 1885 at Listowel, Ontario). There had been dedicated cheese marketplaces in Ontario since the 1870s starting in Ingersoll but these were physical places where buyers and sellers could meet and work a deal.
} 
between the parties) or agreed that the factory would not board its cheese but instead accept a slightly better price than the best price achieved on the board that day. In the latter case buyers would collude to bid low knowing they would get better cheese at a slightly higher price after the meeting. But there were other problems. Factories and patrons were upset over the Montreal exporters' insistence on inspecting in Montreal the cheese they had bought and only then paying for it, sometimes unilaterally lowering the price they had previously offered. All the advantage was with the exporters who simply refused to accept either inspection at the factory or [rail] car door payment (i.e., payment on shipping), even though both were required in many boards' regulations. ${ }^{31}$

No one on the market side of the industry questioned how cheese marketing was structured. Expert insider Isaiah Steinhoff wrote an article for the Farmer's Advocate on the history of cheese in Canada but spent his ink defending the status quo. He admitted that curb-selling happened but denied it was a problem. ${ }^{32}$ Dairy Commissioner Ruddick concentrated on improving the industry by improving the producers. He told producers they would get more for their cheese if it was better cheese. But would they? In 1937 Drummond wrote that curb-selling had eliminated competition and caused prices for the producer side of the industry to drop. He charged that the board system was "a farce." ${ }^{.33} \mathrm{~A}$ modern analysis by Heather Menzies argues that government policy failed to recognize the imbalance caused by the control of British mercantile interests over the Canadian cheese market. She argues the cheese market was based on an imperial-colonial

\footnotetext{
31 "Present Method of Selling Cheese Is Unsatisfactory," OVJ, October 13, 1905, 11.

${ }^{32}$ Steinhoff, "Rise and Progress of Canada's Cheese Industry." Steinhoff was a cheese dealer and a speaker in Canada and the U.S.A. on cheese production (Manuscript census for Perth County, 1891, 1901, and 1911, report on 1906 Wisconsin Cheese Makers Association annual meeting, list of addresses in the Report of Secretary To the State Board of Public Affairs, dated January 15, 1912.

${ }^{33}$ Drummond, "Problems of the Canadian Dairy Industry," 160-64.
} 
relationship in which British interests set the terms of trade so as to keep producers weak and dependent. ${ }^{34}$

\section{Shifting Interventions: From Discussion To Disruption}

Dairying had first became a subject of interest for the urban Ottawa Evening Journal in November 1897 when the Ottawa Board of Trade agreed with the Carleton County Council that a cheese board in Ottawa would benefit the city. ${ }^{35}$ Yet however much the Ottawa Cheese Board was to benefit the city, within three years there were signs it was not benefiting the farmers. Despite this, the first rural Journal editor, Herbert Cowan, stood squarely behind the Board. In doing so, he was in line with the federal government's agricultural policy of encouraging the export of cheese to Britain. The producers, on the other hand, saw fundamental market problems even though they were not able to articulate the cause. Faith was in accord with these farmers when he launched what he called the "Big Cheese Movement." As a result, Faith was able in 1908 and 1909 to mobilize farmers against Eastern Ontario Cheese Boards and the Montreal exporting houses by invoking a narrow producerism which pitted dairy producers against exporters as middlemen. Nonetheless he never questioned the system as such. He simply wanted the farmers to get a "fair" return for their labour.

\section{$\underline{\text { Cowan and Discussion }}$}

The fairness of the Ottawa Cheese Board was first raised in 1900, only three years

\footnotetext{
${ }^{34}$ Menzies, By the Labour of their Hands, 87.

35 "Ottawa and Cheese," Ottawa Evening Journal (hereafter OEJ), November 9, 1897, 6 and Ottawa SemiWeekly Journal (hereafter OSWJ), November 12, 1897, 3; "County Favors A Cheese Board / Carleton Council Backs the Ottawa Board of Trade," OEJ, January 28, 1898, 7 and OSWJ, February 1, 1898, 3; Editorial, no title, OEJ, March 26, 1898, 4 and $O S W J$, March 29, 1898, 4; "Considerable Cheese," OEJ, October 12, 1898, 4 and OSWJ, October 14, 1898, 4; "Ottawa Cheese Board," OEJ, May 19, 1902, 4 and OVJ, May 23, 1902, 4.
} 
after it had been established. Perhaps this is not surprising given that the Journal was fuzzy in reporting the Board's beginnings as to whether it was an urban or rural initiative.$^{36}$ From 1897 to 1900 all of the Journal's discussion about the Board was written for and published in the daily and then copied into the rural Journal. Benefits to farmers were mentioned after enumerating benefits to the city and little attention was paid to how the Board was working. ${ }^{37}$ It was not until 1900 that the rural editor Herbert Cowan reported on dairying activities independently of his parent newspaper. But even as Cowan began making news he remained within limits set by government dairy policy.

Economist Vernon Fowke has described this policy as focused on improving cheese quality using two distinct approaches. First, the government gave bonuses to factory owners who added cold-storage rooms and it funded transportation companies to add refrigeration on rail cars and ocean steamers. Second, the government tried to teach patrons and cheesemakers how to scientifically improve their product. ${ }^{38}$

The rural Journal's alliance with orthodoxy was highlighted in the 1901 announcement that the Ottawa Valley Journal had been named the "official organ" of the Eastern Division (Ontario east of Kingston) of the E.O.D.A. Cowan gave his newspaper a

\footnotetext{
${ }^{36}$ The initial newspaper report quoted the Board of Trade as saying it was making its proposal "at the request of the Carleton county council" (see fn 27, "Ottawa and Cheese") but as the idea came to fruition, it was presented as the Board's idea.

37 “A Cheese Board Now Exists," OEJ, March 25, 1898, 4 and OSWJ, March 29, 1898, 5 and 3. The editor gave his approval to the Board as "a marked benefit to the trade and transportation interests of the city." Near the end of the first season the Journal again summed up the benefits achieved in city terms: about 1,200 visits from out of town over the summer with the visitors making use of Ottawa's banking facilities, a concentration of Carleton county interests in the city, railways bringing business into the city rather than "tak[ing] it elsewhere" while the counties around Ottawa got "the exchange of agricultural product for $\$ 168,000$ in the cheapest and handiest possible way." Editorial no title, OEJ, March 26, 1898, 4 and $O S W J$, March 29, 1898, 4; "Considerable Cheese," OEJ, October 12, 1898, 4 and $O S W J$, October 14, 1898, 4. Even in 1902, when the re-focused rural Journal was taking a stronger rural stance, it still took its editorials directly from the daily and the city editor continued to judge the cheese board in terms of what it brought to the city. "City business is benefitted by it, and the city's standing strengthened in the surrounding country. It is a good thing for Ottawa." "Ottawa Cheese Board," OEJ, May 19, 1902, 4 and OVJ, May 23, 1902, 4.

${ }^{38}$ Vernon C. Fowke, Canadian Agricultural Policy: The Historical Pattern (Toronto: University of Toronto Press, 1946), 214-8.
} 
pat on the back saying that the Ontario Department of Agriculture had approved the decision because the newspaper's work on behalf of farmers exceeded that of other (unnamed) newspapers. ${ }^{39}$ Cowan admitted in the announcement that he did not quite know what being official organ meant (despite having lobbied hard for the title) but he was ready to do his bit to promote an industry so important to his readers. As it turned out, the position involved making him corresponding secretary. ${ }^{40}$

Cowan quickly found an activity to undertake just as he was doing that year with the Ottawa Valley agricultural fairs (Chapter 6) and the Eastern Ontario Good Roads Association (Chapter 7). And just as with those activities he began by talking to "prominent men" to determine what needed to be done. In this case, the prominent men were the local agents of the Montreal buyers who Cowan questioned as to why the Ottawa Cheese Board's sales prices were lower than those of the Brockville Board. He was told that Brockville patrons delivered better milk to the factories, the factories were better built and better equipped and the cheesemakers were better paid (attracting better qualified men). ${ }^{41}$ Cowan accepted the buyers' claim that the dairy farmers and the factories were the problem and proceeded to write a series of articles which doubtless were music to the ears of both the Canada and Ontario departments of agriculture.

Cowan suggested that the factories on the Ottawa Cheese Board band together to

\footnotetext{
${ }^{39}$ The E.O.D.A. (covering southern Ontario east of Toronto) had emerged in 1877, via various splits, from the Canadian Dairymen's Association and remained in existence until 1934. The masthead of the Ottawa Valley Journal carried the designation of official organ until it disappeared without explanation in the June 10, 1905 edition.

40 "Ottawa Valley Journal Appointed Official Organ," OVJ, June 25, 1901, 1 (describes the Journal's activities to acquire the title); "Directors Eastern Division Eastern Ontario Dairymen's Association Have Appointed the Ottawa Valley Journal Their Official Organ,' OVJ, August 13, 1901, 1. Neither item appeared in the city version of the Journal.

41 "As High Prices Are Not Paid for Ottawa District Cheese," OVJ, August 23, 1901, 8; The newspaper customarily referred to a Journal "representative" and as a result we cannot say who wrote the articles but Cowan as editor can be assumed to have set the tone. And it was Cowan who was finally named as proposing a solution. Therefore I have named Cowan as the author in these events rather than the more awkward references to "the newspaper".
} 
hire an instructor for the next season. The instructor would work with the cheesemakers but would also educate patrons on the importance of delivering clean, unadulterated milk. In November 1901 Cowan highlighted the newspaper's readiness to help with the header "The Journal's Offer." The Journal would pay a portion of the cost of an instructor for 1902 if that instructor would spend one morning a week writing the newspaper's dairy column. Once the work began, ostensibly it was the E.O.D.A. and the cheese boards who organized and ran the meetings with Cowan as E.O.D.A. secretary. At the same time the meetings were extensively reported in the Ottawa Valley Journal in terms of its own involvement. $^{42}$

At all points in this project, Cowan presented himself in the newspaper as working with establishment figures. Thus his first article on the subject was written as commentary on a reprint of "important" advice for producers from the federal government's official referee in Montreal. Later Cowan reported that he had asked for and got approval for his idea of funding cheese instructors from Dairy Commissioner J.A. Ruddick, President Hardy of the Ottawa Cheese Board, J.R. Reid from the Board of Trade (a former buyer of the Brockville Board and a founder of the Ottawa Board), seller John Tierney "and by a number of other prominent men." ${ }^{43}$ Another report highlighted that Cowan had "mentioned the matter" to Ruddick who thought "it would be a splendid move on the part of the factories of the Ottawa district." ${ }^{39}$ The next year in 1902 the instructors had been hired and the rural Journal regularly reported on the good work

\footnotetext{
42 "Where the Dairy Conventions Are Likely To Be Held," OVJ, November 1, 1901, 1; "First Local Dairy Convention Held at Vankleek Hill", $O V J$, November 22, 1901, 1; "Dairy Interests of Eastern Ontario Should be Thoroughly Organized," OVJ, November 26, 1901, 1.

43 "Why Poorer Prices Are Paid for Ottawa Section Cheese," OVJ, September 10, 1901, 8; "Competent Cheese Instructor for Ottawa District Factories," OVJ, September 27, 1901, 8; "The Ottawa District Cheese Factories," OVJ, November 12, 1901, 8.
} 
being done as a result of what was highlighted to have been the Journal's idea.

Cowan also asked three members of the Ottawa Board of Trade about charges that prices on the Ottawa Cheese Board were being systematically depressed by curb-selling. The men admitted curb-selling happened but would not condemn it. W.H. Dwyer did use a standard of "fairness" to judge the situation but also pointed out that it was business: "I consider that the buyers are not using Ottawa Cheese Board patrons fairly, but if salesmen choose to allow themselves to be treated in that way, I don't feel like blaming the buyers very much. ${ }^{, 44}$ A month later the newspaper printed a letter from farmer James Kennedy who was salesman and secretary for the Orleans, Ontario factory. Kennedy said the factory was leaving the board because of curb-selling. Cowan signed an addendum as Editor to argue that "[ $\mathrm{t}] \mathrm{he}$ buyers naturally are desirous of obtaining the cheese they buy at as low a figure as possible. ... It appears as if little can be done in this matter until the salesmen realize the fact that they will best serve their own interests by all selling on the board. ${ }^{, 45}$ Cowan was closing the gate on any discussion which questioned how cheese marketing was conducted. The difference between Cowan as rural editor and his successor Robert Faith is apparent in that two of the men Cowan named in identifying the backers of his cheese instruction project, John R. Reid and John Tierney, were men Faith would attack six years later in his Big Cheese Movement as being neither farmers nor having farmers' interests at heart.

\section{Faith and Disruption}

The second editor of the Ottawa Valley Journal, Robert Faith, started his career as rural editor within the dairy establishment, that is, he served as secretary to the Ottawa

\footnotetext{
44 "The Ottawa Cheese Board May Have to Break Up," OVJ, October 29, 1901, 7.

45 "Selling Cheese on the Curb," OVJ, November 12, 1901, 8.
} 
Cheese Board from about 1903 to 1908. Dissatisfaction with the Ottawa Cheese Board had been percolating in the pages of the Ottawa Valley Journal from 1900 but in July 1907 Faith exploded the problem in everyone's face. Despite being the Board secretary, Faith printed a series of numbered articles over July and August 1907 accusing nearly everybody on the Board of misdoings in increasingly strong terms. The Board meetings themselves appear to have been tied up with accusations and counter-accusations on everyone's part. In January 1908 Faith reported that the buyers and a number of factory salesmen had worked to exclude him from the Board. ${ }^{46} \mathrm{He}$, however, had already mentally left it. Every one of the rural Journal's agricultural pages in December 1907 contained articles headlined in large, bold font telling farmers about a counter cheese board idea Faith called "Farmers' Exchanges." He described them as incorporated market organizations run by and for the farmers. They would be different from the Cheese Boards because they would enforce rules against curb-selling and would deal only with buyers who agreed to inspect the cheese at the time of purchase and to pay for the cheese before it was shipped to Montreal. ${ }^{47}$ Faith later underlined that despite the new name the insistence on following the rules was the only difference from the cheese boards. ${ }^{48}$ Faith did not want to change the marketing system-just make it work for the producer.

Faith began to establish the new Exchanges in January 1908 with a call for factory patrons to name their delegates to a mass meeting the Journal was organizing for

\footnotetext{
46 "Farmers Lost Thirty Thousand Dollars by Patronizing the Ottawa Cheese Board," OVJ, January 7, 1908, 10.

47 "Farmers' Exchange Formed for Ottawa Valley Dairymen," OVJ, December 6, 1907, 12: "Dairymen Must Pull Together and Organize," OVJ, December 10, 1907, 10; "Makers Are Interested," OVJ, December 13, 1907, 12; "Farmers Have Started Work in Favour of Factory Inspection," OVJ, December 17, 1907, 10; "Mass Meeting of Patrons Will Be Held at Bonville," OVJ, December 20, 1907, 12; "No Coasters Wanted in the Great Struggle," OVJ, December 24, 1907, 10; "Letters and Visits About Farmers' Exchange," OVJ, December 17, 1907, 12; "Struggle for Factory Inspection Has Commenced in Real Earnest," OVJ, December 31, 1907, 10.

48 "Newspapers Are Jealous," OVJ, May 5, 1908, 10.
} 
February 6, 1908. Every issue that month carried announcements of various factories' upcoming organizing meetings as well as reporting producers' enthusiasm for the idea as seen in meetings which had just taken place. Faith attended each meeting to tell the patrons his vision, a vision in which producers would dominate the marketplace through the Farmers' Exchanges. The February mass meeting was a success in terms of numbers and enthusiasm. The four hundred to seven hundred delegates (the number fluctuated from report to report) apparently supported the establishment of yet another new organization called the Farmers' Produce Association which would be an organizing structure for the Exchanges. Faith declared the Exchanges to be the start of a "revolution." 49

The revolution, however, was delayed. On February 17, 1908, the Montreal Produce Merchants Association (the Association for the cheese exporters) met with the Farmers' Produce Association executive to say they would not do business with the new Exchanges. And even as some factories created Exchanges, the old cheese boards held their usual organizing meetings in the spring of 1908 and readied themselves to do business. Faith continued to travel to meetings, encouraging the faithful and arguing with the enemy as hostile salesmen and factory owners attacked his ideas, his motives and his good sense. He wrote to British wholesalers to enquire whether they would do business with the new Exchanges and he printed the encouraging replies in the rural Journal, for he was ready to carry on business with middlemen a continent away. He also printed

\footnotetext{
${ }^{49}$ A sample of the relevant articles are provided here, all from the OVJ: "Marked Progress is Being Made in Struggle for Factory Inspection," January 3, 1908, 12; "If Factory Inspection," January 7, 1908, 10; "Some Recent Meetings Held by Dairymen," January 10, 1908, 12; "Moose Creek Meeting Large, Embrum (sic) Larger, Metcalfe Largest," January 17, 1908, 12; "Factory Inspection Now or Never Eliminate Some of the Heavy Losses," January 21, 1908, 10; "Dairymen Must Co-operate If They Want Factory Inspection," January 28, 1908, 12; “Revolutionalizing of Cheese Industry Is In Sight," February 7, 1908, 12.
} 
letters of support from across the region. Then the movement seemed to die with only sporadic reports appearing in the Ottawa Valley Journal after July $1908 .^{50}$

Unfortunately ongoing support turned out to be a problem for the Farmers'

Produce Association. This was most visible in its need for operating funds.$^{51}$ Out of the several hundred factories which had claimed at the February 6, 1908 cheese meeting to want a new way of doing business, only about a hundred factories followed through with financial support. Faith's cheese fight, however, came back before readers in late 1909 as the rural Journal reported signs of progress: direct marketing to British wholesalers in Lansdowne, Ontario; car door inspection and payment in Russell and Cambridge Townships; and selling at car door in Grenville to an Ogdensburg man who shipped direct to Britain. ${ }^{52}$ Faith continued to bang his drum through 1910 with examples of small victories even as the cheese boards continued to operate and buyers continued to set the terms of business in their own favour. Then came two high-visibility bankruptcies among the Montreal exporters which hit local factories and producers hard due to the practice of exporters paying only after they had the cheese in their warehouses.

\footnotetext{
${ }^{50}$ A sample of the relevant articles are provided here, all from the OVJ: "Executive of Farmers' Produce Association Meet Exporters," February 21, 1908, 12; "Meetings to Forward the Ottawa Valley Journal's Cheese Movement," February 25, 1908, 10; "Letter from President Farmers' Produce Association" March 3, 1908, 1; "All Arrangements Have Been Made to Ship Cheese Direct to Great Britain," April 7, 1908, 10; "Cheese Board Executive Meet," April 10, 1908, 10; "Latest Developments in Big Cheese Movement, April 21, 1908, 10; "Cheese Board and Exchange," May 26, 1908, 10; "Practical Men Approve of Factory Inspection," June 12, 1908, 10; "British Cheese Importers Delighted with Journal's Idea of Direct Trade," July $31,1908,10$.

${ }^{51}$ The Ottawa Citizen's rural edition gave a fairly balanced report on the progress of the Farmers' Produce Association in reporting on its convention of January 25, 1909 but the damning information was given in the second and third last lines. After an initial meeting with British cheese buyers in Montreal in the summer of 1908, nothing further had been heard from them and the financial report showed the balance on hand to be \$4.05. "Farmers' Meet," Central Canadian Citizen, January 26, 1909, 6.

52 "Lansdowne Dairymen Hold Important Meeting," OVJ, July 6, 1909, 10; "Official Inspection of Butter and Cheese at Point of Shipment," OVJ, August 20, 1909, 12; "Salesmen Are Getting," OVJ, October 12, 1909, 12; "Cheese Goes Direct Board People Squeal," OVJ, November 5, 1909, 10. The readiness of Faith and at least some Exchanges to prefer a long-distance business relationship with British wholesalers to buyers at the local Cheese Board meetings suggests that the comfort of the local versus the disruption of disembeddedness was not as sharply divided in 1900 as might be argued.
} 
Faith used these reports first to say we told you so and then to put forward suggested changes. In October 1910 Faith made a suggestion that they ask the E.O.D.A. to employ someone in Montreal to act as an information exchange on sales and payment. He asked readers to write to either agree or to suggest a better way. ${ }^{53}$ Apparently as of December no one had written but, no matter, as Faith had a better suggestion based on conversations with Western wheat farmers. Close to a thousand farmers had come in December 1910 to Ottawa from across Canada, but in particularly large numbers from the West, to protest tariffs and demand reciprocity with the United States. Faith learned from the grain growers that they had won various legislative protections against the dominance of the grain exporters, including a requirement that the buyers be bonded as a guarantee of their ability to pay the producers. ${ }^{54}$

Faith did not consider the structural differences between Western wheat agriculture and Eastern Ontario dairying or was not aware of their significance. Fowke points out in explaining the grain selling reforms in the West that western farmers were united around one staple product which had become by 1910 Canada's most important agricultural export. As well, the grain growers were opposed by western mercantile interests whom the government did not regard as being of equal political importance. ${ }^{55} \mathrm{In}$ contrast, the cheese issue was largely only an Eastern Ontario issue and cheese in general was one of many Ontario agricultural products. It was also no longer of overwhelming economic importance to the government's calculation of Canada's export market. In

\footnotetext{
53 "F. Fowler, Cheese Exporter Has Made an Assignment," OVJ, October 25, 1910, 12.

54 “A.D. M'Gillis, Montreal Cheese Exporter, Offers His Creditors 25C. on Dollar," OVJ, December 13, 1910, 12; "Mr. Ross Wants some Guarantee of Payment," OVJ, December 16, 1910, 10 (Ross was a factory owner whose losses Faith highlighted because Ross had been a visible opponent of the cheese campaign); "Unjust Rules Govern Weighing of Cheese, $O V J$, December 23, 1910, 12; "Government Protects Western Wheat Growers from Loss Through Failures," OVJ, December 27, 1910, 10; "The Journal's Agitation to Improve Cheese Trade," OVJ , December 30, 1910, 12.

${ }^{55}$ Fowke, Canadian Agricultural Policy, 244-7.
} 
addition, dairy farmers were opposed by powerful eastern mercantile interests such as the Montreal export houses and the E.O.D.A. Shortly after starting the cheese fight, Faith made charges against the E.O.D.A. itself, saying it was spending its government funding without regard for the interests and needs of producers. ${ }^{56} \mathrm{He}$ was not wrong in identifying it as representing non-producer interests. Its president in 1901 and for some years after, Daniel Derbyshire, had originally been a cheese manufacturer but since 1879 had been a buyer for a major Montreal house as well as a seller of dairy supplies, a produce merchant and mayor of Brockville. In 1904 he was elected to the Canadian House of Commons and in 1907 he was named to the Senate. His opposition to the Journal's Big Cheese Movement would have been a significant obstacle. ${ }^{57}$ The E.O.D.A. was functioning as the government's unofficial stand-in on disseminating its policy.

Faith did not have insights into history to see the array of forces against change in the cheese market. So he proceeded on, asking factories to send members to yet another mass meeting in Ottawa. He called this meeting for January 18, 1911 with the purpose of considering how the Eastern Ontario dairymen could obtain the kind of legislative protection from buyer bankruptcies that grain growers enjoyed. The end objective was to present a petition to the Minister of Agriculture. The dairymen came and they agreed with Faith on the need for protection. Several hundred of them immediately marched to Parliament Hill where their leaders met with the Minister of Industry and Commerce (Minister of Agriculture Sydney Fisher being unavailable). All of this was both organized

\footnotetext{
${ }^{56}$ Faith made this charge in a series of articles published in the OVJ between October 1909 and early 1909; "Some Instances of How Public Money is Spent Freely by the Dairymen's Association," October 2, 1908, 10; “Journal Asks Government for Itemized Statement," October 9, 1908, 9; "Ontario Government Refuses to Give Farmers Itemized Statement of How Money Was Expended," October 23, 1908, 10; "Bound to Investigate Finances of Association," November 6, 1908, 10; "Divide Eastern Ontario Have Two Associations," November 20, 1908, 10; "Marketing of Cheese Discussed at Perth," February 12, 1909, 10.

57 "Directors Eastern Division Eastern Ontario Dairymen's Association" OVJ, August 13, 1901, 1-2.
} 
by the Journal and reported in it. ${ }^{58}$

But while this was the petition highlighted in the circa 1920 sales pamphlet, the result was not quite the success the pamphlet suggested. There was a Royal Commission but it was not set up until July 19, 1912 and the commission's report was effectively a slap in the face for Faith and the cheese producers. ${ }^{59}$ Between August and December 1912 the commission heard evidence from fifty people at meetings in Montreal, Kingston, Cornwall, Brockville and Ottawa. Faith gave a presentation on his proposals at the Ottawa hearing. The commission also attended the E.O.D.A. annual conference in January 1913 and heard informally the "views of those directly interested in the matters under investigation." ${ }^{60}$ They asked those men what they thought of Faith's proposal, said they listened to "a full discussion," and witnessed the meeting pass a resolution firmly rejecting Faith's idea of bonding exporters. The commissioners accepted the E.O.D.A.'s claim that costs would be passed on to the producers and that there was no need for legislation as each cheese board set all the rules necessary to protect their factories against non-payment. ${ }^{61}$ In short, the commissioners refused to see the problem of a market imbalance in which exporters imposed terms of trade directly against rules set by the various Boards. The Ottawa Valley Journal said nothing further on the subject that

\footnotetext{
${ }^{58}$ As there was one or more article in every issue in January, a sample is provided from the OVJ: "Are the Ontario and Quebec Farmers Ready to Hold Big Dairy Convention?" January 3, 1911, 10; "Journal Decides to Go Ahead with Big Dairy Convention," January 6, 1911, 12; "Many Prominent Men Coming to Farmers' Big Convention on Jan. 18," January 10, 1911, 12; “The Farmers' Convention,” January 17, 1911, 12; "Farmers Ask for Legislation in Regard to Cheese Marketing," "Dairymen Place Case Before the Ministers," January 20, 1911, 1; "An Appreciative Resolution," and "Presented Watch to Mr. R.B. Faith," January 24, 1911, 12.

${ }^{59}$ The Chair was Ottawa lawyer Robert Alexander Pringle. The Commissioners were Arthur Jacob Hodgson (president in 1904 of the Montreal Board of Trade) and, as the farmer representative, Samuel J. Macdonnell. I have not found any information on Macdonnell.

${ }^{60}$ Report of Royal Commission to Enquire Into Alleged Complaints Relating to Weighing of Butter and Cheese in Montreal, Sessional paper 153b (Ottawa: C.H. Parmalee [king's Printer], 1913): 5 http://epe.lacbac.gc.ca/100/200/301/pco-bcp/commissions-ef/pringle1913-eng/pringle1913-eng.pdf. Accessed May 12, 2017.

${ }^{61}$ Ibid.
} 
year except to ask why a cooperative movement was so difficult to advance in Eastern Ontario. $^{62}$

\section{Farmer's Advocate as Public Forum}

During the campaign Faith had attracted some unwelcome publicity when Dairy

Commissioner J.A. Ruddick devoted part of his 1909 address to the E.O.D.A. to

condemning the cheese campaign, saying:

... the question had been magnified to an extant out of all proportion to its importance compared with other matters affecting the industry. The result of this agitation, as far as it can be said to have had any result has been to divert attention of some dairymen from questions of much more real importance to them. The manner in which the agitation has been conducted has been harmful by creating ill feeling between different classes or interests connected with the trade. ... [wrong practices] will not be put right by wholesale charges of dishonesty or mean insinuations and abuse of those who may offer contrary opinions. Abuse is not argument and is always the resort of a man who has a weak case. ... It will do no good to create unwarranted suspicion in the minds of those who have to deal with each other. ${ }^{63}$

Ruddick was not simply saying that Faith was wrong. His charge was that Faith was

failing to respect the liberal ideal of the mutuality of interests in society which Darren

Ferry names as one of the four key elements of the nineteenth-century doctrine of a

liberal community. This was an ideal which can be seen in the Farmer's Advocate.

William Weld, the founder of the Farmer's Advocate, had seen commercial

interests as adding value to agricultural products by moving the agricultural produce to

\footnotetext{
62 "What is Wrong With Our Co-operative Movement," OVJ, October 3, 1913, 14.

${ }^{63}$ Central Canadian Citizen, January 8, 1909, 3. Farm and Dairy, January 14, 1909, 6 quoted an extract from Ruddick's address under the header "Campaign Denounced" describing Ruddick as condemning "the methods that have been followed in a campaign that had been conducted in Eastern Ontario by a paper that had been endeavoring to introduce changes." Robert Faith took the high road, giving the full speech as was the farm press custom with the Dairymen's convention. He prefaced the speech with the comment that Ruddick was a knowledgeable authority who had given a great and useful address even if neither the Ottawa Valley Journal nor "thousands of farmers" agreed with all of it; "Dairy Commissioner Ruddick Discusses Dairy Situation," OVJ, January 12, 1909, 9.
} 
consumers both physically and through deal making. Weld had been one of the founders of the Grange in its first year in Canada but had resigned his position as an officer in order to be able to critique the Grange in Canada from a position of independence. Ferry comments that Weld was drawn to a liberal ideology of the interdependence of all interests partially from his own status as both farmer and entrepreneur. For while Weld was famous as a practical farmer giving good advice, he was a newspaper publisher selling subscriptions and advertising, including advertising by commercial firms. ${ }^{64} \mathrm{He}$ was also a merchant selling seeds in the Emporium he had established as part of his efforts to improve agriculture. His motive in the Emporium was more than gouging profits and he was not making his living as a merchant. Nevertheless, he was involved in commerce and was selling, not giving away, seeds.

Weld's successor, his son John Weld, does not appear to have traveled far from his father. At the same time, it was his employees who wrote the positions taken by the Advocate and they took a careful stand on issues in which producers and buyers were potentially in conflict. In 1901 the Advocate published a letter from "Butter Merchant" under the heading "Necessity of Co-operation Between Farmers and Merchants." The letter writer argued that any complaints about the prices farmers received would be remedied by producing better quality product. ${ }^{65}$ The Advocate did not question this claim.

A few years later in 1907 the Advocate made a stronger defence of producers but it carefully avoided a possible fight with senior government officials. This defence was worked out in the longest discussion on dairy quality I have found in the Advocate and it centred on one question, shipping "green cheese" to the British market. Green cheese was

\footnotetext{
${ }^{64}$ Ferry, Uniting in Measures, 197-8.

65 "Necessity of Co-operation Between Farmers and Merchants," "Butter Merchant" to Editor, FA, March 15, 1901, 192.
} 
immature cheese which could go off in flavour as well as lose volume in shipping. In January 1907 the Advocate's verbatim report of Dominion Dairy Commissioner J.A. Ruddick's speech at the E.O.D.A. convention included a warning that shipping green cheese the previous year had harmed the reputation of Canada's cheese in Britain. The newspaper report added a comment that this was followed by a "spirited discussion" as to who was to blame. Ruddick was quoted as saying the merchants would buy green cheese if there was money in it and could not be blamed. His solution was that the makers should simply refuse to sell green cheese when buyers tried to buy. ${ }^{66}$

The Advocate came back to the question of blame in May 1907 in responding to an editorial in the Montreal Produce Association's Montreal Trade Bulletin which had attributed the exporters' 1906 losses to shipping green cheese. The Advocate editorialized back at the exporters that it "desires most emphatically to protest." The buyers had insisted factories deliver cheese early because they feared a drop in British prices and wanted to ship the cheese immediately. As well, competition was so strong that dealers feared not acquiring any cheese if they did not buy green. The Advocate added that Ruddick had been wrong at the January E.O.D.A. meeting for placing all the responsibility for the health of the industry on the producers and cheesemakers. The writer made this point, still without confronting Ruddick by name:

... there are those who tell us that the factorymen should not have sold, that they should have refused to let the cheese go, on the ground that the shipping of green cheese would prejudice our national reputation. The buyers, we are complacently told, have no interest at stake, for if the cheese industry is ruined, they can turn to some other business. All kinds of excuses for the buyers, but the farmer and maker must shoulder the whole responsibility. ${ }^{67}$

\footnotetext{
66 “Eastern Ontario Dairymen's Convention," FA, January 17, 1901, 96.

67 "Farmers and Makers Not To Blame," FA, May 9, 1907, 783.
} 
The Advocate called Ruddick's solution of factories refusing to sell green cheese "light and airy talk" but again did not name Ruddick. ${ }^{68}$ The next week it ran an article written by Ruddick chastising factories for shipping green cheese. It did so, however, with an introduction saying that this article seemed to have crossed the May 9 Advocate editorial in the mail. Commenting that "[t]he most casual reader cannot but observe that the two articles do not precisely agree," the Advocate writer reiterated the position it had presented on May 9, still not naming Ruddick. ${ }^{69}$

Ruddick replied in June saying it was more important to find a solution than to attach blame. ${ }^{70}$ When the Advocate next addressed the issue, it presented itself as concerned, like Ruddick, with solutions but said this required "continued discussion.."71 The Advocate then said it had written to "leading dairymen and cheese-buyers" and was now printing the replies to two questions: what was the minimum time cheese should be cured before being boxed [shipped], and, how could the shipment of green cheese be stopped. H.H. Dean, the head of the dairy department at the Ontario Agricultural College (O.A.C.), had commented: "[w]e may safely leave the matter in the hands of the Canadian cheese merchants, who know the consuming public in the Old Land better than do any other persons in Canada." On the other hand the owner of thirty factories, William Eager of Morrisburg Ontario, said the buyers created the problem and the buyers should address it. ${ }^{72}$ Two men whose occupations are unknown, both from Middlesex County, also took opposing positions in letters placed side by side in the Advocate. John Isaac said

\footnotetext{
${ }^{68}$ Ibid.

69 "Shipping of Green Cheese Condemned," FA, May 16, 1907, 837.

70 "Green Cheese Shipments Threatening Trade," J.A. Ruddick to Editor, FA, June 6, 1907, 947.

71 "The Green Cheese Danger," FA, June 13, 1907, 983.

72 Eager's profile as a factory owner was given in the 1901 Ottawa Valley Report on elected officers of the E.O.D.A. "Directors of the Dairymen's Association," OVJ, August 13, 1901.
} 
it was up to the factories to stop selling green cheese. S.E. Facey said buyers should stop trying to buy green cheese. ${ }^{73}$ Having physically demonstrated by this juxtaposition that there was no clear answer, the Advocate summed up the situation in a full page front editorial (an uncommon length for the Advocate.) Its answer was to say that all possible ideas should be discussed. ${ }^{74}$ J.A. Ruddick entered back into the fray the next week with a letter to the Advocate editor objecting to what Dean had written but still unwilling to blame the buyers. Ruddick continued to hold that the interest of buyers was in making a profit while the interest of producers was in the future of the industry. His intent, he said, was to waken the producers to the danger to their interest. ${ }^{75}$

The Advocate continued with its muted defence of the producers against the exporters when in 1909 it editorialized on a complaint against producers made in the Montreal Trade Bulletin. The Bulletin had stated that competition between the exporters the previous year had transferred the exporters' profits to the farmers. Apparently the exporters thought this was bad, but not because of the loss of profit in their own pockets. Rather the farmers' windfall had made them "lazy" so that they were reducing their herds and their production. The Advocate's editorial ridiculed the complaint as nonsense. ${ }^{76}$

In general, the Advocate's response to questions of the fairness of the market was similar to how Journal editor Cowan had addressed statute labour on roads in 1901 (Chapter 7). First, it tried to systematize the discussion with a mini-survey and second, again like Cowan, it addressed the survey to men it saw as leaders on the issue. Unlike

\footnotetext{
73 "Some Views on the Green Cheese Question," FA, June 20, 1907, 1021; "What is Green Cheese?" "Remedy Lies with the Producer," "Cheese Should Be Kept a Week on the Shelves," Jno. R. Isaac to Editor and S.E. Facey, FA, June 27, 1907, 1057-8.

${ }^{74}$ Editorial, "Green Cheese and the Grading System," FA, June 27, 1907, 1049-50.

75 "How to Abate the Green Cheese Evil," J.A. Ruddick to Editor, FA, July 4, 1907, 1091-2.

76 "Producers and Cheese-buyers," FA, April 1, 1909, 525.
} 
Cowan, the Advocate did not claim that it had been asked to intervene by ordinary farmers. Instead, the Advocate had leapt into the question because of what it saw as an unjust attribution of blame. But while the Advocate spoke out to defend producers, it did not intervene even by such moderate steps as Cowan had done with respect to fairs, roads and cheese quality. As well the Advocate differed from Faith. It wrote in line with Weld's embrace of the liberal doctrine of mutualism and interdependence. Faith wrote out of producerism and a general opposition to the moneyed classes. Yet he did not see a need for fundamental changes in the marketing system. He seems to have believed in its essential rightness, if only it were made to work as he thought it should.

\section{Rhetoric}

Both the Farmer's Advocate and the rural Journal opened their pages as public forums on agricultural progress. The Journal, however, was an activist in a way the Advocate was not. Establishing the Fairs Association in 1905 had been a mild affair but Faith's 1907 campaign setting up the Farmers' Municipal Rights Association was noisier and the Farmers' Produce Association was noisier still. Faith's increasingly vociferous language in castigating those he declared the enemy left him with few allies among officials but he did receive votes of thanks from the farmers who attended his mass meetings.

\section{Fairness, Struggle and Producerism}

The cheese campaign went through three phases. In 1907, Faith wrote a series of numbered articles against the Ottawa Cheese Board and the Montreal cheese exporters. At this point Faith thought that it was merely a question of stirring up public outrage in order to force the Ottawa Cheese Board to enforce its own rules. The second phase began 
in late 1907 when Faith decided to establish a counter structure to the cheese boards in the form of Farmers' Exchanges. These would not be hybrid organizations like the Ottawa Cheese Board which had been established by the city Ottawa Board of Trade working with the Council of the surrounding county. They would be true farmers' organizations and would destroy the cheese boards by the simple expedient of luring all the producers with the promise of enforcing rules and thereby making the system work on their behalf. The last phase of the cheese campaign was the February 1912 petition requesting government protective legislation for producers. Throughout Faith was convinced that the global capitalist market would work for the producers if only the moneyed interests could be shamed or forced into following the rules.

It seems there were agriculturists in the Ottawa Valley who were ready to follow Faith through all these phases of the struggle and none of them questioned his basic adherence to the capitalist system. At the same time, they like Faith couched the issue as one of fairness. Fairness had also appeared as the prime criteria of how relationships should work in the earlier campaigns of the Eastern Ontario Fairs Association and the Farmers' Municipal Rights Association on taxes. The call for fairness in the Big Cheese Movement came from patrons and some cheesemakers even before the cheese campaign took off into full flight with Faith's 1907 cheese articles. In 1906, Sandy Gordon, a cheese salesman in Grantley in Dundas Township, wrote that the industry needed factory inspection and pay. He urged salesmen to stand up for their rights as "the only fair way to settle their disputes." 77 The themes of struggle and fairness infused the rhetorical questions headlining the first of Faith's articles: "Are they [the buyers] trying to choke the Ottawa Cheese Board out of existence? Have they dealt fairly with the Ottawa Cheese

77 “The Official Referee," Sandy Gordon to Editor, OVJ, August 17, 1906, 2. 
Board in the past?" The rural Journal invited correspondence on its cheese articles and immediately received a letter from J.H. Jacques the proprietor and salesman for the Edwards cheese factory. Jacques argued for a factory's right to sell cheese in whatever manner it pleased (presumably either on or off the board) but he also commented on "an unjust attack" by the cheese buyers McRae and Welsh. ${ }^{78}$

Readers continued to express their support in the years which followed. In October 1909 "A Pontiac County Cheesemaker" wrote that he wished the newspaper success while commenting on the reasonableness of getting payment for cheese in the same way all other produce was paid for. He expressed his determination to stand up against the middlemen: "farmers and all concerned in the dairy business have been dealt with unjustly long enough ... It is high time the farmers and cheese makers would (sic) unite and stand up for their rights." A few months later Robert McCurdy wrote: "[the Ottawa Valley Journal] is one of the farmer's best friends ... As a farmer I appreciate the good work it is doing in the selling of cheese and municipal rights' association ....,79 $\mathrm{In}$ 1910 the rural Journal asked readers to comment on the Eastern Ontario dairy industry and what they saw as its weak point. Official wisdom would have written about scrub (unpedigreed) cows and failure to use the latest scientific methods. But very few mentioned these. Instead a number of writers focused on the current method of selling cheese. James Ferguson of Russell, Ontario said the weakness lay in selling subject to Montreal inspection and final weighting: "It seems to me that the cheese buyers have us at their mercy; they can make their own prices." Salesman "J.A.M." of Glengarry stated

\footnotetext{
78 “Journal’s Attack Against Ottawa Cheese Board,“ T.H. Jacques to Editor, OVJ, July 23, 1907, 10.

79 "Farmers Must Fight to Win," “A Pontiac County Cheesemaker" to Editor, OVJ, October 29, 1909, 10; "Letters to the Editor," David R. McCurdy, OVJ, January 18, 1910, 12.
} 
they needed to fight the Montreal exporters. ${ }^{80}$

\section{Credibility}

While the Ottawa Valley Journal was stirring up farmers in order to alter power relationships in the cheese market, observers were not blind to the fact that newspapers were businesses. They knew that two major newspapers, Pulitzer's New York Times and Hearst's New York World were infamous for using sensation to sell newspapers. Furthermore, they knew that newspapers created their sensations with large, bold headlines. As a result Faith's campaigns were met with the charge that it was all about the rural Journal's circulation. We know this because Faith reprinted any press comment, whether favourable or unfavourable, along with his own comment of thanks or defense. He rebutted the cynical analysis of various Ottawa Valley weeklies by saying that his only interest was the well-being of local farmers. ${ }^{81}$ A newspaper from Grenville County wrote that "hard-headed and far-sighted" producers were rejecting what the writer called the "'Faith Cure"" by continuing to support the Kemptville Cheese Board. This article attacked both the rural and the daily Journal, saying that Faith was working at the command of his publisher P.D. Ross. Ross and Faith were, according to this report, intent on printing a newspaper which would keep its readers "continually interested, often amused and once in a while thrilled" with "new schemes" to make the paper readable —a description that sounds like fulminations against the Yellow Journalism. ${ }^{82}$

\footnotetext{
80 "The Pooling System of Paying for Milk," James Ferguson to Editor, OVJ, September 9, 1909, 10; “A Salesman Writes Re Short Weight Losses." "J.A.M to Editor, OVJ, December 30, 1910, 12.

81 "Letters to the Papers," OVJ, March 3, 1908, 10, reprint of "City Chap" to Editor Mountain Herald ; "What the Papers are Saying," OVJ, March 6, 1908, 12, reprint of Perth Expositor editorial, "the Ottawa Valley Journal is in business to boom that paper" and John A. Gillis to editor in the "Glengarry] News"; "Senator Derbyshire Not In Sympathy With Farmers' Big Cheese Movement," OVJ, April 10, 1908, 12. 82 "Newspapers Are Jealous," OVJ, May 5, 1908, 10. The unnamed newspaper likened the rural Journal's campaigns to fireworks which cause excitement and then die. Among the "sky-rockets" it said P.D. Ross
} 
Faith also published comments hostile to producers such as that of the Montreal Trade Bulletin. The Bulletin which was the trade magazine of the Montreal produce exporters had said that farmers were getting above themselves. This no doubt confirmed Faith's readers in their opinion of the exporters. On the other hand, favourable comments came from Canadian Farm, Canadian Dairyman and supportive comments by a professor of soil physics at the O.A.C. ${ }^{83}$ But it seems that those wishing to criticize Faith believed farmers would be ready to believe it was all about selling the newspaper.

The question of credibility came up again in Isaac Steinhoff's Farmer's Advocate 1906 article dismissing the complaints of unnamed newspapers against cheese boards:

There has been a good deal of talk and newspaper criticism of the present system of selling cheese in Canada-some of it very extravagant, and carried on by those not engaged in buying and selling cheese or butter, and knowing very little about the business.

Steinhoff said the industry could only be harmed by "inexperienced critics." ${ }^{84}$ While Faith was still a year away from his Big Cheese Movement, he was starting to raise questions about the Ottawa Cheese Board in the rural Journal. Local readers of Steinhoff's article may have drawn a connection. Faith was certainly not an experienced businessman. He was not even an experienced man, as one opponent underlined in calling him “The Journal's young man.” Another opponent said he had been selling cheese longer than Faith had been alive. ${ }^{85}$ Faith ignored (at least in the pages of the

\footnotetext{
had ordered and Faith, as a good employee, had produced, it included the campaign to improve fairs by giving a prize for the best fair ("the Banner Fair sky-rocket") and to improve roads ("the Good Roads Train sky-rocket.")

83 "Newspaper Comments on Cheese Movement," OVJ, March 6, 1908, 10; "Payment at Car Door Is the Only Fair Way," OVJ, November 19, 1909, 10; Ottawa Valley Dairymen Severely Punished by Cheese Buyers Last Week," OVJ, August 9, 1907, 12; "Co-operation the Only Way," OVJ, December 10, 1909, 11. ${ }^{84}$ Steinhoff, "Rise and Progress," in FA, December 13, 1906, 1963. It is possible Steinhoff's target was a Cowansville Observer article reprinted by the Ottawa Valley Journal. ("Present Method of Selling Cheese is Unsatisfactory," OVJ, October 13, 1905, 11).

85 "He Denounced Journal Movement," OVJ, March 27, 1908, 10. Faith was twenty-eight in 1907 at the
} 
newspaper) charges against his youth but he hotly responded to comments about his knowledge of dairying saying "[h]e has milked the cows, stood on the whey platform, between the plough handles and done all kinds of work on the farm."

C.A. Publow of Cornell University (and, as the rural Journal pointed out, a former employee of a Montreal export house) backed the Journal's position in the regular dairy articles he wrote for the newspaper. In July 1909 and again in December 1909 Publow commented specifically on how the export cheese market worked against the interests of producers. In July he stated that Canadian cheese prices were set by a small number of British mercantile exchanges operating in a speculative commodity market. In December he commented that the cheese campaign complaints were real. ${ }^{87}$ Despite Publow's clear statement that the market was tilted against Canadian cheese producers, Faith's campaign did not change how the market worked. Heather Menzies writing in 1994 was mourning the death of the Eastern Ontario cheddar cheese industry as local manufacturing was closing down in the face of large international conglomerates. What we see in the pages of the Ottawa Valley Journal is that the problem of the global against the local market began before the First World War.

\section{A Fine Mix of Radicalism, Business and Religion}

Faith's rhetoric in his seven cheese articles of 1907 mixed talk on the virtue of being business-like with agricultural fundamentalism. He saw a farmer victory as inevitable because farming underpinned the nation's wealth. The question of cheese was about farming as a business in which selling within a fully capitalist global market was an

start of his big cheese movement (manuscript censuses 1881 Winchester Township, no. 3, p. 17 and 1911 City of Ottawa, No. 22, p. 33; marriage registration 1903-017998).

86 "Newspaper Comments on Cheese Movement," OVJ, March 6, 1908, 10.

87 “Are Mercantile Exchanges Detrimental to Dairying?” OVJ, July 9, 1909, 10; “Dr. Publow's Special Article Deals With Journal's Big Cheese Movement," OVJ, December 17, 1909, 10. 
important component. This was made clear as early as 1901 when a cheesemaker wrote the rural Journal and its editor Herbert Cowan to say that the newspaper's focus on production ignored important issues: "I notice you have touched on everything connected with the dairy business, from the milking of the cow till the cheese or butter is ready for the market, but you have stopped right here." He went on to argue that the industry had to change to require payment at the factory or at the point of shipping. After all, no-one would deliver livestock without getting payment first ${ }^{88}$ Faith, however, appealed to the importance of business in negative terms by condemning a lack of proper business methods. But his criticism of unbusiness-like behaviour was accompanied and eventually almost eclipsed by increasingly radical calls for fair play for the masses along with references to struggle:

Were [boards] not organized for the purpose of having the business done openly, fairly, and honestly, so that every dairyman would know what his cheese brought in the market? Would you, Mr. Farmer, trust a man to sell your hay or grain in some nook or corner in an underhanded way? Would you be satisfied with his report to you weekly? ...

Have the buyers dealt fairly with the Ottawa Cheese Board in the past? The Ottawa Valley Journal answer is in the negative. ... Openly [the buyers] advise selling on the board, because they know that curb selling is acknowledged to be crooked business, but every chance they get they coax the salesmen on to the street to do business. And they stand up bravely and say that the prices paid at Ottawa are as high as the figure at other points. The Ottawa Valley Journal challenges them to produce the figures. ... ${ }^{89}$ (my emphases)

The same article also spoke of salesmen "playing into the hands of the buyers who are slashing them right and left."

The headline on Article No. 3 highlighted that the farmers were involved in a battle: "Journal's Attack Against Ottawa Cheese Board / In its Efforts to Protect the

\footnotetext{
88 "Present Methods of Selling Cheese Not Considered Satisfactory," B.S. McConnell to Editor, OVJ, May 23, 1902, 1 .

89 "Cheese Board Is Not Fulfilling Its Mission," OVJ, July 16, 1907, 10.
} 
Farmers From Heavy Losses Fully Justified. Some Convincing Evidence Worth

Reading." The Board meeting upon which Article 3 was reporting had started with a heated discussion over the first article from July 16. Buyer J.A. Welsh gave Faith an opening to proclaim the Journal was an honest advocate when Faith quoted him as saying:

It is very seldom that we get a paper running down an organization in its own city or town. The Ottawa Valley Journal, or any other paper, should boom the board for all its worth regardless of what takes place at the meetings. If the salesmen do not get the highest price the papers should not say anything about it. ${ }^{90}$

Faith responded to this under the header "The Journal's Position":

Why not give the farmers all the information going. You are handling their cheese and they are entitled to the facts. To keep this information from the farmers would be crooked business. The Ottawa Valley Journal has never been a party to crooked work and does not wish to commence at this late date after enjoying the prosperity and confidence of the farmers for many years. Give the information-most decidedly. The Ottawa Valley Journal has never held back facts nor given false reports. If these facts are going to result in the downfall of the Ottawa Cheese Board, then the Ottawa Valley Journal would sooner have the organization eliminated altogether rather than see the farmers lose hundreds of dollars annually. In taking this stand the Ottawa Valley Journal is endeavoring to protect the farmers. ${ }^{91}$ (my emphases)

Article No. 4 called on "progressive farmers" to reorganize the Ottawa Cheese Board or sell elsewhere. Faith and Board members continued to attack each others' honesty but Faith also tried to separate producers from their own salesmen as well as from buyers. He did so by highlighting that certain of the salesmen were capitalists. $\mathrm{He}$ pointed to John Tierney of Arnprior and August Trudell of St. Cecile de Masham as "practically speaking, men of leisure" who made their living off interest from invested capital. He asked if they should not seek the top price possible for the farmers' cheese

\footnotetext{
90 “Journal's Attack Against Ottawa Cheese Board," OVJ, July 23, 1907, 10.

${ }^{91}$ Ibid.
} 
since that was what they were hired to do. In response to comments by John Reid of the Ottawa Board of Trade and one of the original Cheese Board founders, Faith pointed out that this was first time Reid had been at the Board that season. But Faith's rationale for saying Reid could have attended the meetings, that " Mr. Reid is a life insurance man, and lives in the city of Ottawa," served to underscore that Reid was no farmer. ${ }^{92}$

Article No. 5 was somewhat shorter but plowed the same furrow. Faith asked how long "the intelligent farmers of the Ottawa Valley and district" would stand for the weekly losses taken by selling on the Ottawa Board. Faith provided more price statistics this time based on the 1906 Montreal Trade Bulletin. He ended:

How much more evidence will the Ottawa Valley Journal be compelled to publish in order to convince the buyers and Jno. R. Reid that the Ottawa Valley dairymen have lost thousands of dollars in the past by selling their cheese at Ottawa ... The buyers are on one side of the fence; the Ottawa Valley dairymen, supported by The Ottawa Valley Journal- the paper which gives all the facts - are on the other side of the fence. Which side are you on, Mr. John R. Reid? ${ }^{93}$

These articles presented their readers with a world in which dishonest agents of the Montreal exporters sat with Ottawa businessmen at the Ottawa Cheese Board and used bad business practices to steal from farmers. But Faith was not finished. He published another article the following week in which he dressed the buyers in the garb of the most citified and unproductive non-producers a suspicious farmer might have imagined:

They [the buyers] stop at the best hotels in Ottawa. They wear fine clothes. They have an easy time. They live on the fat of the land, while the

\footnotetext{
92 “Ottawa Valley Dairymen Lose Seventy Thousand Dollars Annually,” OVJ, July 30, 1907, 12. John Reid from the Board of Trade was one of the organizers of the Ottawa Cheese Board. He had been introduced as an expert, having worked on the Brockville Cheese Board. He had at that time stressed the benefit of cheese boards in equalizing market knowledge saying: "Everyone has the same knowledge of the price ... In order to be a success a board must supply all parties with equal information as to prices." "A Cheese Board Now Exists," OEJ, March 25, 1898, 3 and OSWJ March 29, 1898, 5.

93 "Dairymen Are Heavy Losers," OVJ, August 2, 1907, 12.
} 
poor farmer must work hard and contribute a share of his income into their coffers that they may live in luxury. ${ }^{94}$

He also presented what John Reid of the Ottawa Board of Trade had to say on the subject while seven times underlining Reid's status as a non-producer (five references at different points in the article to him as " the insurance man," and more obliquely "[Reid] occupied a seat as close to the buyers as he could possibly get Friday" and "in a rather polished tone of voice [Reid] has done considerable sputtering but he has been unable to prove that any of the charges were false"). ${ }^{95}$

Faith had recourse to more than language distinguishing the virtuous producer from the parasite non-producer. In line with other reformers of the period, he had religion. Richard Allen has written on the confluence between the Social Gospel and radical agrarianism on the Prairies. His analysis focuses on the religious background of key leaders. ${ }^{96}$ We can see the same connection in the language Faith used in making his appeals. This was a language heavily laced with Protestant religiosity. It would have been instantly recognizable and even reassuring to many of his readers. For example, he twice wrote that he aimed to be a "pilot":

The Journal is simply offering a few suggestions, for it realizes that action along some line must be taken at once if the Ottawa cheese board is to be piloted safely and profitably to the farmers interested, through another season. $^{97}$ (my emphasis)

The farmers of Eastern Ontario look to it for guidance, and the Ottawa Valley Journal will not lead them astray, but will pilot them safely through all their difficulties. The Ottawa Valley Journal has only one mission, which is to preach the gospel of progressiveness to all farmers. ${ }^{98}$ (my

\footnotetext{
94 “Ottawa Valley Dairymen Severely Punished by Cheese Buyers Last Week," OVJ, August 9, 1907, 10, 12. 
emphases)

Faith and his Protestant readers were likely aware of the many nineteenth-century hymns such as Jesus, Saviour, Pilot Me and Then Never Fear the Billow's Roar with its refrain of reaching safety "with your pilot at the wheel." And the echoes of the social gospel as well as the echoes of the Bible are clear in claiming that the newspaper had a "mission" to "preach the gospel of progressiveness to all farmers." ${ }^{99}$ The Bible also comes to mind when Faith said the buyers "have been right in the farmers" vinyard (sic) and they have proved themselves capable of devouring considerable of the best fruit for which the dairymen have worked hard. They are getting fat." ${ }^{, 100}$

As well as the religious references which would have been very familiar to many of his readers, Faith reflected mainstream liberalism. Faith wrote interchangeably about defending farmers and defending the masses, for example: "[t]he Journal is interested in the welfare of the farmer, and it is going to support any movement, regardless of who proposes it, if it tends to protect the masses." ${ }^{, 101}$ In this case he was quoting from an 1886 speech by British Prime Minister William Gladstone ("All the world over, I will back the masses against the classes"). This was not, however, Weld's liberalism of community interdependence but one laced with the class conflict assumed in producerism. ${ }^{102}$

Faith led the cheese campaign with an appeal to farm men to join in a manly

\footnotetext{
${ }^{99}$ Benjamin Hopper, 1871; Emma Pitt, circa 1875 to 1900. From Hymnary.org. http://hymnary.org/text/jesus_savior_pilot_me. Accessed May 20,2017. The image of Jesus as pilot is related to the story of Jesus calming the sea of Galilee in Luke 8:24. The reference to preaching the gospel to all farmers evokes Jesus's injunction to preach to all nations (Matthew 18:19) and to all creatures (Mark 16:15). Faith is listed as Methodist on the 1881 and the 1911 manuscript census as well as on his 1903 marriage certificate.

${ }^{100}$ This would have evoked for readers Jesus's parable of the landowner who was deprived of the fruits of his vineyard by dishonest tenants as well as Old Testament stories of injustice created by coveting a neighbour's vineyard (Matthew 21:33-46, Mark 12:1-12, and Luke 20:9-19; I Kings 21: 1-19).

101 "Mr. Ross Wants Some Guarantee of Payment," OVJ, December 16, 1910, 10; also see "Ottawa Valley Dairymen Lose Seventy Thousand Dollars Annually," OVJ, July 30, 1907, 12.

${ }^{102}$ Grattan O'Leary, Recollections of People, Press and Politics (Toronto: Macmillan of Canada, 1977), 21.
} 
struggle against parasitical city men while at the same time claiming to be protecting the naive producer against those same city men. He called on farm men to exhibit modern and rational business-like behaviour while his language was grounded in grass-roots religious language. It was a heady mix but his trust in the power of the press and of farmers' willingness to present a unified front was not realized. The Farmers' Produce Association he formed and which was later celebrated in the 1919/1920 sales pamphlet disappeared without a trace. He would not again attempt a revolution. Perhaps, after the cheese campaign ended in 1913, he lost his spirit in its failure. Perhaps newspaper management moved away from the New Journalism style. This does not mean, however, that Faith lost his commitment to the producer.

On February 21, 1918, the rural Journal carried on its front page in a prominent position news of a planned petition to the federal Minister of Agriculture protesting the maximum price which the war-time government had fixed for cheese that year. The organizing meeting would take place at the Journal's office. In the next issue the rural Journal carried the full text of the memorial and a report on the immediate aftermath of the meeting with the Minister. ${ }^{103}$ But this was not the activist rural Journal of the past. Faith was reporting news which others were making. A few weeks later the newspaper carried a letter to the editor from one of the organizers, Alex Snetsinger of Stormont County. Snetsinger complained that the farm press had failed to give support on this issue. He acknowledged that the Ottawa Farm Journal had helped in drawing up the memorial despite being "somewhat justified" in not believing in "movements engineered

\footnotetext{
103 "Dairymen to Meet Minister of Agriculture," and "Cheese Factory Delegates to Meet Hon. T.A. Crerar, Thursday, February 21," Ottawa Farm Journal (hereafter OFJ), February 19, 1918, 1, 10; Dairymen's Memorial for Higher Cheese Price," OFJ, February 22, 1918, 16; The Dairymen's Conference, OFJ, February 26, 1918, 10.
} 
by farmers" because "some few years ago it put up a strenuous campaign for the inspection and payment of cheese at the point of shipment and on this occasion I must say the dairymen failed to give it the support its merits demanded." To which Faith simply replied that the rural Journal had always supported the farmers. ${ }^{104}$

\section{Conclusion}

Robert Faith initially continued Cowan's initiatives on taking over as the rural Journal editor in January 1903. In 1905, however, he began an independent course of action driven by his own convictions. He started small in forming the Eastern Ontario Fairs Association and grew from this to his Big Cheese Movement in 1907. Unlike Cowan, Faith believed that the problem in the cheese industry lay in an imbalance between sellers' and buyers' market knowledge. He was not the only person to sense this as seen in letters to the rural Journal editor and an article by Cornell University professor C.A. Publow on the British monopolistic mercantile group who controlled the cheese market.

The cheese campaign illustrates the limits of a producerism which focused on the clash of interests between the producer and the commercial interests who moved agricultural product between farmers and consumers and across continents. An alternative view was offered by the mutualism of a community-based liberalism as expressed by William Weld, the founder of the Farmer's Advocate. When the Advocate entered into a debate about the rights and wrongs of cheese marketing at the same time as Faith was trying to force the Montreal export houses to respect cheese board rules, its instinct was to invite discussion which it hoped would lead to a consensus. The Advocate

\footnotetext{
104 “Claims Farm Press Not Helping Farmers,” Alex. Snetsinger to Editor, OFJ, March 8, 1918, 18.
} 
was no more successful in bringing harmony between interests than the rural Journal was in imposing producerist doctrine onto the marketplace. Neither producerism nor mutualist liberalism could curb the mercantile forces dominating the global trade system and none of those trying to change the market problems saw that the entire system was stacked against the producer.

The sales pamphlet sent out by the Ottawa Farm Journal in 1919/1920 claimed the rural Journal had pursued agricultural progress through the Farmers' Produce Association and a petition which sparked a Royal Commission to investigate cheese marketing. The cheese campaign like the rural Journal's other campaigns proved shortlived and it left no traces in how agricultural marketing was managed in Eastern Ontario or elsewhere. But failure does not equal insignificance. For nearly six years off and on the rural Journal expressed farm families' frustration with the capitalist market and its control by distant and powerful forces. There was likely never even a small chance that the campaign could have altered how cheese marketing was managed but the issue was kept alive and in front of farm families.

Faith knew in 1907 that something was wrong but he did not understand the systemic problem of the capitalist market. Instead Faith attacked the farmers' traditional foe, the middleman. There were a number of middlemen between the "man behind the cow" who produced the raw material of milk and the British family sitting down to a nice bit of cheese. Each of these had to be paid, from the cheesemaker, to the factory owner and/or salesmen, and to the companies who carried the cheese to Montreal and Britain. Finally there were the British wholesalers. But Faith's jeremiads were all against the Montreal companies who gathered in Eastern Ontario's cheese, warehoused it, shipped it, 
and sold it to the British merchants. And the men with whom he exchanged insults were men from around the Ottawa Valley who acted as agents for these export houses along with the city businessmen who dominated the Ottawa Cheese Board.

Faith believed that, if the producers formed market organizations he called Farmers' Exchanges, they could insist upon, and receive, fair trade from the Montreal companies. But after almost two years of small victories, for most producers it was business as usual with the dominant buyers setting the terms. The high profile bankruptcy of two Montreal exporters in the fall of 1910 exposed the number of factories and producers still vulnerable by being forced to ship cheese prior to payment. This time Faith believed the solution was legislation giving dairy producers a protection which the Western grain growers had wrestled out of the government a few years earlier-bonding buyers to ensure they would be able to pay producers for the product. This led to the other dairy initiative highlighted in the Ottawa Farm Journal's sales campaign, the 1911 petition which resulted in a royal commission to investigate cheese marketing in Eastern Ontario. It came out of yet another exciting mass meeting which ended with hundreds of Eastern Ontario dairymen marching to Parliament Hill to present the petition. The commission came a year later but it too led nowhere perhaps largely due to what it was told at the 1913 conference of the Eastern Ontario Dairymen's Association. The buyer agents and the owners of multiple factories who dominated the Association assured the commissioners that there was no problem in the industry beyond the poor quality of work coming from producers and cheesemakers.

The Farmer's Advocate, like Herbert Cowan, generally supported government policy which focused on improving the producers and cheesemakers. In 1907, when Faith 
was attacking almost everyone involved in the Ottawa Cheese Board, the Advocate launched a much milder and more carefully orchestrated defence of factories and producers against comments by Dominion Dairy Commissioner J.A. Ruddick on the factory and producer responsibility for the previous year's losses from shipping green (unripe) cheese. His comments absolved from blame the buyers who had solicited green cheese on the grounds they were only doing what businessmen do. The trick the Advocate achieved was to criticize Ruddick without directly naming him. In general the Advocate's purpose was different from Faith's. It wanted to find consensus on an issue while Faith wanted to mobilize farmers in a fight for change. This approximates a difference of role for the press between Habermas's public sphere found in the Advocate versus the New Journalism activist style of the rural Journal. For even though Faith would declare the pages of the rural Journal were open to his readers to discuss an issue, as he did for example with the property tax issue, he would then bring the issue forward as requiring direct action.

In all of these post-1905 events, Faith ceased to be a rural improver as Cowan had been and instead became a rural activist challenging both rural and urban elites by siding with the producer against the middleman. But even more, he was a disruptive insider for he reported as newspaper editor on the Ottawa Cheese Board upheaval caused by the Board's secretary—Robert Faith. Then, between 1908 and 1913 Faith reported on the activities of the instigator, secretary and head cheerleader for the Farmers' Produce Association-Robert Faith. The Ottawa Valley Journal was creating its own news and in the manner of the more sensational urban press of the time used strong language, large headlines and pointed accusations to do so. Faith was also mixing together a producerist 
suspicion of the capitalist market with calls to use modern business methods. Integration into a global agrarian economy did not eliminate the clash between the producer's desire to take advantage of the capitalist-driven market and the older fears and anger born out of the realization they had to sell with imperfect market knowledge. It also did not submerge the long-held belief of the labour theory of value that there was a fair price to which all producers were equally entitled. Faith conducted the initiatives using a rhetoric which stressed that the issues in play were matters of fairness, even justice. He spoke of his own dedication to William Gladstone's masses and used biblical imagery to conceptualize his role as the movement's leader and guide. His articles on cheese and readers' letters illustrate the degree to which modern aspirations and traditional fears were intertwined.

Government officials, dairy industry leaders and Cowan talked about improving productivity and quality in order to move Canada's dairy industry forward. Faith talked about fairness for producers. In doing so, even though the rural Journal lost the battle, I suggest it helped to keep alive grassroots agrarian distrust against big interests. 


\section{Chapter 9: Conclusion}

I began this study with a pamphlet from about 1919 or 1920 selling the country edition of a city daily, the Ottawa Evening Journal. The pamphlet told rural readers that the rural Journal, now called the Ottawa Farm Journal, did more than combine world news with practical farm information. It was an activist for the farmers' interests. It did things, and to prove it the pamphlet gave a list of achievements, of which all but two had been carried out under its former name of the Ottawa Valley Journal. Knowing that it had outlasted its competitors by decades I became curious about this city-owned newspaper's dedication to farm issues and wondered what it had given its rural readers. More specifically, what did the rural residents of Eastern Ontario want in the first two decades of the twentieth century? This raises issues of modernity for the rural Journal claimed to be the newspaper for the progressively modern country family. Was then the rural Journal acting as a modernizing agent in the countryside at the beginning of the twentieth century and, if so, what was the nature of that modernity?

In general I find that the story to bemore convoluted than a simple answer that the newspaper was or was not a "modernizing agent." The farm families of the region came out in great numbers to view Herbert Cowan's demonstrations of modernity, yet it seems many chose not to hear the lessons being given. Many did respond to Faith's campaigns which mobilized them to fight for fairness and which mixed the modern ideal of being business-like and progressive with older ideas of the labour theory of value, along with the language of Protestant religiosity and Gladstonian liberalism. Yet the rural people of the Ottawa Valley were not empty vessels for the newspaper to fill with ideas. But this did not mean that they had clearly defined notions on what being "progressive" meant. 
I have puzzled over how to conceptualize the Journal as a newspaper, as an advocate and as a modernizing agent. I have found the best way to approach my bundle of questions was by questioning the reality of the newspaper's success and what may have contributed to whatever success it enjoyed. Was the rural Journal a success in its first thirty years of life from 1887 to 1925 , the years which make up this study? More importantly, what can we learn from either its success or its failure? The answer depends on how one judges success.

First, was it a success in its original purpose of extending the city newspaper's potential market beyond the city limits? I found that when publisher P.D. Ross launched it as the Ottawa Semi-Weekly Journal in June 1887 he was taking a sensible marketing decision in line with that of other city dailies. Even though Ross had at that time only a half interest in the newly-established Ottawa Evening Journal and was wrestling with its poor circulation in the city, he was ready to take the fight for readers to wherever the rival Ottawa Citizen and Ottawa Free Press had their secondary markets, in other words, into the countryside of the Ottawa Valley. This confirms what historians Paul Rutherford and Minko Sotiron have to say about the increasing competitiveness of the metropolitan newspaper market in the late nineteenth century but little more. ${ }^{1}$

The Journal's story becomes more interesting when in January 1899, as part of announcing its name change to the Ottawa Valley Journal, the editor stated that its business had been worse than "stagnating." It had been losing subscribers. ${ }^{2}$ This must have been a concern to management given Rutherford's claim that the purpose of the

\footnotetext{
${ }^{1}$ Paul Rutherford, A Victorian Authority: The Daily Press in Late Nineteenth-Century Canada (Toronto: University of Toronto Press, 1982), 74-6; Minko Sotiron, From Politics to Profit: The Commercialization of Canadian Daily Newspapers, 1890-1920 (Montreal: McGill-Queen's University Press, 1997), 24-6.

2 "Change of Name," Ottawa Valley Journal (hereafter OVJ), January 31, 1899, 4.
} 
country editions was to be another front in the fight among city dailies for advertising dollars based on the size of their subscription lists. ${ }^{3}$ I argue that it is meaningful that the country people of the Ottawa Valley had been abandoning the Ottawa Semi-Weekly Journal despite it being exactly what its competition from the Citizen and the Free Press were and exactly what newspaper publishers writing at the time in Printer and Publisher said such country editions were - a cut and paste of the daily. The rural Journal's failure in these terms is a signal that rural standards were higher than some commentators in Printer and Publisher (as well as a few historians since) have claimed. Rural readers were not looking for a cheap round-up of the news which they could painfully and laboriously read over a week. ${ }^{4}$

The rural Journal's history gives a different picture of rural newspaper readers. The editorial announcing the 1899 name change tore apart the notion that country residents were content to read a "dumping ground" of "second-hand stuff." Readers would still be given a round-up of the news and editorials from the daily and as time went on such city features as comics and syndicated material with pictures and stories of people from far away. But the rural Journal went further than this. From 1899 on, it published an expanded market page and special farming features and arranged for more

\footnotetext{
${ }^{3}$ Rutherford, A Victorian Authority, 74-6.

${ }^{4}$ For examples of commentary on why country readers took the country edition of a city newspaper see Beth H. Garfrerick, "A History of Weekly Community Newspapers in the United States: 1900 to 1980" (PhD. diss., University of Alabama, 2009): 35; Russell Johnston, Selling Themselves: The Emergence of Canadian Advertising (Toronto: University of Toronto Press, 2001): 19-20; "Plated Matter in Country Weeklies," Canadian Printer and Publisher 2, no. 8 (August 1893): 17; James Fisher Confederate, "Markets in Country Weekly (sic)," Printer and Publisher 9, no. 2 (February 1900): 15-6; A.G.F. Macdonald, "The Editorial in a Country Weekly," Printer and Publisher 9, no. 2 (February 1900): 12, 14. Certain of the contemporary commentators came close to saying reader's lips were moving as they picked out each word.

5 "Change of Name," OVJ, January 31, 1899, 4, I give credence to the editor's analysis that the problem was the form of the newspaper and not new competition. As explained in Chapter 4, while there were new weeklies in the rural Journal's targeted market, there was almost as many new weeklies in the years in which it rebuilt its subscription basis. As well its losses occurred more than a decade before the introduction of Rural Mail Delivery which would increase the reach of city dailies into the Valley.
} 
local correspondents so more people could read about their own districts. This

commitment to the people of the Ottawa Valley was encapsulated in the newspaper's new name, the Ottawa Valley Journal. The name was also intended to send a message that the rural Journal was "no longer a mere second fiddle to the daily." Instead it would, like the most successful country edition of the time, the Family Herald and Weekly Star, combine the farm journal formula of agricultural and general household information with the usual country edition strength in delivering synthesized news of the region, the nation and the world.

1899 marked another important change in the rural Journal for at this point it was given a level of independence from the daily in the person of its own editor. An enterprising young man, Herbert Cowan, was the first rural editor. He was succeeded in 1903 by another very young man, Robert Faith. These two men believed in the potential of the New Journalism of the 1880s and 1890s, the potential for newspapers to act and by acting effect change. The result was that the newspaper's agricultural pages became dynamic. It could even be said to have become entertaining. That accusation was made as part of condemning the campaign Faith was pursuing against the cheese buyers but with examples from Cowan's far less controversial initiatives. The charge was that Faith was following the orders of his employer, P.D. Ross, to keep readers thrilled and entertained with stunts for no other purpose than to sell newspapers. ${ }^{7}$

Was the rural Journal a success in selling newspapers to the residents of the Ottawa Valley? To ask this in light of my original question, were these brand new rural editors delivering what residents wanted? It would seem so, given the newspaper's own

\footnotetext{
${ }^{6}$ Change of Name"; OVJ, January 31, 1899, 4.

7 "Newspapers Are Jealous," OVJ, May 5, 1908, 10.
} 
reports of its rising circulation numbers. In February 1917 the rural Journal claimed to have enjoyed increases of a thousand subscribers every year since 1899 , reaching that year 21,000 subscribers. $^{8}$ While it claimed to be growing, it had watched its city competitors close their country editions (the Free Press sometime around 1900 and the Citizen in 1916). I suggest its success was partially about the potential of New Journalism activism to sell newspapers even in the countryside.

The 1917 claim was made as part of another name change to the Ottawa Farm Journal. This third name was chosen because it said two things about itself and its aspirations. First, management had decided to rely more heavily on its agricultural content to attract subscribers with a claim its agricultural material was "the mainspring of [the newspaper's] usefulness and success." Second, management felt confident that this agricultural emphasis would give the newspaper its entrée into the wider Ontario market in a competition against the true farm press. The editor claimed the newspaper's "unbounded limits" were already being seen, for its fame as a farmer's paper had gone beyond the Ottawa Valley. ${ }^{9}$ To prove this, the c.1919/1920 pamphlet compared its own circulation numbers in seventeen Ontario counties east of Toronto against the four competitors it called "the best and most widely read farm and home publications:" the Family Herald and Weekly Star (Montreal), the Farmer's Advocate (London, Ontario), Farm and Dairy (Peterborough) and Canadian Countryman (Toronto). Not surprisingly the Ottawa Farm Journal was the winner in most of the counties but it still had its main

\footnotetext{
8 “'Ottawa Farm Journal' New Name Chosen for Farmers' Popular Paper," Ottawa Farm Journal (hereafter OFJ), February 1, 1917, 1. This was likely an "unaudited" circulation claim. McKim's 1919 newspaper directory states the Ottawa Farm Journal's average annual subscription as of September 30, 1918 was 18,210 while the newspaper advertisement under the McKim's entry claimed the newspaper was a "recognized [agricultural and livestock] authority in twenty-two thousand rural homes." The Canadian Newspaper Directory, (Montreal: A. McKim and Co., 1919), 57. It is possible the missing 3,000 or 4,000 in the numbers reflected exchange copies and free samples but the numbers seems absurdly high for this.

9 “'Ottawa Farm Journal”" OFJ, February 1, 1917, 1.
} 
market in the Ottawa Valley (see map 2, Chapter 4). The rural Journal may have aspired to become the Family Herald when it grew up (in terms of a provincial, perhaps even national, market) but it never really got there. A success then, but a limited success. This success does demonstrate, however, that country readers wanted the same kind of newspaper as city readers. They wanted the news, light entertainment and just as in the daily, business news but instead of stock market prices it was given livestock prices-in short agricultural news.

As well as being a success in terms of subscriptions, the rural Journal was a success in its longevity. After the 1916 closure of its last city competitor, the rural Journal carried on until 1955 when it was finally shut down after almost seventy years of serving the Ottawa Valley. This longevity almost did not happen. In 1934 E. Norman Smith, Vice-President of the Journal Publishing Company, asked the company's business manager if they would save money by eliminating the Ottawa Farm Journal. The report written in response stated that up to then the rural edition had been a business success, meeting its costs and delivering a small profit to the owners. Its balance sheet had only recently gone into the red as its revenues were no longer covering its share of the overall company's indirect costs. It was saved from closure only because doing so would have left the publishing company's balance sheet weighted down with a liability for prepaid rural subscriptions. ${ }^{10}$ And so it continued on even if only as an accounting convenience.

The rural Journal's longevity raises a question about the Journal management. They could have taken the draconian measure the Citizen had in 1916 to convert its rural readers into daily readers. The Citizen had simply announced it would no longer publish a

\footnotetext{
${ }^{10}$ Ottawa Archives, Journal Fonds, Box A2004-0113, minute book. Memorandum from W. Arthur Perry to E. Norman Smith, January 24, 1934.
} 
special edition and would instead deliver the country customers the daily it printed on the Tuesday and Friday, the traditional delivery dates for its semi-weekly. ${ }^{11}$ Presumably readers who became frustrated with wondering what had happened in between those two days either shifted their loyalty to the rural Journal or capitulated and paid the cost of a daily subscription. Country editions had been falling out of fashion since the early years of the twentieth century as can be seen in McKim's Newspaper Directory and a 1901 prediction in Printer and Publisher that weeklies would all be dead by $1950 .{ }^{12}$ After all city newspapers could reach country readers using subsidized postal rates and (after 1908) the expanding range of Rural Home Delivery. Closing down the rural edition was what every daily was doing.

So why did the Journal Publishing Company keep printing its rural edition? One answer might be inertia. After 1916 the Journal had the regional rural field to itself and may have decided to enjoy the lack of competition. Management may have decided that forcing readers to buy the daily would simply have lost them to the Citizen or to the already popular Family Herald. The publisher, P.D. Ross, was said by one of his successors, Grattan O'Leary, to have been a wonderful boss, a great human being and a fine writer—but not a newspaper man. ${ }^{13}$ The decision may then have been a "no-decision taken" in which the company just kept on doing what it had always done. Yet a year later management announced a new name and an expanded target market for the rural Journal. It seems the Journal management saw potential in the Ontario farm market while, perhaps, the Ottawa Citizen under the Southam family had already decided the market of

\footnotetext{
11 "The Editor's Message," OVJ, September 8, 1916, 1.

${ }^{12}$ S.D. Scott, "The Newspaper of 1950," Canadian Printer and Publisher 10, no. 3 (March 1901): 17. See Chapter 4 for analysis of the declining popularity of country editions between 1899 and 1919.

${ }^{13}$ I. Norman Smith, The Journal Men (Toronto: McClelland and Stewart, 1974), 27.
} 
the future was in its national chain of dailies. ${ }^{14}$

It must also be said that inertia was probably at work among the Ottawa Valley readers who could have paid the few extra dollars to take the daily once rural delivery appeared in their neighbourhood but did not. The countryside around Ottawa had been traditionally conservative and readers may have preferred the Independent Conservative Journal to its competitor, the Citizen. Its new status as Independent was moving it further away from its Conservative beginnings. It is equally possible, however, that the Valley farmers found the rural Journal's agricultural material valuable and many may have felt a loyalty to the newspaper which still claimed to have their interests as its priority.

This leads to the question of whether the rural Journal was a success in its selfdeclared commitment to agricultural improvement in Eastern Ontario. Answering this question addresses the rural Journal's significance as a historical actor which aimed to be a modernizing agent in the countryside. I structured my investigation of this question around the Ottawa Farm Journal's c.1919/1920 sales pamphlet. The pamphlet gave a list of "some of the things it had done" as proof of the newspaper's claim to have been “always active in Farmers' interests" and a provider of "expert [farming] information." It is a long list and yet, as I have suggested, with one exception it can be consolidated around three farmer roles:

- as learners at agricultural fairs;

- as township ratepayers responsible for road building and paying local taxes; and

\footnotetext{
${ }^{14}$ This might be the explanation for Charles King and Matt Snyder saying the Journal had gained a reputation as the "Valley" newspaper as opposed to an "Ottawa" newspaper. Charles King, "The Ottawa Papers: The Profits of Parochialism," in Canadian Newspapers: The Inside Story ed. Walter Stewart, (Edmonton: Hurtig Publishers, 1980); Matt Snyder, Ninety-Four Years of The Ottawa Journal (Ottawa: Historical Society of Ottawa, 1998).
} 
- as local producers selling into a global market.

There are problems with the pamphlet's list. It is a question mark as to who wrote it given some inaccuracies and even a mis-statement of the name of one of the associations it claimed as an achievement. ${ }^{15}$ The inaccuracies can be understood as sales hype and perhaps mis-stating a name was a typographical error. At the same time two claims (for Good Roads activities during and after the First World War) were grossly exaggerated. I suggest these last two were included in order to show that the Ottawa Farm Journal continued the Ottawa Valley Journal's record of being both a practical agricultural advisor and a rural activist.

It seems that even though the newspaper was improving its agricultural content, it could not drop its claim to being a rural activist, no matter how limited that role had become. This indicates that the newspaper believed readers wanted good agricultural material and someone with a public voice to speak for them. As this was happening when the United Farmers of Ontario (U.F.O.) were at their strongest, forming the provincial government in 1919, perhaps the newspaper was feeling the agriculturists' demand for attention to their concerns. Kerry Badgley's study of grass-roots U.F.O. members in Lambton, Simcoe and Lanark Counties argues that they saw urban society as antagonistic to rural people and felt that a vague but threatening form of capitalism controlled the metropolitan press and the traditional two parties. ${ }^{16}$ I suggest that the Journal's management decision to claim a continued activism indicates that it saw local country residents were not passively accepting the transition to an urban-dominated capitalism.

\footnotetext{
${ }^{15}$ A thorough reading of the newspaper between 1887 and 1925 found nothing regarding a Farmers' Mutual Rights Association but a good deal was written with regard to the formation of a Farmers' Municipal Rights Association.

${ }^{16}$ R. Kerry Badgley, Ringing in the Common Love of Good: The United Farmers of Ontario, 1914-1926 (Montreal: McGill-Queen's University Press, 2000), 55-69.
} 
To keep its readers, it had to make a claim to be an active friend.

The problem of the pamphlet's accuracy would be an issue if I were trying to prove that the achievements themselves had significance. I will return to this at the end. Here I simply query the significance of the editors' choice of domains in which to be an activist in country life and the response of readers to these choices. I argue that there were significant limits on the newspaper's willingness to be an activist. With one exception, the editors chose to act on issues which centred on farm men and their economic roles. They commented upon but did not act on the community and family issues of the Country Life Movement, in particular on gender issues. They also commented on the class issue of farm labour but did not take a stand for or against them.

The one exception which does not fit this finding was a claim that the rural Journal had inaugurated a movement to clean up the country cemeteries of Central Canada. This is the only initiative that can be related to the Country Life Movement and the urban reform efforts to improve community living in the countryside. The actual "campaign" consisted of a series of annual articles written by a "staff representative" and did not involve the level of activism found in most of the other initiatives. As a result, even though the articles were written under the editorship of Robert Faith, he may have had little to do with them. I argue that the meagerness of this one initiative highlights that the newspaper's activism was limited. Both Cowan and Faith, and even their household editor, ignored women's issues, whether suffrage or the Country Life mission to turn women into household managers rather than farm producers. They also ignored the desire of farm women for a more equitable balance of gender roles on the farm.

The household editor was given a persona, that of a friendly older woman called 
Aunt Joe. This fictional relationship and the header's drawing giving the character a face that invited readers to feel a sense of community. ${ }^{17}$ And it was household advice that women read in the column despite it being written for farm women who balanced full work lives as farm producers with household work while many lacked the household conveniences urban women enjoyed. Gendering of farm roles and the difference in life style between urban and rural was discussed by farm women in letters to the Farmer's Advocate.$^{18}$ I have not found the same discussion in the rural Journal. I believe that a young newspaper woman, Katherine (Kate) Whelan may have been the person behind Aunt Joe. Whoever the editor was, she once made a strong feminist comment on the barriers women faced in a man's work world, from not having a place and time where they could be free from having to deal with other people's needs, to not being paid the same for the same work. ${ }^{19}$ I do not believe the woman who wrote that article would have been uncomfortable pursuing the question of women's roles within the farm family. The absence of further comment is, I suggest, a clear indicator that the ability to make news was confined to the male rural editors.

Along with the acts of omission found in analyzing the pamphlet there are also acts of commission and all these focus on the rural Journal's efforts to be an economic modernizing agent. Both Cowan and Faith larded their writing heavily with the words

\footnotetext{
${ }^{17}$ The manufactured relationship was typical of both women's and children's pages. The Farmer's Advocate carried a page for women in which the editor addressed herself to "my dear nieces" (for example see "Minnie May's Department," May 16, 1898, 243) while Norma Lewis has examined letters published in country newspaper children's pages edited by an aunt or uncle figure; "I Want To Join Your Club": Letters from Rural Children, 1900-1920 ed. Norah L. Lewis (Waterloo, Ont.: Wilfrid Laurier University Press, 1996). The rural Journal was slow to introduce a page where children could see their own words in print but when it did in 1919 it was headed by "Uncle Henry" (believed to be James Henry) and "Aunt Kate" (Kate Whelan).

${ }^{18}$ Monda Halpern, And On That Farm He Had a Wife: Ontario Farm Women and Feminism, 1900-1970 (Montreal: McGill-Queen's University Press, 2001), 30-4.

19 "Why Women Fail," OVJ, January 16, 1903, 2.
} 
"progress" and "progressive." Rutherford has commented that "progress" was part of what he calls "the dogma of modernity" with progress being "the most hallowed maxim of the age. ${ }^{, 20}$ In general, words which form "dogmas" and "maxims" can have a powerful effect which becomes particularly powerful when they lack precise meaning, in other words, when they become natural Good Things which no-one questions. We therefore must ask what the editors meant by being "progressive" but not be surprised if the answer is less than precise. In general, however, both men believed that being business-like was what every modern agriculturist should be. This would have been a natural association for Cowan who grew up in the city as the son of a prosperous businessman. For Cowan, prosperity, business and middle-class respectability would have been the natural way of the world.

Faith was as quick as Cowan to speak of the importance of business-like behaviour but he was the son of a local farmer who had left the countryside because he was lured by the promise of the city's bright lights. ${ }^{21}$ While he said this to tell farm children that he regretted the choice, for the country was best, I suggest it shows that when he came to Ottawa he expected to find modernity in the technology of the city. Yet he paid less attention to technology in his campaigns, making business his main theme as he condemned the bad business practices he found, for example, in the cheese market. Cowan, on the other hand, made technology as well as business an important sign of modernity particularly with the Good Roads Train and model road-building. For Cowan the two themes of being business-like and using the latest equipment and techniques came together whether talking about efficient cheese factories or about municipalities

\footnotetext{
${ }^{20}$ Rutherford, A Victorian Authority, 156-7.

21 “The Editor's Weekly Chat," OFJ, March 19, 1920, 8.
} 
using tax money to pay roadwork specialists rather than making do with the haphazard statute labour of the ratepayers.

Knowledge and expertise are an important part of the story of both technology and business. They were an underlying issue in Cowan's initiatives for the agricultural fair and for road-building as well as for Faith's work organizing orchard and dairy meetings and livestock judging lessons. Both men assumed that modern, scientific knowledge would result in improved productivity but there was a question of whose knowledge mattered. Here we see both editors taking a different tack from the growing official consensus privileging the college man as the best exponent of modern knowledge. Michel Foucault and James Scott show knowledge to be multi-layered. ${ }^{22}$ There is the knowledge of the expert who has been formally trained and blessed with a certificate. His or her knowledge is systematized to address many situations in a common way by erasing the peculiarities of individual circumstance. Then there is "subordinate," "tacit" or "mētis" knowledge of the experienced worker. His or her knowledge comes sometimes from training in tradition, or from watching the more experienced, or even from years of trial and error. Generally it comes from all of these built up over the course of his or her working life. This expert's knowledge is specific and takes into account details which may be lost in the generalized knowledge of formally-trained experts.

Cowan's initiatives on the agricultural fairs and on road-building relied on experts but in the first decade of the twentieth century the professional expert had not yet become the dominant expert. As a result, while Cowan at all times assured readers that work would be done according to the most modern standards and by men whose information

\footnotetext{
${ }^{22}$ Michel Foucault, The Order of Things: An Archaeology of the Human Sciences (New York: Vintage Books, 1973); James C. Scott, Seeing Like a State: How Certain Schemes to Improve the Human Condition Have Failed (New Haven: Yale University Press, 1998).
} 
could be relied upon, he based his assurance on the experts' experience as livestockbreeders and stock-showmen. In road building he relied heavily on the trained expert who had made road-building his career, A. W. Campbell. Campbell himself was keen to professionalize road-building by encouraging municipalities to shift from amateur roadbuilders to trained road-engineers. Yet in reporting on the Good Roads Train initiative and its model road-building activities, Cowan presented Campbell as an experienced man rather than a professional man. He underlined in text and with drawings that Campbell could run the stone crusher and even give a practical demonstration of the "scientific" way to shovel.

The activities of the two rural editors can be summed up by pointing to each one carrying forward a distinct type of activity rooted in somewhat different values. Cowan undertook activities which demonstrated modernity and he expected that demonstration would be enough to convince farmers of the superiority of the technology and knowledge being presented. He also looked at productivity without reference to the market, as one reader pointed out in 1902 with respect to dairying. ${ }^{23}$ When Faith broke away from simply continuing Cowan's initiatives he undertook activities which expressed the disruption rural residents were feeling from their immersion in a global capitalist market and their perception that "big interests" dominated the choices they made in farming. What my study demonstrates is that the countryside between 1900 and 1910 was in a state of transition and this country edition of a daily brings out the ambivalence created by that transition. It can be seen in the disappointment of Cowan's hopes that his initiatives, which were by and large successes in the short term, would translate into

\footnotetext{
23 "Present Methods of Selling Cheese Not Considered Satisfactory," B.S. McConnell to Editor, OVJ, May 23, 1902, 1 .
} 
lasting change, in the ambiguity and sometimes confusion of Faith's rhetoric, and in the response of readers to the campaigns.

Cowan's initiatives were successful in the immediate term but failed to lead to fundamental change. The initiatives for improving the agricultural fair did introduce useful new practices for ensuring societies could easily engage competent judges and would not schedule their fair dates in conflict with each other. This did not, however, turn fairgoers into dutiful learners. Instead they continued to show their preference for the midway and horse races. The Good Roads Train did give hundreds of farm families a better understanding of what modern road machinery could achieve. But Cowan had expected farmers to judge the machinery and the resulting model roads on a cost-benefit basis. He believed that they would see that the benefit from treating roads as a public good would translate for them as private producers into easier access to markets, an improvement which would outweigh the cost to them as ratepayers. He was right that farm families were interested as producers in the potential of good roads for selling their produce and they were interested in technology. Even discounting the entertainment value of the spectacle, there was a real benefit from giving those crowds of rural residents a chance to see close-up how roads could be made better. He did not, however, see why they were reluctant as ratepayers to abandon the statute labour system. The farmers fully realized the problems with the system but they understood those problems. Furthermore the system gave them local control over road work. Ultimately they were not keen to give their municipalities authority to go into debt in order to buy expensive machinery which might or might not be used effectively — or for that matter might or might not be used on their local road versus those of residents with extra pull. 
With respect to the cheese market, the farmers held to the labour theory of value as establishing a fair price because they knew how much labour had been expended in making the cheese. They considered the market method of valuation unfair because it imposed varying values based on a standard of product quality which was not obvious to them. Nor did they or Faith ever show an awareness of the new economic orthodoxy of marginal utility and that market price reflected above all else customer demand against market supply. At the same time Faith was right that in the current cheese market the many small producers could not negotiate fairly on price with the few large capitalist interests. Producers were price-takers. But he did not understand the reason for this because he did not see the overall market. He saw one layer of middlemen refusing to follow the rules of the Cheese Boards and thought this was the obstacle preventing everyone from obtaining a fair price. He believed that demonstrating the problem with facts and figures would cause all participants to become transparently business-like. It did not. Faith's frustration escalated the cheese campaign through a series of phases. He started with public shaming of buyers and sellers and when this brought no change he organized farmer-run boards called exchanges. When the buyers refused to work with the exchanges, he investigated and disseminated information on how the exchanges could sell directly to the British wholesalers. Eventually he brought the farmers together to lobby for government protection.

Faith drew on two different strains of thought in his writings on the campaign as well as on the property tax campaign which he ran concurrently in 1908 . In both he merged the importance of being business-like with the older Producerist ideas of a fair price based on the value of labour, and the producers' right to the value of the product. 
He characterized producers' opponents as oppressors and himself as their deliverer. In his frustration he invoked images of struggle using religious language from Protestant hymns. His articles became personally abusive of opponents. The readers responded if we accept the newspaper's claim that subscriptions had gone up in $1908 .^{24}$ Some may simply have not wanted to miss a single installment of material that is still more entertaining than market reports. But he was saying something his readers agreed with, for they came out in their hundreds to the mass meetings he organized and wrote letters agreeing that the farmers had to keep on fighting for a fair deal. Some set up exchanges and some were successful in selling their cheese at a price and under terms that protected their interests. But it all faded away in a few years as the buyers wielded their economic control over the market and political control over the dairymen's association to maintain the status quo.

Faith had moved through a range of responses to a market which was systemically biased against the small producers. These responses would continue to echo across the century as farmers at times formed cooperatives and at other times formed themselves into a special interest group lobbying government. Yet the specific events of 1908 to 1912 failed to change the conditions under which Eastern Ontario cheese was sold. Even the property tax assessment campaign faded away with nothing changed. What Faith did achieve in these campaigns was to keep farmer issues before the public for nearly five years and during that time he demonstrated that he agreed with farmers that something in the market was not "fair." But even at his most fiery, he did not become more specific than this vague condemnation. No matter how much he questioned the way business was conducted, he assumed that the solution was to make the system work the way he

24 “A Christmas Message from the Editor," OVJ, December 25, 1908, 12. 
believed it was designed to work. He spoke about the masses and the farmers' right to a fair price but he also assumed that there was a mutualist liberal order in which each man's self-interest contributed to a productive society for all. I suggest this confusion of ideas was caused by his underlying adherence to the hegemonic view of the capitalist marketplace even as he was aware that it was not serving producers equitably.

I began my study with a pamphlet making claims of being an activist for the farmer. I end by asking why it had in fact stopped finding wrongs to right after 1913. Faith as editor may have been dispirited by the fate of both the farm property tax assessment campaign and the cheese campaign, the first disappearing into a provincial government committee review and the second extinguished by a Federal Commission ignoring the reality of how the market worked. It is possible that the events of the First World War pushed activism off the agenda while the urge felt by the press to support the war effort, especially by a Conservative organ like the rural Journal's city parent, pushed Faith like others into a hyper-patriotism. In this case there would have been little room to focus on previously compelling special interest issues. It is also possible that the fading away of the United Farmers of Ontario government removed any sense that the newspaper had to publicly demonstrate its commitment to the farmers' cause. Finally, it is possible the arrival of E. Norman Smith (the previous owner of the Ottawa Free Press) as an energetic Vice-President with full decision-making authority created a new spirit of management control which reined in Faith. What is certain is that Faith himself did not change. In 1918 he helped a group organize a petition to the government over the price set for cheese and in 1925 he took a parting shot in resigning as a director of the Ottawa exhibition with a newspaper article charging that the board was corrupt. He remained a 
firm supporter of the farmer but he had stopped making news. The New Journalism had run its course in the Ottawa Valley countryside.

This study has looked at a very small player from among Canada's earlytwentieth-century press, the rural edition of the Ottawa Journal which in itself was a small city newspaper. These rural editions of the city dailies are almost never the subject of scholarly attention or even, for that matter, popular attention. There are problems of finding good examples for study but perhaps the biggest obstacle is that it was a hybrid. It had been born in the city for sale in the country to agriculturists seeking a cheap round-up of the week's national and international news. Can such a hybrid tell us anything useful?

Clearly I believe it can if that hybrid is more than just a hashed-together copy pushed out to the countryside without thought. Through most of its life the rural Journal carried specially-written agricultural material which could be of interest for answering what agriculturists wanted to know. But what made the rural Journal special was activism, even though it was a limited activism. The editors, in making news in the first decade of the twentieth century did not just make the newspaper entertaining. They gave readers the sense that farm issues were important and that the newspaper cared about what farmers had to say. In a period in which farmers were increasingly aware that their economic and social position was changing, it gave them affirmation for both their aspiration to be modern as well as their unease over the resulting sense of disruption. In doing so, the newspaper helped keep alive a radical spirit in the countryside but it was a spirit that looked for fairness, not revolution. 


\section{Appendix A: Ottawa Farm Journal Sales Pamphlet, c. 1919/1920}

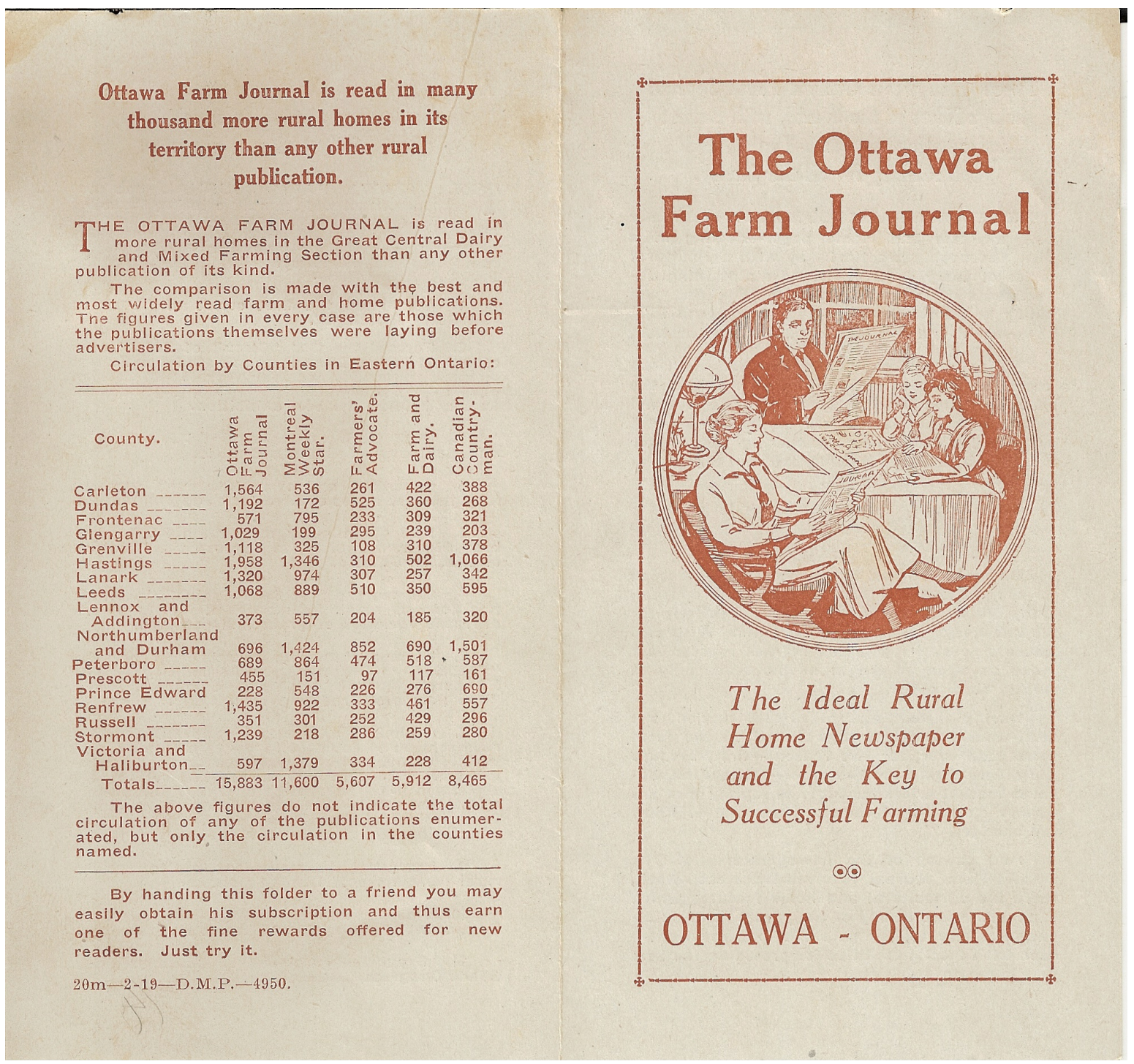

Ottawa Farm Journal sales pamphlet circa 1919/1920, collection of Bruce S. Elliott. 
Twice each week Ottawa Farm Journal brings News of the World, with Expert information on Farm Topics, and good reading for all the family.

THE OTTAWA FARM JOURNAL is essentially a Farm and Home paper-dealing in a thoroughly practical way with agricultural topics of every description and maintaining departments of interest to the mother and the family in the rural home. It is more than this, however-it is a semi-weekly newspaper as well.

Twice each week its readers receive all the important news of the world with many of the special articles which appear in The Journal daily papers. These papers maintain a vast organization for news gathering and their facilities are placed entirely at the disposal of The Ottawa Farm Journal.

The Tuesday issue each week is mainly a newspaper. The Friday issue is a big combined newspaper and Farm and Home periọdical.

One does not need to seek far for the reasons for the popularity of The Ottawa Farm Journal. Many a busy farmer depends upon it entirely for his knowledge of the world's events. With two issues a week he gets his market reports just twice as often as the man who reads only a weekly farm paper.

During these times of re-construction, the semi-weekly paper is appreciated on the farm more than ever, for two reasons-first, because the people must have the news-and second, because market prices fluctuate so rapidly that the farmer cannot wait till the week end to know the changes.

And on top of the news features of The Ottawa Farm Journal, received twice each week, there are agricultural and home features which rank with those of any of the purely farm publications. The reader gets two papers in oneeach with special facilities for providing the best and latest information.
Always Active in Farmers' Interests, Ottawa Farm Journal Activities touch every phase of agricultural progress.

THE OTTAWA FARM JOURNAL has not 1 been content with merely printing the news and its articles on Farming and Dairying. It has become an authority on all question relating to rural life. It has interested itself things it has done:-

1. Conducted the first series of "Orchard and Dairy Meetings".

2. Formed the first "Circuit of Fairs" ever organized in the Dominion, Inittated the Expert Judge System, and for four y a ricultura society holding the best exhibition.

3. Bujlt twelve miles of Model Roadway in different parts of Eastern Ontario.

4. Organized and carried through success fully the first series of Livestock Judging classes.

5. Has given away more than 3,200 purebred Pigs and Poultry, to improve the livestock of Eastern Ontario.

6. Started the first Seed Grain Fair, which has done so much to improve the yield of the different varieties of grain and potatoes.

7. Formed three big associations, namely "The Eastern Ontario Fairs Association", "Th "The "The Ermersual Produce Association".

8. Organized a deputation of 600 farmers representing 16 counties in Eastern Ontario and ion Government in 1911, and asked for certain protection in the marketing of cheese and butter which resulted in the appointment of a Roya Commission by the Dominion Government to inquire into the grievances of the dairymen.

9. Inaugurated a movement to clean up the rural cemeteries of Central Canada.

10. Assisted actively in the promotion of the Permanent Highway from Ottawa to Prescott.

11. Organized rural end of Dominion Good Roads Congress, Ottawa, April, 1917. 
Appendix B. Timeline Rural Activism (sales pamphlet initiatives in bold). Ottawa Valley Journal and Ottawa Farm Journal, 1899 - 1919

\begin{tabular}{|c|c|c|c|c|}
\hline & Year & $\begin{array}{l}\text { The Farmer and } \\
\text { Expert Knowledge }\end{array}$ & $\begin{array}{c}\text { The Farmer and } \\
\text { Labour Value }\end{array}$ & $\begin{array}{c}\text { The Farmer and } \\
\text { Marketing }\end{array}$ \\
\hline \multirow{8}{*}{ 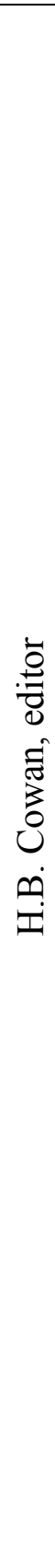 } & 1899 & $\begin{array}{l}\text { Announced pedigree } \\
\text { stock as premiums for } \\
\text { signing new subscribers }\end{array}$ & & \\
\hline & 1900 & $\begin{array}{l}\text { Organized ploughing } \\
\text { matches }\end{array}$ & & \\
\hline & \multirow{4}{*}{1901} & $\begin{array}{l}\text { Ottawa Valley Journal } \\
\text { official organ of the } \\
\text { Eastern Ontario } \\
\text { Dairymen's Association; } \\
\text { Organized dairy } \\
\text { meetings to educate } \\
\text { cheese factory patrons }\end{array}$ & $\begin{array}{l}\text { Organized Statute } \\
\text { Labour petition and } \\
\text { meetings in } \\
\text { Goulbourn Township }\end{array}$ & $\begin{array}{l}\text { Organized a live stock } \\
\text { auction in Ottawa }\end{array}$ \\
\hline & & $\begin{array}{l}\text { Initiated (and } \\
\text { organized) expert } \\
\text { judge system at } \\
\text { agricultural fairs }\end{array}$ & $\begin{array}{l}\text { Eastern Ontario Good } \\
\text { Roads Association } \\
\text { formed, Ottawa } \\
\text { Valley Journal } \\
\text { official organ, Cowan } \\
\text { secretary }\end{array}$ & $\begin{array}{l}\text { Investigated low prices } \\
\text { on Ottawa Cheese } \\
\text { Board; accepts } \\
\text { argument prices reflect } \\
\text { quality }\end{array}$ \\
\hline & & $\begin{array}{l}\text { Organized agricultural } \\
\text { fair athletic contests for } \\
\text { young farmers and } \\
\text { farmers' sons }\end{array}$ & & \\
\hline & & $\begin{array}{l}\text { Organized agricultural } \\
\text { fair competition for } \\
\text { best county exhibit of } \\
\text { livestock }\end{array}$ & \multirow{2}{*}{$\begin{array}{l}\text { Good Roads Train } \\
\text { and Building of } \\
\text { Model Roadways }\end{array}$} & \\
\hline & \multirow[b]{2}{*}{1902} & $\begin{array}{l}\text { Formed (and } \\
\text { organized) first circuit } \\
\text { of agricultural fairs }\end{array}$ & & \\
\hline & & $\begin{array}{l}\text { Expanded agricultural } \\
\text { fair competition to best } \\
\text { fair for exhibits and } \\
\text { buildings }\end{array}$ & & \\
\hline & \multirow[b]{2}{*}{1903} & $\begin{array}{l}\text { Opened first seed grain } \\
\text { fair }\end{array}$ & & $\begin{array}{l}\text { Faith secretary to the } \\
\text { Ottawa Cheese Board }\end{array}$ \\
\hline & & $\begin{array}{l}\text { Organized Orchard } \\
\text { Meetings; continued } \\
\text { dairy meetings }\end{array}$ & & \\
\hline
\end{tabular}




\begin{tabular}{|c|c|c|c|c|}
\hline & Year & $\begin{array}{c}\text { The Farmer and } \\
\text { Expert Knowledge }\end{array}$ & $\begin{array}{c}\text { The Farmer and } \\
\text { Labour Value }\end{array}$ & $\begin{array}{c}\text { The Farmer and } \\
\text { Marketing }\end{array}$ \\
\hline \multirow{11}{*}{ 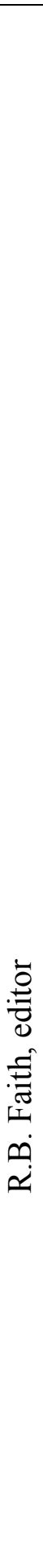 } & 1904 & $\begin{array}{l}\text { Last agricultural fair } \\
\text { competition (prize of } \\
\text { office building) }\end{array}$ & & \\
\hline & \multirow{2}{*}{1905} & $\begin{array}{l}\text { Organized livestock } \\
\text { judging classes and } \\
\text { competitions }\end{array}$ & & \\
\hline & & $\begin{array}{l}\text { Formed Eastern } \\
\text { Ontario Fairs } \\
\text { Association }\end{array}$ & & \\
\hline & 1907 & & $\begin{array}{l}\text { Organized tax protest } \\
\text { meeting; and follow- } \\
\text { on Farmers' } \\
\text { Municipal Rights } \\
\text { Association }\end{array}$ & $\begin{array}{l}\text { Complained rules of } \\
\text { Ottawa Cheese Board } \\
\text { being ignored }\end{array}$ \\
\hline & 1908 & & & $\begin{array}{l}\text { Charged Cheese Board } \\
\text { sellers and buyers with } \\
\text { cheating }\end{array}$ \\
\hline & 1909 & & $\begin{array}{l}\text { Farmers' Municipal } \\
\text { Rights Association } \\
\text { presented a petition } \\
\text { on inter alia taxes to } \\
\text { Ontario legislature }\end{array}$ & $\begin{array}{l}\text { Formed Farmers' } \\
\text { Produce Association } \\
\text { to organize cheese } \\
\text { marketing directly to } \\
\text { Britain }\end{array}$ \\
\hline & 1911 & & & $\begin{array}{l}\text { Organized farmer } \\
\text { deputation re cheese } \\
\text { and butter marketing }\end{array}$ \\
\hline & $\begin{array}{l}1909 \\
- \\
1919\end{array}$ & & $\begin{array}{l}\text { Ottawa to Prescott } \\
\text { highway campaign }\end{array}$ & $\begin{array}{l}1913 \text { Government } \\
\text { Commission on cheese } \\
\text { Selling }\end{array}$ \\
\hline & 1917 & & $\begin{array}{l}\text { Rural session in } \\
\text { Dominion Good } \\
\text { Roads Convention }\end{array}$ & \\
\hline & 1918 & & & $\begin{array}{l}\text { Assisted in organizing } \\
\text { meeting and delegation } \\
\text { protesting the } \\
\text { government-set price } \\
\text { for cheese }\end{array}$ \\
\hline & 1919 & & & $\begin{array}{l}\text { Helped advertize } \\
\text { Cheese Producers } \\
\text { Convention }\end{array}$ \\
\hline
\end{tabular}

1901 Commenced livestock premiums. 1907 Livestock premiums advertised as assisting farmers to improve stock. 1914 Inaugurated cemetery clean-up day. 


\section{Appendix C: $\quad$ Content Analysis ${ }^{1}$}

I an enquiring in this dissertation about the rural-ness of the first thirty-eight years (1887 to 1925 ) of the country edition of a city-published newspaper, the Ottawa Journal. ${ }^{2}$ Since the semi-weekly Journal went out of publication in 1955, this means that I have included in this study about half of the newspaper's total universe of 68 years.

My initial skim of the newspaper over the years being studied suggested that the uniquely rural nature of the rural edition varied over time. The Ottawa Valley Journal, for most of these years, seemed to have devoted space to local correspondents giving the news of villages and farming districts. The January 1917 announcement of a planned focus away from the Ottawa Valley and onto the interests of Ontario farmers generally seems to have been followed by replacing local social news with "expert" articles on farming. Yet I sensed that the newspaper was never quite distinctively rural or agricultural. By 1925 I felt I was reading the daily with a few farm pages added.

These conclusions were impressions. I needed to put some quantified bones into my "sense" of how rural the newspaper was and how this rural character ebbed and flowed over time. To this end, I have defined the purposes of my content analysis as 1) to see how the content of the rural Journal differed from its city parent; and 2) to assess how the content of the rural edition varied between 1887 and 1925 .

\section{Sample Size ${ }^{3}$}

I set the sample size to reflect the full universe of the item under study, my limited goal of contextualizing the rural Journal and my limited resources to do the

\footnotetext{
${ }^{1}$ The results of the content analysis are discussed in Chapter 4.

${ }^{2}$ While there are a few missing and torn issues, the run held by Agriculture Canada is remarkably intact.

${ }^{3}$ This section is informed by Stephen Lacy, Daniel Riffe, Staci Stoddard, Hugh Martin and Kuant-Kuo Chang. "Sample Size for Newspaper Content Analysis in Multi-Year Studies," Journalism and Mass Communication Quarterly 78, no. 4 (Winter 2001): 836-45.
} 
analysis. I chose to take a narrow approach by sampling key years, as follows:

1) 1888 Ottawa Semi-Weekly Journal (first full year of publication as a semi-weekly aimed at rural residents - quantification will provide a base line);

2) 1898 Ottawa Semi-Weekly Journal (quantification will check the editor's January 1899 claim that the previous year the newspaper had increased the amount of rural features);

3) 1900 Ottawa Valley Journal (first full year under new name - quantification will check if the newspaper was emphasizing Ottawa Valley coverage as promised in the 1899 renaming);

4) 1907 Ottawa Valley Journal (mid-way through the period in which the initial read suggested that content had become most intensely rural); ${ }^{4}$ and

5) 1925 Ottawa Farm Journal (last year of study - quantification will check impression from initial reading that the post First World War newspaper largely took its content from the daily edition).

Selection of what to sample within each year requires recognition of the cyclical nature (or "systemic variation") of the newspaper under study: for example in dailies grocery ads can be heaviest on one day, light entertainment on another, and significant holidays or commemorative days skewing content yet again. Lacy et al. found that a representative sample for studying one year of a daily newspaper is nine constructed weeks. I did not find direction on the best sample size to analyze a semi-weekly which had a maximum of nine issues in a month and about 104 issues in a year. The Ottawa

\footnotetext{
${ }^{4}$ I have been ambivalent about whether to include this "interim" year of 1907 . However, my initial reading of the newspaper suggested that there was an arc of "rural-ness" in which the Journal became steadily more local and agricultural in its interests and then slowly lost that character. As a result, it seems necessary to confirm or deny this intuitive sense by taking a mid-period reading.
} 
Valley Journal and even more so the Ottawa Farm Journal varied over a week with Friday tending to have the most agricultural content. The specifics of the content also varied according to season (Farmer Institute news, for example, was published largely in December and January, cheese factory news peaked in summer, and fall fair news appeared in September and October). Since this is in effect a mini-analysis, I decided to create a stratified sample of nine issues representative of both Fridays and Tuesdays and of the four seasons chosen from five excel-generated lists of fifteen random numbers between 1 and 104 .

For each sample year, I numbered the dates on which the Journal was published from 1 to $104 .{ }^{5}$ I then selected nine issues using the random number list working down from top to bottom jumping over a random number which selected a missing or torn issue. To ensure the sample would capture season-specific farm and community news by weighting for the Friday agricultural content, I confirmed that the list contained five or six Friday issues and at least one issue from each of the four seasons (defined as Jan through March, April through June, July through September, October through December). As I wanted to be able to compare content of at least a few of the samples with the city edition, prior to finalizing the list I checked Library and Archives Canada, the Ottawa Public Library and Ancestry.ca to ensure that for the dates selected I would be able to find issues for the three days prior (a rural weekly / semi-weekly was made up by setting aside type each day from the daily and then assembling these bits into the rural edition). ${ }^{6}$

\footnotetext{
${ }^{5}$ It was not possible to use the issue numbers printed on the newspaper's name plate, due to the issue year beginning in June as well as numerous publisher errors in numbering issues

6 John A. McKay, "The Combining of a Daily and a Weekly," Canadian Printer and Publisher 3, no. 6 (June 1894): 9. Comparison confirmed that this was the method used for putting together the rural Journal.
} 


\section{Measurement}

Most newspaper content analysis is based on column inches. I am working, however, with microfilm copies which I have digitized. Since I feel I cannot accurately determine column size, I planned to do a line count. This proved in my test run with the 1888 samples to be time-consuming and subject to error. As well, I discovered that the city edition appeared to have used different fonts within the same column, possibly due to inserting "slugs" of boiler-print material. This increased both the error potential and the time required to do the count. I ended by printing each issue onto legal-sized sheets and measuring the column length for each page. I then measured each item in the column and recorded that number. I used the two numbers to calculate a value which represented an item's proportion of the total column size: i.e., length of item / average length of column on page.

\section{Coding}

As this analysis is only intended to be an overview of subject content and not a textual analysis of word frequency, I chose to use the simplest of comparisons: total columns per category for the year (e.g., two items in the same category each half a column long would create one column count for the category). Coding and calculations were all done using an excel spreadsheet.

After testing my initial coding plan using the 1888 sample, I simplified it to better reflect the amount of work, my purpose and my resources. Thus I eliminated tracking item placement (i.e. above or below the fold indicating whether an item was intended to catch the eye when seen on a news stand or as the newspaper is unfolded to be read). I found item placement was not informative in the 1888 sample as this level of publishing 
sophistication appears not to have penetrated to Ottawa.

\section{Coding Sheet}

Information captured on the final excel spreadsheet is as follows:

- newspaper issue information - A) newspaper name, B) date, C) page number, D) column number,

- item information - E) headline, F) headline structure, G) column measurement, H) item form (text only; graphics only e.g., comics; mixed graphics and text),

- item categorization - I) subject, J) geographic coverage, K) content origin, L) Journal self-endorsement / puffery in news or editorial items.

A full content analysis can have complex sets of categories, at times running into the hundreds. Content type, for example, might separate news, advertising, colour pieces, opinion pieces and then divide news into national politics, city politics, foreign affairs, war, crime, fires, traffic accidents, disasters, sports, business, weather events, scientific advances, awards, and so on. My survey reading shows that the Journal's content did indeed cover such a range of subjects. But as I am interested in quantifying how much rural and agricultural information was in the rural Journal, I used a simpler set of ten subjects with each subject having between three and eleven sub-categories.

Geographic coverage (column J) required a decision as to what was local and what was not. In broad terms it is clear that international events were events which happened outside Canada and where Canada, if involved, was not the focus of the event (example, King Edward's Coronation or a lynching in an American town). I coded events as national and provincial if the reporting focused on the nation (example, federal tariffs or trade negotiations). I arbitrarily defined "provincial" as Ontario and Quebec (for their 
immediate relevance to the Ottawa Valley) and I included in this category events such as provincial temperance legislation. I defined geographic origin for advertising subjects based on who paid for the advertisement. There were only a few US manufacturers advertising a product (a U.S. medical clinic and a resort for example). Most manufacturers were national or provincial (for example, Northern Electric telephones). Sunlight soap and Royal Baking Powder, however, were multinational products advertised on a national basis within Canada. Rather than investigate the story behind each such ad, I treated these and any other ad without a clear statement of origin as national. There were some Ottawa Valley products (for example, a Findlay stove from Carleton Place). Retail advertising was almost all from the city of Ottawa.

\section{Subject Categories}

1. Editorials, letters to the editor and political cartoons
a. Rural living
b. Agricultural (progressive farming, agricultural tariffs, science, farm labour)
c. Environment
d. Miscellaneous and non-agricultural
2. News and colour pieces - Agricultural

a. Cheese factories / dairies / creameries

b. Fairs (including livestock judging classes, fat stock shows and seed fairs)

c. Farmer producer organizations (organized by Journal)

d. Farmer producer organizations (not organized by Journal)

e. Formal agricultural news (institutes, colleges, farm representatives)

f. Federal tariffs for agricultural produce / inputs

g. Classifieds for lost livestock, farm sales etc

h. Agricultural news (disease outbreaks, noteworthy animal sales)

i. Farmer market news

3. News and colour pieces - non-agricultural

a. Politics, war, foreign affairs (incl. temperance in political debates / activity)

b. Crime, accidents, disasters, epidemics, sudden death if not local

c. Civic politics, appointments, teacher names and training, local meetings

d. Celebrities (births, deaths, visits, life style)

e. Business, labour 
f. Weather, environment, science, cultural

g. Sports, human interest, oddities

h. Immigration, migration

i. Church news (governance / theology)

4. Didactic information (no reference to an intended farm audience)

a. male oriented (e.g., car care)

b. female oriented (e.g., decorating, fashion, house care, childrearing)

c. no targeted gender (e.g., science, culture, religious)

5. Didactic information (intended for farm audience)

a. Men (best practices for production, marketing)

b. Women (women's pages with specific farm references)

c. Children (overt references to farm children as farm workers and/or future farmers but excluding school children)

d. General (no specific gender identifiable)

6. Didactic information / rural improvement general

a. Good Roads

b. Farm beautification

c. Churches

d. Cemetery beautification

e. School consolidation / School curriculum

7. Community activities / correspondents

a. School events, exam results

b. Church activities

c. Fraternal organizations including activities for community

d. Births, marriages, deaths (incl. sudden death as news if local), sickness

e. Events, general

8. Advertising, classifieds

a. Farm machinery \& equipment, seeds, fertilizers etc

b. Consumer goods targeting city buyers

c. Consumer goods targeting farm / rural buyers

d. Consumer goods no specific market identified

e. Patent medicines

9. Entertainment

a. Stories, poetry, songs

b. Jokes, comics, non-political cartoons

10. Newspaper publishing data and self-promotion
a. Masthead and terms of business
b. Self-advertising (self-endorsements, circulation numbers)
c. Clubbing
d. Subscriber Premiums
e. Contests
f. Endorsements
g. Content descriptions 


\section{Summary of Findings}

\begin{tabular}{|c|c|c|c|c|c|}
\hline & 1888 \# (\%) & 1898 \# (\%) & 1900 \# (\%) & $1907 \#(\%)$ & $1925 \#(\%)$ \\
\hline Total Column Value & $\begin{array}{l}255.10 \\
(100 \%)\end{array}$ & $\begin{array}{l}504.16 \\
(100 \%)\end{array}$ & $\begin{array}{l}545.45 \\
(100 \%)\end{array}$ & $\begin{array}{l}712.84 \\
(100 \%)\end{array}$ & $\begin{array}{l}784.32 \\
(100 \%)\end{array}$ \\
\hline \multicolumn{6}{|l|}{ SUMMARY Categories } \\
\hline News & $\begin{array}{l}128.75 \\
(50.5)\end{array}$ & $\begin{array}{l}277.06 \\
(55.0)\end{array}$ & $\begin{array}{l}319.15 \\
(58.6)\end{array}$ & $\begin{array}{l}368.56 \\
(51.7)\end{array}$ & $\begin{array}{l}369.09 \\
(47.1)\end{array}$ \\
\hline Informational / didactic & $\begin{array}{l}0.15 \\
(0.1)\end{array}$ & $\begin{array}{l}21.97 \\
(4.4)\end{array}$ & $\begin{array}{l}12.00 \\
(2.2)\end{array}$ & $\begin{array}{l}58.82 \\
(8.3)\end{array}$ & $\begin{array}{l}132.18 \\
(16.9)\end{array}$ \\
\hline Advertising & $\begin{array}{l}55.12 \\
(21.6)\end{array}$ & $\begin{array}{l}63.32 \\
(12.6)\end{array}$ & $\begin{array}{l}54.36 \\
(10.0)\end{array}$ & $\begin{array}{l}120.59 \\
(16.9)\end{array}$ & $\begin{array}{l}84.75 \\
(10.8)\end{array}$ \\
\hline Entertainment & $\begin{array}{l}25.27 \\
(9.9)\end{array}$ & $\begin{array}{l}36.15 \\
(7.2)\end{array}$ & $\begin{array}{l}43.80 \\
(8.0)\end{array}$ & $\begin{array}{l}61.55 \\
(8.6)\end{array}$ & $\begin{array}{l}161.36 \\
(20.6)\end{array}$ \\
\hline Local Personals & $\begin{array}{l}17.95 \\
(7.0)\end{array}$ & $\begin{array}{l}58.59 \\
(11.6)\end{array}$ & $\begin{array}{l}55.26 \\
(10.1)\end{array}$ & $\begin{array}{l}30.92 \\
(4.3)\end{array}$ & $\begin{array}{l}11.09 \\
(1.4)\end{array}$ \\
\hline Op-Ed & $\begin{array}{l}26.73 \\
(10.5)\end{array}$ & $\begin{array}{l}27.77 \\
(5.5)\end{array}$ & $\begin{array}{l}36.69 \\
(6.7)\end{array}$ & $\begin{array}{l}35.45 \\
(5.0)\end{array}$ & $\begin{array}{l}21.79 \\
(2.8)\end{array}$ \\
\hline $\begin{array}{l}\text { Self-Referential (masthead, self- } \\
\text { advertising, contests, premiums) }\end{array}$ & $\begin{array}{l}1.13 \\
(0.4)\end{array}$ & $\begin{array}{l}19.30 \\
(3.8)\end{array}$ & $\begin{array}{l}24.14 \\
(4.4)\end{array}$ & $\begin{array}{l}36.95 \\
(5.2)\end{array}$ & $\begin{array}{l}4.06 \\
(0.5)\end{array}$ \\
\hline \multicolumn{6}{|c|}{ CATEGORIES showing agricultural and none-agricultural elements } \\
\hline Total News & $\begin{array}{l}128.75 \\
(100 \%)\end{array}$ & $\begin{array}{l}277.06 \\
(100 \%)\end{array}$ & $\begin{array}{l}319.15 \\
(100 \%)\end{array}$ & $\begin{array}{l}368.56 \\
(100 \%)\end{array}$ & $\begin{array}{l}369.09 \\
(100 \%)\end{array}$ \\
\hline Non-Agricultural News & $\begin{array}{l}118.94 \\
(92.4)\end{array}$ & $\begin{array}{l}251.51 \\
(90.8)\end{array}$ & $\begin{array}{l}265.99 \\
(83.3)\end{array}$ & $\begin{array}{l}293.04 \\
(79.5)\end{array}$ & $\begin{array}{l}312.83 \\
(84.8)\end{array}$ \\
\hline Agricultural News & $\begin{array}{l}9.80 \\
(7.6)\end{array}$ & $\begin{array}{l}25.55 \\
(9.2)\end{array}$ & $\begin{array}{l}53.17 \\
(16.7)\end{array}$ & $\begin{array}{l}75.52 \\
(20.5)\end{array}$ & $\begin{array}{l}56.26 \\
(15.2)\end{array}$ \\
\hline Total Informational / Didactic & $\begin{array}{l}0.15 \\
(100 \%)\end{array}$ & $\begin{array}{l}21.97 \\
(100 \%)\end{array}$ & $\begin{array}{l}12.00 \\
(100 \%)\end{array}$ & $\begin{array}{l}58.82 \\
(100 \%)\end{array}$ & $\begin{array}{l}132.18 \\
(100 \%)\end{array}$ \\
\hline Agricultural / Rural & 0.00 & $\begin{array}{l}18.97 \\
(86.3)\end{array}$ & $\begin{array}{l}4.29 \\
(35.8)\end{array}$ & $\begin{array}{l}44.79 \\
(76.2)\end{array}$ & $\begin{array}{l}76.87 \\
(58.2)\end{array}$ \\
\hline General \& Household & $\begin{array}{l}0.15 \\
(100)\end{array}$ & $\begin{array}{l}3.0 \\
(13.7)\end{array}$ & $\begin{array}{l}7.71 \\
(64.2)\end{array}$ & $\begin{array}{l}14.03 \\
(23.9)\end{array}$ & $\begin{array}{l}55.31 \\
(41.8)\end{array}$ \\
\hline Total Advertising & $\begin{array}{l}55.12 \\
(100 \%)\end{array}$ & $\begin{array}{l}63.32 \\
(100 \%)\end{array}$ & $\begin{array}{l}54.36 \\
(100 \%)\end{array}$ & $\begin{array}{l}120.59 \\
(100 \%)\end{array}$ & $\begin{array}{l}84.75 \\
(100 \%)\end{array}$ \\
\hline $\begin{array}{l}\text { Valley Classified / farm } \\
\text { ads }\end{array}$ & $\begin{array}{l}5.37 \\
(9.8)\end{array}$ & $\begin{array}{l}15.92 \\
(25.2)\end{array}$ & $\begin{array}{l}19.09 \\
(35.1)\end{array}$ & $\begin{array}{l}36.39 \\
(30.2)\end{array}$ & $\begin{array}{l}37.02 \\
(43.7)\end{array}$ \\
\hline $\begin{array}{l}\text { National consumer } \\
\text { goods }\end{array}$ & $\begin{array}{l}4.28 \\
(7.8)\end{array}$ & $\begin{array}{l}3.65 \\
(5.8)\end{array}$ & $\begin{array}{l}3.60 \\
(6.6)\end{array}$ & $\begin{array}{l}8.91 \\
(7.4)\end{array}$ & $\begin{array}{l}21.96 \\
(25.9)\end{array}$ \\
\hline City consumer goods & $\begin{array}{l}24.60 \\
(44.6)\end{array}$ & $\begin{array}{l}28.18 \\
(45.5)\end{array}$ & $\begin{array}{l}25.12 \\
(46.2)\end{array}$ & $\begin{array}{l}46.53 \\
(38.6)\end{array}$ & $\begin{array}{l}12.09 \\
(14.3)\end{array}$ \\
\hline Patent medicines & $\begin{array}{l}20.86 \\
(37.8) \\
\end{array}$ & $\begin{array}{l}15.58 \\
(24.6) \\
\end{array}$ & $\begin{array}{l}6.54 \\
(12.0) \\
\end{array}$ & $\begin{array}{l}28.76 \\
(23.9) \\
\end{array}$ & $\begin{array}{l}13.68 \\
(16.1) \\
\end{array}$ \\
\hline Total Local Personals & $\begin{array}{l}17.95 \\
(100 \%)\end{array}$ & $\begin{array}{l}58.59 \\
(100 \%)\end{array}$ & $\begin{array}{l}55.26 \\
(100 \%)\end{array}$ & $\begin{array}{l}30.92 \\
(100 \%)\end{array}$ & $\begin{array}{l}11.09 \\
(100 \%)\end{array}$ \\
\hline Local Valley & $\begin{array}{l}10.28 \\
(57.3)\end{array}$ & $\begin{array}{l}47.87 \\
(81.7)\end{array}$ & $\begin{array}{l}48.90 \\
(88.4)\end{array}$ & $\begin{array}{l}28.35 \\
(91.7)\end{array}$ & $\begin{array}{l}11.09 \\
(100)\end{array}$ \\
\hline Local City & $\begin{array}{l}7.52 \\
(41.9)\end{array}$ & $\begin{array}{l}10.72 \\
(18.3)\end{array}$ & $\begin{array}{l}6.42 \\
(11.6)\end{array}$ & $\begin{array}{l}2.57 \\
(8.3)\end{array}$ & 0.00 \\
\hline
\end{tabular}


Appendix D: Demographic and Agricultural Diversity in the Ottawa Valley

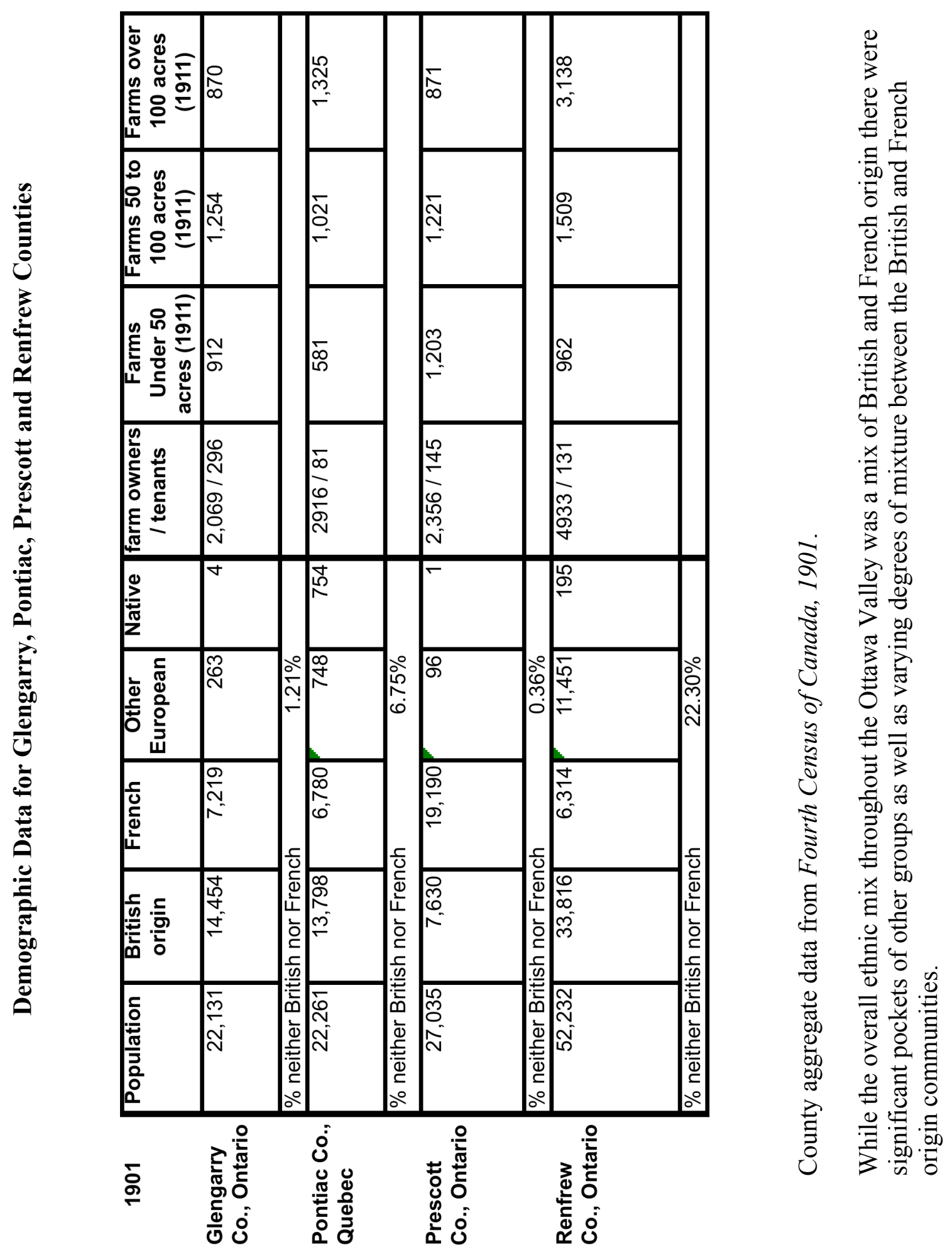


ט.
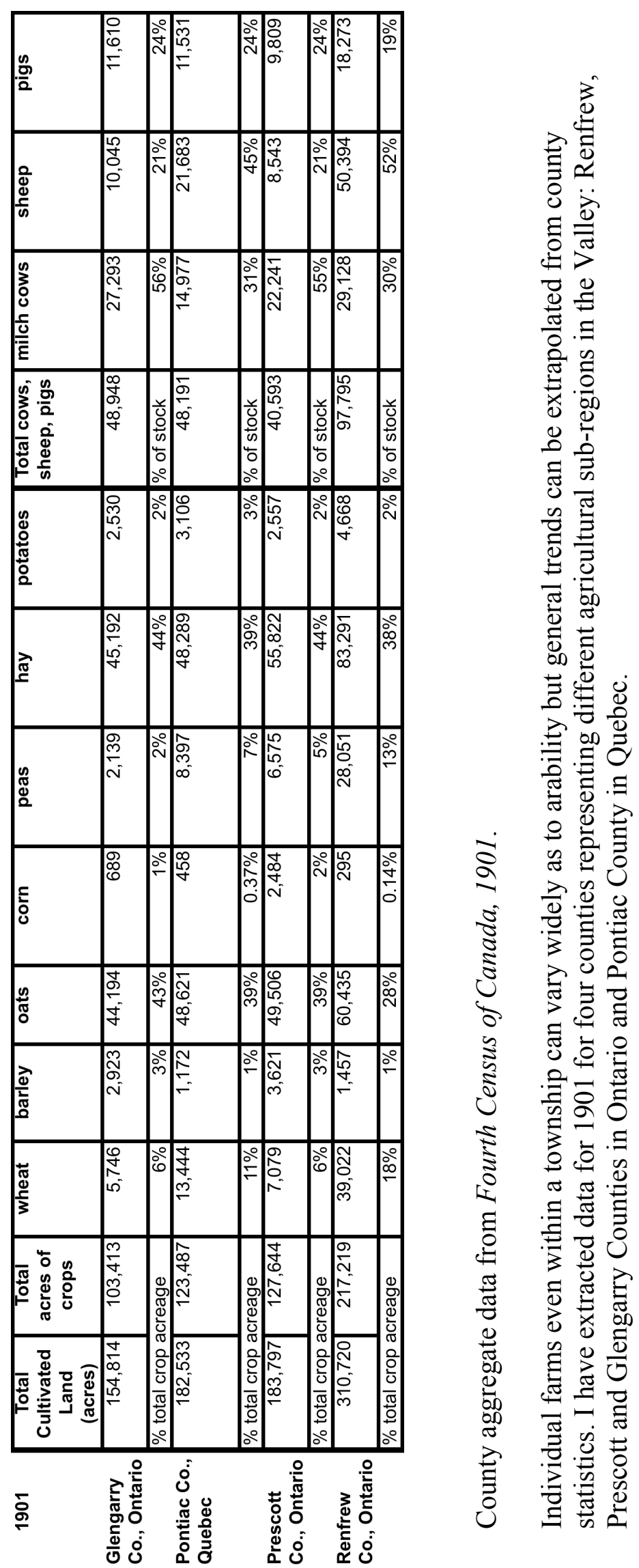


\section{Bibliography}

\section{Unpublished Primary Sources}

\section{Library and Archives Canada}

I. Norman Smith fonds MG 31 D 94

Philip Dansken Ross fonds, R2236-0-7-E MG 30, D98

Manuscript of Canada Census Returns, 1871 - 1921 (online)

\section{City of Ottawa Archives}

Ottawa Journal fonds MG-011

Carleton Council Minutes, 1899-1903.

Private Collection, Bruce S. Elliott

Ottawa Farm Journal sales pamphlet circa 1920.

Booklet, "Fifty Years 1869 to 1919 / Half Century Souvenir."

\section{Published Primary Sources}

\section{Newspapers}

Farm and Dairy (1909-1911)

Farmer's Advocate (broken runs 1888-1922)

Ottawa Evening Journal (1887-1925)

Ottawa Semi-Weekly Journal (1887-1899)

Ottawa Valley Journal (1899-1917)

Ottawa Farm Journal (1917-1925)

Ottawa Citizen (intermittent)

Central Canadian Citizen (1909, 1912, 1913, 1916)

Shawville Equity (1901)

\section{Periodicals}

Canadian Printer and Publisher (1892, 1901-1911)

\section{Government Publications}

Canada, Department of Agriculture

- Fifth Census of Canada, 1911, Vol. 1.

- Ninth Census of Canada, 1951, Vol. 1.

Report of Royal Commission to Enquire Into Alleged Complaints Relating to Weighing of Butter and Cheese in Montreal, Sessional paper 153b (Ottawa: C.H. Parmalee [King's Printer], 1913):5 http://epe.lac-bac.gc.ca/100/200/301/pco-bcp/commissions-ef/pringle1913eng/pringle1913-eng.pdf. Accessed May 12, 2017.

\section{Other Publications}

Batten's Agricultural Directory. New York: George Batten Co., 1908.

The Canadian Newspaper Directory (Montreal: A. McKim \& Co., 1899, 1905, 1907, 1909, 1919). 
Current Periodicals and Serials of the United States and Canada. Compiled by Henry O. Severance. 1907.

Grimsby Park: The Chautauqua of Canada, (Toronto, Braugh A. Caswell, [1891]) http://archive.org/details/grimsbyparkchaut00brou. Accessed April 2, 2018.

List of the Agricultural Periodicals of the United States and Canada Published During the Century July 1810 to July 1910. Compiled by Stephen Conrad Stuntz. Edited by Emma B. Hawks. Washington, D.C.: United States Government Printing Office, 1941.

Ottawa City Directories, Might Directory Company, 1885 to 1945.

R.G. Dun \& Co., Mercantile Reference Book. 1882, 1890, 1912, 1921, 1925, 1928.

Saint Pierre, H.C. Oration Pronounced at the Mount Royal Cemetery on Decoration Day, May 30th, 1899. Montreal: C.A. Marchand, [1899?]

Stiles, H.M. Official History of the Cornwall Cheese and Butter Board. [Cornwall, 1919]. Urban and Rural Development: Report of Conference Winnipeg, May 28-30, 1917. Ottawa: Commission of Conservation, 1917.

\section{Genealogical Records}

Ancestry.ca

\section{Secondary Sources}

AHR Roundtable. "Historians and the Question of Modernity." American Historical Review 116, no. 3 (June 1911).

Abbott, Richard H. "The Agricultural Press Views the Yeoman.” Agricultural History 42, no. 1 (January 1968): 35-48.

Allen, Charles Laurel. Country Journalism. New York: Thomas Nelson and Sons, 1928.

Allen, Gene and Daniel J. Robinson. "Introduction: Media History as Concept and Practice." In Communicating in Canada's Past: Essays on Media History edited by Gene Allen and Daniel J. Robinson, 3-24. Toronto: University of Toronto Press, 2009.

Allen, Richard. "The Social Gospel as the Religion of the Agrarian Revolt." In The Prairie West: Historical Readings edited by R. Douglas Francis and Howard Palmer, 561-72. Edmonton: Pica Pica Press, 1992.

Altschull, J. Herbert. Agents of Power: The Role of the News Media in Human Affairs. New York: Longman, 1984.

Amyot, Chantal and John Willis. Country Post: Rural Postal Service in Canada, 1880 to 1945. Gatineau, QC: Canadian Museum of Civilization, 2003.

Anderson, Peter G. Ottawa School Gardens in the Early 1900's. Bytown Pamphlet Series no. 76. Ottawa: Historical Society of Ottawa, 2010.

Ankli, Robert E. “Ontario's Dairy Industry, 1880-1920.” In Canadian Papers in Rural History Vol. 10, edited by Donald H. Akenson, 261-75. Gananoque, Ont.: Langdale Press, 1992. 
Ariès, Philippe. The Hour of Our Death. Translated by Helen Weaver. 1981. Reprint, New York: Vintage Books, 2008.

Asquith, Ivan. "1780-1855." In Newspaper History: From the Seventeenth Century to the Present Day edited by George Boyce, James Curran and Pauline Wingate, 98116. London: Constable, 1978.

Badgley, R. Kerry. Ringing in the Common Love of Good: The United Farmers of Ontario, 1914-1926. Montreal: McGill-Queen's University Press, 2000.

Bailey, L.H. Farmers' Institutes: History and Status in the United States and Canada. Washington: Government Printing Office, 1900.

Baldasty, Gerald J. The Commercialization of News in the Nineteenth Century. Madison: University of Wisconsin Press, 1992.

Barnhurst, Kevin G. and John Nerone, The Form of the News: A History. New York: Guilford Press, 2001.

Barron, Hal S. Mixed Harvest: The Second Great Transformation in the Rural North, 1870-1930. Chapel Hill: University of North Carolina Press, 1997.

- Rediscovering the Majority: The New Rural History of the Nineteenth-Century North." Historical Methods 19, no. 1 (Fall 1986): 141-52.

Barthelme, Marion Knox. "Women in the Texas Populist Movement: The Letters to the 'Southern Mercury."” Master's thesis, Rice University, 1994.

Beardsworth, Alan. "Analysing Press Content: Some Technical and Methodological Issues." In The Sociology of Journalism and the Press edited by Harry Christian, 371-395. Stoke-on-Trent: J.H. Brookes, 1980.

Beaven, Brian P.N. "Partisanship, Patronage, and the Press in Ontario, 1880-1914: Myths and Realities." Canadian Historical Review 64, no. 3 (September 1983): 317-51.

Belshaw, John and Diane Purvey. Private Grief, Public Mourning: The Rise of the Roadside Shrine in B.C. Vancouver: Anvil Press, 2009.

Benjamin, Walter. The Arcades Project. Translated by Howard Elland and Kevin McLaughlin. Cambridge, Mass.: Belknap Press, 1999.

Benner, Melissa. “The Mediated Counterpublics of Canadian Farm Women.” Master's thesis, Carleton University, 2004.

Berelson, Bernard. Content Analysis in Communication Research. New York: Hafner Press, 1952.

Berger, Arthur Asa. Media Research Techniques. Thousand Oaks, Calif.: SAGE Publications, 1998.

Bittermann, Rusty. "Farm Households and Wage Labour in the Northeastern Maritimes in the Early 19th Century." In Contested Countryside: Rural Workers and Modern Society in Atlantic Canada, 1800-1950 edited by Daniel Samson, 34-69. 
Fredericton, NB.: Acadiensis Press, 1994.

Blanchard, Margaret A. "The Ossification of Journalism History: A Challenge for the Twenty-First Century." In The American Journalism History Reader: Critical and Primary Texts edited by Bonnie Brennen and Hanno Hardt, 28-35. New York: Routledge, 2011.

Blankenship, A.B., Chuck Chakrapani and W. Harold Poole. A History of Marketing Research in Canada. Toronto: Professional Research Society, 1985.

Blaug, Mark. "Henry George: Rebel with a Cause." European Journal of the History of Economic Thought 7, no. 2 (2000): 270-88.

Blumenthal, Albert. Small Town Stuff. 1932. Reprint, Chicago: U.P., 1961.

Bogue, A. "The Fighting Farmer, William Weld," Western Ontario Historical Notes 3 no. 4 (December 1945): 75-8.

Borish, Linda J. "“A Fair, Without the Fair, is No Fair at All': Women at the New England Agricultural Fair in the Mid-Nineteenth Century." Journal of Sports History 24, no. 2 (Summer 1997): 155-76.

Bourne. H.R. Fox. English Newspapers: Chapters in the History of Journalism. Vol. 2. 1887. Reprint, Miami, FL.: HardPress Publishing, [2000-?].

Bowers, William L. The Country Life Movement in America, 1900-1920. Port Washington, N.Y.: Kennikat Press, 1974. "Country-Life Reform, 1900-1920: A Neglected Aspect of Progressive Era History." Agricultural History 45, no. 3 (July 1971): 211-21.

Bowman, Charles A. Ottawa Editor. Sidney, B.C.: Gray’s Publishing, 1966.

Bradley, Ben. British Columbia by the Road: Car Culture and the Making of a Modern Landscape. (Vancouver: UBC Press, 2017.

Bruce, Charles. News and the Southams. Toronto: Macmillan of Canada, 1968.

Buchanan, Carrie Mersereau. "A Changing Sense of Place in Canadian Daily Newspapers: 1894-2005.” PhD diss., Carleton University, 2009.

Burchardt, Jeremy. Paradise Lost: Rural Idyll and Social Change in England since 1800. London: I.B. Tauris, 2002.

"Agricultural History, Rural History, or Countryside History." The Historical Journal 50, no. 2 (June 2007): 465-81.

Buttel, Frederick H. and Philip McMichael, "Sociology and Rural History: Summary and Critique.” Social Science History 12, 2 (Summer 1988): 93-120.

Buxton, William J. and Catherine McKercher. "Newspapers, Magazines and Journalism in Canada: Towards a Critical Historiography." Acadiensis 28, no 1 (Autumn 1998): 103-26.

Calnan, James E. Taylor. “'Blessed Be the Tie That Binds': Voluntary Associations and 
Community in Picton, Ontario, 1870-1914.” PhD diss., University of Guelph, 1999.

Campbell, W. Joseph. Yellow Journalism: Puncturing the Myths, Defining the Legacies. Westport, Conn.: Praeger, 2001.

Canadian Newspapers: The Inside Story. Edited by Walter Stewart. Edmonton, Hurtig Publishers, 1980.

Careless, J.M.S. Frontier and Metropolis: Regions, Cities, and Identities in Canada before 1914. Toronto: University of Toronto Press, 1989.

Carey, James W. "The Problem of Journalism History." In The American Journalism History Reader: Critical and Primary Texts edited by Bonnie Brennen and Hanno Hardt, 22-7. New York: Routledge, 2011.

Carniglia, Edgardo Luis. "Enclaves and Dilemmas of Rural Communication, Family Farmers and the Agricultural Press." Journal of Latin American Communication Research 3, no 1 ([2013]): 103-27.

Cartwright, Donald Gordon. "French Canadian Colonization in Eastern Ontario to 1910: A Study of Process and Pattern.” PhD. Diss., University of Western Ontario, 1973.

Cassidy, David R. “The Content of the Rural Weekly Press in Illinois in 1882.” PhD diss., University of Iowa, 1980.

Christie, Nancy. "Revisiting Canada's Project of Liberal Rule." The Underhill Review, Fall 2009, http://www3.carleton.ca/underhillreview/09/fall/reviews/christie.htm. (Accessed October 12, 2017).

Clark, Christopher. "Rural America and the Transition to Capitalism." Journal of the Early Republic 16, no. 2 (Summer 1996): 223-36.

Clark, Justin T. “Confronting the 'Speaker of Newspaper Notoriety': Pathological Lying, the Public, and the Press, 1890-1920." American Journalism 34, no. 2 (2017): 179-200.

Clark, Krissy and Geoff McGhee, "Did the West Make Newspapers, or Did Newspapers Make the West?" http://web.standford.edu/group/ruralwest/cgibin/drupal/content/rural-newspaper-history. (Accessed September 16, 2017).

Clutts, Betty Carol. "Country Life Aspects of the Progressive Movement.” PhD. diss., Ohio State University, 1962.

Cohen, Marjorie Griffin. "The Decline of Women in Canadian Dairying." Histoire sociale / Social History 17, no. 34 (November 1984): 307-34.

Women's Work, Markets, and Economic Development in Nineteenth-Century Ontario. Toronto: University of Toronto Press, 1988.

Cole, Robert. "The Western Edition of the Farmer's Advocate and Home Magazine." In History of the Book in Canada, edited by Yvan Lamonde, Patricia Lockhart 
Fleming and Fiona A. Black, 321-2. Vol. 2. Toronto: University of Toronto Press, 2005.

Conboy, Martin. The Press and Popular Culture. London: Sage Publications, 2002.

Condray, Kathleen, “Arkansas' Bloody German-Language Newspaper War of 1892." The Arkansas Quarterly 74, no. 4 (Winter 2015): 327-51.

Cook, Katherine. "Deathscapes: Memory, Heritage and Place in Cemetery History." Master's Thesis, McMaster University, 2011.

Cooke, Kathy J. "Expertise, Book Farming, and Government Agriculture: The Origins of Agricultural Seed Certification in the United States." Agricultural History 76, no. 3 (Summer 2002): 524-45.

Cook, Ramsay. The Regenerators: Social Criticism in Late Victorian English Canada. Toronto: University of Toronto Press, 1985. "Tillers and Toilers: The Rise and Fall of Populism in Canada in the 1890s." Historical Papers 191 (1984): 1-20.

Craick, W.A. A History of Canadian Journalism II: Last Years of Canadian Press Association 1908-1919. Toronto: Ontario Publishing Company, 1959.

Creed, Gerald W. and Barbara Ching. "Introduction: Recognizing Rusticity, Identity and the Power of Place." In Knowing Your Place: Rural Identity and Cultural Hierarchy, edited by Barbara Ching and Gerald W. Creed, 1-38. New York: Routledge, 1997.

Crerar, Adam. "Ties That Bind: Farming, Agrarian Ideals, and Life in Ontario, 18901930." PhD diss., University of Toronto, 1999.

"Writing across the Rural-Urban Divide: The Case of Peter McArthur, 1909-24." Journal of Canadian Studies 41, 2 (Spring 2007): 112-37.

Cronin, William. Nature's Metropolis: Chicago and the Great West. New York: W.W. Norton, 1991.

Crouthhamel, James L. Bennett's New York Herald and the Rise of the Popular Press. Syracuse, N.Y.: Syracuse University Press, 1989.

Crowley, Terry. "Experience and Representation: Southern Ontario Farm Women and Agricultural Change, 1870-1914." Agricultural History 73, no. 2 (Spring 1999): 238-51.

"J.J. Morrison and the Transition in Canadian Farm Movements during the Early

Twentieth Century." Agricultural History 71, no. 3 (Summer 1997): 330-56.

Currie, Terence M. The Ottawa Valley's Great Fire of 1870: The Nineteenth Century Press and the Reality of a Great Disaster. [Ottawa]: Creative Bound International, 2009.

Dabbous, Yasmine Jarek. "'Blessed Be the Critics of Newspapers': Journalistic Criticism of Journalism, 1865-1930." PhD diss., Louisiana State University, 2010. 
Daly, Christopher B. Covering America: A Narrative History of a Nation's Journalism. Amherst: University of Massachusetts Press, 2012.

Danbom, David B. The Resisted Revolution: Urban America and the Industrialization of Agriculture, 1900-1930. Ames: Iowa State University Press, 1979.

Born in the Country: A History of Rural America. Baltimore: Johns Hopkins University Press, 1995.

Danhof, Clarence H. Change in Agriculture: The Northern United States, 1820-1870. Cambridge, Mass.: Harvard University Press, 1969.

Davies, Donald F. "Dependent Motorization: Canada and the Automobile to the 1930s." Journal of Canadian Studies 21, no. 3 (Fall 1986): 106-32.

Davies, Steven James. "Ontario and the Automobile, 1900 to 1930: Aspects of Technological Integration.” PhD diss., McMaster University, 1987.

" "Reckless Walking Must Be Discouraged': The Automobile Revolution and the Shaping of Modern Urban Canada to 1930." Urban History Review 18, no. 2 (October 1989): 123-38.

De Certeau, Michel. The Practice of Everyday Life. Translated by Steven Rendall. Berkeley: University of California Press, 1984.

Deacon, David, Michael Pickering, Peter Golding and Graham Murdock. Researching Communications: A Practical Guide to Methods in Media and Cultural Analysis. London: Arnold, 1999.

Demaree, Albert Lowther. The American Agricultural Press 1819-1860. New York: Columbia University Press, 1941.

"The Farm Journals, Their Editors, and Their Public, 1830-1860." Agricultural History 15, no. 4 (October 1941): 182-8.

Devereux, Roy. John Loudon McAdam. London: Oxford University Press, 1936.

Dicken-Garcia, Hazel. Journalistic Standards in Nineteenth-Century America. Madison: University of Wisconsin, 1989.

Dorsey, Mark. "The U.F.O. and the Broadening-out Controversy: Crisis of Farmer Identity in a Changing World." SURG (Studies by Undergraduate Researchers at Guelph) 2, no. 1 (Fall 2008): 39-46; https://journal.lib.uoguelph.ca/index.php/surg/article/view/797 (Accessed July $16,2017)$.

Drummond, Ian M. Progress without Planning: The Economic History of Ontario from Confederation to the Second World War. Toronto: University of Toronto Press, 1987.

Drummond, W.M., W.J. Anderson and T.C. Kerr. A Review of Agricultural Policy in Canada. Ottawa: Agricultural Economics Research Council of Canada, 1966.

Drury, E.C. Farmer Premier: Memoirs of the Honourable E.C. Drury. Toronto: 
McClelland and Stewart, 1966.

Duemer, Lee S. "The Agricultural Education Origins of the Morrill Land Grant Act of 1862." American Educational History Journal 34, no. 1 (2007): 135-46.

Duke, Dorothy Mary. “Agricultural Periodicals Published in Canada 1836-1960. Master of Library Science, McGill University Library School, 1961.

Durflinger, Serge M. Lest We Forget: A History of the Last Post, 1909-1999. Montreal: Last Post Fund, 2000.

Dykstra Robert D. and Jo Ann Manfra. The Gilded Age: Industrial Capitalism and Its Discontents. Malabar, FL.: Krieger Publishing, 2006.

Eley, Geoff. "Nations, Publics, and Political Cultures: Placing Habermas in the Nineteenth Century." In Habermas and the Public Sphere, edited by Craig Calhoun, 289-339. Cambridge, Mass., and London: MIT Press, 1992.

Ellingson, Stephen. "Understanding the Dialectic of Discourse and Collective Action: Public Debate and Rioting in Antebellum Cincinnati." American Journal of Sociology 101, no 1 (July 1995): 100-44.

Ellsworth, Clayton S. “Theodore Roosevelt's Country Life Commission.” Agricultural History 34, no. 4 (October 1960): 155-72.

Elliott, Bruce S. The City Beyond: A History of Nepean, Birthplace of Canada's Capital 1792-1990. Nepean, Ont.: City of Nepean, 1991. "The Great Fire of 1870: A Review of a New Book and New Research on the Fire and Its Aftermath.” Horaceville Herald 54 (March 2010): 1, 6-8, 13-16.

Emery, Edwin. The Press and America: An Interpretative History of Journalism. 2nd ed. Eaglewood Cliffs, N.J.: Prentice-Hall, 1962.

Emery, Michael, Edwin Emery and Nancy L. Roberts. The Press and America: An Interpretative History of Mass Media. 9th ed. Boston: Allyn and Bacon, 2000.

Erdman, H.E. "The 'Associated Dairies' of New York as Precursors of American Agricultural Cooperatives." Agricultural History, 36, no. 2 (April 1962): 82-90.

Fair, Ross D. "Gentlemen, Farmers, and Gentlemen Half-Farmers: The Development of Agricultural Societies in Upper Canada, 1792-1846.” PhD diss., Queen's University, 1998.

Farrell, Richard T. "Advice to Farmers: The Content of Agricultural Newspapers, 18601910.” Agricultural History 51, no. 1 (January 1977): 209-17.

Fecteau, Jean-Marie. “Towards a Theory of Possible History? Ian McKay's Idea of a 'Liberal Order."' The Underhill Review, Fall 2009, http://www3.carleton.ca/underhillreview/09/fall/reviews/fecteau.htm. (Accessed October 12, 2017).

Fedler, Fred. Lessons from the Past: Journalists' Lives and Works, 1850-1950. Prospect 
Heights, Ill.: Waveland Press, 2000.

Ferry, Darren. "'Severing the Connections in a Complex Community': The Grange, the Patrons of Industry and the Construction/Contestation of a Late 19th-Century Agrarian Identity in Ontario." Labour 54 (Fall 2004): 9-47.

Uniting in Measures of Common Good: The Construction of Liberal Identities in Central Canada, 1830-1900. Montreal \& Kingston: McGill-Queen's University Press, 2008.

Fetherling, Douglas. The Rise of the Canadian Newspaper. Toronto: Oxford University Press, 1990.

Filipiak, Jeffrey. "The Work of Local Culture: Wendell Berry and Communities as the Source of Farming Knowledge.” Agricultural History 85, no. 2 (Spring 2011): 174-94.

Fink, Deborah. "'Not to Intrude': A Danish Perspective on Gender and Class in Nineteenth-Century Dairying." Agricultural History 83, no. 4 (Fall, 2009): 44676.

Fite, Gilbert C. "The Historical Development of Agricultural Fundamentalism in the Nineteenth Century." Journal of Farm Economics 44, no. 5 (December 1962): 1203-11.

Folkerts, Jean. "Functions of the Reform Press." Journalism History 12, no. 1 (Spring 1985): 22-5.

Foucault, Michel. The Order of Things: An Archaeology of the Human Sciences. New York: Vintage Books, 1973.

Fowke, Vernon C. Canadian Agricultural Policy: The Historical Pattern. Toronto: University of Toronto Press, 1946.

Friedman, Susan Stanford. "Definitional Excursions: The Meanings of Modern/Modernity/Modernism." Modernism/modernity, 8, no. 3 (Sept 2001): 493-513.

Fry, John J. The Farm Press, Reform, and Rural Change, 1895-1920. New York: Routledge, 2012.

“'Good Farming - Clear Thinking - Right Living': Midwestern Farm Newspapers, Social Reform, and Rural Readers in the Early Twentieth Century." Agricultural History 78, no. 1 (Winter 2004): 34-49.

Gabriele, Sandra and Paul S. Moore. "The Globe on Saturday, the World on Sunday: Toronto Weekend Editions and the Influence of the American Sunday Paper, 1886-1895." Canadian Journal of Communication 34, no. 3 (2009): 337-58.

Garfrerick, Beth H. "A History of Weekly Community Newspapers in the United States: 1900 to 1980." PhD diss., University of Alabama, 2009.

Gates, Warren J. "Modernization as a Function of an Agricultural Fair: The Great 
Grangers' Picnic Exhibition at Williams Grove, Pennsylvania, 1873-1916." Agricultural History 58, no. 3 (July 1984): 262-79.

Giddens, Anthony. The Consequences of Modernity. Stanford, Calif.: Stanford University Press, 1990.

Giddens, Anthony and Christopher Pierson, Conversations with Anthony Giddens: Making Sense of Modernity. Stanford, Calif., Stanford University Press, 1998.

Glazebrook, G.P. de T. A History of Transportation in Canada. 1938, repr. Toronto: McClelland and Stewart, 1964.

Good, W.C. Production and Taxation in Canada. Toronto: J.M. Dent \& Sons, 1919.

- Farmer Citizen: My Fifty Years in the Canadian Farmers' Movement. Toronto: Ryerson Press, 1958.

Gould, Joseph E. The Chautauqua Movement: An Episode in the Continuing American Revolution. New York: State University of New York, 1961.

Graham, Murdock and Peter Golding. "The Structure, Ownership and Control of the Press, 1914-76." In Newspaper History: From the Seventeenth Century to the Present Day edited by George Boyce, James Curran and Pauline Wingate, 13048. London: Constable, 1978.

Gramsci, Antonio. Selections from the Prison Notebooks. Edited and Translated by Quintin Hoare and Geoffrey Nowell Smith. New Delhi: Orient Blackswan, 2011.

Gudis, Catherine. "The Road to Consumption: Outdoor Advertising and the American Cultural Landscape, 1917-1965." PhD diss., Yale University, 2005.

Guillet, Edwin C. The Story of Canadian Roads. Toronto: University of Toronto Press, 1966.

Habermas and the Public Sphere. Edited by Craig Calhoun. Cambridge, MIT Press, 1992.

Hahn, Russell. Farmers Confront Industrialism: Some Historical Perspectives on Ontario Agrarian Movements. Toronto: New Hogtown Press, 1975.

Hall, D.J. "The Commission of Conservation (1909-21)." In Clifford Sifton: Volume 2, A Lonely Eminence, 1901-1929, 236-63. Vancouver: University of British Columbia Press, 1985.

Hall, Roger and Bruce Bowden. "Beautifying the Boneyard: The Changing Image of the Cemetery in Nineteenth-Century Ontario." Material Culture Review / Revue de la culture matérielle [Online], 23 (1 January 1986) journals.lib.unb.ca/index.php/MCR/article/view/17261 (Accessed March 8, 2018).

Hall, Stuart "Introduction." In Modernity: An Introduction to Modern Societies, edited by Stuart Hall, David Held, Don Hubert and Kenneth Thompson, 3-18. Cambridge, Mass.: Blackwell Publishers, 1996.

“Encoding/decoding.” In Culture, Media, Language: Working Papers in Cultural 
Studies, 1972-79, edited by Stuart Hall, Dorothy Hobson, Andrew Lowe and Paul Willis, 128-38. London: Hutchinson \& Co, 1980.

Halpern, Monda. And On That Farm He Had a Wife: Ontario Farm Women and Feminism, 1900-1970. Montreal: McGill-Queen's University Press, 2001.

Hamelin, Jean and André Beaulieu, "Aperçu du journalisme québécois d'expression française." Recherches sociographiques, 7, no. 3 (1966): 305-348.

Hamilton, Bridget and Elizabeth Manias, "Foucault's Concept of 'Local Knowledges' for Researching Nursing Practice.” Aporia: The Nursing Journal 1, no. 3 (July 2009): 7-17.

Hampton, Mark. Visions of the Press in Britain, 1850-1950. Urbana: University of Illinois Press, 2004.

"Representing the Public Sphere: The New Journalism and the Historians." In Transatlantic Print Culture, 1880-1940: Emerging Media, Emerging Modernisms, edited by Ann Ardis and Patrick Colliner, 15-29. Basingstroke, U.K.: Palgrave Macmillan, 2008.

Handy-Marchello, Barbara. Women of the Northern Plains: Gender and Settlement on the Homestead Frontier, 1870-1930. St. Paul: Minnesota Historical Society Press, 2005.

Hardt, Hanno. "Without the Rank and File: Journalism History, Media Workers, and Problems of Representation." In Newsworkers: Towards a History of the Rank and File, edited by Hanno Hardt and Bonnie Brennen, 1-29. Minneapolis: University of Minnesota Press, 1995.

Harvey, David. "Modernity and Modernism.” In The Condition of Postmodernity. 10-38. Cambridge, Mass.: Basil Blackwell, 1989.

Hayter, Earl W. The Troubled Farmer: 1850-1900 Rural Adjustment to Industrialism. [Illinois]: Northern Illinois University Press, 1963.

Heaman, E.A. The Inglorious Arts of Peace: Exhibitions in Canadian Society during the Nineteenth Century. Toronto: University of Toronto Press, 1999.

Hendry, Peter. Epitaph for Nostalgia. Montreal: Agri-World Press, 1968.

Hill, Robert. Voice of the Vanishing Minority: Robert Sellar and the Huntingdon Gleaner, 1863-1919. Montreal: McGill-Queen's University Press, 1999.

Hobsbawm, Eric. "Introduction: Inventing Traditions." In The Invention of Tradition ed. Eric Hobsbawm and Terence Ranger, 1-14. Cambridge, U.K.: Cambridge University Press, 1983.

Hodgson, Gut Richard. "Nurse, Martyr, Propaganda Tool: The Reporting of Edith Cavell in British Newspapers 1915-1920." Media, War and Conflict 10, no. 2 (2017): 239-53.

Hoffschwelle, Mary S. “'Better Homes on Better Farms’: Domestic Reform in Rural 
Tennessee." Frontiers: A Journal of Women's Studies 22, no. 1 (2001): 51-73.

Hofstadter, Richard. The Age of Reform: From Bryan to F.D.R. New York: Knopf, 1955.

Hong, Sun-ha. "The Other-Publics: Mediated Othering and the Public Sphere in the Dreyfus Affair.” European Journal of Cultural Studies 17, no. 6 (December 2014): 665-81.

Hooper-Greenhill, Eilean. Museums and the Shaping of Knowledge. London: Routledge, 1992.

Hugill, Peter J. "Good Roads and the Automobile in the United States 1880-1929." Geographical Review 72, no. 3 (July 1982): 32-49.

Huntzicker, William. The Popular Press, 1833-1865. Westport, Conn.: Greenwood Press, 1999.

"I Want to Join Your Club": Letters from Rural Children, 1900-1920. Edited by Norah L. Lewis. Waterloo, Ont.: Wilfrid Laurier University Press, 1996.

Irwin, Robert. "Farmers and Managerial Capitalism: The Saskatchewan Cooperatives Elevator Company." Agricultural History 70, no. 4 (Autumn 1996): 626-652.

Irwin, Thomas W. "Government Funding of Agricultural Associations in Late Nineteenth Century Ontario.” PhD diss., University of Western Ontario, 1997.

Irwin, W.A. "The House of Weld." MacLean's Magazine (July 15, 1931): 10, 44-5.

Jabbour, Alan and Karen Singer Jabbour. Decoration Day in the Mountains: Traditions of Cemetery Decoration in the Southern Appalachians. Chapel Hill: University of North Carolina Press, 2010.

Jameson, Sheilagh S. Chautauqua in Canada. Calgary: Glenbow Alberta Institute, 1979.

Jaroszyńska-Kirchmann, Anna D. "As if at a Public Meeting: Polish-American Readers, Writers, and Editors of Ameryka-Echo, 1922-1969." In Letters across Borders: The Epistolary Practices of International Migrants, edited by Bruce S. Elliott, David A. Gerber and Suzanne M. Sinke, 200-220. New York: Palgrave Macmillan, 2006.

Jin, Huimin. "British Cultural Studies, Active Audiences and the Status of Cultural Theory: An Interview with David Morley." Theory, Culture and Society 28, no. 4 (2011):130-3.

Johnston, Charles M. E.C. Drury: Agrarian Idealist. Toronto: University of Toronto Press, 1986.

Johnston, J. George The Weeklies: Biggest Circulation in Town. Bolton, Ont.: Leaven Printers, 1972.

Johnston, Russell. Selling Themselves: The Emergence of Canadian Advertising. Toronto: University of Toronto Press, 2000.

Johnstone, Paul H. “In Praise of Husbandry.” Agricultural History 11, no. 2 (April 1937): 
$80-95$.

“Turnips and Romanticism.” Agricultural History 12, no. 3 (July 1938): 224-55.

Jones, David C. Midways, Judges, and Smooth-Tongued Fakirs: The Illustrated Story of Country Fairs in the Prairie West. Saskatoon: Western Producer Prairie Books, 1983.

“" 'There Is Some Power About the Land': The Western Agrarian Press And Country Life Ideology.” Journal of Canadian Studies 17, 3 (Fall 1982): 96-108.

Kealey, Gregory S. and Bryan D. Palmer. Dreaming of What Might Be: The Knights of Labor in Ontario, 1880-1900. Toronto: New Hogtown Press, 1987.

Kellner, Douglas. "Habermas, the Public Sphere, and Democracy: A Critical Intervention.” http://www.gseis.ucla.edu/faculty/kellner/kellner.html. (Accessed October 12, 2017).

Keselman, Thomas A. Death ad the Afterlife in Modern France. Princeton: Princeton University Press, 1993.

Kesterton, W.H. A History of Journalism in Canada. Toronto: McClelland and Stewart, 1967.

King, Charles. "The Ottawa Papers: The Profits of Parochialism.” In Canadian Newspapers: The Inside Story, edited by Walter Stewart, 85-98. Edmonton: Hurtig Publishers, 1980.

Kinnear, Mary. “'Do You Want Your Daughter to Marry a Farmer?': Women's Work on the Farm, 1922." In Canadian Papers in Rural History. Vol. 6. Edited by Donald H. Akenson, 137-53. Gananoque, Ont.: Langdale Press, 1996.

Kirkendall, Richard S. "The Agricultural Colleges: Between Tradition and Modernization." Agricultural History 60 no. 2 (Spring 1986): 3-21.

Kirschner, Don S. City and Country: Rural Responses to Urbanization in the 1920s. Westport, Conn,: Greenwood Publishing, 1970.

Kline, Ronald R. Consumers in the Country: Technology and Social Change in Rural America. Baltimore: Johns Hopkins University Press, 2000.

Kline, Ronald and Trevor Pinch. "Users as Agents of Technological Change: The Social Construction of the Automobile in the Rural United States." Technology and Culture 37, no. 4 (October 1996): 763-95.

Kobre, Sidney. The Yellow Press and Gilded Age Journalism. Tallahassee: Florida State University, 1964.

Krause, Monika. "Reporting and the Transformation of the Journalistic Field: U.S. News Media, 1890-2000.” Media, Culture and Society 33, no. 1 (January 2011): 89-104.

Krippendorff, Klaus. Content Analysis: An Introduction to Its Methodology. Beverly Hills: SAGE Publications, 1980. 
Kulikoff, Allan. "The Transition to Capitalism in Rural America." The William and Mary Quarterly 46, no. 1 (January, 1989): 120-44.

Kyeremateng, Senita O. “The Farmer's Advocate” Guelph University Collection Update no. 19, 2002 - Rural History.

http://www.lib.uoguelph.ca/resources/archival_\&_special_collections/collection _update/19/farmersadvocate.htm (Accessed October 10, 2012).

Lacy, Stephen, Brendan R. Watson, Daniel Riffe and Jennette Lovejoy. "Issues and Best Practices in Content Analysis." Journalism and Mass Communication Quarterly 92, no. 4 (2015): 791-811.

Lacy, Stephen, Daniel Riffle, Staci Stoddard, Hugh Martin and Kuant-Kuo Chang. "Sample Size for Newspaper Content Analysis in Multi-Year Studies." Journalism and Mass Communication Quarterly 78, no. 4 (Winter 2001): 836-45.

Lacy, Stephen, Kay Robinson and Daniel Riffle. "Sample Size in Content Analysis of Weekly Newspapers." Journalism and Mass Communication Quarterly 72, no. 2 (Summer 1995): 336-45.

Landon, Fred. "The Agricultural Journals of Upper Canada (Ontario).” Agricultural History 9, 4 (Oct. 1935): 167-75.

Larson, Olaf F. and Thomas B. Jones, "The Unpublished Data from Roosevelt's Commission on Country Life." Agricultural History 30, no. 4 (October 1976): 583-99.

Latour, Bruno. We Have Never Been Modern. Translated by Catherine Porter. Cambridge, Mass.: Harvard University Press, 1993.

Lauters, Amy Mattson. "More than a Farmer's Wife: Constructions of American Farm Women In Selected Media, 1910-1960.” PhD diss., University of Minnesota, 2005.

Lears, T.J. Jackson. "The Concept of Cultural Hegemony: Problems and Possibilities." American Historical Review 90, no. 3 (June 1985): 567-93.

Lee, Alan J. The Origins of the Popular Press in England 1855-1914. London: Croom Helm, 1976. "The Structure, Ownership and Control of the Press, 1855-1914." In Newspaper History: From the Seventeenth Century to the Present Day edited by George Boyce, James Curran and Pauline Wingate, 117-29. London: Constable, 1978.

Lee, Alfred McClung. The Daily Newspaper in America: The Evolution of a Social Instrument. New York: Macmillan Co., 1947.

Lee, James Melvin. History of American Journalism. Boston: Houghton Mifflin, 1917.

Lee, Jason W. "An Economic Analysis of the Good Roads Movement in the 20th

Century." PhD diss., University of California, Davis, 2012.

Lemmer, George F. "Early Agricultural Editors and Their Farm Philosophies." 
Agricultural History 31, no. 4 (October 1957): 3-22.

Leonard, Thomas C. News for All: America's Coming-of-Age with the Press. New York: Oxford University Press, 1978.

Levine, Gregory J. "The Single Tax in Montreal and Toronto, 1880 to 1920: Successes, Failures and the Transformation of an Idea." American Journal of Economics and Sociology 52, no. 4 (October 1993): 417-32.

Levine, Lawrence W. "The Folklore of Industrial Society: Popular Culture and Its Audience." American Historical Review 97, no. 5 (December 1992): 1369-99.

Levermore, Charles H. “The Rise of Metropolitan Journalism, 1800-1840.” American Historical Review 6, no. 3 (April 1901): 446-65.

Lewis, Timothy D. "Agrarian Idealism and Progressive Agriculture in Maritime Canada: Agricultural Leadership in New Brunswick, 1895-1929.” PhD diss., University of New Brunswick. 2003.

Linden, Blanche M.G. Silent City on a Hill: Picturesque Landscapes of Memory and Boston's Mount Auburn Cemetery rev. ed. Amherst: University of Massachusetts Press, 2007.

Lipin, Lawrence M. "Nature, the City, and the Family Circle: Domesticity and the Urban Home in Henry George's Thought." The Journal of the Gilded Age and Progressive Era 13, no. 3 (July 2014): 305-35.

Llewellyn, Nigel. The Art of Death: Visual Culture in the English Death Ritual, c. $1500-$ c. 1800 . London: Reaktion Books, 1997.

Lockwood, Glenn J. “The Pattern of Settlement in Eastern Ontario," Families 30, no. 4 (1991): 235-57.

Loewen, Royden. "Beyond the Monolith of Modernity: New Trends in Immigrant and Ethnic Rural History." Agricultural History 81, no. 2 (Spring 2007): 204-27.

_Family, Church, and Market: A Mennonite Community in the Old and the New Worlds, 1850-1930. Toronto: Toronto University Press, 1993.

MacDougall, John. Rural Life in Canada: Its Trend and Tasks. 1913. Reprint, Toronto: University of Toronto Press, 1973.

MacGillivray, Royce. "The World of Sandy Fraser." In "Sandy Fraser": A Bibliography of the Writings of John Everett McIntosh (1876-1948) in the Farmer's Advocate Under the Pen Name of "Sandy Fraser," edited by Royce MacGillivray, 1-11. Waterloo, Ontario: privately pub, 1991.

Mackintosh, Phillip Gordon. Newspaper City: Toronto's Street Surfaces and the Liberal Press, 1860-1935. Toronto: University of Toronto Press, 2017.

MacPherson, Ian and John Herd Thompson. "The Business of Agriculture: Prairie Farmers and the Adoption of 'Business Methods,' 1880-1950." In The Prairie West: Historical Readings edited by R. Douglas Francis and Howard Palmer, 
475-96. Edmonton: Pica Pica Press, 1992.

Madill, A.J. History of Agricultural Education in Ontario. Toronto: University of Toronto Press, 1930.

Mah, Harold. "Phantasies of the Public Sphere: Rethinking the Habermas of Historians." Journal of Modern History 72, no. 1 (March 2000): 153-82.

Makker, Kirin J. "Village Improvement and the Development of Small Town America, 1853-1893." Journal of Planning History 13, no. 1 (2014): 68-87.

Maras, Steven. Objectivity in Journalism. Cambridge: Polity, 2013.

Marks, Lynne. Revivals and Roller Rinks: Religion, Leisure, and Identity in LateNineteenth-Century Small-Town Ontario. Toronto: University of Toronto Press, 1996.

Marotta, Jennifer Susan. "A Moral Messenger to the Canadian Middlemost: A Reading of The Family Herald and Weekly Star, 1874 - 1914.” PhD diss., Queen's University, 2006.

Marquis, Dominique. "The Catholic Press: A Challenge to the "Journalism of Information' Paradigm," translated by Patricia Smart. In Communicating in Canada's Past: Essays on Media History edited by Gene Allen and Daniel J. Robinson, 27-46. Toronto: University of Toronto Press, 2009.

Marti, Donald B. "Agricultural Journalism and the Diffusion of Knowledge: The First Half Century in America." Agricultural History 54, no. 1 (January 1980): 28-37.

McCormick, Veronica. A Hundred Years in the Dairy Industry: A History of the Dairy Industry in Canada and the Events That Influenced It, 1867 - 1967. Ottawa: Dollco, 1968.

Mckay, Ian. "A Liberal Order Framework: A Prospectus for a Reconnaissance of Canadian History." The Canadian Historical Review 81, no. 4 (December 2000): 616-45.

McKendry, Jennifer. Into the Silent Land: Historic Cemeteries and Graveyards in Ontario. Kingston, Ont.: Jennifer McKendry, 2003.

McMath, Robert C. Jr. American Populism: A Social History, 1877-1898. New York: Hill and Wang, 1993.

"Populism in Two Countries: Agrarian Protest in the Great Plains and Prairie Provinces." Agricultural History 69, no. 4 (Autumn 1995): 516-46.

McMurry, Sally. Transforming Rural Life: Dairying Families and Agricultural Change, 1820-1885. Baltimore: Johns Hopkins University Press, 1995.

McNairn, Jeffrey L. The Capacity to Judge: Public Opinion and Deliberative Democracy in Upper Canada, 1791-1854. Toronto: University of Toronto Press, 2000.

McNaught, Carlton. Canada Gets the News: A Report in the International Research 
Series of the Institute of Pacific Relations. Toronto, Ryerson Press, 1940.

McNeil, Sherry Lee Ann. "Urban Reform, Middle-Class Values, and Agricultural Society in Ontario, 1880-1914.” Master's thesis, Wilfrid Laurier University, 1997.

McQuail, Denis and Sven Windahl. Communication Models for the Study of Mass Communications. London: Longman, 1993.

McTavish, Lianne. "Learning to See: Vision, Visuality, and Material Culture, 18621929." In Defining the Modern Museum: A Case Study of the Challenges of Exchange, 48-70. Toronto: University of Toronto Press, 2013.

Menzies, Heather. By the Labour of Their Hands: The Story of Ontario Cheddar Cheese. Kingston: Quarry Press, 1994.

Miller, Spencer. "History of the Modern Highway in the United States." In Highways in: Our National Life, Symposium edited by Jean Labatut and Wheaton J. Lane, 88119. Princeton: Princeton University Press, 1950.

Miraldi, Robert. Objectivity and the New Muckracking: John L. Hess and the Nursing Home Scandal. Columbia, S.C.: A.E.J.M.C., 1989.

Mizener, David. "Furrows and Fairgrounds: Agriculture, Identity, and Authority in Twentieth Century Rural Ontario.” PhD diss., York University, 2009.

Moline, Norman T. Mobility and the Small Town, 1900-1930: Transportation Change in Oregon, Illinois. Chicago: University of Chicago Dept. of Geography, 1971.

Monaghan, David W. Canada's New Main Street: The Trans-Canada Highway As Idea and Reality, 1912-1956. Ottawa: Canada Science and Technology Museum, 2002.

Monod, David. "Down on the Farm: Reading Jeffery Taylor's Fashioning Farmers: Ideology, Agricultural Knowledge and the Manitoba Farm Movement." Manitoba History, 32 (Autumn 1996), 2-9.

Morton, W.L. The Progressive Party in Canada. Toronto: University of Toronto Press, 1950.

Neely, Wayne Caldwell. The Agricultural Fair. 1935. Reprint, New York: AMS press, 1967.

Nelson, Colleen Rose. "The Very Best Crop: Rural Children and the Family Economy in Early Twentieth Century Huron County." Master's thesis, University of Guelph, 2005.

Nerone, John, “Theory and History." In The American Journalism History Reader: Critical and Primary Texts edited by Bonnie Brennen and Hanno Hardt, 36-45. New York: Routledge, 2011.

Nesmith, Tom. "The Philosophy of Agriculture: The Promise of the Intellect in Ontario Farming, 1835-1914.” PhD diss., Carleton University, 1988.

Neth, Mary. Preserving the Family Farm: Women, Community, and the Foundations of 
Agribusiness in the Midwest. Baltimore: Johns Hopkins University Press, 1995.

Nixon, Garry B. "Canada." In Land-Value Taxation Around the World: Studies in Economic Reform and Social Justice, edited by Robert V. Andelson, 65-84. The American Journal of Economics and Sociology 59, no. 5, Supplement (2000).

Norcliffe, Glen. The Ride to Modernity: The Bicycle in Canada 1860-1900. Toronto: University of Toronto Press, 2001.

Nord, David Paul. "The Public Community: The Urbanization of Journalism in Chicago." Journal of Urban History. 11, no. 4 (August 1985): 411-41.

"Reading the Newspapers: Strategies and Politics of Reader Response, Chicago, 1912-17." In Communities of Journalism: A History of American Newspapers and Their Readers, 246-77. Urbana: University of Illinois Press, 2001.

Nunnally, Patrick “'From Churns to Butter Factories': The Industrialization of Iowa's Dairying, 1860-1900.” Annals of Iowa 49 (Winter 1989): 555-69.

Nurse, Jodey. "Reaching Rural Ontario: The County of Peel Agricultural Society and the Peel County Fall Fair, 1853-1883.” Master's thesis, University of Guelph, 2010.

O’Leary, Grattan. Recollections of People, Press, and Politics. Toronto: Macmillan, 1977.

Osler, Andrew M. News: The Evolution of Journalism in Canada. Toronto: Copp Clark Pitman, 1993.

Osterud, Grey. "Farm Crisis and Rural Revitalization in South-Central New York during the Early Twentieth Century." Agricultural History 84, no. 2 (Spring 2010): 14165.

Ott, Daniel. "Producing a Past: McCormick Harvester and Producer Populists in the 1890s.” Agricultural History 88, no. 1 (Winter 2014): 87-119,

Owen, Herbert T. "Canada." In Land-Value Taxation around the World: Reports on Current and Historical Efforts to Apply the Principle of Collecting the Community-Created Value of Land for Community Benefit, edited by Harry Gunnison Brown, Harold S. Buttenheim, Philip H. Cornick and Glenn E. Hoover, 61-78. New York: Robert Schalkenback Foundation, 1955, HeinOnline Legal Classics.

Paterson Catherine., "The Heritage of Life and Death in Historical Family Cemeteries of Niagara, Ontario.” PhD diss., McMaster University, 2013.

Peters, Scott J. “'Every Farmer Should Be Awakened': Liberty Hyde Bailey's Vision of Agricultural Extension Work.” Agricultural History 80, no. 2 (Spring 2006): 190219.

Peters, Scott J. and Paul A. Morgan, "The Country Life Commission: Reconsidering a Milestone in American Agricultural History." Agricultural History 78, no. 3 (Summer 2004): 289-316. 
Prescott, Gerald. "Wisconsin Farm Leaders in the Gilded Age." Agricultural History 44, no. 2 (April 1970): 183-99.

Prosterman, Leslie. Ordinary Life, Festival Days: Aesthetics in the Midwestern County Fair. Washington: Smithsonian Institution Press, 1995.

Quaile, Meredith Leigh. "Sisters in Toil: The Progressive Devaluation and Defeminization of Ontario's Dairywomen's Work and Tools, 1813-1914." PhD diss., Memorial University, 2010.

Rawson, Mary. "L.D. Taylor: The Man Who Made Vancouver." The American Journal of Economics and Sociology 75, no. 1 (January 2016): 217-45.

Reaman, G. Elmore. A History of Agriculture in Ontario. Don Mills, Ont.: Saunders of Toronto, 1970.

Reddy, William M. "The Paradox of Modernity: Current Debates and Their Implications for the Seventeenth Century." Modern Intellectual History 14, no. 1 (2017): 217 56.

Reimer, Bill and Ray D. Bollman. "Understanding Rural Canada: Implications for Rural Development Policy and Rural Planning Policy", University of Guelph http://www.uoguelph.ca/fare/FARE-talk/BOOK-Chapter-1-Bill-and-Ray-NELDOUGLAS-09-0405-001.pdf. (Accessed June 9, 2014).

Remele, Larry. “'Things as They Should Be': Jeffersonian Idealism and Rural Rebellion in Minnesota and North Dakota 1910-1920.” Minnesota History 51, no. 1 (Spring 1988): $15-22$.

Rennie, Bradford James. The Rise of Agrarian Democracy: The United Farmers and Farm Women of Alberta. Toronto: University of Toronto Press, 2000.

Richardson, Heather Cox. "Securing the Fruits of Labor: The American Concept of Wealth distribution, 1765-1900." Journal of Interdisciplinary History 30, no. 3 (Winter 1999): 538.

Richardson, John E. Analyzing Newspapers: An Approach from Critical Discourse Analysis. Houndsmill, England: Palgrave Macmillan, 2007.

Rodgers, Daniel T. "In Search of Progressivism." Reviews in American History 10, no. 4 (December 1982): 113-32.

Rose, Albert C. "The Highway from the Railroad to the Automobile." In Highways in Our National Life: Symposium edited by Jean Labatut and Wheaton J. Lane, 7787. Princeton: Princeton University Press, 1950.

Rosenberg, Nathan and W. Edward Steinmueller. "Engineering Knowledge." Industrial and Corporate Change 22, no. 5 (January 2013): 1129-1158

Roshco, Bernard. Newsmaking. Chicago: University of Chicago Press, 1975.

Ross, Alexander M. and Terry Crowley. The College on the Hill: A New History of the Ontario Agricultural College, 1874-1999. Toronto: Dundern Press, 1999. 
Ross, P.D. Retrospects of a Newspaper Person. Toronto: Oxford University Press, 1931.

Rothenberg, Winifred Barr. From Market-Places to a Market Economy: The Transformation of Rural Massachusetts, 1750-1850. Chicago: University of Chicago Press, 1992.

Ruddick, J.A. "Development of the Dairy Industry." In The Dairy Industry in Canada, edited by H.A. Innis, 15-125. Toronto: Ryerson Press, 1937.

Ruffilli, Dean C. "The Car in Canadian Culture, 1898-1983." PhD diss., University of Western Ontario, 2006.

Rugg, Julie. Churchyard and Cemetery: Tradition and Modernity in Rural North Yorkshire. Manchester: Manchester University Press, 2013.

Rush, Anita. "The Bicycle Boom of the Gay Nineties: A Reassessment." Material Culture Review / Revue de la culture matérielle [Online], Volume 18 (6 June 1983).

Rutherford, Paul. "The People's Press: Emergence of the New Journalism in Canada, 1869-99." Canadian Historical Review 56, no. 2 (June 1975): 169-92.

- A Victorian Authority: The Daily Press in Late-Nineteenth Century Canada. Toronto: University of Toronto Press, 1982.

Samson, Daniel. "Dependency and Rural Industry: Inverness, Nova Scotia, 1899-1910." In Contested Countryside: Rural Workers and Modern Society in Atlantic Canada, 1800-1950, edited by Daniel Samson, 105-49. Fredericton, NB.: Acadiensis Press, 1994.

Sandwell, R.W. "Rural Reconstruction: Towards a New Synthesis in Canadian History." Histoire sociale / Social History 27, no. 53 (1994): 1-32.

Schlebecker, John T.” Dairy Journalism: Studies in Successful Farm Journalism." Agricultural History 31, no. 4 (October 1957): 23-33.

Schudson, Michael. Discovering the News: A Social History of American Newspapers. New York: Basic Books, 1978.

Schwarzlose, Richard A. The Formative Years from Pretelegraph to 1865. Volume 1 of The Nation's Newsbrokers. Evanston, Ill.: Northeastern University Press, 1989.

Scott, James C. Seeing Like a State: How Certain Schemes to Improve the Human Condition Have Failed. New Haven: Yale University Press, 1998.

Scott, Roy V. The Reluctant Farmer: The Rise of Agricultural Extension to 1914. Urbana: University of Chicago Press, 1970.

Seely, Bruce E. Building the American Highway System: Engineers as Policy Makers. Philadelphia, Temple University Press, 1987.

Sharp, Paul F. The Agrarian Revolt in Western Canada: A Survey Showing American Parallels. 1948. Reprint, New York: Octagon Books, 1971. 
Shaw, Christopher W. "'No Place for Class Politics': The Country Life Commission and Immigration." Agricultural History 85, no. 4 (Fall 2011): 520-39

Shulman, Stuart W. "The Progressive Era Farm Press: A Primer on a Neglected Source of Journalism History.” Journalism History 25, no. 1 (Spring 1999): 26-35.

Siebert, Frederick S. "Authoritarian Theory" and "Libertarian Theory." In Four Theories of the Press, edited by Fred S. Siebert, Theodore Peterson and Wilbur Schramm, 9-71. Urbana: University of Illinois Press, 1956.

Freedom of the Press in England, 1476-1776: The Rise and Decline of Government Controls. Urbana: University of Illinois Press, 1952

Sim, John Cameron. The Grass-Roots Press: America's Community Newspaper. Ames: Iowa State University Press, 1969.

Skogstad, Grace. The Politics of Agricultural Policy-Making in Canada. Toronto: University of Toronto Press, 1987.

Sloan, William David. "Sidney Kobre and Sociological History." In Makers of the Media Mind: Journalism Educators and Their Ideas, edited by Wm. David Sloan, 99105. New York: Routledge, 1990.

Sloane, David Charles. The Last Great Necessity: Cemeteries in American History. Oxford: Oxford University Press, 1995.

Smith, Dorothy-Jane. "The Community and the Fair: Vankleek Hill, West Hawkesbury Township and the Agricultural Fair, 1900 to 1950." Master's thesis, Carleton University, 2012.

Smith, I. Norman, The Journal Men. Toronto: McClelland and Stewart, 1974.

Smythe, Ted Curtis. The Gilded Age Press, 1865-1900. Westport, Conn.: Praeger, 2003.

Snyder, Matt. Ninety-Four Years of The Ottawa Journal. Ottawa: Historical Society of Ottawa, 1998.

Solomon, William S. "The Site of Newsroom Labor: The Division of Editorial Practices." In Newsworkers: Towards a History of the Rank and File, edited by Hanno Hardt and Bonnie Brennen, 110-34. Minneapolis: University of Minnesota Press, 1995.

Sommerstad, Lena and Sally McMurry. "Farm Daughters and Industrialization: A Comparative Analysis of Dairying in New York and Sweden, 1860-1920.” Journal of Women's History 10, no. 2 (Summer 1998): 137-64.

Sotiron, Minko. From Politics to Profit: The Commercialization of Canadian Daily Newspapers, 1890-1920. Montreal: McGill-Queen’s University Press, 1997.

Spencer, David R. "Alternative Visions: The Intellectual Heritage of Nonconformist Journalists in Canada." In Newsworkers: Towards a History of the Rank and File, edited by Hanno Hardt and Bonnie Brennen, 160-89. Minneapolis: University of Minnesota Press, 1995. 
The Yellow Journalism: The Press and America's Emergence as a World Power. Evanston, Ill.: Northwestern University Press, 2007.

Spike, Sara. "Modern Eyes: A Cultural History of Vision in Rural Nova Scotia, 18801910.” PhD diss., Carleton University, 2016.

Startt, James D. and Wm. David Sloan. "The Historical Search for Significance.” In The Significance of the Media in American History, edited by James D. Startt and Wm. David Sloan 1-15. Northport, Ala.: Vision Press. 1994.

Stevens, John D. and Hazel Dicken-Garcia. Communication History. Beverly Hills: Sage Publications, 1980.

Stromquist, Shelton. Re-inventing "The People”: The Progressive Movement, the Class Problem, and the Origins of Modern Liberalism. Urbana: University of Illinois Press, 2006.

Sturgis, Cynthia. “'How're You Gonna Keep 'Em Down on the Farm?': Rural Women and the Urban Model in Utah.” Agricultural History 80 no. 2 (Spring 1986): $182-$ 99.

Summerby-Murray, Robert. "Statute Labour on Ontario Township Roads, 1849-1948: Responding to a Changing Space Economy." Canadian Geographer 43, no. 1 (1999): 36-52.

Swanson, Merwin Robert. “The American Life Movement, 1900-1940.” PhD Diss., University of Minnesota, 1972.

Swierenga, Robert. “Towards The 'New Rural History': A Review Essay.” In Historical Methods Newsletter 6, no 3 (June 1973): 111- 22.

"Theoretical Perspectives on the New Rural History from Environmentalism to Modernism." Agricultural History 56, no. 3 (July 1982): 495-503.

Sylvester, Kenneth Michael. The Limits of Rural Capitalism: Family, Culture, and Markets in Montcalm, Manitoba, 1870-1940. Toronto: University of Toronto Press, 2001.

Talman, J.J. "Reading Habits of the 1917 Ontario Farmer." In Second Annual Agricultural History of Ontario Seminar 1977, Proceedings, edited by T.A. Crowley, 66-89. Guelph: University of Guelph, 1977.

Taylor, Jeffery. Fashioning Farmers: Ideology, Agricultural Knowledge, and the Manitoba Farm Movement, 1890-1925. Regina: Canadian Plains Research Center, 1994.

"The Language of Agrarianism in Manitoba, 1890-1925." Labour / Le Travail 23 (Spring 1989): 91-118.

Tebbel, John. The Compact History of the American Newspaper. New York: Hawthorn Books, 1969.

Torres da Silva, Marisa. "Newsroom Practices and Letters-To-The-Editor: An Analysis of Selection Criteria." Journalism Practice 6, no. 2 (2012): 250-63. 
Tough, Frank. "Conservation and the Indian: Clifford Sifton's Commission of Conservation, 1910-1919.” Native Studies Review 8, 1 (1992): 61-73.

Trachtenberg Alan, The Incorporation of America: Culture and Society in the Gilded Age. New York: Hill and Wang, 1982.

Tuchman, Gaye. Making News: A Study in the Construction of Reality. New York: Free Press, 1978.

Turgeon, Dana Marie. "Images of Women in the Western Producer 1946-1960.” Master's thesis, University of Regina, 2003.

Turgeon, Mathieu and François Vaillancourt, "The Provision of Highways in Canada and the Federal Government." Publius 32, no. 1 (Winter 2002): 61-80.

Valenze, Deborah. "The Art of Women and the Business of Men: Women's Work and the Dairy Industry c.1740-1840." Past and Present 130 (February 1991): 142-69.

Van Derhoof, Jack. "Eastern and Mid-Western Agricultural Journalism, 1860-1900." PhD diss., Columbia University, 1951.

Van Dijk, Tenn A. "Discourse Semantics and Ideology." Discourse and Society 6, no. 2 (1995): 243-89.

Van Loon, Richard J. “The Political Thought of the United Farmers of Ontario.” Master's thesis, Carleton University, 1965.

Veit, Richard F. and Mark Nonestied. New Jersey Cemeteries and Tombstones: History in the Landscape. New Brunswick, N.J.: Rivergate Books, 2008.

Verrette, Michel and Yvan Lamonde. "Literacy and Print Culture." In History of the Book in Canada, edited by Yvan Lamonde, Patricia Lockhart Fleming and Fiona A. Black, 451-8. Vol. 2. Toronto: University of Toronto Press, 2005.

Vipond, Mary. Listening In: The First Decade of Canadian Broadcasting, 1922-1932. Montreal: McGill-Queen's University Press, 1992.

-The Mass Media in Canada. Toronto: James Lorimer \& Co., 2000.

Vos, Tim P. and Teri Finneman. "The Early Historical Construction of Journalism's Gatekeeping Role.” Journalism 18, no. 3 (2017): 265-80.

Walden, Keith. Becoming Modern in Toronto: The Industrial Exhibition and the Shaping of a Late Victorian Culture. Toronto: University of Toronto Press, 1997.

Walsh, John C. "Performing Public Memory and Re-Placing Home in the Ottawa Valley, 1900-58." In Placing Memory and Remembering Place in Canada, edited by James Opp and John C. Walsh, 25-56. Vancouver: UBC Press, 2010: 25-56.

Weber, Robert Philip. Basic Content Analysis. Beverly Hills: SAGE Publications, 1985.

Wells, Christopher W. "The Changing Nature of Country Roads: Farmers, Reformers, and the Shifting Uses of Rural Space, 1880-1905." Agricultural History 80, no. 22 (Spring 2006): 143-66. 
Wiebe, Robert H. The Search for Order, 1877-1920. New York: Wang, 1967.

Wiener, Joel H. The Americanization of the British Press, 1830s-1914: Speed in the Age of Transatlantic Journalism. New York: Palgrave Macmillan, 2011.

Williams, Raymond. The Country and the City. London: Chatto and Windus, 1973.

Williams, Kevin. Read All About It! A History of the British Newspaper. London: Routledge, 2010.

Wilson, Catharine Anne. "Reciprocal Work Bees and the Meaning of Neighbourhood." Canadian Historical Review 82, no. 3 (September 2001): 431-464. " A Manly Art: Plowing, Plowing Matches, and Rural Masculinity in Ontario, 1800-1930." Canadian Historical Review 95, no. 2 (June 2014): 157-86.

Wood, John Carter "'Those Who Have Had Trouble Can Sympathize With You': Press Writing, Reader Responses and a Murder Trial in Interwar Britain." Journal of Social History 43, no. 2 (Winter 2009): 439-63.

Wood, L.A. A History of Farmers' Movements in Canada. Toronto: Ryerson Press, 1924.

Worpole, Ken. Last Landscapes: The Architecture of the Cemetery in the West. London: Reaktion, 2003.

Wright, Elizabeth A. "Rhetorical Spaces in Memorial Places: The Cemetery as a Rhetorical Memory Place/Space." Rhetoric Society Quarterly 35, no. 4 (Fall 2005): 51-81

Wunderlich, Gene. "The Community Idea in American Country Life." Agriculture and Human Values 19 (2002): 81-5.

Wynn, Graeme. "Exciting a Spirit of Emulation Among the 'Plodholes': Agricultural Reform in Pre-Confederation Nova Scotia." Acadiensis 20, no. 1 (October 1990): $5-51$.

Young, Brian, Respectable Burial: Montreal's Mount Royal Cemetery. Montreal: McGill-Queen's University Press, 2003.

Young, William Robert. "The Countryside on the Defensive: Agricultural Ontario's Views of Rural Depopulation, 1900-1914.” Master's thesis, University of British Columbia, 1971.

Ziegler, Edith M. "'The Burdens and the Narrow Life of Farm Women': Women, Gender, and Theodore Roosevelt's Commission on Country Life." Agricultural History 86, no. 3 (Summer 2012): 77-103.

\section{Tertiary}

Cultural Theory: The Key Concepts. Edited by Andrew Edgar and Peter Sedwick. London: Routledge, 2002.

New Keywords: A Revised Vocabulary of Culture and Society. Edited by Tony Bennett, Lawrence Grossberg and Meaghan Morris. Malden, Mass.: Blackwell 
Publishing, 2005.

Ontario Rural Society 1867 - 1930: A Thematic Index of Selected Ontario Agricultural Periodicals. Compiled by Edwinna von Baeyer (Ottawa: Bhakti Press, 1908). 